\title{
NEAL'S LIBRARY
}

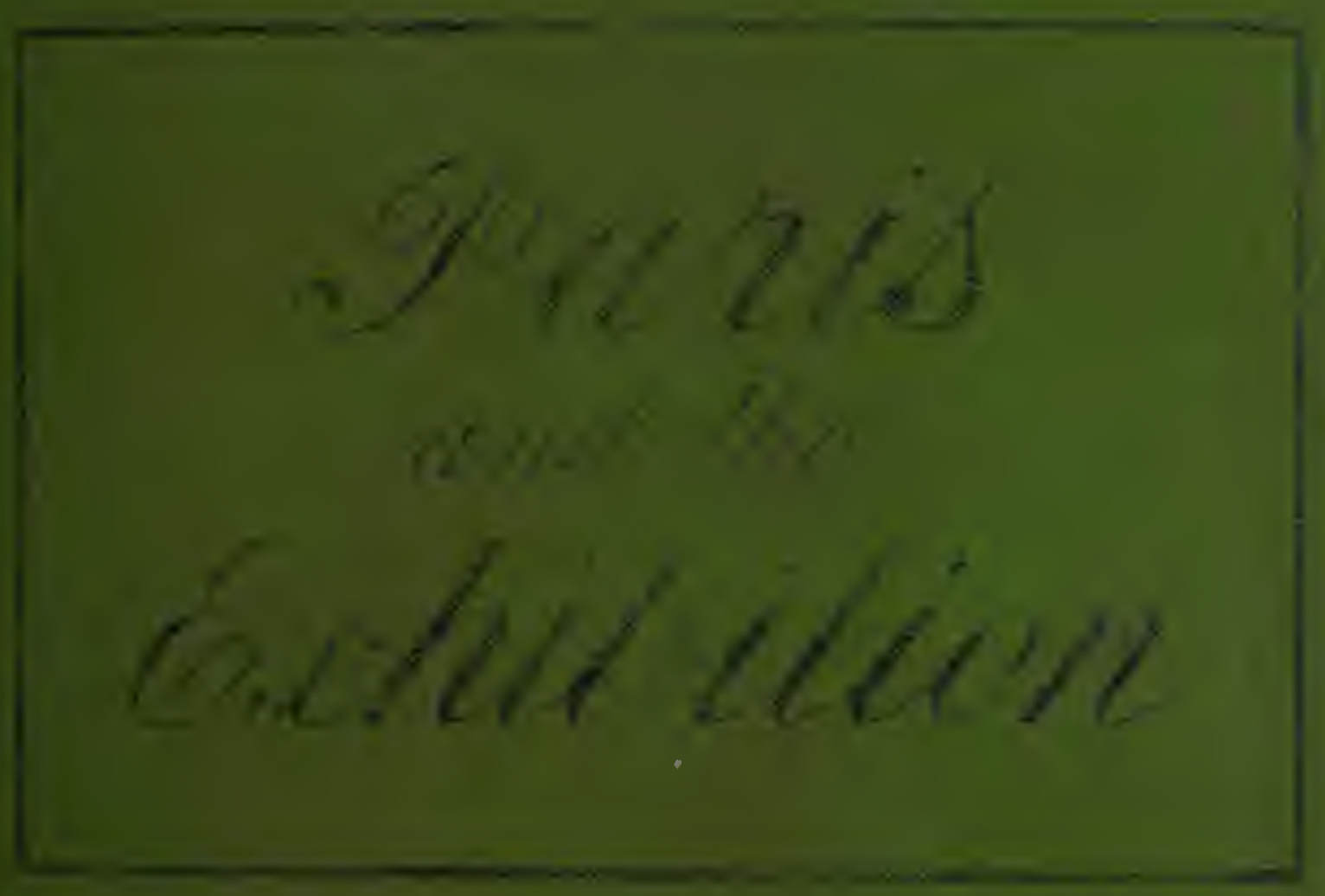

-

243 RUE DE HIVJUI, PAFIS 


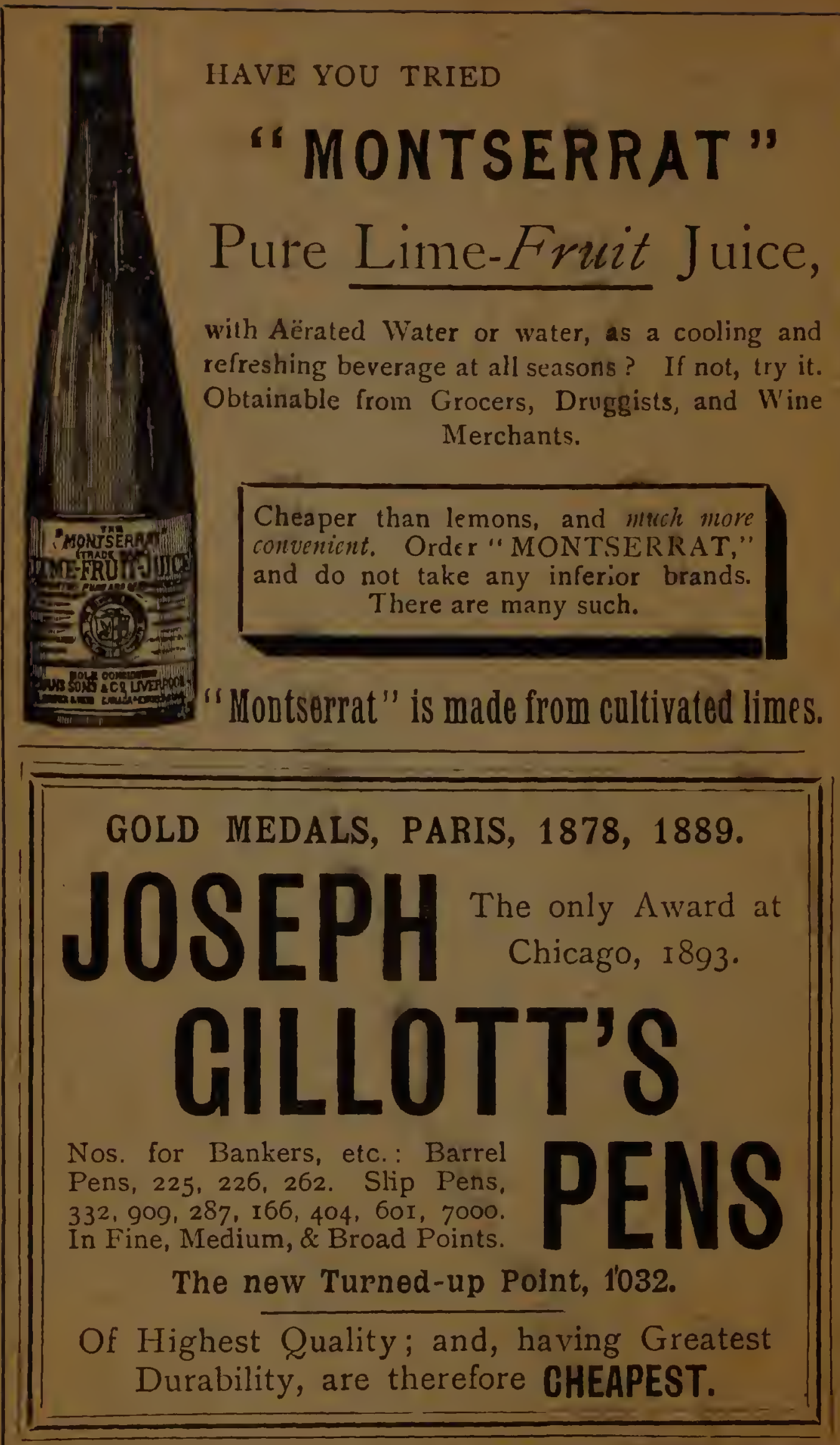


ESTABLISHED 1851.

\section{BIRK B E CK B A N K,}

Southampton Buildings, Chancery Lane, London.

\section{INVESTED FUNDS - - $£ 10,000,000$ Number of Accounts - $-\mathbf{S 5 , 0 9 t}$.}

TWO-AND-A-HALF per CENT. INTEREST allowed on DEPOSITS, repayalle on demand.

TIVO per CENT. on CURRENT ACCOUNTS, on the minimum monthly balances, when not drawn below $\delta$ Ioo.

STUCKS, SHARES, and ANNUITIES purchased and sold for Customers.

\section{SAYINGS DEPARTMENT.}

Small deposits received, and Interest allowed morthly on each complete $£ \mathrm{I}$.

THE BIRKBECK ALMANACK, with full particulars, post free.

FRANCIS RAVENSCROFT, Manager. Telephone No. 3, Holborn. Telegraphic Address: " Birkbeck, London."
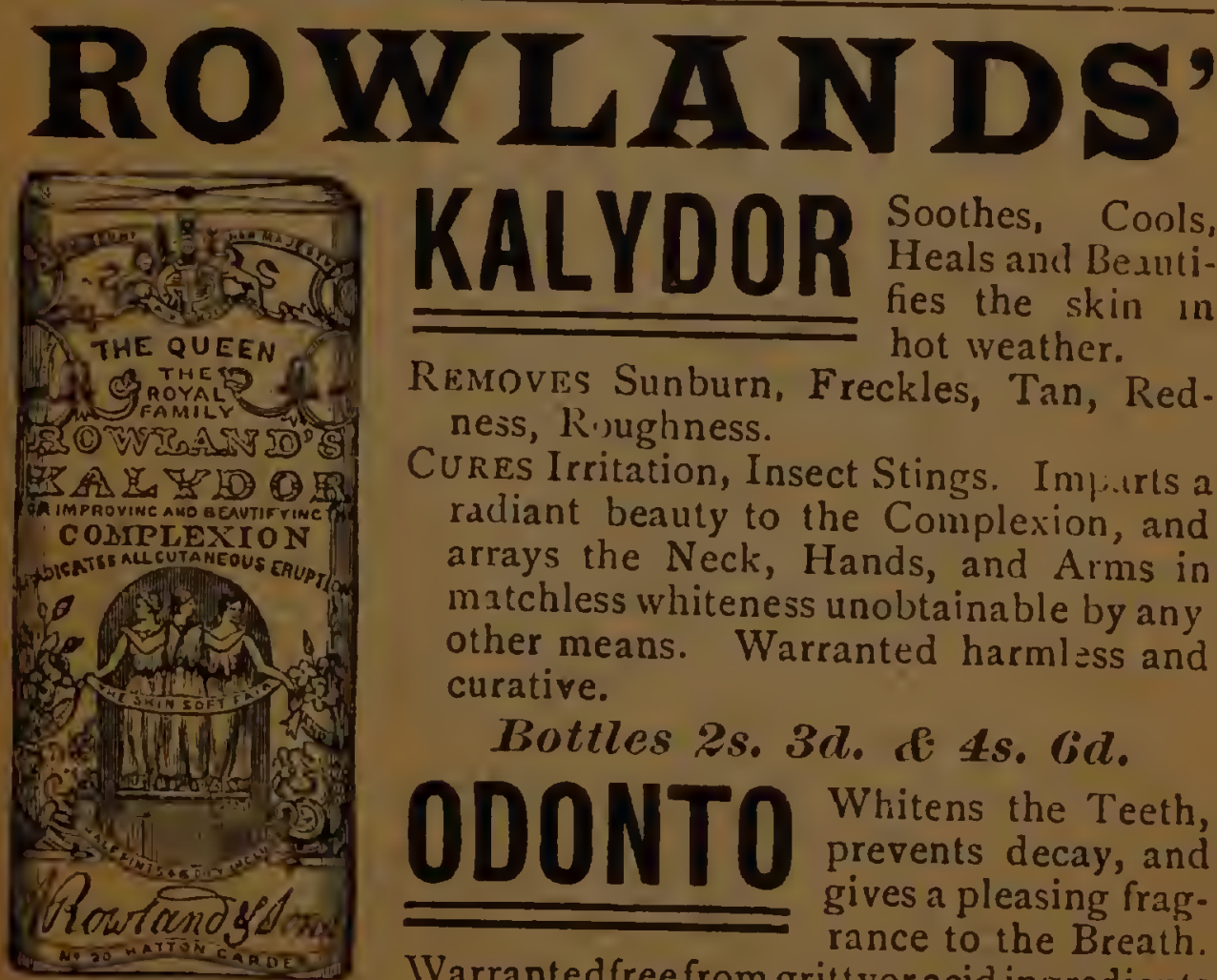

Soothes, Cools, Heals and Bexultfies the skin in hot weather.

Removes Sunburn, Freckles, Tan, Red. ness, R'sughness.

CURES Irritation, Insect Stings. Imp.urts a radiant beauty to the Complexion, and arrays the Neck, Hands, and Arms in matchless whiteness unobtainable by any other means. Warranted harmless and curative.

Bottles 2s. 3d. \& 4s. Gd. $00170 \begin{aligned} & \text { Whitens the Teeth, } \\ & \text { prevents decay, and } \\ & \text { gives a pleasing frag- }\end{aligned}$ IVarrantedfreefrom rance to the Breath.

by Stores, Chemists, and

A. ROWLAND d SONS, Hatton Gurden, LONDON. 


\section{BRANTSONT'S \\ 'SPADE' \\ COFFEE \\ ALWAYS READY. \\ JUST THE THING FOR TRAVELLERS. Sold by all Storis, Grocers, \&e.}
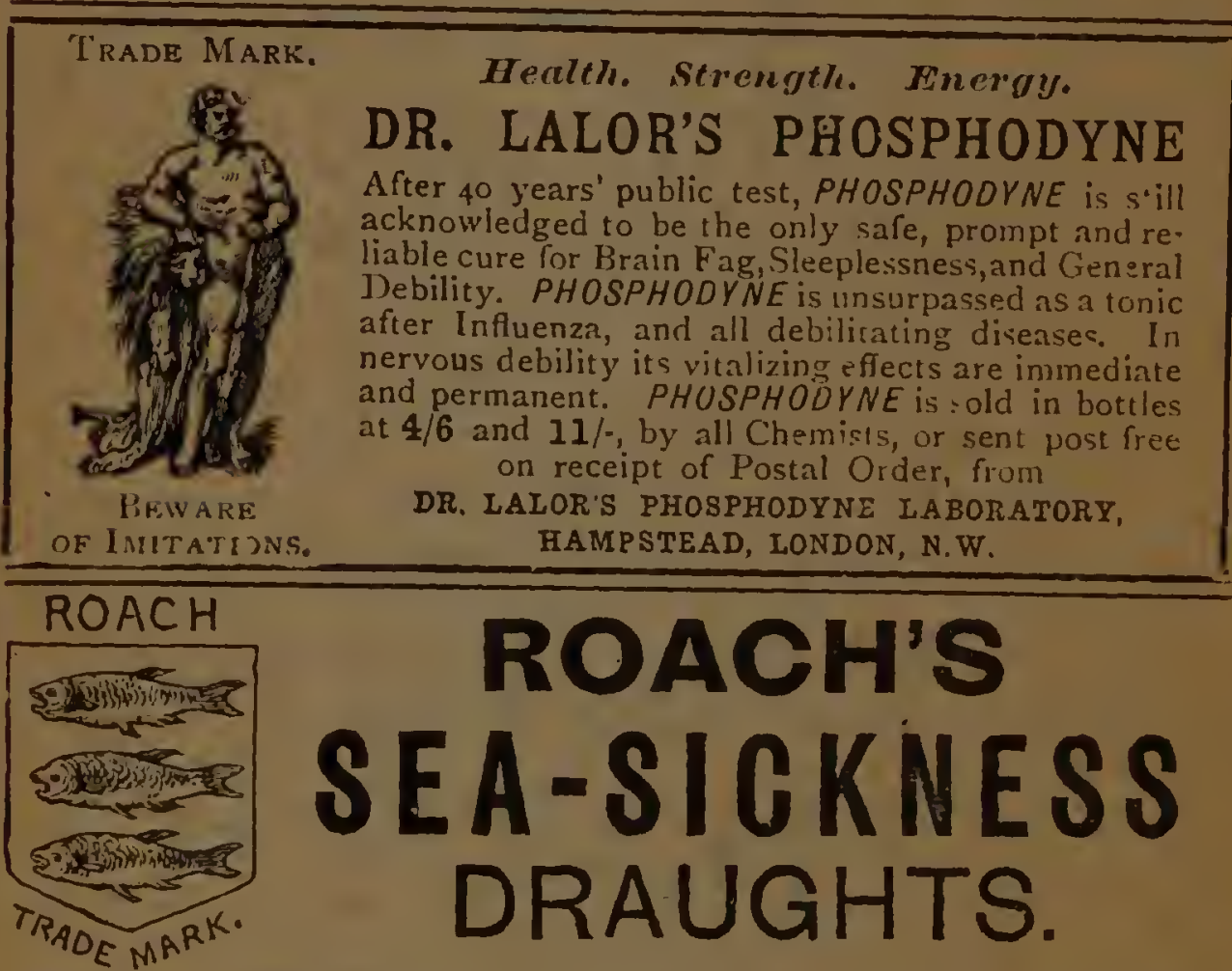

Ext, act frow "Life," Sept. 26th, 189r.--" And here I have something to say which I expect all voyagers to arcept with grateful joy. There is a remedy for mal.de-mer! Last year a distinguished physicim arlvised me to get for a young friend who was going out to Gibraltar, some of POl.E RoACH \& Son's (8, St. James's Street) celebrated draughts for the preven. lion of sea-sickness. This remedy has never been known to fail in its effects.

"The young lady who took them last year found them perfectly efficacious both on the journey out and home, and I have no doubt that I shall hear that they have proved equaliy successful in the present instance, a result which I shall duly record, as a real cure for that distressing malady cannot be ton widely known."

Sold in Boxes, containing Six, for $4 / 6$; or Twelve Draughts, $8 / 6$.

By Parcel Post, 6d. extra. By Foreign Parcel Post, r/6 extra.

\section{PLEI'ARED ONI.Y RY}

POPE ROACH \& SON,

Pharmaceutical Chemists to H.R.H. the Prince of Wales, 8, ST. JA MES'S STREET, LO N D O N. PARIS AGENTG:

ROBERTS \& CO., Foreign and English Chemists, Rup de la Paix, 5. 


\section{VATETED DS surpowing Well=known BOOTS BYPOST DIRECT FROM THE FACTORY-POST FREE.}

MANFIELD'S hold one of the largest and most varied stocks in the World, so that a Perfect Fit can be guaranteed.

SEND FOR ILLUSTRATED
CATALOGUE, AND SELECT
THE STYLE OF BOOTS
YOU PREFER.

Single pairs post free to any prevt of the Uniterl Kingdom.

When ordering Boots by post for the first time. the best and simplest method is to send an old, comfortably fitting Boot or Shoe. Your name and address will be sufficient for future orders.

\section{ADDRESS-}

\section{MANFIELD \& SONS, NORTHA MPTON.}

Branches throughout London and the Provinces. 


\section{JOHN JAMESON'S \\ CELEBRATED}

THREE STAR

\section{WHISKEY.}

TRADE $d \sqrt{8} 8$ MARK.

Each Bottle bears John Jameson and Son's Registered Watermarked Label with name of Bottler, together with the Distillers' Signature and Trade Mark on Capsule, without which none is genuine.

\section{MAY BE HAD OF ALL WINE MERCHANTS.}

FOUNDED 1807.

COUNTY FIRE OFFICE, 50, REGENT ST., W. ${ }_{A N D}$

14, CORNHILL, LONDON, E.C.

No Foreign Business Transacted.

Septennial Returns of Premium on Ordinary Risks.

Liberal Discounts on Prepaid Policies for $7,6,5,4$, or 3 yenrs.

Moderate Rates of Preminm.

Prompt Settlement of Claims.

The Amount Paid for Losses exceeds Four and a IIalf Millions. 


\section{HYDROPATHIC, PEEBLES, N.B.}

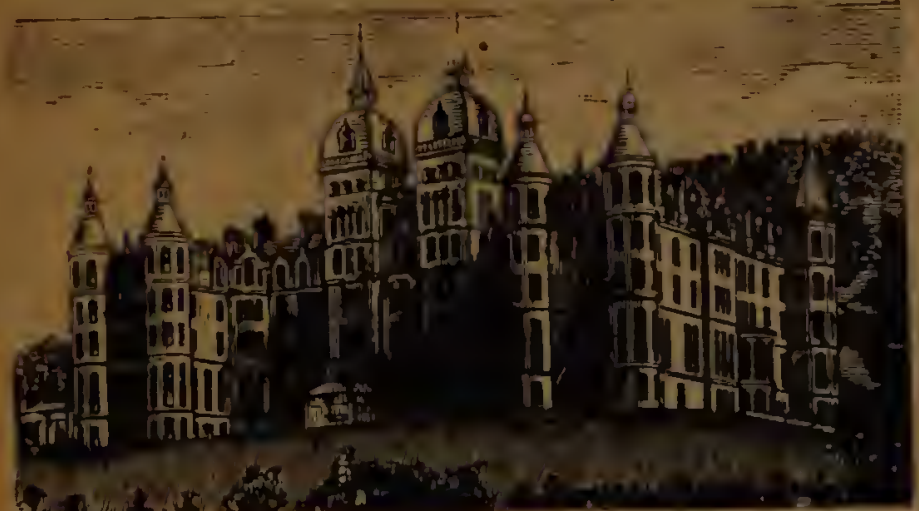

NOW Complete.The Department for the Treatment of Rheumatism, Gout, Sciatica, Neuralgia, Nervous Debility, Sleeplessners, Liver, Stomach, and Kidney Complaints, Obesi. tyal. By a Combination of Douche and Massa:se with the New Powerful Electric Light Therany, the course of treatment is connsiderably shortened. Special arrangements for Pure Air and Sun Bathing, the most reliable Continental Methods of Water Cures, Diet, German and Swedish Medical Exercises, and Electric Massage.

The powerful Earth Treatment and Pastor Kneipp's Meadow, the First in Great Britain. Turkish and Russian Baths, Golf, Tennis, Cricket, Bowling Greens, Residental Specialist, Excellent Cuisine, Electric Light.

A. M. THIEM, Proprielor also of the Windsor Hotel, Glasgow.

\section{THE \\ WINDSOR \\ HOTEL,}

250, ST. VINCENT STREET, GLASGOW.

Patronised by Royalty, Li Hung Chang, The Shahzada, and the Elite from everywhere. Excellent Cuisine, Passenger Elevator, Electric Light. Charges Moderate.

\section{EAGLE}

INSURANGE GOMPANY Lives and Annuities.

79, PALL MALL, LONDON, S.W. City-THREADNEEDLE STREET.

Branches-

BIRMINGHAM, BRISTOL, LEEDS, MANCHESTER. FAVOURABLE RATES.

STRONG RESERVES.

Claims and Bonus Pair-

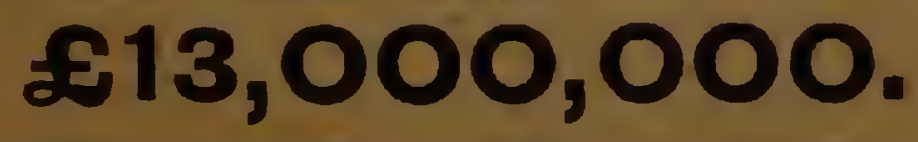



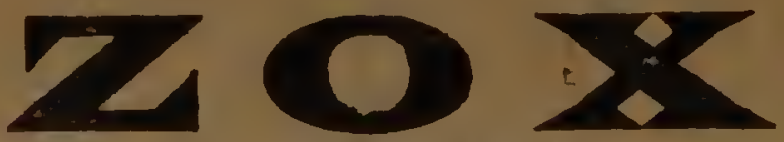

\section{CURES}
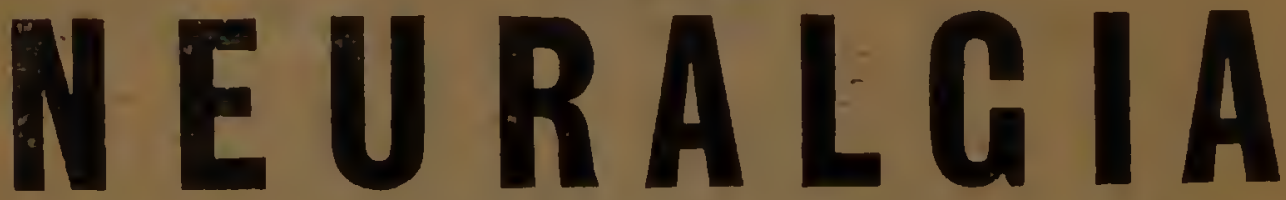

Toothache, Headache, Soiatica, and All Nerye Pains.

Pure, Harmless, and Not Aperient.

TESTIMONIALS.

"Bowes Park, N., October roth, 1898 .

"Dear SiRs, - Kindly send $1 /$ - packet of Zox for Neuralgia. A friend of mine gave me one or two powders, and they certainly acted in a surprising manner in removing the pain.

"Yours truly, A. W."

"Mutrey, October $8 t h, 1898$.

"Sire, - Please send a I/. Box of Zox as soon as possible. I have the Toothache, and several years ago you sent me a sample which eased me at once.

"Yours truly, A. S. M."

ZOX is sold by all Chemists and Stores, $1 /$ \& $2 / 6$ per box. ZOX TONIC, $1 / 1 \frac{1}{2}, 2 \%$ and $3 / 6$ per bottle.

Z0X Manufacluring Co., 11, Hatton Garden, London, E.C.
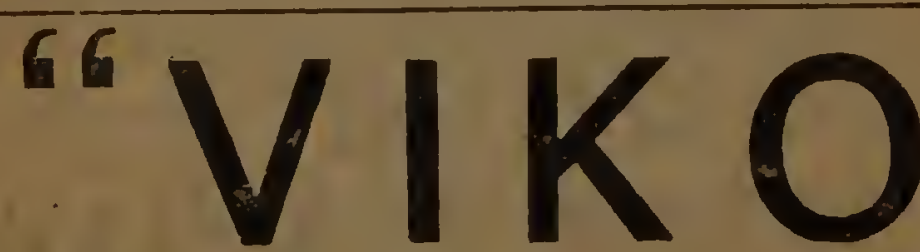

9y

The Marvellous Insect Destroyer.

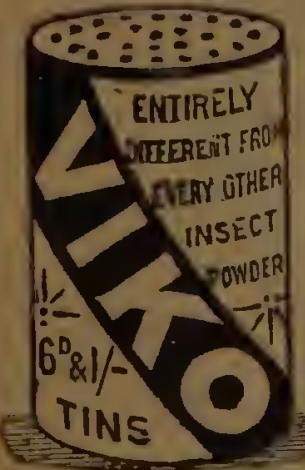

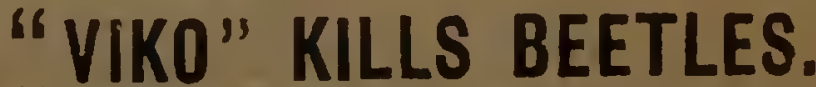

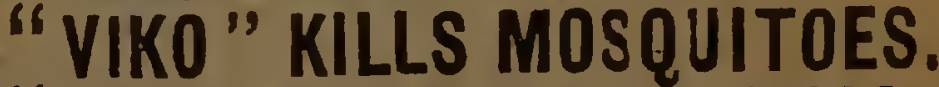
16 M. "VIKO" KILLS ANTS AND ALL INSECTS, BUT

"VIKO" WILL NOT KILL CATS AND DOCS.

Sold in Tins, 6d. and 1s., by all Chemists and Stores, or post free fur Stamps of Sole Manufacturers.

TUNBRIDGE \& WRIGHT, READING. Manufacturers of the celebrated "Fly Cemetery." 
A Pictorial Guide to Paris

AND

๑r THE ExhIBITION OF 1900. 


\section{DELIGHTFUL STEAMER TRIPS}

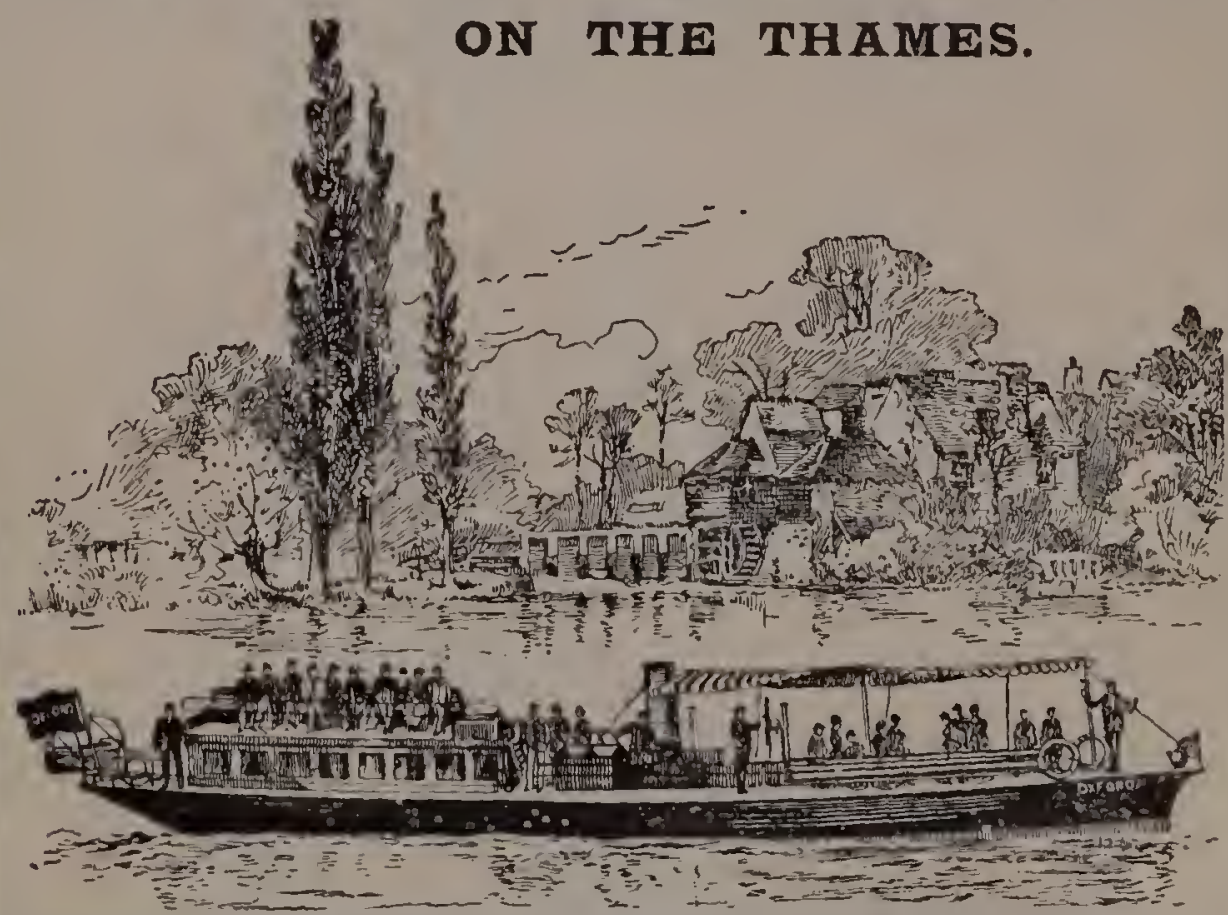

\section{SALOON STEAMERS run daily (Sundays excepted)}

between OXFORD, HENLEY, \& KINGSTON.

DOWN TRIP.

Oxtord clep. . . $\quad 9.30$ a.m

Henley arr about : $7.0 \mathrm{p.m}$.

(lep. 9.50 a.m, 2.40 \%.m.

Windsor arr. about I.45 p.r..,7.15 p m.

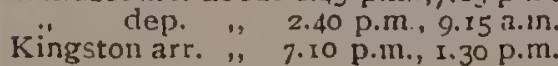

\section{UP TRII'}

Kingston dep. . 00 न.m., 2.30 p.m. lindsorarr. about 1.10 p $11 . .7 .15$ P.m. $\because$ del. \# 2.40 p.11.. 9.15 a.11:. Hënley arr. ", 7.15 p.m., r.40 p.m. oxford dep. $9.0 \mathrm{a.m}$.

The through journey occupies two days each way, but passengers can jois or leave the boat at any of the locks or regular stopping places. Circular 1 ickets for Combined Rail way and Ste uner Trips are issued it most of the principalG. IV.R. Stations, also at Waterloo, Riclmond, and Kingston Stations, L. \& S. W. Railway: Time Table giving rull particulars ol arrangenents, farıs, ctc, post free, 11.

ROWING BOATs of all kinds for Excursions down the Piver at Charg's which inclute Cartage back to Oxford.

Full Particulars on application.

STEAM LAUNCHES for Hire bJ the Day or Week, and also for the Trip.

Boats of every description, Canoes, Punts, Er., built to order.

A large selection, both New \& Second-hand, kept in readiness for Sale or Hire. Illustrated Price Lists may be had on application.

HOUSE BOATS FOR SALE OR HIRE, E ALSO RUILT TO ORDER.

SALTER BROTHERS, Boat Builders, Folly Bridgo, OXFORD. 





Dictorial and Degcriptive

GUIDE TO PARIS

AID THE

\title{
E X H I B I T I O N.
}

\section{Humerous Fllustrations.}

SPECIALLY-DRAWN PLAN OF THE EXHIBITION, AND LARGE PLANS OF THE CITY AND ITS OUTSKIRTS.

\author{
PARIS : \\ NEAL'S LIBRARY, \\ 248, RUE DE RIVOEI.
}




\section{No Charge for attendance. \\ The Westminster Palace Hotel, VICTORIA STREET, LONDON, S.W.}

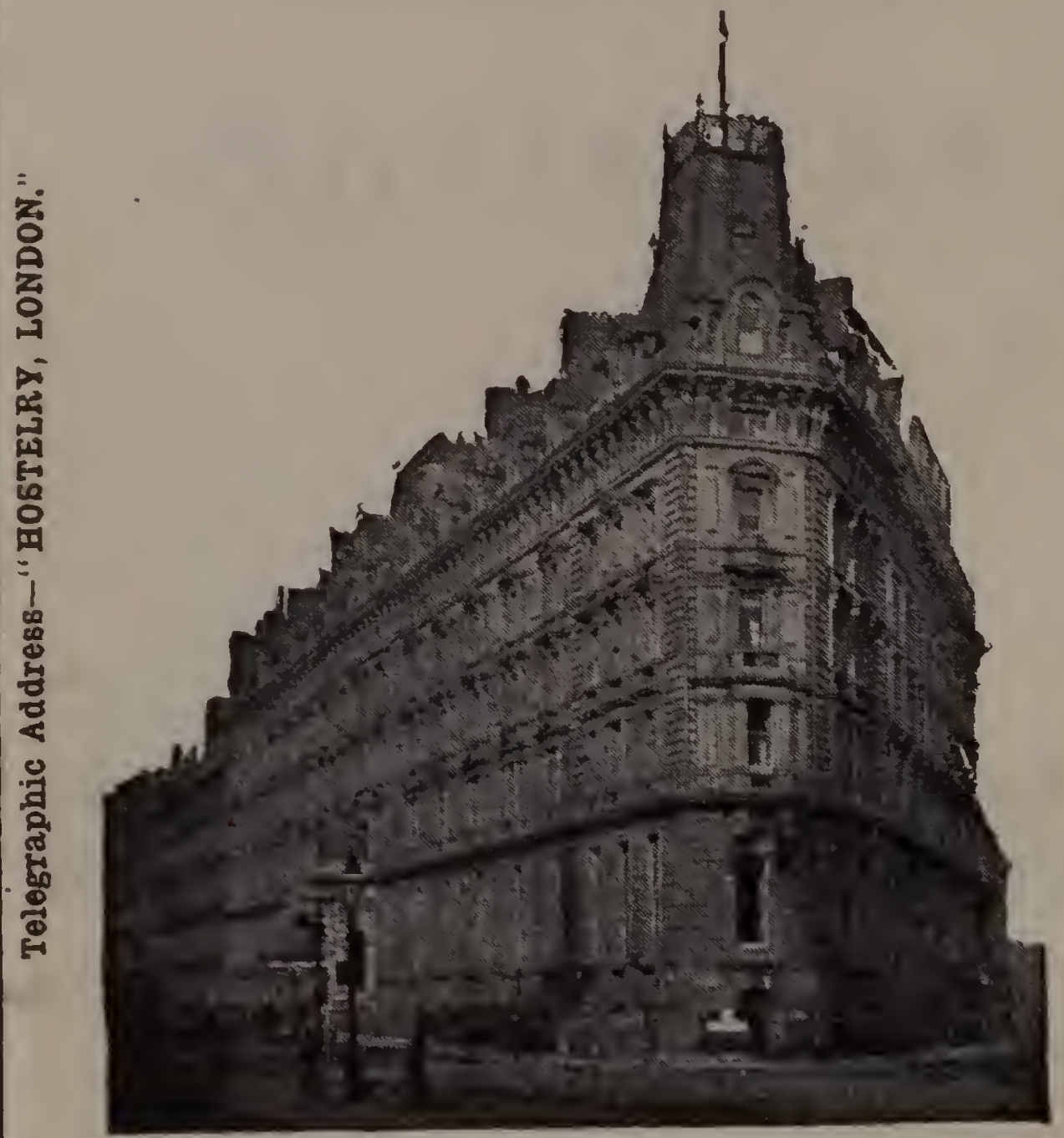

MOST convenient situation for Business or Pleasure. Opposite V1 Westminster Abbey and the Houses of Parliament. The Building is Fireproof. Electric Light throughout, Hydraulic Passenger Lifts, and all the latest modern improvements. Spacious Reading, Writing, Dining, and Drawing Rooms, together with Smoking and Billiard Rooms, are set apart for the convenience of visitors to the Hotel and their friends. Revised Tariff for 1900 on application. Visitors are received at Fixed Inclusive Rates, from 12/- per day.

GHO. J. BRINKWORTH, Manager. 


\section{CONTENTS}

Plan of the Exhibition

General View of the Exhibition (Plate)

Plan of the City of Paris

Plan of Paris and its Environs

\section{The Exhibition of rgoo}

Frontispici Facins p. xiii

" P. I

, p. 177 PAGF: xiii-xlvii

\section{USEFUL HINTS}

Frexch MoNey aNd Measures OF Weight aNd Distance 6- 8

TARIFF OF PARIS CAB FARES. . . . . IO

TARIFFS OF SOME PARIS HOTELS . . . . . II

DAYS AND HOURS OF ADMISsion to THE CHIEF Monumexts,

Palaces, Museuis, Galleries, Gardens, and Sights of

PARIS .

Chapter I.-HOW TO GET to PARIS; AND What IS TO BE SEEN ON THE WAY . . . .

CHAPTER II.-SHORT HISTORICAL ACCOUNT OF PARISANCIEnt, Medietal, Moderi . . 38

Chapter III.-ThE ARRIVAL IN PARIS- What TO DO AND What Not to Do . . . $\quad 57$

Chapter IV.-The Anusements of Paris . . 72

Chapter V.-TOPOGRaphy : HOW TO FINI YOUR IVAY THROUGH PARIS

Chapter Vi.-Itinerary of Paris : First Day's Programme I03

Chapter VII.-ITINERARY OF PARIS (continned): SECOND DAY'S PROGRAMME.

Chapter VIII.-ITINERARY OF PARIS (continlled) : THIRD DAY'S PROGRAMME

Chapter IX.-ITINERARY OF PARIS (contilliled) : FoURTH DAY's Programme-I. Versailles ; II. SÈvres

CHAP'TER X.-ITINERARY OF PARIS (continned) : FIFTH DAY'S Programie-I. Fontainebleau ; iI. St. GeRMaIN EA LAYE 
CHIPTEK XI.-SUNUAY IN PARIS

CHIPTER XII.PARIS IN ONE, TWO, 'THREE, FOUR, OR FIVE D.ASS

CiLOSSARY OR: FRENCH PHRASES

\section{LIST OF ILLUSTRATIONS.}

Gencrall liew of Bablibition
Faces p. xiii

1.e Vicux paris. . . xiii

la Porte Monumentale. xrii

Pont Alexindre III. . . xxiii

The Transvand Pavilion and

Bower Firm

xxrini

\section{Churcli of St. Augustin}

lhe Seine and its Bridyes .

Arce cle Triomplese

The "Tamise" .

Avenne des Chanps lilysies,

Paris

Boulevard cles Italiens

Figure on Notre J)ame.

Palais Royal

The I,ouve

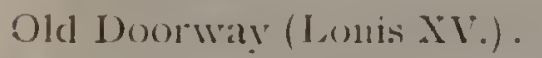

Place de la Concorde . . 51

Place l'encline . . 55

l'arisian Characte!'s . . 05

Grand Opera . . - $\quad 75$

Boulevard des Capticins . \$5.

1)ônc des Invalicles . . Sis

Les Bonlevards (Corner of

Boulevard des Italiens) . 93

Arenue des Champs Elysces go

The lomve . . . Io

Trocadero Palace. . . IO9

The Eiffel Tower . II 2

Tomb of Napoleon 1.
Palais de l'Electricité et Cliâteau d'Eau . . xxis Entréc du Palais des Industries Etrangeres . xixix Royal Pavilion, Great Britain . . . xlii Palace of the United States xily

Church of St. I,ouis (Hotel des Invalicles) . . II Palais Royal (Gardens) . . I 2.3 The Louvre(Galérie d'Apollon) 1,3 I The Louvre (Galérie de Sept Cents Metres) . 1.37 P're La Chaise I +1

Place de la Bastille (Colonne de Juillet) $1+2$ The Hôtel cle Ville •. . 1,50 Notre Dame . . . 150

La Concierserie . . IoI The Panthéon . . ITI

Statuc of Louis XIV. . $\quad 170$ Whe Palace of Versailles 179 Ia Galéric des Batailles o Is.3 Galériedes Glaces . . I87 Bassin de Latone and Tapis Vert (View from Terrace) 19 I La Bourse . . . . 104 Lal Madeleine . . . . 202 Interior of St. Roch . . $\quad 207$ Lake, Bois de Boulosine . 2 Io Cascade in Bois de Boulogine 210 
By Special Appointment "Californian" prepared in England

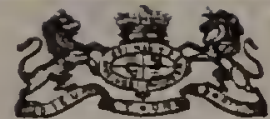

Makers to Her Majesty. from various foreign borates.

The "Household 'Treasure" Borax. A matchless purifier, arrester of decay, faultless deodoriser. It removes taint from joints and steaks, stops putrescency

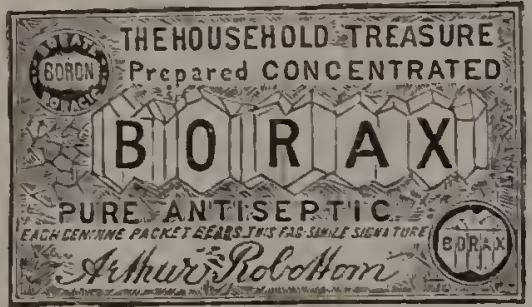

and sourness, and kills infection. Unrivalled for washing, rirsing, cleansing, and other household uses.

\section{Borax Starch} Glaze

Imparts an enamel like gloss, and gives permanent stiffness, brilliancy and beauty to linen, lace, and muslin.

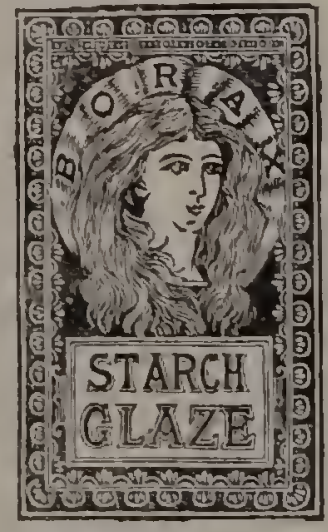

\section{Borax}

Dry Soap.

A pure, antiseptic soap in fine powder that dissolves instantly in cold. warm, or hot water Waslies clothes without injuring them. For general scouring \& scrub. bing purposes.

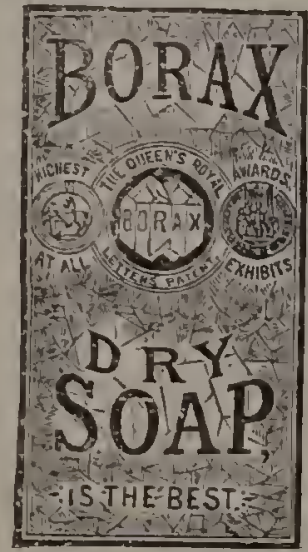

Exhibition Awards

Gold Medals, and

Diplomas.

1892-TASMINIA, Australia. 1893-CHICAGO, U.S.A. 1894-MANCHESTER, Eng. 1894-A N'TWERP, Belgium. 1894-MANCHESTER, Eng. 1895-BELFAST, Ireland. 1896-GLASGOIV, Scotland. 1897-BIRMINGHAM, Eug. 1897-BRISSELS, Belgium. 1898-BIRMINGHAM, Eng.

\section{Other Borax Specialties.}

BORAX EXTRACT OF SOAP.

BORAXALINE FOR THE BATH.

BEAUTY 'TOILET SOAPS. BEAUTY TOOTH POIVDER. BORAX SANITARY

POIVDER,

AND OTHER BORAX

PREPARATIONS FOK HOUSEHOLD, TOILET,

AND LAUNDRY USE.

Proprietors and Manufacturers :

The Patent Borax Co., Litd., Ladywood, Birmingham. London House-r29, HIGH HOLBORN.

Glasgoiv House-69, BUCHANAN STREET. No. 210 
Telephove No. 235.3\%.

Institut Physicothérapique de Paris 25, RUE DES MATHURINS (Opera).

\section{THE DOCTOR SPEAKS ENGLISH.}

NAUHEIM BATHS-ELECTRIC LIGHT BATHS -ELECTRIC WATER BATHS-HOT AIR BATHS - $X$ RAYS - ELECTRO-VIBRATORY AUTOMASSAGE-DR. RIVIEERE'S APPARATUS AND METHOD FOR REDUCING FAT - HYDRO. THERAPY - VIBROTHERAPY-ALL THE FORMS OF ELECTROTHERAPY.

The principal Affections treated are Chronic or Tncurable Maludies, (besity. Iniseasc's of the II errot,

Mrvintions of the sllue, sli, Discrses, Womere's Complaint.s, Gout, llialuetes, dic., dec.

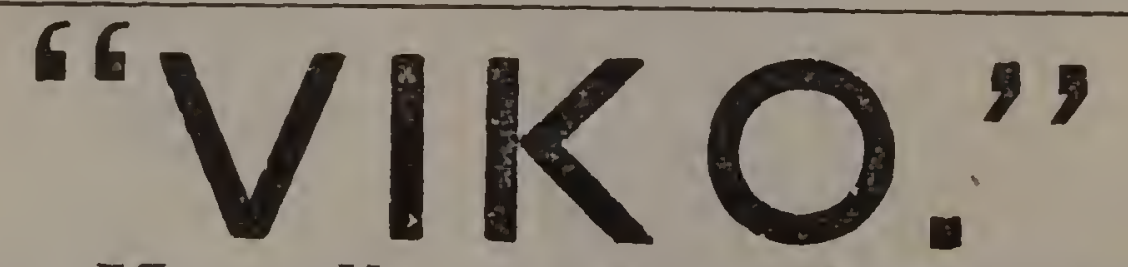

The Marvellous Insect Destroyer.

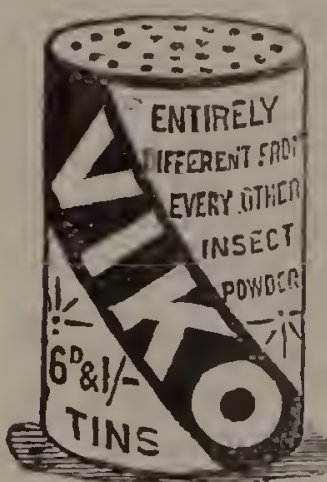
"VIKO" KILLS BEETLES. "VIKO" KILLS MOSQUITOES. "VIKO" KILLS FLEAS, BUGS. "VIKO" KILLS ANTS AND ALI INSECTS, BUT

"VIKO" WILL NOT KILL CATS AND DOGS.

Sold in Tins, 6d. and 1s., by all Chemists and Stores, or post free for Stamps, of Sole Manufacturers.

TUNBRIDGE \& WRIGHT, READING. Manufacturers of the celebrated "Fly Cemetery." 


\section{HARRIS'S} CELEBRATED
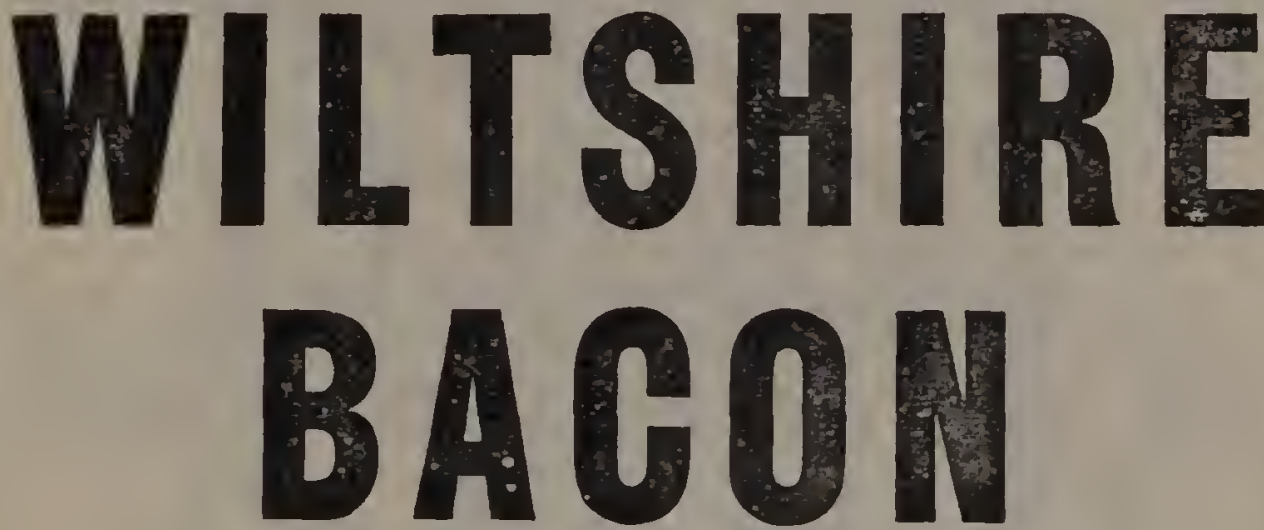

AS REGULARLY SUPPLIED TO

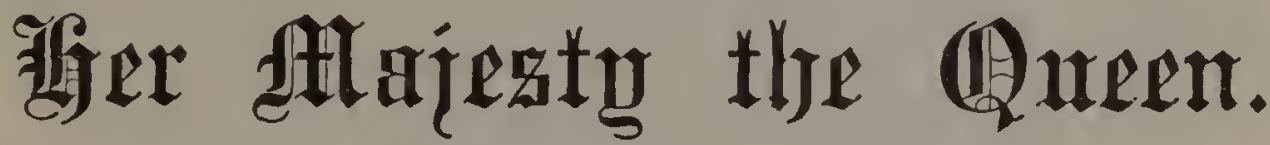
And other Members of the Royal Family.

The Only Bacon exer axarded a

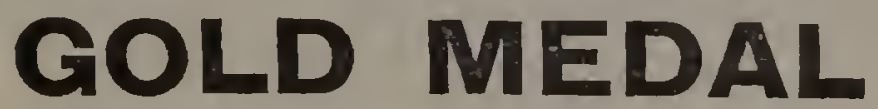

AT ANY INTERNATIONAL EXHIBITION.

SEE THAT EVERY SIDE BEARS THE

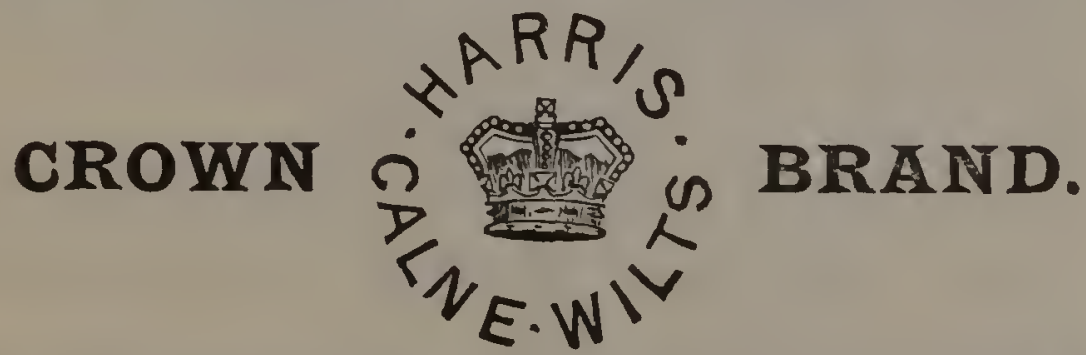

The Consumption of Harris's Wiltshire Bacon exceeds that of any other four or five Curers together.

SEE EXHIBIT IN GROUP I0, CLASS 58. 


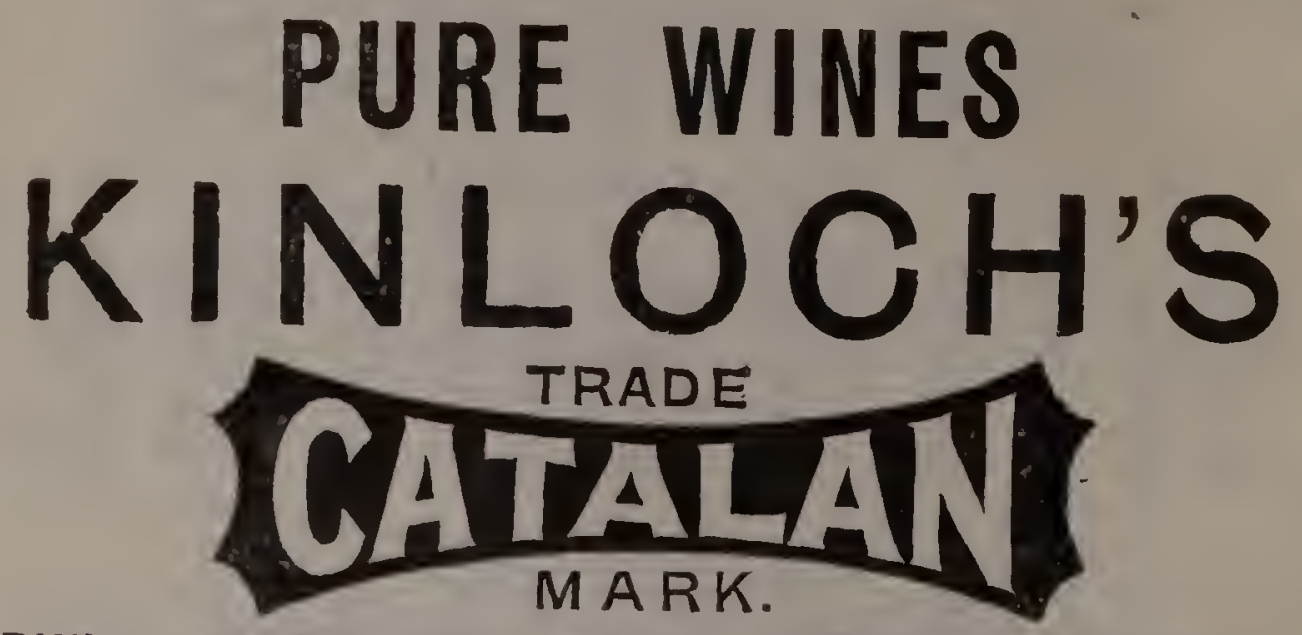

PURE WINES, PORT AND SHERRY CHARACTER.

$$
1 / 3,1 / 5,1 / 8 \text { BOTTLE. }
$$

BOTTLES CHARGED AND ALLOWED FOR ONE PENNY EACH.

THESE WINES HAVE BEEN BEFORE THE PUBLIC FOR OVER 30 YEARS, AND ARE CONTINUALLY INCREASING IN FAVOUR.

AGENTS EVERYWHERE.

IF YOU FIND ANY DIFFICULTY IN GETTING THE WINES, WRITE TO

CHARLES KINLOCH \& Co., Ltd., LONDON, E. For Address of NeArest agent.

The following is a List of a few other Specialities supplied by CHARLES KINLOCH \& CO., LTD.-

KINLOGH'S GONVALESGENT PORT. AUSTRALIAN WINES-BOOMERANG BRAND. KINLOCH'S L.T. SGOTCH WHISKY. KINLOCH'S L.K. IRISH WHISKY.

'D.W.D.' SEVEN YEARS OLD. DISTILLERY BOTTLED BOUVET-LADUBAY'S SAUMUR. EXTRA ROYAL. LIQUID SUNSHINE RUM.

RAYNARD'S OLD GOGNAC BRANDIES.

CLAROT'S THREE-STAR COGNAG.

For Quotations Apply to-

C. KINLOCH \& CO., LTD., LONDON, E. 


\section{Rossendale Belting Co.}

10, WEST MOSLEY STREET,

M A NCHESTER, ENGLAND.

Paris Depot: 38, BOULEVARD VOLTAIRE.

PATENTEES AND

SOLE MAKERS OF THE

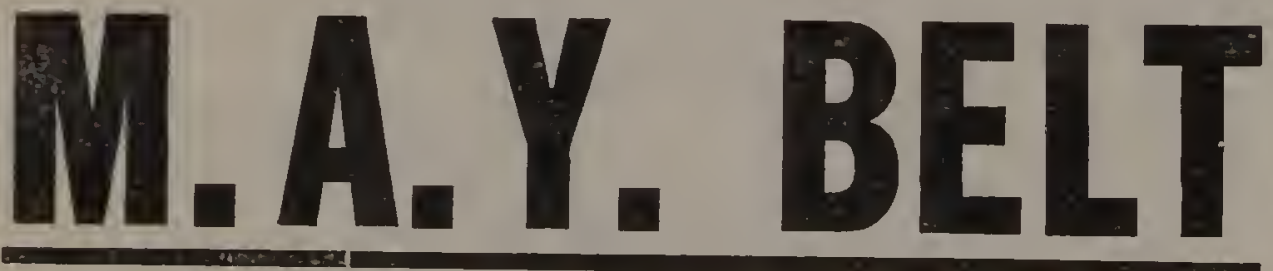

SURFACE-HARDENED CARRYING BELTS.

SEWN DUCK PLY BELTING ALL WIDTHS UP TO 40 INCHES IN STOCK. 


\section{YVARD, LOCK \& Co.'s Pictorial and Descriptive SHILLING G U I D E $=$ B O O KS \\ ENGLAND AND WALES.}

Bath, Glastonbury, \&c.

Bideford, Clovelly, \&c.

Birmingham.

Bournemouth and the New Forest.

Bridlington, File, , \&c.

Brighton.

Broadstairs.

Broads, The.

Buxton and Dovedale.

Canterbury.

Channel Islands \& adjoining Coast of France.

Cornwall, West, North, and South (3 vols.)

Cromer.

Dartmoor.

Dawlish.

Eastbourne.

English Lakes.

Exeter.

Exmouth.

Falmouth, the Lizard, and South Cornwall.

Harrogate.

Hastings.

Herne Bay.

Hexham and the Borderland.

Ilfracombe.
Ilkley.

Isle of Man.

Isle of Wight.

Leamington, Warwick, \&c.

Liverpool.

Llandrindod Wells, \&c.

Llandudno.

London.

Lowestoft.

Lynton and Lynmouth.

Margate.

Matlock.

Newquay \& North Cornwall.

North Wales.

Nottingham and Sherwood Forest.

Penzance, Land's End, and the Scilly Isles.

Plymouth.

Ramsgate.

Scarborough.

Sidmouth.

Stratford-upon-Avon.

Teignmouth.

Torquay.

Whitby.

Windsor.

Wye Valley.

Yarmouth.

\section{SCOTLAND}

Aberdeen and Deeside.

Edinburgh.

Glasgow and the Clyde.

Oban, Fort William, \&c.

Highlands and Islands.

Inverness \& Northern Highlands.

\section{IRELAND.}

Antrim, Giant's 'Causeway, Belfast.

Connemara.

[\&c.

Cork, Glengariff, \&c.

Donegal Highlands.

Dublin and Wicklow.

Greenore and Carlingford Lough.

Killarney, Coast of Kelry, \&c.

Limerick, Coast of Clare, \&c.

Northern Lake District.

Waterford, Wexford, \&c.

\section{THE CONTINENT.}

Belgium and Holland.

Paris and its Exhibition.
Switzerland.

The Riviera.

OTHERS ARE IN PREPARATION

LONDON: WARD, LOCK AND Co., LIMITED. 


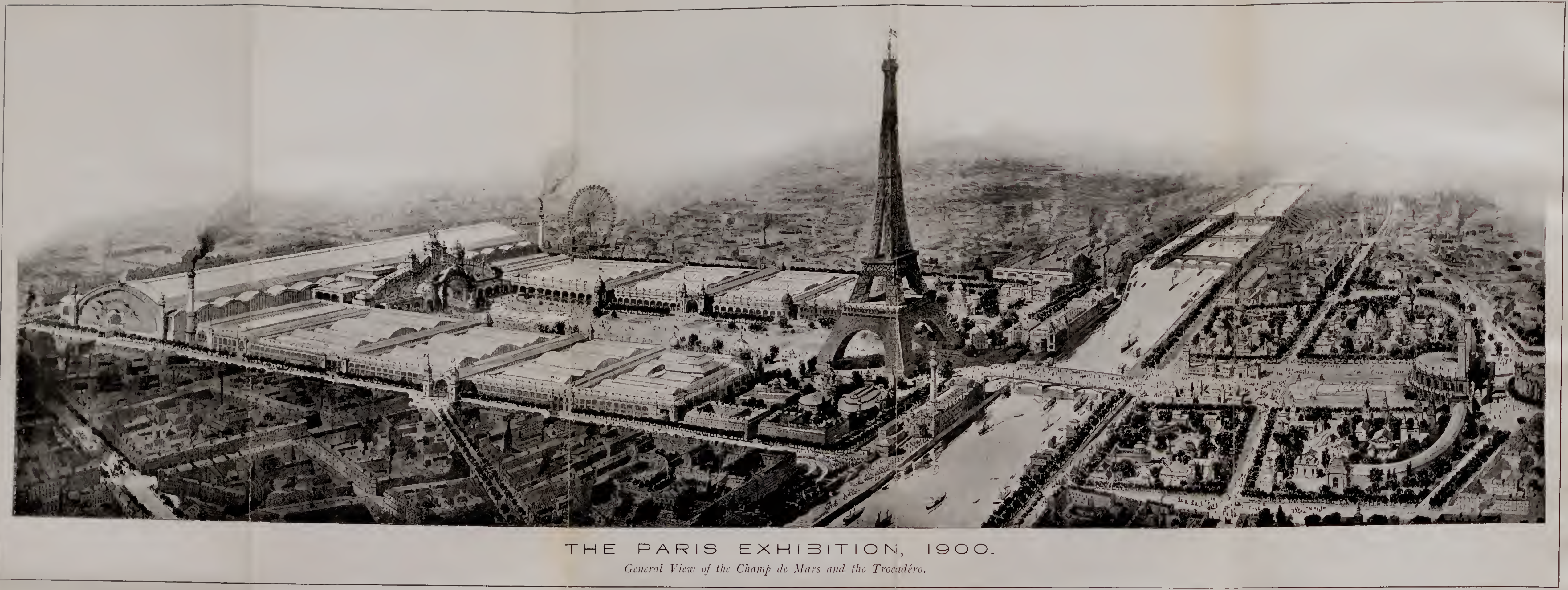




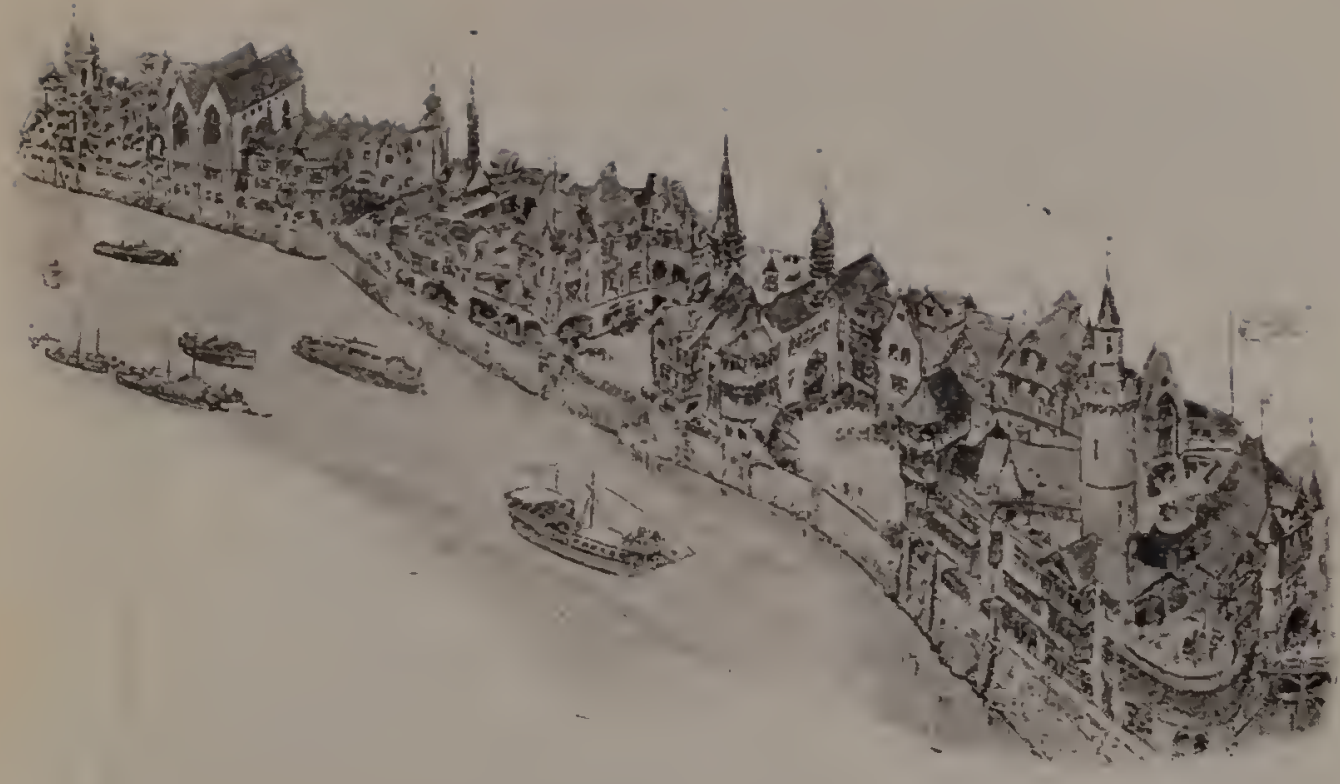

LE VIETX PARIS.

\section{THE EXHIBITION OF Igoo.}

\section{INTRODUCTORY.}

\section{For full details as to Routes to Paris, fares, times, \&.., see Chapter I.)}

TO England belongs the honour of the first Lniversal Ex1 hibition. The French had National and Local Expositions as far back as 1757 , and they were thus ripe to enlarge and extend the idea projected by the Prince Consort's Crystal Palace International Exhibition of 1851 , with their Palais de I'Industrie of 1855 .

Since then, the world has taken up the task. The English Exhibition of 1862 was followed by the "French Gasometer" of 1867 , and this latter by the Vienna fiasen of 1873 . Then followed the first American Exhibition of 1876 at Philadelphia ; and then again Paris, revived grandly from her troubled and terrible experiences of $1870-7 \mathrm{I}$, showed the world her invincible courage and inexhaustible resources by the exposition of 1878 .

After ain interval of ten years, the French people invited the world to yet another Exposition, one of the most important features of which, the Eiffel Tower, still remains, as does also the Galérie des Machines, forming part of the present Exposition. 
In 1855 the Exposition was confined to the Palais de l'Industric, in the Champs Elysées. In I867 the Champ de Mars was selected on account of its more spacious area. In 1878 the Champ de Mars was again selected, but the Trocadèro was included, the magnificent Palace of that name being then built and constituting one of the chief attractions. In I 889 the Champ de Mars was again selected, the Esplanade des Invalides being included and connected by the Embankment along the Seine.

Now, in 1900, the whole of the sites above named are included, and we can enter the Exposition from the Place de la Concorde, viewv the various palaces erected on the Champs Elysées, cross the Seine by the magnificent Pont Alexandre III. to the Invalides, follow the Seine, hedged in on either side with palatial constructions of all nationalities, admire the picturesque reconstructions of the sixteenth century till we reach the Champ dc Mars and the Trocadero, leaving by the gates of Passy of Grenelles, after covering fully four miles from entry to exit.

The world has seen so many exhibitions now that it is quite natural for the intending visitor to ask first what will be the new, special, and attractive features of this one.

We will therefore commence by an informal and general review of the most striking palaces, ponts, and features, serving as a summary. or index to the descriptions which follow in their respective order.

The Pont Alexandre III., connecting the Champs Ely sées with the Esplanade des Invalides, is entitled to the first place, considered either from a practical, picturesque, or political point of view. The former characteristics are self-evident. The latter lies in its name and the circumstances under which the foundation stone was laid. The fêtes given on the occasion of the state visit of the Czar in the autumn of 1897 rivalled in splendour and entlusiasm those of the most magnificent fêtes given under the Napoleonic era.

Almost all the curiosities are on the left bank of the Seine, but the splendid palaces ivhich have sprung up almost as if by magic are quite as wonderful as the things which most people rush to see.

"Topsy Turvy" House is situated on the Cours la Reine (right bank), and is built literally "upside down." Everything is the reverse of what it should be, so the whole affair is curious. 
The different café-concerts, \&c., are also on this arenue, between the Place de la Concorde and the Pont Alexandre III. The Revolving Road is new to Paris, but it formed a feature of the French section at the Chicago Exhibition of 1893 . It is on the Rue Flabert, Esplanade des Invalides.

The Méorama, on the Champ de Mars, is a panorama so arranged that we seem to be on the deck of a ship visiting all the important ports of the world. The illusion is excellent and very interesting. Near the Eiffel Tower we find the gigantic Telescope which is supposed to give us a view of the moon as it appears at a distance of a little over a yard, and beyond this is the huge Celestial Globe, which is one of the marvels of this marvellous Exhibition. The building near by is the Transatlantic Panorama and the Tour du Monde. The Swiss Village is quite at the other end of the Champ de Mars, and on the opposite sicle.

The Venetian transformation of the Seine is a marvellous achievement, and it is impossible to recognise the river or to realise that one is in Paris when passing on one of the popular batcauly monches between the rows of palaces from the Place de la Concorde to Passy.

\section{Down the Seine by Steamer.}

(a) THE RIGHT BANK.-Let us take one of these boats at the station below the Pont de la Concorde, just in front of the Chambre des Deputés, and proceed upon a journey down the river, as far as the Passy station, almost opposite the Trocadero Palace. On our right, as we leave the bridge behind us, is the magnificent Porte Monumentale, whose gigantic height and stupendous proportions are most beautiful, for in spite of its florid style and somewhat excessive ormamentation, it is a very imposing structure, even in the crude light of day, without the brilliant illumination which adds to its glory at night. We notice that the portal is flanked on either side by lofty minarets, studded with countless multicoloured electric lamps, which dominate and frame the statue upon the summil of the beautiful dome.

The immense building beyond is deroted to retrospective French Art, and the Grand Palais, further on, to modern paintings. In the space between the two buildings, at the end of the Avenue Nicholas II., the Pont Alexandre III. spans the river. 
This is onc of the wonders of the Exhibition-perhaps, indeed, the only one which will survive at a lasting monument to France and her great and powerful ally. The pillars on either side are handsomcly ornamented with sculptured figures representing the four epochs in French history - that is, Merovingian France, the France of the Renaissance, the France of Louis XIV., and Nodern France. Now we come to the Pont des Invalides, with the flying bridge constructed specially for the Exhibition. Just beyond, close to the water's edge, is the Aquarium, while a little way back we see the graceful outlines of the Pavillon de la Ville de Paris, a happy comhination of elegance and solidity, which is indeed a fair and fitting emblem of "Lat Ville Lumière" in this the beginning of the twenticth century. The large structure beyond, with the splendicl conscrvatories attached, is the Palace of Horticulture and Aboriculture; and then, before we reach the Pont de l'Alna, IIc see the Palace of Congresses and Sciences, where meetings between the delegates of all the nations of the earth will take place; a most imposing eclifice from our point of view on the deck of the little steamer. Further on, just below the bridge, is old Paris, one of the most curious features of the Exhibition, with its picturesque houses, quaint church, and other interesting things which we will visit later on. This, our first glimpse of the greatest Fair the rorld has ever seen, is merely designed to give us a general idea of the marvels we have come to admire.

Passing under the flying bridge between the Pont de l'Alma and the Pont d'léna we notice the pleasure boats, Sc., placed at the disposal of visitors; and high up on the hill the minarets of the Trocadèro Palace clominate the scetions devoted, on one sicle, to the Foreign Protectorates and Colonies, and on the other to those of rince. These are not all precisely on the banks of the Senne, but are in full view, on account of their altitude, and therefore cntitled to a place on our list. The Soudan is quite near us, Indo-China but a stone's throw away, and a little farther on is the Moorish-Hispano building, which is very beatiful indeced.

This jouney occupies about ten minutes, or fifteen at the most: the price on the boats is two sous during the week, and four on Sundays.

(b) THE LEFT BANK.-On the left bank of the river, starting 


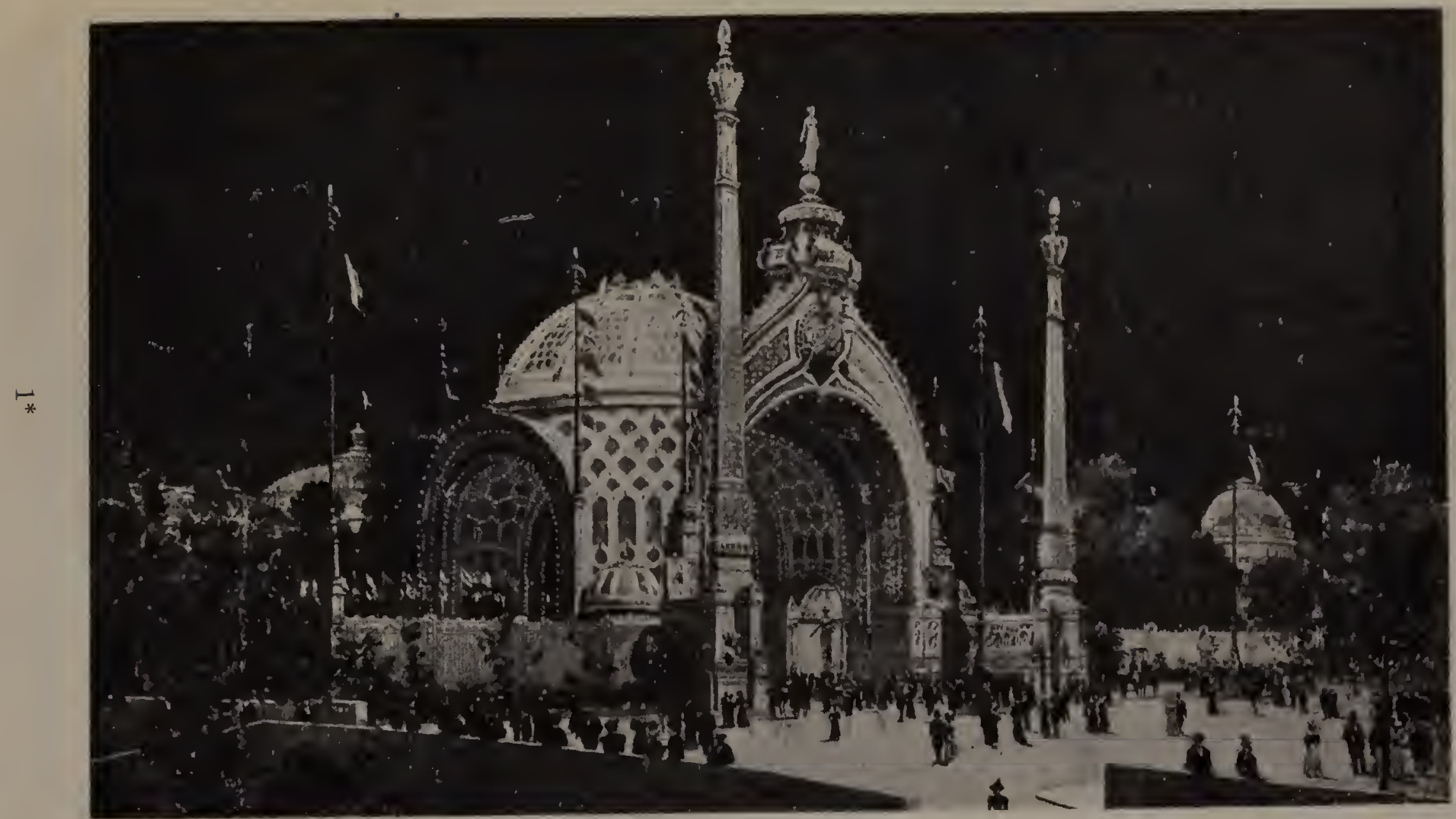

Ë 
xviii THE PARIS EXHIBITION, 1900"i

from the Place de la Concorde again, we "see the palaces and pavilions of the Foreign Powers, each building characteristic of the country it represents, and every one a type of architectural beauty. The first, mentioning them in regular order, is the palace of Italy, which more or less resembles the cielebrated cathedral at Venice. Turkey cómes next, and then a miniature reproduction of the Capitol at Washington, which has been erected by the United States.' Austria, Bosnia, and Hungary sepallate this from Great Britain, while Belgium and Norway are between our palace and that of Germany. Then Spain, Monaco, Sweden, Greece, and Servia follow. In the rear of these buildings, on the magnificent Rue des Nations, still beginning at the Plice de la Concorde, aire the pavilions of Portugal, Peru, Persia, Luxemburg, Finland, Bulgaria, and Roumania. Of all these beantiful strnctures the most striking is perhaps the palace belonging to Spain; with its wealth of onamentation and its oriental character, but they are all interesting and well worth. the time we must devote to then. Beyond this first group, on the other side of the Pont de l'Alma, is the pavilion of Mexico, and next door is the Hygienic exlibit. The building across the way is the headquarters of the Press, and then we pass the palaces of the Army and the Marine. In the regular order of the exhibition, Great Britain occupies the place which is really hers amones the nations, for our's is the first exhibit; then comes Italy, the I'nited States, Germany, Russia, and the work of the famous foundry at Creusot, which are all directly on the river; and on the other side, looking on the street mentioned above, we see Austria, Hungary, and Portugal. The next palace is that of Navigation and Commerce. The bridge under which we now pass is the Pont d'Iéna, which connects the Trocadèro with the Champ de Mars, opposite the Eiffel Tower. Aiter this we pass the Palace of Forests, Chase, and Fisheries, and are at our journey's end.

Before beginning our first detailed visit to the Exhibition, it may be advisable to give some practical information as to the general classification, grouping, \&c., as well as the number of entrances and where they are situated.

\section{Departments.}

'The Exhibition has been classified into eighteen departments 
or divisions, again sub-divided into one hundred and twenty-one classes.

These eighteen departments are as follow's :-

I. Education and Literature.

2. Works of Art.

3. Arts and Sciences.

4. Mechanics.

5. Electricitr.

6. Civil Engineering.

7. Agriculture.

8. Horticulture.

9. Forests, Fisheries, Hunting, \&c.

10. Alimentation.

11. Mines, Minerals, \&c.
12. Furniture and Artistic Decorations.

13. Linen, Cloths, Clothing, \&c.

14. Chenical Industry.

15. General Industry.

16. Social Economy, $\mathrm{Hy}$ sienic Appliances, \&e.

17. Colonisation.

I8. Military and Naval Armaments.

The Administration has required the architects of the huildings dedicated to the respective departments to contrive that these buildings shall symbolise or harmonise with the objects to which they are dedicated, either in the general aspect or by the nature and detail of their attistic decoration.

\section{Entrances.}

There are thirty-six entrances to the grounds, of which the following is a list :--

I and Ibis. Quai Debilly.

2. Avenue d'İ́na.

3. Comer, Avenue du Trocadèro and Rue Madsebours.

+ and 5 . Place du Trocadèro.

6. Place du Trosadèro.

7. Avenue Delessert (left bank of river).

8 and 8bis. Quai d'Auteuil.

9. End of Avenue Suffeen (Champ de Mars).

10. Celestial Globe.

II, I2, I2bis, I3, and I3bis. Avenue Suffien (Champ de Mars).

If. Avenue de la MottePicquet (Galérie des Machines).

15, I5bis, I5ter, and 16. Avenue Rapp.

$17,18,19$. Quai d'Orsay.
20, 2I, 22. Pont de l'Alma (left bank of river, Rue des Nations).

23. Rue des Nations.

24. Esplanade des Invalides.

25. Rue Fabert (Revolving Road).

26. Rue de Grenelle.

26 bis, 26ter, 27,27 bis, and

28. Rue de Constantine

(Esplanade des Invalides). 28 bis. Quai d'Orsay.

29. Place de la Concorde

(Porte Monumentale).

3o, 3obis. Champs Elysées). 3I, 3 I bis, 32. Avenue d'Antin. 33. Pavillon of the City of Paris.

3t, 35. Either side of the Pont de l'Alma (right bank of river). 36. Quai Debilly: 
All the omnibuses, trams, \&e., which pass the Exhihition are so marked, and the means of transport within the grounds consist of the much talked of revolving road, the electric railroad, bath chairs, and the poussi-poussi's, for all of which there is a fixed tariff.

Away on the other side of Paris, in the Bois de Vincennes, we find another part of this wonderful Fair, which may be called an annexe; and althongh it will certainly be less popular than the principal portion, it must not be passed over without mention. The space is devoted to railroad materials, automobiles, cycle and steam engines generally, agricultural machincry and implements, and also athletic sports.

The Metropolitan Railway (underground) has not been opened at the time of writing, but will be inaugurated before the close of the Exhibition. It extends from the Porte Maillot to the Bois de Vincennes, with a branch to the Porte Diuphine (Bois de Boulogine).

For most of the illustrations appearing in this portion of the Guide we are indebted to the courtesy of Messieurs Montgredien \& Cie of the Librarie Illustrée, Rue Saint-Joseph. Visitors desiring a fuller account of the Exhrbition than it is pussible to give here, will find L'Exposition pont Tons, published by Messieurs Montgredicn, very uscful.

\section{THE RIGHT BANK OF THE SEINE.}

WE now begsin our visit, and enter the Exhibition by

\section{The Porte Monumentale,}

on the Place de la Concorde. This magniticent gatewaythough not the Entrée d'Honneur, that being situated at the cutrance of the Avenue Nicholas II.--is one of the most striking leatures of the Exhibition, viewed either as a llork of art, architecture, or ingenuity. The style is Moorish, the architect being $M$. Riné Binct. We first notice the figure upon the summit of the central clome, and are somewhat surprised to discover that the artist has thrown conventionality and tradition to the winds, for M. Paul Morcau-Vauthior has placed thereupon not the classic figure of Peace, draped in flowing robes, but a woman of the present day, arrayed in the latest fashion. The 
figure is 6 metres in height, and represents the City of Paris welcoming her guests.

The width of the main entrance of this wonderful structure is 20 metres. The height is over 45 metres, so that an ordinary house seven storeys high would easily stand in the archway, and the edifice covers 2,3 to metres of ground.

The architect has displayed great ingenuity by so designing this gateway that it will admit sixty thousand persons per hour without crushing or congestion. The plan, like many another great conception, is simplicity itself when explained. There are fifty-eight passages or entries, through which it is calculated seventeen persons per minute can pass the turnstiles, thus admitting nearly one thousand persons per minute, or, in round figures, nearly sixty thousand persons per hour.

These passages radiate like the ribs of a lan, and in order to economise space and to obtain so many entries in such close proximity, the architect has adopted a very clever plan. One entry has an incline of one metre, the next has a decline of onc metre, and the intervening two metres have been ntilised for the suichets or controllers' boxes, thus leaving an unobstructed passage in each case.

There are 3,5 52 electric lamps of different kinds and various colours used in the illumination, and the whole effect is gor geous in the extreme, particularly at night. The façacle of this extraordinary work is preceded by two prolongations, which form an ouler arch, and give the requisite poise to the whole, which otherwise would appeall top-heary; and these outposts, if we may so call them, are ornanented by magnificent sculptures by M. Cruillot, which represent "Lahour." The interior decoration is also very tine; the two colossal figures surmounting the fountains beins particularly worthy of notice. These statues are symbolical of Electricity, and are the work of $M$. Fondet, while the beautiful frieze is the work of $M M$. Bontier and Foni's. The two minarets on either side of the grand entrance are higher than the Arc de Triomphe, and quite dwart the Ohelisk from Luxor, which stands in the centre of the Place de la Concorde, and which was once onc of the wonders of the world. Each of these minarets is crowned by two lights of tremendous power, which add greatly to the brilliancy of the spectacle.

For the benefit of those who wish to visit the Exhibition on bicycles, a special place has been provided. It is at the right 
wi the matu entrance, a short distance from the door. The price is 50 eents for the day per machine.

Passing through the Monumental Entry we enter the beautiful sardens, which extend on one side to the Champs Elysées, and on the other to the banks of the Seine. These gardens are really parl of the Exhihitim, and are comprised in the section devoted t1) Ahoriculture and Horticulture. On our right, between the Champs Elysés and the river, is the Cours la Reine, which leads to the new Avenue Nicholas II. This crosses part of the site of the old Palais de l'Industric-site of the Exhibition of 1855 -and we nutually, inquire why the Palais was destroyed. The origrinal intention was (o) incorporate it with this World's Fair, but it was found that it would break the perspective of the new Arenuc, extending from the Clamps Elysees over the new bricke away to the Juvalides, and further that it was not suited fo the recuirenents of modern Exhibitions, as the interior construction did not lend itself to the purpose of accommodating large numbers for the inaugural and other fetes.

It las therefore bacu replaced by two magnificent buildings, wanced respectively-

\section{Le Grand and Le Petit Palais.}

Le Petit Palais is named after its architect, Giranlt. The ficcade of this building, on the Avenue Nicholas II., is I 29 metres. The sculptures, relievos, general decoration and statuary are all worthy of minute attention and study, as chef d'cuvres of Hugues, Lcionnc, Peynot, Lcmaitrc, and others equally celebrated. This Palace is now devoted to modern Ait, but at the close of the Exhibition it will revert to the City of Paris, and be used as a museum. In fact it was upon this condition that Paris consented to vote the very handsome sum of 2,000,000 francs to the general fund. It is triangular in form, and particularly remarkable for its great simplicity of outline, and the very severe style of ornamentation, which is in strong contrast to-

Le Grand Palais. This edifice is constructed after the plans of three architects, Deglanc having designed the part on the Avenue Nicholas 11. ; Lonict the intermediate portion, which comprises the grand] vestibule; and Thomas the wing on the Avenue d'Antin.

The palace covers 40,000 metres of ground; the façade is 230 metres in length by 20 metres in height. The central portico is 


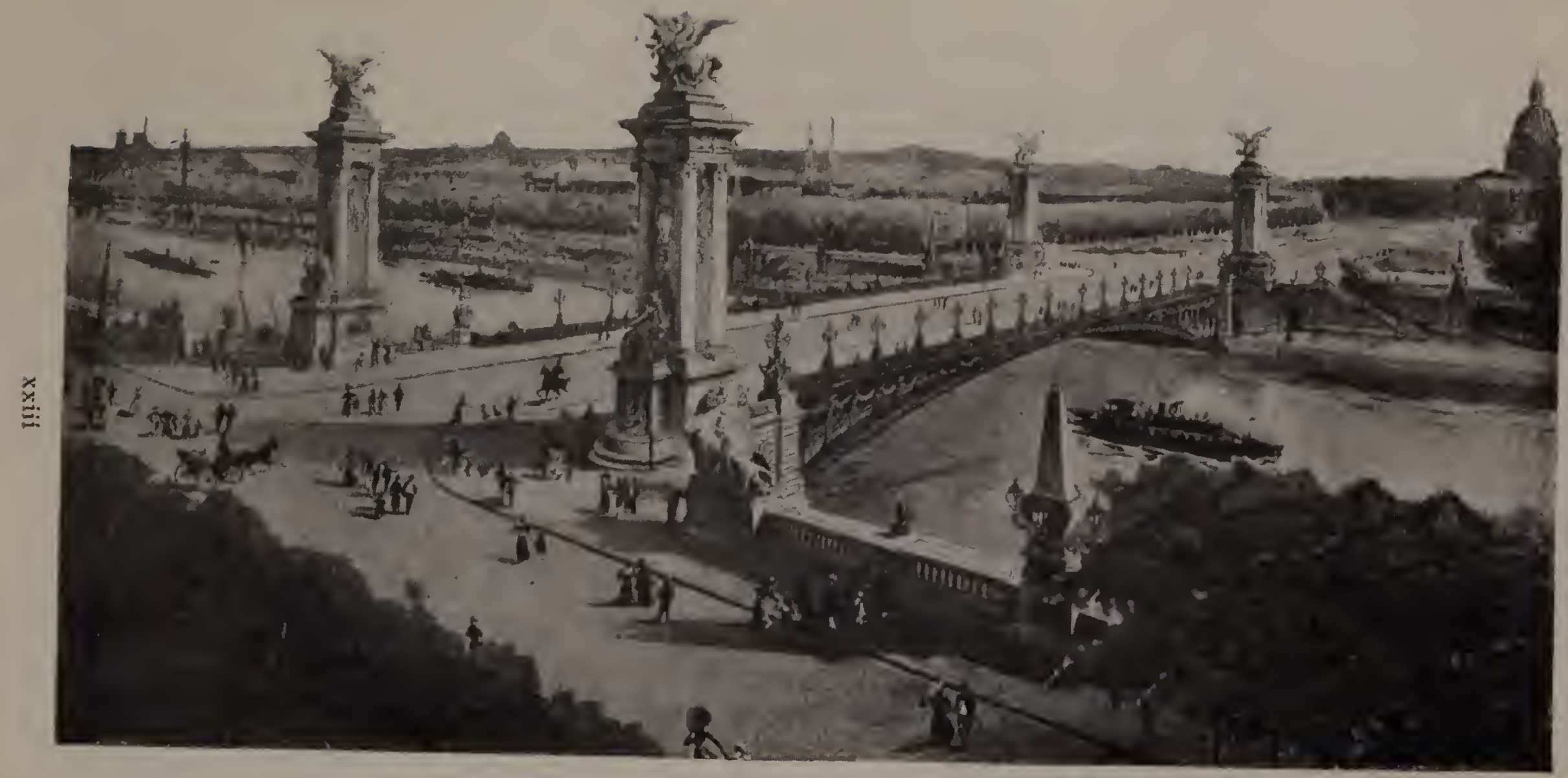

[ONT ALEXANDRE III. 
xxiv THE P.IKIS EXHMBITION, 1900.

decorated with magnificent reliefs by Fonrmier. The principal façade on the Avente Nicholas II. is Roman in style, but the wings ate Renaissance, with a strong resemblance in general appearrince to the Palace of Versailles. Three immense portals culance the shandem of its aspect. On the left are statues represcuting ligyptian, Grecian, Roman, and Byzantine art, While those on the risht are symbolical of sculpture, painting achitecture, and engraving. The high friczes which ornament llac doors and façade are after designs by MM. Blane and burriss, execuled hy the Sives manufactory. Those on the Arenuc d'Antin represent art from its birth to modern times, and ace particularly fine.

Tle inferior of the main huilding consists of an immense hall, in which will be held ultimately the horse shows and exhibitions of scupture and asriculture; hut during the Exhibition it is devoted fo sland cercmonics. It is here that the final distribution of medals, diptomas, and recompenses generally will take place. The roof is of glass. This magnificent Palace is destince to replace the old Palais de l'Industrie, and it is here (hat the anmual Paris silon will take place, but at present it is devoled fo the centennial exhibition of paintings and sculpture, as well as to sixfeen hunclred worls by living artists.

These \{ wo brildings cost $25,000,000$ francs, which is a small stm in comparison with the $52,000,000$ paid for the Gtand Opera, which was in course of construction during trenty yeils, whereas the lwo palices in chestion were commenced (m)ly in 1 (xi) $)$.

Leaving the palace hy the dow which gives on to the Arenue Nicholas II., we sec nn ow right the-

\section{Pont Alexandre III.,}

Which comnects the Avenue with the Esplanade des Invalides. This bridge is so called in compliment to the Tyar, and is certainly a magnificent tribute to the memory of the Emperor whose name it hears. It is constructed with only one arch, the central portion of which is 8 metres $\&$ centimetres above the level of the river, and it is rop metres 50 centimetres long. The width is 40 metres, and it is divided into two passages for pedestrians 10 metres wide each, separated by a carriage-way which occupies the rest of the space. From a distance the view is not imposing, as the one arch takes away from its apparent 
height, but it was impossible to avoid this effect without destroying the beautiful perspective, which begins at the grand entrance of the Elysée Palace on the Avenue Gabriel, and ends with the silded dome of the Hôtel des Invalides. The decoration is most profuse-a little too much gold being used, perhaps - but it is a superb affair, and very heautiful. The entrance at either end is flanked hy two pillars 8 metres high, which are crowned with a figure representing Fame, at back of which is Pegasus. These works are in golden bronze, and the artists are Frimiet, Steincr, and Grumet. At the foot of each column is a colossal figure representing the four principal epochs in French history; those on the right bank being Roman France, by Lenoir, and Modern France, by Michel. The two corresponding figures on the opposite side, facing the Hotel des Invalides, are symbolical of France under Louis XIV. and France under the Renaissance, the first by Marqueste, and the last by Coutan. At the back of the pillars, which form a splendid entrance, are two beautiful bronze candelabra, the bases of which are encircled by figures of dancing children. Cpon either sidce of the bridge are stairs conducting to the qualy immediately on the banks of the river; they are ornamented with granite rases decorated with garlands of leaves in hron\%e on nne side, and on the other, near the parapet, are sroups of lions by Dalon and Gardel. A little further on are pyramids of granite crowned by balls, which recall the style of the Portc Mommmentale. On the whole, this hridge is unique, and in the full blaze of the sunlight lonks like the way to fairyland.

The Pavilion of the City of Paris, which is just berond the Pont des Invalides, next claims onr attention, not only on account of its beauty, but also because it is a typical example of French architecture of the best school. It bears a slight resemblance to the Hôtel de Ville. After admiring its graceful outlines, we enter the building to inspect the specimens of work executed in the different training schools of the city. A most interesting part of this cxhibit is that in which we see the progress made since the introduction of compulsory education. The plans of all the most important public works done in the city of Paris are also to be seen. Then we continue our promenade down the right bank of the Seine, towateds the Trocadèro.

The buildings on our left are deroted to Horticulture, and the 
manniticent conservatories helonging to that section: and the intervening space, which runs pitallel with the Cours la Roine is called lle Rue de Paris. Herc we lind lirst the Maison du Rire, it neighbour being Tableaux Vivants. Then we conc to the cife-concerl, Le chat Noir, beyond which is the equally lamous La Roulotte. The hothouses of the Horticultural department separate this group from Le Grand Guignol, after which we see the theatre of Les Bons Hommes Guillaume. Then the Palais de la Danse claims our attention, and at last we reach Topsy Turvy House. The former is most interesting, ats it gires the history of dancing from time immenorial to the present dat ; and the latter is surely once of the most original things in the Exhibition, as it is actually "upside down."

Proceding on our way to the Trocadero, the next huilding which attracts allention is the-

Palace of Social Economy and Congress, which is of such immense bulk that we are apt to form an erroneous idea of its height; but the many large windows, ormamented with heautifully-carved garlands, save it from appearing either ungraceful or heavy. The rool is flat, and forms a terrace, and it is decoraled with high Venetian masts, from which tricolomed batmers float gally in the breeze. The many Congresses, \&c., which are to take place during the Exhibition, will meet here, and many important questions will be settled within these massive-looking walls.

Now crossing the entrance to the Pont de l'Alma we come to one of the most curious and interesting parts of the Exhibition, for we are in the midst of-

Le Vieux Paris, the Paris of the sixteenth and seventeenth centuries, and as this is "Old Paris," it is naturally inhabited by people of the same age (speaking from an historical point of view), and the costumes are exceedingly quaint and picturesque. This reproduction has a water-front of about two hundred and sixty metres, and as we enter we see the narrow streets which "Once upon a time" led from the Porte Saint Michel to the church of St. Julien des Ménestriers, passing the Tower of the Louve Palace. A little further on we sec some of the huildings eclebrated during the Renaissance period, and also at curious theatre. We must not fail to notice the Chembhre des Compte's ats it existed long ago. We then pass on to the wonderful Pont an Change, which is very different from the bridge so familiar to us 
lo-day. The grim walls which loom so gloomily are, naturally, those of the famous prison, be cirand Chutclit. Then we see the Palace of Justice, the Sainte Chapelle, and many buildings worthy of notice, in this quaint corner, but our space is too limited for a more detailed account. We must not forget to mention that the whole thing is from designs by Robidr, carried out by M. Himarl, architect.

Returning to the present century, the next huilding we see helongs to the French Chamber of Maritime Commerce, and then we come to the exhibit of Navagation de Plaisance, or pleasure hoats, with its gay little flotilla and many flags.

This ends our inspection of the first part of the Exhibition, that is to say, the portion comprised helween the Porte Monumentale and the Trocadèro, so before proceeding on our way thither it may he as well to lunch at one of the numerous restaurants in this vicinity. It is hest to patronise one which gives a lunch "it prix fixe," unless the financial question is of minor consideration.

\section{THE TROCADÉRO.}

TAKING the entrance of the Pont d'Iena as our point of Foreign Colonies, and the Pavilions or Palaces of some of the Oriental and African Powers. Just in front of us, away up on the hill, towers the beautiful palace which gives its name to the place, and on our left is the ground deroted to the Colonies and Protectorates of France; while Algeria, the most important of them all, occupies the central portion opposite the hridge, and facing the Eiffel Tower on the other side of the river. This section belongs to the group on our left, so we will begin with the Foreign Colonies on our right, commencing with--

India and the Indian Possessions. These buildings, which are clustered around a central pavilion, contain priceless treasures of native art. The exterior is handsome, but the interior is far more beautiful, and the artisans of the Far East have sent a most hrilliant contribution to the Fair. The Burmese carvings ou wood are particularly noticeahle, and other provinees have sent rare and beautiful specimens of their work, especially the carpets. In the main pavilion the centre trophy is sent by Cashmere. 
xarii THE PARIS EXHIBITION, 1900.

The next section belongs to Japan. The Tea House, llie collection of ancient Japanese art, the native Bayar, and a lind of Café, are well worth visitins.

Now we go to the Egyptian Building, which is very interesting. On the other side of the way, immediatcly opposite, is the Portuguese Pavilion. Then crossing the gar(len, we erme to the builclings of the Trans. vaal and the Boer Farm, which of coursc excite a greall deal of curiosily all present. The official
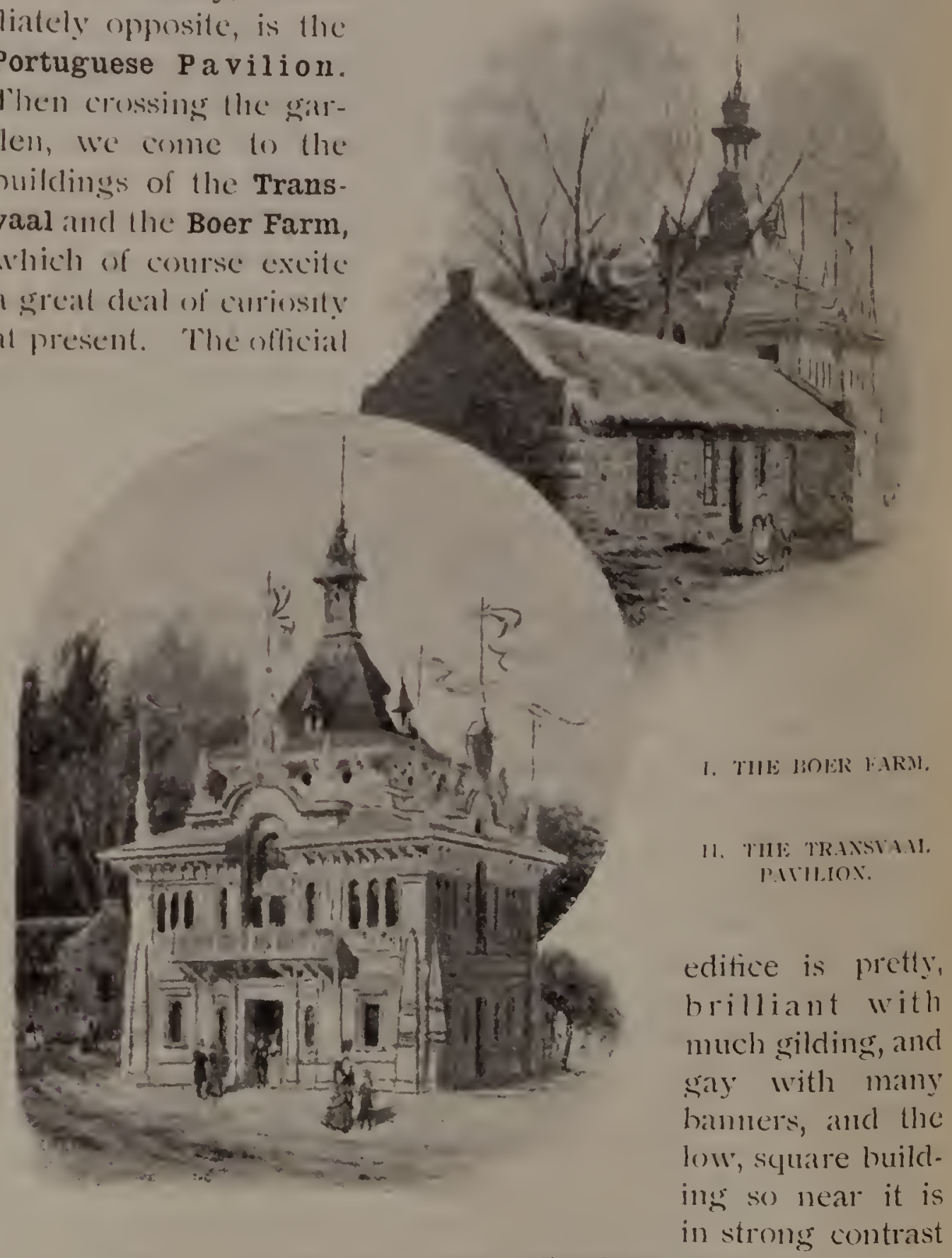

to its light and graceful outlines. The Boer Farm is far from heing an imposing specimen of architecture, with its rough stone pillars, its thatched roof, and small windows, the interest 
in it being more on account of recent events, than for any other reason. Within we see the everyday life of these people, and of course the affair attracts crowds.

Leaving the Transval building, we visit the important section of the Dutch Indies, which has a frontal of about so metres, and covers an area of more than 2,00o metres. Here we find three distinct and separate structures, one of which is the famous Tcmple of Tandii-Sari, an edifice of immense size, profusely ormamented with sculptures which are said to have come from the original building. This is a remarkable example of native architecture in its utmost purity, and is one of the most beatiful buildings of the Exhibition. The other houses represent native dwellings in the island of Sumatra.

Further back, nearer the Palace, we find the Chinese Section, composed of two Palaces. The roof of the larger one is very remarkable; and the smaller building is so finely carved, so beautifully sculptured, so exquisitely coloured, that it looks fragile in the extreme.

On a line with the Dutch Indies, and rather in front of China, is Russian Asia, or Siberia, which occupies so much space that the other sections look like mere togs in comparison. Everything here is curious, but one of the great altractions is a train on the Trans-Siberian railway, as it will be, which takes us straisht through to Pekin in the most comfortable lashion possible. The immense canvasses which glide so easily before us are by the celebrated painter $¥$ ambon, whose name alone is a guarantee of their excellence and beauty. This railroad journey is not, strictly speaking, part of the exhibit proper, but a private enterprise outsicle the high wall which encloses it. Within we see a fine reproduction of a portion of the Kremlin almost as large as the original, and many other interesting things too numerous to mention, but not to visit.

Our next station is Belgium. Then passing over a lew cxhibits of lesser importance, we arrive at the magnificent Palace of the Trocadero. Standing un the portico we look down upon the loot of the Eiffel Tower and the Champ de Mars beyond, where in the distance we see the splendid Palace of Electricity and the Châtea d'Eau, which, with the great tower just mentioned, are among the most conspicuous objects that meet our eye.

The whole view is beautiful, but we have now to visit the 
$\mathrm{xxx}$

THE PARIS EXHIBITION, 1900.

French Colonies, \&c., if we wish to "do " the show methodically" Therefore descending the steps we turn to the right and, passing one of the pavilions of the Exposition des Ministeres, come to the building of New Caledonia, where we notice particularly the plan of that colony. Then we take our way to Camboge, which, with three other colonies (Cochinine, Annam, and Tonkin) form the section of Indo-China. In the Cambosian part of the section there is a native theatre. The mountain which looms so conspicuously is the salcred mountain of Pnom-Peuh. On our left WC see Martinique, Guadeloup, Guyane, and La Reunion, and, entering the part officially designated as Indo-China, we find the pavilion devoted to Tonkin, away in the corner which forms the angle of the Avenne d'lena and the Trocadero sardens.

linom liere we turn to the right and enter the splendid Panurama of Oceanica, Mayotte, Saint Pierre, and Miquelon, where we see the plans of the much talked of railway from Djiboute to Harrar.

Now we cross the Arenue d'éna and enter the exhibit of the Cote d'Ivoir, beyond which is Occidental Africa, with houses, \&c., erected hy Dahomey, and the interesting exhibit of Colonial Government. The other Pavilions alle devoted to the Colonial Press, Senegal, and the Soudan; and at last, after al cursory slance at all these minor attractions, we come to France's great Protectorate-

Tunis. The entrance to this section is on the Avenue d'léna, near the bridge of the same name. It occupies an area of 4,000 square metres, 2,350 of which are covered with buildings. These statistics give us some idea of its importance, and surely a more picturesque spot does not exist in the whole Exhibition. Here we have a corner of a real Eastern town, with bazats and shops, where native workmen ply their different trades.

The narrow streets lead one and all to a spacious square, ancl the rest of the ground is devoted to exhibits of different kinds, ending with the inevitable restaurant, where we are served with a strange mixture of French and native cookery, which possesses the charm of novelty, if it can lay claim to no other recommendation. The best-known monuments of Tunis; a private dwelling-house; the famous café of Sidi-Abou-Said; two mosques, onc of Kef, the other of Kairouan ; a gateway of Tmnis 
and another of Souss, form a heterogeneous collection which is full of liie, interest, and colour. The interior enclosure is occupied by a garden surrounded by characteristic buildings, and in the kiosque in the centre is a Moorish café. The portion of the exhibit situated on the hillside is devoted to the agricultural exhibition, and below the Mosque we find (Oh, shades of the Prophet!) a wine-cellar! There are many attractions in this section, and amusements for hoth day and evening. We now cross the intervening space to the-

Algerian Section, which is supposed to be the most important of all. It covers an area of about 2,000 square metres. From the point at which we enter, the first building we see is an Algerian village, so we will walk a little further on, towards the English section, and begin our visit to the --

Official Palace. It seems almost superfluous to say that the style of architecture is pure Arabic, Above, a minaret rears its graceful height, beautifully decorated with porcelain. The main building is like all Oriental structures, while the exhibit proper comprises branches of every industry of the country as well as art. The house itself is furnished in perfect Eistern style. In spite of the Oriental luxury before us we are glad to tum to the village opposite. Here we are incleed in the Orient, with its clomes, its narrow, windings streets, and its minarets. Directly on the Seine, or at least very near it, is a moving panorama of the country, and without giving ourselves the least trouble we can make the journey from Bone to Oran, or from Oran to Bòne.

Having completed our inspection of the Trocadèro, we will retrace our steps across the exhibit and visit-

Spain under the Moors. This very interesting affair is outside the Exhibition, and is a private enterprise, but it is well worth secing.

Now we will walk through the gatrolens with the beautiful fountains, lovely flowers, and well-kept walks, to the Palace, and, definitely leaving the Exhibition, visit Madagascar. This section occupies the circle in the Place du Trocadero, and a panorama by Tinayre, representing the capture of Tananarive, is the principal feature. A diorama is also connected with the Congo exhibit, which is also without the grounds. This diorama represents Marchand crossing the rapids of Bangui, and is very popular. 


\section{THE CHAMP DE MARS.}

W IV1NC; Horoughly visited the srounds of the Trocadiro, we turn our steps towallds the-

\section{Champ de Mars,}

and conssing the Seine by the Pont d'léna find ourselves in the sirclen at the foot of the Eiffel Tower. On the banks of the river to our right, as we stand facing the tower, is the-

Palace of Forests, Hunting, and Fisheries. It is a large and beatuliful building. All lovers of sport will find the exhibit within most interesting. The acchitects, MM. Troncluet and Rey, also planutued the -

Palace of Commercial Navigation, which is situated on the other sicle of the girden, also on the river's edge. This chatacteristic huilding and the lighthouse, with its new and powerful rystem of lighting, forms one of the landmatks of the Exhibition. Returning to the right-hand side of the lower we visit-

The Celestial Globe, which is just outside the Exhibition grounds. It wats designed by M. Galcron. This Globe, or spluere as it is called, is one of the areat curiosities of the "Show:" It is to metres in diameter, and is crowned by a curatce, 60 metres above ground. It is decorated with astronomical and mythological figures, which ate illuminated at night by electric lishts. A tertible accident occured here hlontly after the opening of the Exhibition, many persons heing killed and injued by the fall of the flying bridge. We also see here the -

Tyrolien Pavilion, between the Palais des Forets and the sarclen. It is very peetty, being an exact reproduction in miniature of a batonial hall in the valley of the Inu. $M$. Deminger is the architect, and certainly deserves great praise (o) his work.

The next thing visited is the Transatlantic Panorama, and not lal away is the famous Méorama, by Hugo d'Alési.

The Palais de l'optique is also here, and before entering we notice that the dome is decorated with the twelve sigus of the zodiac. The first hall is that wherein the huge siderostat is placed. This gigantic instrument weighs 45 tons, the object glass is $49^{-2}$ inches in dianeter, and the tube measures 200 feet. The cylinder is formed of twenty-four separate pieces 
screwed together, and there are two object glasses, each of which weighs one thousand six hundred pounds. It is perhaps not senerally known that the idea of the Siderostat first originated with an English physician named Brown, who lived about a hundred rears ago. The next hall we enter is the Hall of the Telescope, which runs from north to south, and heyond this are the frojections which are supposed to give us a view of the monn and ill the stats as they appear at a distance of one metre. A little to rear of this building is-

Venice in Paris, at heautiful representation of the "Queen of the Adriatic."

Of course there are many other attractions in this part of the Exhibition, but these are perhaps the most important, unless we except the Palais de la Femme, which is next to the Tỵolien Pavilion.

We will now go on to the Champ de Mars. The first building oll our right is the Palace of Letters, Science, and Art, and the next the Palace of Education, which, as its name indicates, is devoted to instruction in all its branches.

Continuing on the same side we now see the Palace of Civil Engineering, one of the most beautiful of these beautiful bu:dings. The interior is as remarkable as the exterior is haidsome, for the salleries correspond with those of the wo Palaces on either side, and give a perspective almost hall a mile long. The Palace of Means of Transportation adds to this wonderful vista.

Now traversing the Palace of Chemical Products we arrive a the beautiful-

\section{Palais de l'Electricité.}

There is no doubt this will be remembered as one of the most striking features of the "WVorld's Show" of 1900. The architect, $M$. H'mard, had a double object to achieve in the erection of this superb structure. The gigantic Galérie des Machines will be recalled by all visitors to the 1889 Exposition. There was considerable debate as to leaving it for 1900 , but the expense of demolition was estimated as greater than the marketable value of the material; further, it was deemed impolitic for the mere sentiment of securing a novelty to demolish this masterpiece of nineteenth-century metallic construction, aud, lastly, the stupendons building being so eminently adapted for colosial 
xixiv

satherings, it wis crentually decided to make it the "Salle des lietes."

The architect, therefore, set to work to disguise or transform the extermal appearance of the Galérie des Machines by constructing the Palais de l'Elcetricite in front of the familiar old structure, and towering 25 feet or more above it, so forming a monumculal entry which will, when its elegant outlines are lighted with thousands of incandescent and are lamps, eclipse anything of the kind ever attempted, and may be characterised as a sorgenus gateway worthy of fairyland.

Thic Chateau d'Eau is just in front of this masnificent building, all alrangenncent which secatly cuhances the beaty of both. Pin itlempt to describe this wonderful structure secims almost a herenlean task, for words are inadeguale lo give an idea of ils grandeur, and liesures and meatsurements appear strangely out of place in conjunction with the fairylike spectacle before us. The archited is M. Pauliu, but the whole thing looks more like the massic of a wizald's wand than the fruit of human toil and man's invention.

On cither sicle of these triumphs of architectural art are the two huidings devoled to Mechanical Exhibits, and at the back we sec the grigantic-

Salle des Fetes. This remnant of the previous Exhibition is so faniliar that only if few words are requisite here, for at the time of its construction it was considered "a wonder of wonders." It world be well to talie a look at the whole Champ de Mars irom this point, hefore beginning our visit to the palaces on the left-hand side, and the visitor will doubtless be struck by the brilliancy of the spectacle. White or a very light cream colour predominates, giving to the great buildings a lightness, we may even say an airiness, which is quite remarkable and exceedingly beautiful.

The two extremities have been converted into Exhibitions of Agriculture and Alimentation. This exhibit is divided into two sections, French and foreign.

Now we hegin our visit to the portion of the Exhibition bounded on the exterior by the Avenue de la Bourdonnais, but hefore leaving the Pavilion of Agriculture we notice that the decoration consists principally of immense bouquets of flowers, the part devoted to Alimentation being ornamented with fruit.

Just outside the grounds at this point is the Swiss Village, 
xxxi

THE PARIS EXHIIITHN, 1900.

which might be called Switzerland itself, for it repiesents no patticular canton, no special town, but is a combination of many of the clistinctive and peculiar features of that sturdy little country. The hills are "mountains high," the precipices most awe-inspiring, and there is a cascade, ending in a stream, which is absolutely true to life.

We now return to the Champ de Mars by the flying-bridge which connects this picturesque spot with the principal part of the Fair, and after admiring the colossal chimney on the opposite sicle, pass on to the-

Palace of Tissues, Threads, and Clothing, which is in the same style of arehitecture, and forms the pendant, so to speak, to the Palace of Civil Engrinecring, just across the waty. Now we come to the -

Palace of Mines and Metals, and then proceed to visit the part of the garden around the Eiffel Tower which we neglected on our arival. It is scarcely necessary to say that these palaces atre not in a direct line, and the infinite variety of their positions, as well as the beat greatly to their grandeur.

The buildings, palaces, pavilions, \&c., on this side of the Eiffel Tower are perhaps more interesting than those already visited, but our limited space precludes the possibility of describing them all, so we will notice only the most remarkable.

The Palais du Costume is one of the most ornate buildings of the Exhibition. The exterior decoration is composed principally of vases and basliets of natural flowers, which are renewed at frequent intervals, and within is a chronological exhibition of costumes, which is not only interesting but cxtremely artistic.

Near by is the Alpine Club, and not far off we see the Palais Lumineux. This is one of the most extraordinary edifices imaginable, for everything in it, carpets, curtains, etc., is made of glass. The architect is M. Punson. It is particularly beautiful at night.

The Pavilion of the Automobile club is the next building. After a glance at this exhibit we go on to the-

Tour du Monde. This is certainly one of the great attractions, but a visit will be more interesting than a description. The building itself is a vast structure, in which no particular style predominates, but a mixture of all is distinctly noticeable, a fact 
which is particularly appropriate to the exhibition within. The excellent paintings are by Lonis Moulin; and there is a restaurant connected with this interesting panorama.

We have now seen nearly all the buildings of interest on the Champ de Mars, so our next visit will be to the Esplanade des Invalides.

\section{THE ESPLANADE DES INVALIDES.}

THE Palaces on the Esplanade are two storeys high, which $I$ is an innovation and an improvement upon those of the former Exhibitions. It is therefore advisable to visit first the ground floor of the line of buildings which extends from the Pont Alexindre III. to the Hôtel des Invalides, returnings to our point of departure by the upper stores, and then walk down the beautiful garden which is in the centre, where we get a good view and a general idea of the exterior of the edifices on either side. We enter the Exhibition by the-

Porte d'Honneur on the Champs Elysées, and walking the length of the Avenue Nicholas II., cross the Pont Alexandre and begin by visiting the--

Palace of National Manufactures. This is the first building on our left, and is deroted to the famous Gobelin tapestries. Architects, MM. Toudoire and Pradelle. On the same side, extending to the Rue de Grenelle, and in the same immense building, which is divided into sections, we find all the French exhibits, the most interesting of which are carpets, crystal and glass, heating and ventilation, electric lighting, jewellery, bronzes, iorged iron, wall papers, \&c. These occupy the whole space between the river and the Invalides, and are entirely of French manufacture. The opposite side of the Esplanade is devoted to foreign products. At the back of this palace, on the Rue de Constantine, we see the exhibits of the Louvre and the Printemps, and a little further on are some very characteristic and interesting houses, among which the building from Lorraine is particularly noticeable. The exhibition of the art of Brittany is wonderful, and is known as "l'art Amoricaill." The fountain of Saint Barbe, the spire of the church of St. Jean du Doigt, and 
a collonade of a cloister at Quimper are the most remarkable itcms. There is also al fune collection of embroidery. The "Mas Proz'mbal" is neall a house from Gascony.

. On lle right side of the Esplanade, as we lace the Invalides, in allother section of the l'alace of National Manufactures. In He part ncillest the bridge we see-

The Sevres Exhibition. This is most interesting, and the furnaces, which ane just behind the exhibit, are well worth visitillg.

From this point the huilding is called the-

Palace of House Decoration and Furniture, architecl, $M$. Troptey-bally. At the hack of the palace we find the foreign sections, which lowk on to the Rue Fabert. Stating from the lituc de Gienclle we visit them in the following order : Belgium, Russiat, Gemniny, United Statles, Great Britain, llaly, Denmark, Hungary, Austria, and Jatpat1.

The Revolving Road is also here. It consists of two platforms of different degrees of speed. The lower one soes at the rate of four kilometres an hour, and the higher one at just double the speed. These platforms are rased seven metres above the wround. The itincrary followed is the length of the Esplanade on the liuc Fabert, the Quai d'Orsay, the whole length of the Rue des Nations, passing the Palaces of the Army and Navy, the Champ de Mars, and the Avenue de la Bourdomatis, where the revolving road leaves the Exhibition grounds and returns to the Esplatuade by the Avenue de la Motte Picquet. There are twelve stations along the line, all of which are within the Exhihition, and the view obtained on the joutncy of $3,5 \otimes 0$ metres is very finc.

The Electric Railroad follow's exaclly the same route, but the speed is more than twice as sreat, for it soes at the rate of seventeen kilonetres an homr, and the journey is not so monotonous, for sonctimes we are seven metres above ground, then on a level, and then the way beconnes subterancan. The price on either of these roads is 50 centimes.

We will now take out way to the Rue des Nations. In leaving the Esplanade ive find this interesting part of the Exhibition on our left, but instead of entering at once, it is preferable to take the Rerolinis Road at the corner of the Quai d'Orsay and go as far as the Champ cle Mars, then work out way down. In this way we get it good general idea of the 
THE ESPLANADE DES INVALIDES.

xxxix

buildings we are going to see in detail, and have an opportunity of visiting the-

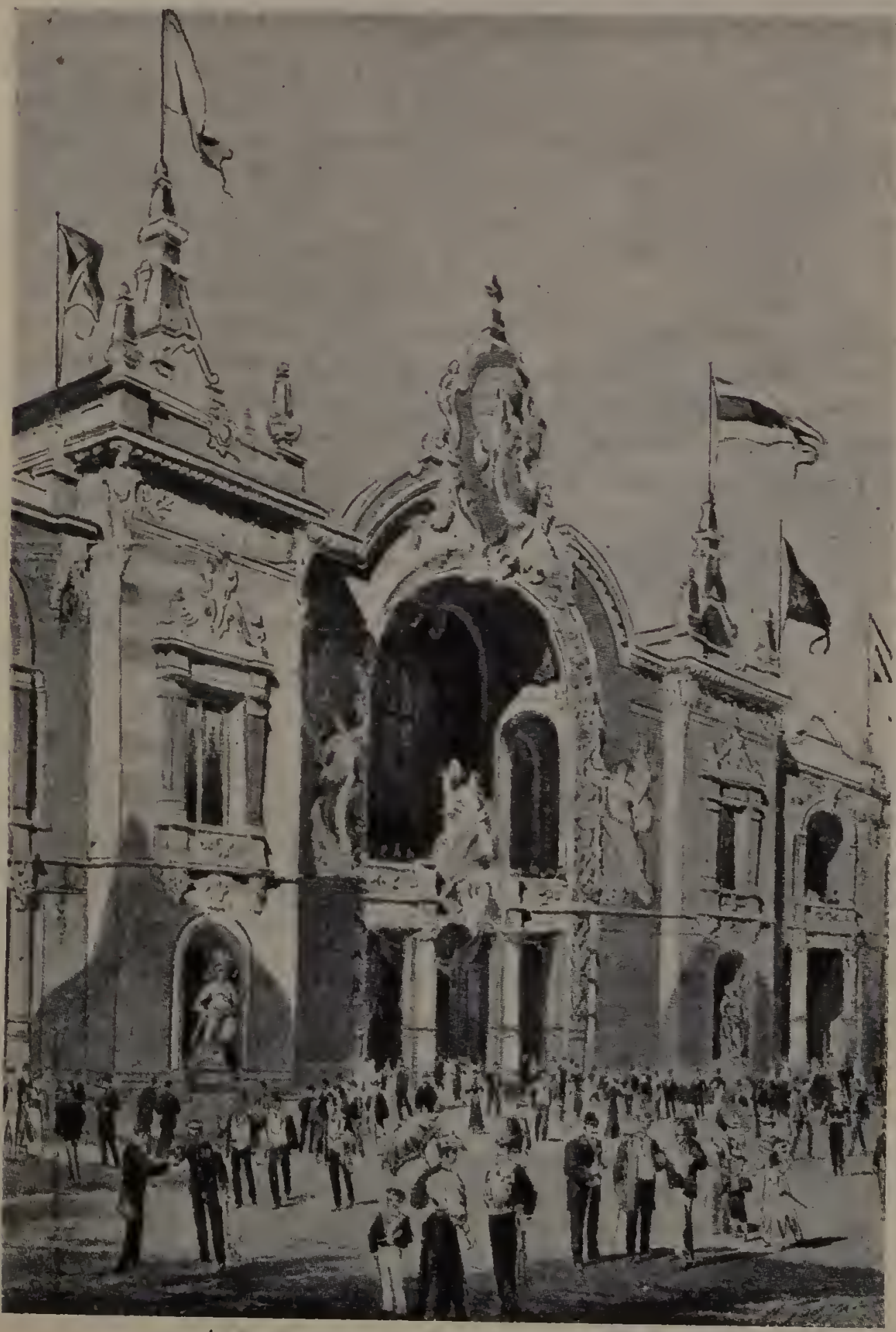

ENTRÉE DY PALAIS DES INDUSTRIES ETRANGERES

Palaces of the Army and Navy, which are just outside the 
Ch mmp de Mats, and directly on the banks of the seine. They are comstrmeted on both the upper and lower quays, the different

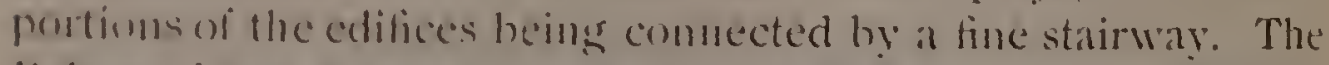
Palsce of the lmmy contitus, among other interesting things, a collection of milituly somvenirs from the Ministry of 17 all and

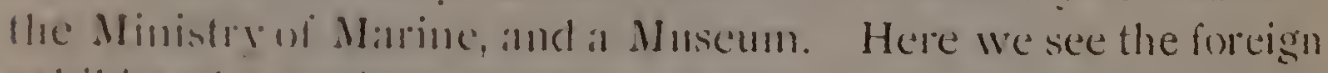

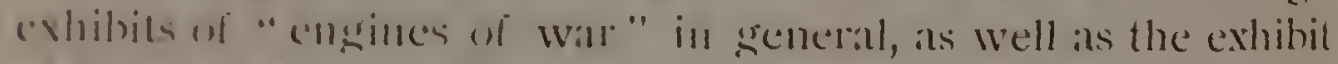

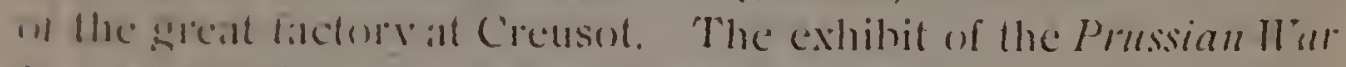
Diforflutul is puticularly inferesting. Alter Creusot, we see

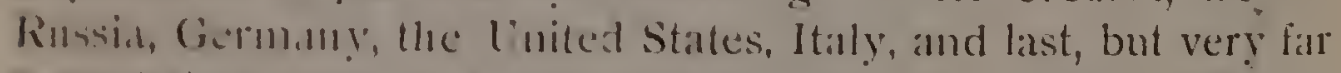
folll leing leart, as a visit will prove, Great Britain. On the opposite side, not on the river, are the Belgian, Austrian, Portusucses, and Humsarian sections, ans amnex of Great Britain, and also unc of Relyinm and anothere of Russial. Between the Pallec of the drmy and the Pavilion of Mexico is the-

Hygrenic Exhibition, of pleall interest to people concerned in

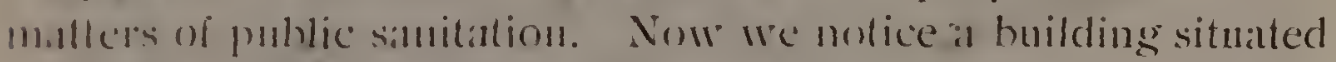
a little bick from the lince. This is-

The Pavilion of the Press. We fund in the sime building a fmalal hurean and a lelesraph office. The postal, telegraphic, and lekphonic aransements of the Exhihition are well-nigh pertect.

lust opponite, lowking on the river, is the--

Pavilion of Mexico, which continins the whole of the Mexican cxhihil, and is once of the most original buildings of the Fair.

Now we crosis the cultance to the Pont de l'Almil and enter the Ruc des Nations, fo which it is perhaps best to devote another section.

\section{LA RUE DES NATIONS, OR THE STREET OF THE NATIONS.}

THIS street is so called from the beautiful Palaces and Pavilions, belonging to the different Foreign Powers, which border its entire length. It is situated on the left bank of the Seine, and extends from the Esplanade des Invalides, along the Quai d'Orsay to the Pont de l'Alma. The Palaces of the Great Powers are all on the "water street" which has been constructed on the very edge of the river, while those of less importince are on the opposite side, with a view only on the street. 
Some of these buildings are used to exhibit the products of the countries they represent, but the more important nations have separate sections on the Esplanade or the Champ de Mars, and the Palaces are simply the headquarters of the Commissioner-inChief.

The first building on the river is the-

Palace of Servia, which is next to the Palace of Greece, and huilt very much in the same style, both heings Byzantine in architecture. The Grecian building is more severe, but not more beautiful than its neighbour.

The Palace of Sweden is exceedingly picturesque, and consists of a high tower flanked by four lesser ones, with a sort of pivilion at the back crowned by a cupola. The main structure is somewhat low, and the whole building is trimmed like a lady's hat, with sarlands of artificial flowers, which appear rather tawdry by day but are transformed into festoons of light at night. The peculiarity of this house is that it is entirely con structed of wond, varnished and painted in the most gorgenus colours.

The Pavilion of Monaco is a typical house of that Principality, which means that it is a villa of Sonthern France. It is imporlant from the fact that it contains the whole exhibit of that State, and a very interesting collection made hy the reigning Prince during his many voyages. At the back of this pavilion we see that of-

Roumania, in the Byzantine style, and the Pavilion of Bulgaria, which is very pretty with its cornice of inverted tulips and its fantastic façade.

After these rather unimportant but decidedly pretty buildings, we come to the-

Palace of Spain, which is a conglomeration of details from almost all the celebrated buildings of that romantic country. The Moorish influence is most perceptible. The fatio with the inevitable fountain is, of conrse, a feature of the construction, and the façades are reproductions of the Alcizar at Toledo, built by Charles Quint, and the university of Alcala, erected in the sixteenth century, while the towers recall a palace at Salamancil. There is a plethora of carving on the exterior; and within the rare collections, both public and private, make this building one of the most interesting of the foreign palaces.

The Palace of Germany is a reproduction of a public building 
slii THE P'.IRLS E.XHIBITION, 1900.

of the sixteenth century, and a masterpiece in its way, with its beatutiful belfry, walcoful gables, and bell-shaped torrers. The rocof is covered with painted and vamished tiles, and presents a most billiant appearance; but the principal interest is in the palintings by fremch artists which are within, and decorate the walls of the official reception rooms. The furniture is also l'cey interesting, as some of it comes from Sans-Sonci. In

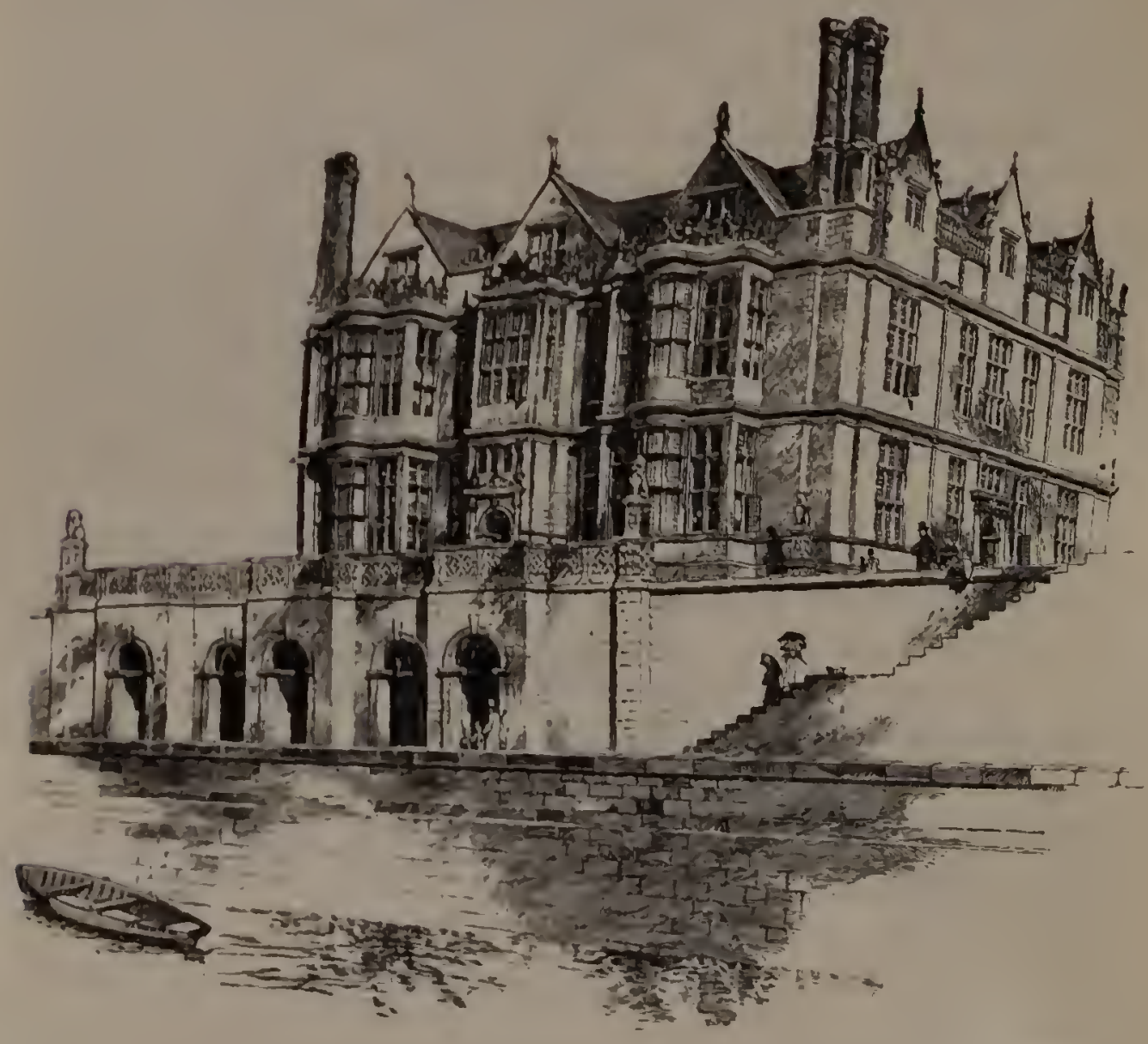

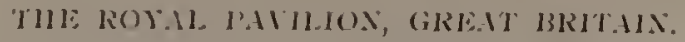

fact the whole thing-palace, paintings, and furniture-is one of the funest in the Exhibition, and leeming with historical interest.

The next great building is-

\section{The Pavilion of Great Britain,}

and well may we be proud of the trimmph of our country, for this 
is the gem of this architectural crown. The architect is $M r$. Edward L. Lutyens, of London, and it is constructed with a framewnot of steel designed by Sir C. B. Baker. The interior is furnished by well-known English firms, the decoration of the great staircase being due to Messrs. Thompson and Co., while Messrs. Waring and Gillows, Collinson and Lock, The Tyne Castle Company, Johnston and Appleyard, and Bertram and Sons contributed to the general furnishing. A room was decorated by the City of Bath; the stained-glass windows are the work of Messrs. W. Smith, of London, and Guthrie, Wells and Co., of Glasgow. Metal Fittings are supplied by Messis. Chubb and Son, Singer and Co., Starkie Gardner and Co., Needs and Co., and Ames, Lyde, Elsum and Co.; while Messrs. Broadwood constructed and decorated the piano especially for this building. Messis. Crossley and Sons provided the carpets.

A complete Fire Department with a steam fire-cngine and all other necessary appliances, equipped by Messrs. Merryweather and $\mathrm{C}_{0}$. of Long Acre, is installed in the basement. The pavilion on the not th side is an cxact reproduction of Kingston House, at Bradford-on-Avon, Wilts, which was built under James I., and the interior represents an English manor house, furnished in modern style, and fitted with all the appliances and comforts of the present day. The rooms are most admirably arranged for the circulation of the public, who pass out by a second cloor. The entrance is on the southern side, and leads into a hall measuring to feet by 20 feet, which is ornamented with magnificent tapestries, designed by the late Sir E. BurneJones, and belonging to Mr. George McColloch. They were executed by Messrs. Morris and Co., as were also the stainedglass windows.

From this hall we pass through the dining and reception rooms, and ascending the grand staircase, visit the upper storey. The bedrooms are on this fluor, but the hall, which is a reproduction of the Cartoon Gallery at Knole House, Sevenoaks, is particularly remarkable. It is $8 \mathrm{I}$ by 18 feet; and it is here that we find the splendid collections loaned by the Prince of Wales, and also an extraordinary map of the City of London. We now pass through a room filled with beantiful specimens of English china, and then on to a second staircase to the door of exit. The public are admitted at all times to the Parilion except, 
xliv THE: PARIS EIHIBITHON, 1900.

of comre, when it is used by the President of the Royal Commissim, He Prince of Malles.

In our adnination of English latent, we have quite overlomliced-

\section{The Chalet of Norway,}

Which, with Hhe Palace of Belgium, is between the German Pillace and the British Pavilion. The first named is, like the swedish huildins, constructed contirely of wood, and is a good upecincen of the architecture of the country.

The Palace of Belgium is an cxict reproduction of the Town H.1l ill Audentrde, the style being Gothic.

It He back of Hesce bullings is the Pavilion of Finland, which, strange fo sily, is the only building representing Russia, and is remoliable on account of its orisinality, hut scarcely of comsush importance for retain one attention long. Now we come 11) the buldius which belougs to the-

Grand Duchy of Luxemburg. This is in the Flemish Renaissance style, and yuant and picturesque in the extrellsc.

\section{The Palace of Persia}

mext clams attention. It is in the real Oriental style, with all the clistinctioc features of the comntry it represents. The interion is cren more allative than the exterior, the rematkable collection of Pcrsian curiosities being almost unique. Its immediate neighbours ate Peru, which building will be crected in Limal later on, and Portugal. Then we come to Denmark. All these small countries are interesting, but our time is too limited to bestow upon them more than a passing glance. On the river, next to Great Britain, is the -

Pavilion of Hungary, which, like so many others has welded into one hamonious whole many details of the most celebrated buildings of that country. The retrospective exhibition, with the reproduction of the room of St. Stephen, first king of Hungary, takes us far from this prosaic age to the days of heroes, martyrs, and doughty deeds.

Bosnia and Herzegovina may be spoken of together, for though their buildings are separate, they are connected by a subterranean 
passage. Il is impossible to give a full description here, hut a

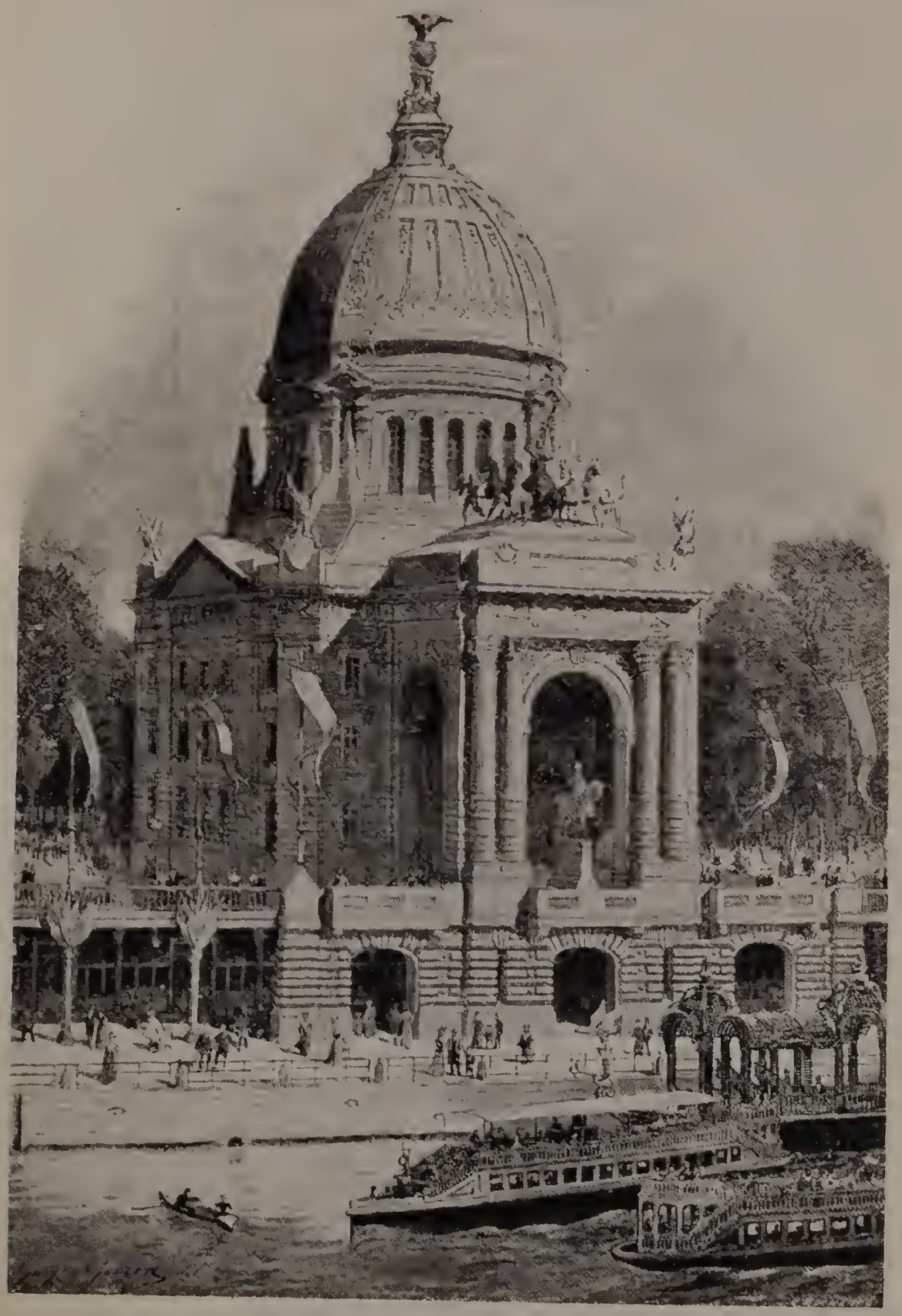

PALACE OF THE UNITED STATES.

visit in detail to these two buildings is recommended, for they form alone an almost complete exhibition. 


\section{The Pavilion of Austria.}

This Pavilion is at a disadvantage on account of its larget and more stately neighbours. The architect is $M$. Bammann. The facade is a reproduction of the celebrated Palais d'Equitation of Fischer, at Vienna. The side wing is a copy of the Hofhurg, the limperor's residence, also by Fischer, and the sucesss wi!h which solid masony has been imitated with the most superficial and composite materials is particularly "worlly of notice. On the lower floor is a larse "Brasserie," where is dispensed the famous Dreher Viemuese Bects, and this practica! utilisation of the huilding will doubtless increase its popularity dmings the hot sumnner nonths.

Next to this building is -

\section{The Pavilion of the United States.}

Whe architect, Mr. Coolidsc, has taken his model from the Washingston Capitol, and it is worthy of note that the building is essentially American, not simply in design, but also as concerns material; wood, metal, flooring, artistic painting, and everything, even to the door locks and handles, heing of American origin. The United States Government placed a large vessel at the disposition of Mr. Peck, the Chief Commissary of the United States Department, to bring over to France the material for this structure and the various other portions of the American Department of the Exposition.

\section{The Pavilion of Turkey}

is next to that of Italy and was designed by a French artist, M. Dubuisson. The seneral ideas have been derived from the principal mosques and bazaars of Constantinople, and the result is a typical Oriental Palace of considerable artistic value and merit.

\section{The Pavilion of Italy.}

This building is a reproduction of the Church of St. Mark at Venice, and portions of the adjacent Dose's Palace. The cffect is characteristic and picturesque. The architects are 
Carlo Ceppi and Saliadori. Italy has devoted approximately three millions of francs to her representation in the rgoo Exposition.

With this building we terminate our visit to the Exhibition of 1900 -the triumph of civilisation in all its branches; a veritable festival of peace; the Fair to which the whole world has looked forward with keen and wondering anticipation, but which, after October, will be among the memories of the past. We cannot close, however, without paying a tribute of admiration to the country, which in spite of recent trials and misfortunes, has given such a proof of strength. Whaterer may be the faults of France, we can but bow in respect and wonder before her great industry, her marvellous power of recuperation, and her indomitable energr.

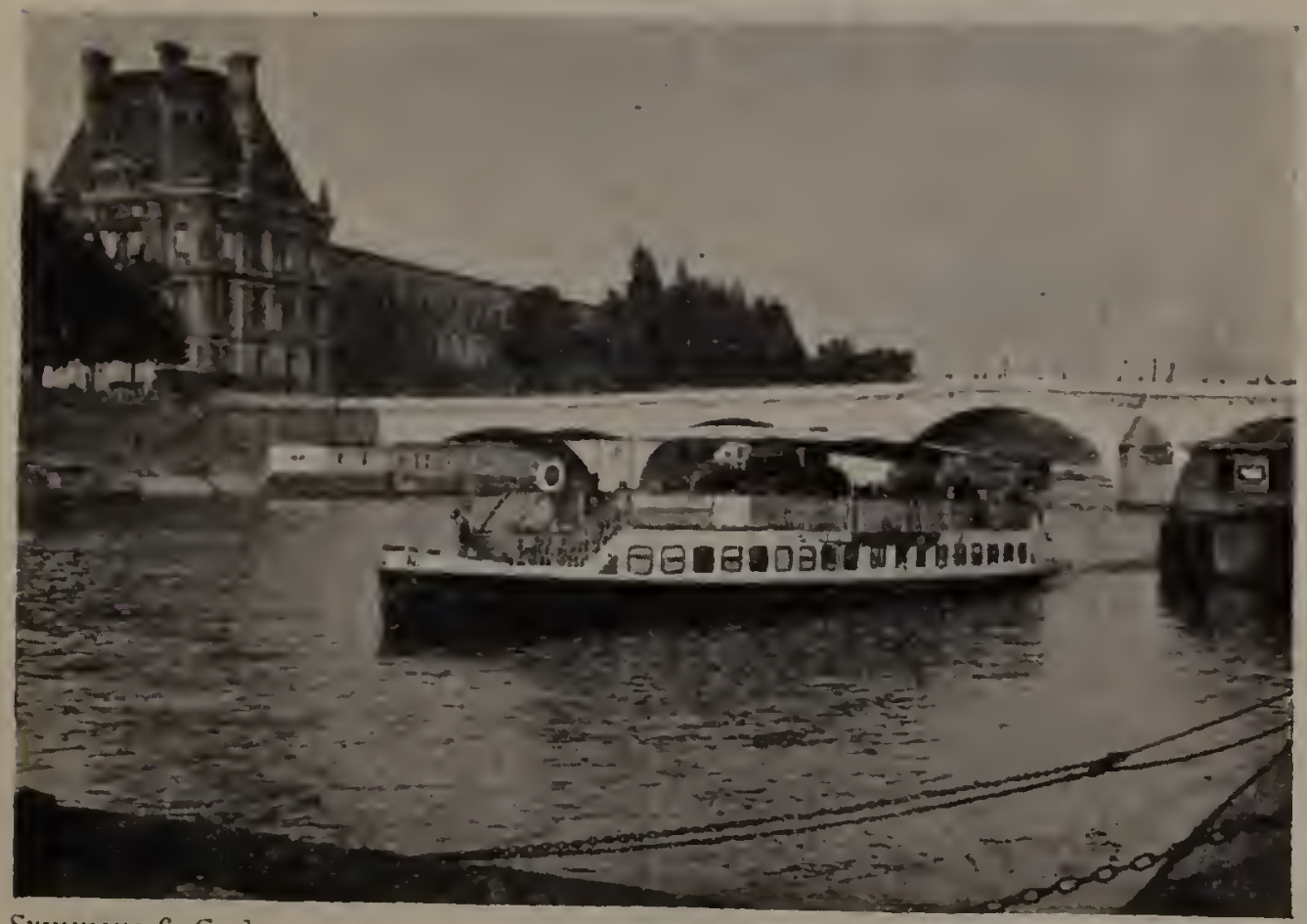

Symmons \& $\left[\mathrm{n}_{*}\right]$

[23, Bouterie Street. ON THE SEINE. 


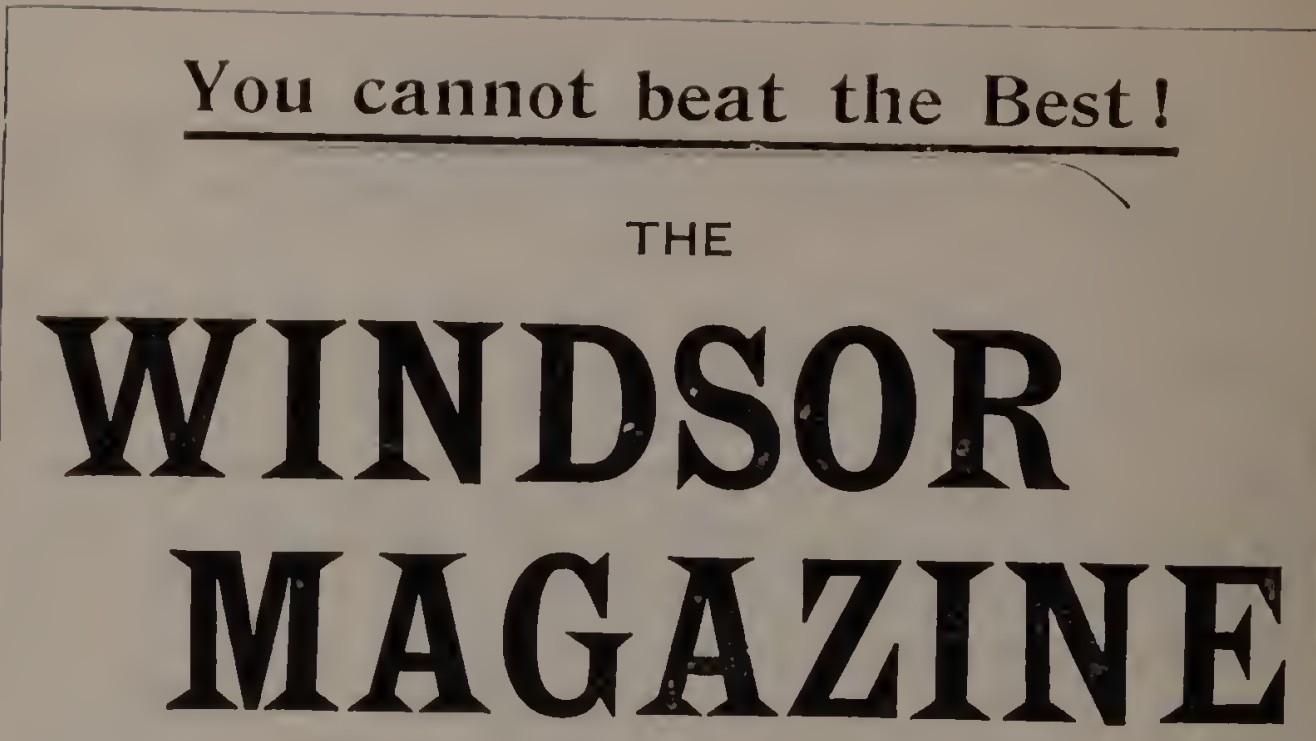

Always contains the BEST WORK by the

\section{BEST AUTHORS AND ARTISTS.}

It has eclipsed every other Sixpenny Magazine, and has achieved the most Brilliant Success of the day.

\section{It Holds the Record}

for giving the Best Serial Story of the Year.

\section{It Holds the Record}

for giving Splendid Exclusive Articles by recognised specialists.

\section{It Hoids the Record}

for being the Most Varied, the Most Entertaining, and the Most Instructive of Magazines.

The "Cimes" calls it "Wonderfui."

LONDON: W.ARI), LOCK \& CO., LTD. 


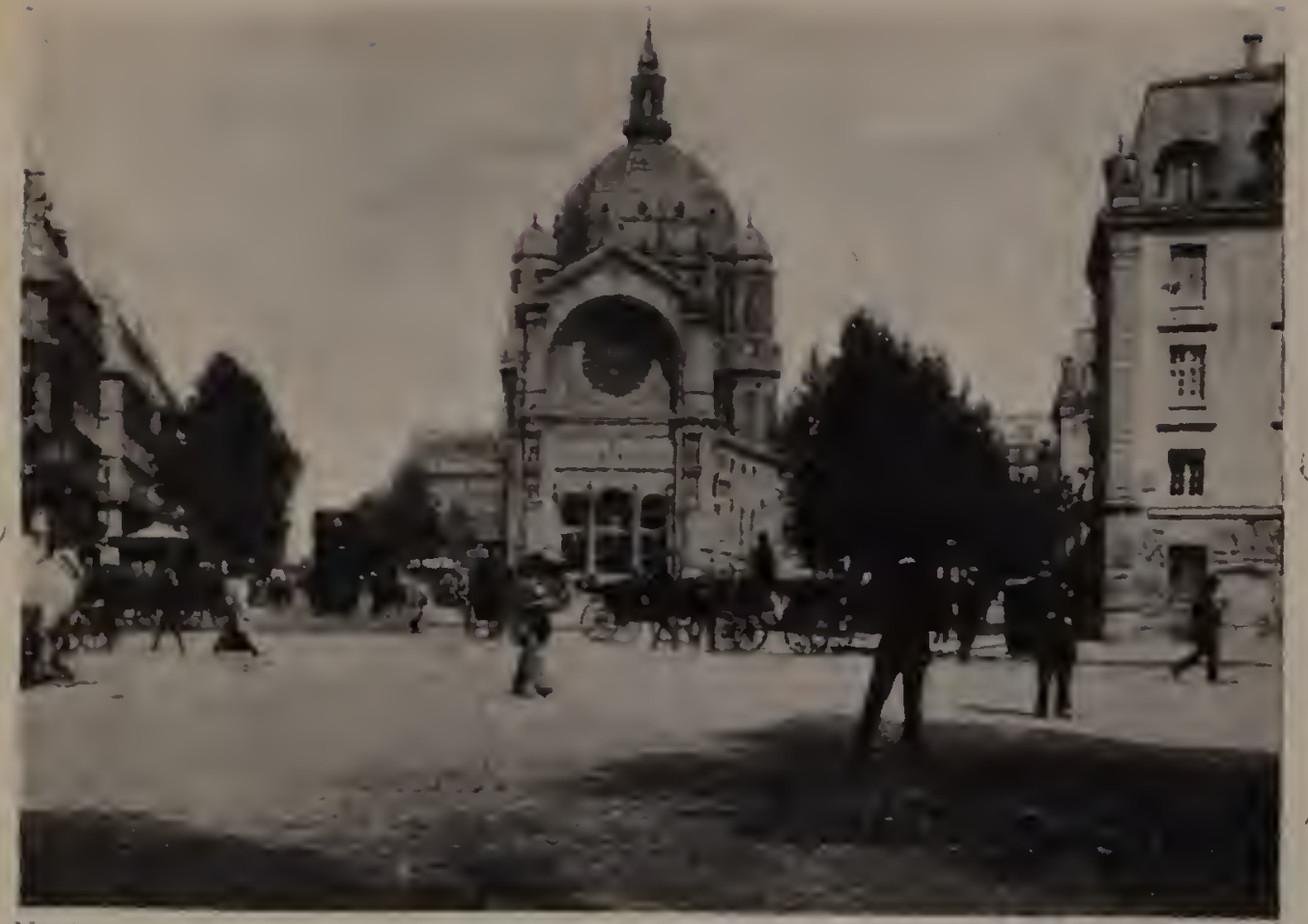

rork or Jure, THE CHURCH OF ST. AUGUSTIN.

LNouzry Hall.

\section{GUIDE TO PARIS.}

INTRODUCTION.

\section{USEFUL HINTS.}

Cost of Visit - Dress - Lngsage-Languagc-French MoneyWcights and Measures-Cigars and Matches-Hotels and their Tariffs-The Sights of Paris: When and How to See Them.

$7 \mathrm{HE}$ first and perhaps the most important consideration in 1 connection with a holiday in Paris is that of -

Cost.-We therefore offer the intending visitor an approximate estimate of the cost of a Parisian holiday by a few of the methods and routes he is most likely to adopt. Our calculations may be fairly based on the inclusive rates and tariffs issued by the wellknown excursion agents, Messrs. Cook, Messrs. Gaze, and others. 
The independent traveller must, of course, be prepared for some increase on these prices, as they are obviously only possible where large partics are concemed. For t.4 14s., second class, (1) 6.510 s. first class, cither of the firms named offer travel to and form Paris, ria Dieppe, (m)mibuses to and from the hotels, hotel accommodation, three day-carriage-drives (including one to Versilles), contrance fees to the sights visited, gratuities, \&c., and the personal escort of a competent conductor throughont. The whole holiday extends over a week from departure to return. Within a pound or so it may therefore be fairly estimated that the same trip may be accomplished independently, alwaty understanding that the sightseer arails himself of the daily corriase drives organised by these furms, as private carriases would of course cutail a far greater expense.

liot the benefit of those who desire to act independently, and require further information than that which is to be obtained by the mere consultation of general rates and tariffs, we offer the following altalysis:

Travel to and from Paris, viâ Dieppe (first*

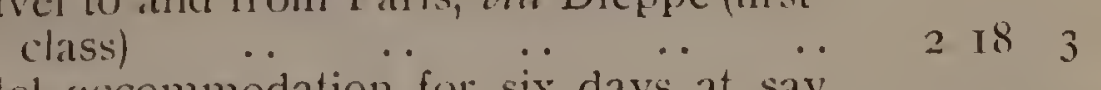

Hotel acommodation for six days at, say,

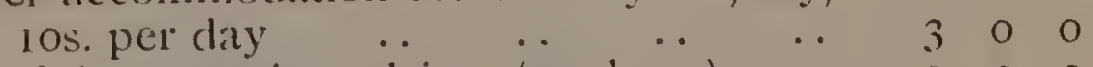

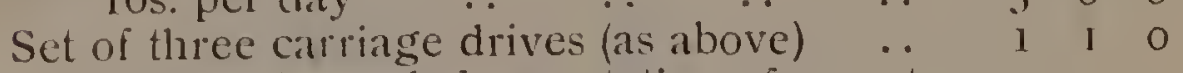

Omnibuses to and from station, fees at

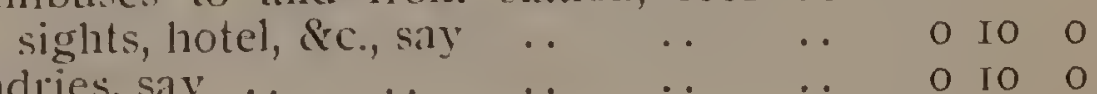

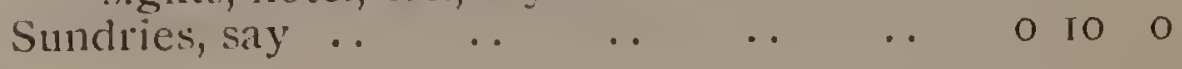

* If the short-sea route is adopted, this will increase the cost somewhat, as the Newhaven-Dieppe is the cheapest inute to the Continent.

\section{Approximate total outlay f7 $19 \quad 3$}

Dress.--The preparatory arrangements for a risit to Paris should be of the same nature exactly as those you would make for a few days' sojourn in the nearest and most important city at home. It is the greatest mistake, and evidence of the worst possible taste, to get oneself up in tourist fashion; and we frequently deplore the unfortunate impression our compatriots. convey to our elegant neighhours on the other side of the Channel by promenading the boulevards or driving through the

* By travelling second class a saving of Ís. can be effected. 
Champs Elýsées with costumes such as would he suitable for shooting on Scotch moors, or exploring Central Africa; while ladies, who camnot fail to be aware that Paris is the centre of the fashionable world, frequently put away before leaving all the attire they would wear on state occasions at home and appear in Paris dressed as one would expect only at some unimportant seaside resort or country village.

These remarks may seem severe, but easy verification of their necessity is to be obtained at any point in Paris where English visitors most do congregate.

Luggage.-An excellent rule is to take one suit or dress for travelling to Paris and for excursions in the surrounding country, such as Versailles, Fontainebleau, \&c.; and an entire change for use in the city itself, for the boulevards and for evening amusements. For the rest, as a general rule, "one on and one off" will suffice, with an abundant supply of small articles of personal linen, \&c.

Language.-The pleasure and profit of a tour in any part of the Cuntinent are, of course, greatly enhanced by familiarity with the language or languages of the various countries through which one passes, and this fact applies in a certain degree to a trip to Paris. It is, however, safe to assert that even utter ignorance of the French language need form no serious obstacle to a risit. If the arrangements of one of the Tourist firms be adopted, the visitor will not be called upon to exercise his knowledge of the language in any way, unless he chooses so to do, as all arrangements are made by the conductor, all the travelling companions are English-speaking people, and all the explanations of the various sights are given in English. The independent tourist may be occasionally inconvenienced, but he is never likely to find himself completely at a loss. During the journey the officials, the attendants at the buffets, \&c., all speak English to a certain extent, or are so thoroughly conversant with the requirements of the tourist that little verbal intimation is required. On arrival in Paris, the cabman will only require the name of your hotel. At the hotel, if suitably chosen, all the attendants will speak English; at the sights a little inconvenience may now and then be experienced, but as a rule the guardians are so used to the large numbers of English and American tourists passing through that they understand enough to give, by pointing and gesticulation, aided by a few words of English, 
.tl the information the tratedled is likely to require. We have, howerer, adeled to the present ceditions of the guide-

$\Lambda$ Glossary of pluates and sentences, which have heen cartfulle chesen will a view (1) pratical use during the journey and risit (sie H. 21\%). 110 susesest that the intending visitor -humld commut a few of these to memory before starting, or during He jomrney, and we renture to believe that if he is not afraid of using llacm frecly, he will have little or no difficulty in m, himg his way maided and alone.

If alleady alceuanted with the language fat any rate to the

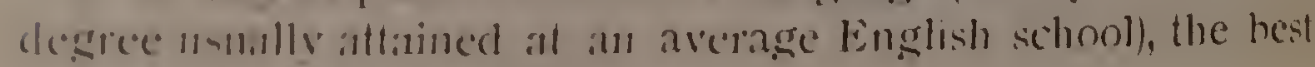

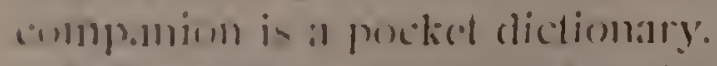

sightsecing.-lindoubledly the hest, casicist, and most ecomonlicil method of mightsceing in Paris is by the organised

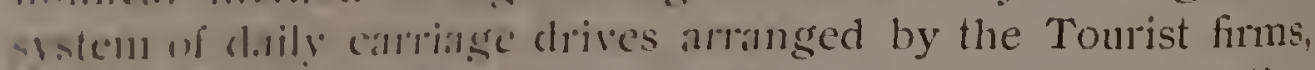
Messs. Gilde and Nesiss. Conk, starting from their respective

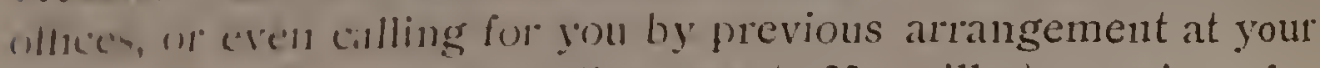
holel. Three drives (including one to Versailles) are given for 6. 1. 'hns a comprehensive idca is obtained of all the principal foulues of interest within three days and at an inclusive and reitumable cost, avoiding all the annoyance of bargaining with cablrivers, finding best bus and train routes, and payment of cultrance fees. If the lime devoted to any of the sights proves too restricted, the visit is easily repeated in the subsequent days of indepconclent action during your stay, with the indisputable advantage of an acquircel acquaintance with locality and situation.

Those who whicet to "organised" sightseeing are recommended (1) malic frec use of the fiacre "licure (cab by the hour) system, slouping the more distant sights in suitable order, or adoptins our practical itineraries. The cab can be discharged at points where several sights of interest are grouped in close proximity, or when protracted stay is involved, as in the case of picture galleries, \&c. Of course a bargain would have to he made for the Versailles trip, a fair price being 25 to 30 francs ; but details and useful hints concerning cab fares and conveyances will be found under respective headings later on. Those who ohject to either of the above methods on the ground of expense must necessarily lose much valuable time in finding suitable omnibus routes or walking from place to place, so that the economy effected proves rather a delusion in the end. 


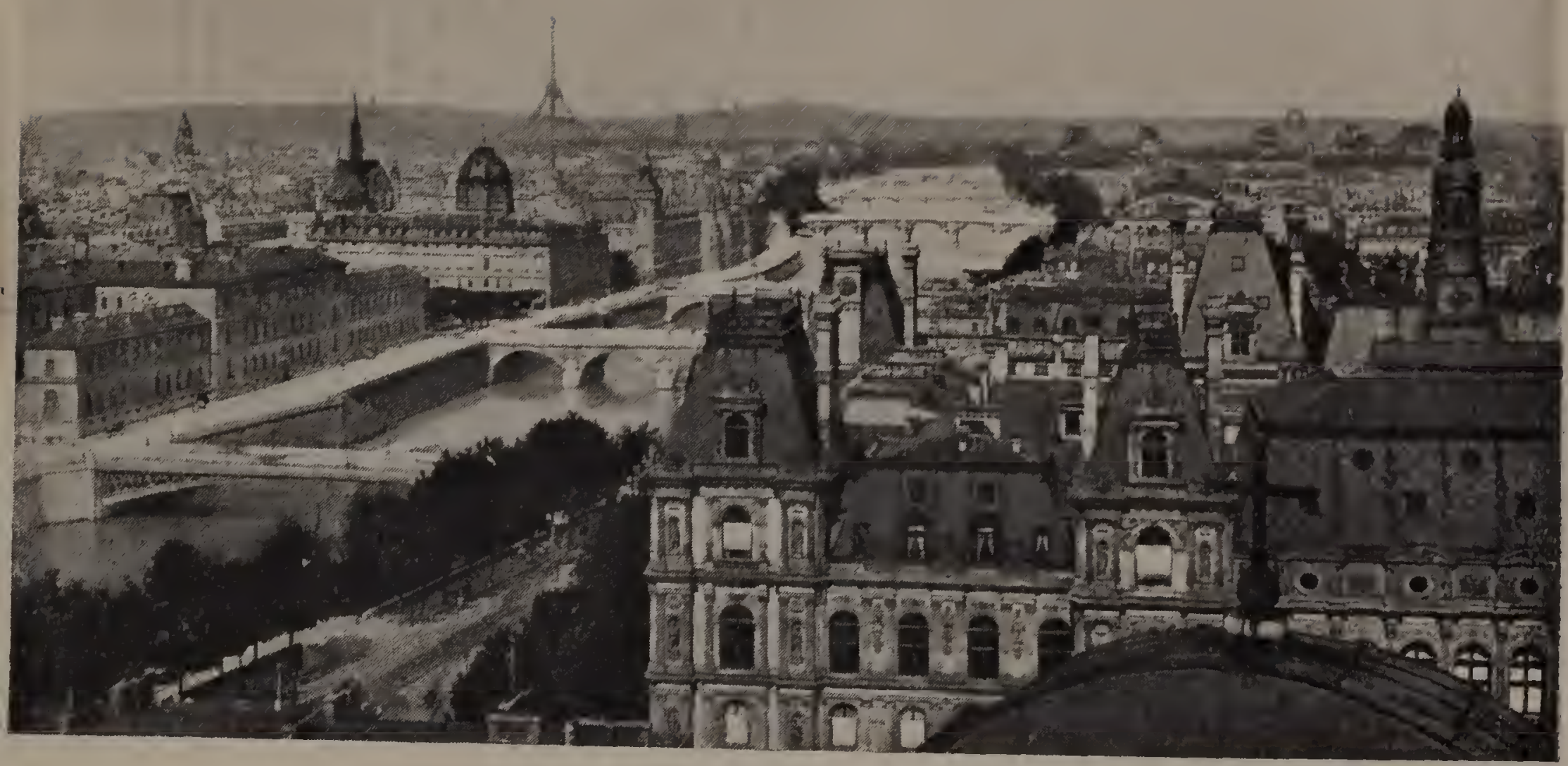

THE SEINE AND ITS BRIDGES. 
In any case, our daily programmes will be found useful bases of operation.

Money.-The money and coinage of France will be found to be remarliably simple, inasmuch as the decimal system is adopted is a uniform method of reckoning not merely money, but weights, measures, and distances. In money the unit is the franc, a piece of silver resembling a shilling, and of the value of about $9 \frac{1}{2}$ pence English. The franc is divided into tenths and hundredths; the bronze ten-centiun piece being almost equivalent to an English penny, and the bronze fivcentimc picic or son to a halfpenny. The ten-centime piece is often called a trov-sous picce, the fifty-centime piece or halffranc a lill-sous ficce, the franc a twomly-sons fiece, and the five-franc piece a hundred-sons fices. For ordinary purposes it is cnougl to renember that the ten centimes or two sous are about a penny, that there are twenty-five francs to the English sovercign, and that 100 lrancs are accordingly four pounds. The English five-pound note is worth 125 francs. The rate of exchange is always in favour of English coinage as compared with Continental money-thus the real value of $E_{1}$ English is about 28 centimes or $2 \frac{1}{2} \mathrm{~d}$. beyond the 25 franes at which it is generally reckoned in hotels and by shopkeepers.

By a convention made between France, Italy, Switzerland, Greece, and Belgium, the gold and silver currency of these countries, in all of which the calculation of values is according to francs and contimes, are interchangeable. Thus Belgian or Swiss francs, and two-franc or five-franc, or gold five-, ten-, or twenty-franc picees, pass current in Paris. Italian grold also passes current, also five-franc pieces, but not the lower values of Italian silver. A useful sheet is sold in the streets showing all coins valid or repudiated, with engravings of each.

The following are the chief pieces of money in use in France, with their equivalents in English currency :

\section{Copper Coins.}

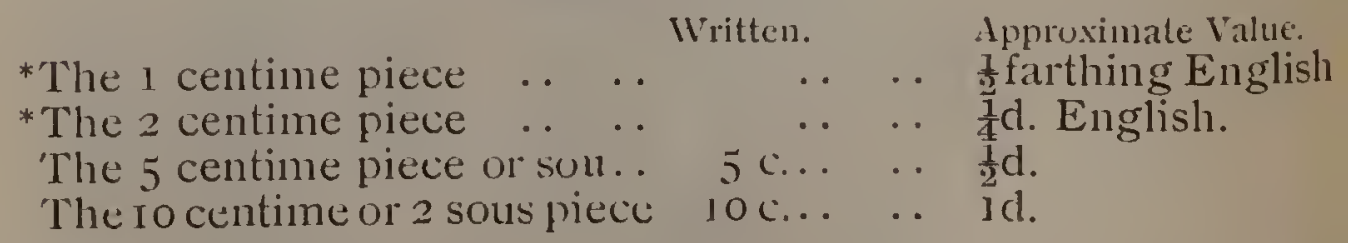

* These are ratrely seen by the tourist, being chiefly used in the markets and amongst the very poor classes. 


\section{Silver Coins.}

The 50 centime, 10 sous, or $\frac{1}{2}$

fianc piece .. $\quad . . \quad \ldots \quad . .50$ c... $\quad .$. nearly $5 \mathrm{~d}$.

The franc or 20 sous piece.. 1 fr. . . " $\quad$ lod. $\left(9 \frac{5}{8} \mathrm{~d}.\right)$

The 2 franc or 40 sous piece $2 \mathrm{fr}$. . Is. $7 \mathrm{~d}$.

The 5 franc or piece of 100 sous $5 \mathrm{fr} . \quad \ldots \quad+\mathrm{s}$.

\section{Gold Coins.}

The Io franc piece. . . . . $10 \mathrm{fr} . \quad \ldots \quad \delta$ shillings.

The 20 franc piece. . . . . . $20 \mathrm{fr} . \quad \ldots \quad 16$ shillings.

The 25 franc piece. . . . . 25 ir. . $\quad$ I pound sterling.

The 50 franc piece. . . . . 5o ir. $\quad \ldots \quad t 2$.

The 100 franc piece ... . . $100 \mathrm{fr}$. . Et.

The liare sterling is the English sovereign. Though the rate of exchange varies, the average value of the English sovereign is about $25 \mathrm{fr}$. Io c., occasionally rising to $25 \mathrm{fr}$. I $5 \mathrm{c}$, , or even 25 fr. 25 c.; but the general method at the hotels and in shops is to give for it only 25 francs, and 125 for a $\$ 5$ note. This makes a little extra bíncifice for the hotel proprietor or shopkeeper. The premium, however, may be obtained by changing at any exchange or "tourist office" in the city. We presume it is hardly necessary to caution the tourist to beware of accepting the gold louis, or napoleon, value 20 francs, as representing an English sovereign (25 francs); and never to put down an English sovereign in payment without calling attention to the fact that it is a sovereign, or it may be complacently accepted as a louis, change given accordingly, and adjustment is then rather more possible than probable.

Weights and Measures.-The decimal system is also followed in the measurement of length, surface, and solidity, and in the estimation of iveight. For the measure of length the unit is the mitre, the ten-millionth part of the spherical distance from the pole to the equator: and its square and cube are taken as standards of surface and capacity. The mètre may be compared with the English yard, to which it approximates. It is somewhat longer than the yard, measuring 393 inches, or in decimals, 39.37 I inches. The decametre is 10 metres, or almost It yards; the kilometre, I, ooo mètres, by which distances are measured, may be taken as $\frac{5}{8}$ of a mile. Thus by multiplying a distance stated in kilometres by five and dividing the product by eight, we get the distance in English miles. The miriametre, or length of ro,ooo mètres, makes $6 \frac{7}{5}$ English miles. Going 
downward from the metre we have the decimetre, or loth of a metre, about $3 \frac{3}{5}$ inches, and the centimetre, $\frac{2}{5}$ of an inch. The siluare metre (mètre carré) comprises $1 \frac{1}{5}$ of a square yard, and the square kilomètre (kilometre carré) $\frac{3}{5}$ of a square mile.

In weight the unit is the srammic, equal to about $15 \frac{1}{2}$ grains avoirclupois; so that 10 grammes are eyual to about $\frac{1}{3}$ of an ounce. The kilogramme (or 1,000 gramme weight) is that by which nncirt, sroceries, Ec., are gencrally sold, one kilogramme being eyual lo $2 \frac{3}{4}$ lbs. avoirdupois. Thus 10 kilogrammes are 22 English pounds. For heavier weights there are the Quintal Inclrigle, cyual to $220 \frac{1}{2}$ lbs. avoirdupois, or within $3 \frac{1}{2}$ lbs. of two covt. The tomneau, approximating to the English ton, is 2,200 lhs. English.

For the untal meatsure of capacity the litre is taken, approximating to the English guat-it contains $1 \frac{3}{4}$ pints. The hectolitre, "10 measure of 100 litres, equals 22 gallons. Wine is frequently sold by the litre, aud a litre will about represent the quart bottle.

Tobacco, Cigars, \&c. - Tobacco being a Government monopoly in France, onc is obliged to smoke the productions of the "Regie," or pily exorbitant rates for foreign importations. Tobacco shops are numerous, and easily distinguished at night-time by a red lamp almost invariably hung over the doorway. Cigarettes are obtainable in packets of 20 from 30 centimes per packet and upwards. The lightest quality, being made from Turkish tobacco, is called the lizicr, and maty be had in packets from 70 centimes or from onc franc. Cigars are obtainable at all prices, from one sou upwards, a fair sort being the Manilla Clicroot, which is sold at 20 contimes. Londres are also good quality, and are gencrally sold at about 30 centimes, though, of course, much higher prices are paid when purchasing at restaurants, bars, calés, or hotels. There are a few establishments, authorised by Government, where foreign tobacco may be obtained; one of the most important and convenent is situated on the Boulevard des Capucines, close to the entry to the Grand Hotel.

The confirmed smoker would do well to carry a fair supply of his favourite weed or mixture for use during his holiday, understanding, of course, that this must be done subject to the observations made elsewhere concerning the Douane or customs on entry into the country Anyway, the visitor is surely justified in having a fair advance supply in his pockets, though the question of quantity is naturally one of some elasticity. 


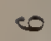

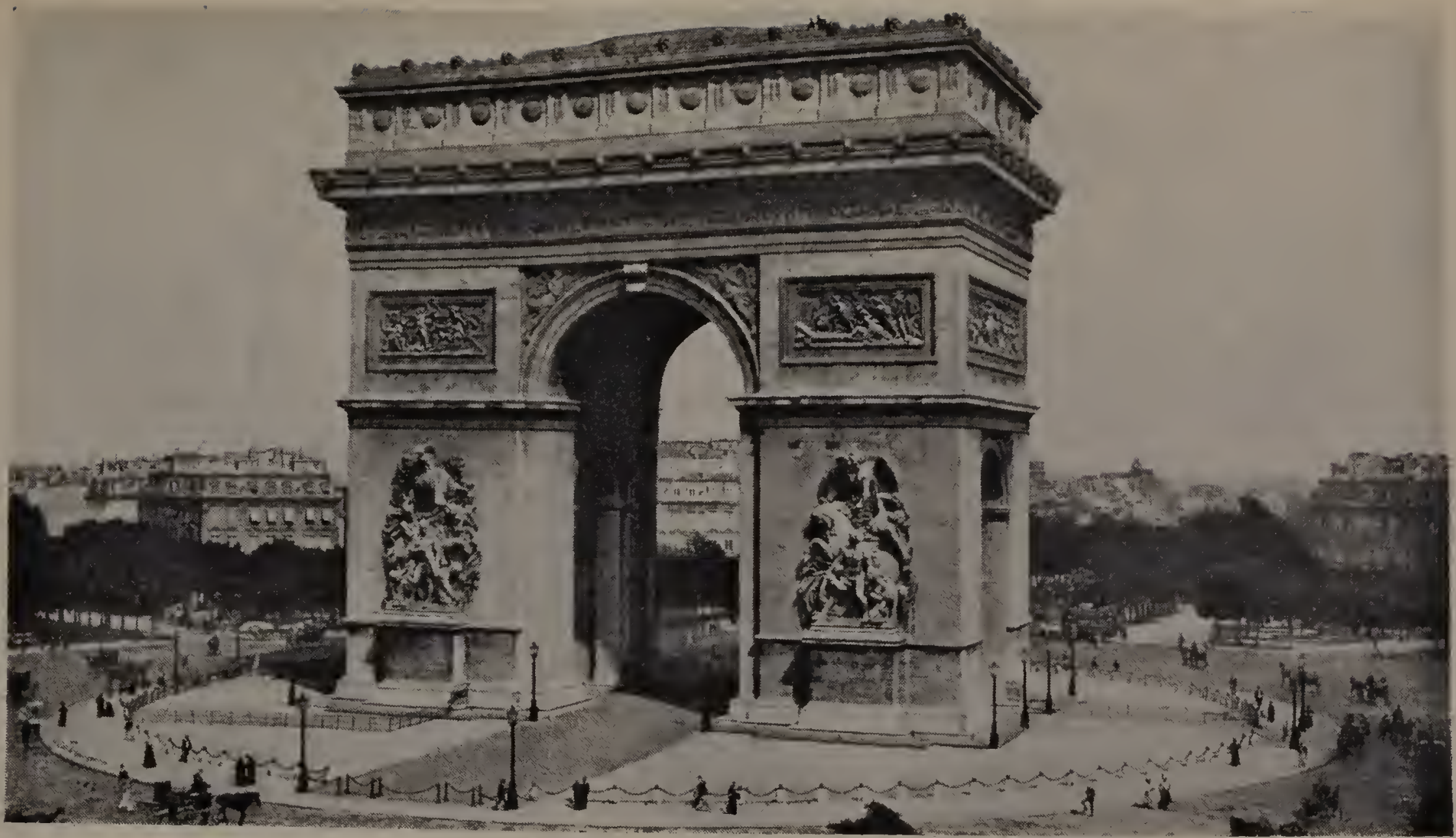


Matches, Fusees, \&c.-These aticles also form a Government monopoly, and the quality supplied is vastly inferior to that obtainable in almost any other part of Europe.

\section{Tariff of Paris Cab Fares.}

Shoming The Farles, by Distance and bY Tiale, of Public Vehicles of Various Classes.

In the Interior of Paris.

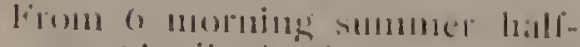
ycal" (April t to sept. 3u), illal firsu 7 morning winter hallyear (Oct. 1 to Mach 31 ) to 12.30 midnight.
From 12.30 midnight to 6

1110118, from

April 1 to Scopt. 30, and 7 moril. from Oct. I lo Milich 31 .

Drivers : are hotund to take up :t the hirer's residence.

Cinss ANT fits PUING; IN THI: PUIBLIC STREETS ANI NT R.IILIIAT STATIONS.

Seating 2.. . 1 50 ir. c. li. c. Scating $+\ldots \ldots 20$

Lalldall scilting 4. 01 Omnibus 250 seatting 6
$13 y+110$ drive (ir by the 'coirse."

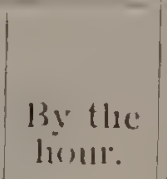

20

2.50

(2)

30
Beyond the fortifications.

Bois de Boulogise and Bois de Vincennes, de., from 6 morning to midnight summer, or to Io night winter.

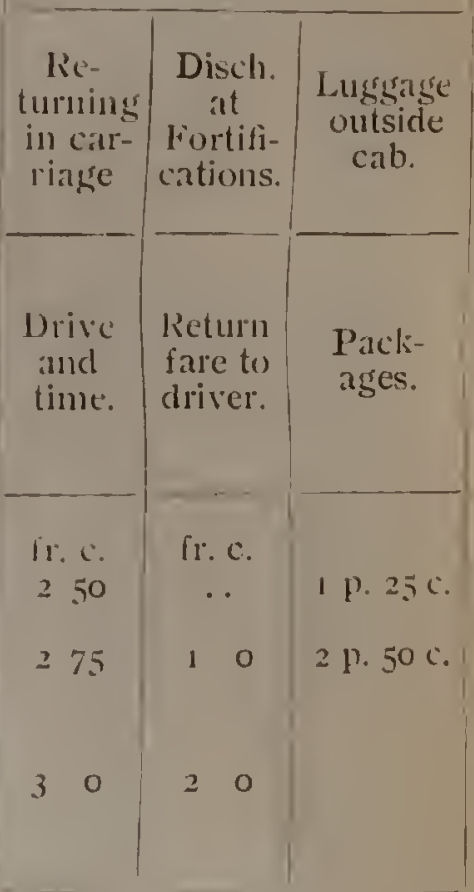

Cabs taken by the hour, if kept five minutes after, are paid for the quarter: $(x$ if that time has elapsed, the laalf-hour is counted. Thus, an hour and five minutes, or al quarter of an hour, $2 \mathrm{fr} .50 \mathrm{c}$; an hour and twenty minutes, or an hour and a half, $3 \mathrm{fr}$, the price per hour being $2 \mathrm{fr}$. A pourloire is invariably added, the amount of which depends entirety upon the fare, but is senerally counted at $50 \mathrm{c}$. the hour.

All packages placed in the interior of the cab alre free of charge, but for those placed on the top an extra fee of $25 \mathrm{c}$. each is demanded.

\section{Hotels and their Tariffs.}

The following are selected with a view of showing some of the best representative houses of each grade. The tariffs were supplied by the hotel proprietors themselves, but as changes are 
of constant occurrence, we can, of course, assume no responsibility for their absolute accuracy. The visitor is recommended also to peruse the remarks as to accommodation on pp. 59-60. Prices are, of course, much higher during Exhibitions.

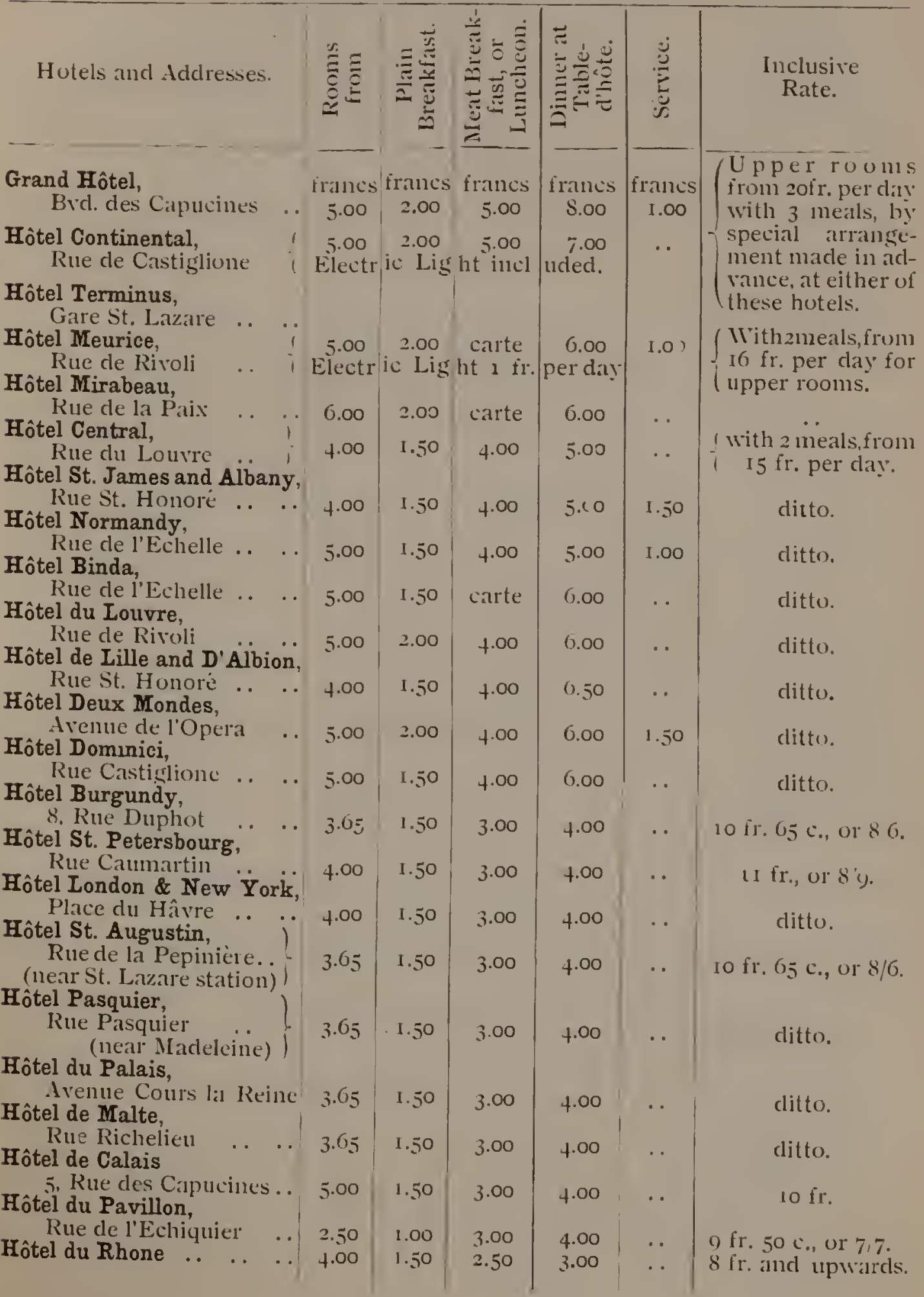




\section{Days and Hours}

TO THE

Monuments, Palaces, Museums, Galleries,

\begin{tabular}{|c|c|c|}
\hline NAME. & AUDKESS. & $\begin{array}{l}\text { DAYS AND TIME FOR } \\
\text { VISITING. }\end{array}$ \\
\hline Arc de Triomphe. & l'lace de l'Etoile & Daily from 9 a.m. till dusk.. \\
\hline Lrchives Nationales & $\begin{array}{l}\text { wo, line des frames- } \\
\text { bourgcois }\end{array}$ & $\begin{array}{l}\text { Daiily from } 10 \text { a.m. till } 3 \\
\text { p.m. }\end{array}$ \\
\hline Bibliothèque de l'Ecole de Medicine & Place de l'Ecule... & $\begin{array}{l}\text { Daily } 11 \text { a.m. till } 5 \text { and } \% .30 \\
\text { till } 10 \text { p.m. }\end{array}$ \\
\hline Bibliothèque Nationale & 3, Rue Colbert & Daily 10 a.m. till 4 p.m. .... \\
\hline Boursc (Exchange) & P'lace de la Bourse & Daily 12 a.m. till 3 p.m. .... \\
\hline Catacombs of Paris. & l'lace Denfert-Rochereatu & $\begin{array}{l}\text { First and Third Saturday of } \\
\text { each Month }\end{array}$ \\
\hline Cluny Muscum. & Buulevard St. Germain & $\begin{array}{l}\text { Daily } 11 \text { a.m. till } 4 \text { p.m } \\
\text { (Mondays excepted) }\end{array}$ \\
\hline Conservatoire des Arts-et-Métiers & Square of same name & $\begin{array}{l}\text { Sundays, Tuesdays, and } \\
\text { Thursdays, } 10 \text { a.m. till } 4 \text { p.m. }\end{array}$ \\
\hline Conservatoirc de Musique ...... & 15, Faubg. Poissionniere & $\begin{array}{l}\text { Mundays and Thursdays } \\
12 \text { till } 4 \text { p.m. }\end{array}$ \\
\hline , $\quad$, (Musical Library) & $"$ & Daily 10 a.m. till 4 p.m. .... \\
\hline Ecole des Beaux-Arts ... & 14, Ruc Bonaparte & $\begin{array}{l}\text { Daily } 10 \text { a.m. till } 4 \text { p.m. } \\
\text { (Sundays } 12 \text { till } 4 \text { ) }\end{array}$ \\
\hline iffel Tower & Champ de Mars. & Daily 10 a.m. till dusk ...... \\
\hline xhibition. & & Dally from 8 a.11..... \\
\hline arde-Meubles & 103, Quai d'Ursay . & $\begin{array}{l}\text { Daily } 10 \text { a.m. till } 4 \text { p.m } \\
\text { (Mondays excepted) }\end{array}$ \\
\hline belins . & Avenue des Gobelins... & $\begin{array}{l}\text { Wednesdays and Saturdays } \\
1 \text { till } 3 \text { p.m. }\end{array}$ \\
\hline primerie Nationale & s7, Rue Vieille du Temple & $\begin{array}{l}\text { Thursdays only at } 2 \text { p.m. } \\
\text { prompt }\end{array}$ \\
\hline $\begin{array}{l}\text { Invalides (Hôtel des) ... } \\
\text { Musée d'Artillerie }\end{array}$ & $\begin{array}{c}\text { Esplanade of sante name } \\
\text { " }\end{array}$ & $\begin{array}{l}\text { Daily } 12 \text { till } 4 \text { p.m. } \ldots \\
\ldots \ldots \ldots \ldots \ldots \ldots \ldots \ldots \ldots\end{array}$ \\
\hline rdin d'Acclimatation ........ & Bois de Boulogne. & Daily 9 a.m. till dusk . \\
\hline $\begin{array}{l}\text { Jardin des Plantes- } \\
\text { "Menagerie" } \ldots . . . \ldots \ldots \ldots \ldots \\
\text { "Conservatories" }, \ldots \ldots \ldots \ldots \\
\text { "Natural History Collections" }\end{array}$ & Place Wallhubert & $\begin{array}{l}\text { Daily } 11 \text { a.m. till } 4 \text { p.m. } \\
\text { (summer till } 5 \text { p.m.) } \\
\text { Tuesdays, Thutsdays, and } \\
\text { Saturdays, } 1 \text { till } 4 \text { p.m. } \\
11 \text { a.m. till } 3 \text { p.m. daily } \\
\text { except Mondays and Wed. } \\
\text { nesdays }\end{array}$ \\
\hline
\end{tabular}


xardens and Sights of the City of Paris.

REMARKS.

FOR

DESCRIPTIVE

DETAILS, SEE PAGE-

$\operatorname{IOS}$

Fine panoramic view of the City. Fee to guardian

I $22-124$

Admission by special permission obtainable from the Hotel de Ville (lefthand entrance, escalio D.. office of Directory and Treasury on first foor) or with Excursion parties organised by one of the Tourist Agencies.

Closed on Sundays and also August ist to October I gatl

By special permission on Mondays, Wednesdays, and Fridays. Closed Saturday's.

Very fine collection of Musical Instruments Magnificent bird's-eye view of Paris and surrounding country for forty-
five miles distance

I II-I I4

See Sp:cial

Section

amous Tapestry Manufactory

$170-172$

By permission of the Director

This does not apply to the Tomb of Napoleon (which see)

II $6-$ II 7

I I $7-120$

dimission I fr. ; Sundays and Thursdays half-price

175 and 209

$174-175$ 
Monuments, Palaces, Museums, Galleries,

NAMk.
Jardin des Plantes (coutd.) - ....
"Botanical Gardens" .....
Louvre (Museum and Galleries) ..
Luxembourg (Modern Paintings).
Musée Carnavalet ..............
Notre Dame ..................
(Treasury) .......

Palais de Justice

Panthéon

Saint Chapelle

Tobacco Manufactory

Tomb of Napoléon I.

Trocadero

Fontainebleau (Palace \& Forest of)

Sèvres Porcelain Factory ........

St. Denis

St. Germain

Versailles
ADNRESS.

Place IValhubert

Rue de Rivoli .

Bonlevard St. Michel .

Rue de Séviginé .......

10, Boul. Montmartre .

Square of same name. $"$

Boulevard du Palais...

Boulevard St. Michel .

Palais cle Justice

Quai d'Orsay ..........

Hôtel des Invalides....

Mondays, Tuesdays, Thursdays, and Fridays, 12 till 3 p.m., or summer months till 4 p.m., excepting Wrednesdays and Saturdays

Aquarium and Concert Hall, daily 9 till 11 a.m. and 1 till 5 p.m. (winter months till 4 p.m. only)

Rail to Fontainebleau .

Village of same name.

Village of same name ..

Village of same name.

Village of same name.
Daily 10 a.m. till 4 p.m. ....

Daily 12 till 4 p.m. ........

Workshops: Mondays, Thursdays and Saturdays

Daily 10 a.m. till 5 p.m. ....

Sundays, Tuesdays, and Thursdays, 10.30 a.m. till 5 p.m. (winter till 4 p.m.)

Daily (Mondays excepted) 11 a.m. till 5 p.m. (winter till 4 p.m.) 
rdens and Sights of the City of Paris-continued.

REMARKS.

FOR

DESCRIPTIVE

DETAILS, SEE PAGE-

174

I 26-I 39

I69-I69

$144^{-1} 4^{6}$

$8+$

$1.55^{-1} 5^{8}, 208$

I 57

I $72-173$

I 58-I 59

I I 4 - I I 6

IIo

194-199

192-I93

200-20I

I76-191

thedral and Royal Tombs

lace, Forest, and celebrated Terrace. By carriage or rail

lace, Museums, Galleries, Trianons, State Carriages, \&c. 


\section{Consulates and Embassies.}

English Embassy .. 39, Faubourg St. Honoré.

U.S. America Embassy 24, Avenue Kléber.

Chancellerie ‥59, Rue Galilée.

Consulate .. .. $\quad 36$, Avenue de l'Opéra.

Russian $\quad$. . . . $\quad 79$, Rue de Grenelle.

German $\quad . \quad \quad . \quad 78$, Rue de Lille.

Belgian.. $\quad . . \quad \ldots \quad 38$, Rue du Colysée

Italian . . . . . . $\quad$ 73, Rue de Grenelle.

Spanish _ . . . 34, Rue de Courcelles.

Siviss .. $\quad . . \quad$.. 15 , Rue Marignan.

Turkish _. .. 10, Rue de Presbourg (Consulate, 3 I, Place St. Ferdinand).

\section{Physicians.}

Dr. A. S. Clarke, 2, Rue Cambacérès. I.30 to 3.30.

Dr. B. T. Deering, 3, Rue Godot-de-Mauroi, near the Madcleine. 1 to 3 . Tele., 242,63.

Dr. J. Faure-Miller, 28, Rue de Matignon.

Dr. Roland Faure-Miller, 8, Rue Miromesnil.

Dr. E. L. Gros, 18, Rue de Clement-Marot. 2 to 4 . Tele., 542,83 .

Dr. Alan Herbert, I8, Rue Duphot. I.30 to 3 .

Dr. Landolt (Oculist), 4, Rue Volney. 4 to 6 , Saturdays excepted.

Dr. A. A. Warden, 6o, Avenue d'léna. Tele., 540,64. Monday, Wednesday, and Friday, 6, Rue Piccini, 2 to 4 . Tele., 532,7I.

\section{Homecopathic.}

Dr. Hecrmann de Hundtermark, 7, Rue Rouget-de-Lisle. 3 to 5 .

\section{Railway and Postal Time.}

It should be borne in mind that, in most Continental towns, the railway and postal authorities and other public bodies observe Europcan or Greenwich, and not the local, time. If this fact be lost sight of, the arrangements of visitors may be very seriously interfered with.

Readers who may chance to discover any inaccuracy in this handbook, are respectfully requested to inform the Publishers, with a view to rectification in future editions, 


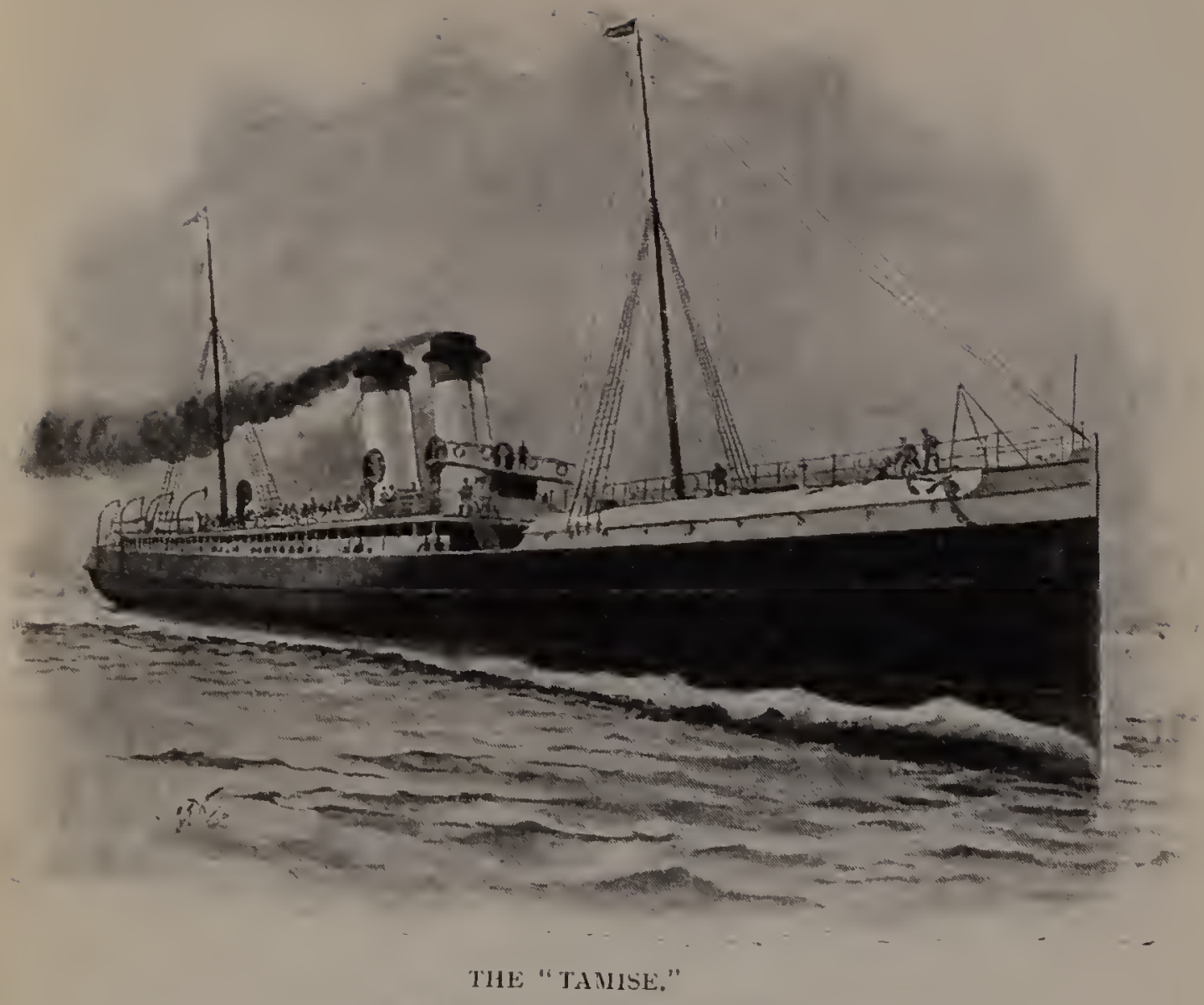

(Nearhazen and Diefpe Route.)

CHAPTER

\section{HOW TO GET TO PARIS; AND WHAT IS TO BE SEEN ON THE WAY.}

Adrantages and pleasures of the trip-Old stylc travelling and new-Rontes from London to Paris. I. The Dower and Calais Ronte. II. The Folkestone and Bonlogice Ronte. III. The Newharen and Dieppe Ronte. IV. Thic Sonthampton and Havre Ronte-The Thanes Service to Bonlogice.

FOR all who desire a thorough change at a small expenditure F of time in travelling, there can be no more direct and practical way of attaining their object than by a trip to the French capital. So soon as the traveller has left the Channel between himself and his native land, he finds himself amid entirely new surroundings. The dress, the manners and customs of the people among whom he has alighted-in so far as he obtains a flying view of them from the railway carriage windows-the names inscribed above the shops and ware- 
houses, all have the impression of novelty. He even feels inclined, like the humorous author of "Paul Pry," to express his astonishment at healling the little children speak French with such facility, and to marvel how they could have acquired the "foreign" languige so carly. Whether the names "our lively neighbours" and "the mercurial Gatul" habitually applied to the French wation, or whether the popular epithet, "Giddy Paris," are allogether warranted, may be open questions; but certain it is, that a livelier trip, or one more full of amuscment and valriety, than a visit to Paris, be it ever s) brief, call scallecly be taken. The visitor in Paris finds himself surromded on all sides with objects of historical, antiquarian and artistic interest; so much so, that the difficulty in his mind atises sentrally from the gieat number of things to be seen, and the small amount of time at his disposal in which to see them. There are the Louvre, the Hotel de Cluny, the Juxembourg, the Invalides, and a dozen other attractions all appealing to him at the same tince. There are the churches from Notre Dame to St. Roch to be done, in the orthodox fishion, and old and new Paris to be explored, the quays and the boulevalds with their manifold altalctions, not to speak of theatres and other places of amusement. Indeed the visitor may in many cases feel inclinced to follow the example of the famous old dame of the ballad, who sat down in sheer desperation at the unconseimable task set her to clo, and looked at it in utter bewilderment ats to where to begint.

We shall cudeavour lo direct the visitur as har as possible how to economise his tinne, and to turn the few days to which, in most cases, the tourist's stay in Paris is limited, to the best account. One advantage the visitor will speedily appreciate, nanncly that Patris, compared with I,ondon, covers at comparattively small alleal, and that it is farly casy, by means of the numerous services of omnibuses and tramcars that ply along the boulevards and in the principal streets to get over the ground speedily and agreeably. As the valious routes are, moreover, inscribed on the vehicles, even the traveller ignorant of the language can easily avail himself of them; hut he must take carc that the car or omnibus he hails is going to, not coming from, the destination he wishes to reach. Of the divisions of Paris, and the readiest method of finding one's way through the capital, we shitl have to speak later on. 
In the first place, it will be necessary to speak of the various ways of reaching Paris; and here it is curious to contrast the present facilities for travel with the old jog-trot methods of past days. Leaving out of the question those remote times -almost pre-historic now - when a sailing packet conveyed passengers between the English and French shores, as a "hoy" took them to Margate, the journey was a sufficiently tedious one, even under the auspices of the General Stean Navigation Company, in connection with the Paris diligence and the Dover stagecoach. Now "Paris in eight hours" is an every-day experience, and we breakfast in the English and dine in the French metropolis as a matter of course.

We will now proceed to give the principal routes and rates, commencing by a condensed and practical table of fares and services between London and Paris. As changes are made occasionally both in times and fares, the table is only given as approximately correct, and should be verified by reference to the official time tables of the companies concerned.

\section{LONDON TO PARIS.}

\section{FARES, SERITCES, AND TIIE TABLES BY ALL ROLTES.}

\section{No. 1,-By Dover and Calais (S.E. \& C.R.)}

(3 Lxpess Services dirily.)

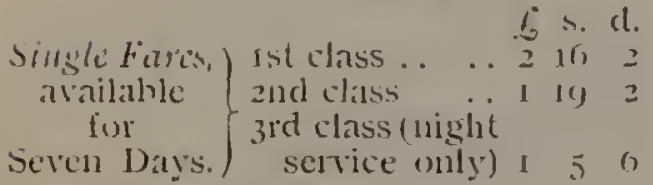

No. 2.-By Folkestone and Boulogne (S.E. \& C.R.)

(2 lised Dily Services.)

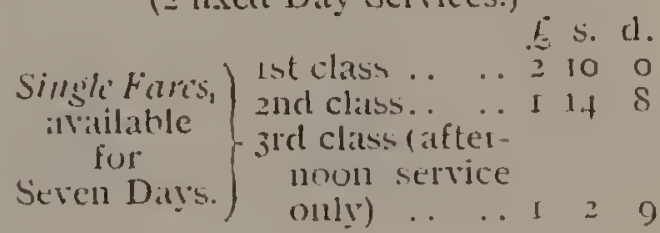

Return Fare:, atialable by EITHER of the above routes and valid for one

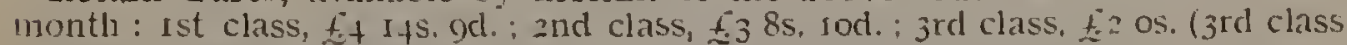
lickets are available by afternoon and night services only).

Returu fares, arailable by the Boulogne route only and ralid for one month: ist class, to $7 \mathrm{~s}$. 1od. . 2nd class, is $3 \mathrm{~s}$. : 3rd class, fi I $7 \mathrm{~s}$. 5d. (3rd class tickets ate available by afternoon service unly).

\section{Special Cheap Excursion Fares.}

Fxcursions take place every Friday and Saturday during the time the Exhibition is open; also at Easter, Whitsunticle, August Bank Holiday, and on the occasion of any Special fête the exact date's being announced abont if days in advance. 


\section{TIME TABLES.}

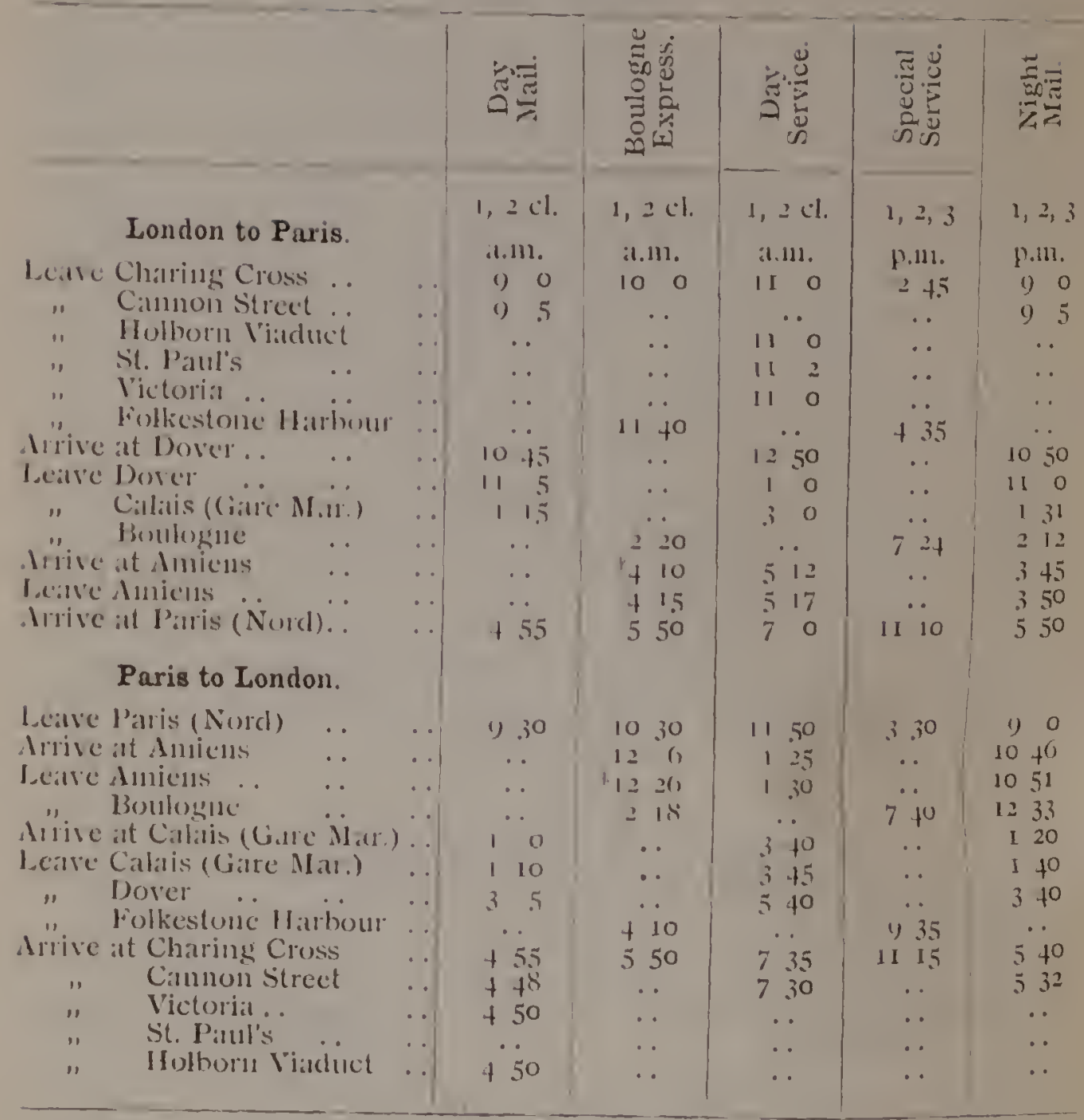

* Lunchcon Car Express.

\section{Paris, viâ Newhaven, Dieppe, and Rouen.}

Two express services daily. Time occupice, about y lours. Sea passage, about

Eares. $3 \frac{1}{2}$ hours.

Single (available for seren days) .. … ist class. 2nd class. $3 r d$ class.

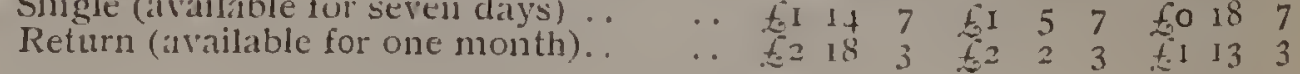

\section{Special Cheap Excursion Fares.}

These Excursions take place at irregular intervals-notably at Easter, Whitsuntide, August Bank Holiday, and on the occasion of any special Fête-the exact dates are announced about 14 days in adrance.

Fares.

Return (available for $1+$ dalys) Ist class. and class. 3rd class.

Whese facilitics are sranted at more frequent intervals from the for 60

England. The cheap tickets will also be issued by night service everth of England. The cheap tickets will also be issued by night service every Friday
and Saturday during the whole period of the Paris Exhibition of Igco. 
TIME TABLES.

\section{London to Paris.}

Leave Victoria (IVest End) (I.R. \& S.C.R.)

"Clapham Junction

" London Bridge (City)

"East Croydon ..

"Brighton . .

" Newhaven Harbinu

"Dieppe

drive at Rouen (R.D.)

"Paris (St. Lazare)

\section{Paris to London.}

I.eave Paris (St. I.azare)

Rouen (R.D.)

Dieppe ..

" Newhaven Harbour

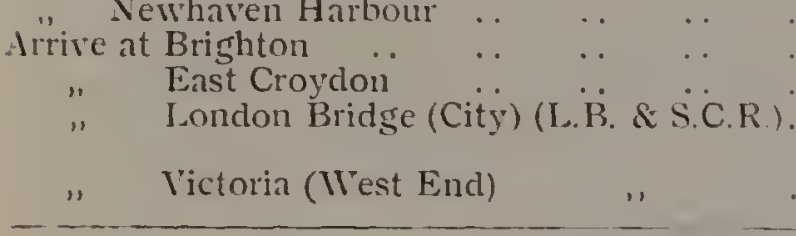

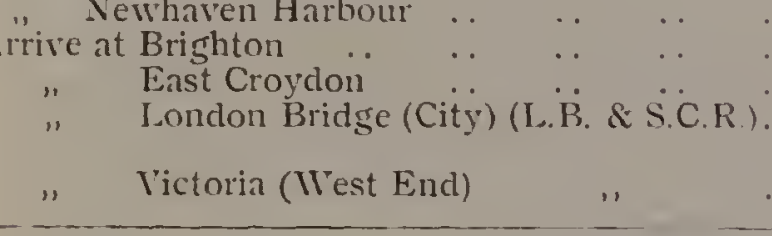

\begin{tabular}{ll|} 
& \\
$\cdots$ & $\cdots$ \\
$\cdots$ & $\ldots$
\end{tabular}

$\mathrm{s}, 2 \mathrm{cl}$

a.m.

I0 0

100

10 20

IO 30

II 30

p.m.

334

$+49$

C. 55

a.m.

100

II 57

p.m.

1 I5

530

$6 \quad 15$

$6+4$

75

75
I, $2,3 \mathrm{cl}$.

p.m.

850

S 57

90

920

10 40

a.m.

$35 t$

54

7 I 5

p.m.

90

I I 16

a.111,

I 255

60

722

7 to

750

\section{Paris, viâ Southampton, Havre, Rouen.-L. \& S. W. R.}

Fares.

One fixed service every week-day. Time occupied, about if hours.

From I

\begin{tabular}{|c|c|c|c|c|c|c|}
\hline & & & & & & \\
\hline & Return (available for I me & & $f_{-1} \mathrm{I}$ & & $4 \quad 4$ & \\
\hline & Boünemouth, Single (available for 7 days & & \pm 210 & & \pm 2 & 8 \\
\hline & Return (avilable for I month) & & t 15 & 10 & \pm 1 & \\
\hline & uth, Single (available for 7 davs) & & \pm 3 & 0 & \pm 2 & 2 \\
\hline & Ith, single (available for 7 days) & . & $t^{2}$ & 4 & $\pm I$ & 10 \\
\hline & Return (available for I month) & & $\$ 3$ & 8 & \pm 210 & 2 \\
\hline "1 & Teovil, Single (available for 7 days) & . & \pm 214 & t & \pm 10 & 2 \\
\hline & Return (available for I month) & & \pm 39 & 2 & \pm 2 & I I \\
\hline & Exeter (Queen Street), Single (available fol & 7 dạss) & \pm 2 10 & 4 & +15 & I \\
\hline & Return (available for I month) & & E4 & 2 & \pm 219 & 2 \\
\hline & th, riâ Exeter, Single (available for & r 7 days) & \pm 2 I9 & 2 & \pm 2 & 7 \\
\hline & Return (available for I month) & & \pm 5 I & 2 & \pm 3 & 8 \\
\hline , & Southampton, Single (arailable for 7 days) & & $\operatorname{tg} 10$ & Io & t & Io \\
\hline & Return (available for I month) & & t.2 II & 8 & 117 & \\
\hline
\end{tabular}

TIME TABLES.

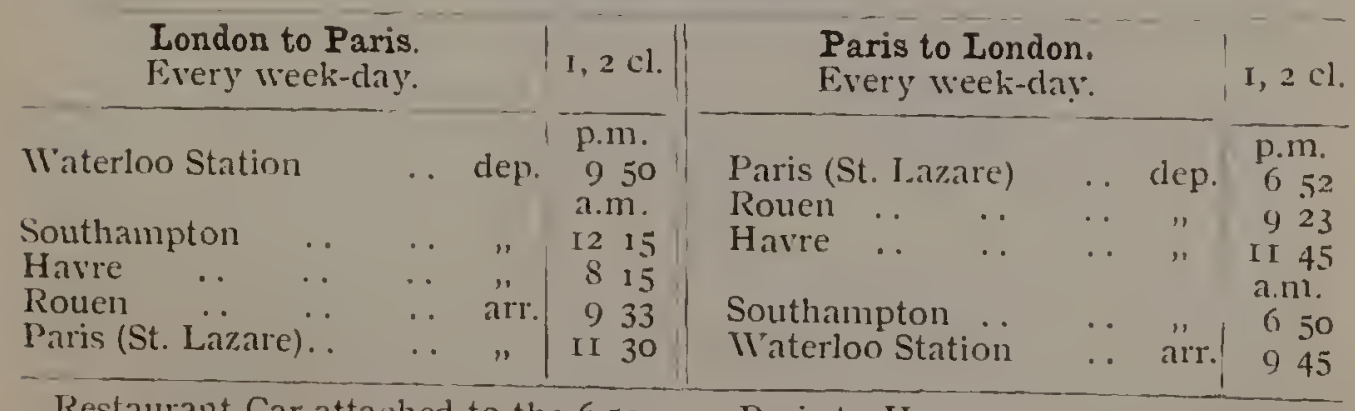

Restaurant Car attached to the 6.52 p.m. Paris to Havre.

Paris passengers are conveyed free by an ommibus between the steamer and the railway station at Havre. 


\section{Routes from London to Paris.}

It will be seen by this table that there are four routes by which Paris is reached from London. I. By Dover and Calais. II. By Folkestone and Boulogne. III. By Newhaven and Dieppe, and IV. By Southampton and Havre. We shall take each in turn, for each has its own advantages and distinctive features.

\section{Dover and Calais to Paris.}

Distance from London about 283 miles. Detailed tables of this and all other services referred to will be found on pp. I9-2I.

'There are (wo) services daily, and one night service. The latter is recommonded for those who wish to effect economy, inasmuch as cheap return ticliets are issued, available for the night service only, during the Summer season. It is, of course, more pleasant to travel by day, but it is also more expensive; and after allowing a few hours in the morning on arrival for rest, a good part of the following day is still available for sightsccing, so that valuable time is gained.

The first part of the journey can be performed either by the South-Eastern or hy the London, Chatham, and Dover Company's line. We will talic the South-Eastern route first. The train, on leaving Charing Cross terminus, crosses the Thames, and after forming a junction with the South-Western Railway at Waterloo, the line runs round in the form of a bow and re-crosses the Thames, at the second or Cily terminus, in Cannon Street. The lraveller then again crosses the Thames, and is soon flying past $\mathrm{New}$ Cross, and so under and through the lofty range of hills cromed by the Crystal Palace. Presently the train rushes past Chiselhurst, one of the most clarming spots in the environs of London, and celcbrated as the place where Napoleon III., Emperor of the French, ended his stormy and eventful life. WC presently pass Tumbridge Junction, a few miles south of which lies Tunbridse Wells.

From Tunbridge the railway runs in a completely straight line to Ashford; and so through the breezy chalk downs until Dover town station is reached. Here tickets are generally inspected ; and presently the train is asain in motion, and glides slowly and smoothly to the Admiralty Pier, alongside which the steamer is moored. Many tourists proceed by an earlier train instead of waiting for the "Boat Express." In this case we 
may first go on board and secure berths by placing our handluggage on the beds or couches, or in the cabins selected, and then proceed to inspect the ancient town of-

\section{Dover.}

Dover lies in a hollow between two tall ranges of cliffs, the hill at the eastern extremity being crowned by the castle, while that at the western end has become famous through "Shakespeare's Cliff," the subject of the well-known lines in King Lear. The town consists chiefly of three long streets, of which Snargate Street is the most important. From the earliest times it has been a place of great consequence, chiefly from its position at the narrowest part of the straits between England and France. The castle, in whose barracks there is accommodation for three thousand to four thousand troops, is built at an elevation of 320 feet above the sea. It has been greatly strengthened, the whole cliff on which it stands having been tunnelled out with passages and casemates, and a huge magazine added, hewn out of the solid rock. The Norman Keep, and Constable's and Peveril's Towers, are the points most worthy of inspection. Here also is the brass cannon presented to King Henry VIII. by the Emperor Charles V., and somewhat oddly named "Queen Elizabeth's Pocket Pistol." Its quaint Low German inscription has heen rendered into English-

\section{"Load me well, and keep me clean, \\ I'll carry a ball to Calais Green."}

Dover witnessed the landing of Charles II. at the Restoration in 1660 ; and it was Dover that was first threatened by Napoleon when he assembled his army on the heights of Boulogne, after the rupture of the short peace of Amiens. The harbour has been greatly improved of late years, and the building of the magnificent Admiralty Pier has been a great boon to travellers. Formerly the steamers could only enter the harbour at high tide; and at other times the landing and embarkation was by means of small boats, which materially added to the discomforts of the journey. The steamers now embark their passengers on either side of the pier according to the tide and weather.

After a comfortable dinner and a leisurely stroll along the sea front we may go on board the steamer and settle down comfortably in our berths, before the mail, with its crowd of passengers, comes rattling down to the Quay alongside the boat at about in p.m. 
A very short delay is necessary for the transfer of baggage, then the gangways are hauled up and the shrill whistle announces nur departure. The paddles give a few fitful turns, presently settling down to steady and regular revolutions, and our channel experiences commence. If travelling by day service, a crowd of seasicle visitors is generally assembled on the pierhead, and with a frantic waving of handkerchiefs we hid farewell for a time to our island home. It is well worth while to remain on deck and watch the receding panorama of the town and the majestic cliffs of Dover; both the heights and the castle are seen to best advantase at a distance of about half a mile from the shore, and when lit up by the morning sun, or by the silvery light of a moonlit sky, the vicw is one of singular beauty.

\section{The Passage across Channel.}

The distance hetween Dover and Calatis is just over twentylwo miles. Under very favourable conditions of weather, wind, and lide, this distance has been accomplished under the hour ; hut the arerage passage may be taken at about an hour and twenty minutes from pier to pier. The new and splendid hoats, such as the Empress, the Calais-Donires, the Victoria, the Calais, the Lard Wroten, the Dorer, Le Nord, and the Pas a Culais, with their powerful engines, have greatly reduced the discomforts of the "middle passage," which, however, still remains, not the "mauvais quart d'lleure" of Rabelais, hut a "mamadisc hcure of un quarl," except in calm weather, for the majority of travellers. Indeed, the short "chopping" morcment in the straits has made many voyagers declare that they have suffered more in ninety minutes between Dover and Calais, or Folkestone and Boulogne, than in the passage across the Atlantic in a Cunarder. A great many specifics and devices of various kinds, all more or less futile, are continually being tried against sea-sickness. The following hints, however, may be useful. It is well to bear in mind that there is far less movement amidships than at the bow or the stern of a vessel, especially when she pitches, and that the best station to take up on a breezy day is between the paddle-boxes under the bridge. Many travellers will be able to defy seasickness on deck, who would immediately succumb to the enemy in the close atmosphere of the cabin. The steamers have small_deck cabins, which may be engaged for the passage 


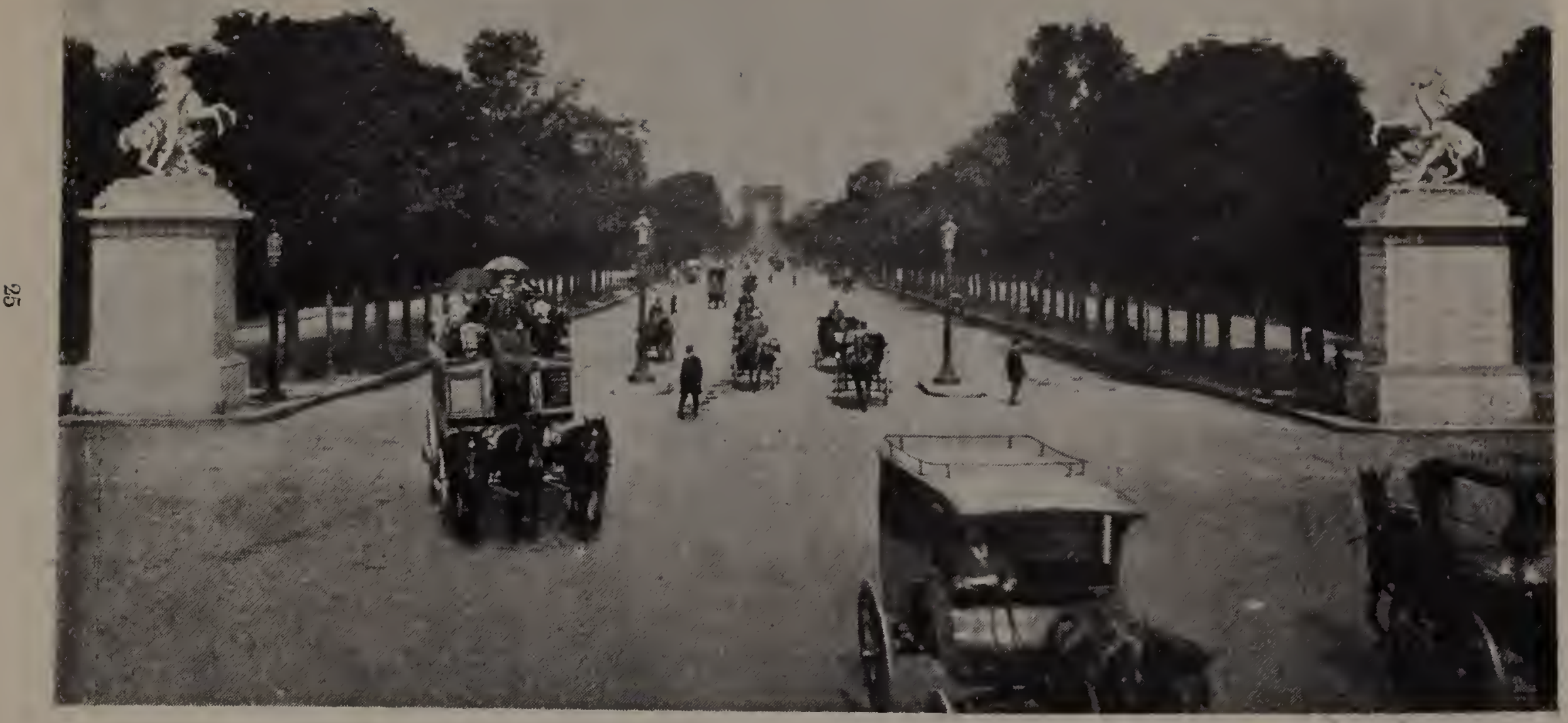

AVENUE DES CHAXIPS ELYSEEES, PARIS. 
by those who choose to pay extra for being sea-sick in an exclusive mamner. As these cabins are limited in number, and the demand for them in the season is brisk, it is necessary to engage beforehand. When the hoats are crowded, and especially for the night passage, they are certainly a desirable luxury.

On il finc, calm day, or when a faromable breeze enables a sail or lwo to be carried to steady the hoat, the passage is full of cugryment. The steamers and sailing ships of all kinds making their way down into the English Channel, or up into the North Sea-from the little coasting schooner or collier brig 10) the stitcly Australian or Ancrican clipper-the opposite shores of England and France both plainly visible from the deck in mid-channel-the surface of the sea itself, with the endless play of cloud and sumshine varying its tints-all combine to interest and amuse the traveller. Thus in many cases there is hardly time to lake in the beantics of the scene before the lighthouse and piers of Calais harbour are reached; the steamer slides smoothly up to the landing-stage, and the passengers are disembating and trooping up the slippery steps to the quay, those who carry hand-bags being greeted with the polite inquiry-"Monsicur, n'a rien i déclarer ?" which means that if there he any catuse or just impediment why the said hand-bag should not pass the Customs of the Port of Calais without paying duly, ye are to declare it. And here it may be noted that civility in dealing with the French officials, whether of the Custom House, the Railway, or the Police, is not only commendable in itself, hut is decidedly, like honesty, "the best policy." The arerage French and German official has a large amount of what he calls amour propre, or sense of personal dignity; and nothing irritates him so much as the "Haw-look here, you fellow," style adopted, without intention of giving offence, by ton many English travellers. Years ago, Thackeray, himself a model traveller, took occasion in his "Snob Papers" in Pllnil, and in other works, to deprecate the rudeness displayed by many English travellers, and their utter disregard of the feelings and susceptibilities of those whom, even when travelling abroad, they insist on considering as "foreigners." "When I note the behaviour of my dear countrymen abroad," said Thackeray, "I camnot wonder that we English are so belnved on the Continent." Much has altered since Thackeray wrote, but there is still room for improvement. 
By the opening of the railway bridge built over the River Liane at Boulogne to shorten the distance between Calais and Paris, a saving of about twenty minutes in the time of the journey between London and Paris by the Calais and the Boulogne routes has been effected so far as the day mail services are concerned. The night mails are not altered.

\section{Calais.}

Here, as at Dover, the railway runs to the pier, and passengers step from the quay at once into the carriages. There is generally an interval, nominally of twenty minutes, but in reality of half an hour, before the departure of the train for Paris, giving time for refreshments; and here again the traveller will note with approval an advance in the comforts of modern travelling. The "Buffet" is a really first-class, well-conducted restaurant ; in fact it is one of the best in France, as unlike as possible to that famous "Mugby Junction" establishment, with its stale buns, petrified pork-pies, and fossil Banbury cakes,-where the facetious American was fain to try and sustain exhausted nature with butterscotch.

Calais, though highly interesting from historical associations, does not offer enough points of interest to induce many travellers to break their journey. It is a quaint, old-fashioned place, the ramparts and fortifications, greatly interfered with now by the requirements of modern building, giving it a mediaval and picturesque appearance. As the railroad for some distance runs along the sands outsicle the walls, the traveller gets a good idea of the town in passing along. There are two principal gates; the one towards the sea has been immortalised by Hogarth in his well-known picture "Calais Gate," now in the National Gallery. From 1347 until 1658 Calais was in the possession of the English, having been taken by Edward III. in the former year, and reconquered in the latter by the Duke of Guise from Queen Mary, whose death is said to have been hastened by the loss.

\section{The Railway to Paris.}

The Northern Railway of France (Chemin de Fer du Nord) takes the traveller on to the capital. The route is first in the neighbourhood of the sea-coast to Boulogne (sec p. 29). We pass Abbeville-famous for its Cathedral, and near which is the field of Creçy-and Amiens, another cathedral town, where we skirt 
Llat River Somme which Edward 11I. had such trouble to cross, until the peasant Gohin Agace told him of the cxistence of the ford of Blanchetaque. Amiens is well worth seeing, and the traveller with lime at his command may find good reason to break his journcy there. The town itself, with its hroad, wellhuilt strects, its museum wilh many noteworthy curiosities, its linc public library, containing 40,000 volumes and many valuable mantuscripts, its molversily, and botanical gardens, is a specimen of a peosperous french provincial capital. But the chice attraction is the Calledral, one of the finest Gothic buildings in Eumope. It was commenced in the twelfth and finished in the fomlecull century. "Its interion exhibits one of the grandest specticles which atrilcotural skill hats ever produced; whilst the mind is deeply impressed hy the exquisite proportions of the huilding, and the noble simplicity of design and ormamentation which everywhere meets the eye. Its length is 442 feet, including the walls and the westem entrance, and the nave is Ifo feet high, from the sround to the crown of the vaulted roof, which is half as high again as that of Westminster. The spirc liati an elevation of 420 fect."

At Amiens there is generally a short stoppage, during which those who, for reasons not unconnected with the Channel passage, have not hecn able to eat at Calais, may have a chance of a cup of coffec nr other light refreshment. Then there is a run of some seventy-two miles hefore the train finally stops at the terminus of the Chemin de Fer du Nord at Paris, and the jounney is accomplished.

\section{The Folkestone-Boulogne Route.}

In travelling by this route the distance to Paris from London is diminished by 28 miles, and by the express train a saving of about forty minutes is effected; but, on the other hand, the sea passage is somewhat longer, occupying about one hour and twenty or thirty minutes, the distance across Channel being set down at 29 as against 22 miles. The single and return tickets to Paris viâ Boulogne are slightly cheaper than viâ Calais (sce p. I9). The return tickets viâ Dover and Calais are available for return viâ Boulogne and Folkestone, and vice rersâ ; and we should certainly counsel our readers to go by one route and return by the other, especially if they desire to break the journey at Calais and Boulogne respectively. 
Tickets issued at excursion fares by the South-Eastern and Chatham Company are available by either route in each direction.

Few towns have undergone so thorough a transformation in the course of time as Folkestone. Charles Dickens many years ago gave a humorous account of the town, under the title of "Pavilionstone" - describing how in the prosperous days of smuggling the lamplighter's was considered a "bad life" at the assurance offices; and how, if that functionary attended too sedulously to his duty of lighting up the town, he "generally fell over the cliff at an early age "-while people who had no ostensible employment made rapid and mysterious fortunes. Dickens also describes the discomforts of the journey many years ago, when the route via first opened - the draughty, barnlike room in which the passenger who came down overnight that he might leave by the boat in the morning, wandered disconsolately, until he was "pushed against the cold beef," and so to bed. The opening of the Folkestone-Boulogne route to the Continent has been the making of the town, which is now one of the most thriving of our fashionable seaside resorts.

The steamers on the Folkestone-Boulogne line are powerful and swift, and, like those on the Dover-Calais route, are furnished with deck cabins for those who are content to pay for exclusive accommodation. The vessels used for the services are the Mabcl Grace, the Princess of Wales, and the Duchess of York. Leaving the promontory of Cape Grisnez on the right, the steamer quickly runs in between the two tall towers at the extremity of the long piers forming the entrance to Boulogne harbour. As at Calais, there is time for refreshment before the train starts for Paris, and there is an excellent restaurant. Another advantage of this route is that twenty minutes is always allowed at Amiens for lunch on the journey from Paris to London by the morning service.

\section{Boulogne-sur-Mer.}

A good view of Boulogne is obtained as the boat approaches the harbour. The steep streets rumning at right angles from the quay, are compused of small but well-built houses. The costume of the fisher-women and girls is picturesque and effective. On the heights may be seen the column erected by order of Napoleon 
I., to commemorate the camp in which the army of France wated to receive the order, which never came, for the invalsion of the opposite shores. Il was from Boulogne that the grand allempt was to have been made, and here was gathered the flotilla that was to convey the army across the Channel. Boulognc, its a seatside place, has many points of advantage and has long enjoyed a great popularity. During the season, which lasts from fuly till the beginning of October, the sands are alive with holidily-makers, bathing, or whiling away the time in the usual seaside fashion. The visitors always comprise a large contingent from fingland; and at various times the place has heen at haven of refuge for Britons compelled by pecuniary difficultics to yuit their native land. Puncli's facetious woodent representings a disippointed creditor gazing on a shut door, whereon is inscribed the legend "Gone to Bolong; back in a lwelvemonth," had a strong foundation in fact.

The Colluedral is a modern building in the Classical style. Its done forms a conspicuous object from the sea. The fashionable part of the lown comprises the bathing establishment, casino, and public square, near the harbour, and the long promenades in front of the scal. The upper town, with its ancient fortifications, gives a very quaint and picturesque look to the place. "I strolled along by those pretty old walls and bastions," Thackeray makes Arthur Pendemis saly, " under the pleasant trees which shadow them, and the grey old gabled houses, from which you look down on the gaty new city, and busy ports and piers stretching into the shining seat, dotted with a hundied while salils or black smoking steancrs, and bounded by the lriendly lines of the bright English shore. There are few prospects more charming than the fannilial view from those old French walls-few places where young childreu may play, and runinating old age repose more pleasantly, than on those peaceful rampart gardens."

The third rute to Paris, and one that is extensively patronised by travellers, is that by-

\section{Newhaven and Dieppe.}

There are two claily services by this route in each direction and the London, Brighton and South Coast Railway Company have so improved the accommudation and steamers, and accelerated the speed, whilst maintaining the cheapest and lowest fares 
charged by any line, that it is only fair to say that this has become the popular route for tourist traffic. The passage across the Channel is rather more than double the length of that to Calais or Boulogne. Fares and details of the service will be found on pp. 20-2I, but in a word, by the day service, leaving London at I0.0 a.111., one arrives in Paris at 6.5.5 p.m., in time for dinner, or leaving at 8.50 p.m., one anives in Paris at 7.15 a.m., in time for breakfast. The objections against night travelling are considerably lessened on this route, on account of the fact that several hours' sleep can be obtained on the steamer, and the arrival at Dieppe in the early morning enables one to travel by daylight through the beautiful Normandy scenery. Thus none of the interest of the route is lost or curtailed, except the Channel passage, to which fact the majority of travellers will make no objection.

The traveller starting from Victoria or London Bridge is swiftly carried past Croydon, Redhill, and Three Bridges. At Keymer Junction the line branches off for Plumpton, Lewes, and Newhaven. Those who have al day or hall a daly to spare may well break the journey at the interesting old town of - .

\section{Lewes,}

the county town of Sussex, lying snugly ensconced annong the glorious South Downs. Lewes is historically important it the scence of the great victory won by Simon de Nontiort in the Barons' war, on May It, 126I. Both King Henry III. and his son Prince Edward, afterwards Edward I., were taken prisoners.

The principal objects of attraction are the Castle and the Priury. The former is one of the most interesting Norman ruins in England, and seems to dominate the town. The Muscum of the Sussex Archeological Society can be inspected at the same time as the Castle. The visitor may also care to see the ruins of the great Priory of St. Pancras, founded by the Earl Warrenne of the Conqueror's time, which continued to be one of the most important religious foundations in England until the dissolution of the monasteries by Henry VIIf. Many interesting details concerning Lewes, Newhaven, and the surrounding country are contained in the Guide to Brighton in this series. 
A short distance from Lewes is our port of embarkation-

\section{Newhaven,}

Which wies its importance to the establishment of the line of stcumers fo the Contincunt, aibi Dieppe. At first the Dieppe steamers used to run oul! in the summer months, and the point of conbarkitim was the now defunct Chain Pier at Brighton. Of conse this lould only do in line weather, and the necessity 101 il harhour catused Newhaven to be selected. The harbour is onc of the lincist on the South Coast, and has recently been still furfher improred. When the French Revolution of Febmatry, Isfor, dowe bouis Philippe from the throne, he landed at Nellhalll with his quecu, Matric Amélic, having crossed the Chamel from Treport in a lishing vessel.

The seib passige between Newharen and Dieppe is usually acomplished in about three and a quarter hours by the new 2l-kned stcinners employed on the day service. The night stcamers litic at little longer, but this is, perhatps, an atdvantage. Benth services are remakably regular. Upwards of 178,000 pilscengers patsed through the port in 1890 .

Althongh the sea portion of the journey occupies a little longer than by Calais or Boulogne, it is generally found that Hhe seit at the point of the Channel between Newhaven and Dicppe, even at its worst, does not cause the bad sea-traveller so much discomfort ats when crossing narrower portions, a fact itlributed to the general absence of "choppiness," so distressing (1) lllally.

\section{Dieppe and Rouen to Paris.}

The seapurt of Dieppe, hongh more important than Newhaven, hats, like that lown, been considerably benefited by the establishment of the line of railway to Paris. It has long been in repule as a bathing-place, and is less expensive than some of its rivals on the coast, which, rightly or wongly; have earned an unenviable notoriety in the matter of the operation the French call "écorcher les royageurs" (skinning or flaying tratellers). It is situate at the moulh of the river Arques, and has ramparts, which form a pleasant promenade, as at Boulogne. The sands present a lively scene during the season, and at all times the sound of the shipbuilders' hammer is to be 
hearl in Dieppe. On the west side of the town is the old castle, an object of interest to the archeologist.

Passing through north-western Normandy, the route from Dieppe to Paris is far more picturesque than the tract traversed from Calais or Boulogne. The features of the country, with it cornfields, meadorvs, and woodlands, in some measure recall the fertile regions of Kent. Through the tumnel of Appeville, nearly a mile in length, and past St. Victor and Clères, the traveller reaches-

\section{Rouen.}

This is a most attractive town, and well worth exploring if the tourist can spare time. It is on the Seine, and was, in the Middle Ages, the capital of the powerful Dukedom of Normandy, and a favourite residence of the Norman and earlier Plantagenet kings of England. It was formerly surrounded by walls, which have, as in various other cities, given place to promenades. Thus the old town, with its quaint, lofty buildings, is within the circle of these, and outside are the modern suburbs. The great attraction of Ronen is the fine Gothic Cathedial, erected at various periods between the thirteenth and the sixteenth century. The north flanking tower of St. Romain belongs to the oldest part of the building. The snuthwest tower is called the Tour de Beurre or Butter Tower, having heen built with money obtained by granting indulgences to eat butter during Lent. The catheclal contains the tomb of Rollo, the first Dulie of Normandy, to whom the fertile district of the Lower Seine was granted by Charles the Simple in the tenth century. Here, also, was deposited the heart of Richard I. of England, whose body was interred at Fontevrault, at the feet of his injured father, Henry II. The heart was found, enclosed in a leaden case, in 1838 , and is now deposited in the museum. The antiquary interested in medieval ecclesiastical architecture will find much to interest him in the churches of Rouen, St. Laurent, St. Gervais, St. Patrice, \&c. The tourist will also find the Departmental Museum full of interest in the way of antiquities; and there is a good gallery of pictures at the Hôtel de Ville. The statues of Joan of Arc, and of the tragic poet Corneille and the musical composer Boieldieu, who wrote the opera "La Dame Blanche," founded on Sir Walter Scott's "White Lady of Avenel," are also noticeable.

The railway from Ronen passes onward through Mantes, the 
(own where William the Conqueror received the hurt that led to his death a few days later at Rouen.

Like London and Vienna, Paris is sitnated in the tertiary formation of clays deposited in a great chalk basin, which shows itself from Mantes to Poissy in the white aspect of the ridges of hills.

\section{The Southampton and Havre Route}

also has its attrations. There is, however, no option in the matter of day or night travel, there being only one service, leaving London al 9.50 p.m. and arriving in Paris either at I 1.30 a.111. $01^{\circ} 3.5 .5$ P.11., depencling upon the state of the weather and other combingencies cuabling the steamer to arrive in time for passengers to take the 8.15 a.111. train from Havre to Paris. The sleamers. Alma, Colmmbia and lirorare well fitted and furnished, and those to whom time is a secondary consideration will find this unc of the most comfortable routes for crossing the Channel.

The tickets from London give the option of proceeding to Southampton by any previous train, thus affording time for a look round this prosperous and interesting town, or even an excursion to Netley Abbey and Hospital hefore embarking, as the steamer does not start until midnight. The steamers between Southanpton and Havre run every-week night. The latest train by which passengers can travel leaves London (London and South-Western Railway Terminus, Waterloo Road) at 9.50 at night, and the boat starts immediately on its arrival. The distance across Channel from Southampton to Havre is II9 English miles, and the passage, under ordinary circumstances, occupies about 8 hours-one and a quarter of these is occupied in the river passage down Southampton WVatcr, so that the traveller has time to get comfortably in sleep hefore the open sea is reached. Passengers with first class tickets leave Havre by the 8. I 5 a.m. express, immediately after the arrival of the steamer, and set to Paris at I I.30 a.m. Passengers for the second class remain in Havre until the 9.30, which will deposit them in Paris at 3.55 . Passengers with second class through steam-packet tickets from Paris to London, or other stations, are allowed to travel first class hetween Paris and Havre by any train on the day of steamers sailing from Havre on payment of 8 francs 30 cents at the railway station, Paris. In returning, the latest train leaves Paris 
(the St. Lazare Station, Chem. de Fer de l'Ouest), at 6.52 P.m. for first and second class passengers, but tavellers may go by any earlier train. The boats leave Harre at $1 \mathrm{I} .45 \mathrm{p} . \mathrm{m}$. and arrive at Southampton about 6 a.m., and the train for London starts from Southampton at 6.50 in the morning, getting to Waterloo Terminus, London, at 9.45. So here again the traveller has the opportunity of a sond night's rest on bourd,

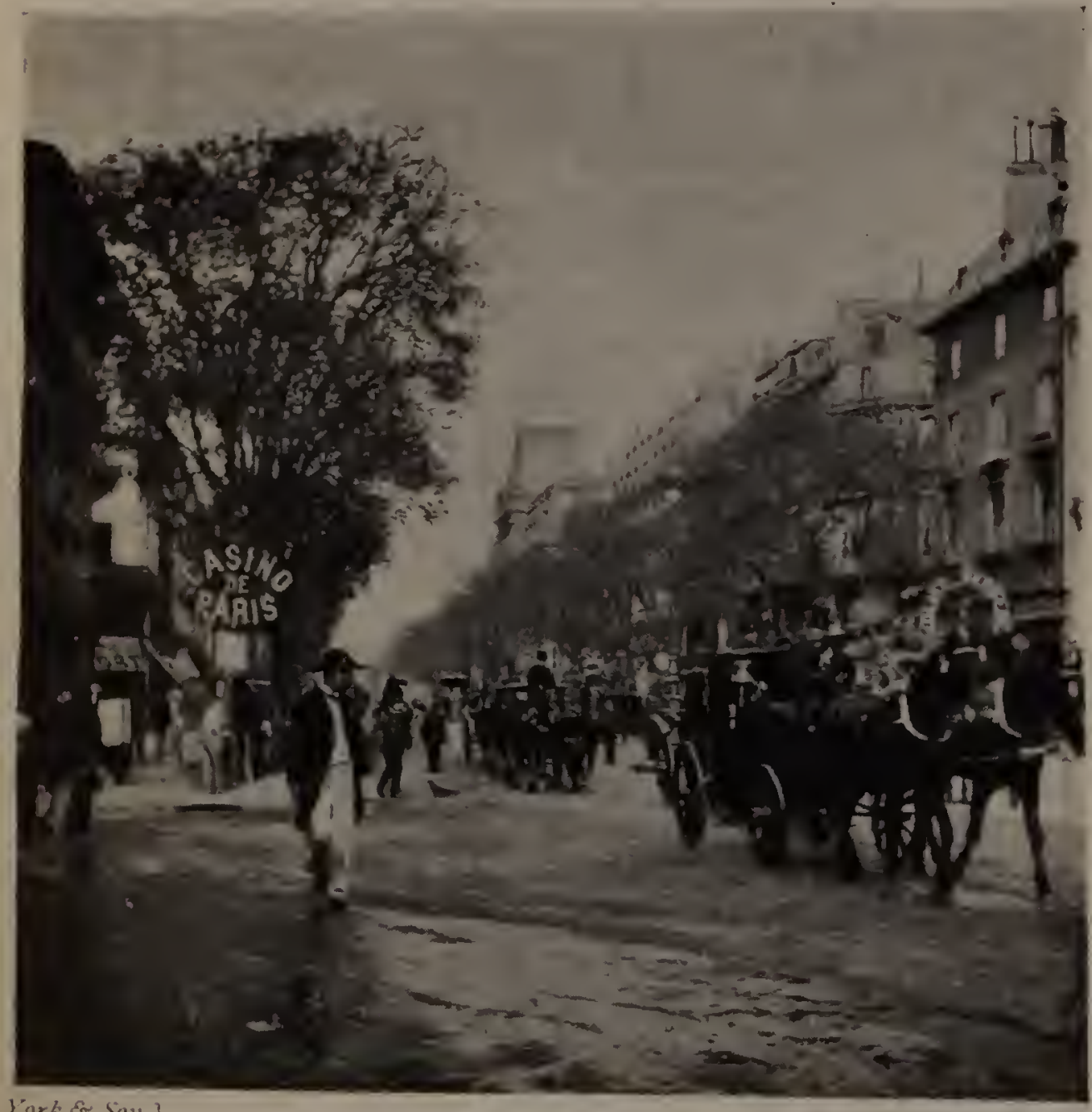

York \& Son,]

BOULWTARD DES ITALIENS, PARIS,

[Notting Hill.

always presuming he is able to sleep on a steamer during a Channel passage.

\section{Southampton}

is one of the most ancient of English towns, and from Saxon limes downwards was important as a place of trade and a port of arrival and embarkation. It was from Southampton that the 
wallike Ileng the fifth embarled on the expedition immor. lalised by the victory of Agincome. The North German Lloyd steamers for New York and also the American Line, the Union, and several other important lines make Southampton their point of departure.

From the Quay, which adjoins the railway terminus, the principal strect runs northward for more than a mile, being divicled into two portions hy the Bar-gate, an ancient edifice which crosses it in the centre. The parts of the High Street on cach side are respectively known as "Above Bar" and "Below Bar." The famous docks are of course the principal featue of the place. Immediately to the east of Above Bar Street are the public parls, tastefully laid out. The principal object of interest in the ncighbourhood is the beatiful ruin of Netley Abery. The Nore liorest, with its wealth of foliage and interesting historical associations, is close at hand. An excursion to Rufus's Stone by one of the four-in-hand breaks rumning almost daily is an enjoyable experience. See the Guidc fo Bonrmemonth and the Now Forcst in this Series.

The steamer starling at midnight from Southampton carries the traveller across the Chammel to-

\section{Havre,}

which, though comparatively a modern town dating only from the time of Francis $I$., is a place of considerahle importance, wilh more than I 0,000 inhabitants.

The magnificent docks are ts chief feature and the principal cause of its prosperity. The most prominent objects on approaching the port are the two lighthouses, each fifty feet high, that have been erected on Cap de Herie, and at night-time shine forth brilliantly with the electric light. Havre is situated at the estuary of the Seine, and is said to have a greater trade than any other French port, Marseilles alone excepted, and of this trade British ships engross a large share. Among the public buildings the handsome Hôtcl de Ville, in the Renaissance style, will interest the visitor. The Museum, which has an important library, is not far from the Pier. The Aquarimm, on the Place St. Roch, should also be seen. Those who have the time should take a walk to the neighbouring Ingourille, a pretty place from whence very fine viers of Havre and its neighbourhood are 
obtained. It was from the town of Havre that Henry of Richmond sailed for Éngland in I485, to do battle with Richard III. for the crown of England. During the reign of Elizabeth it was for some time in the possession of the English, to whom it had been delivered by the Huguenots; but the town was re-taken by the army of Charles II. after an obstinate siege, during which Ambrose Dudley, the English commander, was slain. Admiral Sir Sidney Snith, the hero of St. Jean d'Acre, was captured off Havre in I 796 , and for a time shut up in the Temple prison in Paris, whence, more fortunate than the French royal family, he effected his escape. The train from Havre to Rouen passes Harflcur, once the chief port, at the mouth of the Légarde, besieged and taken by Henry V. in ${ }_{1}+1_{5}$, in the celebrated Agincourt campaign. The old Gothic church was erected as a thank-offering for the great victory. Then past the town of Y'r'tot, immortalised by Béranger's ballad "Le roi d'Yvetot," a satire on Napoleonic ambition, and thus to the junction with the Dieppe railway near Rouen, whence the route is identical with that viâ Newhaven and Dieppe.

\section{The Thames Steamers.}

For those travellers who like a trip down the Thames, there are the ressels of the General Steam Navigation Company, which run from London direct to Boulogne (fares, $11 /$ - and $8 /$ ) two or three times a week; while the new Palace steamer Company run an excellent service by the splendid and commodious passenger steamers La Marsucrite and La belsiqui during the summer months. Details of these services, however, must be obtained from the newspapers, as they are not regular and permanent, but season arrangements, having no fixed connections beyond Boulogne. 


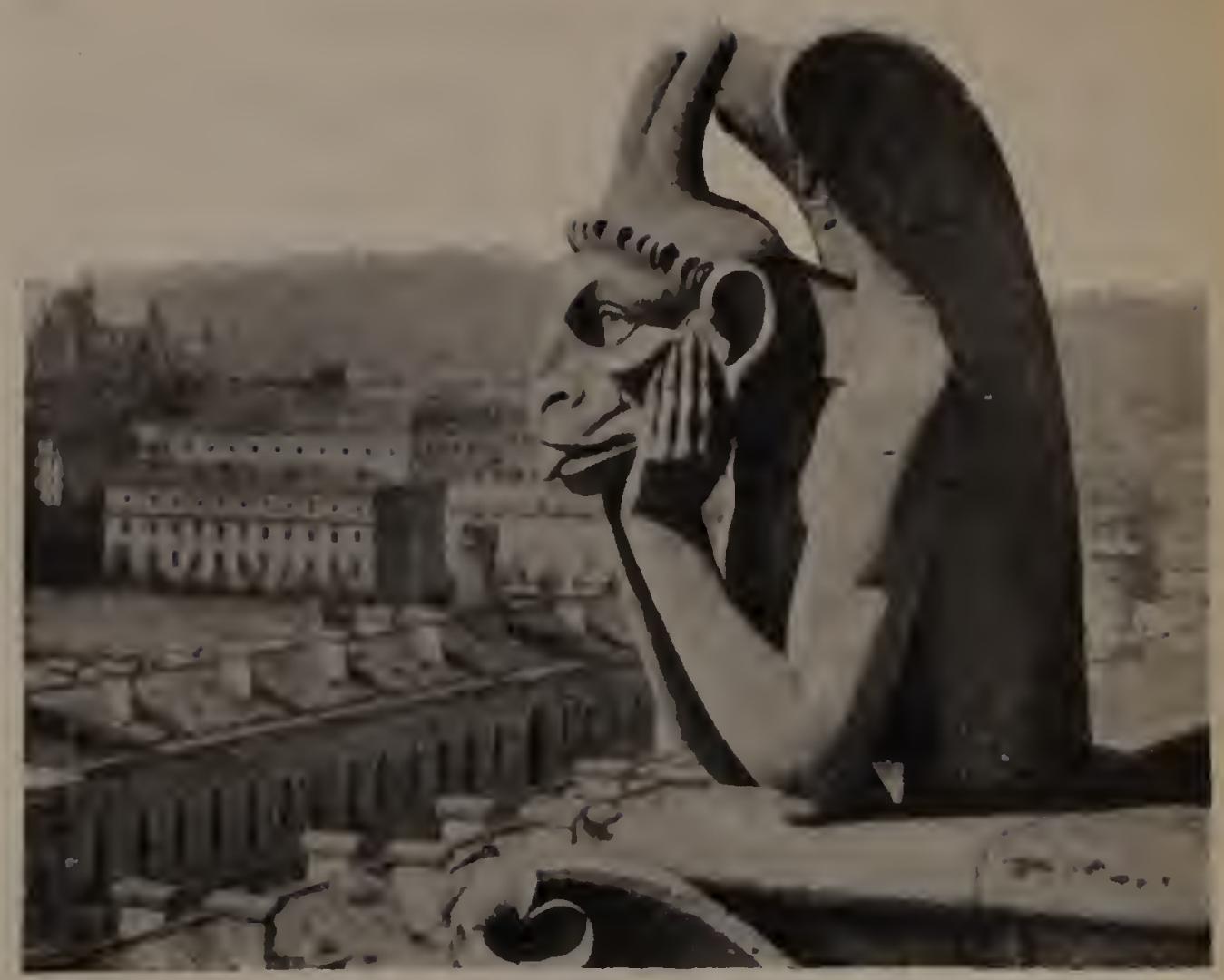

A FIGURL ON THL TOWER OF NOTRE DAME.

CHAPTER 11.

\section{SHORT HISTORICAL ACCOUNT OF PARIS- ANCIENT, MEDI EVAL, MODERN.}

Dimemsions ant Dislances-The Paris of the Romans-The Paris

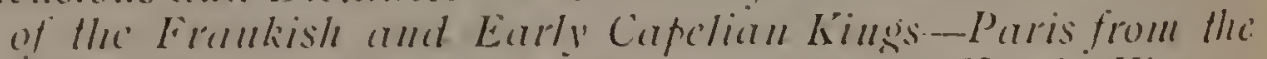

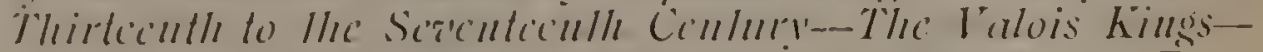
Relletissance P'riod - Lomis XIII. and Lomis XIT.-From

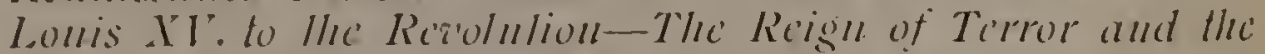
Dircelory-The: Paris of the Comsulati: the First Empire and the Resloralion-Lomis P'liliffe's Improiements-Rebuilding of Paris by Nipolcon III.-The Third Refublic; the Paris of To-da!?.

DARIs, the most interesting of continental cities, is at the circular, and having a circumference of nearly fifteen English miles. According to the last census, taken in $189 \mathrm{r}$, the number of inhabitants was about $2,500,000$. It is about 270 miles from London. The Seine traverses it much as the Thames floris through London, the greater part of the city being to the north of the river. But as the course of the seine is from 
edst to west, a person standing on one of the bridges and looking "dow'n stream" would have the north bank ("rive droite") on his right, and the south bank ("rive saluche") on his left hand.

\section{Lutetia Parisiorum, the Ancient Paris.}

Like London and most other capitals, Paris has a history whose origin is lost in the mists of anticuity. Francus, a son of Hector, says the fable, founded the cily, to which he gave the name of Paris, his uncle-just as the old English Chronicles gravely assert that Brutus, the nephew of Aneas of Troy, founded a city on the north bank of the Thames, which he called New Troy, or Troy Novante, which name was to be found, with slight alteration, in the Trinobantes whom Caesar found in Britain. Putting aside, like Shakespeare's Theseus, as "more strange than true, these antique fables and these fairy toys," we come upon a bit of authentic information, dating thirty-five years before the Christian era-a very respectable antiquity to start from. In that year Julius Caesar was pursuing his career of victory and conquest in Gaul; and in his commentaries we are told how the great Roman general sent his lieutenant Labienus with four legions to Lutetia Parisiorum"the fortress of the Parisii" - situated on an island in the river Sequana. This island was what was afterwards known as the Isle de la Cité in Paris-the oblong space in the Seine, on which the towers of Notre Dame afterwards rose-an area nearly three-quaters of a mile in length, which, with the smiller island of St. Louis, may be considered as the nucleus of modern Paris.

Ciesar besieged and took Lutetia, compelling its inhabitants to submit to his rule, and civilised them according to Roman fashion by compelling them to renounce the worship of their own gods, and burn incense to the deities of Rome. A temple to Mats was built on the heights of Montmartre, and another to Jupiter on the island of the Cité. Lutetia-whose name has been variously derived, the most plausible etymology being from the Celtic, meaning a city on the waters-had become a place of some note by the fourth century, and communication had been already established between the island and the two opposite banks of the river by means of bridges, and some villas had been built here and there in the forest with which 
He laud on the right bank was almost completely corered. Of Hee huildings of this period the most important was the Palais des Plermes, the residence at one time of the Emperor fulian. The rums of this building are to he secel to the present doy adjoining the Hotel de Cluny. Julian has left on record his appleciation of ancient Paris, which he spealis of as "my. deall I.utetia," and he describes the situation of the fown "built in the nidat of the river, upon a little island, bridges joining it lo llac mitin land un each side. The river," he continues, "doces nut alte" will the scitsons, and is as navigable in winter

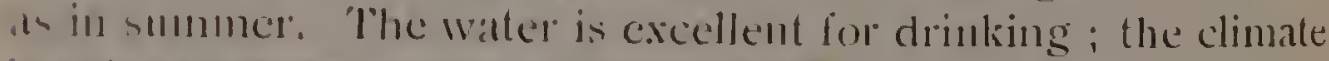
is srit and incuial, perlatps from being near the sea ; the vines .He suod in quallity, and very mumerous." Thus it will be seen Hall the fance of Pants, ats a delightful place to visit, is of very alleient dalc.

\section{The Paris of the Frankish and Capetian Kings.}

In the fourth and lifth centuries the dominion of Rome was more and more menaced by the barbarian nations; and among the most persistent encmies of the great empire were the Franks, (1) Firement, at mion of tribes dwelling beyond the Rhine, some near that river, from which they obtained the name of Ripuarii, (1) unen of the ripa or hatk, and others neat the sale (Salians) and in the district still linown ats Fanconia. They attacked the Romans in Gaml, making predalory incursions across the Rhine: and Childehert, once of their lings, tork Luletia. Then it was that the holy maiden Genevicene, alterwards canoniod by the Roman Catholic Chureh, and looked upon as the patron saint of Ulue city, with her pious sister, did good service to Paris, first by conveying into the place an abundant supply of provisions, and aflerwards by ohtaining for it exceptionally lenient treatment from the victor. Saint Génêviève died at the age of eighty-nine, atter a long life of good works. The earliest saint connected with Paris wats Salint Dionysius, or Denis, who had introduced Christianity into the cily in the middle of the third century, and became the first bishop of Paris. He was beheaded A.D. 272, by order of the Roman governor, and the legend asserts that after his decapitation he marched across the Seine, carrying his head in his hands, before him. The savage concueror Clovis, the real founder of the french monarehy, and establisher of the race of the Merovingian kings in Gaul, chose Paris for his resi- 


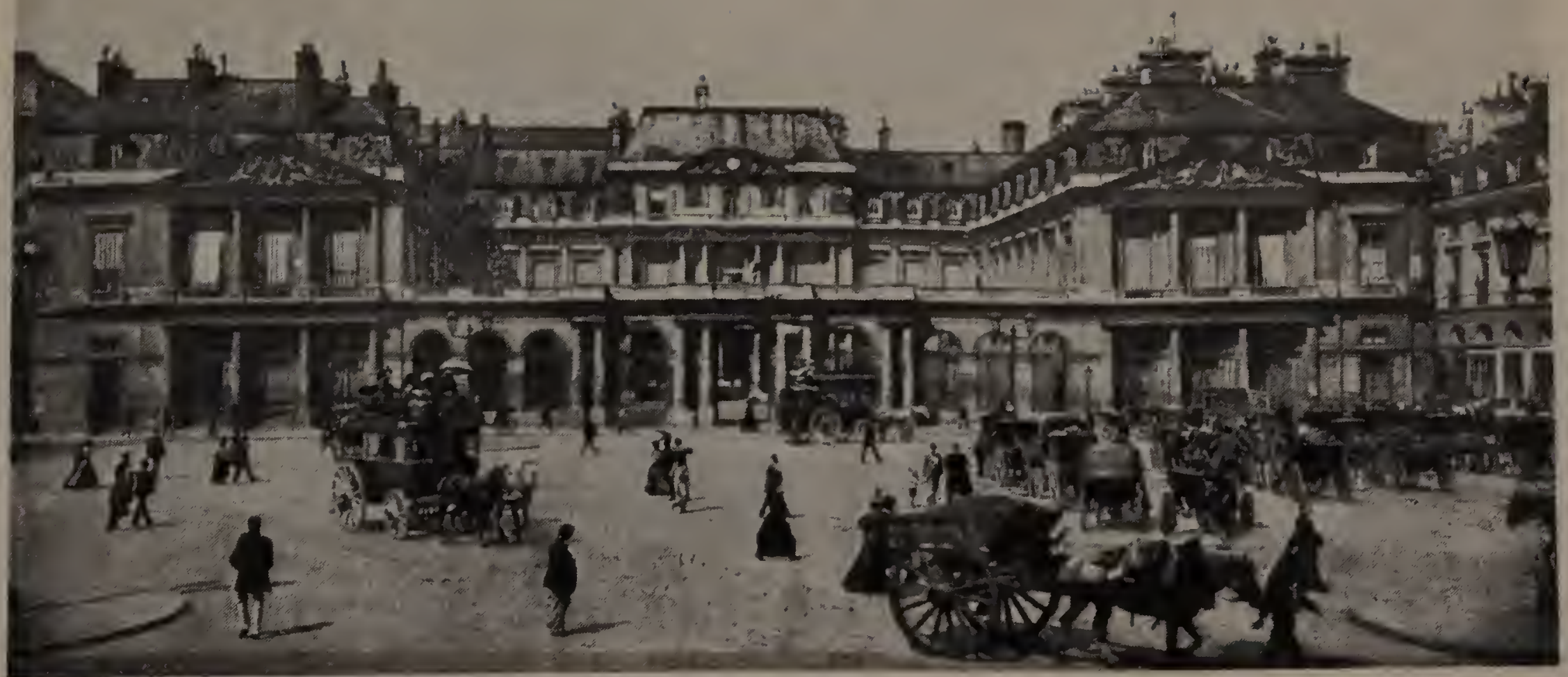




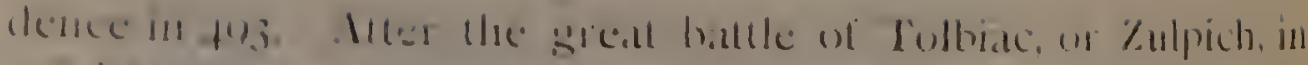

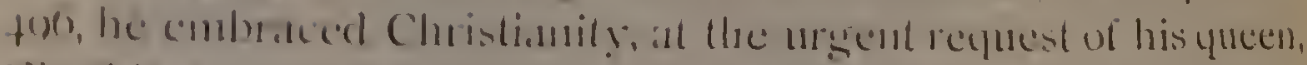

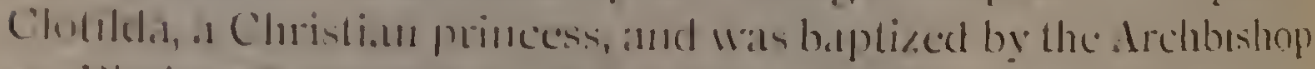
of Rhcinss, Remigim, in lhe callhedral of llat city. "Pstron,"

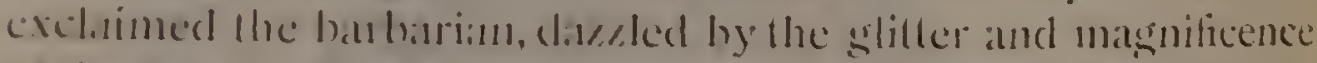
11) the areat cathedral and its ectemonial, " is this the kingdom of leselven llath houn hats promised me?" Being the first among une Fententic iontuerens of Ronte to embrace Christianity; Clusis Mats dignilied hy the lille," Eldest son of the Church," an mpellation ever since ictaned by the kings of France. Though mominally a convert to Christianity. Clovis icmatined a bloodthirsty typant like most of the lings of his race. One of his last ilete llik lo pul to cleall a munber of his relations that they uniglnt ant interfere wilh the pretensions of his four sons, Thiery, Clodomir, Childebert, and Clobare, among whom he divided lis kingdont. Ender lle sons of Clovis the Frankish kingdom h.ud four chice citics-l'us, Orleans, Soissons, and Met\%. But Clestare, afler a lime, obtanted the sole power, and Paris wats for a while the metropolis.

Chalemagne, an Austrasian, of German Frank, chose dix la Chapelle for his eapital; under the Carlovingian kings Paris made little progress. In 885 it was hesieged by a large army of hardy Norscmen, who, however, failed to capture it. The suburbs or laubungs of St. Gencevieve and St. Germain l'Auxcrons wele enclosed within the cily walls at the close of lle lemth eculury: and Hughes Capet, or Hugh with the big heatel, the first kings of the lhird of Capetian race, again made Paris the capilal ; and from that lime its prosperity and increase were rapid, the prevot des Marchands, or provost of the mechants, excreising almost kingly jurisdiction within the circuit of its walls. The city carried on a considerable commerec with foreign countries hy means of the seine; for the trading ships of those days required little depth of waller, and could come easily up to Paris. In these modern days, by the way, the same thing is once more done by means of the little screw steamers, which maly be seen loading or unloading on the quays by the Pont Neuf at Paris, and placarded "pour Londres"- - and a similar line trades between London Bridge and Cologne on the Rhine). It was by commerce that Paris grew into importance; and hence the relevancy of the city arms, a galley in full sail, with "Fluctuat nee mergitur" for a motto. 
The wealthier citizens, such as the merchants, inhabited the northern shore (rive droite) of the Seine; the humbler inhabitants lived crowded together in the "Cite" ; and the souther" bank (rive gauche) was the clerical quarter, with churches, monasteries, and religions foundations generally, whence arose the "Quartier Latin." For under the reign of the ablest king of the old Capetian line, Philip II., surnamed Augustus, the contemporary of our Richard I. and King John, the different schools in Paris, which already contained close upon 20,000 students, were consolidated into a great university, which soon becane renowned as one of the foremost seats of learning in Europe. Thus, at the beginning of the thirteenth century, Paris contained the three quarters known as the town, the city, and the Latin district.

\section{Paris from the $13^{\text {th }}$ to the 17 th Century.}

The French kings found their power much restricted by the feudal nobility. The great dukes frequently acted in disregard or even in defiance of the royal authority, ruling their various domains like independent monarehs. Shakespeare rightly makes his king Henry V. speak of "France and her almost kingly dukedoms." Philip II. wals anxious, as were his successors after him, to curb the power of the feudal nobles; and to effect this he raised the municipal power as a counterpoise, and gave great privileges and authority to the good citizens of Paris. The "bourgeoisie" seemed the natural opponents of the proud nobles; accordingly they became under Philip II, a duly recognised authority in the state, and afterwarcls developed into the "Tiersétat." They had a legal constitution, and were eren allowed to coin money. The fortifications of Paris were strengthened and extended under Philip II. and his immediate successors. The Louvre was buit on the site of a very ofd palace of the Merovingian kings. Notre Dame and the Temple arose; the pious Louis IX. built the Sainte Chapelle, and various churches and monasteries were founded. Thus, under Philip IV., called "Le Bel," little more than a century after the deceatse of Philip II., Paris contained nearly 300,000 inhabitants, and was considered an exceedingly wealthy city, having the pre-eminence in various industrial arts, and possessing many handsome buildings and paved streets. The miserable time of the first Valois kings saw the terrible "guerre de cent ans"- the hundred 
years war-in which the reigus of Philip VI., his son John, and the leign of Charles Vi., the iusane king, were remaliable for

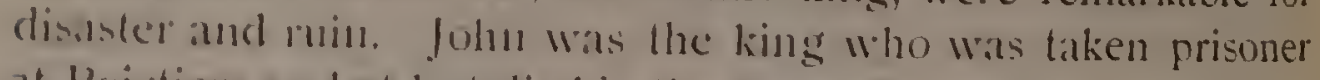
at Proictiers and at hast died in the sarrog Pallace in London. In lle reigu of Charles l., "the wise," an interval of comparative lrancuillity occured for linance, during which the ling greatly strengliencel the fortifications of Paris. Nevertheless, under Charles VI. the capital was taken by the English, who remained masters of Paris for sixteen years. France was regained from fingland mucler Clinles VII. The crafty and active King Louis XI., whose nical aim was to clestroy the purrer of the nobles, r.llece lavenred the municipal institutions of Paris, as likely to mantanin a comnterbalamcing influence aganst the nobility. Printing-nffices llere carly established in the capital, which besune the centre of litcrature, art, and science.

\section{The Renaissance Period-Henry of Navarre.}

The intlucuce of the Renatssance period was quickly felt in Paris, to which it spread from the south of Europe. Francis $I$. clubellished l'aris in vilrious ways; and still more was done by the influcnce of the wicked Catherine de Medicis, the wife of Henry J., Whosc power was paramount during the reigns of her clder soms. At this period the Lourre was pattly rebuilt, and the Palace of the Tuileries was besunt. At this time also the old Heitel de Ville was built, the tirst stone being laid in 1533.

The Tuilcries and Lonve obtained a sinister celebrity, connceled with the horrible massacre of St. Bartholomew on the

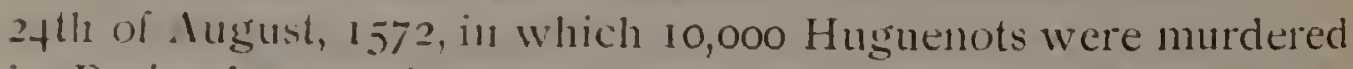
in Paris alone, and 70,000 throughout France. It was from a window of the Lonve, opposite the Church of St. Germain l'Auxerrois, that the signal for the massacre was given; and the wetched, half-frantic King Charles IX., the weak son of Catherine de Medicis, with his own hand fired upon the fugitives as they rushed along the qualy past the Tuileries. The terrible period of the Huguenot wars once over, Paris improved rapidly under the rule of Henry IV., "le bon roi Henri Quatre." Before the contest was settled, however, Paris had undergone a siege, in 5994 , in which it suffered the extremity of famine and other hardships, more than 13,000 persons perishing miserably in the beleaguered city ; while the fauboung were latd desolate, and even sumc of the streets of Paris itself looked deserted and 


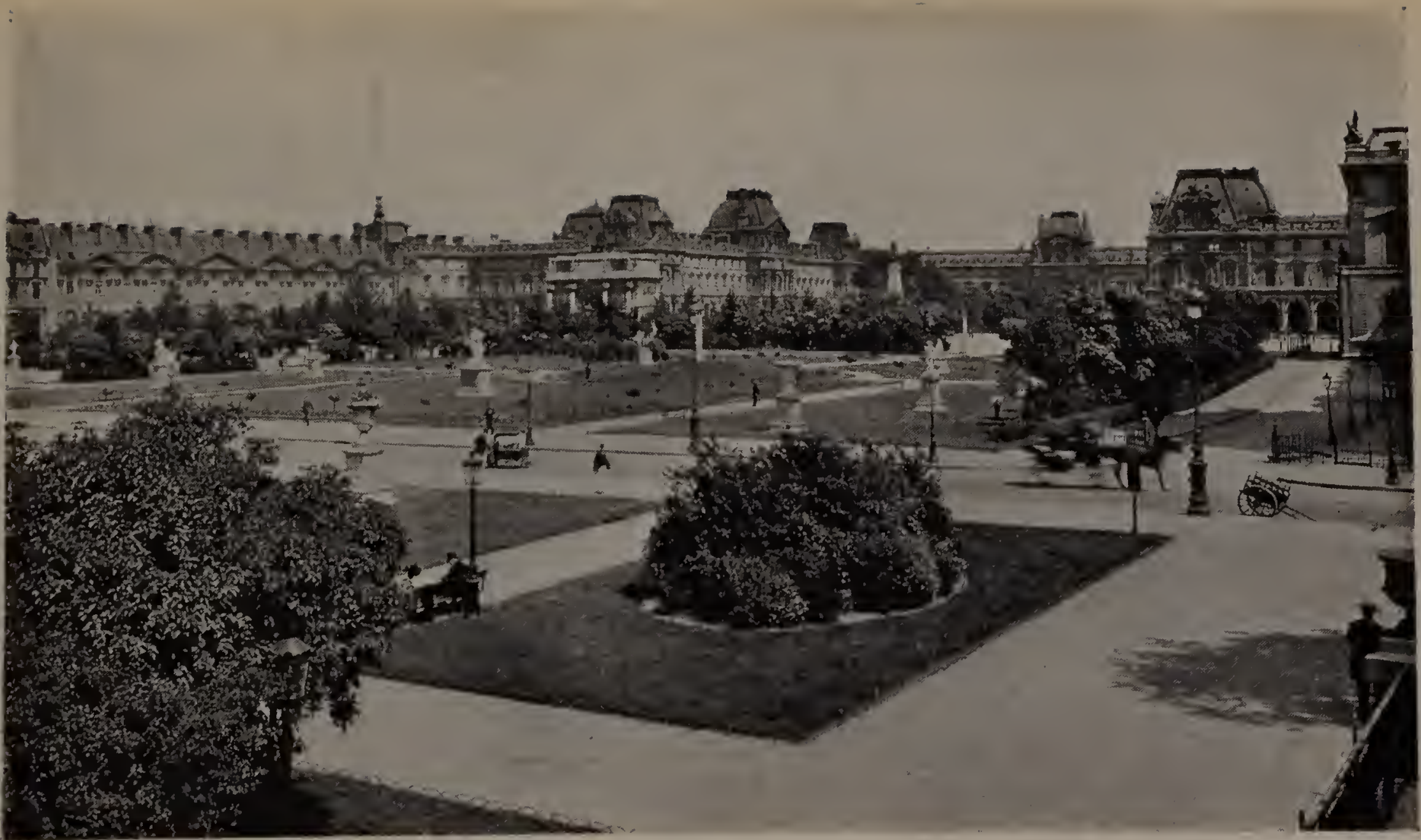

THE LOUVRE. 
rubed when peace was at length restored. During the years of tranquillity which followed, the sallant Henry of Navarre did sicalt things for Paris. Among his achierements may be reckoned llac completion of the Hotel de Ville, the building of lhe Pont Neui, on which his statue was afterwards placed, the chlarging and improving of the Louvre, Sc. Thus he proved a bencfactor to the city, which, according to one of its describers, "Iras, previous to his accessiom, composed only of miserable bujldings, sadly deficient in air and space, and without a single yuarter or stuare of which the Parisians had not cause to be ashamed." In 1010 the reign of the benevolent and kindlyupirited king llats suddenly cut short by the dagger of Ravaillac. liuler his successors paris continued to make great advances allice in citent and in heaty of appearance. From the time of lonis XIII. down'meds, Paris hecame more and more the city upon which others were modelled in Germany and elsewhere; the French style of architecture, French art in painting and sculnture, frouch fashions in literature, and even in dress, and lie habits and customs of ordinary life, became paramount in Emope; so that the boast of the Frenchmen, who declared their capital to he the centre of civilisation, was not enticely nnwarranted.

Maric de Medicis, the widow of Henry IV., became regent of Fiance upon her husband's death; and though this queen was hut a weak ruler-a sort of Queen Anne, with Concini, the Marechal d'Ancre, and his wife Eleonora Galigai, for her Duke and Duchess of Marlborough-Paris is indebted to her for various improvements. Thus she caused to be laid out the Cours de la Reine, now known as the Champs Elysées, and the Luxembourg Palace to be built. Later on, Anne of Austria, the queen of I, ouis XIII., huilt the Val de Grace.

\section{Paris under Louis XIII. and Louis XIV.}

Under Louis XIII. the royal printing-office was founded, and the celebrated "Académie " of the forty members instituted. A commencement was made of what afterwards became the great collection of the Jardin des Plantes; and Richelieu built the Palais Royal, then known as the Palais Cardinal. Paris became greatly widened in its limits ; new houses and streets were built, and under Louis XIV. the old ramparts were converted inio handsome boulevards, the old gates, such as the Porte St. Martin 
and the Porte St. Denis, heing converted into handsome arches of triumph in honour of the "Roi Soleil," the brilliant king, the greater part of whose glory was reflected on him by the eminent men who surrounded his throne. Louis the Magnificent caused the great military college for old soldiers, the Hottel des Invalides, to be built and completed within eight years. The Place Vendôme, and the gardens of the Tuileries - the latter laid out by the celebrated landscape-gardener Le Nôtre-are among the architectural achievements of the "Grand Monarque"; and Versailles, formerly a modest hunting-lodge of Louis XIII., was the talk of all Europe as an evidence of the king's gigantic conceptions. As Louis was a generous patron of the drama and dramatic literature, several theatres also arose during his reign. But the splendours of the Court, and the extravagance of the higher and wealthier classes, were more than counterbalanced by the increasing poverty of the people, and in Paris itself squalid and ruinous houses and streets existed in close proximity with the gorgeous palaces and handsome, sumptuously appointed mansions of the nobility. It was a perpetual source of irritation to a populace steeped to the lips in misery and want to see these evidences of luxury, wealth, and profuse expenditure continually paraded before its eyes. For the few, the privileged classes, Paris offered every sort of luxury, and all that could render life agreeable ; for the toiling masses, the great city, a "stony stepmother," to use De Quincey's phrase, gave nothing but the means of dragging on a bare life under the most deplorable conditions of poverty and suffering.

\section{From Louis XV. to the Revolution.}

The long reign of Lnuis $\mathrm{XV}$., the period hefore the deluge that swept away the ancient French monarchy, saw various changes and improvements carried out in Paris ; though the king himself, especially during the later years of his rule, detested the capital, and avoicled it as George IV. and other sovereigns have avoided London. The Mint, the Madeleine, the Palais Bourbon, the Halle aux Blés, or Corn Exchange, the Ecole Militaire, are among the buildings of this epoch. The walls of Paris were reconstructed, and in the reign of Louis XVI. the area of the city within the walls was widened. The alterations cost more than a million sterling, and excited great discontent among the people, who were certainly not in a con- 
clition to have lheir hurdens increased) $I_{d}$ mm mmram Paris

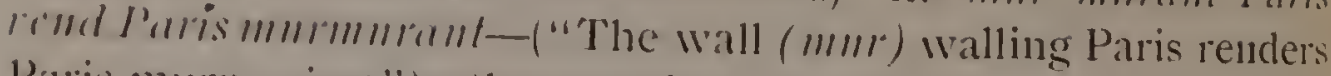
laris mumuring") the pumning line of a wit of the day, correctly cxpressed the popular feeling. The Paris of Lonis XV'. "is in many respects very defective. The streets had no sidewalks, and a gutter, foul with the accumulation of refuse cast forth from the houses, ran down the centre of the road. In the

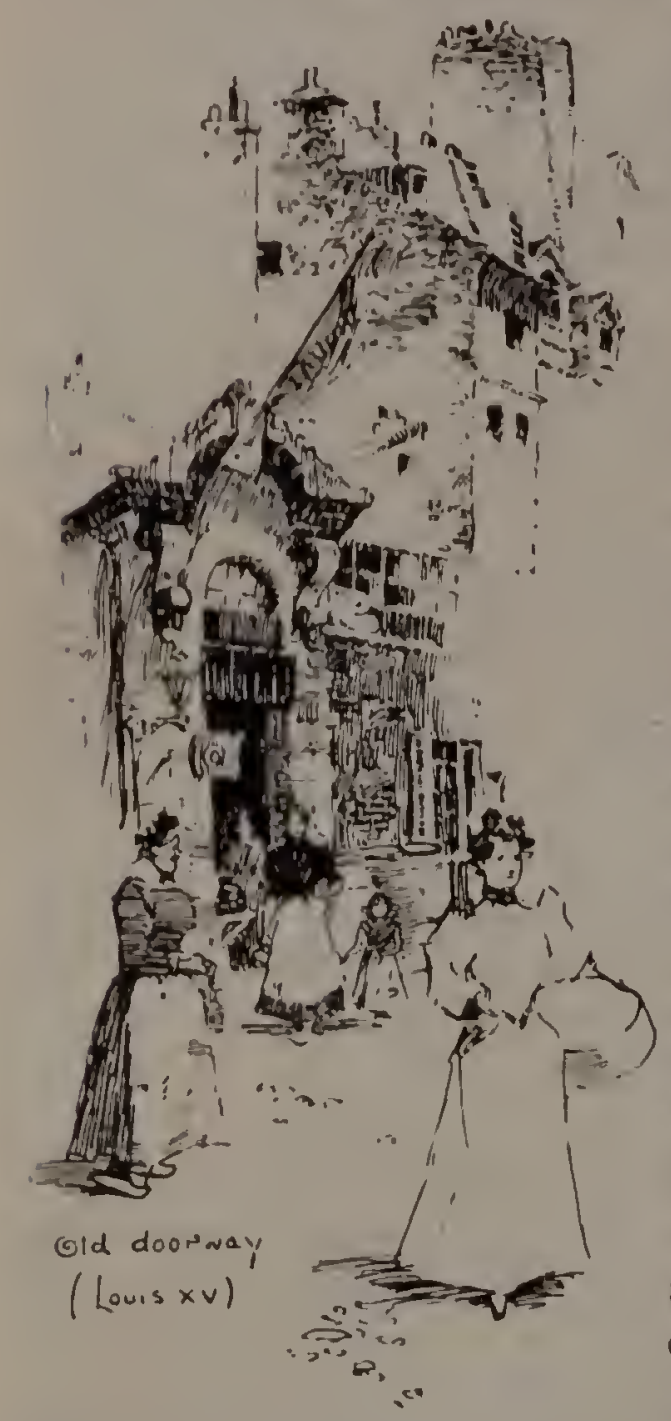
Quartier St. Antoine, and other poor districts, the inlabitants were crowded together to the detriment of health and decency, and the people were more than ever exasperated by the custom much followed by the government of quelling all manifestalions of discontent with charges of cavalry. Taxation had also reached such a pitch that every device had been tried, and at length the king made up his mind to convoke the representatives of the Commons, or Tiers. citat, who had not been summoned to the national council since the reign of Louis XIII. From the day the Etats Généraux met, in May, 1780 , for the next few years Paris was the city upon which the eyes of Europe were fixed; and, indeed, it witnessed strange and stirring scenes. On the $1 f^{\text {th }}$ of July in that year the mob of Paris stormed the Bastille, the great prison-fortress at the head of the Rue St. Antoine, the building which was to them the emblem and sign of despotic government and tyranny. A few months later they marched to Versailles, and brought the king and queen (whom they suspected of inciting the troops against the people) in triumph to the capital; in I790, in the Champ de Mars near Paris. was held, on the anniversary of the taking of the Bastille, the Fête of the Federation, to celebrate the constitution which the king and queen and the great functionaries had sworn to observe. 


\section{The Fall of the French Monarchy.}

In June, I79r, the king and queen and their children, having endearoured to escape out of France, were brought back as prisoners to the capital. In the next year, on the roth of August, the king's palace was attacked ; Louis and his family took refuge in the hall of the National Assembly, and were presently transferred as prisoners to the tower of the Temple, while the monarchy was overturned and the republic "one and indivisible" was set up. Something else was set up at the same time, to wit, the guillotine in the "Place de la Revolution," the "Place de lat Concorde" of the present day ; and from September, 1792, when the massacres took place in the prisons, to the end of July, I79t, prevailed that Reign of Terror which Lord Macaulay called "the great agony of the Fiench revolution," when each day saw a number of persons condemned to "death within twenty-four hours," carried in clunsy tumbrils or waggons to the place of execution, there to be decapitated in the presence of howling, singing, screaming mobs, consisting as largely of women as of men, who seemed literally drunk with the horrible excitement of lawlessness and bloodshed. Paris was the centre of the frenzy that seized on the whole of France, and one party after another, "Girondists" and "Montagnarcls," had each its day and its fall ; for the revolution "devoured its children." The celebrated "clay of the sections," when the young Bonaparte planted cannon at convenient points in Paris, and put down an attempted rising of the citizens with volleys of srape-shot, put an end to the demonstrations in the capital, and a new period of order was inangurated in Paris by the strong hand of despotism.

\section{The Paris of the Consulate, Empire, and Restoration.}

General Bonaparte not only put down the mob of Paris. When the favourable moment came, he put down the govern"ment also, and established himself as ruler of France, first as "First Consul" and then as Emperor. With the restless energy which was a prominent feature in his extraordinary character, the first Napoleon set about the improvement and embellishment of Paris; and naturally, some of the various edifices constructed by his orders were associated with his victories. 
lhus, two of his slealest days were commemorated in the Pont d'. Iu-kerlit and the Pont de fena ; the naunc of the latter bridge an excited the ire of grulf old Field-Marshal Blïcher by recalling the stentest humiliation Prussia had ever experienced, that

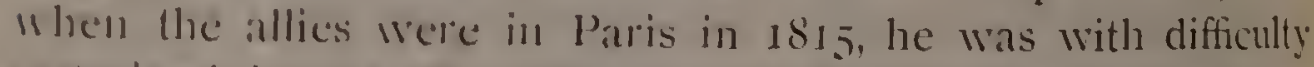
restatalled, hy the remonstrances of Wellinglon, from blowing He liabre inte the are. The Are de Triomphe at the top of the C'homps lilyeses, the lendome Column, the partial completion ") Hhe Chmels of Lat Madcleine and of the Bourse, the erection (1) Silloms other bridges hesides those of Austerlite and Jena,

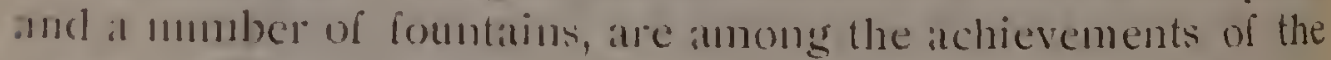
crat of the loirst bomplate.

The close of the rule of Napolem the Great left much that he had mojected to he completed-or left mntinisled, at the calse might be-by the resterced Bourbons. Under Louis XVIII, and Charles X. Hie Church of st. Vincent de Paul was built-and Hhe Chapelle Expiatore, in cxpation of the wrongs done to lanis XVI. and Marie Antumette. (How many chapels would have heen required to cxpiate the wrongs done to the nation luring centuries of misrule and oppression?) The great Entrepot des lins and various public marlets also date from this period; and the year is is also salw gas used for the first lime in lighting l'aris, instead of the old oil-lamps swinging across flec strects, which during the revolution it had been a checrul practice occasionally to haul down, that persons obucious fo lice sovereign people and the "Republic one and indivisible " might be swong up in their places. Fing Louis Philippe, during the serenteen gears' reign which began with sr many fair promises in 1830 and ended with such an ignoble cxpulsion in $18+8$, did much to improve and beautify, Paris and to modernise its aspect. The Place de la concorde was laid out, and the ubclisk of I,usor (the twin monument to the Cleopatra's Necdle now on the Thanes Embankment) was set up where the guillotine had stood during the Reign of Terror. New streets and boulevards were opened out, and the houses on the Place du Carrousel between the Louve and the Tuileries were cleared away. But the Citizen-king incurred much odium by the new fortifications around Paris, erected at great cost at a time when the people could ill bear the increase of taxation they involved, for these fortifications cost six millions sterling. The streets of the Cite were also widened and improved, and 


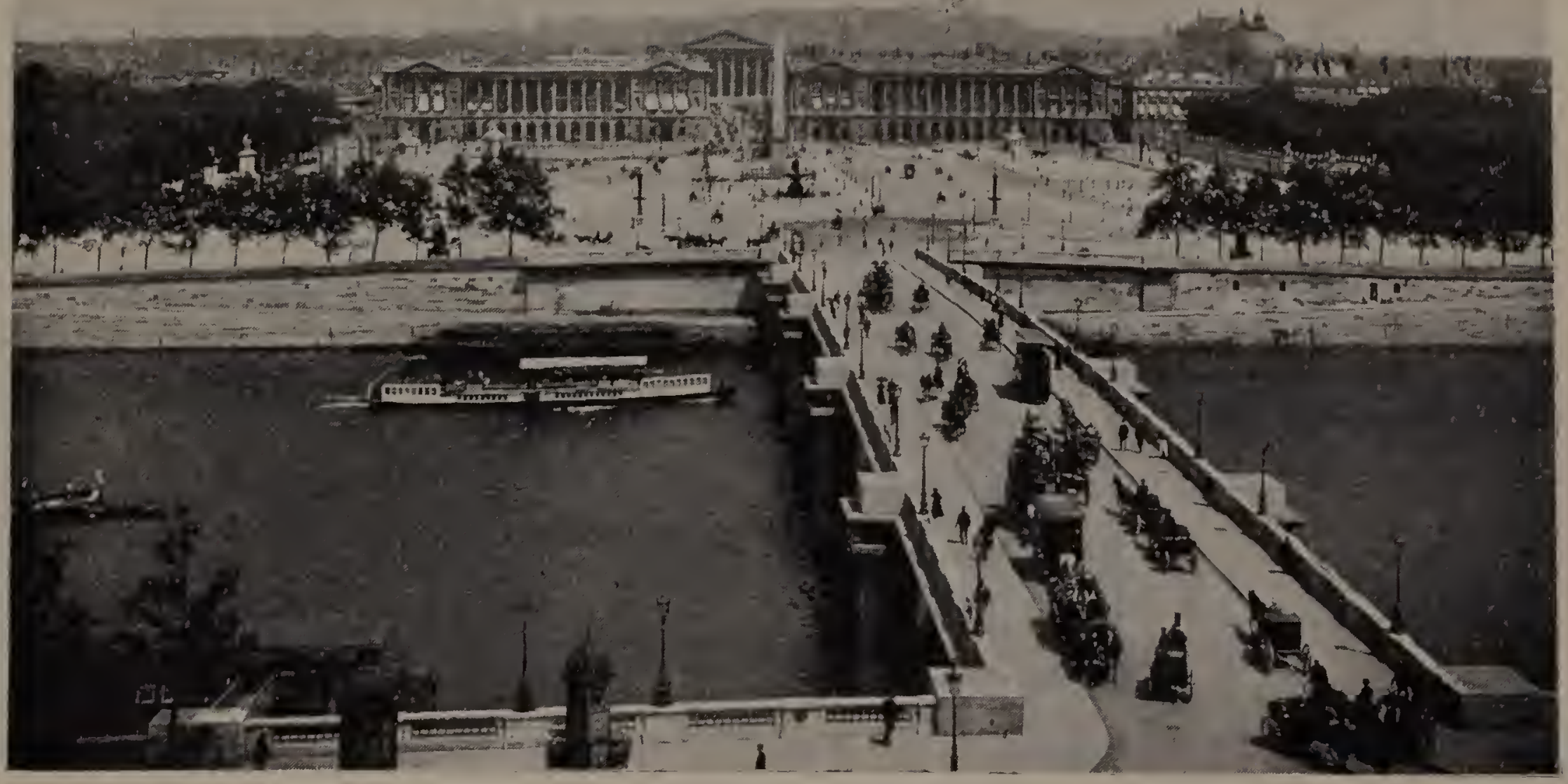

PLACE DE LA CONCORIE. 
kialway Termini made therir appearance. They were not, as in London when railways were first made, confined by Act of Parlionnent to the outskirts of the city, and thus the additional cxpence which, in the cise of London, was involved in bringing the termini into the city. hate not to be incurred.

\section{The Paris of the Second Empire.}

The period of the second limpire, from 1852 to 1870 , that followed mpon lle short-lived second Republic of 1848 , was crecptionally brilliant so fall as Paris was concentled. Louts Napolenn Bonaparte, "Le neven de son oncle," had betrayed the comstitution le had sworn, as president, to uphold. By means of the soldiery, he had crushed the Second Republic, with much shombing down of peaceful citizens, on the $211 \mathrm{~d}$ of December, 1851 ; and it wats part of his policy, alter he became Emperor; to feep the army and the working chasses in good bumour ; the former hy means of the glory and profit to be derived from Crimenu, Anstrian, and Mexicin wars; the latter by finding cumployment for them, and by rendering Paris and the other great tomps of France as attractive as possible to strangers, so as to bring as great an influx as might be of gold and banknotes, British, American, de, into the country.

Banon Hansmann, the energetic Prefect of the Scine, formed in himself a sort of Parisian Boald of ITorks; the French capital assunce an entirely new aspect. Old streets were pulled down, new boulevards were constructed. Whole quarters were recalst and rebuill with marvellous celerily; and the visitor who remembered l'aris in the old days, rubbed his eyes in bewilderment as he looked in vain for the old familiar landmarks. Twelve millions sterling were spent, in a short time, on improrements and reconstructions in the capital. Narrow streets and lortuous alleys disappeared, and were replaced by hroad streets, with brilliant and handsome shops, well stored with those "articles de Puris" in the production of which the French capital has as yet found no rival. Thus it came about that during his reign Paris was, to use the expression in vogue at the time, very thoroughly Hansmanniscd. Never had Paris been so gay and brilliant as she became under the Second Empire. The great exhibition held in 1855 , on the model of the Exhibition of 1851 in Hyde Park (the fruitful parent of similar enterprises), was a brilliant success. Queen Victoria and the Prince 
Consort visited the Emperor and Empress on the occasion; Paris was thronged with guests who spent money freely, "and all went merry as a marriage bell." In 1867 another exhibition was held, and on this occasion, also, there was no lack of royal and imperial visitors-the King of Prussia (soon to become Emperor of Germany), the Emperor Francis Joseph of Austria, and the Czar Alexander II. of Russia being among the guests of Napoleon III.

But already the fair prospects were cloucled with omens of future misfortune and ill. The reconstructive process in Paris had been attended with enormous expense, and the people, at first delighted with the improvements, were beginning to look aghast at the cost. Moreover, the prestige of the Second Empire had seriously suffered, with a people who are eminently worshippers of success, through the lamentable failure of the French arms in Mexico, where the Emperor's ally, Maximilian of Austria, had been abandoned to a cruel destiny, after having been incited to the enterprise that led to his ruin. Paris had been made the handsomest and most brilliant capital in the world, but at tremendous cost. An enormous debt had been incurred; the expense of living had been greatly increased through the heavy town dues or octroi levied on all provisions, wines, \&.c., that passed the barriers; and when discontent was already rife, Baron Hausmann came forward, at the beginning of 1870 , with a budget of more than $\$ 9,000,000$ for the city of Paris. Thereupon he was compelled to resign; and a few months later the Emperor had engaged in the unlucky war that brought the Second Empire to a sudden and disastrous close, and was himself a prisoner of war in that castle of Wilhelmshöhe in which his uncle Jerome had in former years held high festival.

\section{The Third Republic-The Paris of To-day.}

The close of the year saw Paris closely besieged by the German armies. The city held out bravely to the last, but the issue was hardly doubtful when once the hostile lines had been drawn around Paris. For a hundred and twenty-five days the beleagnered city resisted bravely, the sixteen forts and the redoubts protecting it for a time from the enemy's advance. Great efforts were made. Cut off from ordinary means of communication with the outer world, the besieged organised a 
Hratem of ballinon-pusts: and by means of a balloom Leon

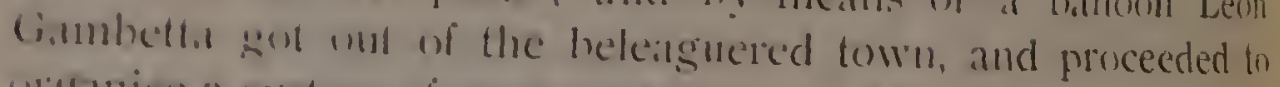

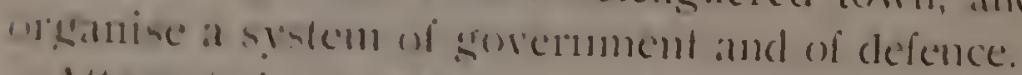

ditempled sortics from the cily latiled: deanth and famine increased d.ay hy diy, and nearly 1,3,000 deaths occurred in l'aris in the momb of Decomber. it length, at the end of

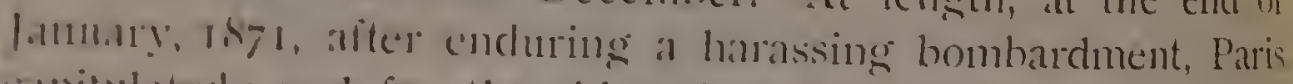
copitulated: and for the third time within the space of sixty reasthe lirench capital was oceupied hy foreign armies. The hardships of the sicuse hat heen frightful. Cots and dogs had bectl deromed, and horseflesh was comsidered a lusury. Evell rals and mice were carserly somght as food. The head, for a limiled supply of which people had patiently to wait for many hems umbide the hakers shope to take their turu, was a coarse misture of bats, rye, peisce, and other ingredients, and was ulterly unciatahle fo llic weak, who accordingly died off in great nmmbers from starvalion, At last even the anmals in the Jardin des Pantes, the chephomts and camels and the rest, were blaughtered as food, canncl's flesh being sold at is francs the lilu (ahout 2 lhs.), while elephant's trunk, as a luxury, fetched 45 francs, and the longher and less popmlar kangaron could he haxd at 12 france per kilo. The march of Prussians down the Champs ligseces and the Boulevards passed off without any mutroad accident; hut when the enemy had retired, there was another foc to be fowsht, in the shape of the National Guards, who, demoralised and rendered savage by the long siege, refused fo hand ores to the regular army the batteries of atillery they had scized on the Buttes Chaumont. They held Parjs for two months, fighting desperately against the French army, while the gorermment of the Commune held sway in the city. They shot the generals who fell into their hands, and in their frengy set fire to various public buildings, burning the Hôtel de Ville, the Tuileries, and other edifices, and pulling down the Vendône Column. As in the first great French rerolution, the fierce women of the lowest classes inflamed the popular fury.

The so-called fetroleuses paraded the streets, carying bottles of petroleum, which they flung into the houses they set on fire. Thirty-one public offices and two hundred and thirty-eight huildings were destroyed during the seventy-three days rule of the Commune in Paris. The Communists erected barricades in 
the streets, and fought the soldiers at the baynet's point to the last. Great numbers of them were shot, for in the fury of the first days no quarter was given to prisoners. Afterwards courts were held, and the prisons were cleared by wholesale exportation of the captives to penal colonies. The damage inflicted

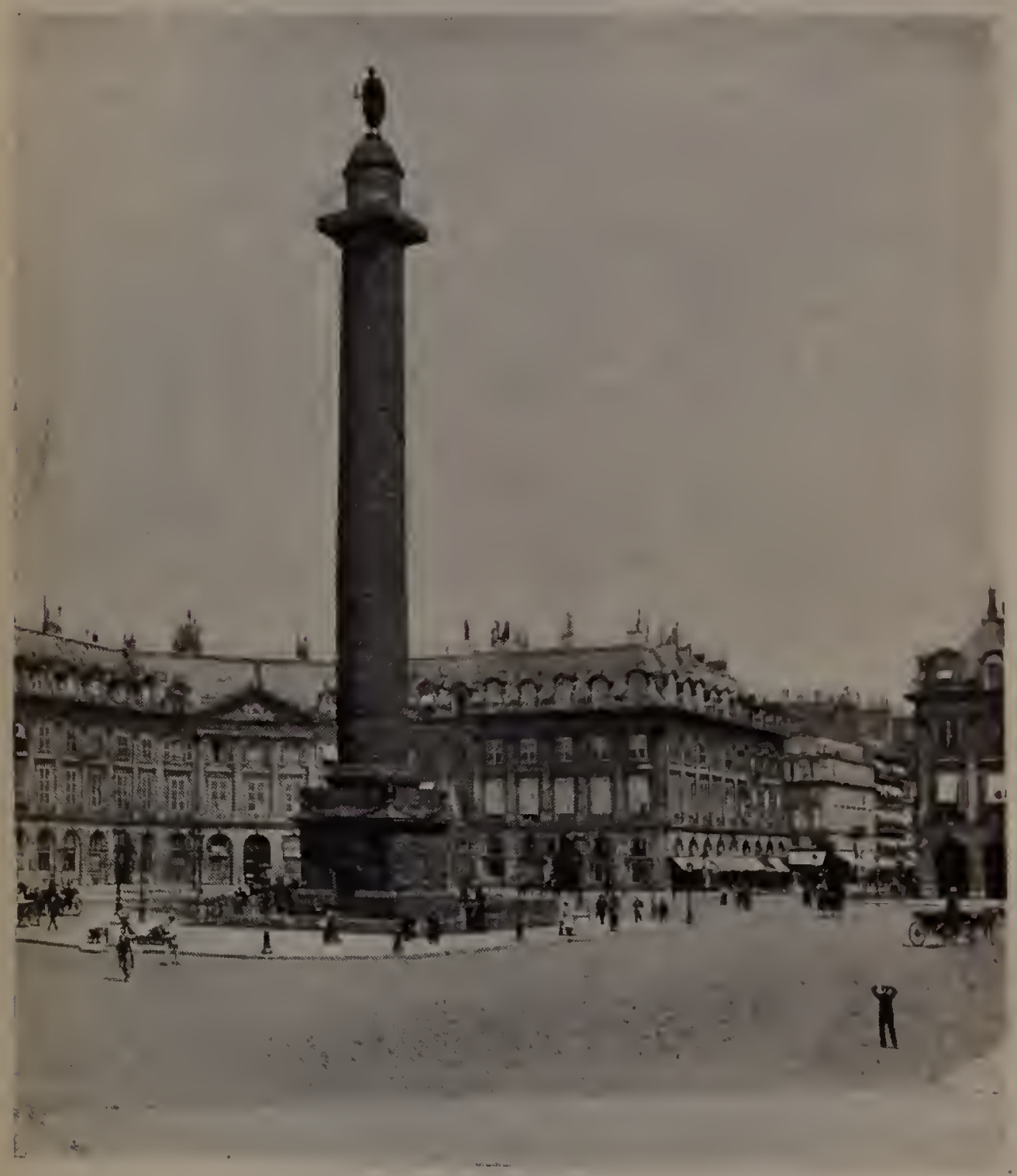

PLACE VENDÔME.

on Paris by this fierce outbreak is calculated at considerably over thirty millions of money.

The third French Republic was established with infinite difficulty, but has proved more stable and lasting than the first and second. For years the blackened and ronfless walls of the Tuileries and nther ruined huildings, remained as a kind of "memento mori" — a shastly reminder of wha! 
mob-rule could ro. But now the ruins are cleared away; the Hotel de Ville has been rebuilt, and the Vendome Column set up isain. The traces of the sanguinary rule of the Commune in l'aris have been happily obliterated, and the city has resumed its normal aspect. Various improrements commenced under the scond limpire have been completed-for instance, the New Opera Housc in 1875; and the Avenue de l'Opéra, connecting the Opera House with the Palais Royal, which was opened some years aso, now forms one of the handsomest thoroughfares of latris. The army of France has been reorganised, and there are various tokens that the grim experiences of the years I 870 and 18 ; have not heen forgotten; but the theatres and amusements of Paris seem to occupy as much of the atlention of the Parisians as fommerly, and the say capital of France presents more attractions than ever to the stranger.

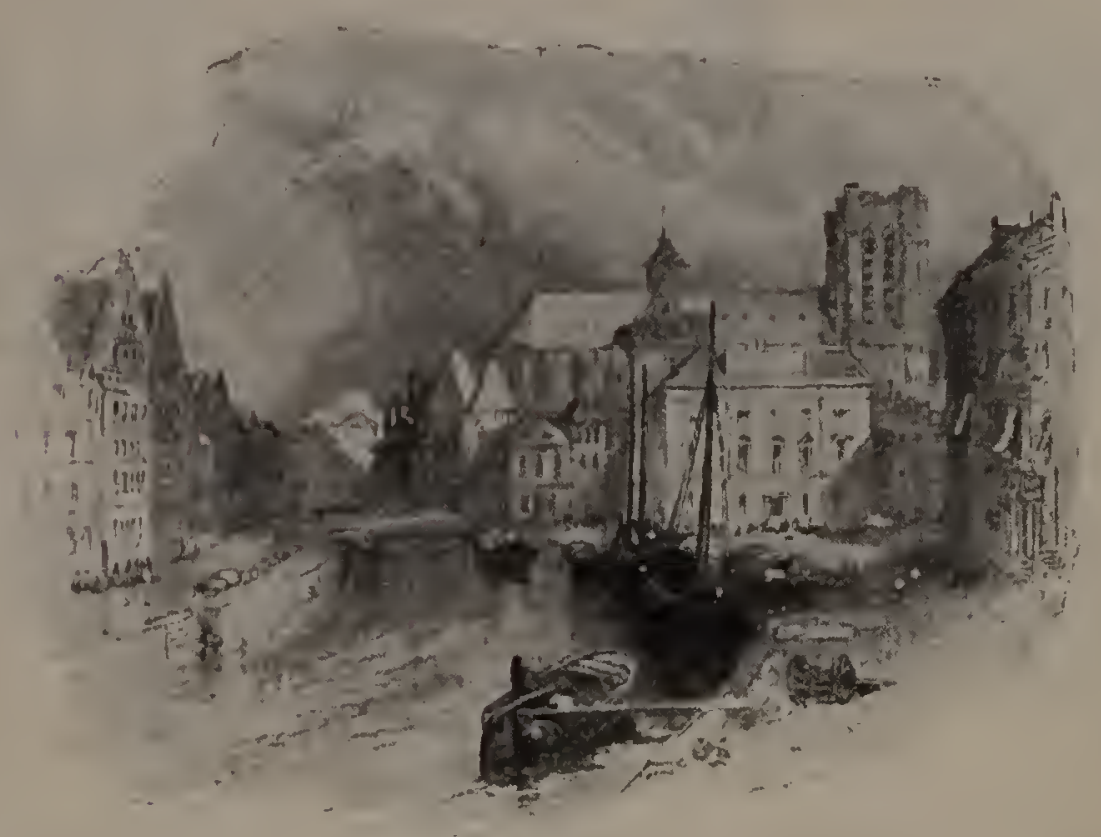




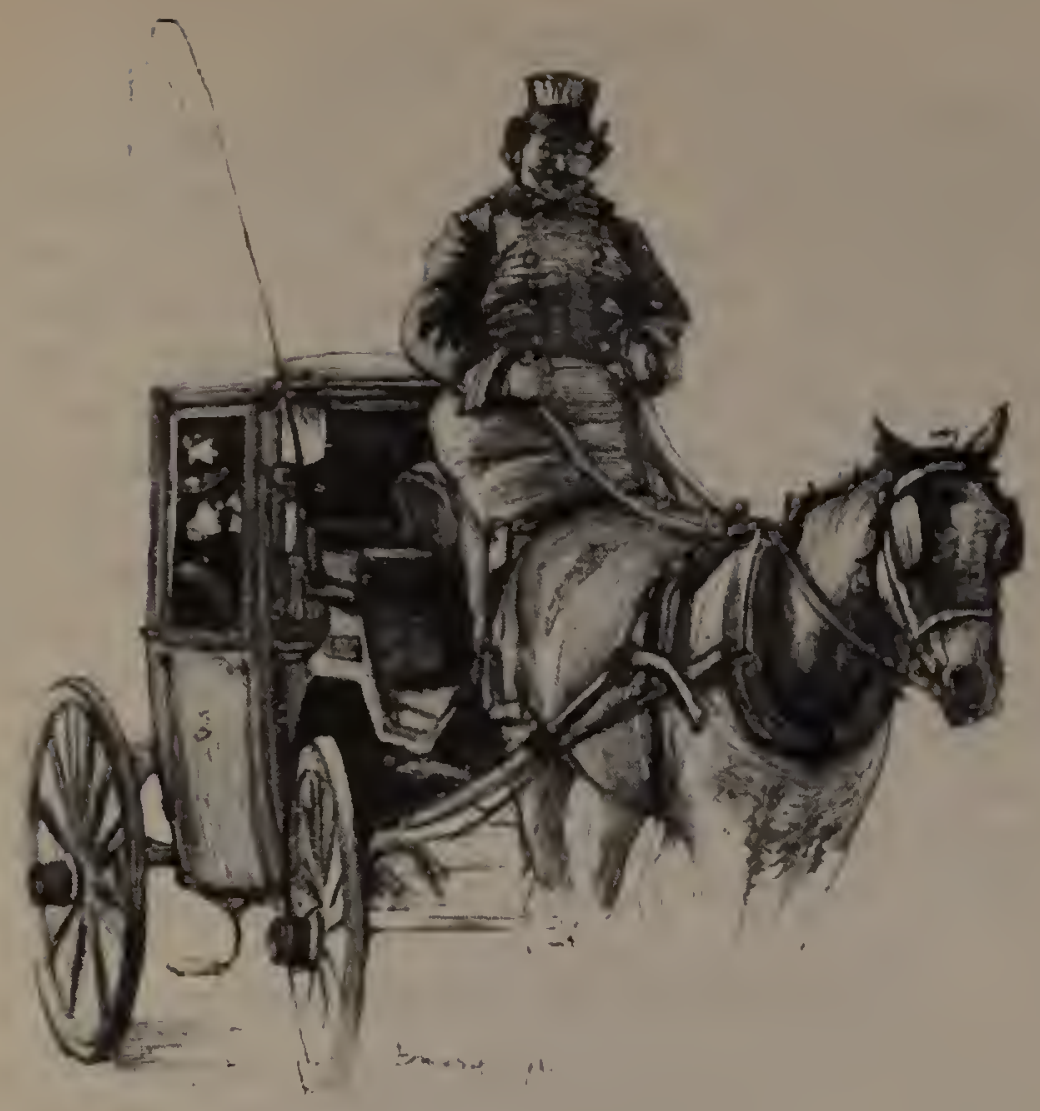

CHAPTER HII.

\section{THE ARRIVAL IN PARIS-WHAT TO DO AND WHAT NOT TO DO.}

The Arrival-" Pourboires" or Tips-The Customs Examination -Cloak-roonis-Hotels and Boarding-honses-RestantantsCabs-Omnibnses and their Rontes-Riner Steamers-Postal and Telegraphic Arrangements - The Telephone - A Prosiramune of Amusements-Shopping in Paris.

THE traveller by night, if taking the short sea route, arrives at the Gare du Nord shortly before 6 a.m. Travelling riti Dieppe, he arrives at the Gare St. Lazare shortly after 7 a.m. If travelling by day, he arrives in Paris in the early evening. If journering under the auspices of either of the tourist firms of Cook or Gaze, he will find their uniformed interpreters on duty at the stations ready to receive them, to release their baggage from the customs, and procure the necessary accommodation for transfer to the hotel. If the tourist is travelling independently, the best plan is to obtain the serrices of a porter (factenr) to carry the hand-luggage and nbtain a cab or 
ommihus, acending fo the mumber of the party. It shonld he rementered that if the eab is taken immediately on arival and the hand-hagsinge cleposited in it, the passenger reluming fo obtain his registered lusgrage, the cab will have In be pilicl for by the hour. In any case this is the most convenicut method of procedure. At all the Paris stations an ahundant supply of the company's own omnibuses will be found waiting the arrival of express trains. The average fare for these is 6 francs, including a pourboire of one franc which is expected by the driver. Cab fares before 6 a.m., no matter if only tilien a few minutes before the striking of the hour, cost unc franc extra. Fomplace cabs maty he obtained at the principal railway stations on arrival, but on departure from Paris llicy are only whined with considerable difficulty, as they have geverally to be fetched from the nearest railway station.

\section{The Customs Examination.}

Passengers having registered luggage will do well to be perfectly frank in their declaration concerning objects liable In cluty. An evasive manner is almost sure to lead to a minute examination of each article of luggage by the officials. Any attempt to hinder them in the fulfilment of their duty is likely to create disagreeable results. English and American tourists are apt in overlook that these officials have power to require cvery piece of luggage to be entirely emptied for examination and repacked hy the owner, and even to search the person if they so please. It is therefore obvious that civility and politeness form the hest policy. If the passenger displays willingness or even avidily in offering to onen his luggage, he will very likely not be required to do so at all. If on the other hand he attempts to "hustle" the officials, he may find himself disagreeably detained for half an hour or more during a tiresome and cxhaustive examination. Registered luggage is delivered in a special room, the doors of which are not opened for from ten minutes to a quarter of an hour after the arrival of the train, thus giving the passenger plenty of time to arrange for a conveyance, is already stated. Articles liable to duty are comparatively few. Tohacco (cigars or otherwise), wines, spirits, laces, and silks, are the chici. We must not forget English matches. These are confiscated if simply a few are found, hut should any number be discovered, and should they not have heen declared, the custom 
officials demand a fee of onc franc por match, without the option of confiscation.

Whilst on the subject of railway stations, we may mention that during the past few years all the French stations have made extensive improvements in the matter of comfort and convenience for travellers. Lavatories with every accommodation are to be found at the stations, as also cloak looms where luggage may be deposited, and either in the station or adjoining it, will be found excellent refreshment rooms. The traveller remaining only a day may, therefore, if he pleases, walk out of the station, after a wash and brush up and a good breakfast, to start on the day's sight-seeing, and return to take up his baggage in the evening, and if needs be to proceed to any other station for continuing his journey to Switzerland or otherwise; unless indeed he shall have elected to cross the city immediately on arrival and at nnce deposit his haggage in the cloak room of the station from whence he is to depart in the evening.

\section{Parisian Hotels.}

At the commencement of this Guide is a table showing the principal hotels of all classes, with their approximate tariffs. A little general information may, however, be of practical service to the intending visitor.

The largest and most important hotel in the city at the time of writing is the Graul Hottcl. Next in importance would be the Hotcl Contiucutal, but one must be prepared to pay at least Io or I2 francs for room, lights, and service, which would make with table d'hôte breakfast and dinner a minimum of 20 to 25 francs per person per day. The Hótcl Tormuinus is a convenient house for those arriving in Paris from Dieppe or Harre, being situated at the Gare St. Lazare terminus of the Chemin de Fer de l'Onest, yet sufficiently removed from the station to avoid any inconvenience from noise of the trains, \&c. This is a fune and commodious hotel, and prices may he ipproximately estimated at from Io francs upwards inclusive tariff per person per day. In the same category may be also placed the Hôtel du Lourver, the Hotel des Dem. Mondes, the Hôtel Belles'mi, the Hotel Bimda, and the Hotel Normamidy. The new hotels are the Palacides Champs Ely'se's, on the beautiful Avenue of the same name; the Ritz on the Place Vencome; and the Rigima nn the corner of the Place des Tuileries and the Rue de 
Rivoli. Many minor hotels have heen opened, and atso a great number of boarding-houses, hut the above list comprises those which are best known.

Those desirous of finding excellent houses at inclusive charges not exceeding 15 francs, are recommended to such hotets as the St. Fumes (near the Tuileries (iardens), the Hôtel Conlrol (near the Iouvec), the Hild Lille and a'Albion (near the Place Vendome), and others shown on the lable at commencement of the Guide.

Those wishing to fund more cconomical arangements can obtain coupons of either of the tomrist firms, Messrs. Cook or Messr.: Gaze, at the fixed and inclusive rate of $8 /$ or $8 / 6$ per person per clay, entilling them to meat breakfast, table d'hote dinner, romm, lights, and service. Lists of hotels are given to cach purchaser of coupons, and will be found to embrace such

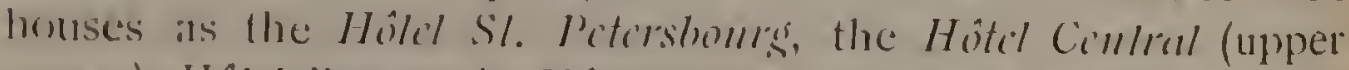

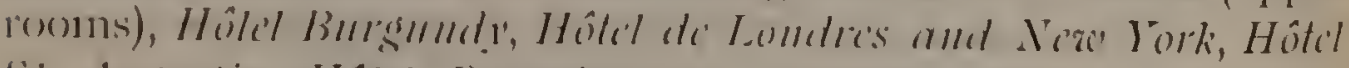
S\% Alsistin, Hôl'l P'rsynior, and a number of other smaller houses. This will he found a very satisfactory arrangement as it dispenses with all the trouble and inconvenience of making hargains, hy assuring in alvance a fixed and inclusive rate.

Boarding Houses (Pensions). There are a number of these in Paris. They are chiefly patronised by Americans. A few of the most important are Hotel de la Trimoille, formerly Pension Iáafond, Madame (ilatz (45, Rue de Clichy), Madanio Thirrry (46, Rue de Clichyl, Holel Porers, formerly Pension Powers (Avenue d'Antin).

\section{Restaurants.}

These may be classified under three headings-Priv firt', it le Corle, and Systeme Durul; and the first and last will be found the most practical and least expensive. A la Cartc, as a rule, means maximum expense and minimum satisfaclion, unless the dincr-out is experienced and is thoroughly conversant with the language.

Prix Fixe.-The Palais Royal is the home of Prix fixe Restaurants. The choice is abmuant, the first floor all round the square being almost entirely occupied by establishments of similar style supplying lunches from 2 francs, and dinners from 2 francs 5o c. Restanraul de Paris (22, Galérie Montpensier) and l'efony ( Io\& Galéric Valois) are recommendahle. J)incl de l'aris (12, Bonlevard Montmartre) and Diner Français (27, Boule- 
vard des Italiens) are excellent. Scossit, Place de Rome, is convenient when in the neighbourhood of the Gare St. Lacare.

Duval System. - These restaurants are to be found dotted all over Paris. All are reliable, though, of course, the largest are the best. Prices are very-low and fixed. A printed tariff is handed to each person or group on entering. One can dine or lunch satisfactorily from 2 francs upwards. The service is carried on by waitresses in snow-white caps and aprons. Convenient for the sightseer are the establishments situated opposite the Madeleine, opposite the Tuileries (Louvre), 19t, Rue de Rivoli, t7. Avenue de l'Opéra, and 35 and 39, Boulevard de Capucines.

A la Carte.-Marsumer (36, Boulevard Bonne Nouvelle) is excellent, as is also Champerun. (13, Place de la Bourse) and Ledoyen (Champs Elysées-open air). Nocl Peters (Passage des Princes) is good, and Paillard (38, Boulevard des Italiens) one of the best, but expensive, this and Cubats (25, Avenue des Champs Elysées) and Iroisin (16, Rue Cambon) being three of the most rechirchic establishments of the kind in Paris. Paillard has also a branch establishment on the Champs Elysées where suppers, dinners, and afternoon teals are served. Expense must nut concern those who patronise these last-named restaurants.

\section{Cabs, Omnibuses, \&c.}

Fiacre (or ordiuary cab). - These are, as a rule, comfortable and well-horsed, though we cannot go as far as to say they are well driven. There are two kinds of uabs: first, the coupr. chiefly used during the winter months, and second, the Iictoria, which is the popular Paris conveyance during the summer months. The majority of guide books give an infinity of detail which is rather confusing to the ordinary tourist. In general terms the most practical information may be condensed in the following facts. Cabs may be engaged by the "course," or by the "hour." If by the course (fare I franc 5o c.), you can drive irom any point of the city to any other point, providing it be within the fortifications, though if the cabman be stopped on the way he has the right to charge each stoppage as a separate course, and it should be remembered that one hour is cheaper than two courses. If engaged by the "hour," 2 francs is the minimum fare per hour, that is, for the first hour or any part of the same. After that, strictly speaking, a proportionate time may be calculated for each five minutes, though it is not 
usual to divide the line into less than a quarter of an hour or cepuivislent payment. Thus, a cab for an hour and a quarter would cost 2 fromes $50 \mathrm{c}$., and an hour and a hall, 3 francs, and so m1. This, of course, only applies within the city, there heing special fares for suburban excursions. In taking a cab by the lome it is nol necessary to be conversant with French, or (1) give any lengthy explanation. You have simply to show fine walleh to the driver, who will immediately understand and cialculate accordingly. Then simply give the names of the slcecssive monnments or establishments you wish to visit. In all casces it is customary to talic the cabman's number, for which the pluase "Bommen-moi anfre mmmero" will suffice. This will cuable you do find your cab casily after leaving it, and in any casc is riseful should any article be forgotten or should a dispute

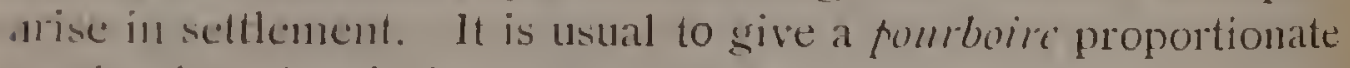
Io He length of the comrse or the time employed. A fair cotimalc is at the rate of 25 centimes for an ordinary course and so centines for an hour, or even two. The lariff, page 11, will he found fo embrace all the requirements of the ordinary lomist.

At night in coming out of the theatres, opera, dec, there is 110 difficulty in ubtaining a conveyance, al long line of cabs always waiting at the dours of the principal places of amusement. It is, however, well to select a cab with some care, the colour of the lamp indicating the quarter of the city in which the stables of that particular conveyance are situated, and of course the cabman is much more easily dealt with in the matter of fare and fonrboire when going towards his destination for the night justead of away from it.

The principal colours are:
"ked."
"Yellow."
(Stables)
Champs Elysees and Passy quarters.
"Green." Montmartre and Poissonnière quarters. Invalides and Observatoire quarters.

Besides the ordinary cabs, there are a certain number of excellent Landaus to be found on the more important cabstands, notably in front of the Grand Hotel. The legal fare for these is 3 francs the hour for the city, but the drivers are distinctly unwilling to quit the stands for a less period than three or four hours, say the equivalent of about 12 to 15 francs. The fare for the day inside the city is 25 to 30 francs, and for Versillles 35 to 40 francs. This remark is specially applicable to 
the Compagnie Générale, but there are many other coach companies in Paris not so particular and equally good. In fact a cabman is bound to accept all fares at all hours.

Voitures de Remise.-These are a superior species of cab or Victoria, and may be found at any time in the Rue Scribe, immediately behind the Grand Opéra. The fare is a question of discussion and bargain, but once agreed in advance there is no further trouble. The usual rates are 20 to 25 francs for morning or evening, and 30 to 35 francs for the day.

In all cases bargains may be made during the summer Inonths, when the majority of the Parisians are at the seaside, but up to and about the end of June the visitor must calculate on paying the prices named.

Private Omnibuses. - Private omnibuses to and from the various stations may be engaged at the station on arrival, or at all the principal hotels for departure; prices being 6 francs for a small omnibus holding six or even eight persons, to which must be added a pourboire of I franc for the driver.

Public Omnibuses.-To the ordinary tourist, whose time is valuable, we would emphatically say, do not lose it in attempting to unravel the intricacies of the Paris omnibus system, or in waiting at the various offices till seats can be secured. A handbook is published by the omnibus company giving all the principal lines of omnibuses, but for all practical purposes we think the following information will suffice. Every omnibus is distinctly marked with the initial and terminal point of its journey, and to avoid possible mistake the direction in which the omnibus is going is indicated by a moveable board just above the conductor's head. When an umnibus is full, a notice to that effect (Complet) is placed over the door. These vehicles can be stopped at any point, and it is not necessary to take them at the office; but if more convenient to do so the passenger names his destination, a number is given him, and he must wait his turn till that number is called before he can enter the omnibus. The fares are low and uniform : outside 15 centimes, inside 30 centimes. Correspondence tickets are given without extra charge, entitling the holder to transfer to any other line crossing the route. These must be asked for on paying the fare, which in that case is the same either outside or inside the vehicle, 30 cents. The simple phrase "Correspondance s'il vous plait" is all that is necessary. 
It mat be uselul to indicate a ferr of the principal lines of ommibuses most likely to be of service to the tourist, and by taking these at the terminal points no difficulty whatever will be experienced.

1. Madeleine-Bastile.-This is onc of the most popular lines of ommibuses, rumning the whole length of the Boulevards as fill as the Batstille. I most interesting ride call he made on the imfermle (or outside), especially during the evening, as an excellent icleat of Paris by saslight maty be thus obtained. Be careful, howevel, lo whtill a seat on the left (or Madeleine) side, as this is the side on which most of the principal cafés are situilled.

$\therefore$ Gare St. Lazare-Place St. Michel.-These are large blué three-hurse ommibuses. Starting from the St. Lazare laailuay station, they run pats the Operal House, down the Avenue de l'Opera, passing the Palais Royal and lle Louve, and crossing the seine close to Notre Dame, a little beyond which is their terminal point. Thus these busses may be used with advantagc hy those visiting the Louve, the Sainte Chapelle, Notre Dance, the Laxembourg or Cluny.

Note- We maty state that both the Madeleinc and St. Lacarc are terminal points and starting points for an infinitude of Ihe most useful ommibuses for the Parisian visitor, and here is also a most useful system of "Special Omnibuses" rumning from the courtyard of this station, in front of the suburban (or Banlicu) side of the St. Lazare terminus, to the Hotel de Ville, the Bon Marché, \&e. The uniform fare for these 'busses is 25 centimes inside or out ; but they can only' lalic up passengers inside the station courtyard on cleparture, or cleposit them in the same place on the return journey. This is a special arrangement to prevent infraction of the monopoly held by the General Omnibus Company.

3. Porte Maillot-Hotel de Ville.-These omuibuses stiut from the Porte Maillot at the further end of the Avenue de la Grande Armée), and are convenient for returning from the Jardin d'Acclimatation side of the Bois cle Bologne. They run past the Are de Triomphe, down the grand Avenue of the Champs Elysées, past the Tuileries Gardens and the Louvre, following the Rue de Rivoli till the terminal point is reached at the Hôtel de Ville.

4. Champs Elysées. -Thesc omnibuses start from the further 
side of the Place de la Concorde and follow the kue koyalc, passing the Madeleine and the Operal House, thence diverging (1) the keft, following the liue Lafayette, passing the Gare du Nord and stopping just behind the Gare de l'Est.

Or comse there is an infunite variety of lines of omnibuses tmming across these main lines for which correspondences may be taken. We have, however, indicated most of the main routes which can be safely and profitably used by the tourist.

The same remates apply to the various-

\section{Tramways.}

Phese are much more numerous than formerly, and having been considerably improved of late years, the visitor may find it convenient to avail himself of them for some of the principal and direct lines of route. The chief starting points likely to he usceful ate:

The Madeleine, from which point electric trancars start at frequent intervils for Asnières, Saint Denis, de.

The Place de la Concorde (close to the Seine), from which tramways or omnibuses may be taken to Sevres, Sant Cloud, Versililles, the Luxembourg Palace and garden, Hotel de Ville, Are de Triomphe, \&e.

The Opéra (immediately bellind the Opera). Tramways run on the one hand to the Are de Triomphe, Bois de Boulogne (Muette), and on the uther hand to the Gare du Nord, Saint Denis, \&ec. Fares are the same as by the omnibuses, and correspondences atre also given.

From the Church of Saint Augustin an electric tram goes to the Cons cle Vincennes, and another behind the Louvre goes to lle famous 1 rend of the same name.

\section{River Steamers.}

These will occasionally be found a convenient and pleasant method of transit during the staty in Paris. The majority of the steamers run from Charenton to Auteuil. There is also a supplementary service to Suresnes. These latter steamers are somervhat larger than the others and are more pleasant, being less erowded on week-days-llough on Sundays and holidays the reverse is the case. The fare from the starting point or the P'ont d'Austerlitz (for the Jardin des Plantes), to any landing stage within the city, is 10 centines during the week and 15 centimes on Sundays and holidays, with 10 centimes supplennent if the 
journey be continued to Auleuil. The fare to Sevres, Saint Cloud or Suresnes is rocentimes in the week and 20 centimes on Sundays and holidays. Piers are to be found as starting points by the side of almost all the principal bridges, notably the Pont Neuf (for Notre Dame), the Pont Royal (nearly opposite the Tuileries), the Pont de la Concorde, the Pont d'Iéna (for the Eiffel Tower), \&c., \&c. Care must, however, be taken to await the steamers at the correct piers, as there is a departure point for up and down stream, and also a separate departure point for the Saint Cloud and Suresnes steamers. Clear indications are prominently posted on each of the Hoating stages in yuestion.

\section{Postal Rates and Arrangements.}

The General Post Office is silualed in the Rue du Loure, but there are numerous branch offices throughout the city, and one will be found wilhin a slone's throw of any of the principal hotels. The "Poste Restante" is situaled in the General Post Office, but we would strongly recommend visitors to have letters sent to their holels, as the Paris Poste Restante system entails considerable loss of time and inconvenience. Even supposing that from any unforeseen circumstance a different hotel should he patronised from that originally intended, it is casier to call or send to a neighbouring hotel than to the Poste Restante, besides which, if instructions are given, letlers are forwarded asain through the post withoul extat charge.

Rates. - The lates for postage for ordinary letters within France are as follows: 15 centimes per 15 grammes, which means as nearly as possible the weight of two sheets of ordinary writing paper with envelope. The supplementary payment for excess is proportionate, being 30 centimes if over 15 grammes until 30 grammes is reached, and so on. The postage for England or any country in connection with the Postal lonion is 25 centines for 15 grammes, and the same alrangement exists for excess weight. Postcards are ro centimes each (for France or the Postal Union), and a very convenient system of letter cards also exists for closed communications, 15 centimes each, or 25 centimes for abroad.

Registered Letters (Lctlres recommandées).-The uniform charge for the registration of letters is 25 centimes in addition to the ordinary postage, and they must not be sent in blackbordered envelopes. 
Delivery and Dispatch. - There are about eight deliveries of local post in Paris, but English and foreign letters are rarely delivered except by the first mail, about 8 a.m., or, if registered, by the second delivery, about 10.30 a.m. By the evening delivery English letters may occasionally be received, but they are generally those which have missed the post when dispatched in London, or letter's dispatched by the previous early evening mail from the large provincial centres.

The lime of mail departures at all the chief offices in the centre of Ihe city is 6.30 p.m. 'The principal hotels generally dispatch letters lo catch this mail about 6.o. This, however, varies according to the discretion of the proprietor, and if not marked on the letterbox of the hotel inquiry on this point should be made. Letters may be dispatched at central offices with a supplementary fee of 5 centines up to 7.15 , or in case of special emergency letters call be posted at the respective stations from which the mail leaves for any given destination, up lo about half an hour of the time of cleparture of the mail train. Information on this point should be ubtained at the liotels, where a request for special messenger to cirily same to the station can be made, if desired.

Newspapers or Printed Matter.-These must be made up with open ends so that the wrapper can be removed if desired. The lee is 1 centime for each 5 grammes up to 20 grammes, beyond which the price is 5 centimes, with an additional 5 centimes for every 50 grammes or fraction of same.

N.B.-It may be useful for the visitor to note and remember that the I sou (copper coin) or the I franc (silver coin) each weigh 5 glammes.

\section{Telegrams.}

Tariff.-Telegrams for any part of France are dispatched at the uniform charge of 5 centimes per word (minimum charge 50 centimes). To any part of Great Britain, 20 centimes per word (minimum charge I franc) ; New York, I franc 25 centimes; Switzerland and Belgium, $12 \frac{1}{2}$ centimes ; Gormany, 15 centimes; Italy and Spain, 20 centimes.

Telegraph Offices are to be found at the principal district post offices, and are generally open for the reception of telegrams up to y p.m. There are, however, a few special Telegraph Offices at which messages are received as late as 1 I.o or midnight, the principal of these being at the Grand Hôtel, the Rue d' Amsterdam (Gare St. Lazare), i, Rue Boissy d'Anglas (Place de la 
Concorde), 4, Avenue de l'Opéra (Palais Royal), and also at the chief railway stations. The most convenient offices for the dispatch of late telegrams will probahly be found to be those situated in the Grand Hôtel, and at the Bourse (Exchange) - this latter office being the only one in Paris which is open day and night.

Card Telegrams.-This is a most useful system of rapid communication applying, however, only within the limits of the city itself. Card Telegrams 30 centimes (open), or 50 centimes (closed) if a private communication be desired. These cards may be obtained at any post office or Tabac (cigar shop). They have simply to be dropped into the special box provided at all telegraph or post offices, and are immediately dispatched through pneumatic tubes, reaching their destination as a rule within the hour, and often considerably under.

Telegraphic Envelopes may also be obtained, price $5^{\circ}$ centimes, in which letters may be placed not exceeding 7 grammes. These are dispatched in the same manner, but it must be understood that it is absolutely necessary to insert them in the special envelopes sold for the purpose, no others being accepted.

\section{Telephones.}

Most of the principal hotels place their telephones at the disposal of visitors, but in case of a private message it may be found convenient to have recourse to the public telephone boxes, which will be found at all the principal post offices, the fee being 25 centimes for each five minutes' conversation after communication is established. Communication is also obtainable with London, but the fee is Io francs for a conversation of three minutes, and as the said communication is somewhat difficult to obtain there would appear to be few circumstances under which the use of the telegraph is not infinitely preferable.

\section{A Suggested Programme of Amusements.}

In another chapter is given a list of the principal Theatres and Amusements of the city. Consultation of this, aided by reference to any of the English daily papers published in Paris, will enable the visitor to obtain any required information concerning the nature of the amusements, situation of the theatre, and details of prices, \&c.; but the stranger visiting Paris for the first time needs something more than a mere list or catalngue in order to select the amusements 
most suited to his taste. We therefore venture to offer a litte general advice and special explanation.

Presuming the visitor has a week of evenings at his disposal, we have found the averase choice will he somewhat as follows-

1st. Grand Opera.

2nd. Operai Comique.

3rd. Cafés Chantants on the Champs Elysées.

th. The Folies Bergère, or Casino de Paris (the two hest varicty entertaimments in Paris).

5th. The Nouveatu Cirque (the only equestrian entertainment of importance in the city).

If the visitor is conversant with French, he will probahly want to visit the "Palais Royal," or the "Nouveautés," which theatres provide a light and humorous performance somewhat similar to our hurlespues at home. Spectacular pieces in Paris are somewhat scarce of late years, as they do not seem to appeal to the steat majority of Parisian playgners; the only theatre mainlaining the traditions of this style of entertainment is the "Chatclet," but we must frankly confess that disappointment sencrally cusues, as our principal theatres and even music halls produce much finer spectacular effects and hallets than those to be found at the Parisian theatre of to-day. On the contrary, high-class comedy is the strongest feature of the Parisian stage. We venture to assert that there is no city in the world where such refined and cultured acting may he witnessed as in Paris, at the "Odéon," the "Gymmase," the "Vaudeville," or the "Renaissance," according to the company holding the management for the time being.

\section{Shopping in Paris.}

A few practical hints and suggestions may be useful under this heading, as whether for extensive purchases or for souvenirs and presents, the visitor is sure to devole a portion of his sojourn in Paris to the specific purpose of "shopping."

We naturally start our list with the well-known and worldrenowned Magasin au Bon Marché. This is one of the largest and most popular dry goods stores in Europe, and perhaps in the world. Articles of clothing of every possible description are far from heing the only attraction, inasmuch as presents, souvenirs, articles de Paris, \&c., \&c., are to be found in infinite variety. Independently, however, of the question of purchasing, his rast emporimm certainly constitutes one of the sights of 
Paris. The most convenient way of reaching the Bon Marche is by cab, which may be discharged on arrival, as another can easily be obtained on leaving the establishment. There are also numerous services of omnibuses both to and from the Bon Marché, details of which will be found under the heading of "Omnibuses."

The Magasin du Louvre is a somewhat similar establishment, though ranking second in size and perhaps in importance, excepting that its higher class goods are generally considered a speciality.

The Magasin $d u$ Printemps is a similar emporium ranking third in size and importance, but it is especially convenient for those staying in the immediate vicinity of the Gare St. Lazare or the Madeleine. The building itself is particularly elegant and attractive.

For those who are desirous of taking back a variety of essentially Parisian toys or presents for the young folk at home, we cannot do better than recommend a visit to one of the many Parisian bazaars. These establishments are peculiar to France, indeed we have often wondered that the idea has never been transplanted to our own country.

The largest and most important of these estahlishments is the Bazar de l'Hôtel de Ville, situated immediately opposite the building from which it derives its name. Any omnibus running along the Rue de Rivoli will deposit the visitor at its doors. An infinite variety of presents for the young folk will be found lere, varying in price from one sou upwards. There are also departments for perfumery, stationery, clothing, household furniture, \&c. We may specially call the attention of cyclists to the excellent choice of all articles and accessories relating to this sport.

The Bazar d'Amsterdam, situated in the street of the same name, immediately alongside the Gare St. Litzare (right hand side facing the station), is a similar establishment, though inferior in point of size and importance.

Other establishments of the kind may be found in any quarter of the city, but as we do not propose to turn this chapter into a list of advertisements, we content ourselves with naming the above as being sufficiently important to he reckoned as representative sights of the city: 


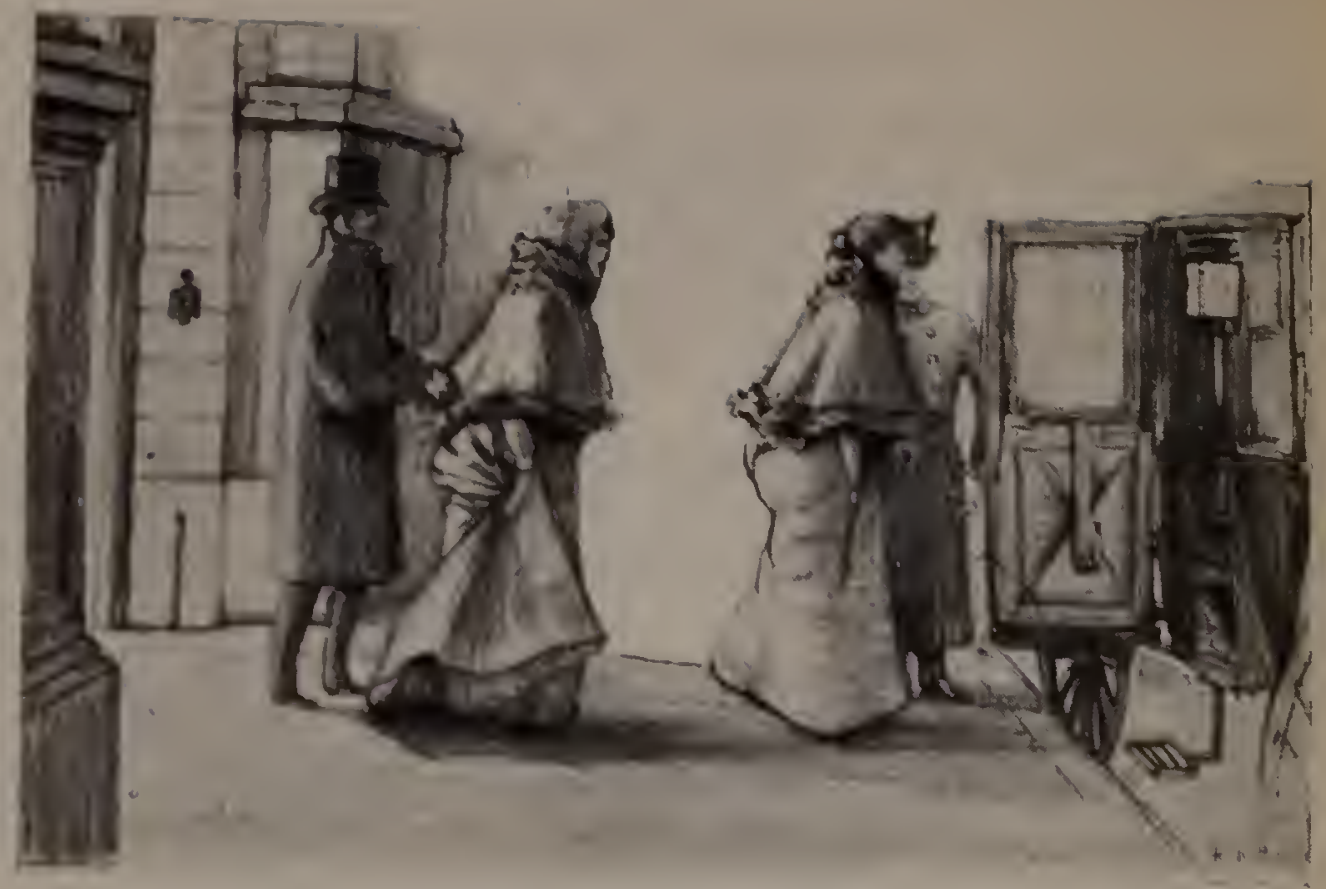

CHAPTER II.

\section{THE AMUSEMENTS OF PARIS.}

Thartres - Open Air Concerts - Music Halls-Equestrian Eutertainmonts-Militury Bands-Panoramas-Balls, Éc.

VOTWITHSTANDING the miversal reputation of Paris a a eity of gaiety, it is an indisputable fact that there is less variety in the matter of evening amusements than in London. The public balls are, it is true, an essentially Parisian feature, but this species of entertainment does not appeal to everybody.

On the other hand the Parisians are justly proud of their theatres, which are regarded as much more important institutions than in England; and the French capital prides itself upon presenting the very best that can be given in every department of dramatic art. The varions theatres have in many cases their specialities in the style of entertainment offered. Four of the principal louses-the Opera, the Théatre Français, the Opera Comique, and the Odéon-receive a yearly subsidy from the Government. 
As in London, the theatres are open every evenings, with the exception of the Opera, where the performances are limited to three, or at most four, evenings in the week. The performances generally begin at from 7.30 to 8.30 , and finish between 1.15 and midnight. Those who are not fluent French scholars will do well to get a copy of the play and study it beforehand. Detailed programmes are sold in all the theatres. With regard to places, the arrangement is in many respects like that of the English theatres. Close behind the orchestra are rows of fautcuils d'orchestre (ansivering to our orchestra stalls), very comfortable, and good both for seeing and hearing; behind these are the stalles d'orchicstre (practically the English "pit," except that each seat is numbered); and then comes the partorrc, which is literally the "pit," though it would not be so accepted hy English playgoers, being simply a few narrow seats or forms at the very back of the theatre, under the galleries and undesirable in every respect, except at the Opera, where they are numbered and excellently situated. At the Opera and in some theatres ladies do not go to the orchestra stalls. Fanteruils di balcon or de premiere galcric are like the dress-circle seats in England; and above these are premic̀res and secondes, first and second circles. There are also amphitheatre stalls, which in the Opera are good places, but in other theatres are generally uncomfortable both for seeing and hearing. Insist on having places not too far from the centre of the auditorium, as in many places the seats at the side give a very imperfect view of the stage, and in some it is difficult to hear. Private boxes can be had in the rez de chanssic (pit boxes), loges on the first or second circle, \&c. There are stage boxes, or loges d'az'ant-scìnc, on each circle. Tickets can be bought and seats secured beforehand at the Bureaun do location or box-offices, but there is an additional fee varying from 50 centimes to 2 francs for booking places in advance. We venture to suggest, however, that the difference is amply repaid in comfort, as you are sure of your seat without either waiting or pushing in a crowd, and need only take your place at the time announced for the "leacr de ridean." We subjoin a list of the principal Paris theatres, and in each case state the price of seats at the time of going to press, but it should be understood that these prices are subject to slight fluctuations, according to the pieces played and the "theatrical stars" who may be necupying the hoards. 
of comse the concierse or porter of your hotel will underfolic (1) obtain your scats in advance, but will naturally expect a trifte for the service. There are also various agencies or hookingeffices on the Bonlevalds and notalnly around the Opera Honse, where ticlicts can be obtained in advance, but the prices asked are frequently domble and sometimes even thee times lle normal value of the seats offered. At the doors of crery" theatre, too, will be iomnd "touts" who offer excellent seats, cren when none are obtainable at the booking office of the theatre itself. Care and discretion are advisable in purchasing these tickeds, as though they are senerally reliable and formine, lamey prices are asked for them. With a little patience and perseverance considerable reductions may be obtained. The most desirahle places in l'aris thealles are the firnternils

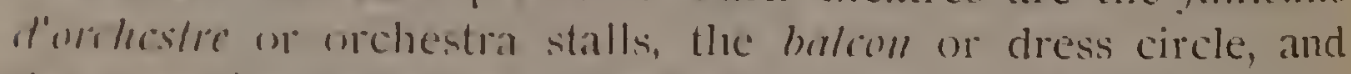
the fremier sulerir or list balcony above the dress-circle. Thence seats will generally be found satistactory, especially for Hose who are unpovided with suitable dress for evening wear. 11 is rnly lin to say that evening dress is not as rigidly imposed, Hoy cren as customary, in French theatres as in England, but it is almost imariahly worm at the Opera, the Comédie Française, the (iymuatic and high-class theatres for the orchestra stalls. We refer specially to sentlemen, as in the theatres just named the orchestral stalls are reserved exchusively for the male sex.

The chyuc is an institution which will at once amuse and :mung the linglish or American playgoer. It consists of a hody of men oremised and drilled to applaud by signal from the iluf de la chrqui. They are sometimes paid, but more often recruited from a neighbouring café and rewarded simply by free admission.

IVe now propose to give a list of the Paris theatres as nearly as possible in their order of importance, showing in each case the nature and style of the piece senerally produced and an outlined tariff for the principal seats.

Undoubtedly, the most important and certainly the most interesting from the English or American visitor's point of view is the Grand Opera (situated on the Square of that name). Performances on Mondays, Wednesdays, and Fridays (sometimes on Saturdays). Needless to say this house is consecrated to the production of classical opera, interspersed with occasional ballets, which are produced in magnificent style. Prices-Stalls : 


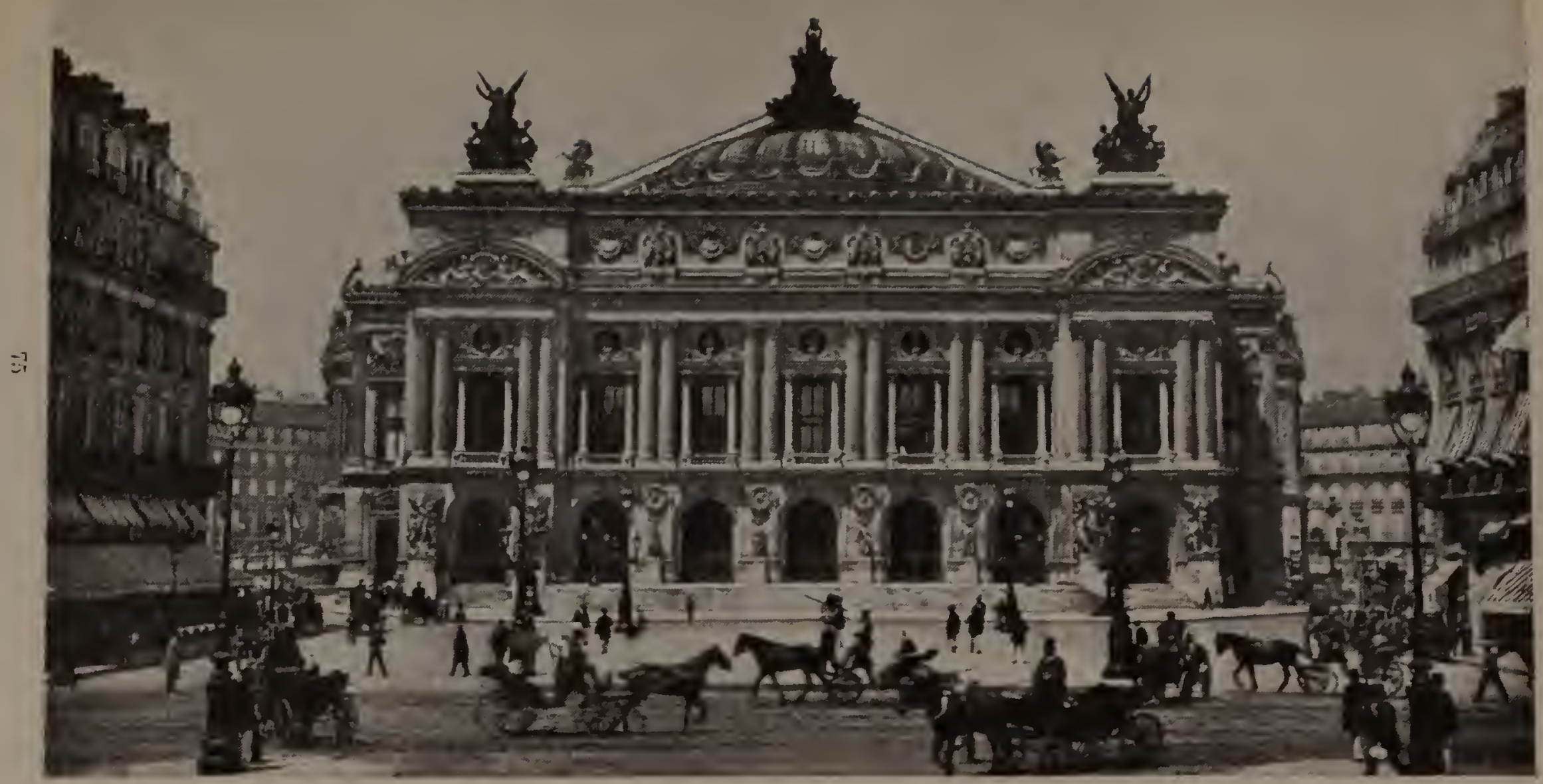


orchestri, $16 \mathrm{fr}$; pit, 9 [r. Boxes (holding six or eight persons): lirst tier, 15 to $17 \mathrm{fl}$; ; second tier, 12 to $1+\mathrm{fr}$; third tier, 8 to 10 ir. ; fourth tier, 4 to $6 \mathrm{fr}$. per scat accordings to situation.

A very linge proportion of English and American visitors who are desirous simply of seeing the Opera House are perfectly satislice with the fourth gallery scats, costing from + to 6 francs, according to situation, and admitting the holder to the grand staircase, foyer and reception rooms, just as freely as the higher priced lickets, It is usual and customary to pro. menade the huilding during the entre-acts in all the principal theatres, and at the Opera this is, of course, specially desirable, as the deconations form one of the principal attractions of the homse.

'lic Opéra comique, which was destroyed by firc in 1887 , has hectr rehuilt on the old site on the Place Boildieu, near the Bonlevard des Jtaliens, and in close proximity to the Café Anglais. Nalurally this theatre is devoted to the production of light operas, rarcly opera houffes-such as Carmen, \&c. Brices: Buxes, to to $15 \mathrm{fr}$. per seat ; orchestra stalls, $8 \mathrm{fr}$. per scat.

The Théatre Frauçais (or Comédic Frunçoise).-The Théatre Français was destroyed by fre on the 8th of March, Igoo. It is to be rebuilt immediately. Meantime the performances are given at the Odéon. This theatre was situated in the Palais Royal, at the corner of the Rue Richelieu. It was the classical theatre of Paris. Here were performed the masterpieces of Moliére, Racine, and Corneille. Generally, however, the programme was composed in part, if not entirely, of more modern productions by such dramatists as Dumas, Sardou, \&c. This theatre was considered to be the school of dramatic art, and the most perfect and refined acting was witnessed, no matter what piece might be produced. The theatre is subsidised by Government with 240,000 francs per annum. The Théatre Français, as an institution, dates back to the seventeenth century. Molière was director from 1658 till his death in 1673. The building lately burnt had no architectural pretensions. It was erected in the year I 782 and restored in I879. In the vestihule were statues of theatrical celehrities, notably of Talma, Rachel, and Mademoiselle Mars. There were also in profusion statues and busts of the principal authors whose works have been produced at the "Françatis," three masterpieces heing full-sized statues of 
Voltaire, Geurge Sand, also a bas-relief representing Molière crowned by the actors of the theatre.

The Odéon (situated close to the Luxembourg Gardens).-This theatre produces classical drama, and is generally considered a second Théatre Français, but as it is situated a considerable distance from the centre of the city, it is not often visited by tourists. Prices-Boxes, 8 to Io $\mathrm{fr}$. ; stalls, 5 to $6 \mathrm{fr}$. ; second circle and pit boxes, $3 \mathrm{fr} .5 \mathrm{c}$. to $3 \mathrm{fr}$. per seat according to situation.

The Porte st. Martin (situated on the Boulevard of same name).-Modern drama generally figures on the play-bill, and at the time of writing the theatre is under the directorship of the well-known actor, Coquelin the elder. Prices-Boxes, 8 to Io fr. ; orchestra stalls, $9 \mathrm{fr}$.

The Bouffes Parisiens (situated in the Passage Choiseul, near the Boulevard des Italiens).- - Here Offenbach first produced some of his popular operettas. It now produces light opera of secondary importance, though sometimes bright and sparkling. Prices-Boxes, Io to $12 \mathrm{fr}$.; dress circle and orchestra stalls, $8 \mathrm{fr}$.

The Renaissance (situated immediately adjoining the Porte St. Martin Theatre) is devoted to music, and under private management. This house produces or revives operas not in the repertoire of either of the subsidised houses, and is sometimes rented to foreign companies. Prices usually-Boxes, Io to I $_{5} \mathrm{fr}$. ; orchestra stalls, $8 \mathrm{fr}$. per seat.

The Théatre Saran Bernhardt, the old Théatre Historique, under the personal management of the fannous actress, is one of the most beautiful theatres in Paris.

The Nouveau Theatre is in the building occupied by the Casino de Paris, but has no connection with it. There are two boxes, however, which have a good view of the dancing hall.

The Théatre du Chatelet (siturated on the Square of same name) has a reputation for spectacular plays, though this reputation has not been over-weell maintained of late, and the visitor who goes expecting something finer than he can see cither in London or New York will certainly be disappointed. The pieces-produced, and also the dresses and scenic effects, senerally savour somewhat of the antique. The fact is, the Parisian public infinitely prefer modern comedy, and the tourist and provincial element is insufficient to maintain the costly 
extratsance of modern spectacular drama. The prices at this house vary somewhat in acordance with the suceess of the pice and eonsecpment demand, hut may be put down as 6 to 7 ir. for dress circle and stalls, and first circle 5 fr.

The Vaudeville fituated on the Boulerard des Italiens just hegend the Opeial House) is a theatre producing high class comedy, and has recently hecome exceedingly popular under the successful management of Madanne Rejane, in such pieces

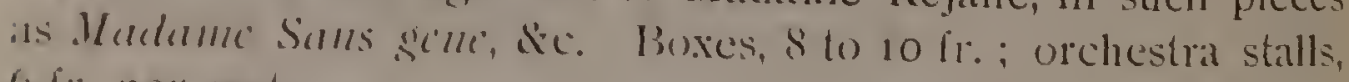
6 fr. per scill.

The Theatre du Gymnase, silnated on the Boulcrard Bomne Nouvelle, poduces modern comedy in hist class and highly linished styke. Il is, lowerer, only hair to say that a knowledge of Finench is ahoulutely ensential to the cujoyment of snch lhealles as this. Prices-Boxes, 7 to si fr.; orehestra stalls, $10 \mathrm{fl}$. per icill.

Théatre des Variétés, situated on the Bonlevard Montinartre, is an essentially l'arisian theatre. It is noted for low farces, and cxecllent opera bouffe is produced. It was at this theatre that the celebrated schneider and the populat Judic made their reputations, and the later productions of Offenbach were originally performed. Prices-Boxes, 10 lo $15 \mathrm{fr}$; orchestral stalls, 8 ir. per seall.

Theatre du Palais Royal. - This is another essentially French entertainment. It produces comedy in its broadest sense, interspersed with oulrageons farec. Visitors camable of appreciating French wit, puns and clonble cutcute unly will be likely to enjoy it visit to this theitre. Prices-Orchestra stalls, $7 \mathrm{fr}$; boxes (sceond tier), + fr. per seat.

The Ambigu Comique, situated on the Benlevard St. Martin, produces melodrantia of the old Adelphi style, one of the most recent productions being Les dent Gosses (which obtained at remarkable and almost unprecedented run of over seven hundred nightu). Prices-Orchestra stalls, 7 fr. ; dress circle, 6 fr. per seat.

The Folies Dramatiques, situated in the Rue de Bondy; neall the Place de lat Republique. This theatre undergoes frequent change of management. It was formerly dedicated exclusively to light opera, and produced the well-known Cloches ale Cormisille, and similat popular operas. At the time of writing, horrever, it is redieated to light eonedy of the same nature, 
but of secondary importance, to that produced at the Variétés, the Vaudeville, \&i. Prices same as at the Renaissance.

Théatre des Nouveautés, situated on the Boulevard des Italiens (just beyond the Opera), produces comic pieces much of same uature as those of the Palais Royal. Ludicrous "situations," not always within the limits of English notions of propriety, form a staple feature, but a knowledge of French is necessary to be either amused or shocked. Prices-Orchestra stalls, 7 fr.; d dress circle and loges, $7 \mathrm{fr}$. and $8 \mathrm{ir}$.

The Athenée Comique, the Cluny, the Château d'Eau, and others are comparatively unimportant theatres, and would hardly be risited by the ordinary Paris sightseer.

IVe now proceed to give a list of the variety entertainments, concert halls, \&c., suitable for the visitor who does not understand French, and is therefore not much interested in theatrical performances.

\section{Music Halls.}

The principal of these is undoubtedly the Folies Bergère, situated in the Rue Richer, the performance being of a similar nature to that of the Empire in London. There is a winter garden which forms a popular promenade between the various performances. Smoking is allowed in all parts of the building. It is therefore advisable to take a box if ladies who object to smoking are in the party. Prices-Promenade, $2 \mathrm{fr}$. ; orchestra stalls, $3 \mathrm{fr}$. ; boxes from 5 francs per person upwards, according to situation. Performances commence at 8.30 , and it is well not to arrive later than that time in order to obtain good seats, unless regristered in advance, as the Folies Bergère is a very popular amusement.

The olympia.--This is a similar place of anusement, but smaller and somewhat less important. It is situated on the Boulevard des Capucines, between the Madeleine and the Opéra Hunse. Prices-Promenade, I fr. (2 fr. Thursdays and Sundays); tirst gallery seats, 2 ir.; orchestra stalls, 3 fr. The Olympia largely owes its success to its convenient situation and low prices.

The Casino de Paris, situated in the Rue Blanche and the Rue de Clichy. Varicty entertainment and ballet-ranks next to Folies bergere in importance, and has at much better promenade. Aclmission, $2 \mathrm{fr}$; fatuteuils, 4 fr.; sallery, $3 \mathrm{fr}$. 


\section{Cafés'-Concerts.}

Where atic quitc a number of these places of amusement in Bass. The cutertamment somewhat resembles that of the

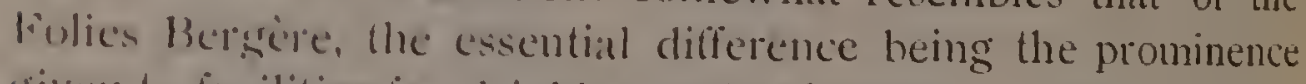
viven fo facilities for drimling and refreshment during the performance. During the summer months the Caré Concerts are held in the Champs Elysers; during the winter the companies are clabled off lo llicir respective winter quarters. The al freso conlerfanments on the Champs Elysees are well patronised by Enslishand Auterican visitors, but it is only fair to state that the winler quaters are chichly propular with French people. Over the salces of all these places of cultertamment is inscribed

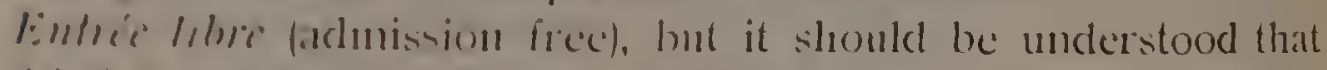
this is rather in the nature of a delusion and a sllare, inasnuch is the visitem mont take a seat, and when seated must take refleshment of some sort, the prices being in the front seats i ri. $50 \mathrm{c}$; sccond sealts, $2 \mathrm{fr}$. $50 \mathrm{c}$; balck seats, I fr. The principal open air Carés Chantants are-

The Ambassadeurs, situated on the right hand side of the Chanps lilyseces, close to the Place de la Concorde. This is the ment popular, beins essentially Parisian in the quality of its enterfaimnent, the atudience frequently joining in with the performers on the stinge in the chorus of any well known or popula melody.

The Alcazar, situated a little beyond the Ambassadeurs, is, senerally spealings, more suited to English and American lisiturs, heing somewhat quieter in the nature of its performmees. Seats are ahont the sane price as at the Ambassadeurs.

L'Horloge.-This is situated onl the opposite side of the Champs Elysees. The entertaimment is similar. Prices are atritle higher than at the beforenamed. This is perhaps the least desirable of the three so far as English and American visitors are concerned.

The Winter Resorts for these entertainments are-

The Scala, situated in the Boulevard de Sébastopol. Prices of admission I fr. and upwards. This place of entertainment ranks first in importance and popularity.

Alcazar d'Hiver, situated in the Faubourg Poissonnière.

The Parisiana, situated on the Boulevard Poissonnière.

The Concert Parisien, situated in the Rue de l'Echiquier.

La Cigale, situated on the Boulevard Rochechouart. 
In each of these cases prices of admission and nature of entertainment are similar to the Scala, and a fair average price for a good seat, including café or other drinks, is $2 \mathrm{fr}$. to $3 \mathrm{fr}$.

There is also a new and rather popular concert called the Petit Casino, situated on the Boulevard Montmartre, at which the best seats (fauteuils d'orchestre) are only i fr. $50 \mathrm{c}$.

\section{Equestrian Entertainments.}

The Nouveau Cirque, situated at No. 25I, Rue St. Honore, is decidedly the best circus in Paris. It is open during the winter and spring months only, and closed from about the middle of June to the early part of September. The performance is of the nature one would expect at a circus, so far as the first portion of the entertainment is concerned. The novel feature, however, peculiar to the Nouveau Cirque, is the introduction of "acquatic burlesque." During the interval, the floor of the arena is lowered, forming a basin or pond into which a number of the performers are constantly making a fall or plunge, in unsuitable attire, at unexpected moments. Prices-Reserved seats, $3 \mathrm{fr}$. ; boxes from $5 \mathrm{fr}$. upwards per seat. There is also a promenade gallery, in which there are no seats, price $2 \mathrm{fr}$.

Cirque d'Hiver, situated on the Boulevard des Filles-duCalvaires. Reserved seats, $3 \mathrm{fr}$.; secondes (or back), $2 \mathrm{fr}$.; promenade, I fr. In each case, however, it should be stated that these performances have considerably deteriorated of late years, and since the death of the celebrated Franconi.

The Cirque Fernando is situated on the Boulevard Rochechouart. Prices-Front seats, $2 \mathrm{fr}$. ; admission, I fr., but this is not the same class of entertainment as the ahove, and is in hardly recommendable to the English or American tourist.

The Hippodrome, which was formerly on the Avenue de l'Alma, is being rebuilt on the Rue de Caulincourt. It is very much larger than the former building, and the "ring" is so immense that $I, 500$ performers on horsehack can appear with ease at one time.

The Big Wheel is an entertainment similar to the same affair in London. It is situated on the Avenue Suffren, and comprises a theatre, music hall, \&c., in addition to the IVheel. It can be visited either during the day or in the evening, and if the former is more convenient, it is easily taken in with the Hotel des Invalides, as it is not very far from that historical building. 
There are two Cafós in Paris well worth visiling, though they me not perhaps places to take young ladies, though many ladies have been to each from curiosity. One is called "Le Neant" (Nothinguess) the ofler "Le Ciel" (Heaven). Both of these extraordinaly places ane on the Bunlevard des Batignolles.

\section{Balls.}

These furm onc of the striking and popular amusements of Parinians, and curiosity leads a large number of visitors to allend.

The Moulin Rouge, situlted on Hic Bonlevard Rochechouart in cortatimls the most populat. The first portion of the erening is revorted to a sort of cafc-concert entertainment, after which d.mcings continnes lill abunt midnight, the principal feature of allatction leings the call-rall. This is performed by paid dancers. It is essentially coarse and vulgar, and in our opinion llisis and similar cntertaimments are ntterly unsuited to ladies, though large numbers attend out of curiosity. Prices of admission are $2 \mathrm{fr}$. on ordinary nights, and 3 to $5 \mathrm{fr}$. on special nights, gencrally Wednesdays and Saturdays, but the newspapers slould be consulted in confirmation.

The Bal Buller, situated near the Luxembourg Gardens, as an entertamment is of the same nature as the Moulin Rouge, but considerably more Jarisian and noisy owing to the fact of its leins situated in the heart of the Latin-quarter, and chiefly palronised by students and their friends. Prices of admissionI fi. on urdinary nights, and 2 fr. on Thursdays and fête nights.

There are of course a number of others, but the two abovemamed are thoroughly characteristic and will certainly suffice.

\section{Skating Rinks.}

There are at present two rinks for skating on real ice, open to the public during the winter months in Paris. The first and most important is-

The Palais de Glace, situated in the Champs Elysées. This is a popular and showy entertainment, and those who desire to see an assembly of the latest styles of Parisian fashions in dresses and bonnets will find their utmost expectations realised if they select Sunday afternoons or fête nights for visiting this establishment. Prices of admission-Ordinary nights, $2 \mathrm{fr}$, ; lëte nights, $5 \mathrm{fr}$. 


\section{Velodromes.}

Since bicycling has become one of the most popular forms of amusement in Paris, several large and well-arranged velodromes have sprung into existence, the principal races taking place on Sunday afternoons, and sometimes on Thursdays, during the summer months only. The most important is the velodrome de la Seine, situated at Clichy-Levallois, the first station out of Paris from St. Lazare station; frequent trains on race days, Prices of admission-Pesage, $5 \mathrm{fr}$. ; premières, $3 \mathrm{fr}$.; admission I fir.

Velodrome Municipal, situated in the Bois de Vincennes, though larger and more commodious, is less popu'ar on account of its distant situation.

Velodrome Buffalo, situated in the Avenue de Villiers.-This is under the sime management as the Velodrome de la Seine, but is considerably smaller and therefore less used.

Velodrome des Princes. - This is the largest velodrome in Paris, and the most recently opened. It is situated at Auteuil, and is reached by the Chemin de Fer du Ceinture from St. Lazare station, booking to Auteuil.

\section{Horseracing.}

This sport has become increasingly popular of late years, and during the summer season there are races on one or other of the many courses almost every day, and invariably on Sundays and Thursdays; Sunday being the day on which the "Grand Prix," the "Grand Steeplechase" and all the principal events are run. During the greater part of the summer season races are held on the Longchamps course. This is situated on the further side of the Bois de Boulogne, and accessible by frequent trains from the St. Lazare station, or by char-à-batncs collecting visitors on the principal boulevards, and also (and most conveniently) by cabs taken by the hour, for which the bargain should be made in advance for the afternoon.

Auteuil.-This course is also situated in the Bois de Boulogne, and is devoted exclusively to steeple-chasing, chiefly during the spring and autumn. In all other respects the foregoing remarks apply.

Vincennes, Bois Colombes, Maisons-Laffitte, and other racecourses situated in the environs of Paris, are of secondary importance. Details will he found in the local papers. 


\section{Waxworks.}

The Musée Grévin, sitnated on the Boulevard Montmatre, may be mentioned as being a suitable and conrenient place to piss an hour cilluer during the afternoon or evening. It resembles the Lendon Exhibition of Madame Tussaud's, excepting llat the arrangement and grouping is in some respects superior. The collection, though considerably smaller, is certatily cqually altractive. Admission, $2 \mathrm{fr}$; Sundays, I fr.

\section{Panoramas.}

It mil be well to mention that this form of entertainment havius fallen inlo distaronr, there only now remains one panoramit of any importance in the cily. This is situated near the lent d'Austerlite, and represents the enrolment of volmutecrs during the Revolutionary period of 1792. Admission is I fr. If passing the doors during a shower, it makes a conrenient sheller-otherwise it may safely be onitted.

\section{Military Bands.}

These play during the summer months in the gardens of the l'alais Royal and the Tuleries, as also in the Luxembourg. As both days and times of performances vary according to the seatson of the year, we must refer readers to the local papers for precise informalion.

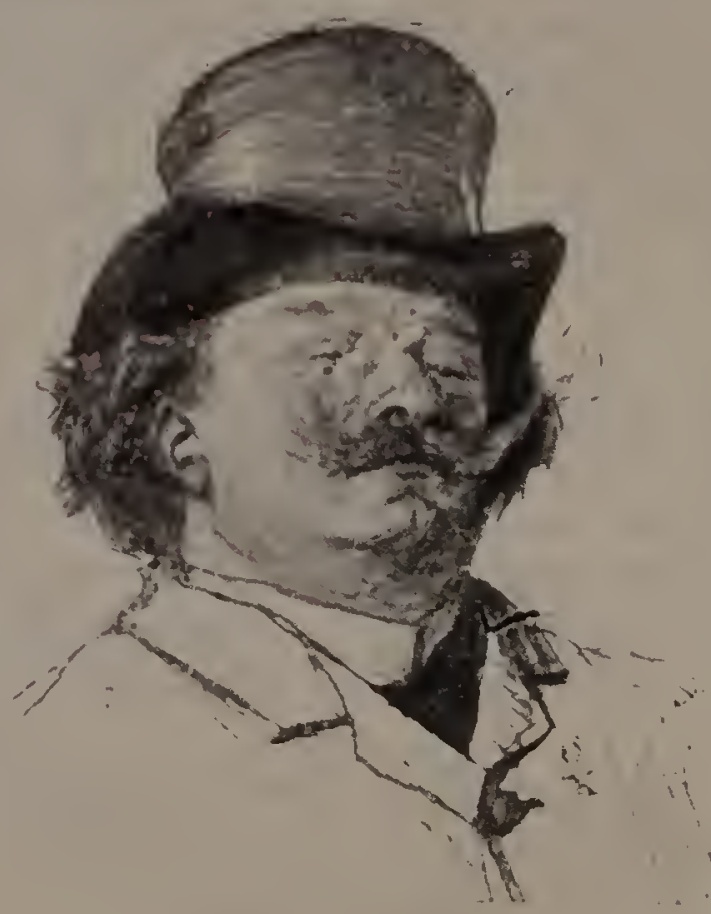




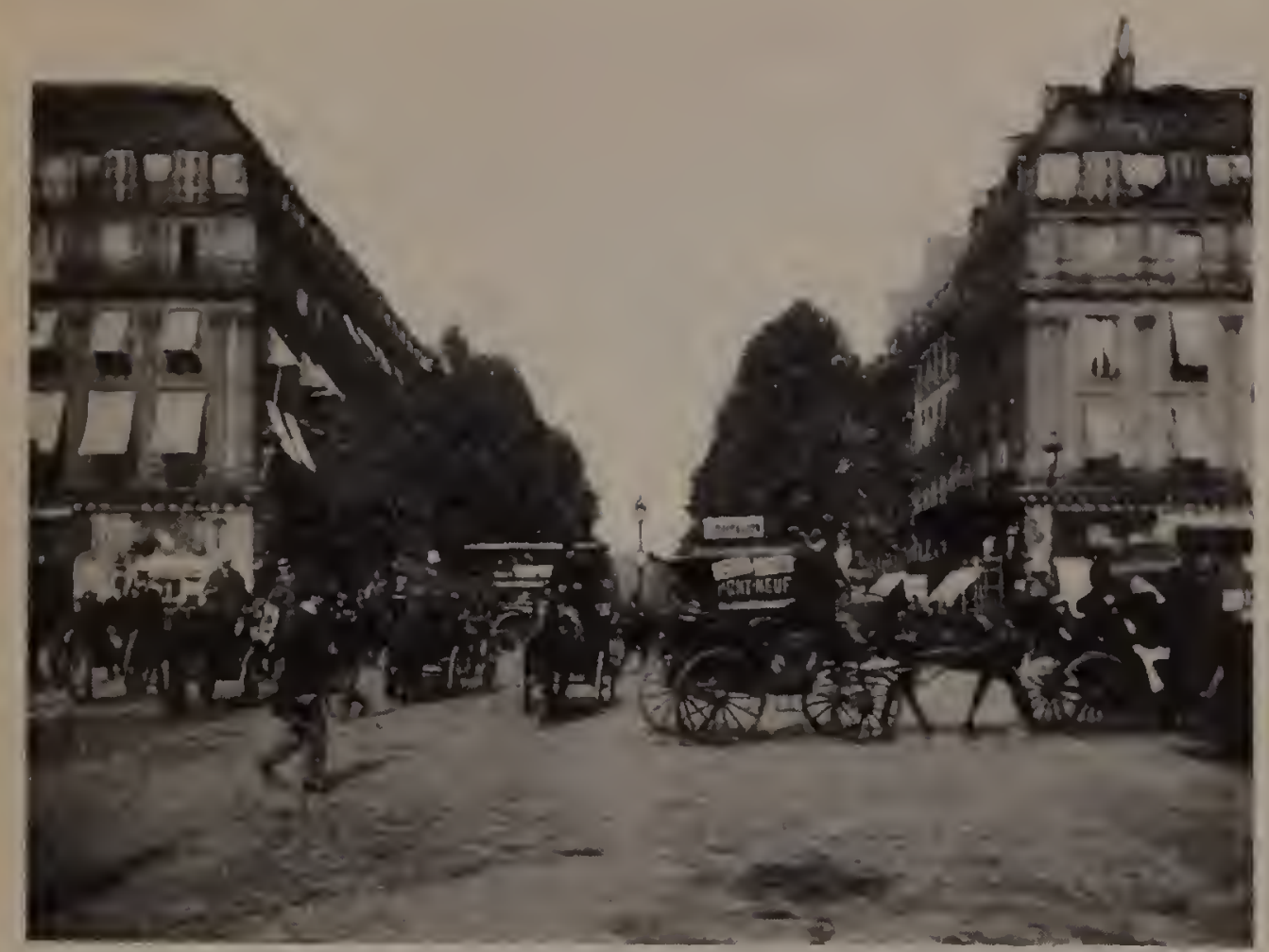

York $\leq$ Son, ]

BOLLEYARD DES CAPCCINS.

[Notting Hill.

\section{CHAPTER I:}

\section{TOPOGRAPHY. HOW TO FIND YOUR WAY THROUGH PARIS.}

Great Main Arteries-Contres, branches, and circles-The Seinc and its comrsc-Heights aronnd Paris-The Quais, \&c.Bridges across the Scinc-Fortifications of Paris-The Arrondissements of Paris-Strects, Places, and ConrtsRents-Drocllings-Flats-The Bonlciards-Old and Ncou Boulcoards of the Rice Ganche-Bonlewards de CeintureGeneral Summary of the Topography of Paris-Suburban districts of the Banlicuc-The differcut Quarters.

\section{The Great Arteries and Landmarks.}

7 HE topography of Paris is easily learnt, and is, indeed, far 1 less puzzling than that of many places that camnot compare with it in size. It is necessary to keep in mind a few chief features, and to notice on the plan the direction of the sreat arteries traversing the city from north to south and from east to west; then to observe the circles formed by the Inner Boulevards and the great avenues and extensions of boulevards branching out from them; finally to fix upon some of the public places, such as the Place de la Bastille, the Place dela Concorde, the Place de l'Etoilc, \&c., as landmarks of the various parts of Paris. 
lis He first place it will be noticed that the seine llows Hrongh Paris from catst to west, contering the city at Bercy suntly afler it has been joined (about a mile outside the fortificillinns) by the Malle. The grealler pall of Parls, and the most important huildings and historical localities, are situated on the norlherle side flhe "rive dioite," of light-hattd bank, lookings

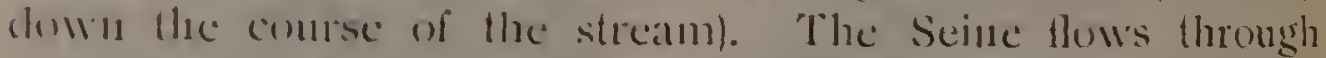
lanis in lle slape of He alle of a how, tralersing it for about file mike. dround Panis ane low hills, the loftiest, Montmartre and Bolleville, heing under joo fect in height. The arerage elevalton of Paris above sea-level is moler 200 feet.

The seine yuits the city at Autenil. Its alverage width beymet the He de la Cile and the He st. Louis is about 000 leet, fure-thires of the hreadtl of the Thatmes at London Bridge. denge catels side of the river lans a series of Quays, some of Hern planted wilh trees like lle Thames Embankinent, and forming agreable promenades. Along the right-hand or monther" batk, folloming the consse of the strean, they are as Inllow: :- The Quai de Berey in front of the Entrepot of the sume nanc, gencrally crowded with merchandise; the Quai de la kapéc and Place Marats. Then, to the north of the two slands of St. Louis and la Cité, lhe Quai Henri Quatre, Quai des Celentims, and Quali de l'Hotel de Ville. Then comes the Quati du lomire, in front of the palace of that wame, and the (Juti des Tulerics, in front of the Tuileries gardens ; the Quai de Conférence, Quai Dehilly, and Quai d'Auteuil. On the soullern batuk w "rive satuche," stating from Bercy we have He (llati de lat Galle, in frout of the Gare des Marchandises or surels station of the uld Orleatus railivay ; the Quati d'Aușterlity. Quai st. Bernard, and Quai Montebello, all awakening reminiscences of the glories of France; the Quai de Conti, Quai Ioltaire, and Quai d'Orsay, the last named after the accomplished Count d'Orsay-il great friend of Louis Napoleon Bonaparte while the prince was a refugee in London, and nominated by Lim Minister of the Fine Arts, when the exile of other days became President of the Second French Republic-this is the nost magnificent of the cuats.

The series is completed by the Quai de Grenelle, and Quai de Javel, the latter extending to the point where the Seine quits Paris. These quays, besides their commercial and promenading value, are very important in banking up the river, and prevent- 
ing inundations after an unusual downfall of rain has swollen the Seine and the Marne. Communication between the "rive droite" and "rive gauche" is kept up by a number of-

\section{Bridges across the Seine.}

Following the course of the stream from east to west, the names of these bridges are als follows :-First comes the Pont National, just inside the fortifications, and next to this is the Pont de Tolbiac, the name, like that of the Rue de Tolbiac, recalling the famous victory gained by Clovis, the first real King of France, at Tolbiac or Zulpich, near Cologne, in +96 , which proved the chief stepping-stone of his greatness. Next comes the Pont de Bercy, and after this the Pont d'Austeriitz, leading to the Jardin des Plantes-a handsome structure, 480 feet in length and 37 feet wide, with five cast-iron arches resting on stone piers. It was built in $180 \overline{7}$, as a memento of the celebrated victory of Austerlitz, gained by the Emperor Napoleon I. over the Austrians and Russians, on the 2nd of December, 1805 . It was almost rebuilt in 1855 , and enlarged in I $884-85$. Anid its decorations are inscribed the names of the principal officers who fell in the famous battle which put Austria into the power of Napoleon. The Pont de Sully, at the western extremity of the Ile St. Louis, unites the Boulevard St. Germain on the left bank with the Boulevard Henri Quatre on the right. It was built between $187+$ and 1876 , and is named after Rosny duc de Sully, the friend and counsellor of the "bon roi Henri Quatre." Then comes the Pont Marie, the Pont de la Tournelle, originally built between $161+$ and 1618 , and several times rebuilt, and the Pont St. Louis, a short bridge of a single arch at the back of the Cathedral of Notre Dame. The Pont Louis Philippe, almost the only building in Paris whose name recalls the memory of the Citizen-king; the Pont d'Arcole, recalling the brilliant deeds of Napoleon's Italian campaign of 1796 ; the Pont Notre Dame, built in I joo, and the Pont au Change; the Pont de l'Archevèché, or of the archbishop's palace; the Pont ou Double, the Petit Pont and the Pont St. Nichel, all join the Ile de la Cité with one or other banks of the Seine. At the western extremity of the island stands the famous Pont Neuf, built between 1578 and 1604, renovated in 1852, and since repaired and strengthened. This is the largest of all the Parisian bridges, and has twelve stone arches. It is adorned 
with a finc equestrian statue of Henry IV. Next comes the Pont des Arts, for foot-passengers only, opposite the Louve, an elegant bridge of nine arches, and the Pont du Carrousel, between the Place du Carrousel on the north bank and the Rue des Saint Pires on the south.

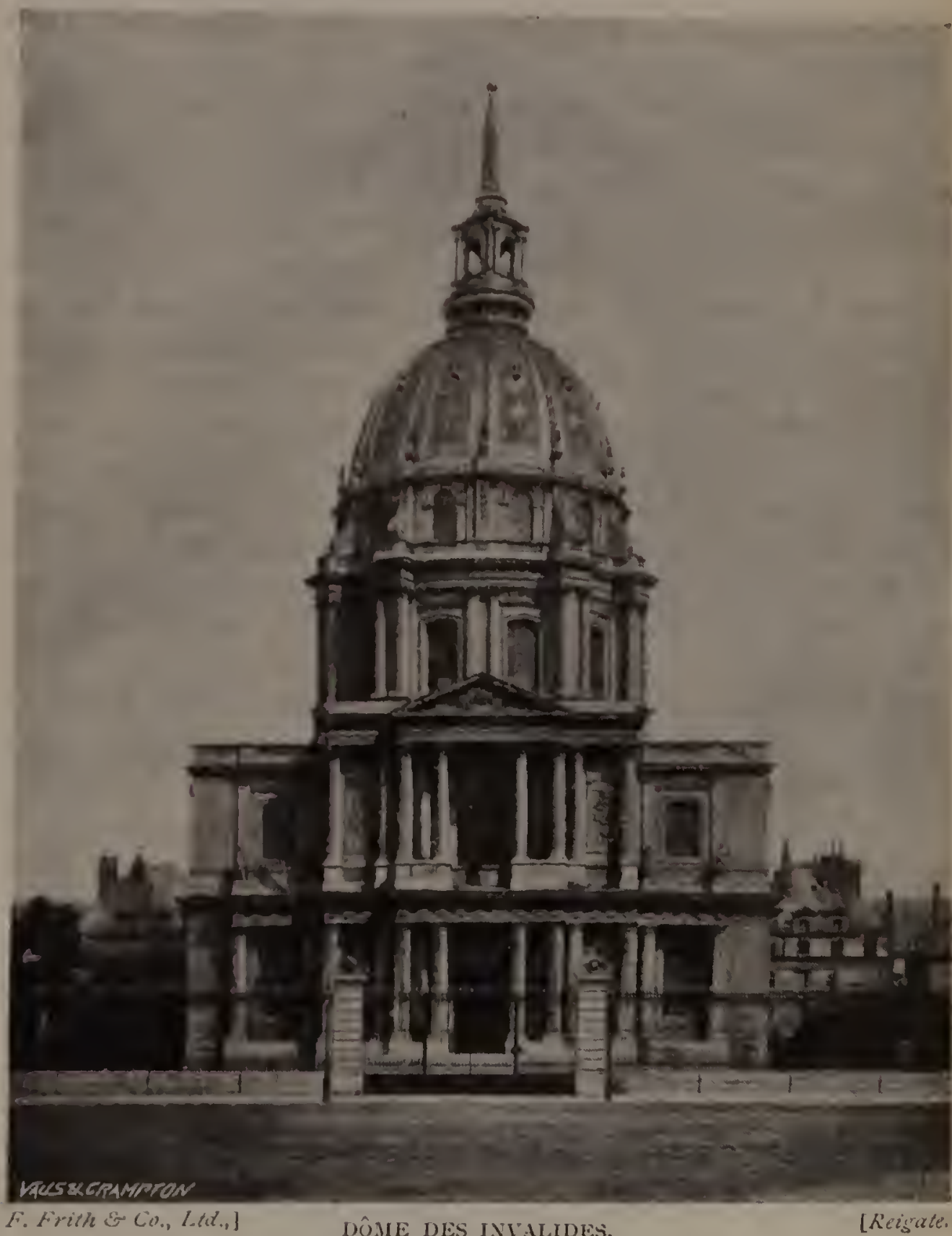

(See P. II6.)

The Pont Royal, an old bridge, is the starting place of the St. Cloud, Suresnes, and St. Germain steamers; the Pont Solferino, a memorial of the victory gained by the French over the Austrians during the campaign of 1859 ; the Pont de la Concorde, 
joining the Place de la Concorde and the Ministry of Foreign Affairs; the Pont des Invalides, between the Avenue d'Antin and the Boulevard de la Tour Maubourg, leading to the Hôtcl des Invalides. The Pont de l'Alma is a trophy recording the Crimean $\mathrm{V}^{\mathrm{T}}$ of $\mathrm{I} 857$, and offering in its adormments counterfeit presentments of members of four branches of the military service. Further on the river is crossed by the listorical Pont de Jena, with five elliptical arches, and a classic cornice from the Temple of Mars at Rome. This bridge was built between 1606 and 1813 , and was the one whose name, recalling the tremendous defeat that laid the Prussian monarchy at the feet of Napoleon in I806, roused the ire of choleric Ficldmarshal Blücher to such a pitch, on the second occupation of Paris by the allied armies in 18I5, that he was with difficulty withheld from blowing it up. The Pont de Passy, another bridge for foot-passengers only, was built in 1878 , and traverses the eastern end of the Ile des Cygnes. The list of Parisian bridges is appropriately closed by the handsome and artistic Pont du Point du Jour or d'Auteuil, with its separale roads for pedestrians, for carriages, and for the Chemin de Fer de Ceinture, or circulin" railway, that surtounds Paris. The Pont Alexandre III., between the Cours la Reine and the Esplanade des Invalides, of which the corner stone was laid by Nicholas II. with great ceremony at the time of his famous visit to Paris in 1897 , has been very severely criticised, but on the whole is a very imposings structurc. This bridge rightly belongs to the portion of the Guide devoted to the Exhibition, and a further account will be found therein.

\section{The Fortifications of Paris}

form a complete belt around the city, having a circuit of 21 miles. The wall is 34 feet high, and is surrounded by a mot 34 feet in width. It is pierced throughout its whole extent by 56 sates, besides nine openings for railways, and four for the passiges of the Seine and the Canals of St. Denis and Ourques. The Wall the taxes levied for carrying on the work at a time when there was much distress in Paris. They were greatly strengthened by of which have been built since the war of 8 - To-7s, eightecn strengthen Paris against the attacks of an en 18jo-71, iurther older series of forts (nearer Paris than those recently comong llic 
are the Forts de Romamaille, du Vord, de Noisy, and de Charentom. on the right bank; and on the left bank, the forts of Bicetre, Mont Ronsce, and the famous Mont Volerien, a prominent object to the Irest of the Bois de Boulogne beyond the river. The fort of Noisy is the farthest to the east, of the older series.

\section{The Arrondissements of Paris.}

The city of Paris is clivided into twenty districts, or arrondissemenls, to each of which is attached a "Maire" and two deputies for the transaction of public business. These divisions correspond to the parishes in London and other English towns, and have their peculiar features, some of them differing as much from others its St. James's from St. Giles's ; though, as in London, the march of improvement and reconstruction has effaced many of the old landmarks and peculiar features that distinguished certain yuarters. The names of these arrondissements are as follows :-

I., of the Louvre; II., of the Bourse; III., of the Temple; IV., of the Hotel de Ville; V., of the Panthéon ; VI., of the Luxemhourg; VII., of the Palais Bourbon; VIII., of the Elysée ; IX., of the Opera; $\mathbf{X}$., of the Enclos Saint Laurent; XI., of the Popincourt ; XII., of Reuilly; XIII., of Gobelins ; XIV., of the Observatoire; XV., of Vaugirard; XVI., of Passy ; XVII., of Batignolles-Monceaux; XVIII., of the Butles-Montmartre; XIX., of the Buttes-Chatumont; XX., of Ménilmontant.

\section{The Houses.}

Paris cuntains about 3,700 streets, places, courts, quays, and minor thoroughfares, more than 300 separate public edifices, and about 60,000 houses, chiefly built of stone, and in general very much higher than the houses in London. The custom of making one house a clomicile for a large number of families, and the existence of a definite enceinte, or boundary, in the shape of an encircling wall, has led to the lofty method of construction adopted in the majority of the houses. In the modern edifices built for working people, there are in some instances as many as ten or eleven stories, lifts being used instead of staircases. The old fashion of building houses in quadrangles, with an inner court, has been preserved, and in many cases huge edifices of this kind rise, with a porter's lodge, where the "concierge" gives information regarding the numerous inmates. The suburban 
villa style, with its snug little garden and commodious artangement, must be sought outside the barriers, for want of space prevents its introduction anywhere inside the enclosure of the fortifications. Rents in Paris are high, and seem on the increasc: the price that would secure a roomy honse in London has to be paid for a very confuned "Hat" or suite of rooms on the firth or sixth floor, in a good street. A very argreeable feature of the topography of Paris, and one which conduces greally to the comfort of the resident and the enjoyment of the visitor, is found in the numerous and still increasing avenues, generally planted with trees, and forming the various series of -

\section{Boulevards of Paris.}

The first set of these avenues marks what were the ancient boundaries of Paris, the name Boulevards, or bulwarks, indicating that they are built on the site of the old wall and its surrounding ditch. The Grands Boulevards will be found extending in the form of a bow from the end of the Rue Royale, near the Place de la Concorde, to a point on the Seine not fal from the Pont d'Austerlitz. They are the favourite lounges of the Parisian, being to the club man what the "sweet shady side of Pall Mall" is to his brother of London, and are never withoul their full complement of passengers and occupants. For here are to be found some of the most brilliant shops, the most sumptuous cafés, and the most tempting restaurants in Paris. As the quays form the farourite lounging-place of the idlers, in "flineurs," of the lower classes-who seem never weary of watching the little steamers passing to and fro on the seine, or of following with intense interest the movements of the persevering gudgeon-fisher, whose pursuit is suggestive of the triumph of hope over disappointment-and are the happy hunting-ground of the amateurs of cheap literature, for whose delectation long rows of volumes are displayed along the parapets of the "rive gatuche,"-so the Grands Boulevards are the hatunt of the lounger of the higher class, the locality where he feels himself thoroughly at home, and which he looks upon as the pride and boast of Paris.

Starting from the Place de la Concorde, and proceeding up the Rue Royale, we come first to the Boulevard de la Madeleine from the Place de la Madeleine, where is held a flower-market near the church of that name. Next is the Boulevard des Capu- 


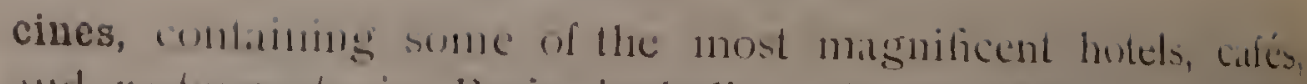
and lesturants in Paris, including the approprately-named Grand Hotel, the fashionable Cafe de la Pais, Boissier's confectionery cstablishment, dece, and many hrilliant shops for the sile of l'arisian objects of ant and luxury of various kinds. The high lisle of l'aris outdoor life is to be seen during the seatson (n1 this line of boulerats, where are situated the magnificent Opéral Housc and the Vaudeville Theatre; the Jockey Club lover He Grand Café), and ofher points of interest. The Boulevard des Italiens, the next in order, from the Rue de la Chausseie d'Antin to the Rue Dronot, also presents a series of cafés, icstinnants, and dining-houses, such as camnot be equalled for lavish luxwy and extravagant decoration in any other capital in the world. The 'Theitre Robert-Houdin, named after the famous conjuror, is on this houlevard, which leads to the Boulevard Montmartre, helween the liue Drouot and the Rue Montmartre. Here are situated the Théatie des Variétés, the Passage des P'anoramas, numerous cafés, and the Pâtisserie Frascati (most clengunt and lempling of Parisian pastry-cooks). The Boulevard Poissonnière, hetween the Rue Montmatre and the Rue Poissonnicie, hats some attractive shops, especially several for the silc of hromses, cimpets, art fumiture, Sc. The Boulevard Bonne-Nouvelle, from the Rue Poissomniere to the Rue Saint 1) culis, alud the Boulevard Saint Denis, from the Rue Saint Denis to the kue Saint Martin, conne next in urder. The latter has Hee lwo trimmplat arches, the Porte Saint Denis and the Porte Saint Martin, at its extremities. Here the Place de la République intervences, at the castern extremity of which begins the Boulevard du Temple, in front of wlich is the Marché du Temple. It extends lo the Rue des Filles du Calvaire. On this boulevard is the Théalle Déjazet, so named after a clever actress, described fifty years ago by Mis. Gore, in her account of the Paris of 1830 , as "that ematic child of genius, the witty and andacious Déjazct." Here is situated the Grand Hotel Moderne (formerly the "Magazins Réunis"). The Boulevard des Filles du Calvaire follows next. Here is situated the IVinter Circus, or Cirque d'Hiver. The Boulevard Beaumarchais, leading to the Place de la Bastille with its Colome de Juillet. It is named after the popular dramatist, the author of The Barber of Scrille and The Marriasc of Figaro, which house-in which he died in 1799-stood on the site now occupied by No. 2. The house of 
Ninon de L'Enclos, one of the celebrated women of the reign of Lunis XIV., stood here. She was the friend of Moliere and Fontenelle, and of her it was observed that, though she thought like Epicurus, she lived like Lais.

From the south sicle of the Place de la Bastille three boulevards extend lo the seine, the most westerly being the Boulevard Henri Quatre, leading to the Pont du Sully ; and the (wi) rithers, which skirt the Western and eastern banks of the Cillal St. Martin, are the Boulevard Bourdon and the Boulevard de la Contrescarpe, the latter extending to the Pont l'Austerlit\%.

On Hhe south bank (rive sauche) the fons Boulevard st. Germain extends, likewise in the form of a bow, from the Pont du Sully to the Pont de la Concorde. Along it are situated the Furdin de Clmmy, continining some interesting archaeological rematins of ancient Paris, and the Music de Clmmy; the Ecoli

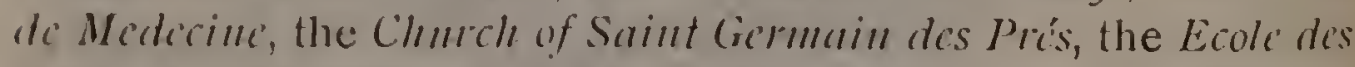
l'outs el Chumssic's, and at the western extremity the Chamber of Depullos. This is the first, southward of the Seine, of the New Boulevards, which were commenced in 1854 , and owe their existence to the encregy of Napoleon III. and the indefatigable prefect of the Seine, Baron Hausmann. These boulevards are rery nmmerous, and with the stately Avenues, which resemble them in their handsome proportions and in being generally panted with trees, have quite altered the appearance of Paris. Thus in the noth-western part of Paris (the fashionable quarter) a number of these stately avenues extend, like the spokes of a wheel from the liave, from the Place of the Arc de Triomphe de l'Etoile. The twelve are thus named :-

The Avenue du Bois de Boulogne, formerly called Avenue de l'Imperatrice, leading to the Porte Dauphine and so to the Bois de Boulogne.

The Avenue de la Grande Armée, leading to the Porte de Neuilly.

The Avenue Carnot, named after the great statesman of the First Republic, the grandfather of the assassinated President, and leading to the Ruc des Acacias.

The Avenue MacMahon, named after Marshal MacMahon, and leading to the Rue Montenotte (named after one of the earliest of the great Napoleon's victories), and thence extended to the Avenue des Ternes. 


\section{BOULEVARDS AND AVENLES.}

The Avenue Niel, between the Avenue des Ternes and the Place de Courcelles, joining on to the Avenue MacMahon.

The Avenue de Wagram, named after Napoleon I.'s great victory over the Austrians in 1809 , extends to the Place of the same name.

The Avenue Hoche, named after the brilliant young republican general, Lazare Hoche, (who clied at 29 years of age in 1796 , after gaining a military reputation a veteran might have envied), extends to the Parc Monceau.

The Avenue de Friedland, named after the great victory of Napoleon I. over the Russians in $\mathrm{I} 807$, extends to the open space formed by the junction of the Boulevard Hausmann with the Rues de Washington, de Monceau, and du Faubourg St. Honoré.

The Avenue des Champs Elysées with its magnificent hotels and other gorgeous buildings, leading to the Place de la Concorde.

The Avenue Marceau, stretching to the Pont de l'Alma.

The Avenue de Jena, named after the famous battle of 1806 , and leading to the Parc du Trocadero.

The Avenue Kléber, named after the general left hy Bonaparte in command in Egypt in 1799. It extends to the Place du Trocadero ; and-

The Avenue Victor Hugo, leading to the Porte de la Muette.

On the southern bank (rive gauche) of the Seine, are the following old boulevards :- The Boulevard des Invalides, extending from the Boulevard de Montparnasse to the Rue de Grenelle, at the corner of the Esplanade de Invalides, near the Hôtel des Invalides (the Chelsea Hospital of Paris), where rest the ashes of the great Napoleon, in conformity with the wish expressed in his will made at St. Helena; the Boulevard de Montparnasse, extending from the Avenue de l'Observatoire to the Rue de Sèrres, with the church of Notre Dame des Champs; and the Boulevard de l'Hôpital, so named from the Hôpital de la Salpêtrière, or Hospice de la Vieillesse, a vast institution, a house of refuge for paupers and imbeciles, containing nearly four thousand inmates. This boulevard extends from the Place Walhubert, close to the Jardin des Plantes or Botanical and Zoological Garden, to the Place d'Italie. A number of new ways have been formed by the union of the old exterior boulevards and the circuit roads. Thus on the right (north) bank we have 
Hhe Boulevard de Bercy, from the Quais de Bercy and de la Kirpéc to the Rue de Charenton; the Boulevard de Picpus, exlending to the Cours de Vincennes, close by the Place de la Nation; llue Boulevard de Charonne, from the Cours de Vincennes 10 the Aventue de Philippe-Auguste:-and thence the series continues, forming a complete stretch of boulevards extending in an unbroken line from the Pont de Bercy to the neighbour-

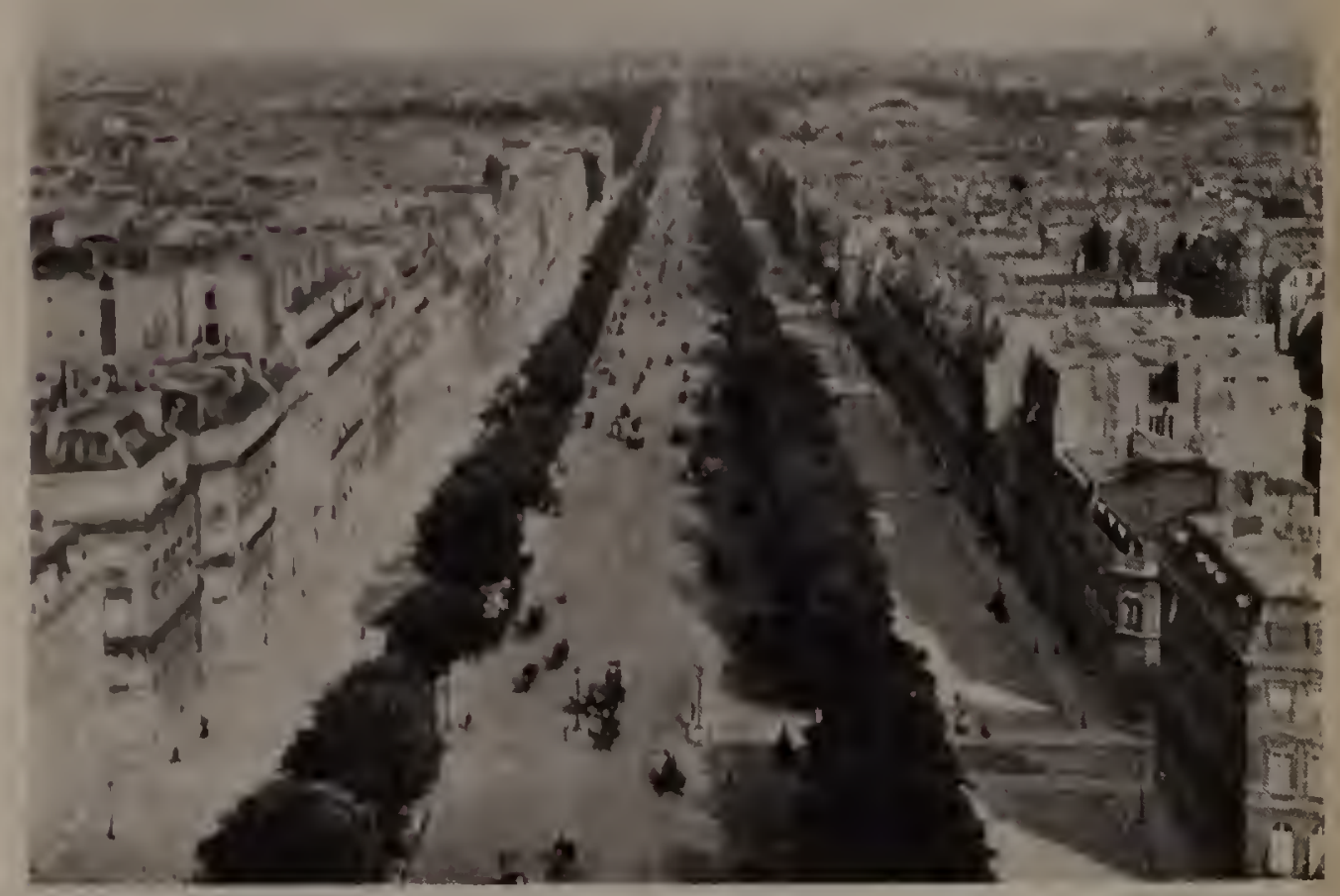

AVEXLE DES CILMMIS FLTSEES.

(1,oking Iowatis the Place de lat Conconde.)

hood of the Arc de l'Etoile-the Boulevard Ménilmontant coming next and extending to the Ruc Oberkampl and the Rue de Ménilmontant; the Boulevard de Belleville, next to the Rue de Belleville and the Rue du Faubourg du Temple; the Boulevard de la Villette to the Rues d'Aubervilliers and de Chateau Landon; the Boulevard de la Chapelle extending to the new boulevards of Magenta and Barbés; the Boulevard de la Rochechouart as far as the Rue des Martyr's; the Boulevard de Clichy to the Place de 
Clichy; the Boulevard de Batignolles to the Rues du Rocher and de Levis ; and finally the Boulevard de Courcelles, which ends at the Rond Point des Ternes, close to the end of the Avenue Wagram, which itself leads to the Place de l'Etoile.

A similar series of New Boulevards on the South side of the Seine (rive gauche), runs in a curve from the southern side of the Pont de Passy on the Ile des Cygnes, starting from the point of junction of the Quai de Grenelle and the Quai d'Orsay, and terminating at the Place Valhubert by the Pont d'Austerlitz. They are the Boulevard de Grenelle, extending to the Rue de Sivres; the Boulevard Vaugirard, terminating at the Gare de I'Onest, the terminus of the Bretagne and Versailles raihway, on the Place du Maine, where commences the Boulevard Edgar Quinet, which runs into the Boulevard d'Enfer; and here hranches off the Boulevard Arago, named after the celebrated François Jean Dominique Arago, philosopher, astronomer, and man of science, one of the most distinguished of modern French savants. The boulevard leaving the Boulevard Arago to the left, the way leads past the terminus of the Scéaux and Limours railway on the Place Denfert-Rocheveali, whence the Boulevard St. Jacques extends to the Rue de la Santé. Here commences the Boulevard d'Italie, which extends to the Place d'Italic. From this point two boulevards branch off, one the Boulevard de l'Hópital, terminating in the Place Valhubert at the southern end of the Pont d'Austerlitz, and the other the Boulevard de la Gare, terminating at the Pont de Bercy between the Quai de la Gare and the Quai d'Austerlit\%.

Among the other boulevards of Paris the visitor should especially notice the spacious Boulevard Voltaire, extending in a perfectly straight line from the Place de la Nation to the Place de la République; the Boulevard de Magenta, named after the great victory over the Austrians in 1859, and extending from the north-east corner of the Place de la République to a point hetween the Boulevard de Rochechouart and the Boulevard de la Chapelle; the Boulevard Hausmann, a worthy memorial of the great redile of Paris under the second Empire, and extending from the Avenue Friedland to the Boulevard des Italiens, forming with the avenue a magnificent walk from the fashionable centre of Paris to the Arc de l'Etoile; the Boulevard de Port Royal, from the Avenue des Gobelins to the square of the Ohservatory; the Boulevard de Latour-Maubourg, from the Quai 
d'Otsay lo the Invalides : and the Boulevard Pereire, extending, as a double arenue, on hotli sides of the Chemin de Fer de Ceinture from the station of the Porte Maillot to the Rue Jouffroy, near the Batignolles station.

The Militiry Road that runs round Paris, just within the fortifications, has also been erected into a series of boulevards, llamed after distinguished military chiefs of the first Empire. 'There are nineteen of these Boulevards de Ceinture, and they are thus designated, heginning from the north of Paris at the Porte St. Otren, and turning eastward: The Boulevards Ney, Macdonald, Serrurice, Morticr, Davoust, Soult, Poniatowski, Masséna, Kellermann, Jourdan, Brunc, Lefive, Victor, Murat, Suchet, Litnnes, Gouvion St. Cyr, Berthicr, and Bessière-in themsclves an epitonce of Napoleonic glory, and calling up reminiscences of the nueteoric splendours of the great period of ivar.

There are also a number of avenues which the curious visitor will find delineated on the plan of Paris, though our space forbicls a special mention of each. These avenues are quite a modern development of Paris, and, like the new boulevards, add greatly to the attractions. The writer of an entertaining article on Paris that appeared some time since in the Graptic, justly remarks on the various attractions offered by the boulevards and avenues, the Clamps Elysées and the Tuileries gardens, at all lnours of the day, and especially on the usefulness of that typically French institution the "café." "Paris," he says, "is certainly an carlier riser than London, though perhaps, as the life is more of an out-of-doors nature, the fact is more apparent than real. Be this as it may, however, Paris is very early astir ; and as the visitor drives in, grim, tumbled, and dirty from a night's journey, he feels his discomfort all the more keenly from the contrast of the trim, clean look of the people he passes, although they may be the white-capped market girls, or the ever-energetic waiter of a café (when do these waiters sleep ?) setting his tables for the morning coffee of his first customers. The Englishman with his indoor habits can hardly understand how large a portion of Paris life is spent in the cafés and similar haunts on the boulevards-how much business is done, and how many affairs of importance are settled, over the absinthe or vermouth, the coffee and the 'grogs, of these neverfailing, ever-ready houses of entertainment." 


\section{General Summary of the Topography of Paris.}

The readiest way to obtain a general knowledge of Paris is to take a few preliminary drives along the main arteries in the tramcars, and make a journey or two on a Seine steamer, from the Pont de Grenelle to the Pont d'Austerlitz, or vice versiâ. The visitor can best understand the capital from a topographical point of view by dividing it into concentric circles, taking the great square in front of the Palais Royal-on which is situated the Theatre Français-as the common centre. Here the first enclosure or "enciente" is formed by the Grands Boulevards on the north, extending (with the Rue Royale) from the Place de la Concorde to the Place de la Bastille, on the northern or "right" bank of the Seine, and by the long Boulevard St. Germain from the Pont de la Concorde to the Pont de Sully, on the southern or "left" bank. This circle contains the oldest part of Paris, and, especially on the right bank, includes many of the important and interesting public buildings.

As these interior boulevards mark the limits of old Paris, being erected on the site of the old city wall which was levelled about 1670 , the second line, that of the houlevards exterieurs, marks the circle of the old barriers, at which town dues or octroi used to he levied on all goods coming into Paris. The third circle or enceinte is formed by the wall built under Louis Philippe, and now adorned with the nineteen houlevards already mentioned as being named after celebrated generals of the first Empire.

Beyond the second circle or exterior boulevard, the old haunts of the octroi, and included within the outer enceinte or circle of the fortifications, are-

\section{The Suburban Districts}

annexed to the city of Paris in the year 1860 , and known as the Banlieux. Starting from the south-eastern corner of the capital on the northern bank (rive droite) of the Seine, these outward districts are: Bercy, the head-quarters of the great dealers in wine and spirits, with its great depôts and cellars, its quay and numerous counting-houses, all dedicated to varions branches and developments of the wine trade ; Charonne and Montreuil, with large market-gardens and orchards, and the great cemetery of Pere la Chaise; Ménilmontant with a dense industrial popu- 
lation, and Belleville, the favourite quartere of the retired artist or lateler and the small proprietor, with the Buttes Chaumont and its pretty park in the immediate vicinity ; then the somewhat repulsive and insalubrious Villette, with its abattoirs and more or less offensire industries, hordered by the canals St. Martin and St. Denis; La Chapelle, another industrial quarter, largely peopled by the workmen of the Chemin de Fer du Nord and de l'Est;

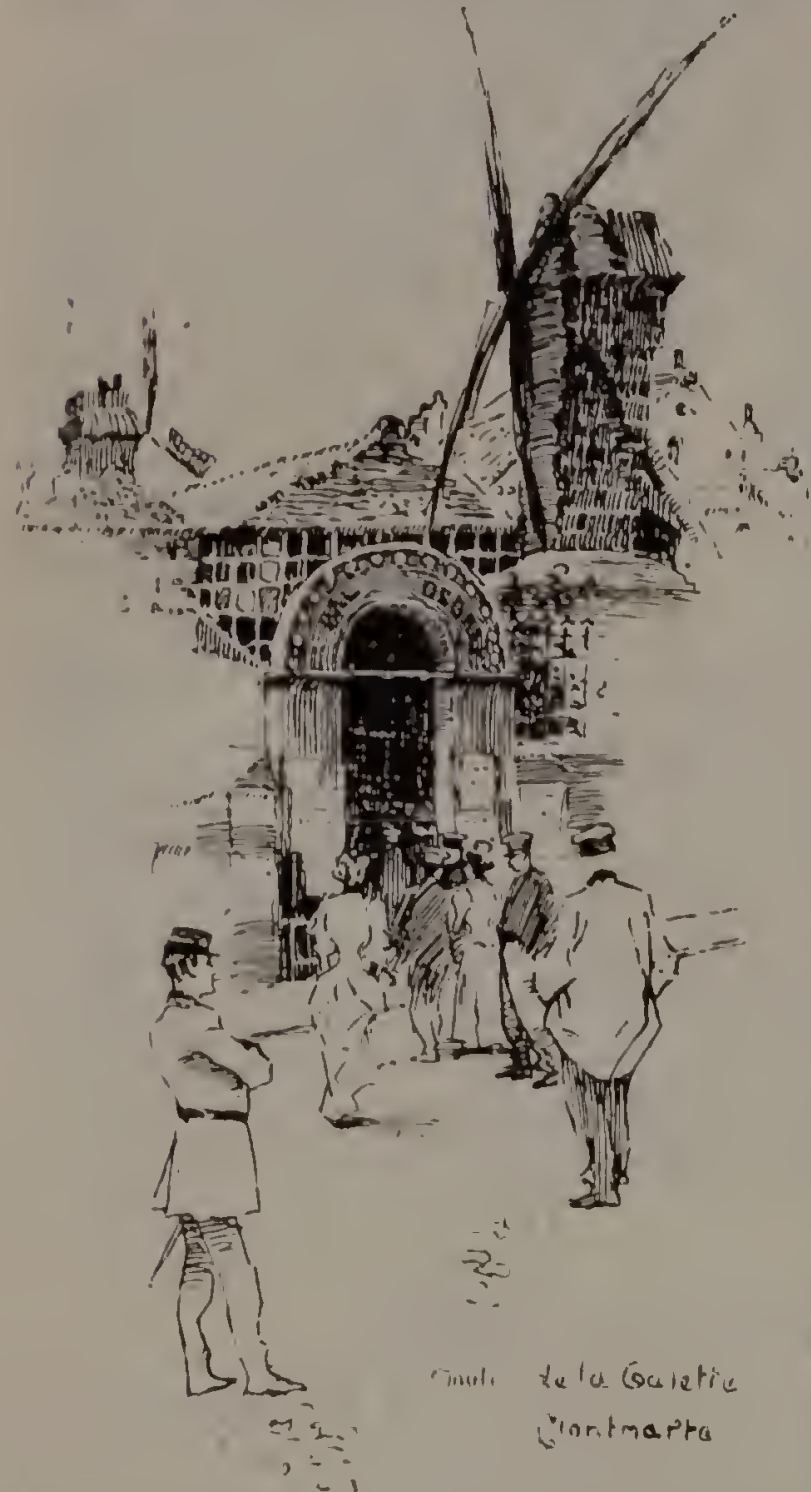

Montmartre, in the north of Paris, is inhabited by small proprietors and workpeople, and with its steep streets and old houses has an air of picturesqueness, though hardly of comfort; "Les Batignolles," partly occupied by the sicat gondsstation of the Chemin de Fer de Normandie et de Versailles-the Western Railway, in fact, whose numerous employés have their dwellings here; and the rest is occupied by modest bourgeois establishments. Very different in appearance from Les Batignolles are the quarter's of Passy and Auteuil (with the new outlying districts of Courcelles and Monceau), Les Ternes, \&c. These form an entirely modern and extremely elegant quarter of Paris, in immediate proximity to the charming Bois de Boulogne; and it is here that the wealth and luxury of Paris are displayed in their most agreeable form, in the elegant mansions, villas, and cottages (the cottage with the double coachhouse, the "cottage of gentility" of Porson's poem), alternating with stately huildings many stories high, and sumptuous hotels. The district of La Muette and Ranelagh, opening as it does directly upon the Bois by the Porte de la Nuette, is especially favoured in point of situation. 
Very different in nature and appearance is the portion of Paris included by the "banlieue" on the south, or left bank, of the Seine. There is first Grenelle, abounding in manufactures, chemical works, and similar useful but unsavoury institutions -a kind of compound of what Lambeth used to be and Bermondsey still is; then Vaugirard, decidedly superior to Grenelle in appearance, being not without tokens of comfort and well-being; Plaisance and Petit Montrouge, the natural outcome of the improvements which have driven the working population from the heart of Paris to its outskirts ; Montsouris, with its park and reservoir, by the Porte d'Anceuil; finally La Glacière and La Gare, the latter being an industrial district. with the great warehouses, workshops, \&c., of the Orléans railway, densely inhabited by a working population.

To sum up the various features of the divisions of Paris, it should be remembered that the most fashionable quarter of the metropolis extends between the Tuileries and the Barriere de Neuilly, and that the most brilliant shops and the streets that may be compared with the Regent Street and Bond street and the Piccadilly of London, are to be sought about the Boulevinticl des Capucins, des Italiens, the Madeleine, the Avenue de l'Operar, and in the neighbourhood of the Rue de Rivoli ; that ats the visitor travels farther eastward, between the Place de l'Hotel de Ville and the very quaint and interesting Place des Tosges which latter he must on no account omit seeing), he comes upon at yuarter that, like some of the streets in Soho and about the northern side of Holborn, were once the domiciles of persons of wealth and station, but are now fallen from their high estate. This is especially the ease with the Rue St. Antoine, in which may be seen many houses once inhabited by the nobility under Louis XIV. and his predecessors, but now devoled to various manufacturing industries, or let out in squalid flats and sets of rooms to needy tenants. Among them, besides the Place de Vosges itself, are many editices that furnish good specimens of the architecture of the Renaissance period. The Isle de la Cité contains the great Cathedral of Notre Dame, the Hôtel Dieu or great hospital of Paris, the Palais de Justice or Law Courts, the beautiful Sainte Chapelle, the Tribunal of Commerce, \&c. The Faubourg St. Germain, on the south side, or "rive gatuche," is the quarter affected by the gentry of the old rigime, and conhains many clwellings of the old aristocracy of the times before the 
Sreat year $15 \delta$ y. The learned quarter of Paris, formerly known as the Quartice Latin, is now called the Quartier des Ecoles. In this yuarter are to he found the schools of law, medicine, science, and theology, and here also is situated the Lusembourg Palace: i lasge student population, and votaries of letters generally, inhahit this classic quarter of Paris. The military quarter of l'aris is farther west, comprising the fine Hotel des Invalides,

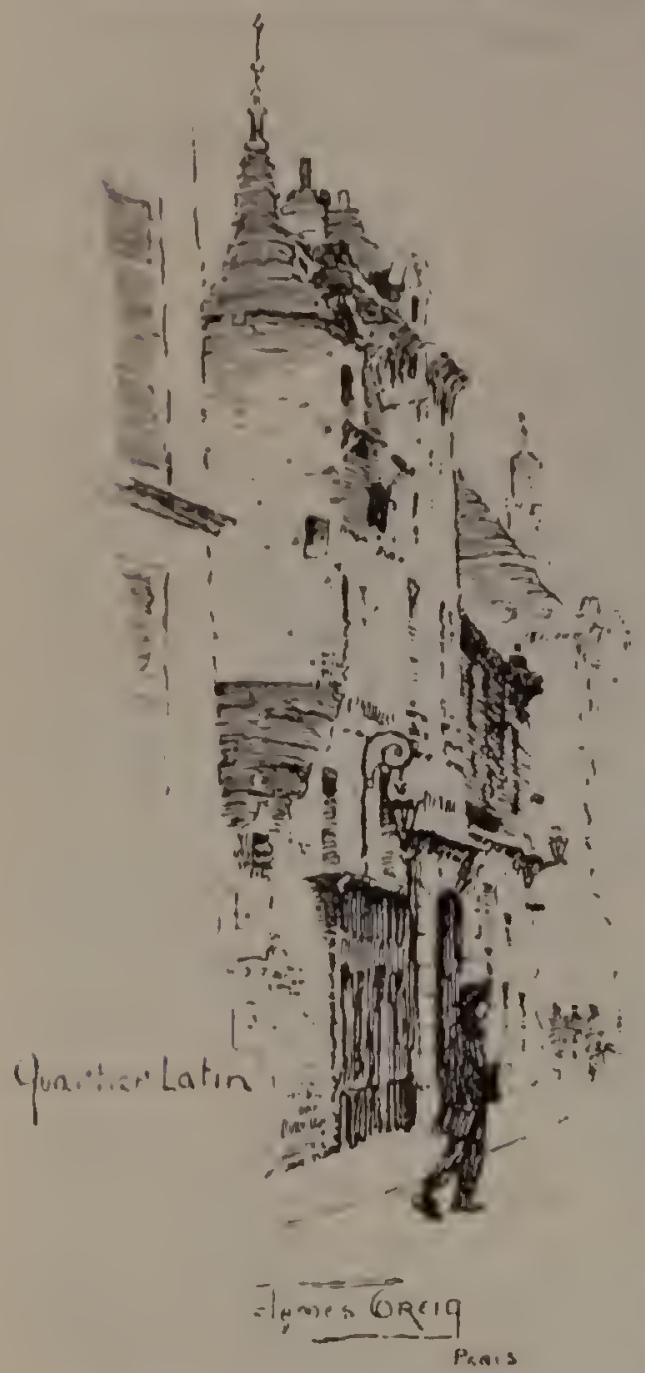
with its esplanade, Sc., and the Champ de Mars, both now devoted to the Exposition of 1900.

IYe will now proceed to give some instructions and advice to the visitor on the best manner of seeing Paris, according to the time at his disposal. The method will be to take a certain area every day, distributing the places to be visited over the time, with due consideration to the important questions of interest and proximity. Of course it will be understood that the ideat is only to indicate what is to be seen; the reader will sometimes find it to his advantage to alter the order of the cays, according to weather, public lêtes, Ec.

IVe would especiatly direct attention to lhe list of fublic places, and the days and homts of admission to cach, given in the carly part of this volume-for the reader will thus be able to arrange his time according to the day of the week on which he begins his explorations. For each diy, the places and objects of interest situated in the area set apart for it will be described. For the outlying districts the visitor will do well to make use of the tramears and omnibuses, the Chemin de Fer de Ceinture, and the steamboat services on the Seine. Further on will be found schemes for the utilisation of shorter visits to the city, with suggested programmes for a one or more days' sojourn in Paris. 


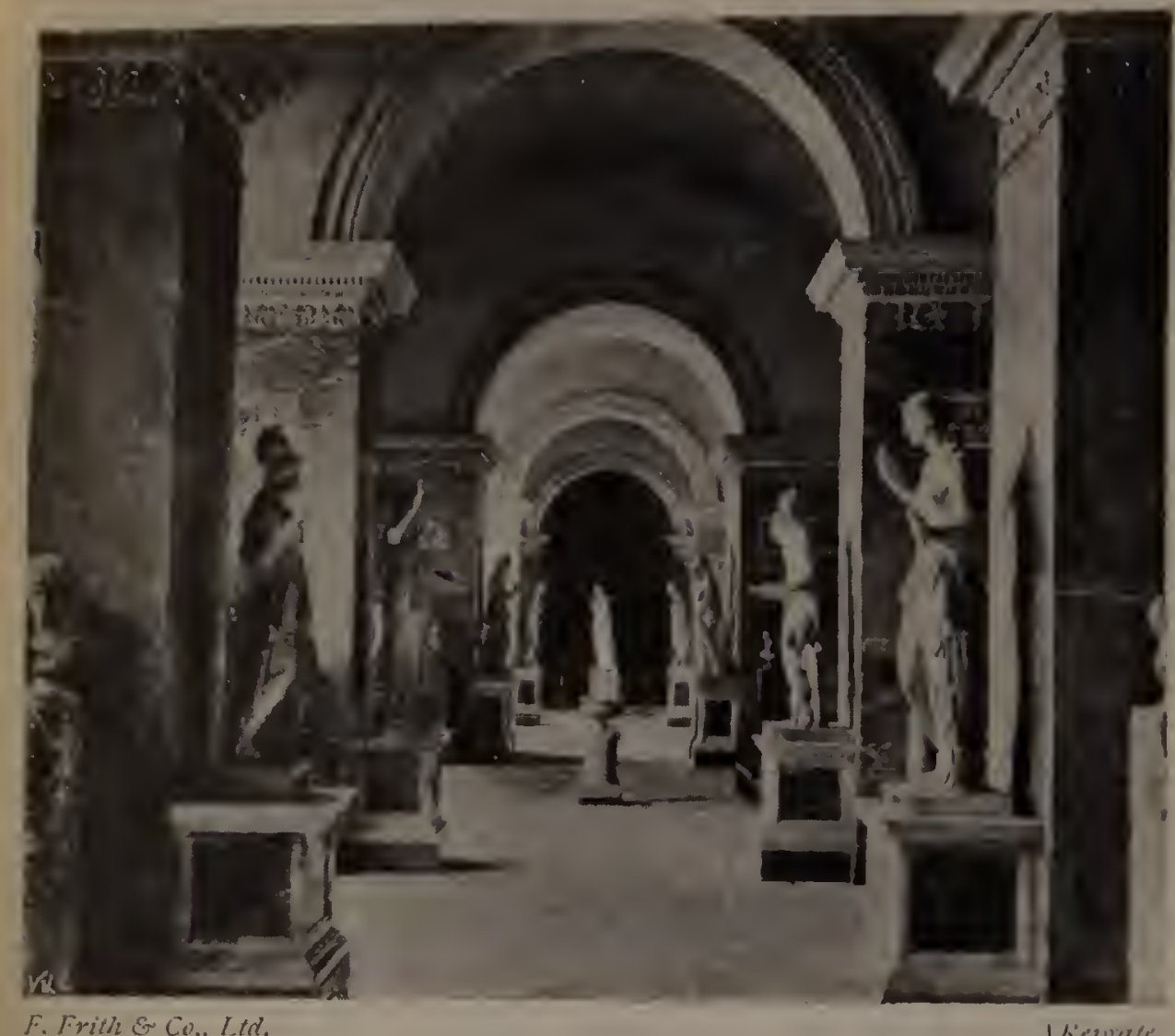

THE LOT'TRE.

(Scupture Galleries.)

CHAPTER VI.

\section{ITINERARY OF PARIS.}

\section{FIRST DAY'S PROGRAMME.}

Place de la Concorde-Obelisk of Luxor-La Madeleinc-St.

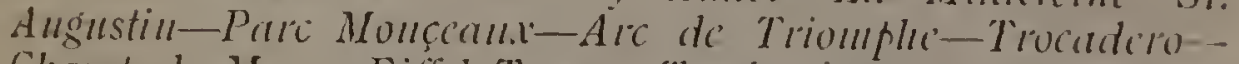
Clame de Mars-Eiffel Tore'r-Tomb of Nafolion I. - Hôtel des Inialides-Muscic d'Artillario-Clamuber of DefuliesPalais Royal-La Bomrse-The Tuilerics-Thi LomitrClumele of St. Germain l'Auxerrois.

WE will select for our rendezrous a site which is not only well known, but thoroughly central and easily reached from that part of the city in which nearly all the hotels frequented by the visitor are situated, namely the-

\section{Place de la Concorde.}

This manificent area, one of the finest public syuates in the world, is situated between the Tuileries gardens and the Clamps 
Elysecs, and is bounded on the north by the Munistry of the Matrinc and the Hotel de Crillon (the old Garde Meuble), on the cint hy the Tuileries gitudens, on the south by the Seinc, and on the went hy the Champs Elyseces. It was formerly called the l'lace Lomis Xl', alld Wals adomed with an equestrian statue of th.t protligatc and worthless monarch; which monument was un valtus oceisions the butt of satirical wits of the Voltairean schex). In 1790 a lamentable catastrophe occurred in the Place Lomis XV., some hundreds of people being crushed to death in a great crowd assembled to see the liveworlis on the occasion of the marriage of the datuplin (afterwats Lonis XVI.) with Hatre Antoinctle of dustria, datighter of the Empress of Germany. Afler the fill of the monarchy on the roth August, 1792, the tilluc of Louis XV. Was taken away and melted down into bronze moncy. The syuate then became the "Place de la Révolution."

When the tempesturous period of the great Revolution was

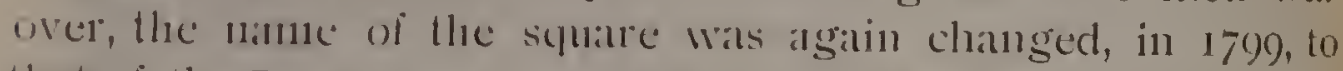
th.1t il the Place de la Concorde. In is'it, at the restoration of llac Bumbons, it was re-baptired "Place Louis XV." In 18,30 it astain becance the Place de la Concorde, which designation it has relaned ceer since. The two fountains throw water to a height of neally thirly feet, forming a striking feature of the square. The monuments, situated at intervals around, ate worthy of lotice, and erens special and separate inspection, if time permits. They represent the chief towns and departments of France. The nust interesting is the statue situated on the side of the Tuileries sardens, nciucest the Ruc de Rivoli, representing strasbourg, and which will be easily recognised from the fact wi its heing perpetually cowered by weaths and immortelles. These are rencwed annually on the great Republican fête of the Ifth of July, and somewhat inflammatory speeches are often made, with the object of lieeping alive the supposedly patriotic sentiment, intended to encourage the notion that the lost provinces must and shall eventually be restored to France.

The centre monument of the syuare is the-

\section{Obelisk of Luxor.}

The obelisk monolith, 76 feet high and weighing 240 tons, is the sister stone to Cleopatia's Needle on the Thames Embankment. This ubelisk wis presented by the Khedive of Egypt, Mohammed Nli Pashat, to the Government of Louis Philippe, 
and was erected on its present site on October $5,18,36$. The designs on the pedestal of the monument represent the history of its embarkation in I83I, its transit from Eigypt to Paris, and its erection on the present site. The hicroglyphics on the column itself are chiefly dedicated to the glory of Ramses II. (Sesostris the Great, King of Egypt, about fourteen centurics before Christ).

The great interest of the obelisk, however, consists in the site it occupies, rather than in the monument itself. Here in 179.; was set up the guillotine that cut short the lives of so minly' victims during the fearful year and a hall, the Reign of Terror, from January, 1793, to July, 1794. King Lonis XVI., his quee'11 Marie Antoinette, his sister Madame Elisabeth, his cousin Louis Duke of Orléans, called Egalité, the chiefs of the various political parties, Girondists and Montagnards, Royalists and Republicans, all came in turn to bend their heads benceith the fatal knile; for, as Madame Roland justly observed, the Revolution devoured her own children.

The views from the square towards the Trimmphal Arch, the Tuileries, the Madeleine, and the Seine will he duly appreciated. while the magnificent vista of the grand Aveme des Champs Elysées is unique.

\section{The Champs Elysées.}

This beautiful garden may be called the Hyde Park of Paris. Its magnificent avenues are not, like Hyde Park, closed against the modest fiacre and democratic omnibus, but are open to the enjoyment of all ranks and classes alike-all improvement, it will be thought by many, on our English system.

The aternoon, from about 3 to 6 o'clock, is the time when the greatest number of carriages may be seen in this popular resort ; but during the whole day, and far into the night, the restanrants and places of amusement are frequented by throngs of peoplc. The Champs Elysées are naturally divided into the Carré or park, extending from the Place de la Concorde to the Rond Point, and the great Avenue des Champs Elysées, more than hali a mile in length, between the Rond Point and the Arc de l'Etoile. Here in the Champs Elysées are situaled the Café Chantants, the Théatres Guignol, the Punch and Judy of Paris, and the Marionettes, the clelight of the children. The spring and summer months see the Champs Elysées in all their glory. 
(uitling the Plate de la Concorde and proceeding by the Rue Royale, we turn to the north and pass by the Ministere de la Marine, a spacious and handsome palace with a colonnade of Corinthian pilliks, huilt after the design of the architect Gabriel bedween is60 and 1770. Thence we proceed up the broad, handsome Rue Royale, with its avenue of trees, to the Place de la Madeleine, behind which is the Marché, or market, of the same name. The vendors here have the title of "Purveyors to the Presidence." It is one of the hest marliets in Paris, but is soon to be pulled down.

Before us we sce a clissical building with lofty front and broad stcps. This is the-

\section{Church of "La Madeleine,"}

once of the linest modern churches of Paris. In architeclure it is structly clitssical, being built in the form of a Greek tcmple, with a splendid colomade around it of fifty-two Corinthian pillars. Colossal statues of saints adorn the niches in the Walls. The sculptured pediment on the southern front in the litesent linumn to exist. The interior is exceedingly handsome, the rich matbles of various colours and the rows of staceful Corinthian pillars contributing sreatly to its splendour. This church was hegun in 170,3 , and not completed until is 4.3 , in Lonis Mhilippes reign. The pictures in the church generally reperent sume crent in the life of Ste. Mary Magdalen; the itatues of the sivionr and of various saints that decorate the huilding are pliced with these in the various chapels around the nave. Entering by the broad flight of steps from the Place de lil Madcleine, the visitor has on his right the sculpture by Pradicr, representing the marriage of the Virgin. On the right hand, procecding onwalls, are found Schuct:s Conversion of Mary Magdalen, the Magdaten at the foot of the Cross, and the Pratyes Magdalen, with Brer's statue of St. Amelie, Daret's Christ, and Baryc's St. Clotilda (a Christian princess, who persuaded her fierce lussand, King Clovis, to embrace Christianity). By the high altar, Marochettis Rapture of St. Mary Magdalen. Returning to the western door, the risitor passes the statue of St. Augustine, by Etex, and Siguol's picture of the Death of St. Mary Magdalen; Coigncl's picture of St. Mary at the Sepulchre, and Simrre's statue of the Virgin and Child; Conder's Feast of Simon, and Rusing statue of St. Vincent de Panl; finally, near 


$$
\text { ST. MGUSTIA-THE PARC MONÇEAl'. }
$$

the entrance, the Baptism of Christ, by the celebrated sculptor Rude. The music at Mass at this church is especially grand and imposing. High Mass on Sunday mornings begins at I 1 o'clock.

We suggest that the independent sightseer shall now take : cab by the hour (the fare being two francs, accompanied by a few coppers as fonrboirc). By this means, in about an hour's ride, one is able to embrace a number of sights, for which no omnibus or tramway would exactly serve. No hesitation need be felt as to the contingency of trouble with the coachman on account of your not being familiar with the language; you have simply to draw your watch from your pocket, and compare it with his-he will understand the movement instinctively-lhen name the monuments in the order in which ithey follow in the itinerary, or even show them to the driver, if necessary.

Driving along the Boulevard Malesherbes, a few moments will bring you to the-

\section{Church of St. Augustin,}

one of the most elegant modern churches in Paris. It is especially associated with the family history of Napoleon III., and was built by Baltard about 1866 . The dome is 160 feet high. The interior is worthy of a visit on account of its attistic decorattion, and is remarkable for the absence of pillars and column-. It does not, however, call for any lengthy or special description. In the square immediately opposite is a fine Statue of Jeanne d'Arc, recently erected.

Still following the Boulevard Malesherbes, we reach the-

\section{Parc Monçeau.}

This pleatsant place of recreation, which was unce at portiun of the grounds around the country house of the beautiful Gabriclle d'Estrees, was laid out more than a century ago hy Louis Esalité, Dule of Orléans. It is situated between the Boulevard de Courcelles and the Rue de Monçeau, not far from the Arc de l'Etoile. It was a fashionable resort of the higher classes, and balls and fêtes were given by the ducal proprietor, until the Revolution of 1789 brought in a dance and a song of another kind, known as "La Carmagnol" and "Ça ira." The park became national property. It reverted to the Orléans family after the Restoration, but became national property once more after the Revolution of $18+8$, and was sold to the city of Paris, which after disposing of half its areal for building purposes, laid 
out the rest in its present form. It boasts some good statuary, and hats, besides, two relies of past times, in the Nammachic (place of naval combats), a large sheet of water, partly surrounded by a row of Corinthian columns, and a large Renaissarrce Arcali from the old Hotel de Ville. The park is accessible to carriages as well as to foot passengers.

The coachman will, therefore, drive us through the park and continue in at straight line along the Avenue to the-

\section{Arc de Triomphe de l'Etoile,}

a splendid monument, and one of the chief architectural glories of the capital. It was commenced in 1805 by the order of the limperor Nitpolcon 1., who puposed that it should be a memorial of the triumphs achiered by the French troops in the memorable Austerlit/ campaign of 1805 , but it was not completed until the reign of Louis Philippe. It is the largest triumphal arch in the world, being 160 feet in height, 164 in width, and 72 in depth. It is adorned with groups of sculpture representing scenes in the history of fratlec, from the breaking out of the revolutionary wat in 1792 until the peace of 1815: such as the departure of (roop) in 179)2, the battle of Aboukir, the defence against the invaders in 1814 , Ec. On the arch are inscribed more than 050 names of officers in the armies of the Napoleonic perind, those of generals who died in battle heing monderlined.

A very fine view is ubtained from the top of the Are over the Champs Elysees, the Bois de Boulogne, and over the city of Paris itself; but, ats the ascent is made by climbing $26+$ steps (fee, 25 centimes to the suatidian), it maty be advantageously explaced, a little later on, by an ascent of the Trocadero Tower by a commodious and comvenient lift, thus aroiding all fatigue. The coachman should, however, drive round the arch, for the sake of the views which are obtained of the magnificent avenues radiating from the Are de Triomphe. It is stated that the Napoleonic idea in this arrangement was more profound than simply the picturesque aspect thus obtained. It will be readily seen that cannon planted around the arch would sweep the city for many miles on almost every hand, and, in point of fact, this consummation was unfortunately obtained by the Communists in May, 187I, and they were only dislodged with the utmost difficulty.

IVe nuw proceed by the Arunue Kleber to the Trocadero. 


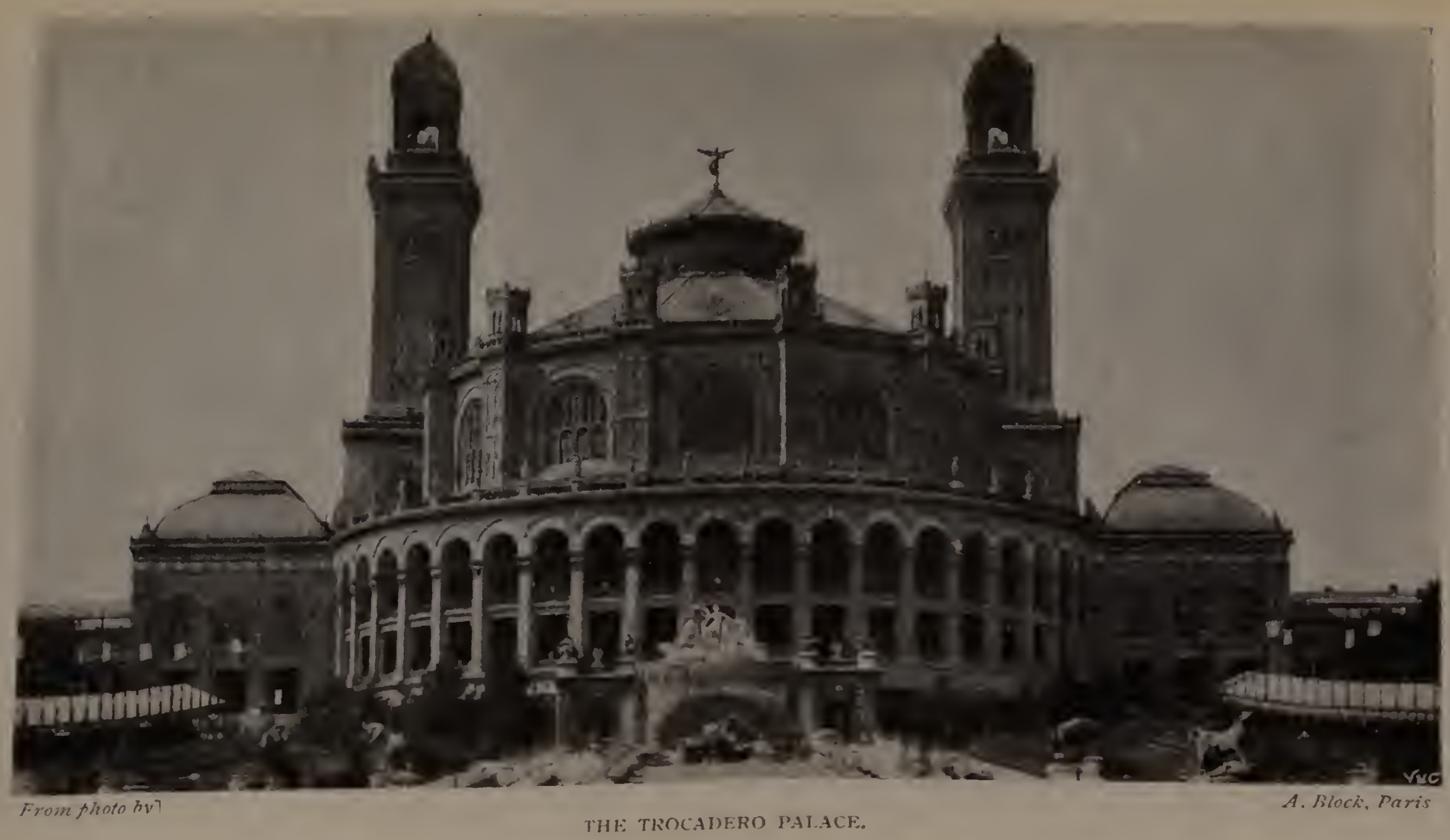


Here lhe ("ab) for fiacre) may, if clesired, be discharged, as the howr will probably be cxhalusted, laking care, however, to be set down in front of the Aquarium fopen from 9.0 till 11.0 and from 3.0 In 5.0 ), which is well worth a visit.

\section{The Palais du Trocadéro,}

was crected for the Exhibition of 1878 , half by public subscription throughout the French provinces, and half by the city. It was presconted to Paris on condition that it should be kept in order. The name is taken from a fort at Cadiz, captured by the French amy under the Duc d'Angouleme in 1823. The central huildins is circular, with a dome and two minatrets. The dome is one hundred and eighty, and the mindrets two hundred and screnty feet in licight. The whole huilding is in the Orientil style, after designs by Dariond and Bomrtais, From the main huildins two long crescent-shitped wings extend on each side, cleveled fo sculpture and ethonosiaphical collections.

The salle des Fêtes forms a sreat feature of the interior. It has accommudiation for five thousand spectators, and possesses an organ of enormuns power. From the balconies and galleries, it splendid ricw of Paris and its environs may be enjoyed. The Trocalere is surrounded by a small but pleasant park.

A finc view from the lerrace around the hall is ohtained orer the Champs de Mars, the sile of the 1878 and previous Expositions, also the Eiffel Tower and over the grounds. In order, how'erer, to obtan one of the finest possible panoramas of the city of Paris, lie have only to take the lift, situated in the corner under the fower nearest the city itself (fee, 50 centimes). Aided by the map, the visitor will readily distinguish most of the principal buildings of the city, and by this means an excellent idca may be formed of their relative positions.

Onc of the principal features of interest in the view is the-

\section{Champ de Mars.}

This, the chosen site of the Exhibitions held since $186 \%$, is a large rectangular expanse, bounded on the north by the Seine, westward by the Arenue de Suffien, eastward by the Avenue de la Bourdomnaye, and on the south by the great Ecole Militaire, erected in the reign of Louis $\mathrm{XV}^{\mathrm{r}}$. for the education of five hundred gcutilshommes for the military career. In 1792 it was turned into a barrack, and is now the Ecole Superieure de Guere, Napoleon I. Was a pupil in the Ecole Militaire. 


\section{The Eiffel Tower.}

For those who do not contemplate the ascent: the Lest plan will be to drive round to the front of the tower, and then walk under and around it, in order to form some idea of its colossal proportions. We would suggest, however, that a separate afternoon could most pleasantly be employed in its ascent, for the visitor is rewarded with a panorama such as camnot be equalled in extent or interest.

The Eiffel Tower is undoubtedly one of the modern wonders of the world, and is considered the crowning labour of the career of its constructor, M. Eiffel, who had already won welldeserved fame by such work as the railway station at BudaPesth, the cupola of the observatory at Nice, the Porto bridge over the Douro, the Szegedin bridge, and various other buildings. The idea of building a tower a thousand feet high had already been mooted several times, notably at the exhibition in Philadelphia to celebrate the centenary of American independence, in 1876 ; but it was reserved to M. Eiffel to carry it out. The tower is, so to speak, leased to its distinguished constructor, remaining in his possession for twenty years ; and at the end of that time it becomes the property of the State, and the intention is to utilise it as one of the defences of the capital for strategic purposes. Our illustration will give a good idcat of its general appearance. If forms a most imposing object, and its position, standing as it does parallel with the four sides of the Champ de Mars, is happily chosen. Its dimensions are bewildering. Fancy five London "Monuments" set up one on the top of another; and you have the height of the Eiffel Tower. Just multiply the height of "London's tall column pointing it the skies" by five, and you get the altitude of this modern Colossus. Other particulars of the giant are as follows: The basis of the Eiffel Tower covers an area of nearly four acres (I6,000 square metres). The building is divided into three storey's, and on the first and second storeys cafés and restaurants
have been established. A glass cupola, surmounted by a power-
ful electric light, forms the apex of the third ful electric light, forms the apex of the third storey; and there are intermediate floors as resting places between the second storey and the highest. The lightning protector surmounting the whole stands just over a thousand feet above the gromind. The first flooi is at an elevation of about 186 feet $(57$ metres 03 centim.) above the ground; the second floor about $377 \mathrm{fecl}(115$ 
metres 73 centim.); the third flone about 642 feet (196 metres)

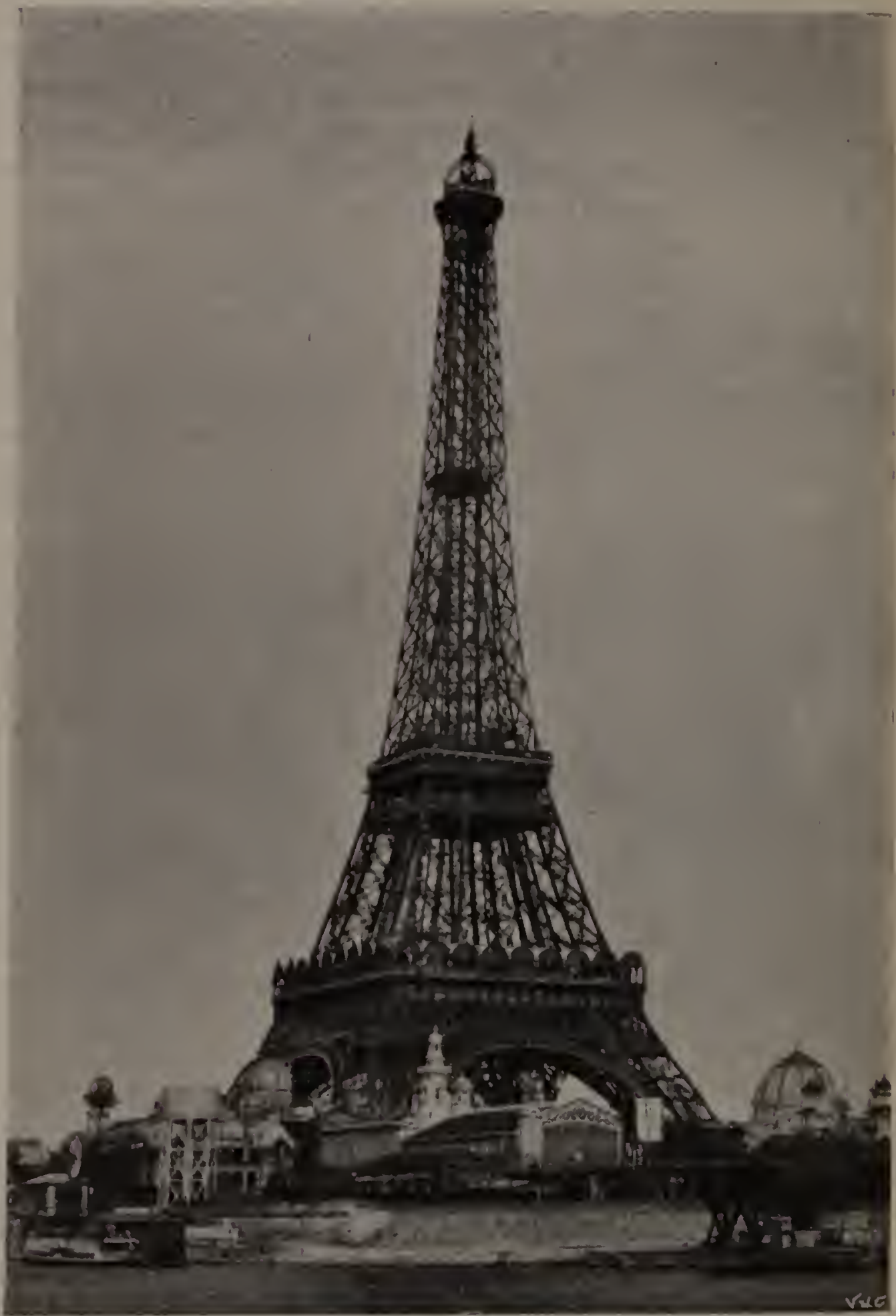

From flente by]

[A. Bileck, Paris.

THI: EILFF, TOMER.

and the column above about 906 feet $(276$ metres), while the glass roof, surmounted by the electric light, rises $9 \&_{4}$ feet 
(exactly 300 metres) from the ground, and is reached by means of a winding staircase, which runs up the centre of the colmmn.

"To judge of the tower from an architectural and picturesque point of view," say's a writer, recording his experiences of an ascent, "is difficult, from the simple reason that nothing else exists with which it can be compared; so that one has nothing to serve as a standard but one's own more or less instinctive appreciation. . . . It is only when seen from a distance, and when compared with the domes, the spires, and the lofty houses of Paris that one can realise the effect of its phenomenal altitude. Perhaps the truest judgment upon it is to say that it is a work constructed with the most extraordinary ingenuity, and that its lines are by no means without grace." The base of the tower consists of four great piers, which bear the names of the cardinal points of the compass, and to them, to a great extent, the stability of the edifice is attributable. In consequence of the open "lace-work of iron" of which it consists, it is almost entirely free from oscillation, in spite of its vast height. Of course, an elaborate system of ascensors is employed in conveying visilors to the different storeys ; for something of the form. and training of an Alpine climber is suggested by the idea of ascending its heights. The lifts on the lower storey are constructed to contain a hundred persons; those on the second storey, built on the Otis system, can hold fifty persuns eitch; beyond this, to the third storey, the adventurous "ascensionist", must trust to his own feet. This storey is, however, the one which contains the chief attraction, alike to the sight-seer and lo the man of science. For on it is a great saloon, more than fifty feet square, and shut in on all sides by glass; so that, sheltered from wind and weather, the visitor, who has climbed so high, can contemplate at his case a vast panorama of the city, stretched out like a map before him, with the Seinc meandering, through it, and the open country as a background on every side. Above this room are laboratories for scientitic purposes. At the time of opening M. Eiffel said he considered the tower. would be of great utility in this respect. "It will be," he says, "a wonderful meteorological nbservatory, whence the direction and the force of atmospheric currents can be usefully studied, from the points of view of science and hygiene, as well as the condition and lice chemical composition of the atmosphere, the amount of electricity and moisture it contains, the variations of temperature at 
different heights, almospherical polarisation, $\mathrm{Ec}$. It is specially adapted for an astronomical observatory; for the purity of the ait at this great height above the low-lying mists, which so often clond the horizon of Paris, will allow of a number of observations often impossible in our clinate. . . It will be an observatory and a laboratory such as was never until now at the disposal of science; and from the first all our scientific mcn have encouraged me with their warmest sympathy. On my side, and in urder to express in a striking manner that the mommment which l have raised is cledicated to science, I decided (1) inseribe in letlers of gold on the sreat frieze of the first palform, and in the place of honour, the names of the gleatest men of science who have honoured France from 1780 down to mu" own dity." The tower will also he of use in the defeltce of lhe city; from it accurate observations may be taken of the movencents and strength of an approaching foe. The prices for ascending the tower are proportioned to the various heights.

We 110 proceed to visit the--

\section{Tomb of Napoleon I.}

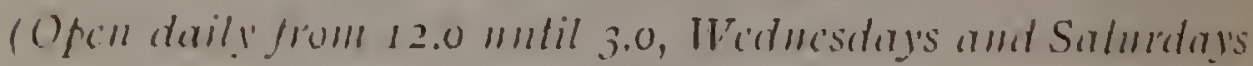
cisciplcil.)

We may cillere take a steaner from the Trocadero to the luvalides piers, or a tramway from the front of the Trocadero Palace, or a cab; but the whole distance mat be covered un foot in about fifteen minutes, the waly being unmistakable, as the grilded dome is a conspicuons object from the Trocadero or Eiffel Tower.

The dome forms in itself a separate church, and was erected by the famous architect Mansart in 1706. The handsone exterior clevation is adorned with Doric and Corinthian columns, and approached hy a boud flight of sleps. Statues representing Justice, Temperance, Prudence, and Strength, and effigies of Chatemagne and St. Louis, add to its appearance. The height of the building to the summit of the cross is above ifo feet, and the dianneter of the dome $\$ 6$ feet. Like St. Paul's in London, this dome is not of stone, but of wood covered with lead. The pavement displays a handsome mosaic design of the time of I,ouis XIV. In the chapels around the dome are the tombs of two members of the Bonaparte family; Joseph, king of Spain during the time of the Peninsular war (died 18+4); Jerome, the 


\section{IOIIB OF NAPOLEON I.}

great Limperor's youngest brother, once king of Westphalia who died in 1860.

From the floor of the church, the spectator, leaning over a balustrade, looks down into the open crypt, 20 feet deep and 30 feet in diameter; and here, exactly beneath the lofty dome, in a great sarcophagus of red Finland granite, the gift of the

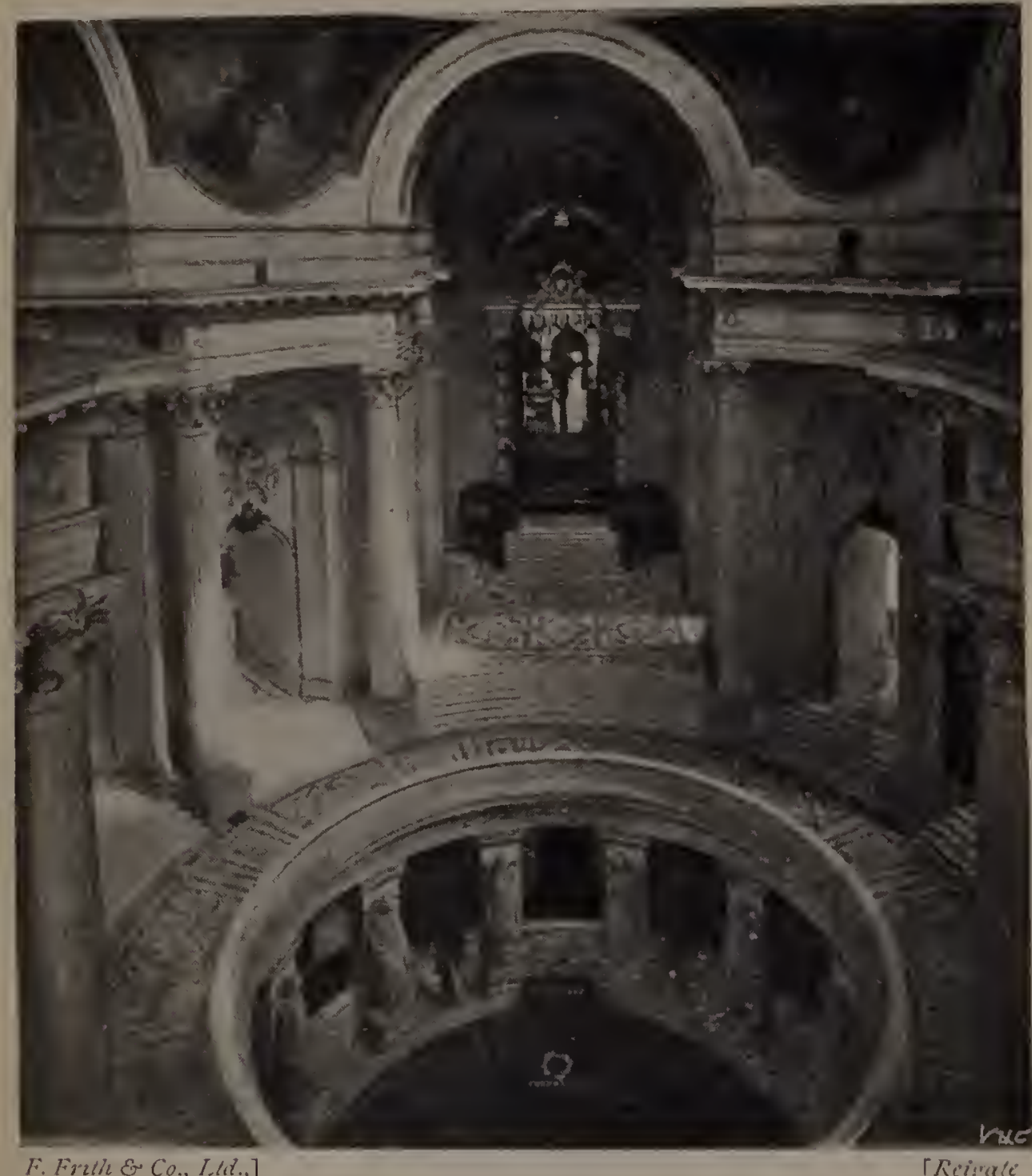

TOMB OH NAPOLEON I.

Emperor Nicholas of Russia, are deposited the remains of the great Napoleon. It was in 1840 , nineteen years after his death, that the Emperor's remains were brought to France by the Prince de Joinville, a son of King Louis Philippe, in the warship La Bclle Poulc, in fulfilment of the dead Caesar's wish, expressed in his will, and now inscribed over the bronze 
entrance to the crypt: "Fi desure qui mes ciudres refosint sum

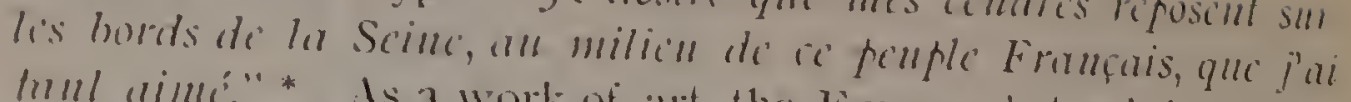
mul aime." * As a work of ant, the Emperor's tomb is chanclerised by a grandenr and solemnity thoroughly in keeping with the circumstaric's. Twelve colossal figures, representing the chief victorics of Napoleon, surround the gallery and contemplate the sarcophagus. They are one of the best works of Pradier. Between the statnes atre aptly placed fifty-four flags, arranged in six trophics. They were taken at the battle of Austerlit\%. The palement of the crypt is mosaic work, representing a laturel wreath. The dome, looking down upon the crypt, is divided into two sections, the lower containing in its fwelve compartments statues of the apostles, and the higher, inside the cupolat, st. Louis offering to the Saviour the sword with which lie has fonght for the Christian fath. The crypt itself is culced from the church of St. Lonis, but adninission can only be procured hy a permit from the War Minister, or the Minister of the Fine Arts. This tomb is one of the most impessive of the sights of Paris, and should on no account be omitted from the visitor's programme.

l.aving the tomb, a special gateway leads the visitur into the courtyand of the -

\section{Hôtel des Invalides.}

The majority of visitors are content simply to walk through llie courtyard and inspect the rescos, perhaps visiting the bining Hall, but, if lime and inclination permit, the tourist can pass several hours inspecting the Museum of Artillery, Armour and IVar Costumes, of which we will proceed to give a description.

This great institution, one of the most interesting sights of l'aris, corresponds as to its intention and design with the London "Chelsea Hospital." It was founded by Louis XIV., in 1670 , for the reception of soldiers who had grown old or had been wounded in the service of their country; and of all monarehs the "Grand Monarque" was the one most called upon, in right and justice, to do something for the disabled "militaires," considering the vast quantity of "food for powder" he used up during his long and warlike reign. The Invalides, easily * "I desire that my ashes repose on the borders of the Seine, in the
midst if the Frenclh people whom I have lored so well." 
recognised from a clistance by its fine gilded dome, is situated on the south bank of the Seine. The chief front is towards the Esplanade des Invalides, a handsome square extending from the Quai d'Orsay to the Jardin des Invalicles, and the principal entrance is facing north. The eastern side is occupied by the Boulevard des Invalides, the southern by the Place Vauban, and the western by the Boulevard de la Tour-Manbourg, and the Avenue de la Motte-Picquet. Entering from the Esplanade, the visitor finds himself in the "Jardin," or rather the outer court, and notices the "batterie triomphale" of fourteen guns and four" mortars, used for firing salutes, and some Algerian and other camnon. Notice the fine statue of Prince Eugene by Dum!nt, in front of the principal façade, which is above 650 feet in length, and three storeys high. In contains 133 windows. Orer the chief entrance, in the centre, is a bas-relief of Louis XIV., on horseback, surrounded by Justice and Prudence. The front half of the building behind the façade is clivided into five courts -the central or Cour d'Honneur, with two courts, the Comr d'Angouleme and Cour de la Victoire on the we'st; on the opposite side the Cour d'Austerlit\% and Cour de la Vileur. The western side is occupied by the Museum of Arms and Armour (Musée d'Artillerie), the eastern by the refectories, clormitories, \&c., of the inmates. Behind this portion, directly at the back of the Cour d'Honneur, is the Church of St. Louis, and behind this the Dome, beneath which rest the remains of the first Napoleon. In the rear an open space leads to the Place Vauban. We shall describe these various portions in turn.

\section{Musée d'Artillerie.}

Entering the Musée by a cloor in the centre of the restern side of the Cour d'Honneur, the visitor steps into a vestibule in which are various cannon, including two Spanish pieces from Ifexico, two others of Algerian manufacture, a wooden, ironhooped piece from Cochin China, and some Roman military autiquities from the Rhine. To the right and left of this vestibule, looking on the Cour d'Angoulème and the Cour des Victoires, are: On the ground floor the two Halls of Armour and on the first floor Models of Artillery and Costumes of War.

The two "Salles des Armures." The hall on the right of the

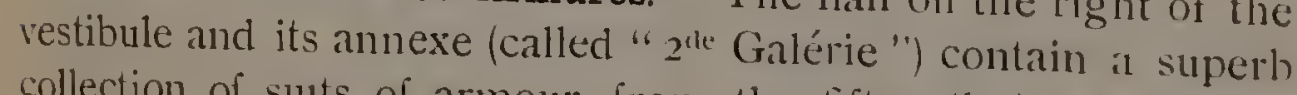
collection of suits of armour, from the fifteenth to the seven- 


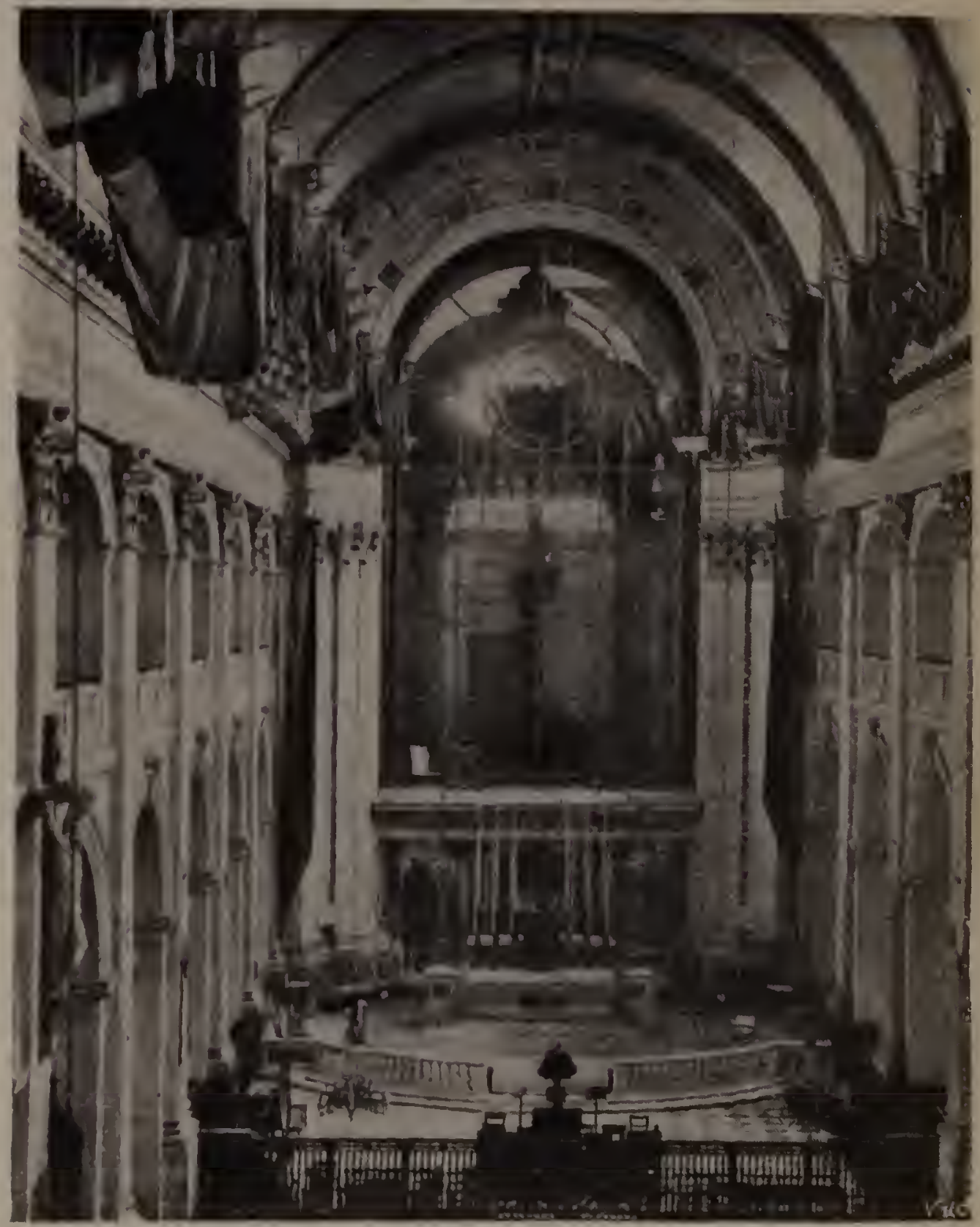

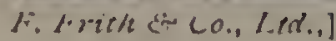

TReisrate.

CHIRCH OF ST. LOUIS.

(Hötel des Invalides.)

teenth century, with numerous helmets, cuirasses, shields, coats of mail, \&c., \&c., from the Middle Ages downwards. Especial notice should he given to the splendid series of suits of armour of the French kings from Francis I. to Louis XIV.; some high art specimens of inlaid armour, French and Italian, of the sixteenth century; to the collection of swords, and the Italian suit of armour after designs by Julio Romano. The visitor, to his great comfort, will find all the specimens in the various 
Ialls plainly and adequately labelled.-The hall on the opposite side of the vestibule, called Première Galérie des Armures, contains, besides suits of armour belonging to the Montmorencys, the Guises, Turenne and other celebrities, a splendid collection of guns and pistols, some of them in the highest style of ornamental art, including a gun and pistols ornamented with diamonds and other precious stones, intended hy Napolenn I. as a present to the Emperor of Morocen, and a collection of French standards, illustrating the periods from Charlemagne downwards. The Invalides, in its various halls, also offers a number of flags taken from various nations during the wars from Louis XIV. to the fall of Napoleon I., although on the 3 oth March, I8I4, the day hefore the allied armies entered Paris, a huge holocaust of 1,500 captured flags was made; all these trophies being burnt in the courtyard of the Invalicles, to prevent their falling into the hands of the enemy. The valuable collection of arms made at Pierrefonds by Napoleon III. has heen deposited in this hall. Beyond it is the Galérie Ethnographique. This interesting collection, organised hy Colonel le Clerc, consists of a number of model figures, representing various savage types of humanity, especially the Oceanic, African, and American races. The walls are hung with weapons, horse-saddles, and harness, \&r. Above these two halls are to be found, on the first floor, two series of rooms, one containing Modèles d'Artillerie, models of canon and military engines, and machines of various kinds, besides flags and standards of various periods; and the other Costumes de Guerre, a magnificent collection of the war panoply of all ages, from the prehistoric times of flint and bronze weapons, down through the Merovingian and Carlovingian periods in France, and so onward, through the middle ages and modern times even to the days of the first French revolution, besides authentic representations of the Greek and Roman perinds.

The second portion of this interesting Museum, which is approached by a passage between the Cour de la Victoire and the Cour d'Angoulème, consists first of an entrance hall, containing a collection of Oriental weapons, and the war panoply' of an Emperor of China; and then of two Salles des Armes blanches et Armes à feu. We have here, arranged in a series of four rooms, a systematic collection of weapons with wooclen shafts, firearms, \&c, Among them are some bistoric weapons, 
such as the sword of Marshal Augereau, and that of the republican gencral Hoche; war-saddles of the Emperor Maximilian II., Napolcon I., and others; with modern helmets, crossbows, \&c., \&c. These curiosities are all clearly labelled, so that interesting facts resarding their proprietorship and mature may be readily understood by visitors. On the lirst floor of the central pavilion is the "Bibliotheque." This lihrary comprises 60,000 volumes, including some very curious manuscripts. Here is to be seen also the camnon-ball that killed the famous Marshal Turenne at Sassbach, in I67.5. It is in the Salle du Conseil. The salle des Maréchaux contains portraits of some of Napoleon's renowned generals, and in the vestibule are Io he seen various relics and memorials of the great Emperor.

The Eglise Saint-Louis is at the back of the Cour d'Honneur. lls inlerior comsists of a lofty nave and two aisles, and contains a tumber of flags and banners, trophies of French victories in different parts of the world. Various Mashals of France and (6) vernors of the Invalides have monuments in this church. Amones the persons buried in the vaults are Marshal Tureme Gencrals Jourdan and De Moncey, Marshal Duroc, the friend of Napoleon 1., who fell at Bautzen in 181.3 ; General Bertrand, who accompanicd the Emperor to St. Helena, and remained faithful to hin till his death; Marshal Mortier, who was killed by the "infernal machine" of Fieschi in the attempt on the life of Louis Philippe in 1834, and the other victims of that diabolical outrasc; hesides Grouchy, to whose absence Napoleon ascribed the defeat at Waterlon, Marshal Bugeaud, famous for his exploits in Algeria, \&c., \&c. Herc, too, are cleposited the heart of Vauban, the sreat military engsineer; of Kléber, the brave republican general assassinated in Esypt ; General Négrier, and Madlle. de Sombreuil, who, in the Revolution, drank a goblet of blood as the price of her father's life.

We presume the tourist will now begin to have admonitions to the effect that it is high time for lumch, and we recommend that a cab he taken, i la coursc (fare I franc 75 cents) to Palais Royal for that purpose. On the way we pass-

\section{The Chamber of Deputies.}

\section{(Palais Bowbon.)}

This is chiefly interesting as being the French Parliament House, the meetings of the legislative body being held here, 
It is a handsome classical building, with Corinthian columns and a sculptured pediment, and is appropriately adomed with statues of Minerva, Themis, and other mythological and classical personages symbolic of the majesty and beneficence of law and order. The celebrities of France connected with good government and administration are represented by figures of Sully, Colbert, d'Aguesseau and l'Hôpital. The salle des séances, where the sittings are held, is a handsome semicircular hall adorned with Ionic columns; in the salle du Trone, or throne room, are some fine paintings by Eugene de la Croix. The library contains 150,000 volumes. This palace extends to the Quai d'Orsay, on the south bank of the river.

Now crossing the Bridge and the Square of the Concorde, we descend the Rue de Rivoli, and alight at the Palais Royal.

The Midday Meal. Before reading historical descriptions of this interesting locality, the question of the midday meal will probably require consideration.

The Palais Royal is specially recommended for lunches and dinners at reasonable and fixed prices, the variety and choice of restaurants being larger than in any other part of the city. We subjoin the names of some of the best known-

Catelain, Restaurant de Paris, 29, Galérie Montpensier ; Catelain aine, Restaurant de Valois, I73, Galérie Valois; Tavernier, I42, Galérie Valois; where excellent lunches may be obtained at 2 francs 50 cents (or 2 s.), wine included.

Most of these restaurants are situated on the first floor, and the visitor will have to be careful, if he is studying the question of price, to avoid the Café Restaurants on the ground floor, where it is usual to serve it la carte, which is quite another matter to fixed prices. If the tourist has no objection to paying 10 or 12 francs at least, an excellent meal can be obtained at Vefour's, 106, Galérie Valois, but we find as a rule that the firstnamed class of restaurants are more suited to the requirements of the average visitor to Paris.

Descending after lunch into the Gardens of the Palais Royal, an agreeable promenade may be made, inspecting the wonderful collection of jewellers' shops situated in the corridors around these celebrated gardens. 


\section{The Palais Royal.}

This building, one of the most popular edifices of Paris, was originally built for the great Cardinal de Richelieu, in the reign of Louis XIII., and was called the Palais Cardinal. It was considerably altered and modified under Louis XIV., and subsequently became the residence of the Dukes of Orlérns. Under Iouis X'I. it was inhabiled hy Philippe, Duke of Orléans, surnamed Esalite, the father of King Louis Philippe, who himself lived there between the Restoration and his accession to the throne in 1830 . It is situated just opposite the Louve, at the point where the Rue St. Honoré joins the Rue de Rivoli. It was partly hurnt down by the Communist mob in 187 . ITder the second Empire the Palais Royal was the residence of Jerome, the youngest brother of the great Napoleon, and of his son, Prince firome Napoleon.

The chicf attraction of the Palais is in the shops round the sarden. These were built in the first instance by Duke Philippe Egalité, who, being marvellously in deht, thus turned his palace into a source of revenue. It was in the garden of the Palais Royal that the hot and eloquent Camille Desmoulins, in I 789 . mounting on a chair, delivered the fiery oration in which he urged those present to bind themselves, by the symbol of a green leaf, to stand logether for the purpose of achieving freedom for France. Under the Restoration, the Palais Royal had a bad reputation as the head-quarters of the numerous gambling houses, that were regularly farmed, and paid a lax to the State. After the abolition of those dens of iniquity, the Palais regained a more respectable fame, which it has retained to the present day, as the locality where dinners may he had sufficiently appetising in quality at a moderate price. The other attraction of the Palais Royal is found in its shops for cheap jewellery, of attractive designs. There is no better place to choose a sourenir which is to look prefly, and not to cost too much. Profiting by the farourable opportmity, and the fact of its proximits, we may now visit-

\section{La Bourse,}

or Stock Exchange of Paris. Leaving the Palais Royal hy the further or north side, and following the Rue Vivienne, a walk of five minutes will bring us to the square in which the Bourse is situated, and its proximity will be assured some distance hefore 


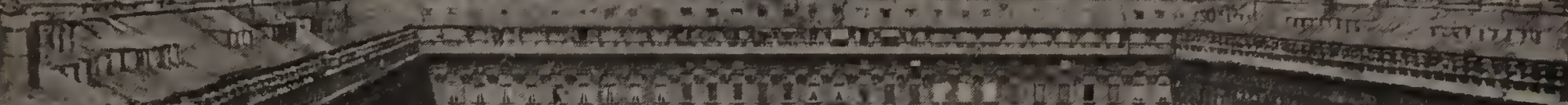
$-2=\operatorname{sen}$

nimini:

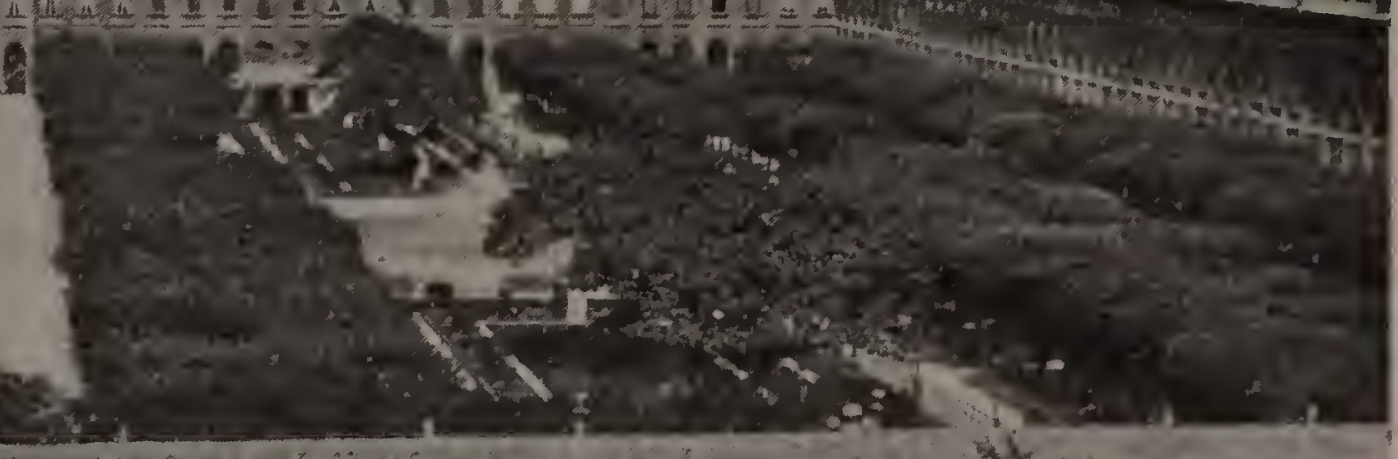

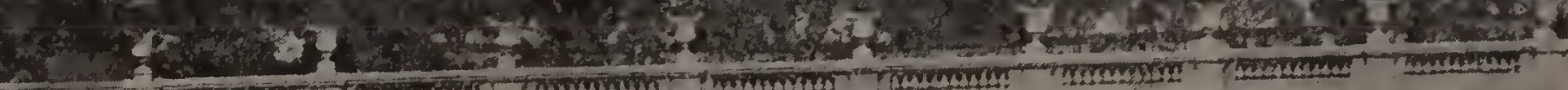


the building is reached, for it is perhaps the noisiest stock exchange in Europe. The time selected is favourable, as the "hours of business" ate 12 till 3. Visitor's may ascend the staircase on the left-hand side, and look down upon the turbulent scene; but the experience is not recommended to ladies, and requires some little moral comage, as hustling is the order of the day, and the sightseer is rrequently made to feel that he is out of place.

The Bourse is built in classical style, being an imitation of the temple of Vespasian in Rome. It forms a great parallelogram of about 220 feet long by 135 feet broad and 100 feet high. The exterior is adorned with sixty-six Corinthian columns, and approached by a broad flight of steps at each end.

We may now retrace out steps, taking the Rue de la Banque, and thus passing the--

\section{Banque de France}

(formerly the Hofel Vrillive) which is under gorernment control, and possesses the sole right of issuing hank notes in France.

A branch of this establishment necupies the old salle Ventadro, Cormerly the Italian Opera.

Again crossing the Palais Royal, we reach the Rue de Rivoli. IVe enter the Tuileries Gardens, mostly interesting as being the site of the once celebrated-

\section{Tuileries Palace,}

for three centuries the abode of the sovereigns of France. It was commenced by order of Catherine de Medicis, in 1564 , after the plans of Philibert de l'Orme: the building was continued hy Henry IV. and completed under Louis XIV. The Palace took its name from being erected on a site occupied by brickfields or tilc-works (twili, a tile). The Tuileries Palace was stormed by the people of Paris on the roth of August, 1702. During the first Empire it was the residence of Napoleon, and subsequently of Louis XVIII., Charles X., and Louis Philippe. In I830 it was again ransacked by the mob; and in February, I $8+8$, when Louis Philippe was driven from the throne, a choice collection of the riff-raff of the capital bivouacked in the halls of the Tuileries, and held high festival until driven out by order of the provisional government. Napoleon 11I. greatly enlarged the Tuileries and built the Pavillon de Flore. When the Communists for a time obtained possession of Paris in $18 \overline{1}$. 
they burned the main building of the Tuileries; the ruins were afterwards sold for building materials and removed. The Pavillon de Flore, however, and the gallery along the Seine towards the Louvre, escaped with comparatively little damage. This part had been rebuilt in the style of the gallery of Henri II. by Lefuel, whose work was scarcely completed when I87o brought the fall of the second Empire. Part of the wing of the Tuileries facing the Rue de Rivoli, with the Pavillon de Marsin, burned by the Communards in 187I, have been rebuilt; they extend from the Tuileries gardens to the Guichets, or largearched entrances leading on to the-

\section{Place du Carrousel.}

The Carrousel is the open place between the Louvre and the court of the Tuileries. The name Place du Carrousel originates in a festivity with military games, \&c., given by Louis XIV. in 1662 (a carrousel was a kind of minor linightly tournament). Napoleon I. ordered the erection, on this place, of a monument to celebrate his victories of 1805 and 1806 ; and thus arose the Arc de Triomphe du Carrousel, designed by the Emperor's architects Fontaine and Percier, on the model of the arch of Septimius Severus at Rome. The monument is 48 feet high, 63 wide, and $2 \mathrm{I}$ deep, and is profusely adorned with sculpture representing the wars of the first Empire. Napoleon I. caused the summit to be adorned with the famous quadriga, or chariot with four horses, brought from St. Mark's at Venice; but in I8I4 that trophy had to be sent back to its former home, together with other spoils of the Imperial Conqueror. By order of Louis XVIII. the vacant place was filled up by another quadriga, the four horses being driven by an allegorical female representing the "Restoration." At present the extensive clearances made around this monument make it appear somewhat small, especially in comparison with the neighbouring Louvre.

\section{The Statue of Léon Gambetta,}

just beyond the $A r c$, is worthy a .closer inspection. It is a nation's appreciative memorial to this distinguished statesman, whose services to the State raised him to the highest position under the third Republic, and whose unexpected and untimely death was mourned as an irreparable loss by his party.

The visitor whose time is not limited may now prefer to give 
11p systematic sight-secing and either take a stroll on the Champs Elysces, or a drive in the Bois, or he may visit the Louvre Galleries; or by proceeding to the Madeleine, walking the length of the Avenue de l'Opéra, he may continue and finish the greater portion of the programme assigned to the second clay.

\section{The Louvre and its Treasures.}

We now come to the greatest artistic treat Paris can offer. A single visit can do little : it must be repeated over and over again, during whatever odd hours the visitor can spare from the other days' work during his stay-and even five or six repetitions of the first visit will hardly exhaust his enjoyment.

The Palace of the Louvre, with the exception of Notre Dame, is the most ancient, as it is undoubtedly the grandest, monument of Paris. The original palace was huilt as a fortress by Philip Augustus, the contemporary of Richard Coeur de Lion and King folm ; and was enlarged and altered throughout successive centuries by various kings of France. As in the case of the Bastille, the lines of the original fortress have been traced on the pavement of the present huilding, as revealed by recent researches. Charles V. (the IVise) considerably enlarged the fortress, and under Iiancis I, the transformation from fortress into palace was begun by the construction of the Southern and IVcutern façades of the present Louvre. From a window on the Western front, the wretched King Charles IX. is said to have fired upon the flying Huguenots, during fhe St. Bartholomew massatere. Henry IV., Louis XJJI, and Louis XIV., each contributed to the culargenent and embellishment of the palace, but as a royal residence it was superseded by the Tuileries. Louis XV. opened part of the palace to the public, and at the period of the Revolution the different objects and works of art from various palates werce collected here. "The Great Napoleon enriched the collection with various pictures, \&c., "conveyed" from different countries, and Napoleon III, conceived and carried out the design of uniting the Lonvre and the Tuileries into one harmonious whole. The Louvre now contains eleven different collections of art treasures, forming one of the most magnificent and complete displays in the world, and comprising splendid salleries of paintings, especially rich in specinens of the Italian, Flemish, Spanish, and modern French schools; Grerk, Koman, Egyptian, and Assyrian antiquities; sculpture, 
articles of jewellery, ancient and medieval, porcelanin, canneus, a naval and an ethnographical collection, Oriental curiosities, a library of rare books, \&c., \&c.

Exterior of the Louvre: General design.-The main building of the Louvre is in the form of a hollow square around the large Cour du Louvre, looking upon the Rue de Rivoli to the rorth, upon the Place du Louvre and the church of St. Germain l'Auxerrois to the east, the Quai de Louvre and the Seine to the south, and the Place du Carrousel to the west, two long amnexes stretching out towards the Carrouscl, the northern extension being occupied by the Ministere des Finances, and the southern onc by part of the collections (the Galérie Daru, \&c.). The different parts of the building belong to different periods.

On the eastern front, looking towards the clurch of St. Germain l'Auxerrois, is the Colomnade of the Louvre, a fine series of fifty-two Corinthian pillars, in pairs. 'The bust of the "Grand Monarque" on the pediment, and the inscription of "Ludovico Magno," fixes the period of this colonnade. It was erected in 168.5. Garden beds extend in front of this colonnade, and to the right and left, along the northern and southern sides of the building. At the western extremity of the southern parterre is a portion of which the lower storcy was built under Catherine de Medicis, and the upper one under Henry IV. In the centre of this building is the Pavillon de Henri Quatre. Beyond this, along the bank of the river, extends the Gallerie du Bord de l'Eau, restored and beautified from I $\$ 50$ to $1 \$ 53$. The side of the Louvre looking upon the Rue de Rivoli was built partly by Levan and partly by Lemercier. The central pavilion opposite the Place du Palais Royal is especially rich in decoration. The façade of the Pavillon de Rohan is modern. The interior court of the Tuileries, one of the finest specimens of French architecture, exhibits various epochs of the art. On the south-western angle are to be seen the monogram of Henly II. and his Queen, Catherine de Medicis. The opposite cornce of the western front of the court shows the cipher of Louis XIII. and his Queen, Anne of Austria. On the northern side of the courtyard, the initials of Louis XIV. and of his Queen, Marie Therése of Spain, are to be seen; while the eastern façade exhibits eagles, commemorative of the first Empire. The fine Pavillon de l'Horloge, also called Pavillon de Sully, after the famous friend and minister of Henry IV., occupies the centre of 
the western or principal façade of the Court of the Louve. In front of this courtyard is the Place du Carrousel, flanked on the northern and southern sides by the extensions of the façades of the Louvre. At the left-hand corner, on the Place du Carrousel, looking towards the old Louvre, is the Pavillon Turgot, with Cariaticles by Cavalier. Next is the Pavillon Richelieu, with Corinthian pillars and elaborate sculpture ; the Pavillon Colbert, and the Pavillons Daru, Demon, and Mollien, along the southern extensions and along the Place du Carrousel. The Pavillon Richelieu was burnt by the Commune, but has been since restored. The fine archways, known as the Guichets des Saints Pères, with a double entrance for carriages, and two narrower arches for loot passengers, give access to the Rue de Rivoli. Those who have but little time to spare may be reminded that the Crande Galiric di Pinture, with the masterpieces of the Italian, Spanish, Dutch, and Flemish schools, is on the first floor of the façade on the southern side of the Place du Carrousel, extencling along the Quai du Louvre, the pictures of the French school being in the same wing and floor, in the gallery looking towards the Carrousel Court; also that the Greek and Egyptian antiquities are on the first floor of the south wing of the part looking upon the Quai du Louve.

For the tourist who wishes to see the museum of the Lonve systematically; the following method is the best. The visitor enters by the Pavillon Denon, in the southern extension, from the Place du Carrousel. On the left is the Galérie Mollien, and on the right the Galérie Daru. In the former are mouldings from the antique, and in the Galérie Daru fragments of ancient sculpturc, and modern castings of celebrated ancient statues, such as the Apollo Belvedere, the Litocoon, the Ariadne of the Vatican, \&c. After traversing the Galérie Daru, the visitor ascends and descends a few steps into the Vestibule Daru, where he remarks in the centre the magnificent sarcophagus of Salonica, with a combat of Amacons, various capitals, and a collection of funeral urns with inscriptions. A head of Alcibiades and an altar dedicated to Jupiter Custos are to be noted. Thence the Salle de la Rotonde is entered. In the centre is the famous statue known as the Borghese Mars or Achilles, and before wo of the ivindows, two very ancient Greek tower's, discovered in the Temple of Apollo at Actium. The Rotunda opens southwards into a series oi halls of antique 
sculpture, divicled into the Salle de Mécene, with colossal heads of Macenas and Caracalla; the Salle des Saisons, with busts of Roman Emperors; the Salle de la Paix and Salle de Septime Sévère, with busts of Roman Emperors and Empresses; the Salle des Antonins leading to the Salle d'Auguste. In the centre here is one of the most perfect antique statues of the Roman Orator, known also as the Germanicus; and the Roman Emperors from Augustus to Trajan. Returning to the Rotunda, we now pass on to the right into the Salle de Phidias, containing some exquisite antique Greek sculpture, especially a treasure in the form of a piece of the frieze from the eastern façade of the Parthenon, and some fragments of the Temple of Jupiter at Olympia. Then through the Corridor de Pan, which takes its name from the seated statue of the god Pan, to the salle du Tibre, and so through the Salle du Gladiateur, with a colossal bust of Theseus, and a Hero combating, signed by the sculptor Agasias of Ephesus, and a wounded Amazon, \&c.; the Salle de la Pallas, containing the Pallas of Velletri, a fine bust of Alexander the Great found at Tivoli, the Homer of the Capitol, and the magnificent sarcophagus of Actaon, \&c.; the salle de la Melpomène, so named from the grand statue it contains of the tragic muse; the Salle de la Vénus de Milo, containing the Venus of Milo, one of the masterpieces of ancient sculpture, and one of the chief treasures of the Louvre; the salle de la Psyché, with a charming statue of Psyche, a grand head of a victorious young athlete, and a curious statuette representing Euripides seated, with the name of his tragedies inscribed on the back of his chair, and two curious sarcophagi found near Bordeaux in $\mathrm{ISO}_{5}$. The Hall of Adonis, so called from a sarcophagus on which are represented three scenes from the story of the youthful favourite of Venus, namely, I. Departure for the chase ; 2 . Wounded by the boar ; 3. Death of Adonis. The Salle de l'Hermaphrodite, with the statue found at Velletri ; the Salle de la Medée, with a grand sarcophagus with four scenes from the story of the famous enchantress, Euripides' heroine. Coming again to the Corridor de Pan, the visitor reaches the Salle des Cariatides, so named from the colossal figures placed there by Jean Goujon, the celebrated sculptor, to support the gallery. This apartment, which in old times was called the Grand Salle Basse, was the guard-chamber of the Swiss Guards, and formed the ante-room to the apartments of Catherine de 
Medicis. In this room Heny of Navare was married to Marguerite de Valois, his first consort, and in the gallery over the Cariatides his corpse was laid out after his murder by Ravaillac in 1610.

Now the visitor passes under the Passage of the Pavillon Sully, and procecding onward to the court on the opposite (the righi) side of the pavilion, enters the galleries devoted to modern French seupture. This is contained in six Salles or rooms. The first is the Salle du Puget, with various fine works by Le Puget, such as the Perseus and Andromeda, Mito of Crotona, Hercules, Sc.; al smaller copy of the equestrian statue of Louis XIV., executed for the Place Vendome by Giraton; various works by Legros, such as the scasons, Winter, Summer; a capital bust of Boileau hy Giratom, \&e. To the left of the Salle de Puget is the Salle de Coyzevox, containing the wotks of that sculptor, busts of Richelicu, Bussuct, the Great Conde, dec. On the right of the sialle du Puget is the Salle des Coustou, witl the works of Nicolas and Guillaume Coustou, Allegrain, Falconet, Pigalle, \&c. Nexi, to the riglit, is the Salle de Houdon, with works of Houdon, Pajon, Butchardon, \&ce, inchuding good busts of Washington, Franklin, and Voltairc. The Salle de Chaudet, besides Chatudes works, has fune picees by Cinova, namely, two groups of Cupid and Psyche, the Soldier of Marathon, by Cortot, de. Next is the Salle de Rude, with Rude's works, such as the Mercury, Jeanne d'Arc, de., and some fine pieces, such as the Sappho, Psyche, Sc., by Pradier. On the north side, facing the Rue de Riroli, the visitor now comes to the-

Musée de Gravure ou de Chalcographié. The musenm of chisaving is situated in the eastern portion of the south wing of the Louvre, and is entered hy the Porte Jean Gouzon on the Quai du Louvre. The splendid collection of engravings it contains owes its existence in the first instance to Louis XIV., who ordered engravings to be made of his palaces, gardens, \&c. This collection was increased under his immediate successors, and under the furst Republic. Thus arose the Chalcographie Francaise. The visitor who wishes to purchase copies of the engravings exhibited will find a catalogue of nearly 6,000 different works, with the prices duly set forth. The northeastern and eastern portion of the ground floor of the Louvre is occupied by Phonician, Assyrian, and Greek antiquities. The Assyrian Gallery, to which the entrance is on the west side 


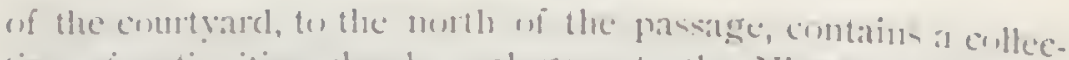
tion of antiquitice clencly analugous to the Ninereh scuptures in the British Mtuseum. 'The specincens are chiefly the result of the researches of .1. Botta, the Consul of France at .lluts:oul, who nearly half a century ago began to lay hare the treasures of lihorsabad, as Layard subsequently dicl those of Nimroud. Iinged human-headed hulls from Nincech, and has-reliefs representing the humting of the lion, dic., are to be secul here. Other has-reliefs represent secenes of royil promp and religious ceremonics. It the farthere cull of the Assytian Gillery is the Hall of the Sarcophagus of Esmunazar, which, in acklition in screctal sarcuphagi, contains a collection of ancient jewels, monments, enamels, dic. Then comes the Salle Phénicienne, after pitsings through a restibule containing a uniyue collection of sareophagi. The Phenician Hall contains a splendicl vase, hrought from cypress in 1866 , and linown as the vase d'Amathonte, hesides a number of antipuities enllected by .1 . Reman, and various inscriptions, some of which have only recently heen deciphered.

The Salles des Monuments de Milet, as its namc implics, presents the mont curious and interesting antiquitices found in Diletus: sume of the hest have becn presented by Gustare and fidmond de linthichild. The cullection here has alos heen enriched hy the generosity of . I. Waddington.

The salle de Magnésie, next in order, cxhibits the Grect: inscriptions brought from the tenple all Magnesia, and some very curious bas-reliefs representing combats of Amatons. The southern hatf of the castern portion of the Cour du lousre is nccupiced by the-

Galérie Egyptienne and Galérie Algerienne. The Egyptian Gallery was aranged, at the desire of king Charles $X$, in 1826 , hy the great antiquary and investigator Champollion, and since his time has heen enticlued by a number of new acquisitions. It is rich in statues of the Esgyptian kings of the various dymasties, statuc of the soddens Pasht, the head and fort of a colossal statuc of Hemnon (Anchuphes 111.). Tle specimens hele, as in most parts of the Ienve collections, have descriptions npun then snfficienty explicit to chucidate their meanings.

The southern portion of the hnilding east of the passage, looking on the Seinc, is necupicel ly the Museum of Sculpture of -the Middle Ages and the Renaissance. 'Tlis collection has 
been partly inate out of a former musemm, comsinting uf tratsments and remains of buildings destrovecl at the time of the Great Revolution. The entrance is from the comb of the Lenre, easten division of the sumth side. In the enriden on entering, notice the thirteenth-century statue of king Cluildebert,

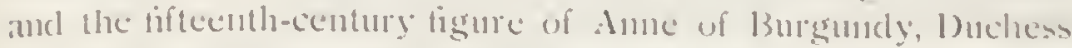
of Bedford, taken irom lace tomb; also four inngels frem the Ibbey of Poissy, thirtcentl century.

The Salre de Jean Goujon cuntains works by that sculptor, screral of them takien from old churches, stucts ats the "Christ and the four biangelists" from the elutrels of St. German l'Auxcrots. In the econtre is Goujon's Diana, fom the Chatean d'dnet. Notice Barthelémi l'rieme's monument to the memong of the Cunstable Anme de Mcontmotency, and German l'ilens marble busts of Charles IX. and Hemry 11 . Fingment of the fontaine des Imnocents hy Jean Goujon, representins tritons and nercids, are also interesting. In the Salon de Michel Ange (yichacl Angelo) are shown finc specintens of the ltalian schoes from the fourteenth to the sixtecnth ecutury, especially une line bronze bas-relicts showing fifteenth-century work. Notice especially the two slaties of . Wichael Angelo, and the Rohert Malatesta ol l'aolo Konnano. In the Salle de Michel Colomb the specimens are mosty of the sixternth century, inclueling efigicen of lomis xll. and Francis 1. , kinss of liance : a group of painted sculpture represcutins the Xativitg of the Virgin, a fine

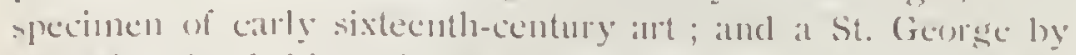
Michel Colomb himscli. At the cxitemity of the hall, on the other sicle of the Salle Jean Gonjon, is the Salle des Anguier. Votice here Simon Guillatis shoup from the montunent of the lont au Change, representing Lonis .1111, and Anne of Austriat. with the damphin Lomis, after Lomis XW. : and a finc lecad and

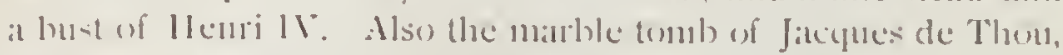
hy lirançois . Mnguice.

The salle de la Cheminée de Bruges likess its natne from it

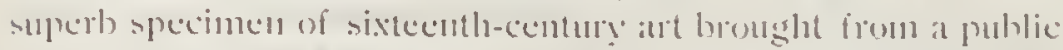
hall at bruges, where it wats profleced hetwecell 1520 and 1.3 .32 Anether interesting piece of medicual work is secen in the casting frem the lomb of Charles and Mary of Burgundy at Bruges. Notice also Patolo Bermini's the bat-redicf, represent ing the indant Cluriat platying with the natil that in to pierce his

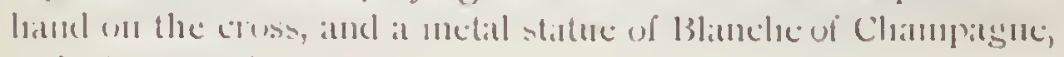
cully fumlecuth century. 
The salle chrétienne is most interesting from its various memorials in inscriptions, sarcophagi, and various monuments connected with the furst centuries of the spread of Christianity, from Rome, Greece, Asia Minor, Sc. The sarcophagus of Livia Primitiva, from kome, is one of the most ancient memorials of Christian times. Next to this is the Salle Judaique, which contains a number of antiquities connected with the Jews and Palestine; the sarcophagi from the Tombs of the Kings; a monument of Herod; a Phoxnician inscription recording the war of the Moabites against Isracl at the death of Ahab, nearly goo years before the Christian era, \&c. This collection also has some very curious and ancient Jewish relics, in the shape of coins, poltery, fragments of textile fabrics, gold ornaments, and other objects.

The visitor maty now make his way across the Cour du Louvre to the Pavillon Sully or de l'Horloge, and mounting by the stinirase bencath the clock, he reaches the first floor of the-

\section{Louvre Picture Galleries.}

Here, on the staircase, which dates from the time of Henri II. and Catherine de Medicis, are some fine sculptures attributed to Tean Goujon and his school. At the head of the staircase the visitor turns into the Salle La Caze, so named from the munificent benefactor who left a splendid collection of paintings to the nation in 1870 . 'The Jutch school and the French school of the eighteenth century are especially well represented. Various Ostudes (Adrian and Isuac) and Gerard Dowes ate here to be seen. Notice also Velusqué' Portrait of a Young Voman, D. Tinier's Kermesse or Village Festival; Tinlorello's portrait of Pictro Mocenigo; A. a'cull Osturle's Man Drinking, and Man Reading; Rubens's portrait of Marie de Medicis, and Wattcu's Assembly in a Park. Then the visitor passes into the Salle de Henri II, which contains pictures by French artists; - the French schuol is, however, far more completely displayed in the next apartment, the Salon des Sept Cheminées. Among the masters here, Gúricault is especially well represented. Notice his colossal and ghastly picture representing the unhappy survivors of the shipwreck of the French frigate La Midusc on the raft, on which, deserted by the boats that were to have towed them, the greater number perished miserably. Other notable Gericanlt pictures in this room anc-The Wounded 
Cuirassier, a Race at Epsom, Officer of Mounted Chasseurs charging. Here also are two historic pictures by Gros illustrating scencs in the history of the Great Napoleon-one representing General Bonaparte visiting the plague-stricken soldiers in the hospital at Jaffa, and the other the Emperor Napoleon on the battlefield of Eylau (February, 1807). Notice also Resinamit's "Education of Achilles by the Centaur Chiron."

Salle des Bijoux. This, the next apartment, in the wing on the south side of the Place du Carrousel, contains some splendid treasures of ancient ornaments in goldsmith's work, and torques and necklaces, ear-rings, buckles, finger-rings, bodkins for the hair, \&c., \&c. Especially noticeable are the three gold crowns in the centre case, and a gilt helmet, found in an old branch of the Seine near Rouen. There are also specimens of metal work in the Etruscan, Greek, and other styles. Nost of these treasures were found in various parts of France.

Through a circular vestibule, the centre of which is adorned by a copy of an ancient vase of basalt in the Vatican, and paved with a mosaic designed by Belloni, the visitor reaches the-

Galérie d'Apollon. In this splendid gallery the chief points are, first, the two great compositions under the arched roof at each end of the apartment representing respectively the Triumph of Neptune and Amphitrite, called also the "Réricil dis Ealu.x," and the "Réveil de la Terre," and the various paintings by Lebrun and others that adorn the roof and the walls. In the glass cases placed along the room are a number of art treasures, comprising facsimiles of some of the ancient regalia of France, various reliquaries, a splendid collection of vases in rock crystal, jasper, \&c.; sceptre and sword, said to have belonged to Charlemagne; a splendid collection of enamels, \&c. At the end of the Galérie d'Apollon is-

The Salon Carré. This is devoted to paintings, and contrins some of the most famous and valuable pictures in the Lunvre. The apartment itself belongs to the time of Henri IV. Among the numerous pictures in the Salon Carré the following should be especially noticed: Burial of Christ, Titian; Antiope and Jupiter; Corregio; Rape of Dejanira, Guido-Rcui; Apollo and Marsyas, Raphacl (purchased in I883 for $f 8,000$ ) ; Descent from the Cross, Lescur; Holy Family, Rembrandt; King Charles I., Yran Dyck: Feast at the House of Simon the Pharisee, Pan l'cronte'sc. 
On leaving the Salon Carré, the visitor has on his right the Salle de sept Cents Metres. Here are to be found the works of masters of the early Italian school-Giotto, Cimabuc, Pcmsino, Philiffo Lippi, Giovanili Bellini, \&c. Especially worthy of attention are Philippo Lippi's Nativity ; Ponsino's group of the Virgin, the Infant Jesus, Saint Joseph, and Saint Catherine; Giovmm Bcllini's Holy Family, and Lucas Signorelli's Adoration of the Magi. After making the tour of this room, the visitor enters the-

Grande Galérie de Peinture, extending along the side of the Quai du Louvre, and containing numerous treasures of the Italian, Spanish, Dutch, and Flemish schools. In this gallery the visitor will notice the series of pictures painted by Rubens for Marie de Medicis, the second queen of Henri IV., representing, partly in an allegorical manner, historical events in the life of the Queen and of her young son, Louis XIII., The Flight intu Egypt, The Triumph of Religion, The Kermesse or Country Fair. The Dutch and Flemish schools are also richly represented. Notice especially the works of Gerard Dow, Albcrt Cuyp, Adrian van Ostadi, Hobbcula, and some fine specimens of Tinicrs. 'This gallery deserves especial altention, as one of the richest of the Louvre. The visitor turns to the left into the-

Salons Français, a series of rooms devoted to paintings of the French school, capitally arranged in chronological order, beginning with a fourteenth-century work, the Martyrdom of St. Denis, and some fifteenth and sixteenth century pictures. The second hall is devoled to the series of pictures painted by Euslache Lesucur for the Chartreux convent, which stood on the site of the present Palais du Luxembourg. The lifth hall will be especially interesting to visitors from its containing some works by English artists-W Weymouth Bay, a Cottage Scenc, and The Rainbow, Constable; The Park of Versailles, Bonninston; A Lady in White, Ofic; a Portrait piece, Beceley', sc. Turning to the right along the northern terrace, we come to two great galleries devoted to paintings of the French school. The first of these is the-

Galérie Mollien. In this great hall notice especially the works of Lonssin, the portraits by Rigand, landscapes by Clunde Lorrain, historical pieces by Lebrun. After traversing the Salon du Pavillon Denon, the second great hall is reached, namely, the- 


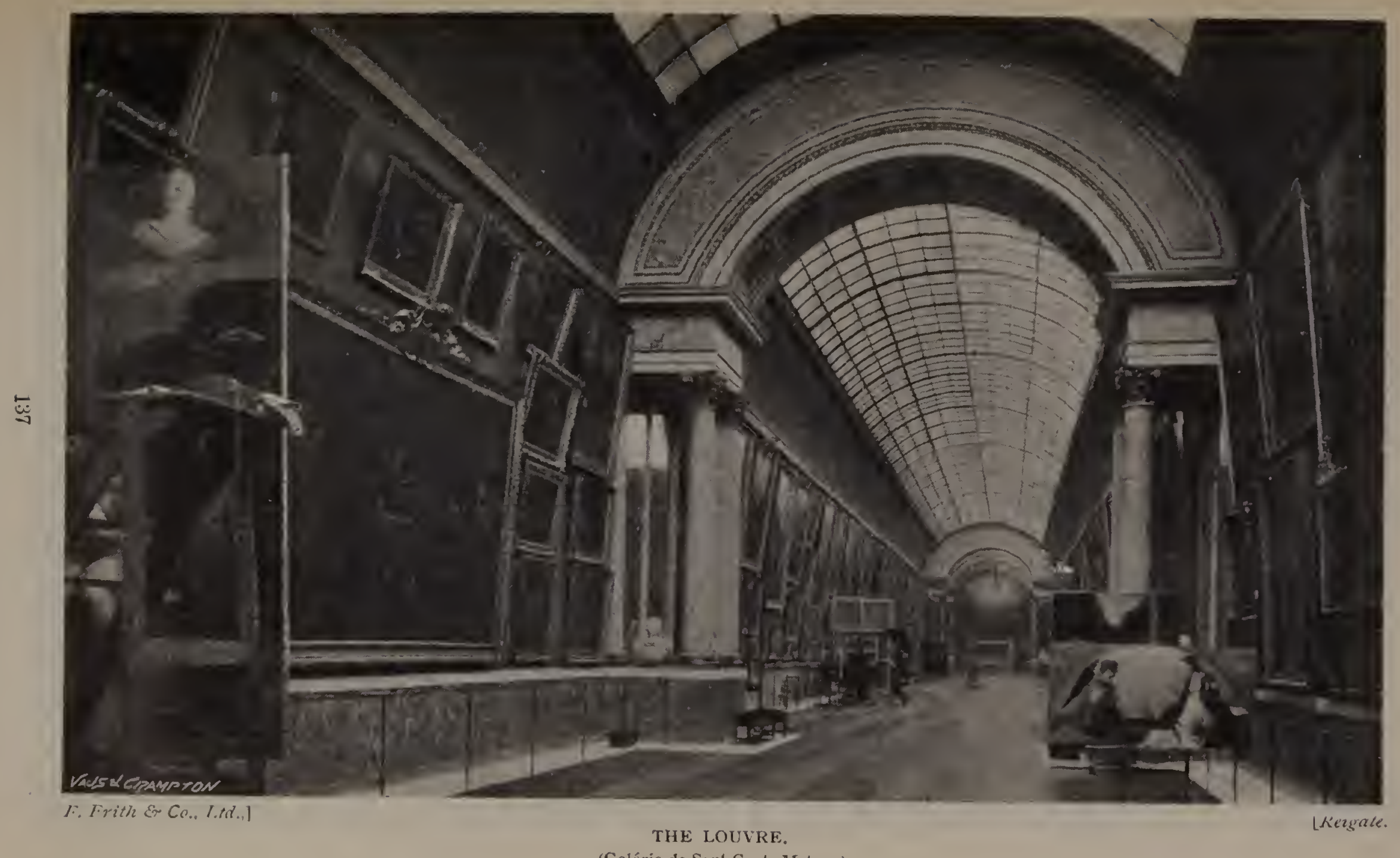


Galérie Daru. This hall contains some well-known historical pictures by David, such as the Belisarius, and the Oath of the Horatii. $G$. and $F$. I'rmet are also represented by some inportant works. Notice also "Les Naufragés," a wrecked ship's company, by Ensinc Dchucroix; and as a curiosity rather than a work of art, the portrait of Baroness de Kudner and her daughter, by Goldsmith's Alsgilica Kinuffunaun. After making the round of the Galérie Daru, the visitor may quit the building by the Pavillon Denon and cross the courtyard to re-enter by the Pavillon Sully. Turning to the left into the galleries leading to the northern front facing the Rue de Rivoli, the visitor will find a long series of rooms devoted to a collection of sketches and drawings by the various painters whose works he has been achniring, and by various others. Starting from the Pavillon Sully northward, the first room is found to contain drawings of the old masters of the Italian school, including Lifpi, Signorelli, P'rugino, Tadalou Gadali, Manteğla, \&c. In the second room will be found clrawings by great Italian masters, Lcomardo da Vinci, Michacl Angelo, the series of cartoons by Fuliv Romano, representing the Triumph of Scipio, \&c. In the third room, drawings by Panl V'ronesc, Corregio, Nicolu dell'Abate, Rosso, \&c. The fourth room, besides Italian masters, exhibits drawings by Spanish painters, Mmrillo, V'clasquer, \&c. In the fifth room are drawings of the Flemish, German, and Dutch schools, incluching specimens of Albert Dïrer, Lacas Cranach, Holbein, Temicrs, Memling, \&e. In the sixth, drawings of the French school of the eighteenth century, and some English dravings by Sir Thomas Larorence. Rooms seven to ten, other clrawings chiefly French. In room eleven notice some fine water-colour slietches by Bumington, Gíricanlt, \&c. The twelfth room is remarkable for a large sketch of a picture left unfinished by David, representing the Serment du Jeu de Paume-the oath taken in the Tennis Court at Versailles, in 1789 , by the representatives of the people, pledging themselves not to separate until they had obtained a constitution for France; also for a number of enamels, portraits of seventeenth-century celebrities (Anne of Austria, Louis XIV., Madame de Maintenon, \&c.). The thirteenth room has some curious furniture to show; and the fourteenth room, the last of the series, is called the salles des Pastels, from containing a collection of pastel portraits. The Salle des Pastels teads into the first of two rooms devoted to the 
Collection Thiers, bequeathed to the nation by the celebrated statesman and President, and his widow. The principal objects in the first hall are bronces, ornaments and jewellery, caskets and other articles of ortu. The second is devoted to a collection of porcelain. Beyond, the visitor reaches the-

Musées Moyen Age et de la Renaissance. Here are to be found in a series of rooms magnificent collections of medieval and renaissance art-pottery, porcelain, chefs d'weuvres by Bernard Palissy, bronzes, glass, statuettes in ivory, bronze, carved wood, Lic., while on the eastern façade to the south of the great central passages, and opposite the Assyrian Gallery, are the-

Anciennes Salles du Musée des Souverains. These were royal apartments occupied by the lings from Henri II. to Henri IV. and Louis XIII. The decorations and ormaments are exceedingly curious. It was in one of these rooms, called the Chambre d'Alcove, that Henri IV. expired, after having been mortally wounded by the knife of Ravaillac. At the north-west corner of the building, at the angle of the Rue de Rivoli and the colonnades, is the staircase leading to the Second Floor, in which is the Musee de la Marine et d'Ethnographie, containing models of ships of various periods, the interesting relics of the voyage of " $\mathrm{Lit}$ Pérouse," and vạrious kinds of implements and arms, \&.., of savage nations. Here also is the Salle de Lesseps, with at model of the Suez Canal, and the Salle des Boites, where are liept, with great care, the rarest drawings and sketches in the collection of the Louvre. - We have thus endeavoured to give an idea of the contents of this vast treasure-house of art; those visitors who desire to study it more particularly, will do well to buy the official catalogue, to be obtained at Galignani's book warehouse, in the Rue de Rivoli, nearly opposite the Louvre.

Leaving the palace by the Place du Louvre, the visitor has before him another important monument of mediaval Paris, in the-

\section{Church of St. Germain l'Auxerrois,}

once of the most ancient of the Parisian churches, and alike interesting from its architecture and its historical associations. It dates originally from the twelfth century, but has been several times retouched and restored, the last restoration being in the reign of Louis Philippe. The present façade chiefly belongs to the fifteenth and sixteenth centuries, though the principal door 
is of the thirteenth. The bell tower is of the twelfth century. Some of the statues decorating the exterior date from the thirteenth century, hut the statue of St. Nichael that crowns the edifice is by Baron Marochetti. Historically this church will always be noted for the fact that from its tower, which faces the palace of the Louve, was wiven the signal for the conmencement of the horrible massacre of the Huguenots on St. Bartholomew's Day; the $2 f^{\text {th }}$ of August, 1572. In Paris alone, 500 persons of rank and 10,000 of inferior condition perished during this massacre, which was continued for days throughout Fance, the victims including persons of both sexes and of all ases. The entire number of victims is very variously stated at from 30,000 to 100,000 .

The interior of the choir is of the thirteenth century, partly later; the nave, transepts, and chapels of the fifteenth and sixteenth centuries. The church contains some fine sixteenthcentury stained glass. Near the entrance to the right transept is a holy water font in white marble, designed by Madame de Lamartine and executed by fouffroi. In proceeding round the church, entering by the Place du Louvre, the visitor finds on his right hand in the Chapel des Catéchismes a curious "tree of Jesse," of the fourteenth century, and frescoes by Amamy Duial; over the transept entrance, frescoes by Guichard, and farther on a vindow of the twelve apostles by riollet le Duc, whose hand is seen in the restoration of many of the churches of Paris. In a chapel on the left hand is a picture of the Last Supper, supposed to be by Lnimi, and in another a Virgin and Child, by Landelle. There are also line stained-glass windows by Didron and L.usson.

Thus we conclude our first day's excursion, and the visitor will easily find his way along the Rue de Rivoli, back to his hotel.

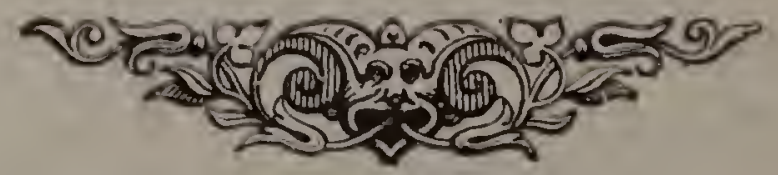




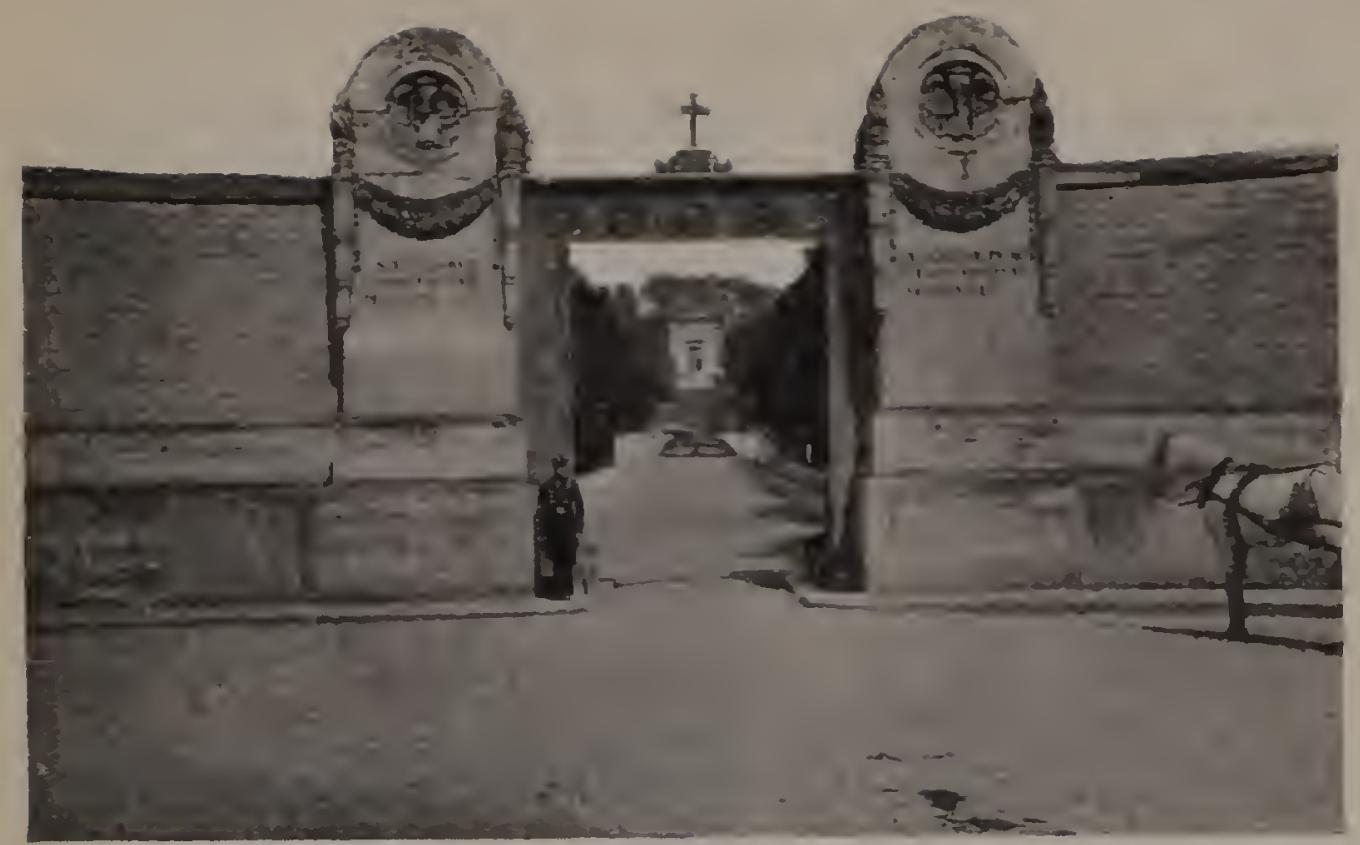

EXTRA.NCE TO PERE LA CHAISE.

see lp. rf(6-).)

\section{CHAPTER YII.}

\section{ITINERARY OF PARIS.}

\section{SECOND DAY'S PROGRAMME}

Place de la Bastille-Colonne de Fuillet-Père la Chaise-ButtesChanmont-St. Vincent de Panl-Place T'endôme.

$7 \mathrm{HE}$ economical sightseer cannot do better than commence 1 this day's excursion by taking a ride on the Imperiale of one of the most popular lines of omnibuses, namely that running from the Madeleine to the Bastille. Starting from the Madeleine Church, the route follows the whole length of the Grand Boulevards, passing on the way the-

\section{Opéra House,}

A special paragraph may be appreciated by those who are desirous of seeing the house itself quite as much, or more perhaps, than the actual performance. The Opéra is generally open three times a week, namely, on Mondays, Wednesdays, and Fridays, and occasionally on Saturdays. The high-class seats require that ticket holders shall present themselves in dress suit, \&c. The fourth tier places, however, require no special 
preparation, except that readers are strongly urged not to

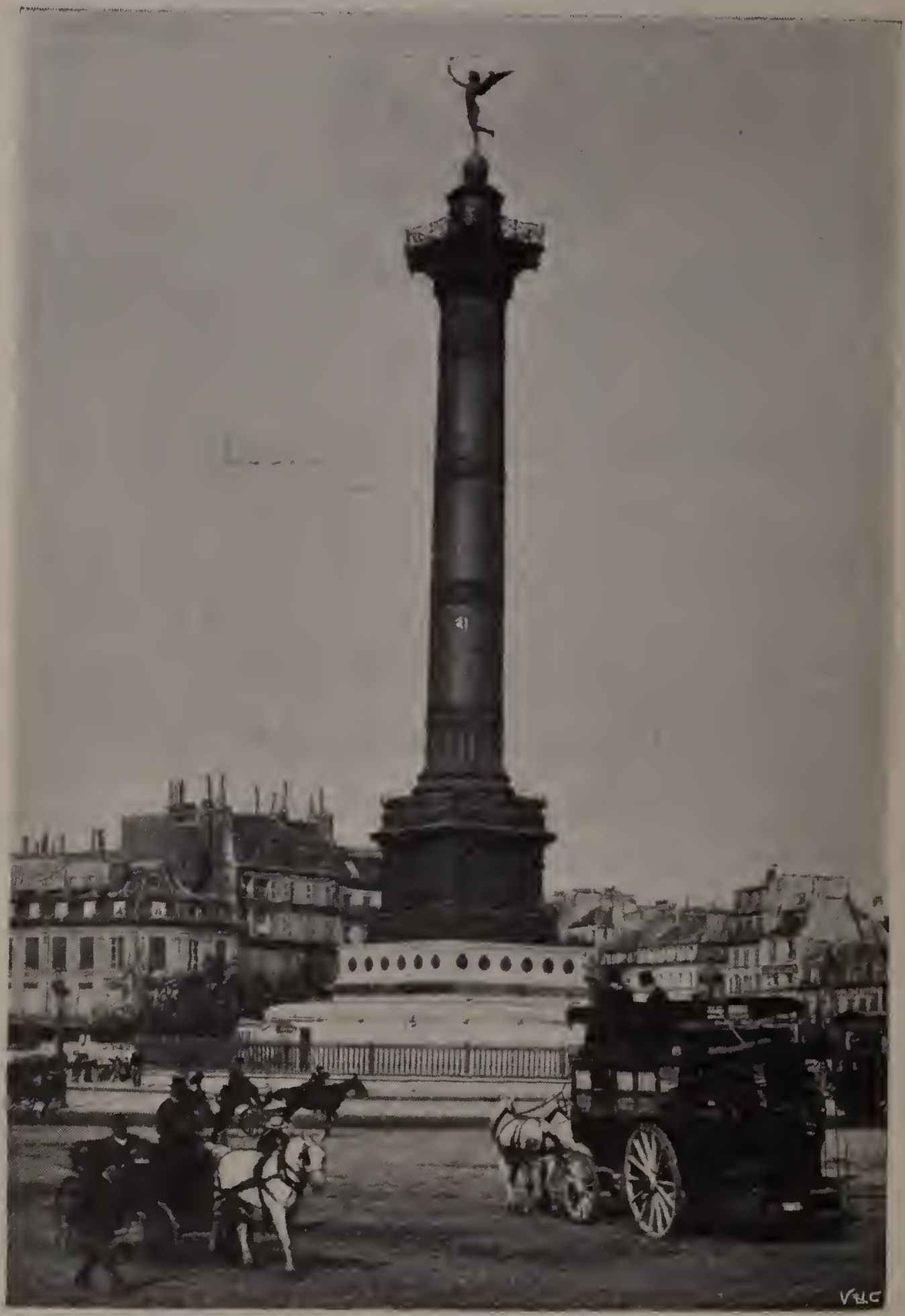

PLACE DE LA BASTILLE. (Colonne de Juillet.)

appear in light tweed tourist-suits as, though they may be admitted, the impression produced is distinctly undesirable. 
These seats enable the holders to circulate frecly on the grand staircase, through the foycrs or reception, waiting and refreshment rooms, and in fact throughout the building, with the same freedom and liberty as though holding tickets for the best situated boxes on the first tier of the house. The intervals between the acts (cntractes) are much longer than is usual in England or America, hut this is one of the features which is appreciated by the French playgoer, as he has a partiality for promenading the theatre, conversing with his friends, and taking refreshments by way of diversion.

En routc we pass some of the most important Parisian theatres, notably the Porte St. Martin, and cross the Square of the Republic, with its celebrated statue of Liberty, and descend at the-

\section{Place de la Bastille,}

situated at the extremity of the Rue St. Antoine. Here, until the close of the eighteenth century, stood the formidable Bastille, originally a castle for the defence of old Paris against the English, built by Charles V. in 1369 , and in subsequent times the dreaded and hated state prison, in which many persons who had offended the despotic government pined away forgotten and unheeded. When the walls of Paris were levelled in 1670 the Bastille was left standing. Among the prisoners confined there under Louis XIV. was the mysterious "Man with the Iron Mask," whose identity has remained one of the puzzles of history. On the $14^{\text {th }}$ of July, 1789 , the Bastille was attacked by a crowd of determined Parisians, who, infuriated at the resistance they encountered from M. de Launay, the grim old governor of the fortress, and his garrison, took the place by storm, cut off the heads of De Lamay and several of his officers, and carried the gory trophies in triumph through the streets. By a decree of the Republican Government, the Bastille was afterwards levelled with the ground, some of the stones being used in the construction of the Pont de la Concorde. The foundations of the Bastille were rediscovered some years ago, and a line of white granite on the western side of the pavement of the place, at the entrance of the Rue St. Antoine, marks the boundary of the ancient fortress. Under Louis Philippe, it was determined to erect a monument there in commemoration of the Revolution of July, 1830 ; and thus arose the- 


\section{Colonne de Juillet,}

a lofty and handsome pillar, built by Alavoine and Duc, and inaugurated in 1840 . It is 154 feet high, and rests on a substructure of white marble. The column is adorned with the names of six hundred and fifteen combatants who fell in the struggle of the 27 th, 28th, and 29th of July, I830, and whose remains are deposited in the vaults below. The statue at the summit represents the genius of Liberty standing on the globe. A lion (a sign of the zodiac for July) is sculptured on the west side of the column over an inscription commemorative of the French citizens who died for liberty in 1830 .

\section{The Musee Carnavalet,}

open on Thursday's and Sundays, is one of the most interesting in Paris and well worth visiting. It is situated on the Rue de Sévisgné, at the corner of the Rue des Francs-Bourgeois, not far from the Place de la Bastille, and occupies the house which was formerly the residence of the famous Marquise de Sévigné, whose celebrated letters to her daughter are models of elegant French. This museum takes its name from François de Kernevenoy (corrupted into Carnavalet), who was tutor to Henri III. It was built in $\mathrm{I} 55^{\circ}$, by the architect Picrec Lescot, for Jacques des Ligneries, President of Parliament; and the admirable ornaments, of which some few still exist, were by Fean Gonjon. In I660 Mansart added to the original building the first storey, which extends around three sides, and the façade on the street is also due to him. The ormamentation of the exterior of the building, the wings, different storeys, \&c., is a strange mixture of ancient and modern art, for the work extends over the period between I550 and 1870 .

Ground Floor.-The First Gallery is devoted to relics of the Gallo-Roman period found in and around Paris. In the Hall of Tombs we find a fine collection of tombs, sarcophagi, \&c., dating from the Merovingian period. The Cellar, which is only open to visitors during the summer months, conlains a kitchen of the I6th century, arranged as a crypt ; sarcophagi which date from the $4^{\text {th }}$ and roth centuries; and a collection of funeral urns containing the ashes of the first bodies burnt in the crematory at Pise la Chaise in 1887 . W'e now return to the ground foor, and enter Hall No, 1, which, like the first room described, is devoted to Gallo-Roman relics. In this hall the ceiling has been completely restored, and the double PHI of François and Françoise de Carnavalet, the $S$ which in the symbolical language of that period stood for "Grandesse et Fermesse" (Grandeur and Fidelity), as well as a chimney dating from the 16th century, are to be particularly noticed. In Hall No. 2 there is a collection of bronze's, medals, pottery, \&c., also of the Gallo-Roman period. Hall No. 3 contains divers monuments, \&c., of the Meroringian and Middle Ages. The 
Vestibule comes next, and after a glance at the plaques which fummerly indicated the different streets of the metropulis, we cross the Garden, with its iragments of buildings (all of which are duly ticketed), and enter the Middle Hall. This room is devoted to the old Hutel de Ville, destroyed by the Communc in 187 r. To the right is the Salle du Palais Royale, which contains a collection of medils by the contemporaries of David d'Angers, and a model of the Palais Royale as it existed in I8+3. On the left of the Middle Hall we find the Salle Dantan, devoted to caricatures hy Duutun.

IVe now ascend the grand stairway to the First Storey, on our waly nuticing the plans of Paris as it existed between the 16th and ISth centuries, the mouldings of the most celebrated bas-reliefs by Jean Goujon, and a finelycarved wooden door. The two Small Galleries are separited by the Arch of Nazareth, a graceful structure which served as a kind of passage-way between the "Chamber of Accounts," or Palais de Justice, and the building in which the archives were liept during the reign of Henri II. (1550). These gallerics contain views of old Paris, and scenes in the every-clay life of the city. ITe now enter the bedroom which originally belonged to Dangeau, and formed part of the house on the Place Royale (now Place de la Concorde). It is an immense room, richly decorated in the ormate style of Louis XVI., but it is in a state of absolute delapidation. In addition to many pictures, this room contains some interesting mementos of the great singer . Mboni and her portrait, and a bust of the Prince Imperial, by Carpean, taken when the Prince was only ten years old. In the central cabinet we see the Travelling Casc of Vapolevn. I., which he leit to General Bertrand. W'e then pass on to the Dining Room. The ceiling is by Librm, and represents Mercury presenting Hebe to Jupiter. There is a fine collection of ceranics in this room, which will tell its own story, as it records the history of the Revolution. The ditterent orders of the General Assembly; the clergy, the nobility, and the "third estate," are symbolised by the cross or the crozier, the sword, and the spacle or the plough. The II, which is so prominent, is meant to signify the word "Vive"; a tomb is intended for the tomb of Mirabeau; a battlemented castle figures for the Bastille. "The plate representing the "Carmannole" is very interesting. Almost the entire collection is from the famous factory at Nevers; and the peculiarity of the colouring is that there is no bright red used, that colour being replaced by yellow for the llars, caps, Phrygian bonnets, dic. Work from this factory can almost always be distinguished by this detail. The pieces in which bright red appears alle invariably from the south and east of France. The small hish cabinets are devoted to rare pieces of Serres. In the gallery there is a case of fans ornimented with patriotic subjects, the badges of magistrates, and some of the decorations accorded to the heroes of the Bastille in 1789. The portraits of the leaders of the Revolution-Robespierre, Marat, Danton, \&c.-are very interesting. In this Gallery there is also a fine numismatic collection. In the beautiful Salon which separates the two galleries is some fincly-carved woodwork dating from the Regency. The two chairs, or fautenils, we see in the corners are those in which Voltaire and Beranger died, and the coins, \&c., in the cabinets are the work of Dupri, who was the engraver to the Mint under the Revolution. The collection is unique. In the Hall of the Revolution are drums and llags of the difierent districts, military banners, "lettres de cachet" and passes, pilies carricd hy the "sood citizens," and onc small one evidently intended for il woman. Playing-circls, in which the fatce cards are portraits of the notabilitics of the day; a panuply of revolutionary arms above the miantelpiece, and the medillions on the doors of the two presses, representing the fall of the Bastille, arc worthy of notice. In the centre of the room is a model of the famous prison carred in stone from its walls, while near the ceiling wo sec an anti-Republican banner decorated with the arms of the Allied Porrers. In the cabinets is a lock of Rubespierre's hair, a box in irory upon which is cared the tomb of Louis XVI. and MaricIntoinste, and another representing the Bastille. The Small Salon is entirely devoted to souvenirs of the Rerulutions of 1830 and 1848 .

We return now to the ground floor by the stairway to the left, and see the bolts which were on the door of Madame 
Roland's cell in the Conciergeric; a door from the old prison of the National Guard; and a most peculiar combination of at bayonet and umbrella, which is truly original. Now we come to the Library, which contains I00,000 volumes and 80,000 prints or engravings. Then we visit the Salon of Madame de Sévigné, which has been preserved almost intact, and passing through the courtyard on our way out we notice the magnificent bronce statue of Louis XIV., by Cuyserox.

Unless the visitor is inclined to take a walk through the industrial part of Paris, which will occupy about twenty minutes, it will be necessary to take a cab to our next destination, as the lines of omnibuses will not suit. Ascending the Rue de la Roquette we pass the former site of the gloomy prison of that name, the building having been recently demolished.

Just beyond are the gates of the world-renowned-

\section{Cemetery of Père la Chaise.}

This is, properly spealking, the cemetery for the eastern part of Paris (Cimetière de l'Est), though most of the celebrities who die in Paris are buried here. It forms one of the nineteen burial-grounds belonging to the eity of Paris, of which thirteen are within the cuccintc, Montmartre heing the chief cemetery for the north, and Montparnasse for the south. The funerals, from the most magnificent to the humblest, are undertaken and furnished at fixed prices by a company called the "Pomfes Funcbres." The cemetery of Père la Chaise was laid out in ISof. The ground had in former times been at garden belonging to the Order of the Jesuits. Père la Chatise wats the Jestit confessor of Louis XIV. His country house was situated here.

The cemetery is open every day from 6 a.m. to $7 \mathrm{p.m}$. in the summer months, and from about 8 a.m. to 5 p.m. in the autumn and winter. Hall an hour's notice is given before the gates are shut.

The general division of the vast cencetery is into broad parallel avenues, with lateral ones, and narrower paths, or "chemins," diverging from them. The gireat area of Père la Chaise, about I Io acres, causes a visit to even the principal tombs of interest to occupy the best part of a morning or afternoon.

Just within the principal entrance, which is situated on the Boulevard de Menilmontant, there is a fine monument by 
Burtholoní. It is dedicated simply "To the Dead," and tells its own story. The late President Fèlix Faure is also buried here, and a fine monument is soon to be erected to his memory.

Advancing up the frincipal a'tellic', we find, among other graves of distinguished men, on the right, those of Arago the astronomer, Auber the composer, Ledru Rollin the republican leader of $18+8$, \&c. ; on the left, Dantan the artist, Achille Fould, Rossini, and Alfred de Musset, the poet; in the Aveme laterale din Nord, on the leit (north) side of the principal arenue, the monument of General Grouchy; in the Aicume lateralc du Sud, to the right of the Avenue Principale, Paul de Saint Victor, Ravrio, Sc. Rachel, the great tragic actress, lies in the Avenue Enclos des Israelites, to the right of the entrance; Talma, the actor, near the lateral Avenue de la cinapelle, in which are also interred Thiers the statesman, and Gericault the painter. In and round the crescent-shaped area inclosed by the Chemins de Mehul, de Denon, and de Talma, are several great musical composersBellini, Cherubini, Herold, Boieldieu, and Chopin. In the Grand Rond is the elaborate cenotaph of Casimir Perier, soldier, statesman, and financier. In the long curving Avenue des Acacias are the tombs of Champollion, the great Egyptian traveller and antiquary ; brave Marshal Kellermann ; the Abbe Siéyes, a Liberal statesman ; Marshals Gouvion de St. Cyr and Macdonald, \&c. Pursuing the Arenue des Acacials to the end, we find it divide into two great branches, rumnings northward-the Aicumc Transicrsalc No. 1. and the Chemin des Anglais. Just at the point of junction is the tomb of the Duchesse de Raguse, the wife of Marshal Marmont. In the Chemin. de's Allglais is the tomb of a very distinguished Englishman, the old seil-lion, Admiral Sir Sidney Smith, the successful defender of St. Jean d'Acre against Napoleon, who paid him the high compliment of saying, "That man caused me to miss my clestiny" -alluding to the discomfiture uf the French in Egypt. Southward of the Avenue Transversale is the Clnemin Molierc ot Lafontainc, containing the tombs of these distingnished poets, and near them the Chemins Suchet and Masséna, named after the two generals of the Empire. Indeed, whichever path the visitor follows through this great silent city of the dead, he is certain to come upon the names of celebrities in war, politics, art, science, literature, or commerce, Père la Chaise is, so to speak, a record of the genius, not only of Paris, but of France, for many generations. 
On leaving the cemetery, we can take the tramway rumning the whole length of the outer Boulevads, which will deposit us close to the picturesque-

\section{Park of the Buttes-Chaumont,}

containing about sixty acres, and forming a picturesque and liealthful spot in the crowded cuarter of Belleville, in the northcast of Paris. The park contains a lake with a lofty island rising from its centre, on which has been constructed an exact reproduction of the Temple of the Sybil at Tivoli, in Italy. From this temple a good view is obtained. The park is further beatified by an artificial cascade, a grotto with stalactites, two bridges, Ec.

On leaving the Buttes-Chanmont, we must take a short walk to the Rue Lafayette, where we shall find lines of tramways and unnibuses which will takes us back asain to the heart of the city, in the Opéra quarter.

On the right hand side will be noticed the elegant church of-

\section{St. Vincent de Paul,}

on the Place de Lafayette, a modern classical church in the basilica style, commenced in $182+$ and completed abont twenty years later. The font exhibits a statue of St. Vincent de Paul, the missionary priest, accompanied by Faith and Charity. The terrace by the towers is adorned with statues of the four Evangelists, and the towers themselves with figures of St. Peter and St. Paul.

Descending at the Opéra House, we atre in a central position and suitable france of mind for lunch. Restaurants to suit all purses will be found in abundance, and we would suggest a lunch to-clay at one of the well-known popular restaurants known as "Bouillons." The "Restaurant Boulant" is a good specinnen of these, and is siluated at the corncr of the Ruc Datunou, No. 35 Boulevard des Capucines, where an excellent lunch may be obtained at from two to three francs. The dishes have to be chosen from the menu, and the waitresses ate sufficiently used to tourists to understand whatever may be required of then, even in the most broken of French.

Following the Boulevard des Capucines to the curner, upposite the Grand Opéra House, we turn southwards into the Rue de la Paix, famous for jewellers' shops, the windows glittering 


\section{PLACE VENDOAME-BRIDGE OF ALEXANDER III. 149}

with magniticent displays ni diamonds and jewels of all kinds. On coming to the end of this handsome street, we reach the-

\section{Place Vendôme,}

a large old-fashioned square, situated midway hetreen the Rue de la Paix on the north and the Rue Castiglione on the south. It belongs to the last epoch of Louis XIV.'s reign, having been built by the younger Mansart at the heginning of the eighteenth century, of which period it forms a good architectural specimen. During the first Revolution the square was appropriately re-named "Place des Piques." Napoleon 1. caused its nomenclature to be again altered to Place Vendôme, and in the centre erected the Colonne Vendome. It is in imitation of Trajan's column in Rome, is 142 feet high and 13 in diameter. Like Trajan's column, it is encircled with a spiral band commemorating the victories of the military chief. The bronze covering of the Vendôme column is cast from cannon taken from the enemy, and records the exploits of the Austerlitz campaign. The summit is surmounted by a statue of the Emperor. In I8It this statue was taken down, and a Bourbon derice set up in its stead. Louis Philippe, however, had a statue of the Emperor in the wellknown "redingote" and "petit chapeau" put up on the column, and Napoleon III. substituted for this a statue in Roman imperial robes, like the original one. During the rule of the Communists in ISTI, the column was purposely orerthrown at the instigation of the painter Courbet, who was subsequently heavily fined for the offence, and committed suicide. The column has been re-erected with the bas-reliefs and statue complete.

Continuing down the Rue Castiglione, we lurn to the right on reaching the Rue de Riroli, and cross the Place de la Concorde to the banks of the Seine. Just to the right of the rridge will be found a pier, from which boats run in both lirections every few minutes. Taking our place on one of the fiers on which the arrow is pointing to the right, the risitor will soon pass the new Bridge of Alexander III., built for the Exposition of 1900. Thence on either hand we have the extensive Exposition buildings, until the pier of the Eiffel Tower is reached. The tower is fully described in our previous day's programme, but the time allowed was insufficient for a detailed and careful inspection and view. In any case it forms a full and pleasant nccupation for one alternoon. 


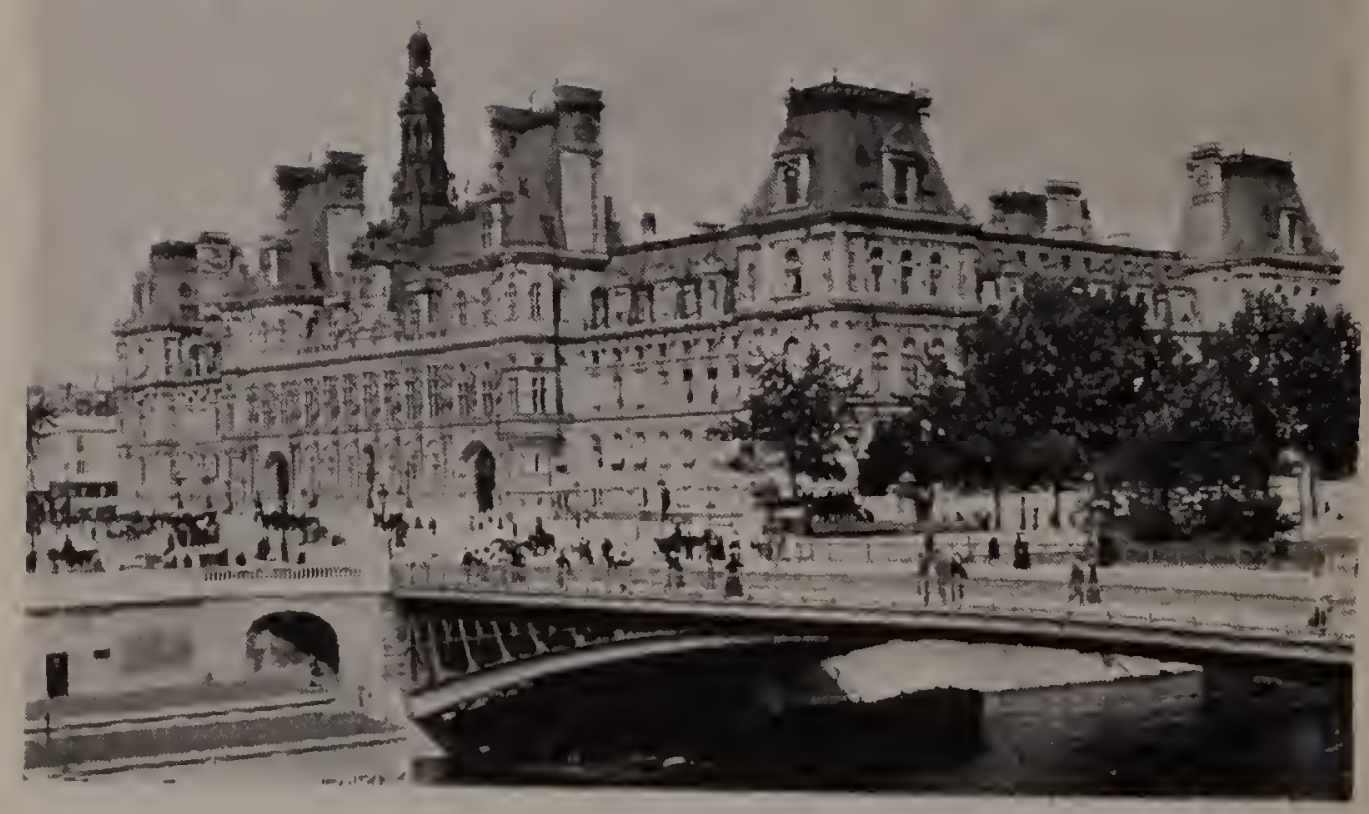

THE HÔTEL DE VILLE.

\section{CHAPTER ITIII.}

\section{ITINERARY OF PARIS. THIRD DAY'S PROGRAMME.}

The Halles Cenlrales-Sl. Eustache-Hôlel des Postes-Toun St. Facques-Hôtel de Ville-Nolre Dame-The Sainle Cluapelle -Palais ale Fuslice-La Concicrocric-Hôtel Clmuy-Palais ales Tliermes-Palais du Luxembonro-Statuc of Marslial Ney-Gobclins Tapeslry Mannfaclory-Panlliéon-St. Eticume dir Mont-Fardin des Planles-Bois de Boulogne.

X TE commence our third day's excursion by a visit to the Cathedral of Notre Dame, to which the visitor may proceed either by cab, omnibus, or steamer. If by steamer, we cross the Place de la Concorde and descending the steps to the right of the bridge, take a vessel running to the left, and descend at the quay close to the cathedral.

The steamer passes the Chamber of Deputies on the right, then the Tuileries Gardens on the left, and almost opposite may be observed the new Gare of the Orleans Railway, built on the 
site of the once stately Cour des Comptes. A little further along, on the right hand side, we pass the well-known State prison, known as the Conciergerie, and immediately afterwards descending at the pier, two minutes' walk will hring us to the square in front of the cathedral.

If hy omnibus, we walk to the Opera House, and thence take one of the large blue omnibuses drawn by three horses, and marked Gare St. LAZARE-PLACE ST. Michei.. These run down the Avenue de l'Opéra, past the Palais Royal, along the Rue de Rivoli, over the Pont Neuf, and put us down close to the cathedral.

But we recommend a cab for the commencement of this day's programme, as it will enable us to include several feature; of interest cll ronte.

According to the situation of our hotel we pass the Opera or the Place de la Concorde e'n ronte in either case for the Palais Royal, passing which we continue along the Rue de Riroli, directing the driver to the-

\section{Halles Centrales.}

These are the great markets of Paris, and are seen to best advantage in the early morning, indeed the early riser who will force or cajole himself into arriving at the Halles at about 6 a.m. will see a sight he will never forget. The wholesale business is then transacted "à la criée," or by auction, and this is the time to see how Paris is fed! The scene is altogether more novel and interesting than that presented at Covent Garden.

By nine or ten n'clock the markets will have assumed quite another aspect-the wholesale element has disappeared, the market carts have emptied and left, the roadways have heen swept, the retail stalls have been stocked, and the markets are filled with white capped bommes or frugal housewives with the baskets and filcts, making their purchases for the day. By eleven o'clock all is over and the markets possess comparatively little interest.

The Halles Centrales consist of two divisions, each comprising six square pavilions-of the second group, four only of the six are completed. They are mainly constructed of iron and zinc, exceedingly conveniently arranged, according to the design of the architect Baltard. They are intersected by broad streets, and a boulevard runs through the centre. The rent of a stall, of 
which each pavilion contains 250 , is 20 centimes per diem. The market stands on the site of the old Marche des Innocents, the Fontaine des Innocents, which formerly stood here, having been removed to the square on the east of the Rue Lescot, in 1858 . (This fountinin, with sculptures by Jean Goujon and Pagou, is worthy of notice.) The pavilions in the Halles are devoted to the sale of meat, fish, regetables, butter, poultry, and game-in fact, to the food of the great city. The most interesting pavilion is undoubtedly the fish market. Here one sees the veritable "Mêre Angot" in all her glory, while the variety as well as the enormous quantity of fish of every description cannot fail to interest the stranger. Live fish in enormous tanks, snails in huge haskets, and any quantity of frogs ready "sliewered" for the table, ace to be seen on erery hand. The visitor will he importuned to purchase, and frequently "chaffed" if seen to he curions or amused, hut it is all in good-tempered fashion if so accepled; if not, practical jokes of an umpleasant sort are frequently played on the indignant sightseer with live specimens of the stock-in-trade. Underneath the pavement are mighty: cellars, in which heaps of edible and potable merchandise are stored. During the siege, strange and wonderful articles of consumption, including various contributions from the Jardin des Plantes and the Jardin d'Acclimalation, were displayed for sale in the Halles Centrales. This market is a very important institution in Paris.

Opposite the Ruc Baltard, which runs between the tron divisions of the Halles Centrales, at the corner of the Rue Montmartre and the Rue cle Turbigo, the visitor comes upon one of the finest and most important of the Parisian churches, and one which he must not fail to inspect. This is-

\section{The Church of St. Eustache.}

'This church, huilt on the site of an earlier one, is a sixteenthcentury edifice, the present building having heen begun in 15.3 .3 ; it was not finished until more than a century later, in I6 42 . The classic porch was added in I 788 , while those on the north and south sides helong to the sixteenth-century style. The interior, with its lofty pillats, is very handsome, and the church has an especially fme organ. The high altar of white marble, with its sculptured canopy, is also remarkable. Among the pictures are a Burial of Christ by Lucas Giordano, a Martyrdom of $\mathrm{St}$ 
Eustachius by Simon I'onct, and a Disciples' Walk to Emmaus, of the Rubens school. In the high windows of the choir and of the lady-chapel are some fine painted glass windows of the seventeenth century, after designs of Philifpe de Champaignc. Among the sculptures notice the tomh of Colbert, the great minister of Louis XIV., designed by Ccbonn, and sculptured by Coy'scrov and Tuby'. The statues, besides that of Colbert, represent Plenty and Religion, in reference to the public works of the statesman. In the fourth chapel of the choir are some curinus seventeenth-century frescoes.

The visitor proceeds along the Rue Coquillière, then turns to the right up the broad Rue du Louvre, past the-

\section{Hôtel des Postes.}

This is the General Post Office of the capital. It consists of a handsome and commodious set of buildings, the chief façade heing in the Rue Etienne-Marcel (named after the famous Provost of the merchants in the time of Charles V.). The architect was M. Jean Guader. The service had for a long time been carried on, at much inconvenience, in the baraques or wooden huts on the Place du Carrousel.

Now returning to the Rue de Rivnli we pass the Place or Square and-

\section{Tour St. Jacques.}

This handsome Gothic tower (about a hundred and serenty feet high) is the only relic of the old church of St. Facques ia Boncheric, built somewhere early in the sixteenth century and pulled down during the great revolution of 1789 . The tower is said to have been saved by the timely and clever suggestion of the guardian to the effect that it was a pity to destroy such an excellent watch tower instead of using it to survey the morements of the "enemy," meaning, of course, the Government troops. The statue under the tower is of Blarise Pascal, the philosopher, who made numerous scientific observations from the top of the edifice. Some of the witty guides tell the visitor that one of these observations proved that it was considerably casier to jump from the top to the bottom than it was to jump back again!

The garden around the tower is a favourite breathing-space and recreation-ground for the residents of the quarter. 
Proceeding along the line of the Rue de Rivoli, we next come to the Place de l'Hôtel de Ville, opposite the Ile de la Cité, on the Seine, north of the Pont d'Arcole, formerly the Place de Greve, where for centuries the public executions of Paris took place (sco Victor Hugo's Notre Dame de Paris). Here Foulard, one of the first victims of the French Revolution, was hanged, in 1789 , by the mob, whom he had exasperated by saying that the hungry" cormaille might "eat grass" ; Ravaillac, the murderer of Henri IV. ; Damiens, who, for attempting the life of Louis XV., was put to death with cruel tortures; Lally, who was dragged to execution with a gas in his mouth, lest he should exculpate himself to the people; the Comte de Montgomeri, who hy accident wounded Henri II. fatally at a tournament-were amones the hundreds who perished on the Place de Grève. Here statuds the:-

\section{Hôtel de Ville,}

the Parss Town Hall, one of the most splendid and important huildings of the capital, which has heen recently built, with alterations and enlargements to a sweater extent, on the lines of the former town-hall, hurnt by the Communards in $187 \mathrm{I}$. The present Hôtel de Ville is a grand and spacious structure in the style of the French Renaissance, with elaborately decorated Mansard windows, and handsome columns enriched with a profusion of sculpture. It contains three interior courts, of which the first, or Cour d'Honneur, is embellished with the fine bronze sroup, "Gloria Victis," hy Mcricr. Various statues, some of them from the former huildins, adorn the courts, and ten gilded figures of heralds decorate the ronf. In the small garden of the Prefect of the Seine's apartments appropriately stands thic statue of Etienne Marcel, the great "Prérnt des Marchands," or Provost of the Merchants of Paris, and champion of civic and popular rights in the fiftecnth century. The halls in the interior are well worthy of a visit, especially the Salle de St. Fean and the Sallc des Fêtes. But a special "permit" is necessary to visit the interior of the Hotel de Ville; it is therefnre rarely included in the programme of the ordinary visitor.

We now cross the seine, and in a few minutes reach the Cathedral of Notre Dame, and here, if economy is an object, the fiacre may be discharged. 


\section{Cathedral of Notre Dame.}

The Cathedral is situated at the eastern end of the lle de la Cité. The present edifice has had several predecessors, for already about A.D. 365 a cathedral church was built on the site where the towers of Notre Dame now rise ; and the first Christian cathedral was erected on the place where a temple of Jupiter had stond. Childehert, the successor of Clovis, the real founder of the Frankish kingdom in Gaul, built a second cathedral on the northern side of the Ile de la Citć, and dedicated it to St. Etienne. The two cathedrals wure united into one by the Archbishop Maurice de Sully; and in I $6_{3}$ Pope Alexander III., then staying in Paris, laid the first stone of a new cathedral, the present building, which was completed in r235, hut has undergone extensive renovations and alterations in the course of centuries. Viollet le Duc, Lassus, and Boeswillwald have completely restored the edifice since the year is +5 . It $110 \mathrm{w}$ presents one of the finest specimens in Europe of the decorated Gothic. Vinllet le Duc, like Sir Gilbert Scott in England, thoroughly understood the characteristics of the mediaral Gothic, and reproduced them most successfully in his restoration of the Parisian cathedral. A new steeple was built to replace one that had been removed at the beginning of the century, and on the 3 Ist of May, 1864, the dedication of the renovated cathedral was performed hy the Archbishop of Paris, Monseigneur Darboy.

The principal dimensions of the cathedral are: The width of the western front, 128 feet: height of the two fanking towers, 204 leet; length of the cathedral, 390 leet; width of transept, Itt feet; and height of the raulting, I $_{2} 2$ feet. The great western façade is divided into three stories, the lower one heing nccupied by three dons's, surrounded hy elaborate sculpture. Ahove the central door is depicted the Last Judgment; and the central donr is adorned by a colossal statue of Christ, the righthand door with a statue of St. Marcel, and the left-hand door with one of the Virgin Mary. In the niches above the doors are twenty-eight modern statues of kings. The statues of Adam and Eve and the central figure of the Virgin, above the niches, are by Geofficy Dechanme; the two kneeling angels by Tomsaint and Chcnillow, respectively. The towers were originally meant to support spires. Admission is given at a door in the left tower 
to those who wish to ascend the towers, which may be done by paying a small fee of 50 centimes. Viollet le Duc's steeple,

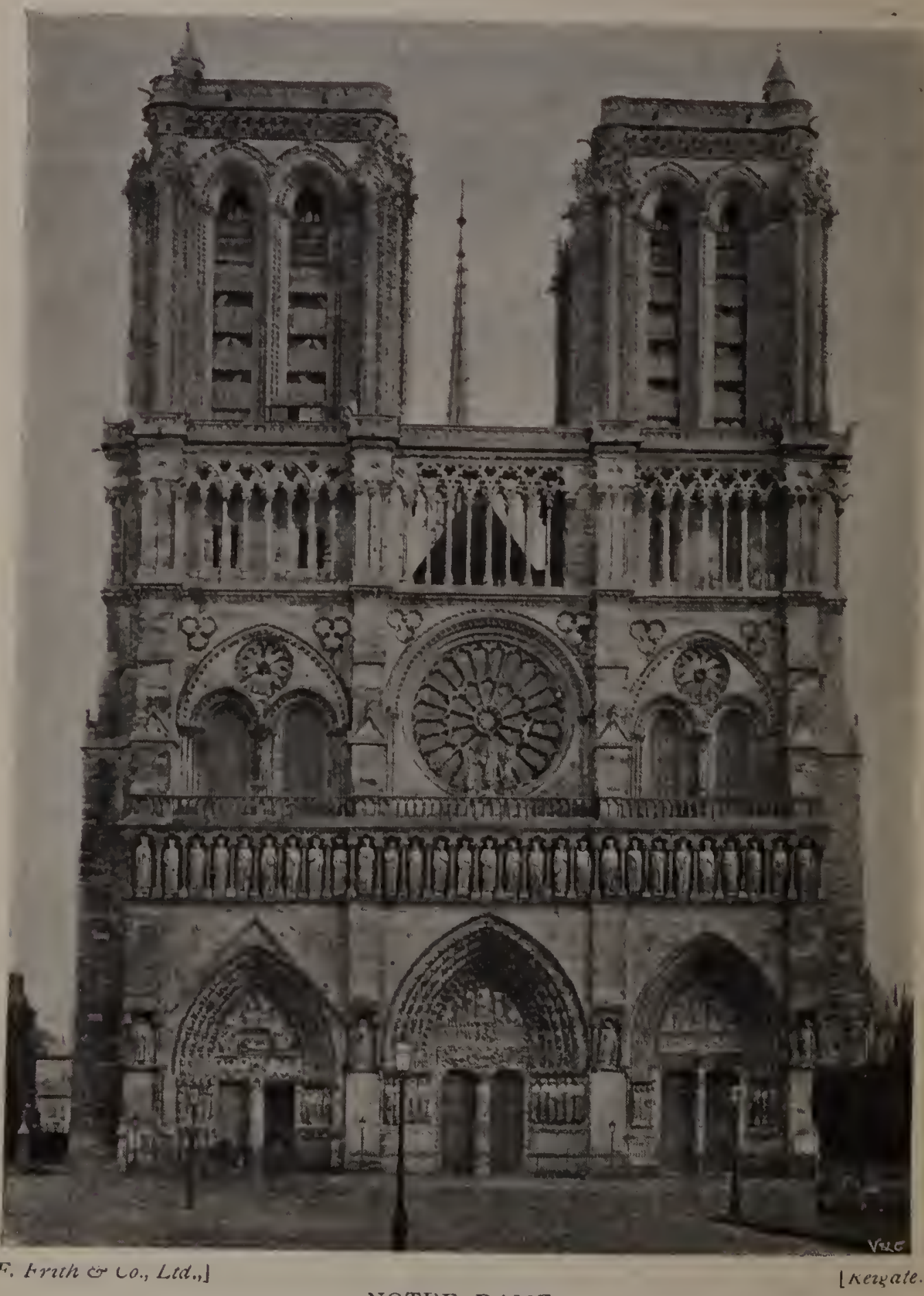

NOTRE DAME.

rising to a height of 285 feet from the ground, is worthy of special remark for its heauty and lightness. It is of timber 
corered with lead. The interior consists rif a principal nave and a double series of aisles.

Around the walls of the church are thirty-seven chapels. The pulpit is from a design of Viollet le Duc; the fine organ by Cliquot, and restored by Cavaillé-Coll, is a marked feature of the church. Especially deserving of notice are also the fine rood carvings of the choir, and the decoration of the stalls. Monuments of the Archbishops of Paris surround the choir. The first on the right is that of Monseigneur Affee, who was shot deat on the barricades in Paris, in I $\$ \&$, while trying to mediate between the insurgents and the defenders of the city, to stop the bloodshed. At the back of the choir are some frescoes of the thirteenth century restored by Maillut; tombs of the Duc d'Harcourt, the Cardinal de Belloy, the Maréchal de Guebriant, dec. The heart of Prince Talleviand, the veteran diplomatist who served su many governments, regal, republican, imperial, dc., and finished his public career at the age of eighty-one as ambassaclor of Louis Philippe to the Cuurt of St. James's, is also deposited here. He it was who called Napoleon's Russian campaign "the beginning of the end," and who, in enumerating the necessary qualifications for a diplonatist, emphasised as a sine quâ non, "Surtout, pas de zèle "- above all things, no zeal.

A graphic account of Notre Dame and its surroundings, with a picture of Paris of four centuries ago, is given in Victor Hugo's wonderful romance, Notre Dame de Paris. Looking up at the west laçade, the visitor can well realise the most powerful scene in that bouk, in which the Canon Claude Trollo and the dwarf Quasimodo play the chiei parts. The cathedral is well worthy of a deliberate visit. For a fee of 50 centimes to the custodian, the "trésor" of the cathedral may be seen any. day between the hours of ten and four. The objects exhibited comprise the "crown of thoms" brought from the Holy Land by St. Lunis; various historical sacerdotal ornaments-a piece and in nail of the true cross, one of the cervical vertebra of good Archbishop Affe, with the bullet by which he met his death while on his errand of nerey, \&c. The coronation robes of Nipoleon I., who wats crowned in Notre Dame with the Empress Juscphine, by Pope Pius VIl, in Decentiber, isof, are alsu shurvn. In leaving Notre Danle and passing round to the Ruc du Cloitric Notre: Dame, especial notice should be taken of the beautiful fying buttresses. 
On passing round behind the garden in the reall of the cathedral, between the Pont St. Lonis that unites the Ile de la Cité with the Ili St. Louis and the Pont de l'Archevéché, uniting the eatstern extremity of the Ile de la Cité to the southern shore of the Seine, is a peculiar and dismal building, which nevertheless is looked upon as one of the sights of Paris, allike by strangers and inhabitants. This building is the Morgue, the receptatcle for the corpses of persons found in the Seinc or killed in the streets of Paris, and brought here to be seen and identitied. The reminins are cxhibited on stone slibbs, behind a high sereen of plate glass, and after havings lain a certain time unclaimed, are taken away and buried, their clothes, however, being retained in case of future inquiries. It is seldom that the grisly stone couches of the Morgue are altogether untenanted, for in a great city the seamy side of humall nature will constantly assert itself, and nurder, robbery, and sucide are nowhere more rife than in this, the galyest city of the world. That strange impulse which draws men, and even women and children, to gaze on a ghastly sight, brings thousands of visitors and tourists annually to the Morguc.

Asain returning to the front of the cathedral we observe the silded spire of the Sainte Chapelle, which is but a short distance avay. We commence our visit by the Palais de Justice, through the courtyard of which we find the entrance to the church itscll.

\section{The Sainte Chapelle.}

This elcgant chuch, perhaps the most beautiful and interesting of all the ecclesiastical buildings of Paris, is situated in a courtyard of the Palais de Justice. It belongs to the thirteenth century, having been erected by Pierre de Montereatu at the order of Louis IX., or Saint Louis, the pious king who twice took part in a crusade, and died on the second of these cxpeditions at Tunis. Louis having received a holy relic from Constantinople in the shape of a piece of the true Cross, deposited it temporarily in the chapel of St. Nicholas, then occupying the site now covered by the Sainte Chapelle, which the king caused to be built that so priceless a treasure might be deposited in a shrine worthy of it. The whole huilding was completed within three years-a fact that excited the astonishment of Viollet le Duc, the great archieological architect and restorer of ancient monuments, who writes concerning the Sainte Chapelle: It can hardly be 
imayined how this work, so astonishing in the multiplicity aind variety of its cletails, the purity of its execution, and the beaty of its materials, could have been accomplished in so short a time." The steeple, which was not erected till half a century later, was destroyed by fire in 1680, and the one built under Louis XIII. to replace it was, in its turn, demolished at the time of the Great Rerolution. Under Louis XVIII., in $1 \$ 24$, the present lofty and graceful spire was completed, under the direction of Viollet le Duc, in the style of the fifteenth century. The chief points of interest in the interior of this buildingwhich, indeed, consists of two chapels one above the other-are the fifteen splendid stained-glass windows of the thirteenth century; the statues of the Apostles placed at intervals against the pillars; the private niches occupied by the king and his attendants during divine service; the grating behind which the jealous tyrant Louis XI. used to watch the proceedings; and the magnificence of the decorated pillars and walls, brilliant with gold and colour, but restored strictly in accordance with the original design. The Sainte Chapelle is open to visitors every day except Monday and Friday, from twelve till four ; but on these days also permission can be had by application to the sacristan, who lives at the left of the porch. The relics formerly exhibited here are now in the truasury of Notre Dame Cathedral.

On leaving the Sainte Chapelle, we find ourselves in the corridors of-

\section{The Palais de Justice.}

This palace correspunds with our "Law Courts," and forms an extensive pile of buildings, in the form of an irregular square, towards the western extremity of the lle de la Cité. The northern front looks on the Quai de l'Horloge, the eastern on the Boulevard du Palais, the southern on the Rue de la Sainte Chapelle and the Quai des Orfèvres, and the western front on the Place Dauphinc. It contains a number of galleries, courtyards, and halls; and the ground-plan bears some resemblance to that fanciful "gridiron" on which the Palace of the Escurial is said to have been modelled hy Philip II. The site of the Palais de Justice was occupied many centuries ago by a palace, which for a long time was the residence of the kings of France. Of this ancient palace some traces remain, 
in the Tuur de l'Horloge and the two adjacent towers, the Cuisines de St. Louis-part of the Galérie de St. Louis-and above all, in the exquisite Sainte Chapelle described further on. The palace, almost entirely rebuilt towards the close of the eighteenth century, suffered severely by the vandalism of the Communists, who in I87 I tried to burn it down; and the present building is therefore to a great extent new, having been restored in the style of its predecessor:

The principal front of the palace is that which looks upon the Boulevard du palais. This front consists of two piles of buildings, with a courtyard between them, separated from the road by a handsome railing piereed for three gates. This is the Cour du Mai, or Cour d'Honneur, at the end of which is the Galéric Marchande. On the right of the railing the building terminates in the Tour de l'Horloge, or Clock-tuver, which stands at the corner of the quay of the same name. This clocktower has been completely restored, and the great dial from which it takes its name is copied from an earlier one, the work of Germain Pilon, in the Renaissance style. The building to the left of the railing of the Cour du Mai is occupied by the offices of the Police Correctionnelle, and was, as might be expected, an especial object of the Communist vengeance in I87 I. The Police Correctionnelle also occupies the part of the south side that looks upon the Rue de la Sainte Chapelle, and within the angle thus formed is the Cour de la Sainte Chapelle. The visitor entering by the Cour du Mai, and mounting the steps to the Galéric Marchande, on turning to the right finds himself in the waiting-room or antechamber of the Civil Courts, approximately desisnated the Salle des Pas perdus (or Hall of the Lost Footsteps); and indeed many an anxious suitor has paced to and fro, losing time, patience, and health in vain pursuit of justice. In this hall notice a statue of Malesherbes the brave and eloquent defender of Louis XVI, at the king's trial, and afterwards himself one of the victims of the Reign of Terror; and another of Berryer, one of the most renowned of French advocates. The hall is double, with a long row of arches rumning down the middle. Beyond the hall, the long Galéric des Prisonniers leads to the Vestibule de Harlay, over the entrance to the Palais looking upon the Place Dauphine. At the northern end of this vestibule are the statues of Saint Louis and 


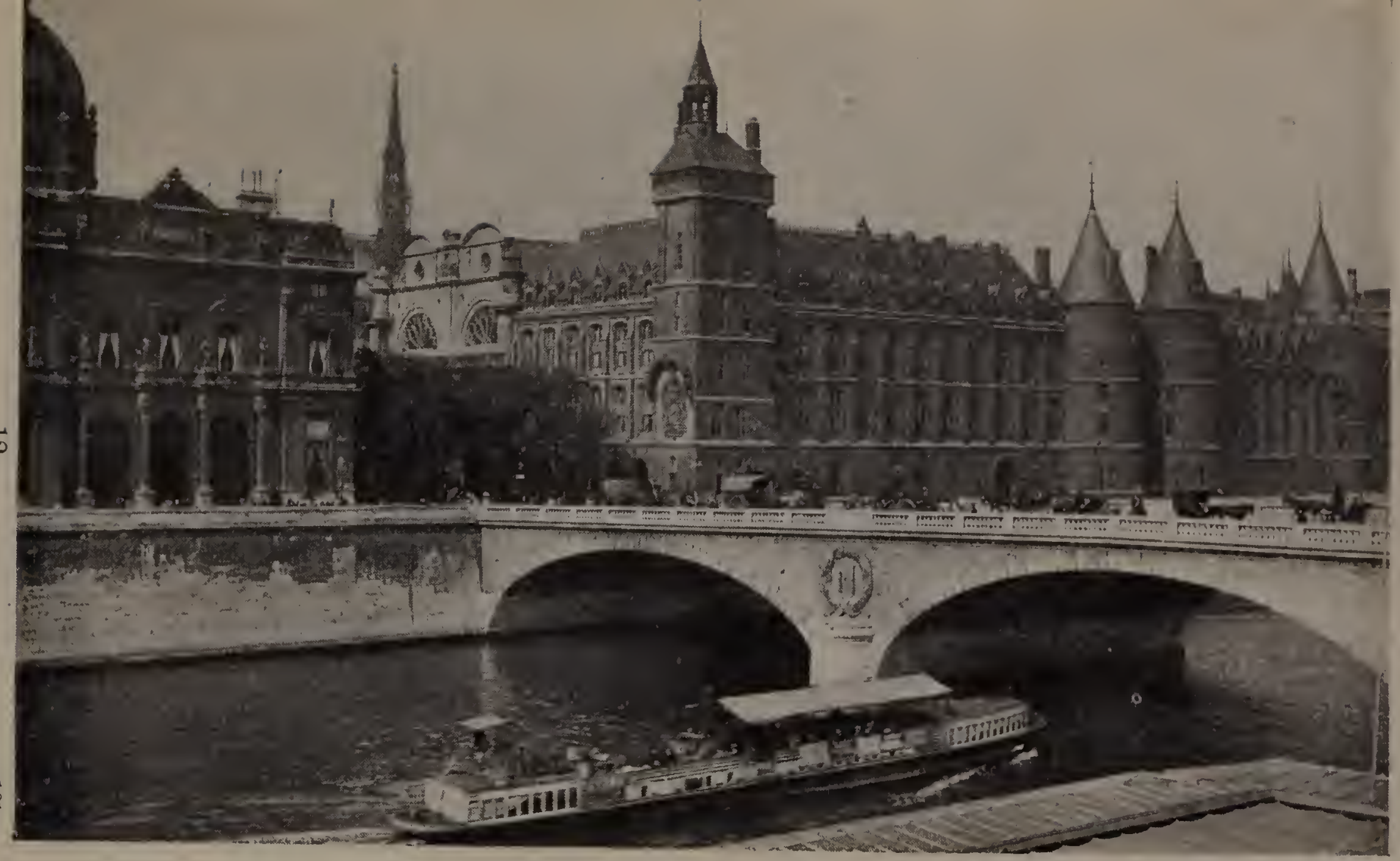

LA CONCIERGERIE.

(Talais de Justice and Ste. Chapelle.) 
Philip Augustus, and at the southern end those of Charlemagne and Napoleon I.: all four monarchs having been connected with the development and administration of the laws. Along the façade looking on the Quai de l'Horluge, between the Tour de l'Horloge and the Place Dauphine, are thee towers, remains of the ancient building, and called respectively Tour de César, Tour d'Argent, and Tour de Montgomeri.

The Hotel de Lauzan, on the Quai Conti, not far from Notre Dime, belonged to the Duc de Latuan, the fannous romi, and has recently bec'n purchased by the City of Paris from the heirs of the late Baron pichot. It is a perfect genen in its way, and is eventually to be converted into a muscum of some kind, but at present it is interesting as a typical residence of a s/rand scigncoll during the reign of Louis XIV. It was here that De Latlyatl-then the husbilld of Jal Grande Mademoiselle-Wals confined, with orders not to diace cross his threshold, but nothing damited, the prisoner went out by a passige which gate on to the river, silying that really his Majesty was most hind to have remembered his love for the water.

\section{The Conciergerie}

Was once a prison famous in the amals of the First Revolution-for here the unhappy Queen Marie Antoinette was contined, like many other prisoners of that period, for the few days preceding her execution. Lamartine, in his "Histoire des Girondins," and the elder Dumas in his "Chevalier de Maison Runge," have given graphic aceounts of the unfortunate widow of Louis XVI. and of her sufferings in this prison. The eell in which she was confined has been converted into a chapel, and is shown-as is also the adjoining cell, the prison of Robespierre -only on Thursdiy's. To view it, a permit must previously be obtained at the bureau of the Prefecture de Police opposite the Palais. The adjoining hall is also shown, in which took place the famous banquet of the Girondin prisoners, who supped there together on the night before their execution.

On leaving the Palais de Justice, we turn to the right, crossing the bridge (Pont Louis Philippe) and ascend the Boulevard St. Michel, till we come, after about five minutes' walk, to a garden on the left-hand side, enclosed by iron railings, surrounding the- 


\section{Hôtel Cluny.}

This is one of the most noterworthy buildings in Paris, and one of the most interesting museums in France. It is one of the few in which all the features of the earlier architecture have been preserved. On entering the courtyard before the old mansion, we seem to be taken three or four centuries back, into the day's of halberts and crossbows. The fine old mansion of Cluny is interesting alike for its architectural beatuty and its wonderfully varied and valuable contents. Its history is as follows: In the old Roman times there existed here a palace of the emperors, comnected with which were certain Therme or baths, of which the ruins still remain. This palace was a royal residence under the early Frankish kings, whose successors, however, transferred their abode to the Cite, and the site of the old palace, with its ruins, came into the possession, in the fourteenth century, of the Abbey of Cluny in Burgundy. The authorities of that brotherhood, in the fifteenth century, caused a house to be built by Jean de Bourbon, to serve as a residence of the abbots of Cluny during their visits to Paris, and thus arose the present Hòtel de Cluny, a handsome and wellpreserved specimen of the later Gothic style mingled with that of the Renaissance.

Various royal personages sojourned in the Hotel de Cluny, among others, Mary, the sister of Henry VIII., the spirited princess who, after marrying for the first time to please her brother (when she became wife of the old king Louis XII.), declared that she would marry for the second time to please herself, and accordingly espoused the handsome and gallant Charles Brandon-a proceeding which bluff king Hal regarded rather with approval than otherwise. Her room is still designated "Chambre de la Reine Blanche," from the widowed queen's white mourning garments. Here also was celebrated, in 1537 , the marriage of Madeleine, daughter of Francis I., with King James V. of Scotland. The Hôtel de Cluny is just south of the Boulevard St. Germain, in the space between the Rue St. Jacques and the Boulevard St. Michel, by which latter it is bounded on the west. On the north is the Boulevard St. Germain, on the east the Rue de Cluny, while on the south is the main entrance, in the Rue du Sommerard. This is named after M. dir Sommerard, an antiquarian of great intelli- 
gence and energy, who came into possession of the grand old mansion early in the reign of Louis Philippe, and there established a collection of curiosities of all kinds, connected with archeology and mediceval manufactures and arts. On his death the Government purchased the collection, which has been enlarged until it consists of I0,000 objects of art and curiosities of various linds, in painting, sculpture, carving; metal work, textile fabrics, medicval artistic furniture, porcelain, and glass.

Entering the courtyard, or Cour d'Honneur, from the Rue du Sommerard, the visitor turns to the right and cnters the hotel at the opposite corner. The collection is arranged on the ground floor and in the first storey of the building. The various objects are labelled, and a very slight knowledge of French will enable the stranger to understand the titles. The series of rooms and their contents are as follows :-

Ground floor, first room or vestibule-Finc carved wood. especially fine screen from the church of Augerolles, Puy de Dome, $5^{\text {th }}$ century; mosaic, I $5^{\text {th }}$ century; by David Ghirlandajo, the Virgin and Child; German $15^{\text {th }}$ century triptych, painted and gilt. 2nd Room-Bench from a refectory of one of the royal abbeys, with arms of France, 15 th century; stone chimneypiece, with sculptures by Hugh Lallcmant, uth century, representing Christ at the well; allegorical ligure of the forsaken Ariadne, representing Diana of Poitiers; Sleep, a marble figure, Ioth century. In the glass cases, a curious collection of shoes from various parts of the world, and of various periods. Marble group, Precentation in the Temple, I 5 th century. 3rd RoomOld s gth century fumiture, especially a sreat table from the sacristy of the Church of St. Pol de Lcon, Brittany, ${ }^{1}$ th century ; Flemish altar-piece of the I6th century; double cabinet of the time of Louis XIII., \&c. 4th Room-A fine triptych, in sculptured wood, painted and gill, German work of the I5th century; sculptured stone chimney-piece by Lallemant; Diana surprised by Actieon; cabinet inlaid with mother of pearl, gilded; Ioth century altar-pieces, \&c. 5th Room-A number of objects illustrating the Jewish religion; furniture, jewellery, fine goldsmiths' work, manuscripts, embroideries, \&c. This room contains a chimney-piece dating from the 15th century. From Room 5 the visitor enters the Corridor, in which are ecclesiastical paintings and sculpture of the 15th 
century, and a fine but mutilated bas-relief of the 13 th century. Very curious is a series of alabaster bas-reliefs, representing the life of Christ, from a French altar of the It th century; also some fine tapestry of the end of the Ithth century (reign of Henry III.). From the corridor the 6 th Room is entered. Here the chief feature is a splendid series of tapestries, continued in the next room. They belong to the beginning of the ibth century, being made in Flanders in the reign of Louis XII., and represent the story of Darid and Bathsheba. A marble group of the three Parcie or Fates attributed to Germain Pilon, and a Madonna and Child, $15^{\text {th }}$ century, are also here. In the glass cases are some superb ecclesiastical vestments of various periods, and beautiful specimens of lace. Beyond this is the 7th Room, containing the continuation of the David and Bathsheba tapestries. Twro marble medallions, from the Chateau d'Anet, attributed to Ge'main Pilon, are remarkable. They represent Catherine de Medicis as Juno, and Diana of Poitiers as Venus. Ecclesiastical vestments and embroidered fabrics in the glass cases. A gallery runs round this room and the preceding one; it is entered from the first floor. The visitor now passes into the Gallery of Carriages. This room has been built out into the garden of the hotel, and contains a highly interesting collection of sumptuous state and gala carriages of the 17 th and 18 th centuries, sedan chairs, sledges, sets of harness, \&c. From the corridor a staircase leads to the first floor, where the visitor enters the galleries over the rooms 6 and 7 , which are lighted from above. In the first of these galleries are magnificent specimens of Italian Faience, arranged systematically in cases; and in the second gallery, fine works in glass and enamel, and some valuable specimens of tapestry of the $15^{\text {th }}$ century, \&c. Three rooms, entered from the second sallery, and numbered respectively $1,2,3$, are devoted chiefly to a collection of Faience of the Italian and French schools, including some fine works of Bernard Palissy. To the right of these, in the 4th Room, is a great canopied bed of the time of Francis I., foth century, and some fine cabinets and pieces of carved furniture of the same period. The 5th Room, the next to the right, is called the salle du Sommerard, after the founder of the collection. It is especially rich in specimens of carved ivory, some specimens dating from as early as the oth century. Especially noticeable are a 
Byzantine bas-relief of the loth century, representing the marriage of the German Emperor Otho II. with Theophano, daughter of the Greek Emperor Romanus II.; a carved ivory casket from the treasure in the Abbey of St. Denis, and said to represent Louis IX. (Saint Louis) and his mother, Blanche of Castille, niece to king John of England; a picture painted on panel, French school, Isth century, representing the coronation of Louis XII, oratory of the Duchesses of Burgundy; a plaque of ivory of the 1 th century, with figures in relief, representing the life of John the Baptist, from the Chartreuse of Dijon; covered cup in enamel, from the manufactory of I imoges, representing Lot and his daughters, hy Piere Rémond, 1554; another cup, representing Moses in the desert, visited by Jethro and Vipporah; an abbot's crosier mounted on its staff, and ronamenled with fleurs-de-lys and the Montmorency arms, of massive silver, a splendid specimen of French metal work of the roth century; some large Limoges plaques, signed Pierre Courtoys, 15.59, and representing Justice, Prudence, Charity, Salurn, Jupiter, the Sum, Mars, Hercules, and Mercury. The next, the 7th Room is chiefly devoted to objects of art in gold and silver; among them are a curious collection of watches, another of spoons, forks, \&c.; also a number of ecclesiastical objects, crosses, reliquiaries, chalices, with many splendid specimens of the goldsmith's art in the Middle Ages, and before. Notice especially the ships of gilt enamel, with figures of the Emperor Charles V. and his chief courtiers; the golden antipendium of early ith century work, presented by the German Emperor Henry II. to the cathedral at Bale, a most interesting object, probably of Italian manufacture; a number of Gaulish torques, and other ormaments; Merovingian swordbelt with buckle, and sword-scabbard; and nine golden crowns of the 7 th century, found in 1858 at Fuente de Guarrazar, near Toledo, one of them being that of the Gothic King Reccesvinthus, who began to reign in A.D. 649.

Retracing his steps through the last four rooms, the visitor turns to the right out of Room 4, and comes into the Salle de la Reine Blanche, or hall of the white-robed queen (Mary, wife of Louis XII.), devoted to a collection of musical instruments. Here is also some 17 th century furniture, including a great state bed with rich 1 th century hangings. Notice also Primaticcio's. Venus and Cupid, the Venus being a portrait of 
Diana of Poitiers. This apartment leads to the Chapel, rich in Gothic ornamentation. Among the objects here, notice the large Flemish altar-piece ( $15^{\text {th }}$ century) from the abbey of Everborn, near Liège, and the altar of the chapel, around which some of the old fresco painting of Cluny may still be seen. Contiguous to the Hôtel de Cluny is the Palais des Thermes, the ruins of the old palace of the Roman and Merovingian governors of Lutetia. The entrance is through the Hotel de Cluny. The best view of the remains as a whole is obtained from the Boulevard St. Nichel side. The remains of the Tepidarium or warm-bath chamber, and of the Frigidarium or cold-bath hall, are the chief features of the Thermes. Here is to be seen a collection of Roman and early Gaulic remains, found in various parts of Paris. In the Jardin, or Square Cluny, a number of architectural fragments and relics belonging to ancient and medireval Paris have been brought together.

On leaving the Cluny, we still continue due southwards, when we reach the Luxembourg Gardens after a walk of about ten minutes.

\section{Palais du Luxembourg.}

This important palace is situated in the Rue de Vaugirard, its extensive gardens being bounded by the Rue de Luxembourg on the west, the Rue Auguste Comte on the south, and the Boulevard St. Michel and Rue de Medicis on the east. The palace was originally built, between 1615 and I620, for Marie de Medicis, the mother of Louis XIII. It was inhabited throughout successive generations by members of the royal family of France until the time of Louis XVI., whose brother, the Comte de Provence, afterwards lising Louis XVIII., was its occupant when the commencement of the Revolution induced many of the aristocracy of France to emigrate to safer shores. During the revolutionary period the government of the Convention turned this royal palace into a prison. It was made the seat of government by the Directory, and Napoleon I., as Emperor, installed the Senate there. Under the Restoration and Louis Philippe it became the House of Peers, and the Senate was again installed there hy Napolenn III.; then it became the office of the Prefecture of the Seine, and the Palais du Senat once more in 1879. It was at the magnificent fêtes given at this palace during the Consulate that Napoleon met Robespierre's sister, with whom he fell des. 
perately in love, and it is thought that had this romance not been nipped in the bud, and had she shared the Imperial throne, instead of Josephine de Beauharnais or Marie Louise, the fate of France might have heen changed. Lamartine was once lodged in this paliace, and complained bitterly of his quarters, saying that the place was large enough for his servants and a few of his scerctaries, but there was no room for him.

The smaller building contigurous to the palace, and called the Petit Luxembourg, is the official residence of the President of the Scnate. It is supposed to have been built by Marie de Medicis. The garden of the palace is as popular a lounge to the Parisians of the "rive sauche" ats that of the Tuileries is to the more fashionable inlabitants of the nortlern section. It is very prettily laticl out. The visitor should especially notice the Fontaine de Médicis, with its sculptured group of Polyphemus, Acis, and Galate:i. Equally worthy of notice is the Fontaine de Léda, with its sculpture representings the metamorphosis of Jupiter into a swan.

The Luxembourg Galleries are deroted mainly to the works of modern French artists, and a most casual inspection of these interesting galleries will occupy at least an hour. It is rarcly possible to inspect the Palace itself, as it is used for the sittings of the Senate. During the vacation, or when the Senate is not actually sitting, a special permission has to be obtained, hut a fec to the suardian will often effect the purpose.

The chief interest of the Luxembourg is connected with the great collection of paintings hy artists of the present century that occupies a wing of the palace on the furst floor. The entrance is from the Rue de Vaugirard. The pictures are arranged in a great gallery, with a hall at the further end, which latter is closed during the session of the Senate, except on Sundays and festival days, and various other rooms branching off to the right and left. On entering the building the visitor will find two new rooms lately added on the right-hand side of the Sculpture Gallery. In the salle Caillebotte special attention may be given to the following: The Moulin de la Galette, by A. Renvir; The Harbour of Ville Franche, by E. Bindcn; The Dejuener, by Claude. Monet; and the Parquet Floor Polishers, by Cuille'bottc. Opposite is the Écoles Etrangères. Notice The Mecting, by the Russian artist, Marie Bashkertseff; Mass at the Scaside, by A. Edelfolt: Grandmama's Fête, Saying Grace, by 
7. H. Lorimer; Portrait of his Mother, by F.M. Whistler; and Carmanita, by $\mathcal{F}$. Sarscut. Continuing through the Gallery of Sculptures and Bronzes, which are not very important from an artistic point of view, the visitor proceeds to the General Picture Galleries.

Room I.-No. 205, Napo!eon III. at Solferino, Mcissonier ; 179 , Releasing the Prisoners of the Inquisition, Laurells; 96, Miracles of St. Cuthbert, Dnez.

Room II.-No. 21, Job, Bomnat; 36, Blessing the Harvest, Breton; 178 , Excommunication of King Robert the Pious, Lanrens; 19, Oxen at Plough, Rosa Bonhenr.

Room III.-No. 7 , The Exiles of Tiberius, Barrias; 287 , The Death of Robert Barras, Weerts; 62, The Last Rebels, Constunt.

Room IV.-No. 3I, Youth and Love, Bongerean; 257, The Last Dar's of Corinth, Hemry'; 193, Herculaneum, Lerour. ; I84, Truth, Lifibere.

Room V.-No. 9I, The Soldier's Dream, Ditaille; IIS, All Saints' Day, Friant; 200, Paying the Reapers, Lhermitte; 92 , French Troops Marching out of Austrian Citadel of Huinge with Honours of War, August, I815, Detaille.

Room VI.-No. I85, Amende Honourable, Legros.

Room VII. is devoted to the works of Pllits de Char'anmes The greater part of these sketches are in crayon, and all are studies for the great painter's celebrated works. We particularly notice No. 3 , a Study for a Hand; 6, Ecce Homo; 7, A Flagellation ; 8, a Sitting Figure, which is a study for a Christ ; 12, Salome ; $\mathrm{I}_{5}$, Study of a Figure of a Woman carrying two pails, intended for the painting called "A Fire" ; $x 7$, the Study of a Head. The studies for the decoration of the Museum at Amiens comprise the numbers between 18 and 30 ; and then we come to $3 \mathrm{I}$, the famous work which is in the same collection, "Ludes Pro Patria." The drawings for the Hotel de Ville at Poitiers begin with No. 43, and represent studies for The Victory of Charles Martel over the Saracens in $732 ; 46$ and 47, Radegonde, after her retirement to the Convent of the Holy Cross, receives the Poets, and Protects Literature from the Barbary of the Epoch $;+8$ is in the Museum at Lyons ; 49-5o, Inter Artes Naturem-Studies for the Museum at Rouen. Now we come to the sketches and studies for the different public buildings in Paris. The Panthéon : Nos. 51 to 50 , The Childhood of St. Geneviève; 5 to 58 , St. Garmain d'Auxerre pre- 
dicting to Geneviève's Parents the Mission she is called upon to Fill; 69, The Old Age of St. Geneviève. The Provisioning of Paris. Decoration of the Hemicyle of the Sorbonne: 132 to I42. Decorations for the Hotel de Ville: I 4.3-I44, Summer; $1.53-154$, Paintings for the Grand Stairway-Victor Hugo offering his Lyre to the City of Paris ; 155 to 159 , portions of the same work. The miscellaneous sketches are not very numerous. The portraits include: I 84, M. Baudoin ; 185, M. Dezauney; I86, August Flanneng; 187 , Ary Renan; all of which were intended for a large canvas called "Puris de Chavannes and his Friends."

Room IX.-No. 272, Nero and the Poisoned Slave, Sylitstic: 135, The Conspirators, Glaize; 224, The Flas of 'Truce, Nerrilli: 3to, Inauguration of the New Opera, Ditaillt.

Room X.-No. 30, Consolation, Bunsucreall; 2.3, The late Cardinal Latvigcrie, Bonmat.

Room XI.-No. I17, Daphne and Chloe, Franculs : 126, Patrie, Berlirllil.

These are some of the principal pictures of interest, but many others are worthy of study.

The thrce Salles des Vernet also offer various paintings of great excellence, and a valuable collection of slietches, \&c. On the ground floor are several apartments devoted to sculpture.

After quitting the Luxembourg, the method of procedure must be adapted to the day and the hour as to the best course next to pursue. On a IVednesday and Saturday the Gobelins Tapestry Works are open for inspection from I 2.0 to 3.0 , and providing arrangement has been made to fit this prosramme, the best plan is on leaving the Luxembourg Galleries to take a cab direct to the Gobelins. Should this plan, however, be impracticable, the next object of interest, in oreler of proximity, would be the Panthéon. In either case it is well to take a cab by the hour. We will, however, presume that arrangement has been made to visit the Gobelins. On the way we pass the striking statue of Marshal Ney. Ney was one of the most famons of Napoleon's generals; the statue marks approximately the spot on which he was slot in 1815 .

IVe now follow the main line of Boulevards until we reach the Arenue des Gobclins, in which is situated the celebrated-

\section{Gobelins Tapestry Manufactory.}

$\because$ This celebrated tapestry manufactory takes its name from a 
medizeval family of dyers, one of whom is said to have discovered the secret of dyeing scarlet. They already had a dyeing establishment here in the reign of Francis I. Colbert, the

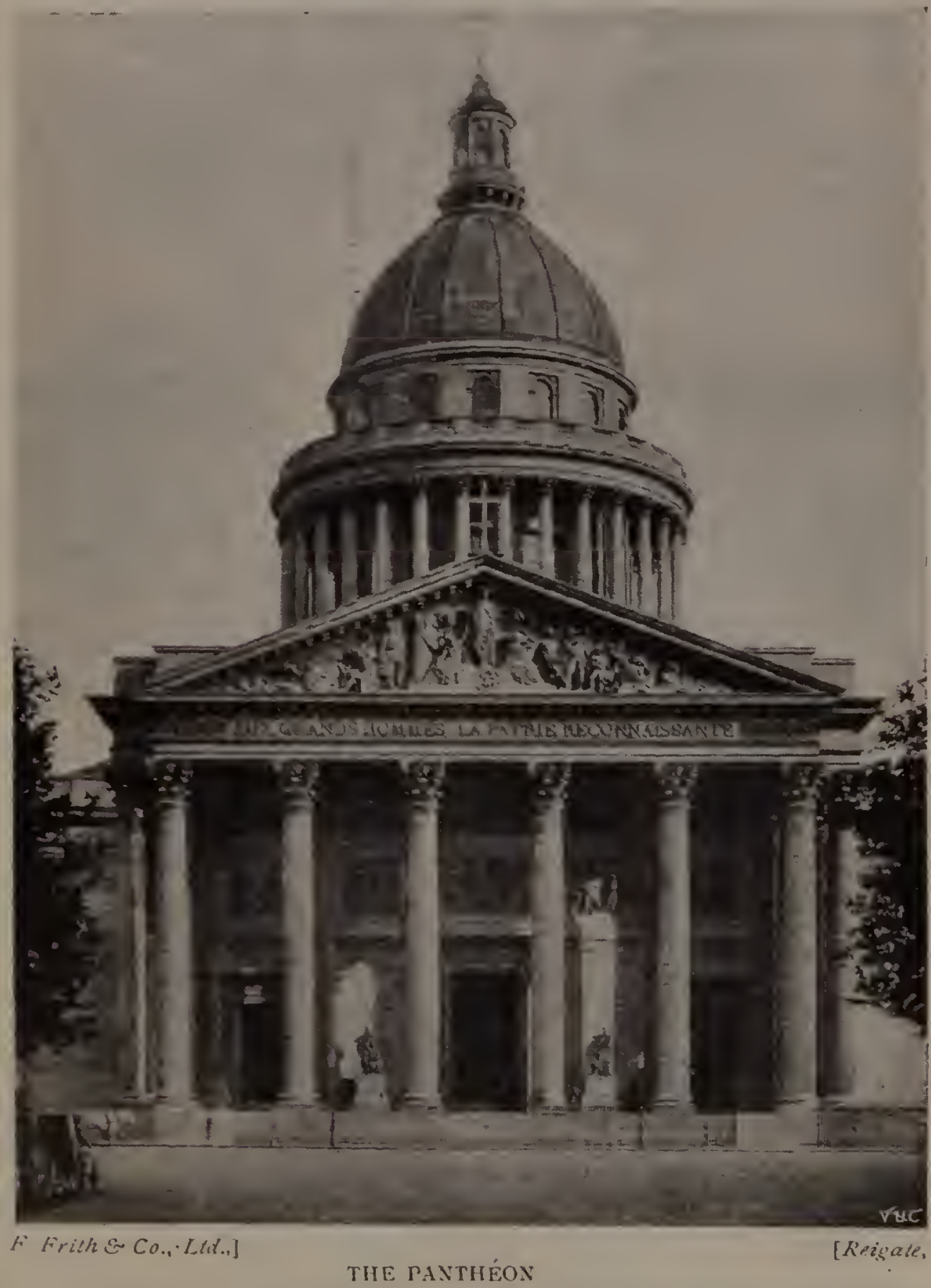

famous minister of Louis XIV., to whom the silk manufacture of Lyons was greatly indebted for its development, persuaded Louis XIV. to purchase the establishment, which thus became a state institution, and was noted far producing works of art 
unrivalled throughout the world. The Gobelins tapestries were not purchasable in the market, but specimens were presented from time to time to royal, princely, and high diplomatic personages. The beautiful specimens are arranged in several halls, and duly labelled. The Gobelins is at present greatly shorn of its glories, having been made one of the objects of the fury of the Communists in 1871 . Many valuable specimens were hurnt by the insurgents, who also fired a portion of the building. This national manufacture is still maintained at the expense of about Ero,ooo anmually to the state.

On leaving the Gobelins factory we proceed to-

\section{The Panthéon,}

siluated on the Place du Panthéon, near the Boulevard St. Nichel and llic Luxembum. This church is cledicated to the patron saint of Paris. It is of modern construction, Louis XV. having laid the foundation stone in 1704 , on the site where an ancient abbey had stood. Soufflot was the architect. Soon after the completion of the church, the Great Revolution turned the thoughts of men rather to glory than to religion. It was then cletermined that the Church of St. Gencviève should be called the Panthéon, and dedicated to preserving the memory of notable Frenchmen. Accordingly the inscription was written over the façade: "Aux grands hommes la Patric reconnaissante" -and here the tombs of many French celebrities were erected, the remains of Mirabeau, Voltaire, Rousseatu, and many others finding their final resting-place there. After the Restoration of the Bourbons, Louis XVIII. restored the Panthéon to the Church; but it became a Temple of Fame again under the July monarchy. It was restored to ecclesiastical purposes by the Emperor Napoleon III, and yet again constituted a Temple of Fame just prior to the funcral of Victor Hugo. With its lofty dome, and handsome façade adorned with Corinthian pillars, the Church of St. Genevicve is one of the most noteworthy buildings of Paris. From the gallery encircling the lantern at the summit of the dome, a glorious view of Paris and the surrounding country can be obtained. The interior contains some fune frescoes and mosaics recently executed, among which are the Batle of Tolbiac, the Baptism of Clovis, the Death and Burial of St. Ganerieve, the Coronation of the Emperor Charlemagne, \&c. The church 
also contains some fine statues. The dome may be visited at any time. A visit to the vaults is interesting, but it should be understood that a special permission has now to be obtained; and we may mention that there is no longer the once famous attraction of the magnificent echo, as the guides have been requested to desist from this somewhat theatrical method of producing effect, which has been considered a desecration to the memory of the many celebrities interred, and sacrilege to the Church itself.

Immediately behind the Panthéon is-

\section{St. Etienne-du-Mont}

(or the Church of St. Stephen of the Mount), looking on the Place Genevière, and Hanked by the Rue St. Etienne du Mont and the Rue de Clovis. This church has long been held in especial reverence as the depositary of the ashes of the patron saint of Paris, and is one of the handsomest churches in the city. Especially interesting are the curious stainedglass windows of the choir, of the sixteenth and seventeenth centuries. Notice the carred pulpit by. Lestocard; also the sixteenth-century mural paintings, the tomb of St. Generière in the second chapel on the right of the choir, the epitaphs of the poets Racine and Boileau on the same side, and various well-executed pictures, including worlis by Philippe de Champaigne, Giocomotti, Lenain, Timbal, \&c. This church was the scene of the assassination of Monseigneur Sibour, Archbishop of Paris, on the 31 d of January, 1857 , by Verger, a half-maniac priest, who stabbed the archbishop during divine service, and was afterwards tried, condemned, and executed for the crime.

We have now completed as much as can be accomplished with satisfactory results in one day's sight-seeing, always understood that the visitor is finding his own way, and not travelling under organised arrangements. We therefore, either by cab ol on foot, descend the Boulevard St. Michel, and, continuing in a direct line in a northerly direction, soon reach the Rue de Rivoli, and thus regain our hotel.

If time and inclination admit of an extention of the excursion, the following supplementary arrangement might be added :-

On reaching the Seine we take any steamer proceeding to the right, and in a few minutes land at the Quay d'Austerlitz, immediately opposite the- 


\section{Jardin des Plantes,}

at once the botanical and zoological gatrden of Paris, besides containing an ethnological and an anatomical museum, \&e., and various highly interestings and valuable mineralogical and palieontological collections.

We enter the Gardens by the Place Walhubert. Right before us is situated the botanical section, with its parallel wallis or alley's extending throughout its entire length, and planted with elms and chestnut trees.

The Botanical Garden is laid ont in rectangular beds, divided by broad alley's and well-kept paths. On entering by the gate in the Place Walhubert, the visitor hats to the right the division devoted to aquatic plants, and before him the "plantes alimentaires et industriclles" vincing along the garden, he will find the division on the right hand devoted to the Ecole Botanique, or School of Botany; a complete collection of plints duly labelled and classed.

The Zoological Garden, the most popular portion of the grounds, is reatched by turning to the right after entering the grounds by the Place Walhubert. The animals are divided into two great classes, the ferocious and the peaceable "Animaus féroces" and "Animaux paisibles"). The fierce animals have their dens immediately to the right of the entrance; the peaceable animals, antelopes, the ox tribe, \&c, have their domiciles scattered throughout the gardens. The monkey-house is somewhat to the left of the "Animax féroces"; further on are the birds of prey and the reptiles, \&c. To the left of the monkeyhouse, the "Grands Animaux," elephant, rhinoceros, de. The visitor should by no meins onnit seeing the "Cabinets d'Anatomie Comparative," behind the division occupied by the birds.

In the pleasure garden, or Partie Haute, is the "Labyrinthe," a mound carefully planted and kept, and with the ciloricttc, a pavilion, commanding an extensive view. Notice here on the hill the grand Cedar of Lebanon, to feet in circumference, brought from Syria in 1735 by Jussieu the elder.

In any case we must return to the same gate by which we entered, in order to find convenient means of transit. Wc can again take the steamer, which is, perhaps, the simplest method, or the tramway, if preferred, either of which will convey us without change to the Place de la Concorde. 
Again, supposing that the conclusion of our third day's sightseeing leaves us with a grood portion of the afternoon unoccupied, we maly, as an alternative to the Jardin des Plantes, proceed in the uppusite direction, and spend a few hours in the beautiful-

\section{Bois de Boulogne,}

which may be considered the "Richmond Park" of Paris. It occupies a large space un the west of Paris, and, in the shape of an irregular oblong, runs along the northern hall of the western part of the capital. It extends on the west to the Seine, and covers an area of more than 2,200 acres. The Bois was formerly part of an extensive forest, the Forit de Rousiray. It was considered part of the crown property until after the fall of the monarchy in 1848 . The municipality of Paris came into possession in 1852 , and turned the Bois into an extensive park, with numerous roads, alleys, ormamental waters, \&c.

A cab (ficti) may be taken by the hour, making bargain in advance as to cust. The route followed ivould be along the Quay's which border the Seine. We pass the new Gare d'Orleans, which is situated between the Pont Royale and the Pont de Solferino. It is built on the site of the former Cour des Comptes, which was destroyed by fire during the Commune, and is a very handsome building with a fine hotel adjoining. Continuing our drive, we cross the Place de la Concorde to the Champs Elysées, thence to the Avenue du Bois de Boulogne (formerly the Avenue de l'Imperatrice), where we see near the entrance, on the right, a statue of Alphand, the great architect. A little further on we sec the "hotel," or residence, rented by the French Govern. ment for the accommodation of the royal visitors to the Exhibition. This house forms the angle of the Avenue Malakoff, the Avenue du Bois de Boulogne, and the Rue de la Pompe, and stands in a large garden. It was the property of the American dentist, the late Dr. Thos. Evans, and is of historical interest, as it was here that the Empress Eugènie sought refuge after the fall of Sedan, when she fled from the Palace of the Tuileries. Now we pass the Lakes, to the Cascade and the Racecourse of Longchamps; and then taking the Avenue des Acacias (the lashionable drive from 3 to 5 p.m. in winter, and from 5 to 7 in summer) to the Jardin d'Acclimatation.

The Jardin Zoologique d'Acclimatation, situated on the west side of the Bois, is worth a visit. 


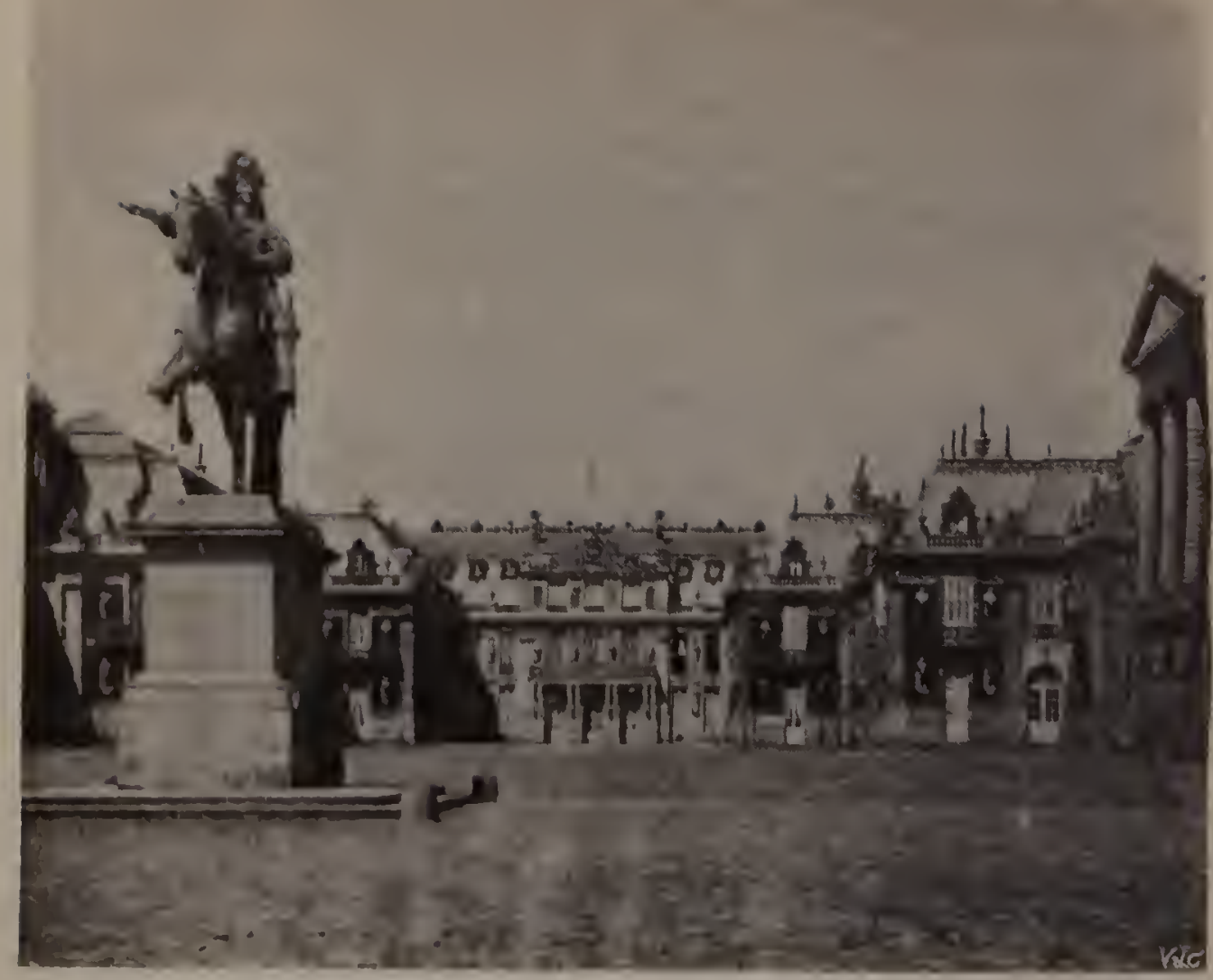

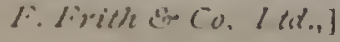

[Reigale.

STATVE OF LOEIS IN", VERSAILLES.

CHAPTER IX.

ITINERARY OF PARIS, \&C.

FOURTH DAY'S PROGRAMME.

I. Versailles.

JERSAILIES is about twelve miles south-west of Paris. The visitor has the following options in making the journey:-

Firstly : Carriage drives, organised on alternate days by the tourist firms of Gaze and Cook, the day's excursion costing Io francs, and including carriage drive through the Bois de Boulogne, St. Cloud, and Ville d'Avray, visiting the Grand Trianon and State Carriages, and, after luncheon, the Palace and galleries, returning to Paris through Sevres by about 6.0 p.m. Carriages start at Io.o a.m.

Secondly: Railway. Trains start from the Gare St. Lazare almost every hour. Visitors should remember, however, that on arrival at Versailles they are about two miles from the Trianons, and fully one mile in another direction from the Palace. Cab fares must, therefore, be considered in the cost. 
WARD \& LOCK'S PLAN OF PARIS AND ITS ENVIRONS

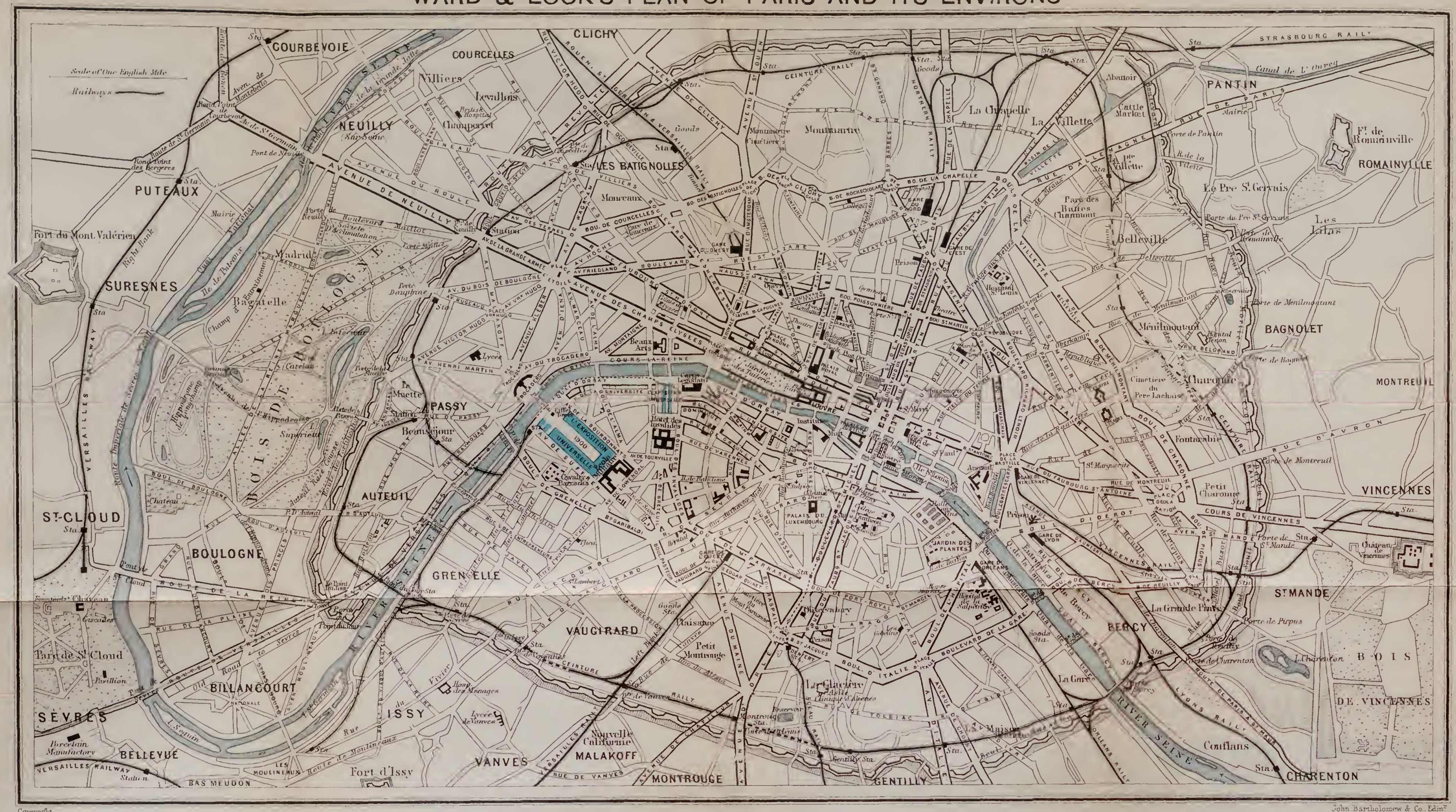

Ward, Lock, \& Co., Ltd., London 
Thirdly: Tramway. From the Place du Lourre trams run at intervals of about one hour. The trams pass by Sèvres, and put the visitor down in front of the Palace. Cabs must therefore be taken, as in the previous case, for visiting the Trianons.

The best days for visiting Versailles are on Tuesdays, Thursdays, Saturdays, and Sundays. Sunday has the disadvantage that the galleries are more crowded with French people than on any other day. On the other hand, the fountains play on the first Sunday of the month, and occasionally on other Sundays also, as per announcements to be found in the French ners papers, or on bills in the Gare St. Lazare.

In any case, on arrival at Versailles the best plan is to proceed immediately to Trianon. In the case of carriage drives, alluded to in the first paragraph, this is the plan adopted, and the visitor is conducted through the State Carriages, Trianon Palace, and thence driven back to lunch. The same method should be observed if the journey has been made by railway, except that a cab would have to be engaged by the hour, and the price should be agreed in advance. Three francs is a fair price, but the cabmen invariably try to obtain more. If the visitor has arrived by tramcar, the best plan will be to visit the palace first then lunch, and take a cab by the hour for Trianon, and back to the railway station for Paris.

Presuming, however, we adopt the most pleasant plan of driving to Versailles, the route taken is through the Place de la Concorde and up the Arenue des Champs Elysées, passing the Arc de Triomphe and then traversing the Bois de Boulogne, passing the lakes, the cascade, and the celebrated Racecourse of Longchamps, afterwards skirting the Seine till we cross the bridge of St. Cloud, and the carriage is drawn up in the square to afford an opportunity for visiting the-

\section{Parc de St. Cloud.}

This has lost much of its interest since the demolition of the ruined château, but is well worth the ten minutes' walk involved in crossing the park on foot and meeting the carriages on the further side, a plan adopted by the majority of organised excursion parties.

The panoramic view obtained over Paris from the terace is very fine. 
The site of the palace is now laid out as a flower garden, and no vestige of the building remains.

St. Cloud was a favourite residence of French royalty from the time of Louis XVI. Here Napoleon I. made himself First Consul, and here Napoleon III. and the Empress Eugènic resided continually. The chateau was occupied by the Germans in 1870 , and it secms still an open question if the fire which laid it in ruins was due to that occupation, or if it was ignited by French cannon from Fort Valerien.

The smandes calli play on alternate Sundays during the summer months from + till 5 .

The park is very extensive, and is a favourite holiday promenade and picnic siromel with Parisians.

Again taking the carriages we pass through Ville d'Array, and soon enter the Royal Park of Versailles by the Trianon gates.

\section{Grand Trianon.}

This palace is situated at the extremity of the Grand Avenue of the same name. It is a chateau or villa of the Italian style, all the rooms being on one floor. It was built in 1688 by Louis XIV. for Madame de Maintenon, who had become wearied of the pomp and immensity of the Grand Palace itself. It was occupied successively by Louis XV. and his queen, Marie Leczinslia of Poland, whose portraits are hung on the walls of the reception rooms. It was also occupied by Louis XVI and Marie Antoinette, and, later on, by Napoleon I. and Josephine, and, lastly, by Louis Philippe.

The first room is called the Salon des Glaces. Here the council of ministers was held during successive court occupations. In the centre of the room is a massive table of Malabar oak, the tablet being in one single piece. IYe now cross the Peristyle or Grand Entrance. This was used as a dining-room under Lonis XIV. It contains some fine statuary and rases, and is interesting as being the hall in which Marshal Bazaine was tried. There are also two sedan chairs used by Marie Antoincte. We next visit the deeply interesting but absolutely unpretentious apartment occupied by Napoleon I., with furniture bed, bath, writing-table, \&c. The most interesting feature of the Trianon, however, to English people is the suite of apartments prepared by Louis Philippe for the reception of Queen Victoria in 1846 . The bed hangings are of the richest Lyons sillis. Her 


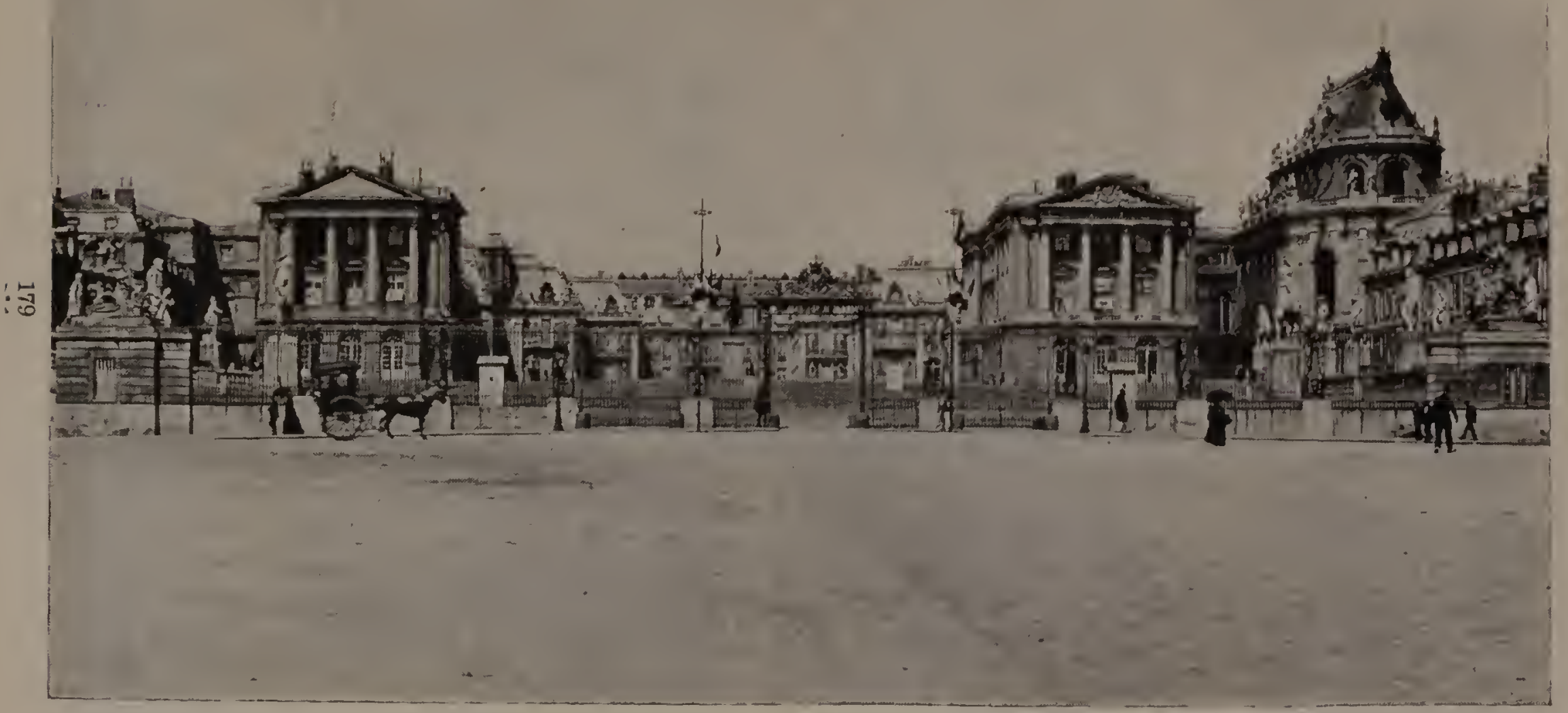


Majesty, however, did not see fit to avail herself of these rooms, despite the extravagant preparation.

The gardens behind the palace are laid out in geometrical circles, squares, and triangles of the period of Le Notre, but of course these gardens are not to be compared with those surrounding the palace itself, which will be visited later.

On leaving the Trianon (attendant expects a fee, amount optional), we simply cross the courtyard to the left, when we come to the celebrated collection of-

\section{State Carriages.}

These should certainly be visited. The principal carriages of interest are those used by Napoleon I. and III. respectively, but perhaps the chief feature is the coronation carriage of Charles $\mathrm{X}$. This is one of the most gorgeous and costly carriages in existence ; it is said to have cost from lirst to last about $\$ 40,000$, and its approximate weight is nearly seven tons. This carriage was last used for the baptism of the Prince Imperial in 1856 at the Cathedral of Notre Dame, the carriage being occupied by the emperor, the empress, the nurse, and the infant prince.

If time permits, a visit may now be made to the-

\section{Petit Trianon.}

This is a small chateau, built after the designs of the architect Gabriel for Louis XV., who presented it to Madame du Barry. It was afterwards given by Louis XVI. to Marie Antoinette, and some of the ronms are still shown with the furniture of the period, including a favourite piano of this unfortunate queen. Maric Antoinette had the gardens laid out in the English style, and built a Swiss Village, where the queen and court amused themselves by playing at farm life, making butter in the dairy and rearing poultry, the profits of the sale of produce being distributed among the poor of the neighbourhood. A theatre was also built in the grounds, where plays were performed in which the exalted personages took part.

It will now be high time to proceed for the midday meal. This can be taken in the immediate proximity of the palace. There are a number of restaurants on either side of the great square, where lunches are supplied at fixed charges. At the Hôtel de la Chasse a very good lunch may be obtained, wine 
included, for about 3 francs, providing the bargain is made in advance.

The most fashionable, though of course the most expensive resort for first-class luncheons and dinners is the Hotel des Resevoirs, which gives on to the gardens of the palace itself. Visitors must, however, be prepared to pay at least 5 or Io francs a head for the most ordinary repast, but the quality of everything supplied will be found to be excellent.

We now proceed to visit the-

\section{Palace of Versailles.}

Before entering the palace, it is a good plian to walk to the centre of the courtyard, where stands the equestrian statue of Louis XIV., and examine the exterior of the palace.

The Palace of Versailles was formerly a hunting chateau of Louis XIII. Louis XIV. was so much struck with the possibilities of its magnificent situation that he enlarged it considerably, spending fabulous sums of money upon the decorations and laying out the magnificent gardens, and it then became the court residence, instead of St. Germain, which had become rather distasteful to the king, as it overlooked the Cathedral of St. Denis, the royal burial-place, where in all probability the king himself would be interred.

Louis XV. continued the work of his celebrated ancestor, and added the theatre and chapel. Louis XVI. and Marie Antoinette made the Palace of Versailles their state residence. Napoleon I. never resided in the palace, but he spent some time at Trianon. Louis Philippe restored and redecorated the palace, at a cost of nearly a million sterling, but since the time of Louis XVI. it has never been used as a royal residence for any consecutive period, though state balls, receptions, \&c., have frequently been held in it. It is now famous as one of the grandest picture galleries of its kind in existence, the battle pictures being specially celebrated.

Exterior of the Palace. On approaching the palace by the Place d'Armes, the visitor passes two large piles of building, one on each side of the Artunc alc Paris. These were formerly the stables of Versailles, and are now converted into barracks for artillery and engineers. The great gates lead into a cour d'honneur or outer court, behind which is the Cour Royale, into which, in the old days, only the equipages 
of royal and princely personages were admitted. Behind and around the Cour Royale is the old part of the palace, erected by Louis XIII. North and south of the ccntral building are two long wings. The northern wing contains the Conr de la Chafullc, from which an entrance leads unto the gardens, the Cluapel, the Cour de la Bouche, and the Cour du Maroc, and terminates in the historical Thiatri, in which the sittings of the Senate were held until 1879 . The southern wing contains the Cour des Princes, with an entrance into the gardens, and then the long Galéric des Sculpturcs, leading to the Théatre used for the meeting of the Chamber of Deputies under the third Republic, till 1875 .

Cour de Marbre, immediately behind the statue, is so called from its marble pavement, and is interesting, as during the time of Louis XIV. the king often spent his summer evenings there, s111rounded by his court. Here, too, asscmbled the Parisian rioters and the infuriated Dames des Halles (or market women), in 1789, clamouring for the heads of Louis XVI. and his Austrian Queen, Marie Antoinette, who courageously went out on to the balcony overlooking the great courtyard, taking her little boy in her arms, hoping by this appeal to maternal sentiment to pacify the mob-unavailingly, as we know, since the king and queen left the palace as state prisoners and were shortly afterwards executed on the Place de la Concorde. Readers of Thomas Carlyle's French Rerolution will remember the vivid chapters in which, in his own incomparable manner, these tragic events are related. Here, too, King William of Prussia was proclaimed Emperor of Germany, on the memorable I 8 th of December, 1870. The three centre windows belong to the state bedroom, and from the adjoining window on the left the time at which the king would rise in the morning was announced by a huge playing card, as the king's toilet was a daily event of importance in those clays of abject servility to royalty.

At the death of each ling, one of the courtiers appeared on the balcony and breaking the staff of office in two, exclaimed, "Le roi est mort," then taking a new staff he would wave it in triumph immediately afterwards, shouting "Vive le Roi." This ceremony was retained as recently as 1824 (Louis XVIII.).

We now proceed to examine the interior of the palace. Entering by a little door on the left hand side of the marble 


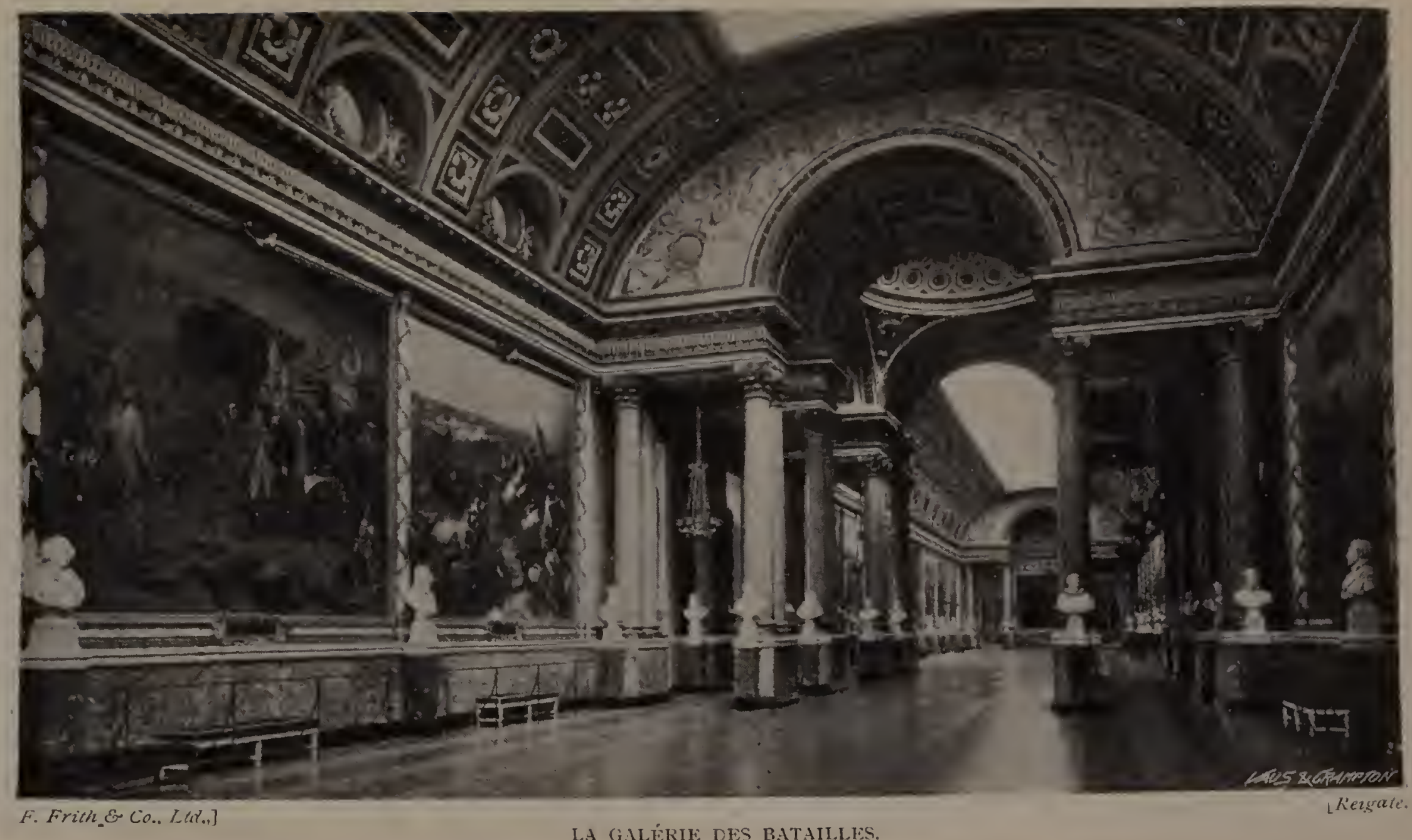


courlyard, we find ourselves in the Gallery of Fortraits. The pictures are of secondary importance from an artistic point of view, but represent the lord constables, senerals and marechals of France from the time of Louis XIV. to that of Napoleon I. Beyond this again is a room containing a series of portraits of the kings of France. The visitor whose time is limited could, however, llell dispense with a minute inspection of this portion of the palace, and mounting the srand staircase close to the entrance, conducting to the first floor picture galleries, we commence our inspection at the-

Coronation Hall, so called after the magnificent painting by Marid repressuting the coronation of Napoleon I. and the Empress Josephine at Notre Dame, in 18of. This painting is now, however, removed to the Gallery of the Louvre, and in its plice is substituted a more modern painting representing the reception of the late President Carnot at the Tuileries. Inmediately opposite is the celebrated painting by Darid representing the distribution of eagles to the National Guard by Napolcon 1. in 1Sof. The third colossal picture represcnts the battle of Aboukir.

A particular feature of this room is the statue of Napoleon $I$. standing in the ecntre of the room. This magnificent work Was scuptured by the celebrated artist $16 / a$, in 1867 , for the exposition of that ycar. It represents the Emperor during his last years at St. Helenil. The altitude and expression of the weary, disappointed despot are masnificently depicted, and the statue is well worthy of a close inspection.

Passing through the room adjoining, containing chiefty a number of portraits representing gencrals of the first Napoleon, mostly of secondary importance, we enter the celebrated-

Galérie des Batailles (or Gullery of Buttles). This is one of the linest features of the Palace of Versailles. The magnificent gallery measures nearly 400 feet in length, and is dedicated to the battle history of France from the earliest times down to the principal victories of the first empire, thus the pictures on the left as we enter are to the glory of Clovis and Charlemagne, while the unmistakible figure of Napoleon is conspicuous in the pictures on the right-hand side. Before proceeding to a minute inspection of the paintings it may be well to hall a moment at the entrance and note one or two features of historical and artistic interest. Over the arches immediately 
below the ceiling are some very striking imitation bas-reliefs: the imitation is so good that you must place yourself immediately underneath to verify that they are painted on a perfectly flat surface. It will be remembered that the Palace of Versailles was occupied by the Germans during the winter of $1870-71$, and it is interesting to note that this gallery was then used as a hospital, the pictures being carefully protected and every precaution used to assure that no damage whatever should be done. The fact that the ceiling and walls have not been regilded since speaks highly for the care exercised by the German authorities. The only visible traces of the occupation are to be found about half way up the room on the left hand side (the first picture beyond the column, representing the triumphal entry of Charles $\mathrm{V}$. into Naples). This picture has been somewhat cracked and dried by the heat of a stove placed too near it. It will be remembered that the winter of occupation was very severe.

Proceeding with our inspection we walk on the right hand side and look on the left, thus getting the pictures in their chronological order. Neither catalugue nor description is necessary, as the name and date of each picture is distinctly described at the foot of the picture, as also the name of the artist. It may be mentioned that some of the most valuable paintings from an artistic point of view are those by Horace Vernet, notably the triumphal entry of Henry V. into Paris, which is perhaps the master-piece of the gallery. A more moder'n and perhaps more striking picture is that of Napoleon at the battle of Rivoli. This is by Philipoteaux, the celebrated painter of some of the most popular modern panoramas. The incident chosen is the momcnt when Napoleon has had his horse shot under him and having mounted another, immediately proffered by one of his generals, is apparently entirely ignoring his narrow escape and concentrating his entire attention upon the progress of the battle itself.

A few pictures further on another striking episode is selected from the battle of Jéna. A young private, carried away by enthusiasm, is cheering the emperor as he passes before the ranks. Napoleon's first idea was that of insubordination. The legend runs that when the matter was explained as being simply an outburst of irrepressible loyalty, the lad was immediately promoted by the emperor. 
Retracing our steps, we again cross the Coronation Hall and proceed through the suite of rooms known as-

The Queen's Apartments. The pictures are not worthy of detailed description or study, being mostly wall decorations. The rooms are interesting, however, as having been occupied by Marie Antoinette. Passing successively the drawing-room and the bedroom, we reach the corner room of the palace serving as an ante-room to the celebrated-

Galérie des Glaces This is one of the finest rooms in Europe. The pictorial decorations are all to the glory of the "great king" (Louis XIV.). Magnificent views are obtained from the window's over the celebrated gardens, which should be visited after inspecting the palace. This was the state ballroom of the palace, and in it were held some of the most celebrated festive gatherings of French history, from the time of Louis XIV. down to the celcbrated ball given, during the Exhibition of 1878 , by Macmahon, then President of the French Republic. In this room also was held a celebration which can only have a most unpleasant association for the patriotic Frenchman : here, King William of Prussia was proclaimed Emperor William of Germany.

Leaving the ballroom by the door on the righthand side, we find ourselves in the private apartments of Louis XIV., including the ante-chamber in which the courtiers and valets used to await the rising of the king. The next room is the bedroom, which contains the state-bed on which Louis XIV. died, by the side of which is an interesting cast of his head in wax, surmounted by the veritable wig he was wearing at the time of his death. The next room contains an interesting mechanical clock, said to be the handiwork of Louis XVI., though how much he may have had to do with its construction is difficult to determine. In this room is a door leading to the private apartments of Louis $\mathrm{XV}$., which contain little of special interest. We now regain the ballroom, and proceeding to the right pass through the series of rooms linown as-

The King's Apartments, which it must be confessed are among the least interesting rooms in the palace. Turning to the left we find ourselves in the vestibule from which doors lead on to the gallery of-

The Eglise St. Louis. This was the State Church of the palace It was completed towards the end of 1710 , and is interesting on account of its profuse decorations and especially the paint- 


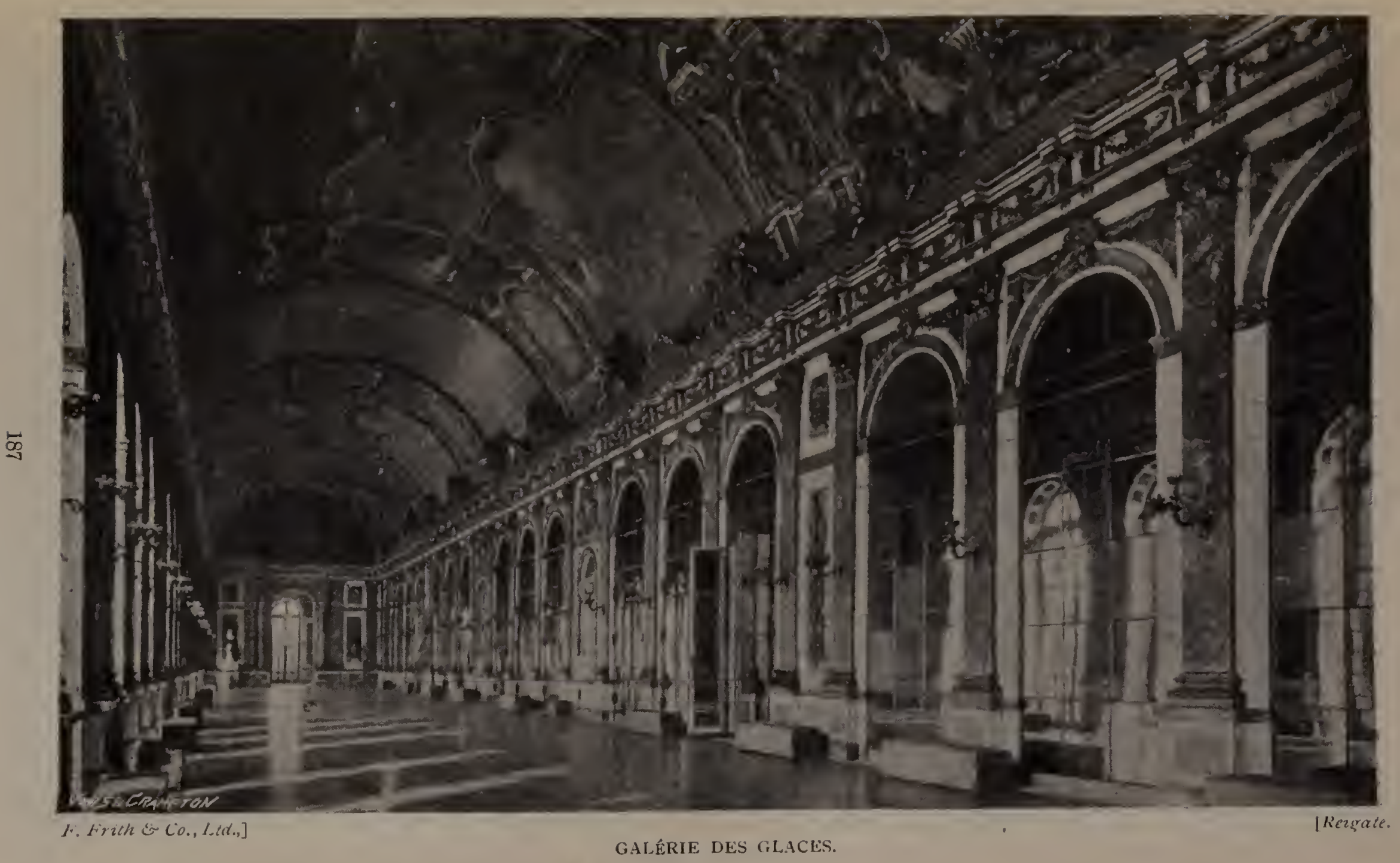


ings on the ceiling by the celebrated artist Coypel. Proceeding by the corridor we enter-

The Gallery of Constantine. These rooms contain a number of pictures connected with the more modern history of France, being chiefly incidents of the time of Louis Philippe and Napoleon 1II. The principal feature of interest in this gallery is the celebrated picture by Horact Vernet, representing the taking of Abd-El-Kader. This picture is over 70 feet in length and nearly 16 feet in height, the principal personages being portraits. This is the largest picture in the gallery, and one of the largest in Europe. On leaving this room we find ourselves close to the doors of -

The Theatre. This is not open for public inspection. It is chicfly interesting to the moderu tonrist as having been used for the sittings of the French Parliament or National Assembly from 1871 till 1875 , when the seat of government was again lransferred to Paris, though the Senate continued to sit at l'crsailles till 1879. Retuming by a series of rooms containing pictures of sceondary importance and interest connected with the early history of the First Empire, we descend by a small circular staircase by the sidc of the chapel. On reaching the sround floor we turn to the right and enter the celebrated-

Crusade Gallery, containing some of the most striking and artistic pictures in the palace. Here again catalogue or description is unnecessary, as the details are appended to the pictures, as also the names of the artists.

After the inspection of these rooms the visitor may safely be said to have seen all the principal features of interest in the Palice of Versailles, and certainly as much as can be condensed into one day's visit, in fact, unless making an inspection under organised arrangements or with a guide, it is very difficult to accomplish as much as has been described.

For the visitor's satisfaction, however, we may state that the larger portion of the second floor is devoted to portraits of celebrities and incidents of secondary interest in connection with French history. If it is intended to visit these rooms, it will be well to do so first instead of last, as they will appear absolutely uninteresting after the inspection of the first floor, which we have described.

The same remarks apply to the ground floor, except that it is devoted almost entirely to portraits of political and military 
celebrities. In a word, we have conducted the visitor through the "regular run" of the palace as it is made by the large majority of sightseers, and we are certain that by the time this itinerary has been completed he will be very glad to find himself in the open air, and ready to make an inspection of the gardens.

\section{The Park, Gardens and Fountains.}

The principal point of view is of course at the head of the stone steps at the back of the palace overlooking the grand lake. Immediately at the foot of these steps is the Fountain of Latone. The allegory represented by this fountain is the goddess transforming the Lycian peasants into frogs as punishment for their having refused her a drink of cooling water. Readers of Ovid will remember the legend. Immediately beyond the fountain is the Tapis Vert, a beautifully kept lawn about a quarter of a mile in length. Beyond this again is the magnificent Fountain of Apollo, but the one-day visitor will not have time to do more than descend the steps and turning to the right proceed to visit the Bassin de Neptune. This is the most celebrated collection of fountains in Versailles, and perhaps in Europe, though the visitor cannot form a just and fair conception of their attractions unless he is able to witness the Grand Eaux, or "Playing of the Fountains," which takes place on the first Sunday of each month, from May till September, and at occasional intervals, such as the Fête of Général Hoche, the flower show and other local fêtes. The playing of the fountains is always conspicuously announced by placards in the Saint Lazare station, as also in the newspapers; and there are always a number of excursions and special carriages and trains running to Versailles on such occasions.

We take this opportunity of giving a little general information and a few practical hints to those who may be visiting Versailles independently for this celebration.

After visiting the palace, or in any case soon after 3.30 p.m., obtain a good place on the steps overlooking the Latone Fountain. The waters commence to play at 4 o'clock, and those who make for the steps at the last moment carn sec absolutely nothing on account of the crowd at the top of the steps, through which it is impossible to pierce. From this 
point a magnificent view is obtained of the whole series of fountains, down to that of Apollo, already described, and the scene at the moment of the opening of the waters is a most magnificent sight which will not he easily forgotten. After due inspection from this vantage ground, the visitor can descend the steps, and proceeding to the left visit the remarkable Cascade de Rocailles, where a novel and striking effect is produced by the reflection of the sun on sheets of falling water. The fountain will be easily found by following the stream of visitors which invariably observes this routine. Then, under the same guidance, passing a number of fountains of secondary interest and importance the Bassin de Neptune is reached. This is not played until all the other fountains have been turned off ; so as to assure the necessary pressure for this magnificent masterpiece. The water is tnrned on at 5.30, and the fountains play for twenty minutes only. Of course it is very desirable to talie up one's position in good time, the best vantage ground being at the further side of the Amphitheatre, immediately facing the group of Neptune itself.

It may be of interest to note that the whole of the water for this display of the fountains is pumped up from Marly, a visit to the waterworks of which place is certainly most interesting, though of course impossible during the period usually allotted to a Parisian holiday. The cost of playing the fountains is estimated as nearly as possible at 10,000 francs (or $E 400$ ).

As soon as possible after the inspection of the fountains the visitor should malie his way to the station, through the gates immediately opposite the fountain, from which point the walk occupies about ten minutes, trains running at frequent intervals, and the crowding is not so great as might be expected, because a large proportion of the visitors on these fête dar's is composed of Parisians who make a complete holiday and generally remain to dine before retmrning to Paris.

In either case, our visit to the palace and grounds of Versailles may be considered as terminated at this point, and whether by train or carriage, the visitor will find that it is about time to return. Of course the Palace of Versailles is well worthy of a second visit, or the tourist may arrange to spend a night at Versailles, and thus obtain two days for the closer study and inspection of the magnificent works of art with which the palace abounds. 


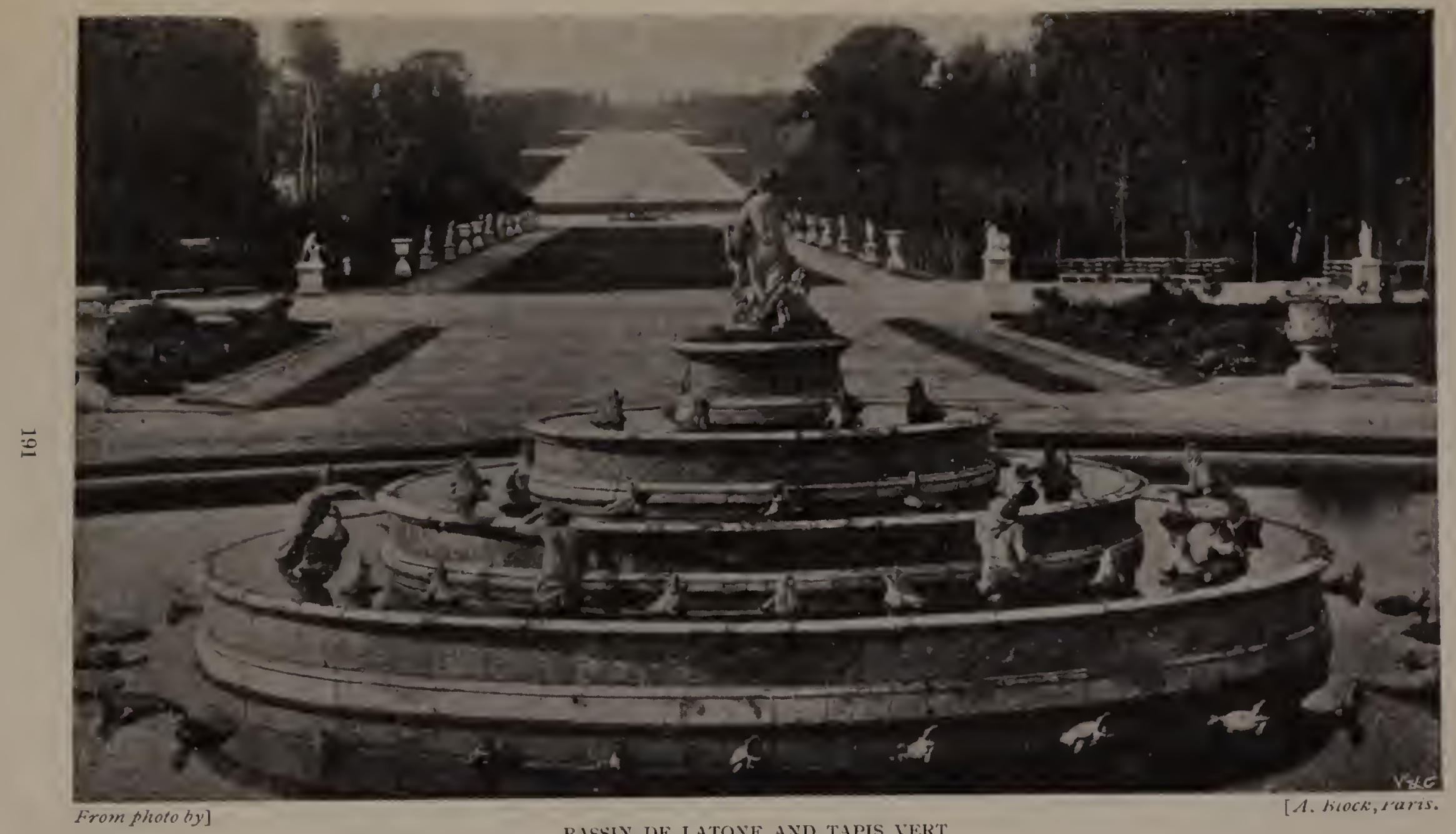

BASSIN DE LATONE AND TAPIS VER'T

(View rrom the Terrace at back of the Palace.) 


\section{SEVRES.}

An excursion to Sèves, including a visit to the world-famed Porcelain Manuiactory, should certainly be made if time permits.

The general impression that this can casily be incorporated with the Versailles excursion is a mstake. It is impossible to do justice to both in the same day. The workshops at Sèvres are closed to the public at 4 p.m. Sevres is an hour's ride from Versailles, so one must leave at 2.30 to allow only half an hour for inspection of the works. This means devoting barely one hour to the Palace of Versailles to gain half an hour only at Sirres.

The hest and most agreeable plan is to devote an aftemoon to Sivres, and proceed as follows :-

Crossing the Place de la Concorde, and descending the steps on the right hand side of the bridge, we take a steamer marked Suresnes (departures about every hall-liour-fare, 20 c.). Passing the Eiffel Tower and the Trocadero, and gliding under the magnificent "Pont du Tour," we leave Paris and soon reach Bilianconrt, after which some really fine views are obtained of the wooded heights of Mcudon, and in less than an hour Sevres is reached.

'Tramcars also run, starting from the Louvre and crossing the Place de la Concorde (same fare) ; or a cab may be hired for, say, I 5 francs, if the bargain is made in adrance, and a most enjoyable drive may be taken, passing the Bois de Boulogne and skirting the Seine and Parc of St. Cloud.

The village of Sevres (about seven thousand inhabitants) has little of interest, and does not eren possess the attraction of a good restaurant; therefore, if lunch is contemplated, the best way is to continue in steamer or tramway to the neighbouring town of st. Cloud, where good restaurants are legion, and then stroll leisurely through the magnificent park to Sères, a walk of about twenty minutes.

The chief object of the excursion is of course the-

\section{Porcelain Manufactory.}

opin duily' 12.0 till +.o.

The Museum is free at all times. The workshops may be visited on Mondays, Thursdays and Saturdays hy means of cards, obtainahle of the Secretary, Beaux Arts, 3, liue de Valois, 
Palais Roval ; but there is no difficulty whaterer in dispensing with this formality if the visitor is willing to fee the guardian at the door, who will for a franc or two easily obtain the necessary permission from the directors' office on the spot.

It should be clearly understood that the interest of Sères is purely artistic, as the production of an ordinary Staffordshire manufactory will exceed in a week the output of Sères in a year; but for artistic excellence Sèves has few, if any, rivals in the world.

The manufactory has for nearly one hundred and fifty years been a government monopoly, and the masterpices rarely, if ever, come direct into the market for sale. They are given by the government as presents to foreign courts or to crowned heads visiting France, or in commemoration of anniversaries or. other events of personal or historic interest.

The Exhibition Rooms, on ground floor, contain a magnificent show of sample productions from the colossal vase to the "eggshell" tea-cup; and many of the articles are marlied in plain figures showing the estimated value.

The Musée Céramique, on first floor, contains a number of specimens of pottery-porcelain and faïence-of all periods and from all countries, being in fact an illustrated history of the art of manulacturing and decorating porcelain.

The Workshops are somewhat disappointing, as the more interesting processes are not shown. A workman is generally deputed to turn a vase or cup in wet clay, and to illustrate or explain in outline some of the modus operandi. The furnaces are also shown, and large quantities of material in various stages of perfection may he seen on every hand.

The visit may be accomplished leisurely in an hour, and the return to Paris can be varied as already explained. Thus a visit to Sèrres forms material for a rery pleasant afternoon's excursion.

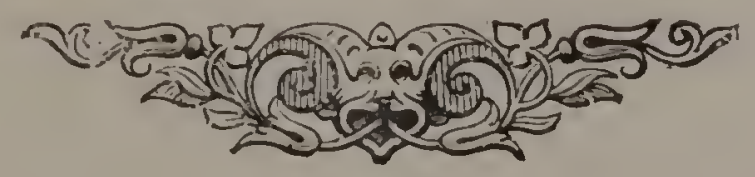




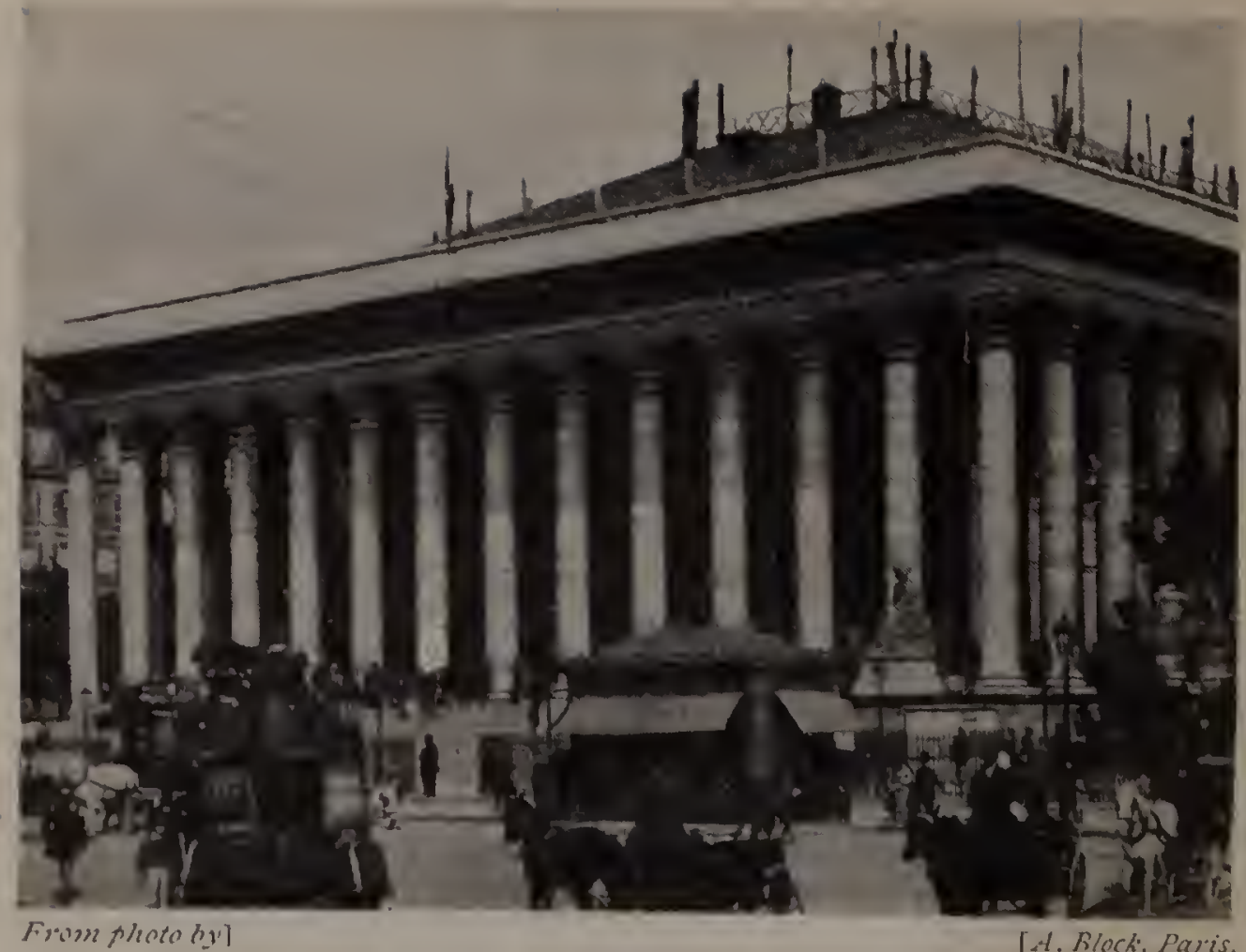

LA BOCRSE.

[A. Nlock, Paris.

(SeC Pr. 122.124.)

CHAPTER X.

ITINERARY OF PARIS, \&C.

FIFTH DAY'S PROGRAMME.

\section{I.-Fontainebleau.}

THIS is an excursion which will amply repay the visitor, and standing that if time only permits of a choice between this excursion and the visit to Versailles, the latter would naturally take the preference.

The various tourist agencies organise excursions to Fontainebleau at regular intervals during the season, Tuesdays and Saturdays being selected for fixed and regular departures. The price of the excursion is about 26 francs, including first-class rail to and from Fontainebleau, conveyance to the palace, an excellent lunch of several courses, carriage drive through the forest in the afternoon, and all fees and pourboires. 
This is a recommendable arrangement, inasmuch as the traveller is relieved of all the difficulties attending an excursion which is rather more tiresome to effect successfully than the trip to Versailles.

The journey to Fontainebleau is made by rail from the Gare de Lyon (or Lyons Railway Station). The latest train it is possible to take in order to allow sufficient time for visiting both the palace and the forest, is that which leaves at $9.40 \mathrm{a} . \mathrm{m}$.

Return Tickets : First class, 9 fr. 90 c. ; second class, 7 fr. 15 c.

The journey by express train occupies approximately about an hour and a half. On reaching the station at Fontainebleau cabs and omnibuses are in waiting to convey passengers to the Château. There is also an electric tramway, to take which visitors must first cross the railway bridge. It is best to commence the day by visiting the palace. The entrance is by the great courtyard in front of the building known as the "Cours des Adieux," being the spot where Napoleon I. bade farewell to his generals before his departure to exile in Elba, in I\&It, and is also interesting as being the spot on which he reviewed his Grenadier Guards before marching with them towards Paris.

The present building was erected in the sixteenth century by Francis I, on the site of a fortified chàteau which dated from the twelfth century. It has been a favourite hunting seat of the hings of France for the last six hundred years. Louis Philippe spent large sums of money on its restoration and embellishment. The celebrated horseshoe staircase by which we enter the palace was built hy Louis XIII., who was born here. The visit is commenced by an inspection of the Chapel of the Trinity, the ceiling of which is worthy of notice, having been painted by Frminct after the style of Michael Angelo, of whom this painter was a great admirer. The painting over the altar represents the "Descent from the Cross," and is by Fean Dubois. Louis XV. was married in this Chapel; the little King of Rome (the only child of Napoleon I.) was baptized here, as also was the third Napoleon. The last royal marriage which took place in this chapel was that of the Duke of Orléans (eldest son of Louis Philippe), who was married here in 1838 to the Princess Helena of Mecklenburg.

We now ascend the stairs to the first floor, and proceed to-

The Apartments of Napoleon I. Passing through the anteroom and bathroom we reach the "Salle d'Abdication," where 
is shown the identical table on which the cmperor signed his abdication in $181+$ before his exile to Elba; and there is also a very famous marble bust of the emperor by the celebrated Italian sculptor, Canoz'a. IVe now reach the emperor's study, which contains a portable writing-table, with movable legs, and afterwards visit the bedroom occupied by himself and Marie Louise.

We next pass through-

The Council Chamber, the furniture of which is of the period of Louis XV., and is covered throughout with Beauvais tapestry. We now enter-

The Throne Room, the principal feature of interest being the handsome chandelicr made of rock crystal. This has been valued at two thousand guineas. Next follow-

The Apartments of Marie Antoinette. The boudoir is funished in the style of Iouis XVI. The hed-chamber is one of the most magnificent rooms in the palace. Notice especially the gorgeously gilded ceiling and the superb satin hangings. These latter ivere presented to the young queen on her marriage with Louis XVI. in 1770 by the city of Lyons. The Queen's Music Room contains some splendid Sèvics porcelain vases, and also a very handsome table. We now enter the Library of the Palace. This is known as-

The Gallery of Diana, sn named after Diana of Poitiers. This apartment is $26+$ feet in length, and contains about 35,000 books. A fac-simile of the abdication of Napoleon I. is preserved here under a glass case. There is also a shirt of mail and a sword worn by the Marquis of Monaldeschi, who was put to death in this palace by order of Queen Christiania of Sweden, who was residing here in 1657. The King (Louis XIV.) was exceedingly angry with Queen Christiania on account of this murder, but strangely enough permitted her to remain in the occupation of the palace for several years afterwards.

The State Apartments follow next. The Tapestry Chamber is hung with ancient Flemish tapestry, recording scenes in the life of Psyche. Passing through the Salon of Francis I., we reach the Salon of Louis XIII., interesting as being the room in which that monarch was horn. It contains further the first mirror which was ever brought into France, having been presented by the Republic of Venice to Marie de Medici. 
Proceeding through the Hall of St. Louis (a part of the old chiteau), we reach the ancient Guard Chamber, transformed by Louis Philippe into a Dining Hall-notice the beautiful parquet floor and white marble mantelpiece. This latter is dedicated to Henry IV.

We next visit-

The Private Apartments of Madame de Maintenon. These consist of a reception room, a boudoir and bedroom. Some of the tapestry is worthy of notice, but otherwise the rooms are less interesting than those we have already traversed. It was while occupying these apartments that she persuaded Louis XIY. to revoke the Edict of Nantes in 1685.

We now enter the magnificent-

Ball Room of the palace, generally called the "Hall of Henri II." This is one of the finest rooms in Europe. It measures go feet long by 30 feet wide. It was magnificently decorated by the king after whom it is named, by the artist Prinatricio, and dedicated to Diana of Poitiers. The panelled ceiling is also worthy of notice on account of its age, as likewise owing to the fact that it is made entirely of walnut. This hall was frequently used by Napoleon III. as a banqueting room when cntertaining large hunting parties at the palace.

We now retrace our steps in order to reach-

The Gallery of François I. This is a very fine apartment, panelled with walnut, and richly decorated, chiefly with pictures commemorating incidents or allegories from the life or to the glory of François I. Passing through the vestibule, we enter-

The Apartments of the Reines Blanches, so called because they were formerly reserved for the widows of the kings of France, whose custom it was to dress in white. The principal interest of these rooms, however, is centred in the fact that they were set apart for the use of Pope Pius II., who was confined here by Napoleon I. for eighteen months, because he would not sanction the divorce of the Emperor and Josephine. The incidents of this captivity are well worth reading before paying the visit to Fontainebleau, though most of the guides and conductors taking parties through the palace make a point of narrating them, not forgetting the famous interview during which it is stated the Emperor lost his temper to such an extent as to have positively boxed the ears of the Pope, because he 
refused to sign away the Papal States of the Church. The Gobelin tapestry in the bedroom of Anne of Austria and in the principal reception rooms are valued at $f 17,000$. These apartments were occupied by Charles I. of Germany when he visited François I. of France in 1539, and also by Queen Victoria when she visited Fontainebleau, and again hy the Duke and Duclıess of Orléans, who passed their honeymoon here after their marriage in 1838 .

The Galérie d'Assiettes is the last room visited before leaving the palace. It is remarkable on account of the fanciful way in which it was decorated by order of Louis-Philippe when he restored the palace. One hundred and twenty-eight Sèvres porcelain plates are fastened in the panels of the oak walls, eacl plate being dedicated to a reproduction of one or the other of the palaces or residences of the kings of France.

The Bijou Theatre of the Palace may also be visited if time permits. It is situated on the opposite side of the courtyard. It was buill by Napoleon III., and is richly upholstered in coloured silk. It has, however, little historical interest owing to its modern construction.

We now proceed to-

The Terrace with its fountain at the back of the palace, where visitors can feed the large carp which are preserved in the lake. These fish are of enormous size, and some of them are satid to be more than a hundred years old.

This will terminate our inspection of the palace and park of Fontainebleatu, and hy this time the visitor will be reatdy for lunch. We venture to advise those to whom expense is a consideration, that it would be well to order a lunch at fixed prices, the restaurants immediately around the chateau charging exceedingly high prices when meals are taken il la cartc. The Hôtel du Cadran Bleu, a few minutes from the front of the palace (walking towards the station) furnishes an excellent lunch of several courses, wine included, for three francs, providing it is alvay's understood in advance that the meal has to be supplied at inclusive rates. After lunch a drive should be taken to the principal points of interest in the-

\section{Forest of Fontainebleau.}

This is one of the most extensive forests in France. It is about sixty-three miles in circumference, and covers over 42,000 acres. The principal features and the best points of view may 
be embraced in a drive of about two hours, a bargain being made with the coachman to finish the promenade in time to take the afternoon express for Paris, leaving shortly after four o'clock. The ordinary trip of this nature will include the Gorge of Franchard, the Pharamond (the oldest tree in the forest), the Moving Rock, and the Brigands' Cave. If returning by later train the visitor may, perhaps, go as far as the Fort of Napoleon. From this point a magnificent panorama, extending more than thirty miles, is obtained, and the Eiffel Tower may be distinctly seen in clear weather. The Gorge d'Apremont is also very interesting, but can hardly be included in the programme of the ordinary visitor. Barbizon is a picturesque little village situated in the heart of the forest, and much frequented by artists. Those intending to embrace a visit to Barbizon will do well to take the train at Melun (a station nearer Paris), always understanding that this will mean dining at Fontainebleau, as Paris cannot be reached till quite late in the evening if these distant points are visited. Presuming the visitor, however, to have talien the ordinary programme, he will easily arrive at the station in time for the 4.23 afternoon express, as already stated, reaching Paris about $5 .+0$, in ample time for the lable d'lote at the respective Paris hotels.

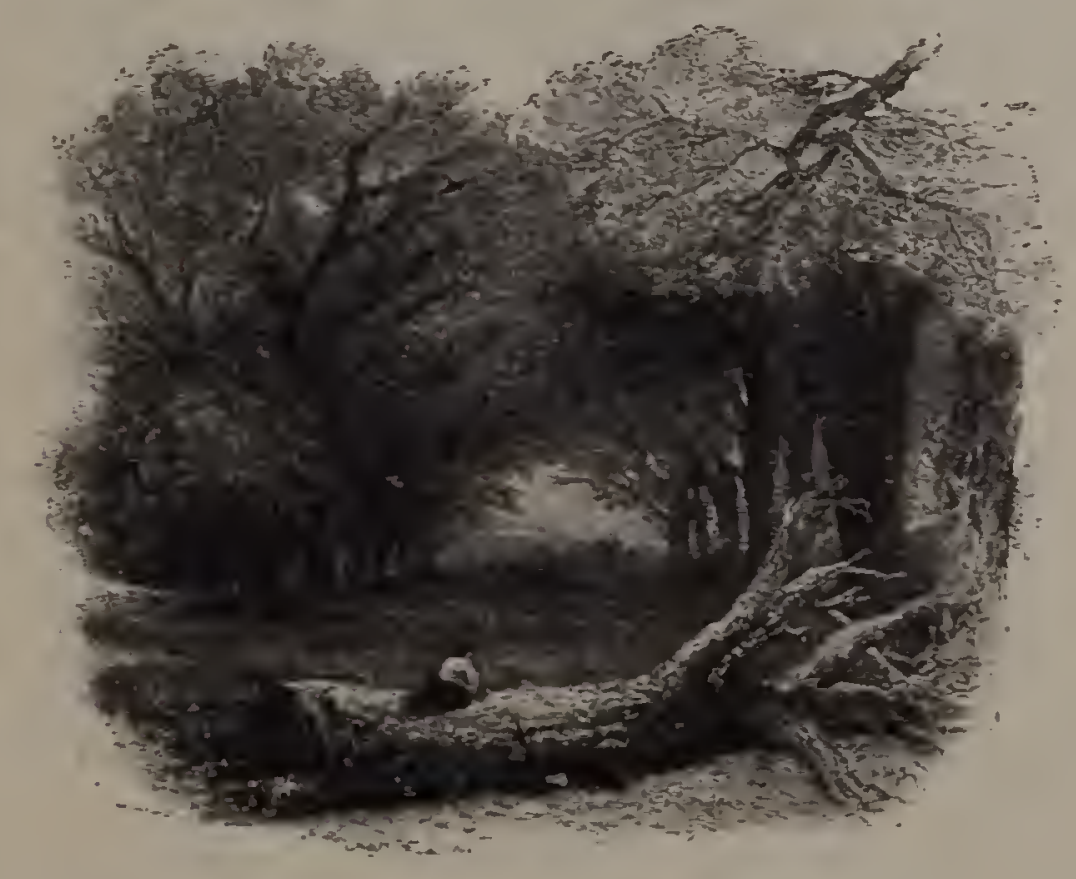




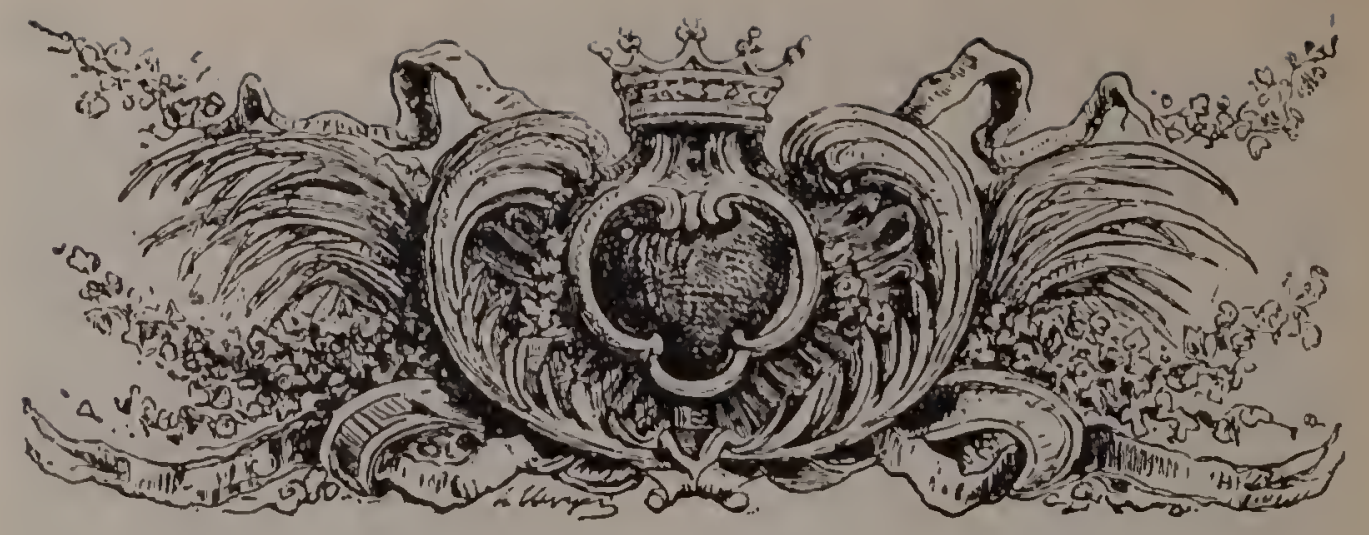

FIFTH DAY CONTINUED. (Allermatiaci)

II.-St. Germain en Laye.

A NOTHER plcasant excursion from Paris is to St. German A en Laye ( 13 miles). The attractions of the town and palace are less important than those of versailles, but the journey is well worth maling by the pleasure steamer Le Touriste, which starts daily from the Pont Royal at $10.30 \mathrm{a.m}$. Seated on the deck of the steamer, under the awning, one can enjoy the varied and picturesque scenery on each side of the river, and partake of an excellent lunch at a moderate tariff. Passing Sères, St. Cloud, Suresnes, obtaining splendid view's of the furest of Bois de Boulogne, then passing Asnicres (a favourite boating resort of the Parisians), then St. Denis (the manufacturing district), eventually Chaton and Le Pecq are reached, at which point one leaves the boat ahout two o'clock, immediately opposite the world-famed terrace of St. Germain. The early French kings had a palace here from very old times. The chapel of the original château, which still exists, was built by Louis the Pious, the son of Charlemagne, who died in 840 . Francis I. almost entirely rebuilt the old palace in a much larger and more magnificent style; and from his time it became a residence of the kings of France. Louis XIII. frequently lived there; his son Louis XIV. was born at St. Germain, and Lonis XIII. clied there, a few months after the decease of his great minister Richelieu, in $10+3$. Louis XIV. gave up this palace as a residence in favour of Versailles, and made a present of it to Madame de Montespan, 
the successor in his affections to Mdlle. de la Valière. When James II. of England was driven from his throne in I688, Louis XIV., welcoming the exile with royal hospitality to France, gave him St. Germain for a residence; and there, after twelve years, the last of the English Stuart kings died in 1701. St. Germain wals neglected under Louis $\mathrm{XV}$. and Louis $\mathrm{XVI}$., and was turned into a military school by Napoleon I. It afterwards became a military prison, but has of late years been restored in the style of its original period. We visit the palace, now transformed into at Museum of Armoury, and then stroll on to the terrace, from which is obtained an extensive and magnificent panorama over the valley of the Seine, including the distant city of Paris. Behind the town is the beautiful-

\section{Forest of St. Germain,}

consisting of about II,000 acres entirely walled in. The roads through this forest, and notably the magnificent "Route des Loges," are very popular with cyclists. They are straight, level, beautifully kept, besides being exceedingly picturesque. Two fairs are held annually at St. Germain. The Fîte des Logess, held in the forest during the month of August, is one of the most important of the autumnal attractions to Parisians. The steamer leaves again for Paris at four o'clock, but the return journey being against the stream Paris is not reached until nearly 9.0 p.m. We advise the tourist to return by rail. The station is situated immediately behind the palace, and the journey occupies about forty minutes. Trains run at frequent intervals, but it will be well to fix the time of return by a consultation of the time-table before leaving Paris in the moming. The fare by tourist steamer is 3 francs for single journey (or + francs 50 centimes both ways); the raikway journey, single fare, first-class, I franc so centimes; second-class, I franc 20 centimes. We venture to suggest that the tourist should not make the visit to St. Germain unless he has previously visited Versailles and Fontainebleau, both of which are infinitely more interesting and attractive. 


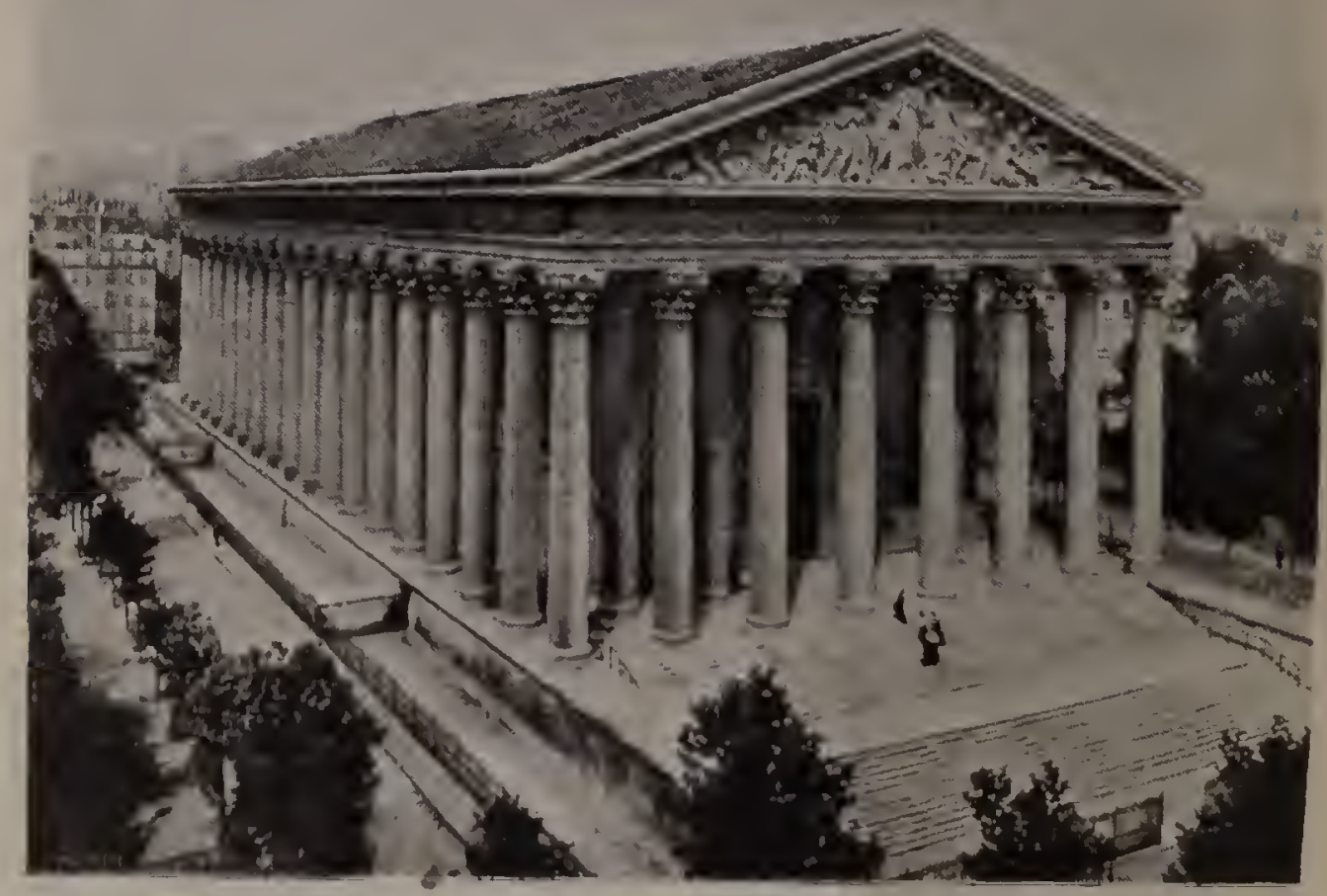

L.) MABLI:LIXF.

\section{CHAI'TER। Y' \\ SUNDAY IN PARIS.}

Mormus scrices-Aflemoon flasures-Enslish Churdes and Chapels-Hiuls lo Worshippers-Musical Scrvices-Eurcursions aud Anulsciuculs.

A $\mathrm{S}$ the stay will include at least one Sunday in Paris, we A propose to devote a chapter to showing how the day may be most advantageously employed.

In undertaking this somewhat delicate task we must premise that in Paris, as indeed in all Catholic countries, Sunday is considered the day of enjoyment and recreation. Of course at home there are many who hold the same views, but the vast majority of English people are accustomed to consider the Sunday absolutely as the "clay of rest." It is outside the province of a guide-book to discuss religious opinions, or to compare the relative sanctity of other mationalities with our 
ow'n, but we cannot refrain from pointing out that the wholesale condemnation indulged in by English visitors against the "giddy, godless Parisians" is to a large extent based upon superficial examination, ignorance of the requirements of the Catholic religion, and some insular prejudice.

From six o'clock in the morning, and even earlier, all the principal churches of the city are open, and what is more, are crowded with devout worshippers. The servants attend the earliest mass, commercial middle class follow later, the upper classes and tourists generally attending the later service, or High Mass with music, which in the majority of churches takes place at eleven o'clock. By about midday religious services are over, and the thousands of devout worshippers of the moning will be found in the "Bois," the forest and the country in the afternoon, and rational recreation and enjoyment become the order of the day.

Now the writer's personal experience of over twenty-five years' residence in the French capital shows that the majority of English people abroad elect a middle course in disposing of a Parisian Sunday, and for these we shall especially frame the present chapter. But in order that all may be provided for, we lave been careful to include the fullest possible information concerning churches-Protestant and Catholic-and also the amusements both in and out doors.

The middle course to which we allucle means a visit to one of the Catholic churches, so timed as to hear some of the magnificent music for which Paris is so justly celebrated ; then attendance at one of the English churches during the morning; in the afternoon a quiet drive in the Bois de Boulogne, and in the evening a stroll on the Champs Elysées or on the Boulevards to conclude the day.

To those who are absolutely "on pleasure bent," we may premise that the great majority of Galleries, Museums, \&c., described in this guide are open on Sundays, with little exception, from 10.0 a.m. to $4.0 \mathrm{p.m}$. Besides these, any temporary exhibition of interest, such as the Salon, the Exposition de Travail, \&c., are visited by thousands of Parisians of the middle and lower class, who could never find any other time than Sunday afternoons.

The Theatres and Music Halls have afternoon performances on Sundays (for details the visitor must consult the newspaper 
of the day); but granted fine weather, it is out of doors we find the vast majority of Parisians on the Sunday. Whole families may be seen trotting off to the "Bois," or further afield to the country with their picnic baskets.

liaces take place in the Bois de Boulogne erery Sunday afternoon during the spring, concluding with the celebrated "Grand Prix," which takes place on the second Sunday in June. The autumn season commences about September ijth.

Cycling races take place almost every Sunday in the spacious Velodrome de la Seinc at Clichy-Levallois, or the Parc des Princes at Autenil, and as some of the money prizes are for considerable sums the attendance is generally very large.

The fountains at Versailles play on the first Sunday of each month, and on special additional occasions during the summer months, the dates being announced by placards about the strects, and notably at the Saint Lazare station, whence special trains are always run at frequent intervals for these occasions.

The locil fites form a great feature in Parisian Sunday amusements. These fîtes are held in the surrounding villages during the season. It is impossible to give concise information in this matter, as of course the dates are not fixed. The best plan is to consult any of the daily Parisian newspapers, or inquire of the porter of your hotel. The two most notable fites, however, are-

The Fête des Loges at St. Cermain. This takes place on the first Sunday after the 3oth of August, and lasts for some nine day's. As this ficte is held in the grand forest behind the park of St. Germain, it forms a most attractive and enjoyable manner of passing an afternoon.

The Fête de st. Cloud. This lakes place during August, and lasts throughout the month. Each Sunday the fountains play, and there are the usual attractions of the country fair as understood by us at home, though of course with a variety of continental innovations.

There are also the similar fairs of Neuilly (during July), and the "Foire au Pain d'Epice" at Vincennes during the month of June.

Of course this is but a cursory idea of suburban attractions. $I^{\top}$ e may mention Robinson, with its celebrated "Tree Restaurant," popular on account of the novelty of dining among the branches of a capacious tree; Bougival, where bathing and 
hoating is added to the general list of attractions; Nanterre, where the crowning of the Rosière takes place on Whit Sunday; but we think the ordinary tourist will decicle that these amusernents are altogether too Parisian for English tastes, and prefer a quiet drive in the Bois de Boulogne during the period of the popular drive, namely, from 3.0 until 6.0 p.m.

We now subjoin a more concise list of churches and distractions for the visitor's use, dividing Sunday into three sections, namely :-

I. The English churches and chapels in Paris.

2. The Catholic cathedrals and churches.

3. Galleries and sights open to the public.

\section{English Churches and Chapels.}

EPISCOPAL.-English Church. 5, Rue d'Aguesseau, Fauhourg St. Honore-close to the British Embassy, and near the Madeleine. This is the English Church of Paris. Services: $8.30,10.30,3.30$, and 8.0.

Christ Church. Boulevard Beneiu Neuilly (trams from Madeleine). Services : 10.30 and 4.0.

Victoria Jubilee Church (St. George's), Rue AugusteVacquerie, Avenue de Jena (not far from Arc de Triomphe). Services : 8.30, 11.0, 3.0, and 8.0.

AMERICAN.-Holy Trinity. Avenue de l'Alma (trams from Place de la Concorde pass close by-descend Place d'Alma). Services: 8.30 , I I.0, and 4.o.

St. Luke's. Rue de la Gde. Chaumière (near the Boulevard Montparnasse). Services : 9.30 and 8.o.

American Chapel. 2I, Rue de Berri (near the top of Avenue Champs Elysées, right-hand side). Service : Ir.o ; Bible Class, 3.0. No evening service.

CHAPELS.-Wesleyan Methodist. 4, Rue Roquèpine (near the Madeleine and close to Eglise St. Augustin). Services: 10.30 and 8.0 (also Wednesdays, 8.0 p.m.).

Congregational. 23, Rue Royale. Morning Service only, at 10.30 .

First Baptist Church. 72, Rue de Sèvres (near the Bon Marché). Service at 2.0.

Scotch Presbyterian Church. I7, Rue Bayard, Champs Elysées. Services : 11.0 and 3.0.

Mcall Missions. There are many of these scattered over 
Pinis, the principal heing 23 , Rue Royale (close to the Madeleinc). Services: 4.30 and 8.0.

Young Men's Christian Association. 160, Rue Montmartre. Always open for young men.

\section{Catholic Cathedrals and Churches.}

Descriptions of the churches from an historical and architectural point of view are given in their respective places in the various itineraries outlined for the sightseer in the foregoing chapters; we have now simply to deal with the various services and musical attractions of the principal churches. As already stated, Low Mass commences from the very earliest hour on Sunday morning at all the Catholic churches. This, houvever, will hardly attract the sightseer, unless, heing himseli it Catholic, le wishes to altend Mass.

Visitors may take any moccupied seat to witness High Mass. We venture, however, to suggest that it is unvise and indelicate for Protestant sightseers to go too near the altar. Being unable to follow the Mass, their movements indicate only too clearly the object of their visit, and must be irritating to those whose object is worship; nor should seats be taken at all if the visitor intends leaving during the performance of Mass. The writer has often noticed, with feelings of sincere regret, the manner in which sightseers circulate in Paris churches during service, with little or no consideration for devout worshippers. It is perfectly true that a great deal more licence is tolerated in continental churches for coming and going than is usual at home, but ive have seen a group of sightseers rise from their seats and prepare to leave (thereby turning their backs to the altar), just at the solemn inoment when the little bell announces the raising of the Host and every knee is bent, while a most solemn and impressive silence prevails throughout the church.

We shall be excused for these straightforward remarks, and cannot do better than offer this practical suggestion to those who are unwilling to remain cluring the whole of the service - either remain standing outside the railings (whence you can leave without causing a disturbance at any time), or else take seats just inside the railings, and let your movements be guided entirely by imitation of those around you. 
During the service two collections are generally made, one being for the church expenses (Frais de l'Eglisc). This is often taken up by an official connected with the church, who is always accompanied by the beadle with his cocked hat and mace. The other is for the fee payable for the seats or chairs you may occupy; this varies according to the church, but as

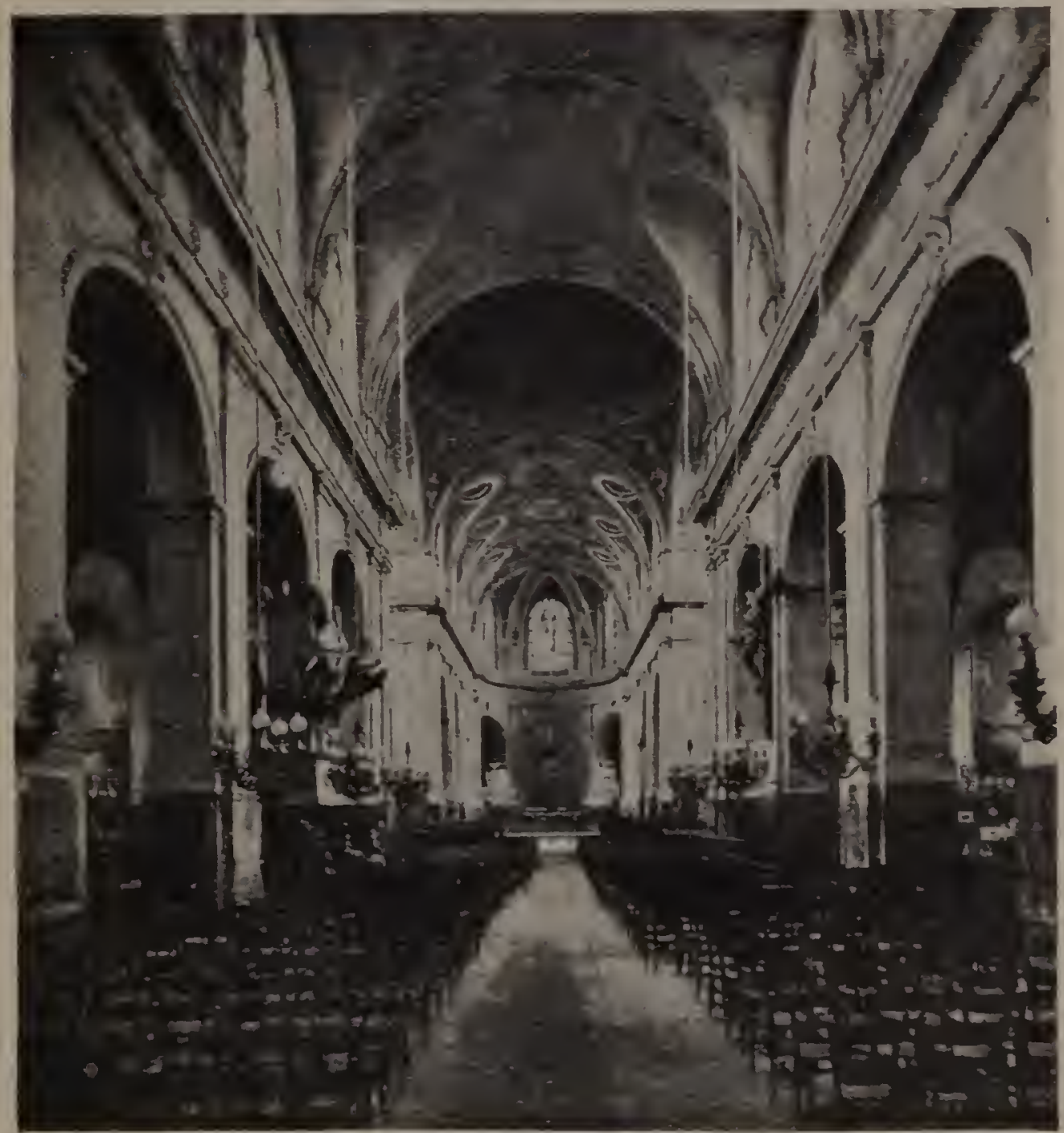

) अ.

[Nothmg Hill.

INTERIOR OF ST. ROCH.

a rule the charge is three sous, or I $_{5}$ centimes, and it is well to have the necessary coppers ready, so as to avoid unnecessary explanation and conversation when payment is requested. These observations apply to any church which the sightseer may elect to visit during service on Sunday or in the week. 
The following are the principal-

\section{Musical Services.}

Notre Dame. High Mass 10.30 a.m. Service in this cathedral under any circumstances must necessarily be very imposing, owing to the granderr of the surroundings, but it is only fair to confess that the music at Notre Dame is far inferior to that which will be heard at the majority of the churches in the more fashiomable quarters of the City ; for it must be remembered that Notre Dame is situated on the Ile de la Cite, where there are very few residents, the island being almost entirely corered by Government buildings, Law Courts, \&c. The molinary cathedral services are gencrally but poorly attended, onc might almost say not attcuded al all except by the sightsece from the provineces or abroad.

St. Roch, siluated in the Rue St. Honore, near the bonve, hats onc of the finest musical services in Paris, beings me of the richest churches. High Mass commences at 1 I.o, but it is necessary to arrive in good time to obtain seats.

La Madeleine. High Mass with music commences at 11.0 a.m. This is one of the most imposing services in Paris, and as it clashes in point of time with St. Roch we venture to suggest that the visitor will do hetter to choose the Madeleine, unless le is passing more than one Sunday, in which case he can attend both, if so inclined. On special occasions, notably the Fite Dicu in June, the exterior of the building is handsomely draped with red cloth and gold decorations, an altar is erected at the back of the church, and a procession, headed by military music, threads its way around the corridors, under the magnificent Corinthian columns, the effect being most impressive. bxcepting on these special occasions no processions take place at the Madeleine.

St. Eustache (near the Central Markets). This church has a very fine musical service, which commences with extraordinary precision as the chimes are ringing out the hour of Io.o a.m. The interesting feature consists in the procession, which starts from the high altar and makes the tour of the cathedral, the organ meanwhile pealing out its magnificent tones. It is a notable instrument, being one of the finestand largest in the city.

st. Sulpice (near the Luxembourg), has also a fine service but is somewhat out of the way for those who wish to 


\section{C.ATHOLIC CHLRCHES.}

During the service two collections are generally made, one being for the church expenses (Frais de l'Eglisc). This is often taken up by an official connected with the church, who is always accompanied by the beadle with his cocked hat and mace. The other is for the fee payable for the seats or chairs you may occupy; this varies according to the church, but as

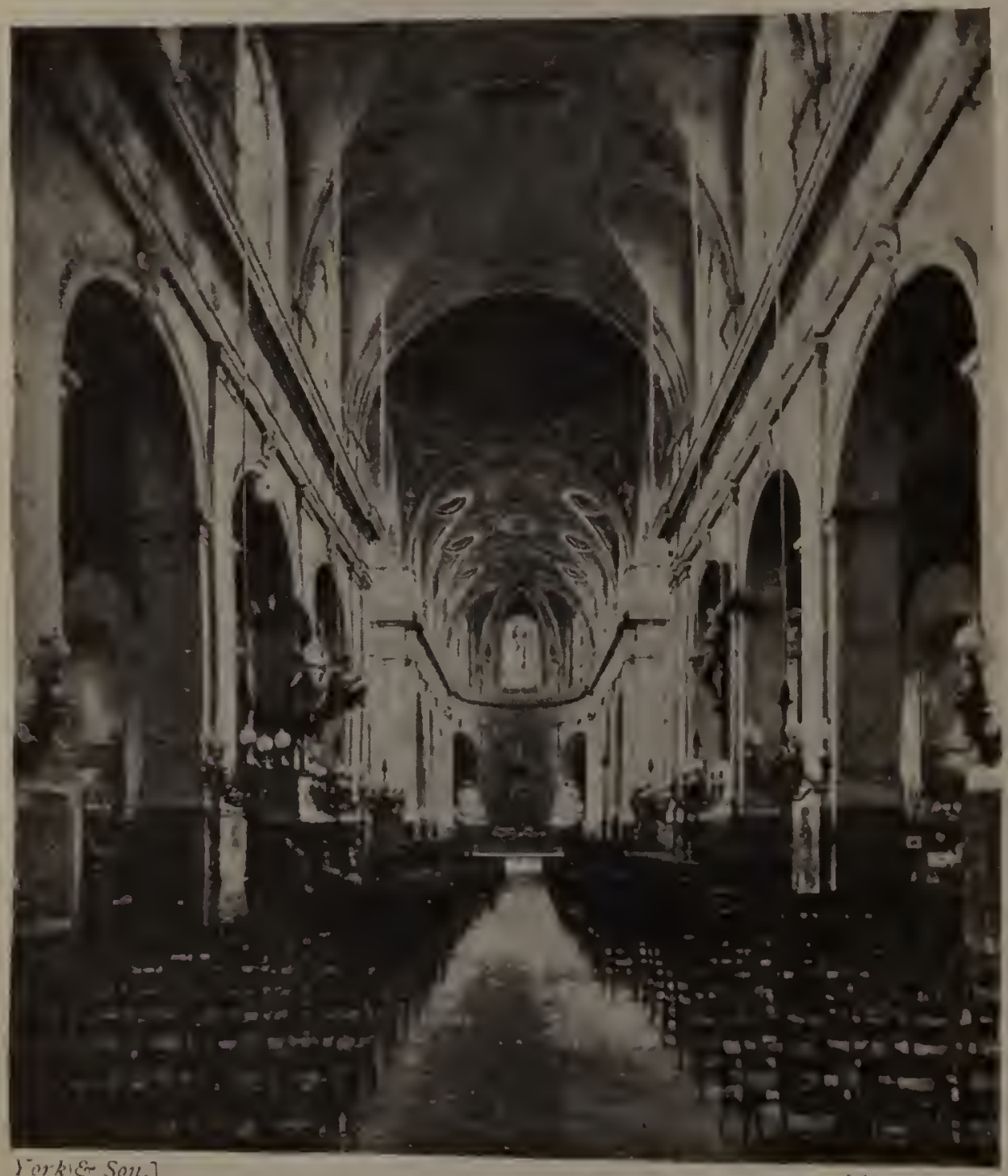

INTERIOR OF ST. ROCH.

[Notring $/ 1 / l l$.

a rule the charge is three sous, or 15 centimes, and it is well to have the necessary coppers ready, so as to avoid unnecessary explanation and conversation when payment is requested. These observations apply to any church which the sightseer may elect to visit during service on Sunday or in the week. 


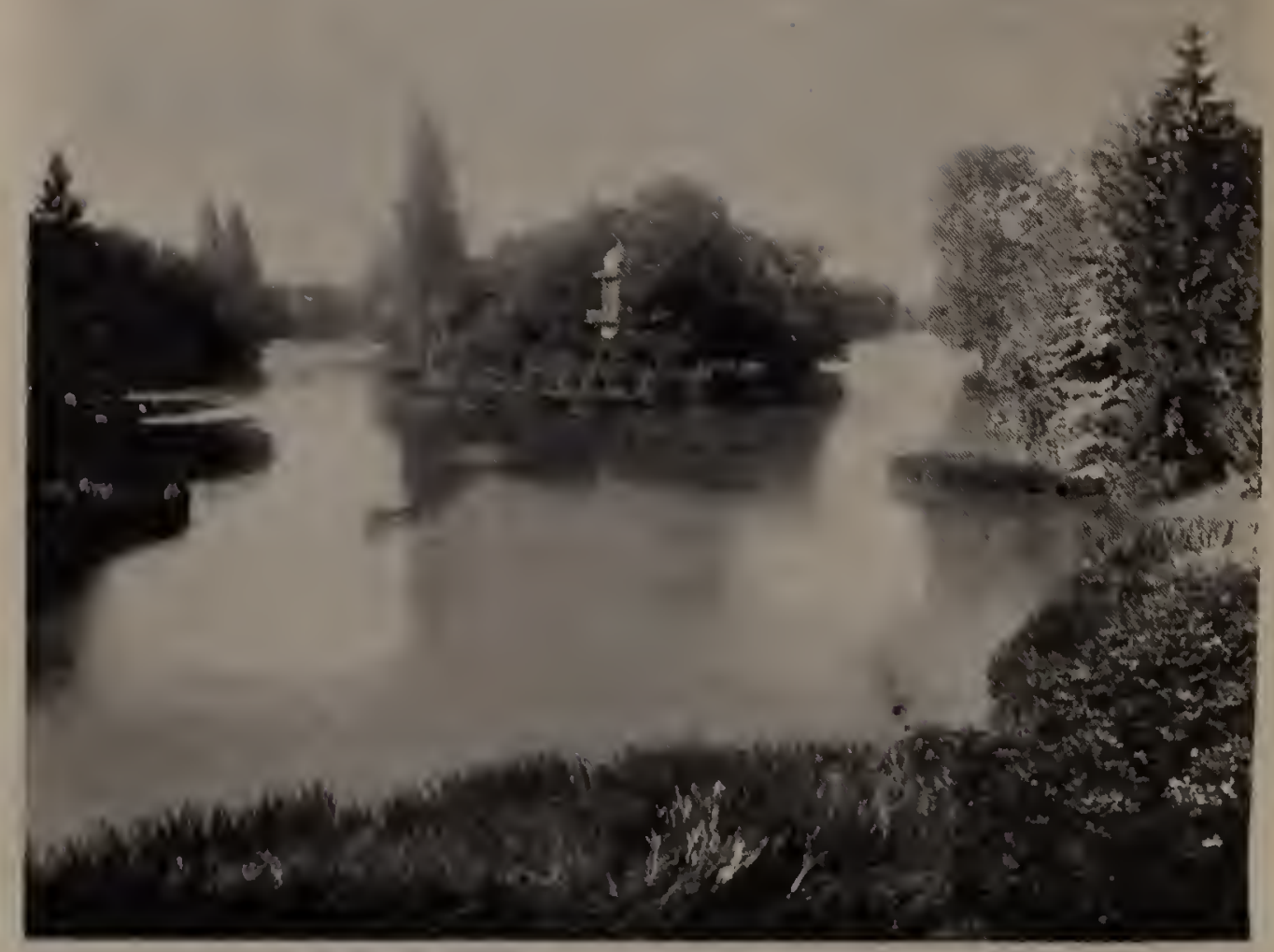

LAKE, BOIS DE BOULOGNE.

CHAPTER XII.

\section{PARIS IN ONE, TWO, THREE, FOUR OR FIVE DAYS.}

\section{Paris in One Day.}

T $T$ is natually impossible in one day to obtain more than 1 a mere hird's-eve view of the cily of Paris. 'This chapter, therefore, is specially designed for the benefit of those travellers who are simply passing through Paris and proceeding to other destinations.

It frequently happens under such circumstances that the traveller arrives in the morning, and having the day hefore him wishes to malic the best use of his time, and to get at any rate an idca of the city and obtain at least a glimpse of its principal monuments. It is perfectly possible under such circumstances 


\section{P.ARIS IN ONE DAY}

to pass the day without incurring hotel expenses, as on arriving at any of the principal stations, conveniently fitted lavatories are at the disposition of the traveller, and after a wash and brush up breakfast may be obtained at the buffet or restaurant either in the station or in the immediate vicinity. We venture to suggest that in case the latter plan is adopted special care should be taken to order a meal at fixed prices if economy is a consideration, inasmuch as these restaurants do not hesitate to run up expensive little accounts when reclioning every item separately (ia la carte).

In case the traveller is proceeding in the evening from another station, the best plan is to cross the city at once with the luggage and deposit it at the cloak-room (Consignc des Bagoages), so that the rest of the day may be entirely at liberty for sightseeing.

We cannot, however, deny that the more comfortable and satisfactory plan is to proceed to a hotel in the immediate proximity of the station from which the departure will be made in the evening. In this case we simply get the hotel porter to explain to the driver (cocher) the object we have in view, and engage him by the hour. In any case, whether the traveller desires to avoid this extra expense or not, after having clisposed of his luggage, he should carefully select a good fiacre or cab, for they vary very considerably not only as to the variety and comfort of the carriages themselves, but also in the matter of the coachmen and horses, the night coachmen being specially undesirable.

There will be no difficulty in either case in making oneself understood, even without an extensive knowledge of French. The traveller has simply to mention to the coachman the destinations named in the following programme; he will readily understand the route to be followed, and will in each case deposit the traveller at the entrance to the church or gallery he may be desirous of visiting.

We simply, therefore, sketch out in this chapter a slieleton programme, and ask our readers to refer to the index for the descriptive matter in each case.

Starting from the Madeleine (which may be visited), we pass in front of the Grand Opéra (open only in the evening), then descending the Avenue de l'opera and passing the Louvre, we cross the Seine, and passing in front of the old State Prison, the Conciergerie, we reach the Palais de Justice, through the court. 
yird of which we find the entrance to the mignificent sainte Chapelle; the sortie brings us into the corridors of the Law Courts, which may next be visited, and then a drive of a few minutes brings us to Notre Dame. A walk round the cathedral, 3uide-book in hand, and then, if inclination prompts, a visit to the Morgue (or Dead-Honse) just behind; now following the Boulevard St. Michel, we arive at the Panthéon, just behind which is the church of the Patron Saint of Paris, Ste. Genevieve. The interiors of both of these should at least be casually inspected.

Then a few minntes' drive brings us to the Picture Galleries of the Luxembourg, and if time will not permit of a careful examination, we may at least form an idea of modern French art, as the gallery only contains worlis from the brushes of celebrated French artiots either still livin:s or who have not been dead more llan three years.

Now we may direct our cocher to the Palais Royal, where an cxiellent lunch may be obtained for two francs and a half, if coonomy is an object. Our cabman may now be discharged as we must otherwise pay his hour, and be expected (though not repuired) to pay his luncheor as well as our own. Besides this a pleasint hour maty he spent after lunch by strolling about under the colonnades of the Palais Royal, inspecting the magnificent display of jewellery.

The afternoon must depend upon the lastes of the sightseer. Close at hand, in fact almost opposite to the Palais Royal, will be found the entrance to the world-renowned art collections of the Louvre, and though it is manifestly impossible to do more than walk leisurely through the galleries, yet an hour will at lcast enable us to say we have seen a few of the masterpieces and priceless pictures.

Having either clone or omitted the Louvre, we again charter a fucre, and crossing the Place de lal Concorde make for the Tomb of Napoleon, the gilded dome of which is conspicuous from almost any part of the city of Paris (open Monday, Tuesday, Thursday, and Friday), now a wall through the Hotel des Invalides (Chelsea Hospital of Paris), and thence to the Trocadero, visiting the underground aquarium and then mounting to the Terrace, and if time permit making an ascension in the lift (fee 50 centimes), for the sake of the magnificent panorama of the city. The Champs de Mars and the Eiffel Tower will com- 
mand special attention, though time will probably not admit of the ascent of the tower itself.

From the further side of the Trocadero we may take either tramiray or obtain a cab by the hour, and proceed to the Arc de Triomphe, where we descend for a more careful inspection of this magnificent monument, and thence if we decide to proceed by tramway the line Muette Tuitbout will take us to the opera House. If, hniverer, we are adopting the wiser course of using cabs instead of trams, we should next proceed by the grand Avenue des Champs Elysées to the Place de la Concorde. On the right-hand side, going towards the Place de la Concorde, was formerly situated the Palais de l'Industrie, now demolished, and a riew is obtained of the preparations for the forthcoming Exhibition. Ite next notice on either side Cafés Chantants, or open-air music halls. These are characteristic specimens of Parisian amusements, and well worth a risit. Now crossing the Place de la Concorde, and descending for a few moments at the Obelisk in the centre, we glance orer the description of the numerous points of interest around, already described, and then drive on to the Madeleine.

It will now be time to consider the question of dinner (for information concerning restaurants, see p. I2I, \&.), and our departure, if leaving Paris the same evening, in any case a stroll on the Boulevards will conclude a rery pleasant and satisfactory day's sightseeing.

\section{Paris in Two Days.}

It is impossible in any case to do better than follow the first day's programme, as traced in loregoing chapter, excepting that as that programme is distinctly overcrowded it would be well to omit the Luxembourg Galleries when the visitor has two days at his disposition, and commence the second day's programme hy taking a cab there direct in order to visit more leisurely this very interesting collection of modern paintings. The same observation also applies to the Panthéon, as it is situated in the immediate vicinity.

After having visited the Luxembourg and subsequently the Panthéon, a few minutes' walk, descending the Boulerard St. Germain, will bring us to the Cluny Museum, which is well worthy of a visit, being one of the most interesting collections of its kind in existence. After about an hour's inspection we 
shall find ourselves ready for lunch, and may then proceed either by cab or, if preferred, by steamer from the pier close to Notre Dame (about five minutes' walk), to the Tuileries landing-stage. Thence traversing the Gardens we find ourselves in front of the Palais Royal. As already stated, this is one of the most suitable and reasonable places for lunch; after which the Galleries of the Lourre may very well occupy the greater part of the afternoon. It will be remembered that the Lonve is situated immediately upposite the Palais Royal.

A most casual inspection of this world-famed collection of paintings and statuary will occupy at least two hours, by which time the visitor will doubtless have had enough for one day of salleries and paintings, and will be glad to saunter through the Tuileries Gardens, taking the centre avenue leading direct to llec Obclisk. From this point, or immediately on leaving the gallerics, we would suggest that the most pleasant termination to the day's sightseeing would be to take a cab by the hour to the Bois de Boulogne, lelling our cabman to drive us through the Pre Catelain, thence to the Cascade (view over the Racecourse), and returning by the Avenue de Acacias, at the time of the fashionable promenade, to our hotel. If, however, the expense involved in this arangement forms an objection, a stroll in the Champs Elysées will pleasantly conclude the day's sightsecing.

If we happen to be carrying out this programme on either a Wednesday or a Saturday, we should so arrange our time as to visit the Gobelins Tapestry Manufactory. This is one of the most interesting sights of the city, but it is only open to the public from I.O till 3.0 on the two days named. The Gobelins is a considerable distance beyond the Panthéon, though in the same direction, and we would suggest that a cab should be taken by the hour in any case for making this visit, as otherwise there is little chance of funding a suitable conveyance for the return to the centre of the city, and there is absolutely nothing else in the district worth visiling.

The Jardin des Plantes may he conveniently visited after leaving the Gobelins, but it should be understood that this is a Zoological Garden vastly inferior to our own in Regent's Park, and may well be omitted from the programme 


\section{Paris in Three Days.}

Still leaving the two previous itineraries as being the most satisfactory and profitable method of dealing with the short time at disposal, the three-day visitor should undoubtedly derote the third and last day to Versailles.

As full details concerning this excursion and the various methods of taking it are already given in the form of a complete day's excursion, we need only refer the reader to the index.

\section{Paris in Four Days.}

Still leaving previous itineraries as indicated, the four-day visitor cannot do better than make the excursion to Fontainebleau, to which also a separate chapter is deroted. The excursion will occupy the whole day, leaving by train at 9.40 a.m. and returning at 6.30 p.m.

We would suggest, however, that this excursion should not be left to the last day, especially if the homeward journey has to be taken the same night, as it is a long and somewhat fatiguing day's outing.

\section{Paris in Five Days.}

Still leaving the previous itineraries, the visitor may devote the fifth day to a River Excursion to saint Germain. Taking the Tourist Steamer which starts from the Pont Royal (opposite the Louvre) at 10.30 a.m., the windings of the Seine are followed past the Eiffel Tower and Trocadern, the villages of Sèvres and St. Cloud, the Bois de Boulogne. Asnieres, St. Denis, Chatou, and the picturesque boating resort of Bougival, are passed respectively, and the steamer reaches St. Germain at two o'clock. An excellent luncheon may be taken on the deck of the steamer at fixed prices or it la carte. single tickets for this interesting trip are 3 francs, the price for the return journey being 4 francs 50 centimes.

On arrival at St. Germain the celebrated Terrace and the Chateau with its interesting museum will pleasantly occupy the greater part of the afternoon, and we would then advise the visitor to return to Paris by train (the station being exactly opposite to the palace). There are frequent trains, and the 
journey only occupies about forty minutes, whereas the steamer, returning against the stream, does not arrive in Paris till nearly. 9.0 p.m.

Assuming the return journey to be made by train, on arrival at St. Lazare station cabs and ommibuses in profusion will afford means for returning to the hotel.

[For Inder sec ph. 219-224.]

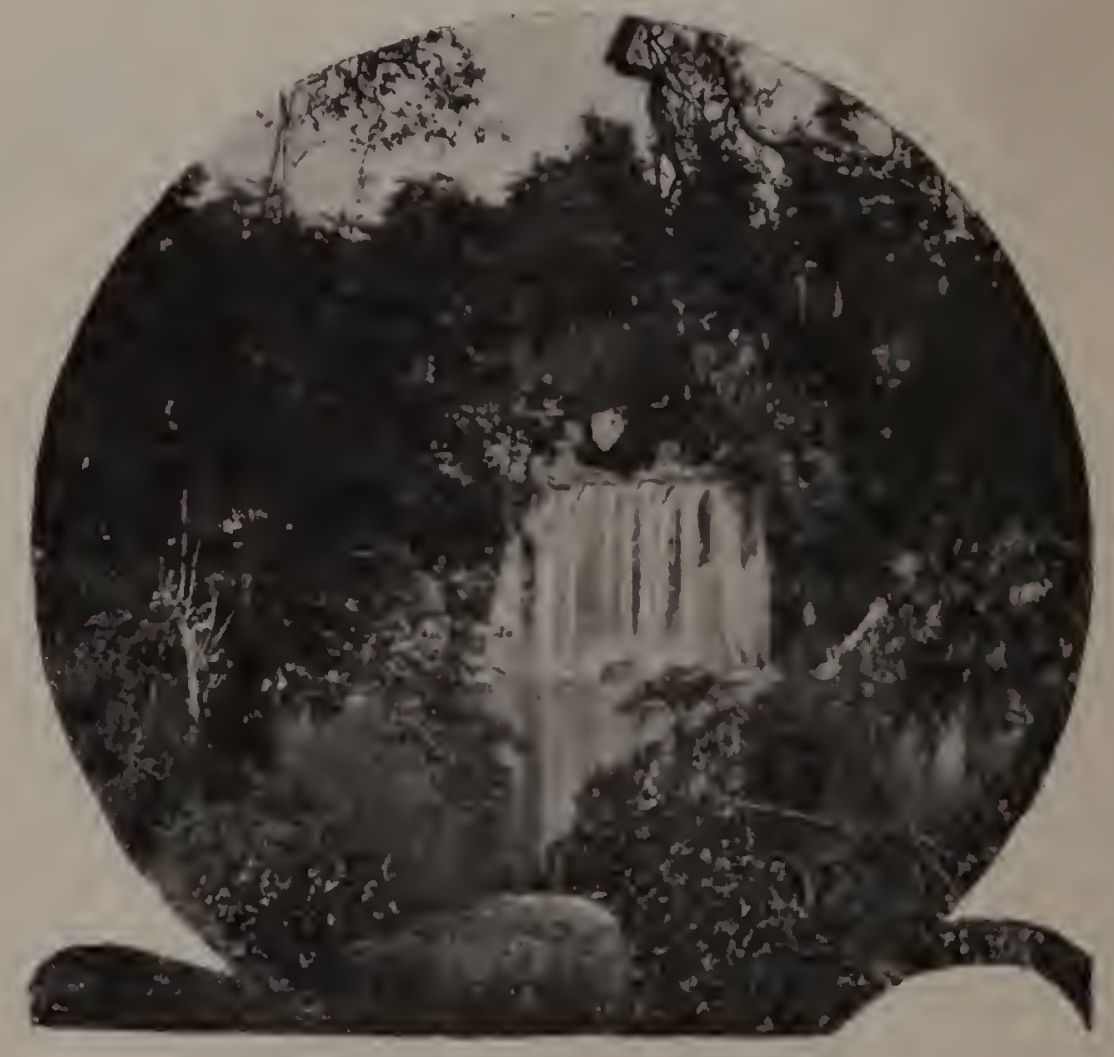

CASCADE IN BOIS DE BOULOGNE. 


\section{A GENERAL VOCABULARY, WITH SHORT PHRASES FOR THE USE OF VISITORS TO PARIS.}

\section{THE JOURNEY AND ARRIVAL.}

Are you going to Paris?

What route will you take?

Which is the triin for ...?

Does the train stop at wayside stations?

Gire me a first-class ticliet.

A second-class tichet.

Make laste.

This seat is engaged.

Tickets, Gentlemen, if you please.

How long do we stop here?

Luggage, Booking-window, Ticket.

I have nothing to declare.

I have only articles fol personal use.

\section{HOTELS AND}

Please tell me of a good hotel.

Not tno dear, but quiet and clean.

I should like a room at 5 francs.

Show me my rom.

Dn you require a sitting-room ?

Is that the lowest price?

The sheets must be well aired.

Please call me at eight o'clock.

Where are the lavatories?

\section{RESTAURANTS.}

IVaiter, the bill of fare.

Give me some beef, . . .

Chicken, Fish, Poultry, Game, Cheese.

V'egetables, Potatoes, Salad, Eggs.

IVater, Irine, Beer, Brandy, Bottle.

Half a bottle of wine. A tumbler.

Please give me the hill.

Here is 20 francs, please pay for me at the casli desk.

\section{PROMENADING.}

Where is the Opera?

Go straight on.

Get us a cab.

A calh by the hour.

A cal by the course.

I laive lost my way.

This way. That way.
Allez-rous a Paris?

Ouelle route prenez-rous?

Quel est le train pour ...?

L̃e traiu s'arrête-t-il aux Stations intermédiaires?

Donnez-moi un billet de premicie classe.

Un billet de deuxième classe.

Dépechons-nous.

Cette place est prise.

Vos billets, Messieurs.

Combien de temps restons-nous içi?

Le baggage, Le Guichet, Le billet.

Je n'ai rien á declarer.

Je n'ai que des effets pour mon usage personnel.

\section{APARTMENTS.}

Indiqucz-moi, s.v.p. un bon Hôtel.

Pas trop cher mais tranquille et propre.

Je roudrais une chambre à cinc frances.

Montrez-noi ma chambre.

Désirez-vous un salon?

Est-ce le dernier prix?

Les draps doivent être bien secs.

Priere de me reveiller à huit heures.

Ou se trouvent les cahinets?
Garçon, la carte s'il vous plait.

Donnez-moi du bœuf, . . .

Du poulet, du poisson, de la volaille, du gibier, du fromage.

Des legumes, ponmes de terre, de la salade, des oeufs.

De l'eau, du vin, de la bière, du cognac, une houteille.

Une demi-bouteille. $U_{1}$ grand verre.

Donnez-noi l'addition s'il rous plait.

Vnici vingt francs, priere de payer pour moi à la caisse.
Ou est l'Opèra?

Allez tout droit.

Allez nous chercher un fiacre.

I'ne voiture à l'heure.

Une roiture it la course.

J'ai perdu mon chemill.

P’ar içi. P'ar là.

\section{AMUSEMENTS.}

Give me a good place and you shall

- have a gond tip.

Fetch me the text of the piece.

I am badly placed. I cau see nothing.

Where do you go in?

Where do you go out?

I should like to go there.
Innne\%-moi une boune place el vous aurez un bon pourhnire.

Clierchez-moi le livret de la pièce.

Je suis mal place. Je ne mis ricu.

Par ou entre-t-on?

Par ou sort-on?

Je voudrais bien y aller 
An open-air eoncert.

IVill you have a game at cards?

A game at billiards.

It is my turn to play.
Un coneert en plein air.

Voulcz-vous faire une partie de cartes?

Une partie cle billard.

C'est ì moi à joner.

\section{A FEW GENERAL QUESTIONS.}

Can you wail ten minutes?

Wrater, where is a newspaper?

IVho is there? Come in!

1 thank you kindly.

I am slad to milke your acquain tance.

I shall be pleased to sec you.

Tilke a seat.

W'ait a while.

That is it.

Do you smoke?

A gentleman wants to speak to you.

As you please.

Wiil that do? That will do.

When do you want it?

1 find it very dear.

Here is the very thing I want.

Give me your lowest priec.

1 want to write a letter.

I am in a speat hurry.

Ahove all, do wot fail to send it todisy.

What lime is it?

When do you leave? At once.

Are you ready?

I do unt feel very wetl.

Please call in a doctor.

I atu fecting hetler to-clay.

Gondbye, pleasiant voy'ase.
Pouvez-vous attendre dix minutes?

Garçon, ou est le journal?

Qui est-ce qui est lì ? Iintrez!

fe vous remercie bien.

Je suis eharme de faire votre connaissance.

Je serai heureux de vous voir.

Asseyez-vous.

Attendez un peu.

c'est bien ccla.

Fumez-vous ?

Un monsieur demande à vous parler.

Comme vous voudrez.

Cela vat-il? C"est bien.

l'our quand rous le faut-il?

le le trouve fort cher.

lovici precisiment ce qu'il me fant.

Dites-moi votre dernier prix.

fe voudrais ecrire une lettre.

Je suis très pressé.

Surtout ne manquez pas de l'enroyer aujourd'hui.

Quelle heure est-il ?

Cuand parter-vous? De suite.

litesi-vous prêt?

le ne me sens pas très bien.

Priere de faire chercher un medecin.

le me porte mieus atiourd'hui.

Arlicu, bon voyage.

A banknote.

MONEYS AND EXCHANGE.

Rate of exchange.

silver moner.

Un billet de banque.

Le conrs du change.

Des pieces en argent.

Des pièces en or:

NUMBERS, DAYS, MONTHS, \&c.

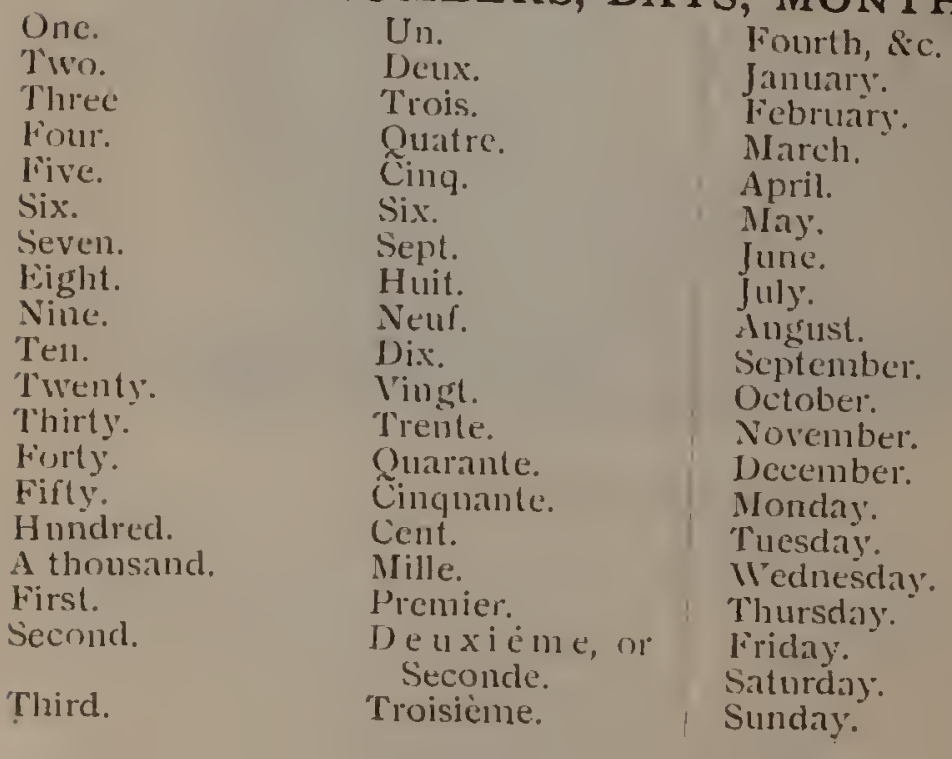

Quatrième, sc.

Janvier.

Fevrier.

Mars.

Avril.

Mai.

Juin.

Jinillet.

Août.

Septembre.

Octobre.

Novembre.

Decembre.

L.undi.

Mardi.

Mercredi.

Jendi.

Vendredi.

Samedi.

Dimanche. 
THE OLDEST PURELY FIRE OFFICE IN THE WORLD.

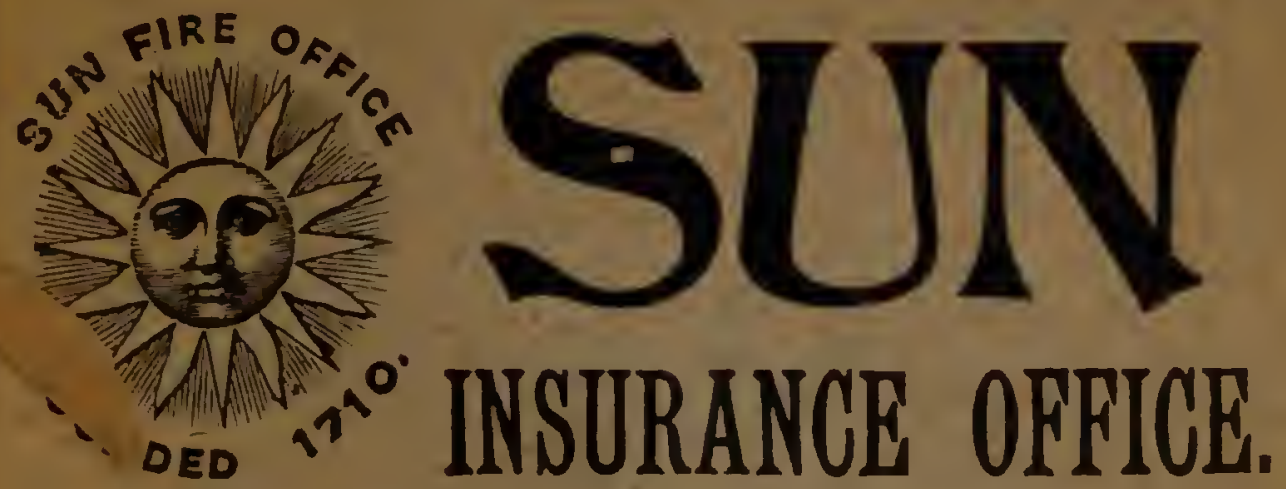

Moderate Premiums.

\title{
PROMPT BETTLEMENT OF CLAIMS.
}

HeAd Office :-

\section{3, THREADNEEDLE STREET, LONDON, E.C.}

\begin{abstract}
BRANCHES IN $\left\{\begin{array}{l}\text { 60, CHARING CROSS, S.W. } \\ 40, \text { CHANCERY LANE, W.C. }\end{array}\right.$ LONDON * $\{332$, OXFORD STREET, W. 42, MINCING LANE, E.C.
\end{abstract}

BIRMINGHAM-10, Bennett's Hill BRISTOL-Corn Streot. LEEDS-8un Buildings, 15, Park Row. LIVERPOOL-6, Chapel Street. MANCHESTER-7I, King street.

NEWCASTLE-ON-TYNE-

19, Collingwood Street. EOINBURQH-40, Princes Si reet. GLASBOW-Sun Buildings, 42, Renfleld Street. DUBLIN-12, Trinity Stroet. And Agencies in all parts of the United Kingdom and abroad.

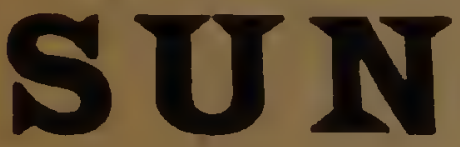

INSURA NCE

\section{OFFICE.}

Sum Insured in 1898 exceeds

\section{$£ 430,000,000$}

Series, 1899-1900. To face matter at cud.] 


\section{THE PATENT \\ CONSTRA CYCLE SADDLE \\ A. Perfect saillle for both Sexes.}

HEALTH,

COMFORT,

COOLNESS.

INUURY

IMPOSSIBLE.

Gives a FIRM, ELASTIC

SEAT. No jar to

nervous

system.

Adjusta-

blotosize

of rider.
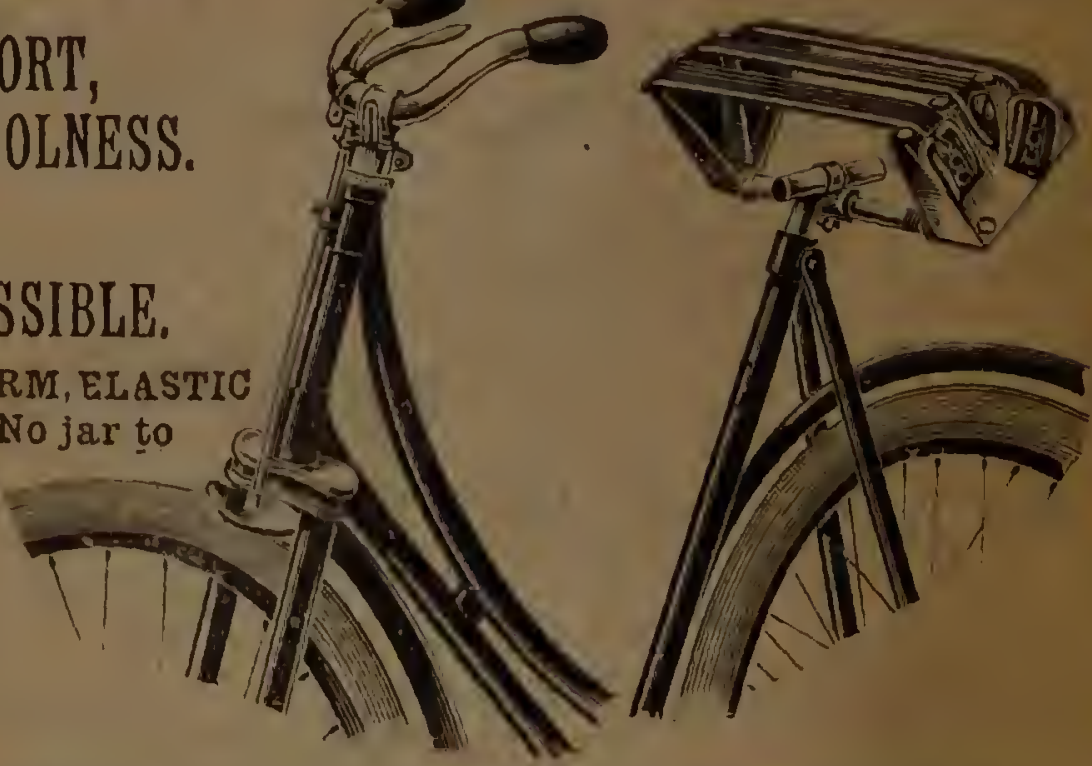

ORNAMENTAL AND SMART IN APPEARANCE.

Persons who under medical advice had given up cycling now ride the CONSTRA Saddle.

Thonglt the Constra Saddle has been claimed as par excellence "The New Ladies' Sndule," the folloteing fero extracts from letters recerved prove its popularity anang genllemin:

NeTHER WAl.LOP, 23 d May, 1898.

THE REv. EDM. LACON writes:-" One thing I have decidedly proved. The roads in .... are simply awful, and yet 1 have with the Constraas a learner under certainly unfavourable circumstances-gone easily and comfurtably where I dared not go on niy . . . saddle."

Devizes, inth June, 1898 .

Mr. B. HOWARD CUNNINGTON writes:- "Mrs. Cunnington likes it iminensely, and says it is perfect."- - And later on (18th June) writes: "I liave used the one Mrs. Cunnington had. . . Without a doubt they are far and away the best out, and I have ridden bicycles since $1870-$ the old boneshaker days." I 5 th Prussian Hussars, Germany, 2nd Oct., 1898.

LIEUT. CARL FREDERICK VON ESMARCH wites:-"1 have been riding the Constra saddle every day, and am quite delighted with it; it goes beautifully."

Lady's Well Brewely, Cork, 5th October, 1898.

Mr. JAS. N. HEALY writes:- "I am glad to say that after an exhaustive trial, Mr. Murphy is much pleased with the Constra saddle."

The Lady', June $2 n d, 1998$, says:- " $\Lambda$ very delightful cycle saddle has lately been irvented. It is called the Constra, and is especially suitable for ladies, who will find it most comfortable. It is composed," \& c., \&c.

The price of the CONSTRA SADDLE is 25s. A fortnight's free trial allowed. 


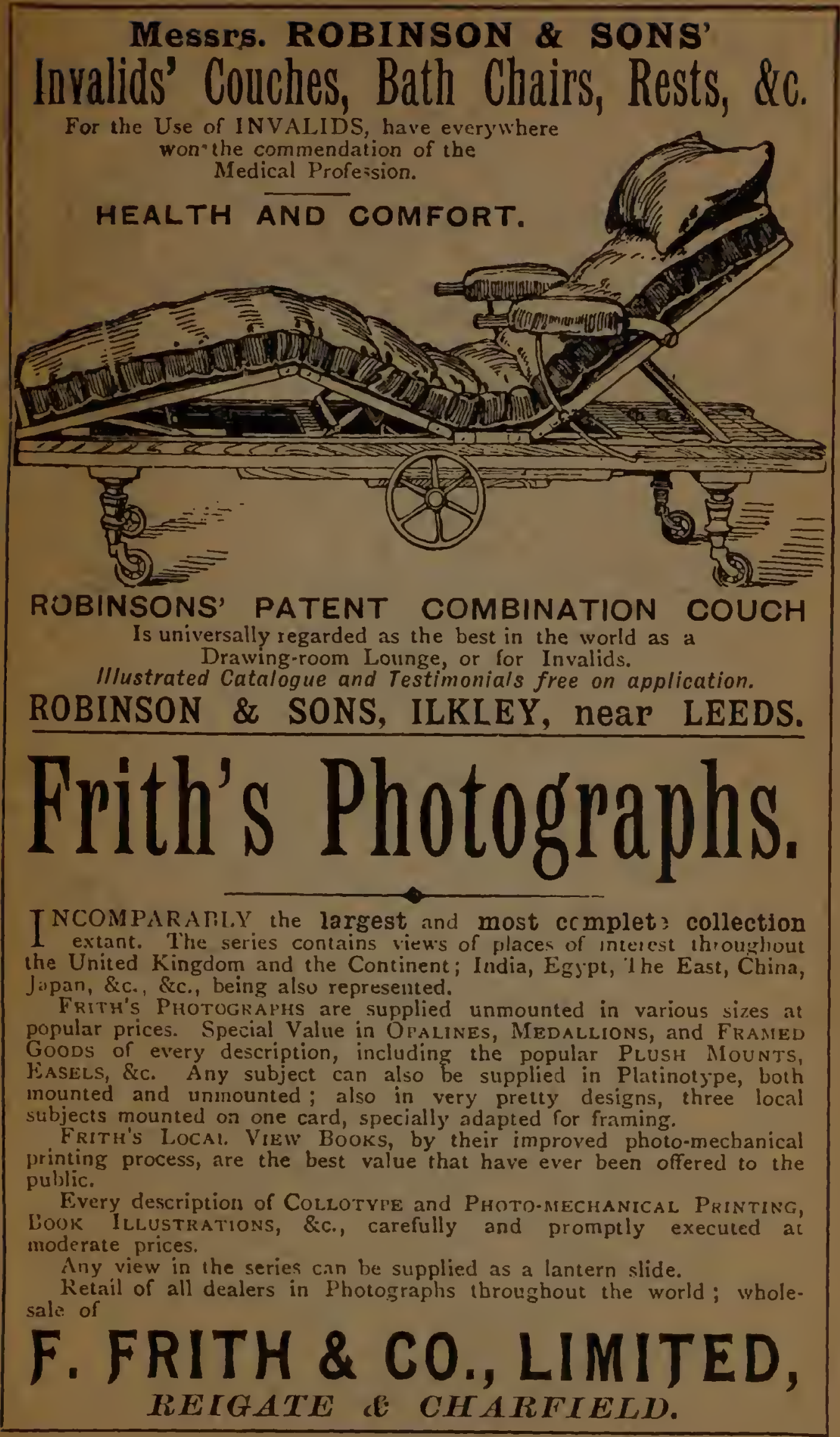




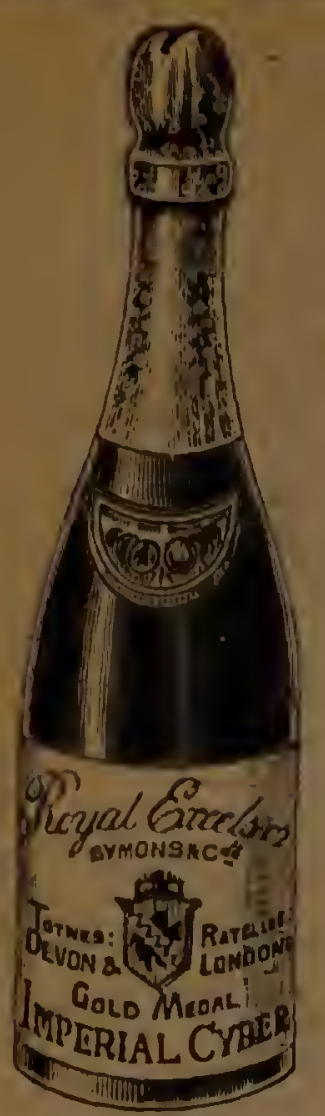

\section{ENGLAND'S GLORIOUS VINTAGE
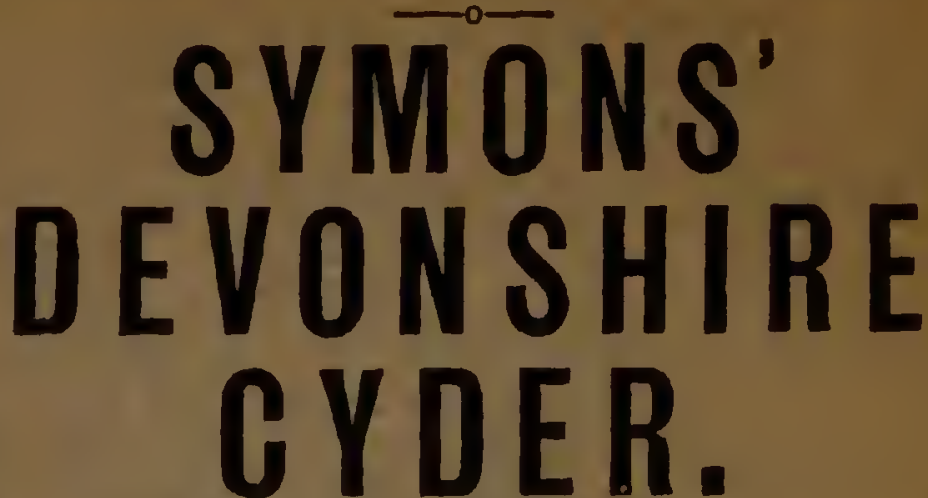

HAS NO EQUAL. - See Analyst's Report.

SPECIAL BrandS:

'IMPERIAL' AND 'APPLE AND BLOSSOM.' SOL.E MAKERS OF

DEVONSHIRE CHABLIS AND HOCK.

Sold in Casks and Bottles by all the leading Bottlers.

JNO. SYMONS \& CO., LTD., Totnes, Devon, and Ratcliff, London, E.

\section{UNDER ROYAL PATRONAGE.}

\section{EDWARDS'}

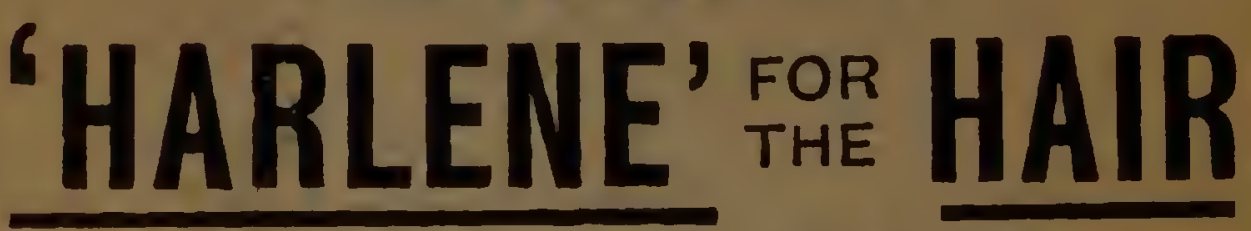

The Great Hair Producer and Restorer.

The Finest Drassing. apecially Prepared and Delicately Perfumed. A Luxury and secessity to every Modern Tollet.

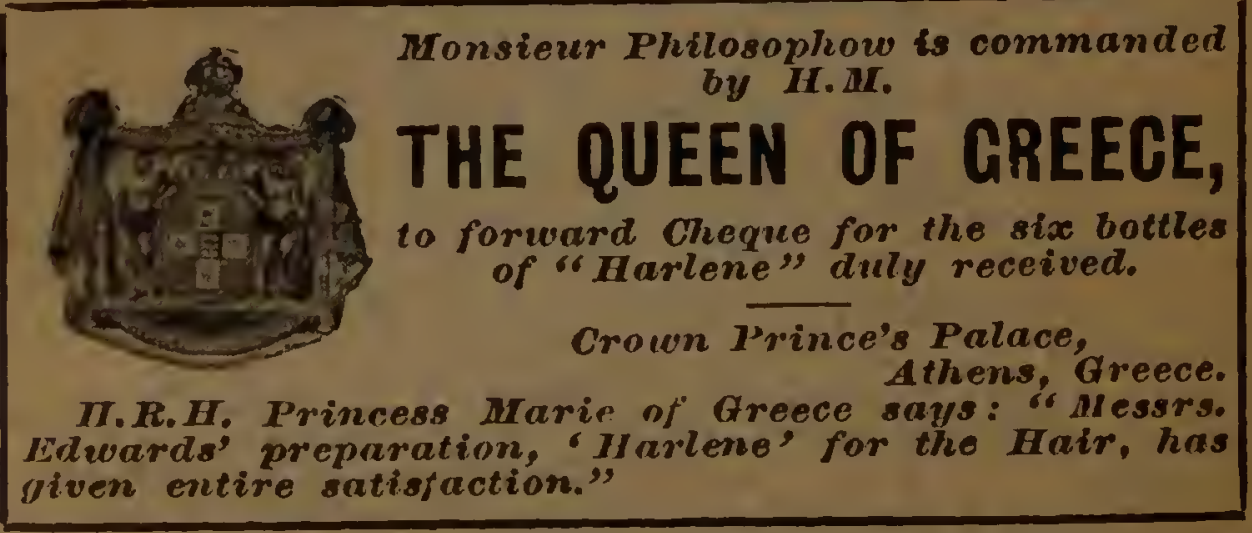




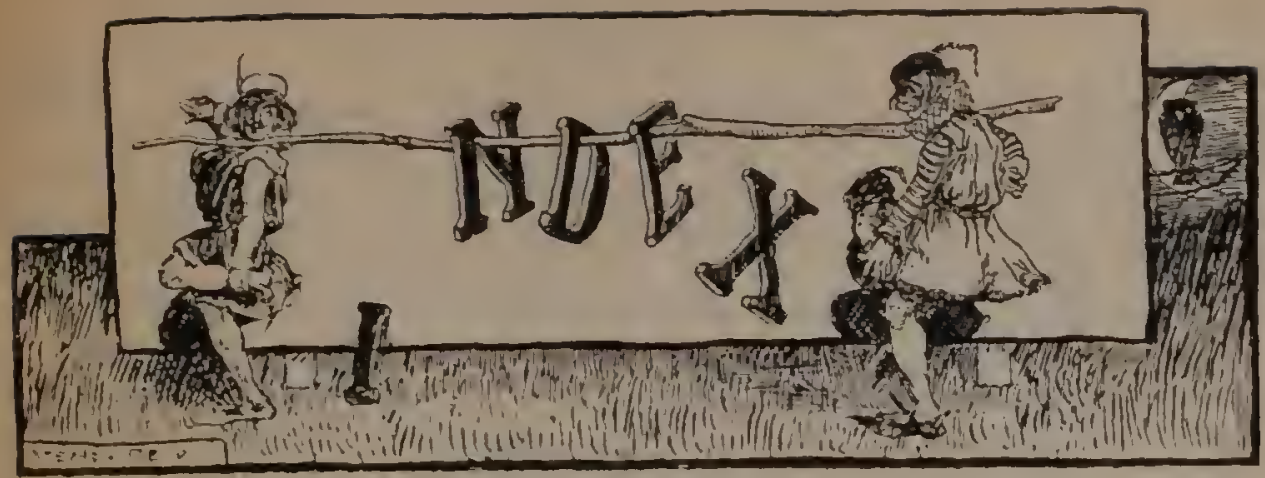

\section{N D E X.}

A.

ABWEVILI.E, 27-2S

American Churches-

American Chatpel.

Thes, 205

Holy Trinity, 205

St. Lulie's, 20.5

Anitens, 28

Amusements, 72-S

Suggiested Programme of, 69-7o

Sce also Balls, CatésConcerts, Equestrian Entertainments, Horseracing, Military Bands, Music Halls, Operas, $\mathrm{Pa}$ noramas, Sliating Rinlss, Theatres, Velodromes, and IVaxworlis.

Ancient Paris, 30-to

Acputritum, The, I 10

Are de Triomple du

Cirrousel, 12.5

Are de Priminple de l'Etoile, ros

Arondissements, The,

Auteruil, 100

Avenues, $9+-9.5$

Címot, 94.
Arenues-iontimuct

de Friedland, 95

de Jena, 95

de la Grand Armée, of de IVagram, 95

des Champs Elysées,

$$
95.105
$$

des Ternes, of

dis Bois de Boulogne.

Hoche, 95

() 4

Kléber, 95

MacMallom, of

Marceat, 95

Niel, 95

Victor Husso, 9.5

B.

BAL BULLIER, THE, 82

Balls, SI-S2

Banlieux, Tle, 99

Banque de France, I $2+$

Barbizom, I 90

Bazar d'Anisterdam, 7 I

Batzar de l'Hoited de Ville, 7 I

Belleville, I0O

Bercy, 90

bis IIheel, 8 I

Poatrding Houses, 60

go boisde Bumlosne, The,

I75

Butanical Galden, The,

IIT
Bougival, 204-205

Bomlevards, 9I-c)s

Araso, 97

Beammarchais, 92-03

Bumne-Nourclle, 92

Bourbon, 93

de Batignolles, 97

de Belleville, ós

de Berey, go

de Ceinture, of

de Charonne, of

de Clichy, o( 0797

de Courcalles, 97

d'Enfer', 97

de Grenelle, 97

d'Italie, 97

deLatour-Mauboures, $97-9 \mathrm{~s}$

de la Contrescarpe. 93

de la Chapelle, g6-07

de la Gare, 97

de l'Hoipital, 95, 97

de lat Matdeleinc, of

de la Villette, gu

de Magentat, 97

de Montparnasse, 95

de Picpuss, go

de Port Royal. 97

de Rochecliouat, $06-97$

des Capucines, $91-92$ des Filles du Calvaile, 92 
benlevards-cont. des Invalides, 95 des Italiens, () 2 dil Temple, 92 Edgar Quinet, 97 Hat1smimn, o7 Henri Quatre, 9. Mćnilmontint, of Montmartre, 92 Porcire, os Poissonnière, 92

St. Dennis, 92

St. Germain, 93

St. Jacplles, o7

Vaugirared, 97

Voltaire, 97

buulngne-sur-Mer, $27,20-30$

limirse, Lat, I22-1 24 liridge of Alexandlex IfI., Tlie, 89, I49 Briclges across the Seine, $87-89$

Pont au Changse, 87

Pont d'Arcole, 87 Pont d'Austerlit\%, $S_{7}$ Pont d'Auteuil, 89 Pont de Bercy, 88 Pont de Jena, 8 ? Pont de l'Alma, So Pont de I'Archevèche, 87

Pont de la Concorde, $88-89$

Pont de la Tournelle.

Pont de Passy, 80 Pont de Sully, 87 Pont de Tolbiac, 87 Pont des Arts, 8S

Pont des Invalides,

Pont du Carronsel,

so Concicigerie, 15I, I62

Pont du Point du Jour, So

Pont Louis Philippe.

Pont Marie, 87 $8_{7}$

Pont National, $8_{7}$

Pont Neuf, 87

Pont Notre Dame, 87

Pont ou Double, $8_{7}$

Pont Rnyal, 88
Concicrgerie, I5I, I62
Consulates and Emhassies, 16

Bridges-continued

Pont St. Louis, 87

Pont Solferino, sis

Bntles-Chatumont C.

CABS, 6I-63

Cal, Fares, 10

Calfés-Concerts, So-si

Alcazar, So

Alcazar d'Hiver. So

Ambassadeurs, 8o

Concert Parisien, so

La Cigale, 80

Le Ciel, $s_{2}$

Le Neant, 82

L.Horloge, so

Parisiama, so

Jetit Cissimn, S I

Scillil, so

Calatis, 27

Card Telegrams, on

Cathedral of Notre

Dame, 154-158, 207

Chamber of Deputies,

The, I 20-I 21

Champ de Mars, i Io

Champs Elysées. The, I05-106

Chapel of the Trinity,

Charonne, 99

Churches, see English Churches and Roman

Catholic Churches

Cigars and Cigarettes, $8-10$

Colnnne de Juillet, I 44 Colonnc Vendôme,

\section{The, I 49)}

Cost of a Holiday in Paris, I-2

Courcelles, roo

Customs Examination, The, $5^{8-59}$

$1)$.

DAYS AND HOYRS OF ADMISSION TO THE SIGHTS OF PARIS,

Dover, 23 [I2-I5
Dover-Calais Passage,

The, $24-27$

Dress, 2-3

Dural Restaurants, or

E.

ÉCOLE MILITAIRE, I IO

Eglise Saint-Lotis, I 20

Eiffel Tower, The, I IO-II4

Eiffel Tower, Pier of the, 149

English Chapels-

Congregational, 205

First Baptist, 205

McAll Missions, $20.5-206$

Sentch Preshyterian, 205

Wesleyan Methom dist, 205

English Churches-

Christ Church, 205

English Chtrrch, The,

Victoria Jubilee 205

Church, 205

Equestrian Entertainments, 81

Cirque d'Hiver, 8I

Cirque Fernando, 8 I

Hippodrome, 8 i

Nomveau Cirque, 8 I

\section{F.}

FARES, ETC., FROM LONDON TO PARIS BY THE VARIOLS ROUTES, I9-2I

Fête de St. Cloudl, $2 \mathrm{O}_{4}$

Fête des Loges, 204

Fiacres, 6I-62

Follecstone, 29

Fontainehleau, I95-199

Forest, The, I08-199

Palace of, I95-108

Fontaine de Léda. Ios

Fontaine de Médicis, I 68

Fontaine des Innocents, I 52

Forest of Fontainebleau, I9S-199

Brigands' Cave, I 99 
Forest of Fontainebleau-continued

Fort of Napoleon, 199

Gurge d'Apremont, I99

Gorse of Franchard, The, I99

Noving Rock, 199

Pharamond, I99

Forest of St. Germain,

Fortifications, The, 201

G.

$89-90$

GLOSSARY, 4, 217-2IS

Gobelins Tapestry

Manufactory, The,

I 70

Grand Trianon,

I $78-180$

Great Arteries and Landmarks of the City, $85-87$

Grenelle, Io I

$\mathrm{H}$.

Halles CeNTrales,

Havre, 36-37

I5I-I52

History of Paris, $3 S-56$

Horscracing, $8_{3}$

Hôtel Cluny, I63-167

Chapel, The, I66-I67

Cour d'Honneur', I04 de Liluzan, I6z

Gallery of Ciurriages, Tle, 165

Ground Floor.

$164-105$

Salle de la Reine

Blanche, I66

Salle du Sommerard.

Hôtel de Ville, I5t

I $65-166$

Hôtel des Invalides, I $16-1$ I 7

Hôtel des Postes, I 53

Hotels and their

Tariffs, IO-I I, 59-60

Houses, The, 90-9I

How to reach Paris,
J.

JARDIN CLUNY, I67 Jardin des Plantes,

Botanical Gaclen The, I 74

zoologsical Garden, The, $174-175$

Jardin Zoolugique d'Acclimatation, 175,209

L.

LA BOURSE, I22-I 24

La Chapelle, Ioo

La Gare, IOI

La Glacière, Io I

La Muette, Ioo

Language, $3-4$

Landaus, 62

Les Batignolles, I0o

Les Ternes, Ioo

Lewes, $3 \mathrm{I}-32$

Lines of Onmibuses,

$\begin{array}{ll} & 64-66 \\ \text { Lonschamps Race- }\end{array}$ course, The, I Ti

Louvre, The, I 26-I 39 Assyrian Gallery, The, I30-I 32 Corridor de Pan, I 29 Exterior, I $27-\mathrm{I} 28$ Galérie Algeriemne,

Galérie Daru, 128

I32 Salle du Coyzerox,

Galérie Egyptienne, I 32

Galérie Nullien, I 28

Hall of Adonis, I 29

Hall of the Sarcophagus of Esmunazar, I32

Musée de Gravure ou de Chalcosraphié, I 30

Museum of Sculpture of the Middle Ages and the Renaissance, I32-I33 Salle Chrétienne, I34 Salle cl'Auguste, I 29 Salle de Chaudet, 130 Salle de Houdon, I 30
Lourre, The-cont.

Salle de Jean Goujon,

Salle de la Cheminée de Bruges, I33

Salle cle la Meclèe.

Salle de la Paix, I 29 Salle de la Pallas, I 29 Salle de la Psyclié.

Salle de la Vénus de Milo, I 29

Salle de l'Hermaphrodite, I 29

Salle de Magnésie,

132

Salle de Mécène, I 29

Salle de Melpoméne,

I 29

Salle de Michel Ange, I 33

Salle de Phidias, I 28 Salle de Rotonde, I 28 Salle de Rude, I 30

Salle de Septime, I 29 Salle des Anguier, I 33 Salle des Antonius,

I 29

Salle cles Cariaticles, I 29-I 30

Salle des Monmments de Milet, 132

Salle des Saisons, I 29

Sille du Gladiator, I 29

Salle du Haget, I jo Salle du Tiber, I 29

Salle Judaique, I jt

Salle Phénicienne,

Vestibule Daru, Iis

Louv'e Picture Galleries, The,

I $3 t^{-1} 39$

Anciennes Salles du Musée des Sonverains, I 39

Chambre d'Alcove,

Collection Thiers,

I39 
lourte l'icture Galleries, The-conl.

Galćric d'spollon,

Galleric Darri, 1.38

(ialérice Mollicil, I.36)

ciratucle cialéric de reinture; I 3 (1)

Musé de la Marine et clethonosraphice,

I.39)

Musces Moyen dige et de la Renatissillice, I 3 3 )

Siton Catré, 135

Sille de Cater, 1.37

Sille de Henri hl.,

134

Sille de Sept cints Mctress, 1.36

Salle des IBijoux, 135

Salle des Boites, 139

Salle's des Pastels,

138

Silon de Sept Clieminées, I34-1.35

Salons Française.

Latctia Parisiorum, 130

$30-40$

Luxembourg Galleries,

The, I $68-160)$

\section{M.}

MAGAZIN DU BON

MARCHE, 7o

Magazin du Lourre, 7 I

Masaizin du Printempls,

71

Matches, Fusces, die,

10

Ménilmontant, 90-100

Military Bands, 8t

Ministère de la Marine, 106

Monceaux, 100

Moner, $6-7$

Montinatre, 100

Montreuil, 99

Montsouris, 10 I

Morgue, The, I58

Moulin Ruitse, 'The, 82
Musée d'Artillerie.

Bibliothèue, I 20

I $17-120$

Costumes de Gucree.

Galérie IEthno-

IIV)

staphique, I16)

Premiére Galéric des Armures, I 19

Salles des Armes Blanches et Armes i) Fuct $110-120$

Salles des Armmes. I I \&

Salle des Maréchaux, 120

Music Cillonatet,

Musece Grévin, st $1+4-140$

Museum of the Luxienbours. 169

Salle Caillebotte, I 60

Écoles Etrangers, 169

Salles des Vernet. I 69 Music Halls, 79

Casino de Paris, 79

Folies Berugere, 79

Olympia. 79

N.

NANTERRE, 205

Notre Dame Cathedral, $15 t^{-1} 5^{8}, 208$

\section{O.}

OHELASK OF LUXOR,

Ommibuses, $6.3-66$

Opera House, Tle.

I + I-I +3

P.

1'ALACE OF IFONTAINEBLEAU, I94-198

Apartments of Nitpoleon 1., 195-190

Apartments of Maric Antoinctte, 106 Apartments of the Reines Blanclies, The, I $97-108$

ball Roun, The, sy-
Palace of Fontainebleau-iont.

Bijou Theatre, The. Igs

Council Chamber, The, Igo

Galérie d'Assietes. The, igs

Gallery of Dianti, The, 190

Gallery of François I., 197

P'rivale Apartments of Marie de Maintenon, 197

State Apartments, The, $196-197$

Terrace, The, igs

Throne Room, The, I90

Palace of the Tuileries. $124-125$

Palace of Versailles, r $8 \mathrm{I}-\mathrm{IgO}$

Cour de Marbic, I 82 Coromation Hall, $18_{+}$

Crusale Gallery, The, I 88

Ėglise St. Louis, I $80-188$

Exterior, I $81-182$

Galérie des Batailles, $184-185$

Galćric des Glaces, I 86

Gallery of Constantine, I $S s^{\prime}$

Gallery of Portraits, 184

King's Apartments, The, iso

Queen's Apartments, The, iso

State Ballroom, The,

Theatre, The, is 88 is 86

Palais de Glace, The,

Paldis de Justice,

l'alais des Thermes. I $59-\mathrm{I}(12$ 167

Palais du Luxembour: $167-108$ 
Palais du Trocadéro. I 10

Palais Royal, The, 122

Panoramais, $S_{4}$

Panthéon, The, I 72

Parc de St. Clund, 177 Parc Nonceaux, IO $7-108$

Paris-

Ancient, 39-40

Arondissements of, .

Arteries of, $85-86$

Avenues of, 94-95

Boarding Houses of,

60

Boulevards of, $91-98$

Bridges, $87-89$

Capetian kings of, $40-42$

Churches of, 205-208

Consulates, 16

Embassies, I6

Empire 111, 49-50

Exposition I900, $8+$

Fiacres, 6I-62

Fortifications of.

Frankish, fo- +3 $88-89$

Hotels of,

Money, 6-7

IO-I I, 59-60

Omnibuses of, $6_{3}-66$

Postal Service of.

Restoration in,

$6--69$

$5^{0}-52$

Revolution and, 48

Routes to, 3-37

Second Empire in.

Seeing, It-16, $50-54$ $210-215$

lin One Day, $210-213$

In Two Days, 21

In Three Day's, 215

In Four Days, 215 Shopping in, 70-7 I

Siege, Durings the,

Sightsecing, $+0^{5}$

$53-55$

Sunday in, 202-209
Paris-continucel

Telegrams, 68

Telephones, 69

Theatres of, $7+-79$

Third Republic in,

Tramways of, 66

Velodromes, $82-83$

Weights and Neasures, $7-8$

Park of the Buttes-

Chaumont, I 48

Passy, 100

Pere la Chalise Cemetery, If $6-7$

Petit Luxembours, I68

Petit Montrouge, IoI

Petit Trianon, ISo

Pier of the Eiffel

Tower, The, I 49

Place de la Bastille,

I $43^{-1}+4$

Place de la Concorde,

Physicians, I6 IO3-105

Place de la Madeleine, Seine, 86

Io6, Sèvres, 192-193

Place de l'Hôtel de Ville, I54

Place du Carrousel, I 25

Place V'endôme. The,

Plaisance, IOI

Pole Nord, The, $S_{2}$

Postal Rates and Ar-

rangements, $67-68$

Private Omnibuses, $0_{3}$ Programme of Amusements, A Sugigested, $6(y-70$

R.

RAXELAGH, 100

Restaurants,

$60,121,148$, ISI

Rubinson, 204

Roman Catholic

Churches-

Chapel of the Trinity, 195

La Madeleine. IOO, 208

Notre Dame Cathedral, $154^{-158,208}$
Roman Catholic

Churches-cont.

St. Angustine, IOT

St. Etiemne-du-Mont,

173

St. Eustache.

I 52-I 53,208

St. Germain l'Auxerrois, I 39- 140

St. Louis, I 20

St. Roch, 208

St. Sulpice, $20 \%$

St. Vincent de Faul

Sainte Chapelle, The, $158-159$

Rouen, 33

Rue Royale, The, Io6

Russian Church, 209

S.

SAINTE Chapelle, THE, I 5̧-159

St. Germain en Laye,

200-20I

Sevres Porcelain Manufactory, 192-193

Exhibition Rooms, The, 193

Musée Céramique,

Workshops, The, I93

Shopping in Paris,

I93

Sightseeing, $4^{-6}$ $70-71$

Skating Rinks, 82

Soutlampton, $3.5-36$

Square Cluny, 167

State Carriagses, Collection of, ISo

Statue of Blaise Pascal,

153

Statue of Jeanne d'Arc,

107

Statue of Léon Gam-

betta, 125

Statue of Marshal Ney,

I jo

Steamers, River, 60-67

Sinday in Paris,

202-209 
't.

TELEGKAMS, 68

Telephones, 68

Thames Steamers, The,

Theatres of paris, 37 $74-79$

Ambigu Commume, 78

Athence Cominute.

7)

Bonties latrisiennes,

Chitcau d'Eatu, 79)

Chuny, 79)

Coméclic Françatise, $70-77$

finlics Dramaticues, $78-70$

Giand Opera, $7+-70$

Noveall, 77

Odćrm, 77

Opérar Comique, 79

Pont St. Martin, 77

Renaissance, 77

phéatre des Varictés,

78

'liciatre du Chatelel,

'lnéntre Françatise,

$70-771$
Theatres of Paris, The

- - continned

Théatre du Gymnatse, 78

Théatre du Nouveautess, 70

Théatre du Palatis Royal, 78

'lieatre Sarah Bernlaralt, 77

Vaudeville, $7 \mathrm{~s}$

Tubaces, 8-10

Tomb of Napoleon I.. $114-116$

Tour St. Jacques, I 53

Trammatys, 60

'rianom, I77

Trocadéro, 1 lo

$V^{\prime}$

VAUGIRARD, IOI

Velodromes, 83

Velodrome Butlalo,

Velodiome de $\delta_{j}$ Seine, 83

Veludionie des

Princes, $8_{3}$

Velodione Munici- Zoological. Garien, pal, 83
Versailles, $176-191$

Versailles Park,

Bassin de Neptune, I $89-190$

Fountain of Apollo,

I 89

Fountain of Latone,

Grand Eau, The, 189

Tapis Vert, 189

Villette, 100

Voitures de Remise, 03

IV.

IVAXIVORKS, St $_{4}$

Veights and Measures, $7-8$

Y.

TOUNG MEN'S CHRIS-

TIAN ASSOCIATION, 206

Z.

THE, ITA-175
Cascatcle de Rocitilles,

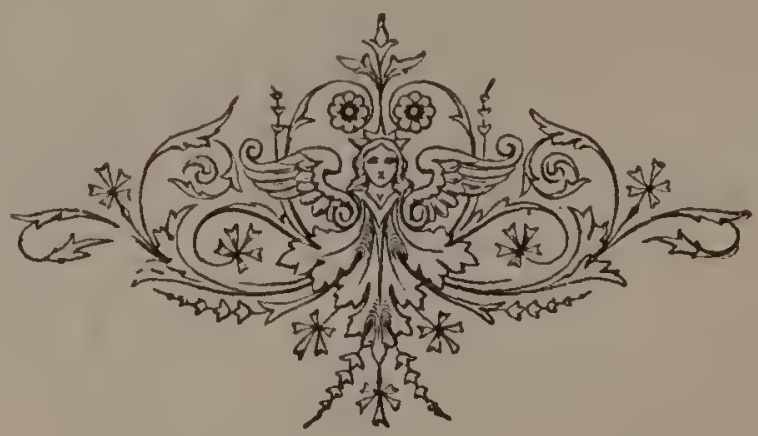




\section{WARD, LOCK \& CO.'S \\ GUIDE BOOK ADVERTISER.}

For Terms, Ecc, apply Mr. Henry S. Thomas, Advertising Mlanager, WARWICK HOUSE, SALISBURY Souare, Fleet Street, London, E.C.

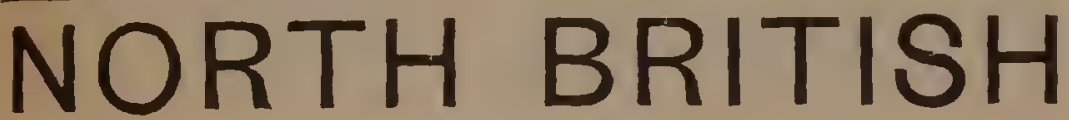

AND

Established 1809.

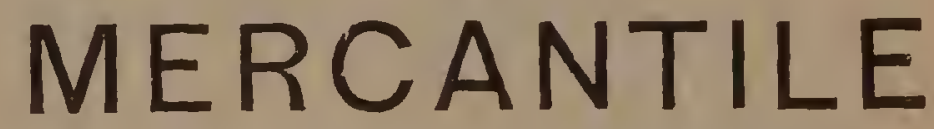

INSURANCE COMPANY.

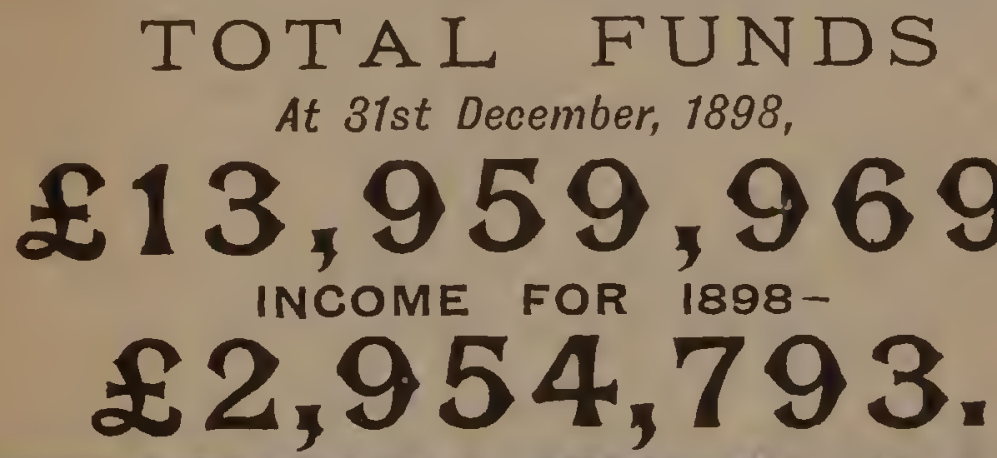

\section{Life Department.}

Most Policies are World Wide from date of issue.

Policies free from vexatious conditions.

Claims Paid on proof of Death and Title.

New Systems of Insurance.-Family Settlement Policies; Threefold Option Policies, etc.

NINETY PER CENT. of the Profits in the Life Department are reserved for distribution among the Assured on the Participating Scale. The profits are divided every five years. Next Division, 3 rst December, Igoo.

Annuities of all kinds granted on the most faveurable terms.

\section{Fire Department.}

Nearly every description of Property, at home and abroad, insured at the Lowest Rates. Losses by Lightning, Damage by Explosion of Gas in buildings not forming part of any Gas Works, made good. Rents of Buildings insured.

SECURITY, LIBERALITY, AND PROMPTITUDE in Settlement of Claims are characteristics of this Company.

Prospectuses and every information can be abtained at the Chief Ofices: London: 61. Threadneedle Street, E.C. :

(West End Branch), 8, Waterloo Place, S.W. Edinburgh : 64, Frinces Street. 


\section{HAND-IN-HAND}

FIRE \& LIFE INSURANCE SOCIETY, 26, NEW BRIDGE STREET, LONDON. E.G.

Instituted in 1C96. Extended to Life Insurance, 1836.

The oldest Insurance Office in the World.

There being no Shareholders, all Profits are divided amongst the insured. Fire as well as Life.

BONUS RETURNS.

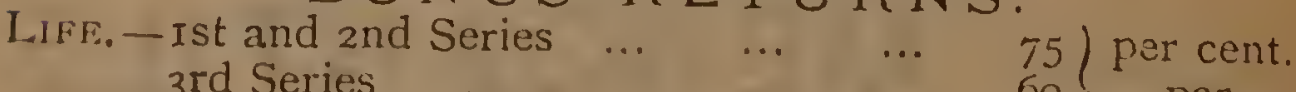
$\left.\begin{array}{llllll}3 \text { rd Series } & . . & \ldots & \ldots & \ldots & 60\end{array}\right\}$ per $4^{\text {th Series }} \quad \ldots \quad \ldots \quad \ldots \quad 45$ rising to $50 /$ Annum.

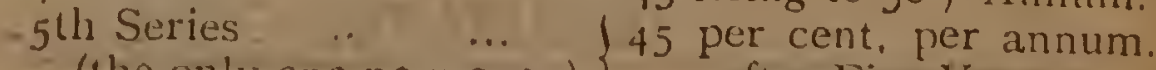

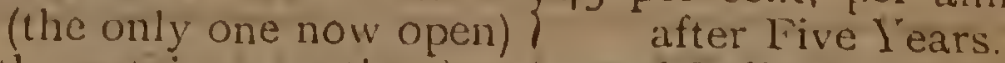

FrRe (ivith certain exceptions).-Annual Policies, one year's premium out of five. Septennial Policies, varying with the nature of the risk, 25 to 50 yer cent. at the end of each 7 th year.

No Poltcy holder is subject to any Personal Liability.

The Directors are willing to appoint as Agents persons of good pusition and chtracter. H. H. RAY, SECRETARY.
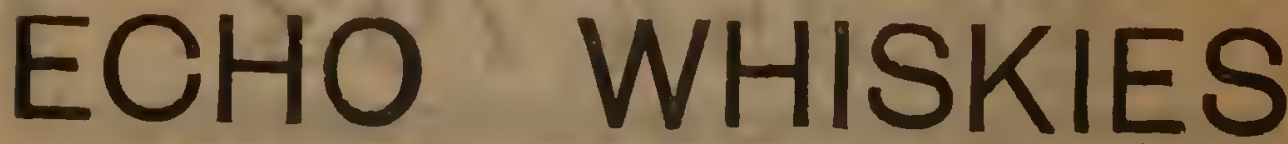

TRADE

$3 /-$
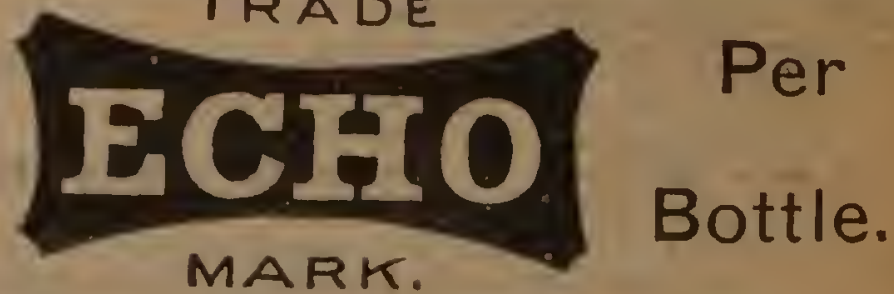

THE BEST YALUE ON OFFER.

AUSTRALIAN WINES

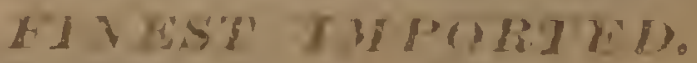

"BOOMERANG" BRAND.

2/- Per Quart Flagon.

TO BE OBTAINFD OF ALL LICENSED DEALERS.

WHOLESALH OF-

C. KINLOCH \& CO., Ltd., London, E. 


\section{EVERY HOUSEHOLD AND TRAVELLING - TRUNK}

\section{ought to contain A BOTTLE OF
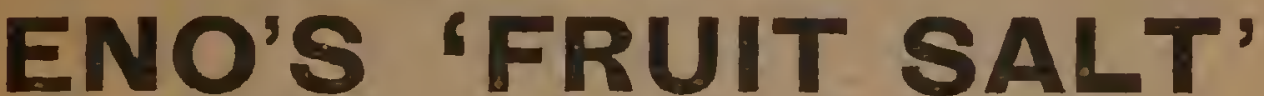

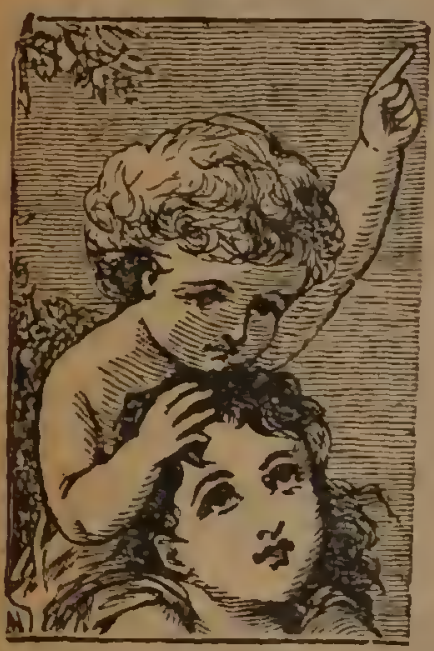

It prevents any over-acid state of the blood, it should be kept in every bedroom and traveller's bag in readiness for any emergency. Be careful to avoid rash acidulated salines, and use ENO'S 'FRUIT SALT' to prevent the bile becoming too thick and (impure) producing a gumny, viscous, clammy stickiness or adhesiveness in the mucous membrane of the intestinal canal, frequencly the pivot of diarrhœa and disease. ENO'S 'FRUIT SALT' prevents and removes diarrhcea in the early stages.

WITHOUT SUCH A SIMPLE PRECAUTION

THE JEOPARDY OF LIFE IS IMMENSELY INCREASED

ENO'S 'FRUIT SALT' is the best and simplest preparation for REGULATING the action of the LIVER that has yet been discovered, and removes effete gouty, rheumatic matter, or any form of poison, from the blood. No one should go for a change of air WITHOUT a SUPPLY of THIS INVALUABLE PREPARATION.

\section{FEVERISH COLDS, SCARIET FEVER,} SMALL POI, PYEMTA, ERYSTPELAS, MEASLES, GANGIENE, and almost every mentionable disease. - "I have been a nurse for ten years, and have nursed cases of Scarlet Fever, Pyxemia, Erysipelas, Measles, Gangrene, Cancer, and almost every mentionable disease. During this time I have not been ill for a single day, and this I attribute to the use of ENO'S F FUIT SALT:' which has kept my BLOOD in a PURE STATE. I recommend it to all my Patients during convalescence Its VALUE as a MEANS of HEALTH CANNOT be OYERESTIMIATED."- A PROFESSIONAL NE"RSE (Qunlificd.)

The effect of ENO 'S 'FRUIT SALT' U Upon anY DISORDERED, SLEEPLESS and FEVERISH condition is SIMPLY MARVELLOUS. It is, in

fact, NATURE'S OWN REMEDY, and a a UNSURPASSED ONE.

C d UTION. - See capsule marlied ENO S 'FRUIT SALT: Wishout it you have a WORTHLESSIMITATION. Prepared only by S. C. IENO, Ltd., - FRUXT SALX' WORES, LONDON, by T, C, ENO'S Patent. 


\section{READ FENNINGS' EVERY MOTHER'S BOOK.}

Ask your Chemist or Grocer, for a FREE Copy, or one will be sent POST FREE on application by lotter or post card. Diract A. FENNINGS, West Cowes, I.W.

\section{DO NOT LET YOUR CHILD DIE} Fenning, Children's Pocuders Prevent Conuulsions,

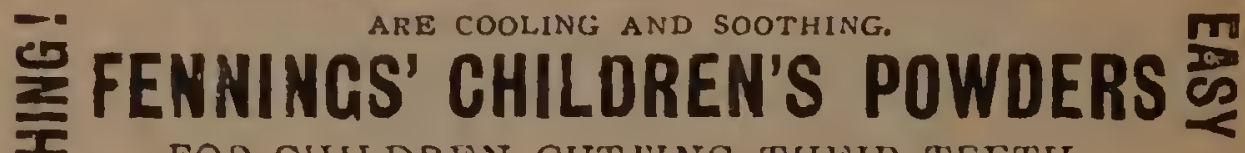
FOR CHILDREN CUTIING THEIR TEETH.

F To preve Il Convulion (D) not contrin Antimony, Calone

U To preve il Convations. (D) not conthin Antimony, Calomel, -

un Opium, Morphia, or anything injurious to a tender babe.)

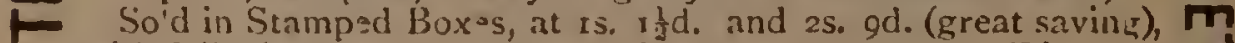
with full directions. Sent post free for 15 stamps. Direct to

U At.Fred Fenvings. West Cowes, 1.W.

4 Read FENNINGS EVERY MOTHER'S BOOK, which contrins Viluable Hints on Feedint, Teething, Wcaning, Sleep. ing, \&ce. $A$-k yo 1 -Chernist for a firee Copy.

FEVNIVGS LVIERV II TTHERS BUOK sent Post Free on applicatis't by letter or post card. Direct, Alfred

FEvnIigs, We t C iwes, I.W.
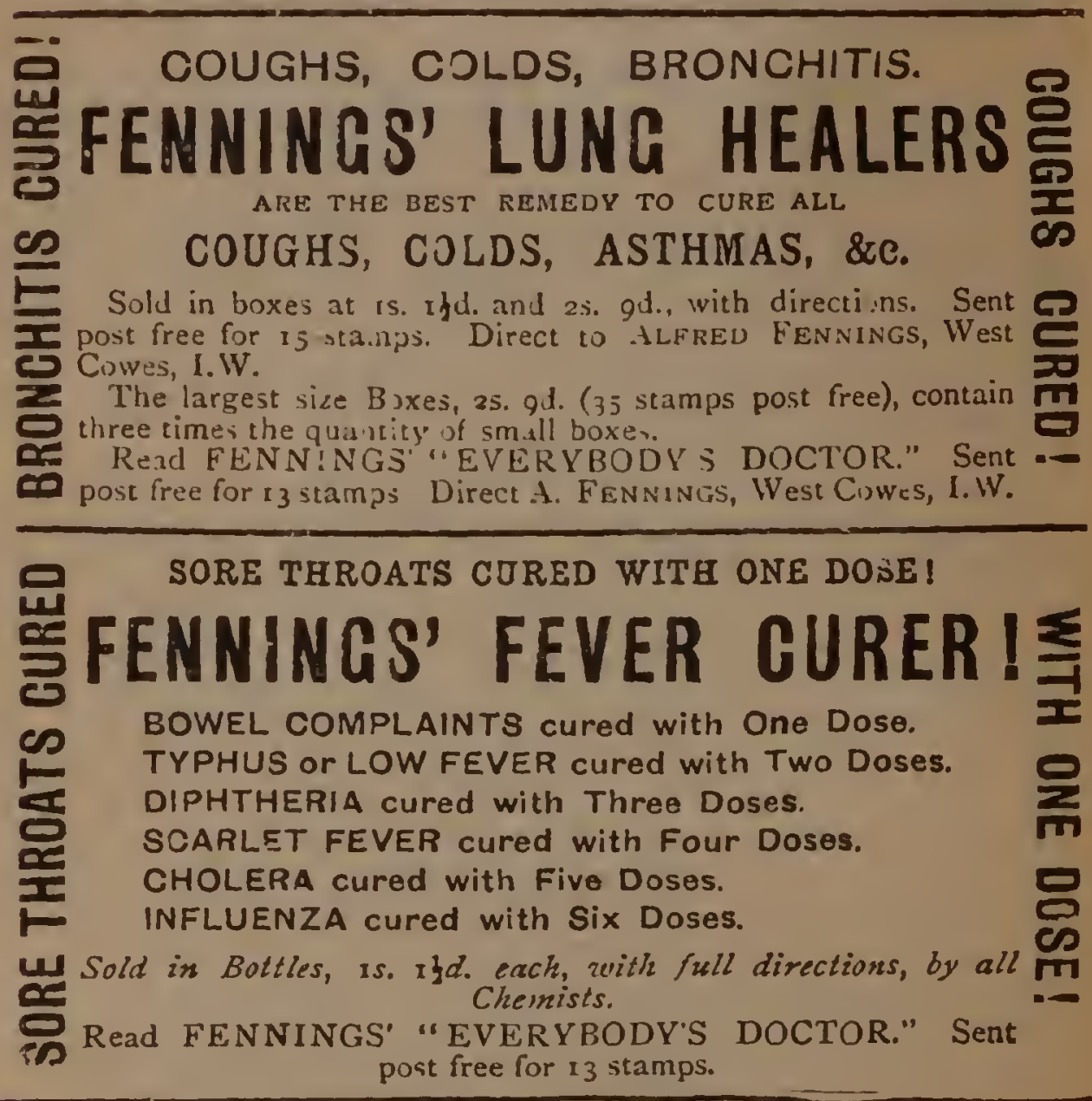


\section{DR. J. COLLIS BROWNE'S}

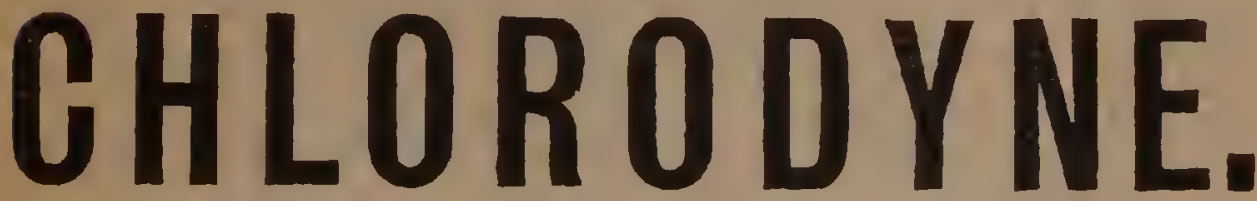

\section{THE ORIGINAL AND ONLY GENUINE.}

14 RORVNE is admitted by the Profession to be

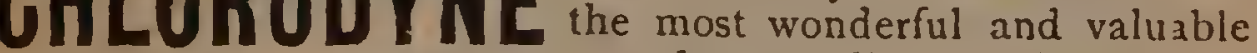
remedy ever discovercd.

A 1100 D 12 is the best remedy known for ULU1] C Coughs, Consumption, Bronchitis, Asthma.

CHLORODYNE

effectually checks and arrests those too often fatal diseases - Diphtheria Fever, Croup, Ague.

CHLORODYNE acts like a charm in Diarrhœa, and is the only specific in Cholera and Dysentery

CHLORODYNE effectually cuts short all attacks of Epilepsy, Hysteria, Palpitation, and Spasms.

is the only palliative in Neuralgia, Rhematism, Gout, Cancer, Toothache, Meningiti;, \&c.

From Dr. B. J. BOULTON \& CO., Horncastle. "We have made pretty extensive use of Chlorodyne in our practice lately, and look upon it as an excellent direct Sedative and Anti-spasmodic. It scems to allay pain and irritarion in whatever organ, and from whatever cause. It induces a feel ng of comfort and quietude not obtainable by any other remedy, and it seems to possess this great advantage over all other Sedatives, that it leaves no unpleasinnt after-effects."

"Earl Russell communicated to the College of Physicians that he received a dispatch from Her Majesty's Consul at Manilla, to the effect that Cholera had been raging fearfully, and that the only remedy of any service was CHLORODYNE."-See Iancer, Ist December, 1864.

\section{CAUTION. - BEWARE OF PIRACY and IMITATION8.}

Caution.-Vice-Chancellor Sir W.PAgE Wond stated that Dr. J. Collis BROIVNE was undoulutedly the Inventor of CHLORODYNE; that the story of the Defendant FrREMAN was deliberately untrue, which, he regretled to say, had been sworn to. - See Times, 13th July, 1864 .

Sold in Bottles at 1s. 11\% 25. 9\%, and $4.5 \%$ each. None is genuine without the word; "DR. J. COLLIS BROWNE'S CHLORODYNE" on the Government Stamp. Overwhelming Medical I'estimony accompanies each bottle.

SOLE ManUfacturer :-

\section{J. T. DAVENPORT,}

33. Great Russell Street, Bloomsbury, London. 


\section{Remember}

\section{D $\mathrm{R}$.}
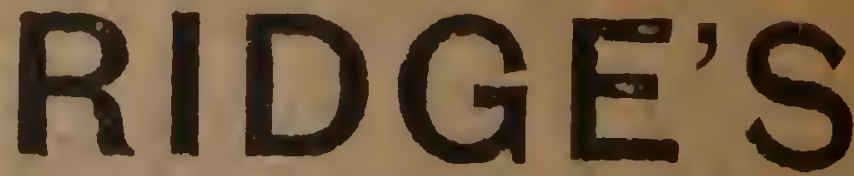

PATENT
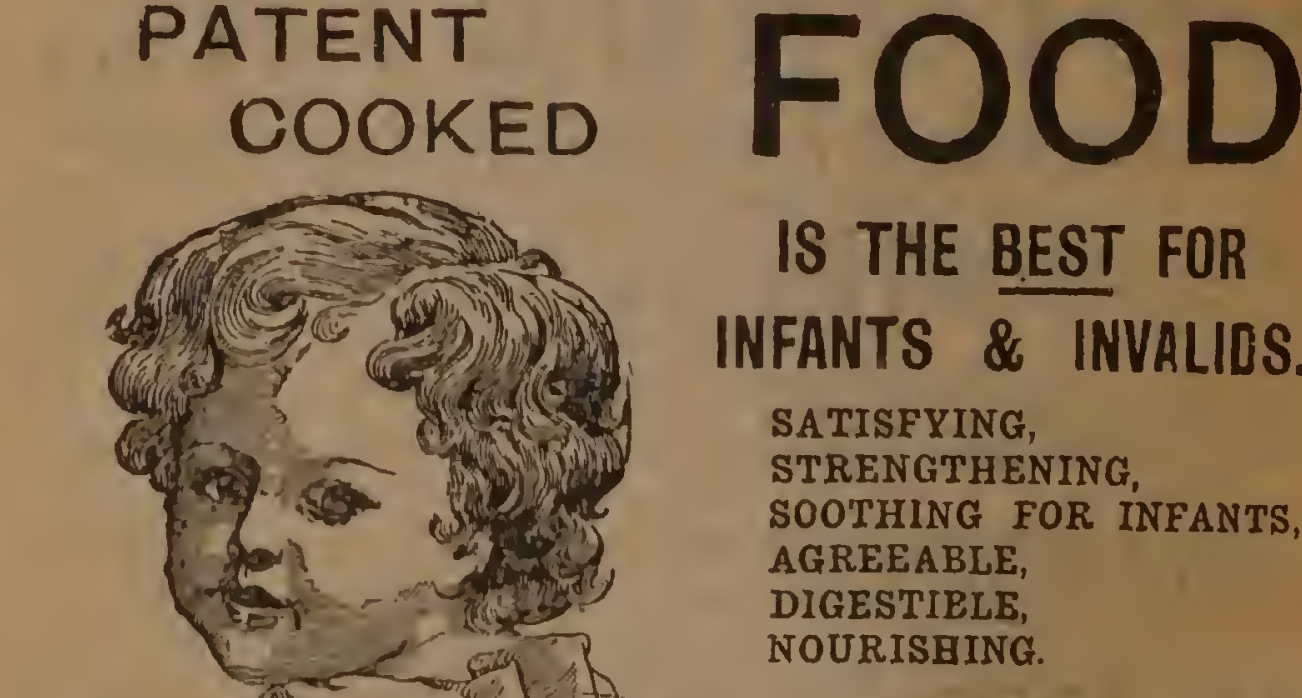

\section{IS THE BEST FOR INFANTS \& INVALIDS.}

SATISFXING, STRENGTHENING, SOOTHING FOR INFANTS, AGREEABLE, DIGESTIRLE, NOURISBING.

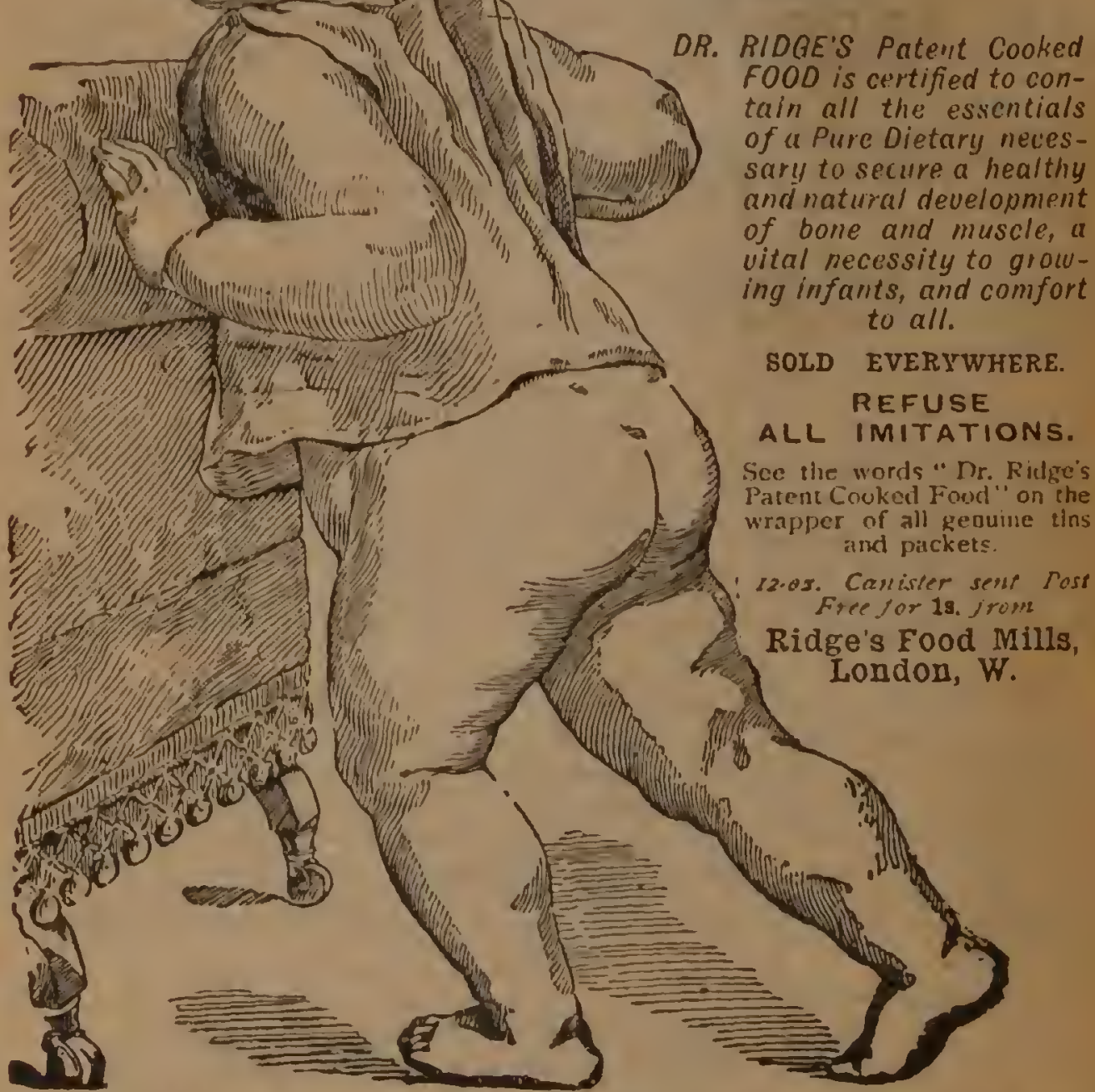

"He's had his Rldge's Food-and now goes trotting along." 


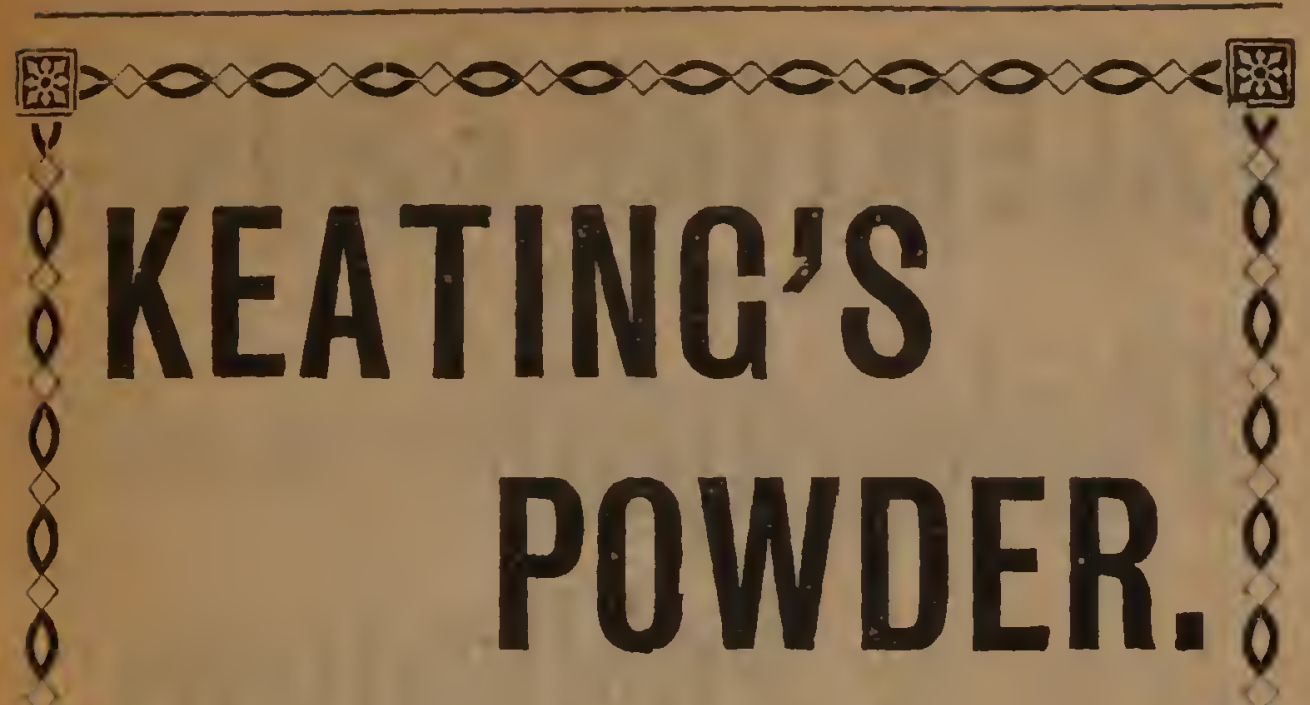

0

HARMLESS TO ANIMALS.

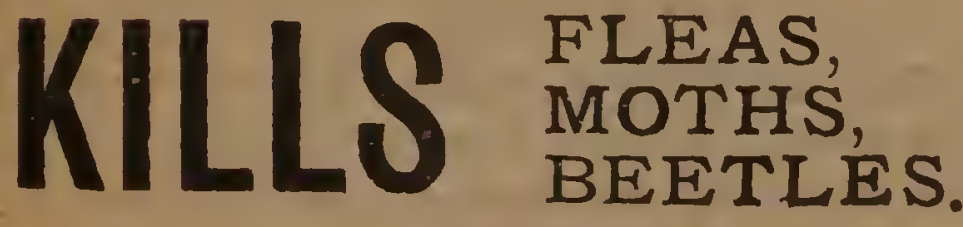

HARMLESS TO ANIMALS.

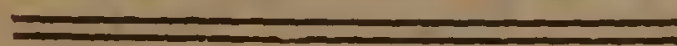

Sold in Tins, 3d., 6d., 1s. each.

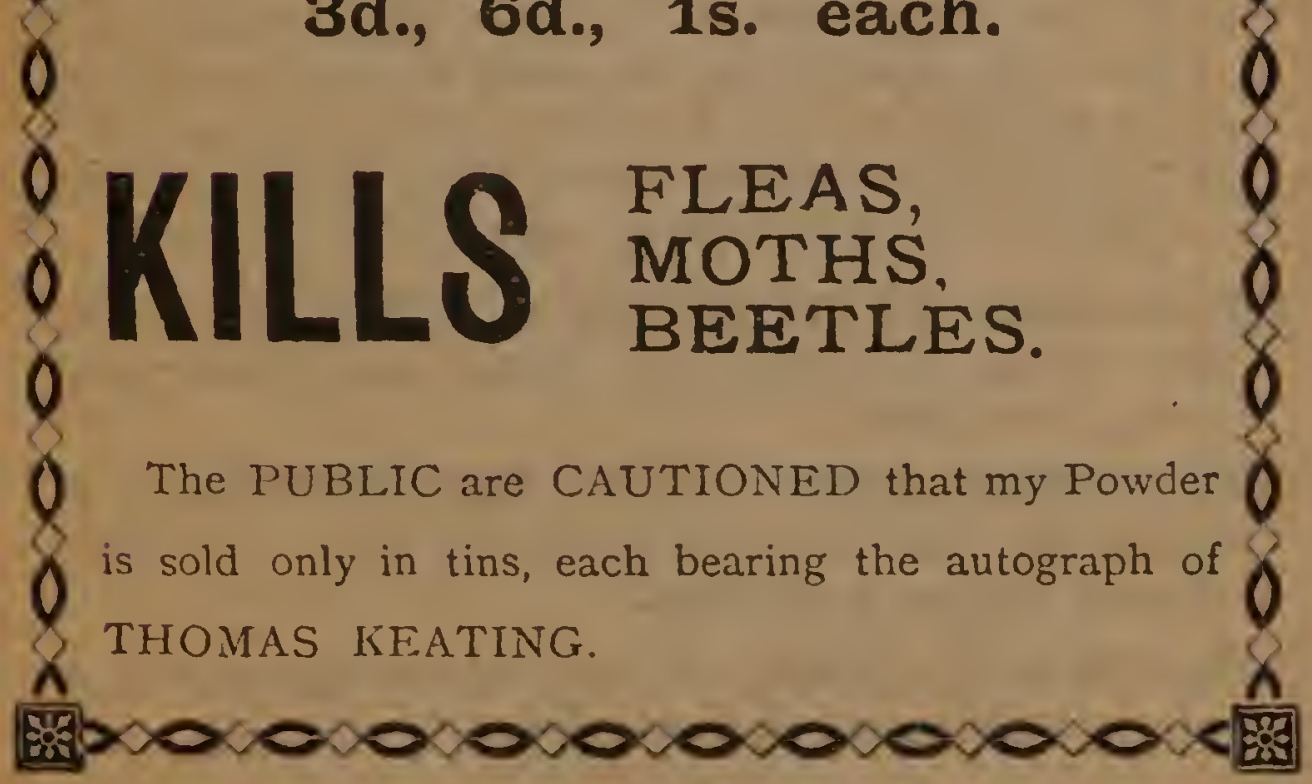




\section{VALENTINE \& SONS' (LIMITED),}

Photographic 橉 潾

潇 棌 㴽 Publications

Comprising over Eight!l Thousand Fiews of the rinest scener!y in Euglamd, Scothand, "rales, Irelaud, Nomury, New" Zealand. spain, Movocro, Jameraca, Marleiva, dic. 'to be had from Agents and Dealers throughout the World.

YALENTINE \& SONS' LOCAL YIEW BOOKS, by an improvel Collotype Process. These books are unequalled in quality and style at moderate cost. A chaste and cheap Souvenir of Home Scenes.

COLOUR PHOTOGRAPHY.-The latest and nearest approach to Photography in Natural Colours, by which very charming Coloured Views are produced at prices which place them within the reach of buyers with the most moderate means. A Splendid Series of the United Kingdum, in this process, is now ready, and can be had in various furms-unmounted, mounted, and framed.

PICTORIAL POST CARDS \& NOTE PAPER, in a variety of processes, of almost every locality, can now be obtained.

CHRISTMAS, NEW YEAR, AND BIRTHDAY CARDS, with local views, in the latest and most popular designs, a speciality.

LANTERN SLIDES, Plain and Coloured, can be had of any View published by the Firm. 


\section{READ FENNINGS' EVERY MOTHER'S BOOK.}

Ask your Chemist or Grocer, for a FREE Copy, or one will be sent POST FREE on application by letter or post card. Direct A. FENNINGS, West Cowes, I.W.

\section{DO NOT LET YOUR CHILD DIE} Fennings' Children's Powders Prevent Conuulsions.

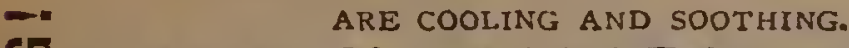 \\ FENIIYGS' CHLLREN'S POWDERS}

FOR CHILDREN CUTIING THEIR TEETH.

To prevent Convulsions. (D) not contain Antimony, Calomel, -

Opium, Morphia, or anything injurious to a tender babe.) $\boldsymbol{m}$

So'd in Stamped Boxes, at IS. $1 \frac{1}{2} \mathrm{~d}$. and 2S. gd. (great saving), in with full directions. Sent post free for 15 stamps. Direct to

U Alfred FenNings. West Cowes, I.W.

IL Rad FENNINGS EVERY MO'THER'S BOOK, which

contains Valuable Hints on Feeding. Teething, Weaning, Sleep.

ing, \&c. Ask you Chemist for a Firee Copy.

FEVNINGS LVERY MOTHER'S BUOK sent Post Free

on application by letter or post card. Direct, ALFRED

Fennings, We it Cowes, I.W.

COUGHS, COLDS, BRONCHITIS.

FENNISGS LUAG HEALERS
COUGHS, COLDS, ASTHMAS, \&C.

Sold in boxes at $15.1 \frac{1}{2} d$. and 25 . gd., with directi.nns. Sent $C$ post free for 15 stamps. Direct to Alfred Fennings, West Cowes, I.W.

The largest size Boxes, 2s. 9d. (35 stamps post free), contain three times the quantity of small boxes.

Re id FENNINGS' "EVERYBODV'S DOCTOR" Sent "post free for 13 stamps. Direct A. FENNings, West Cowes, I.W.

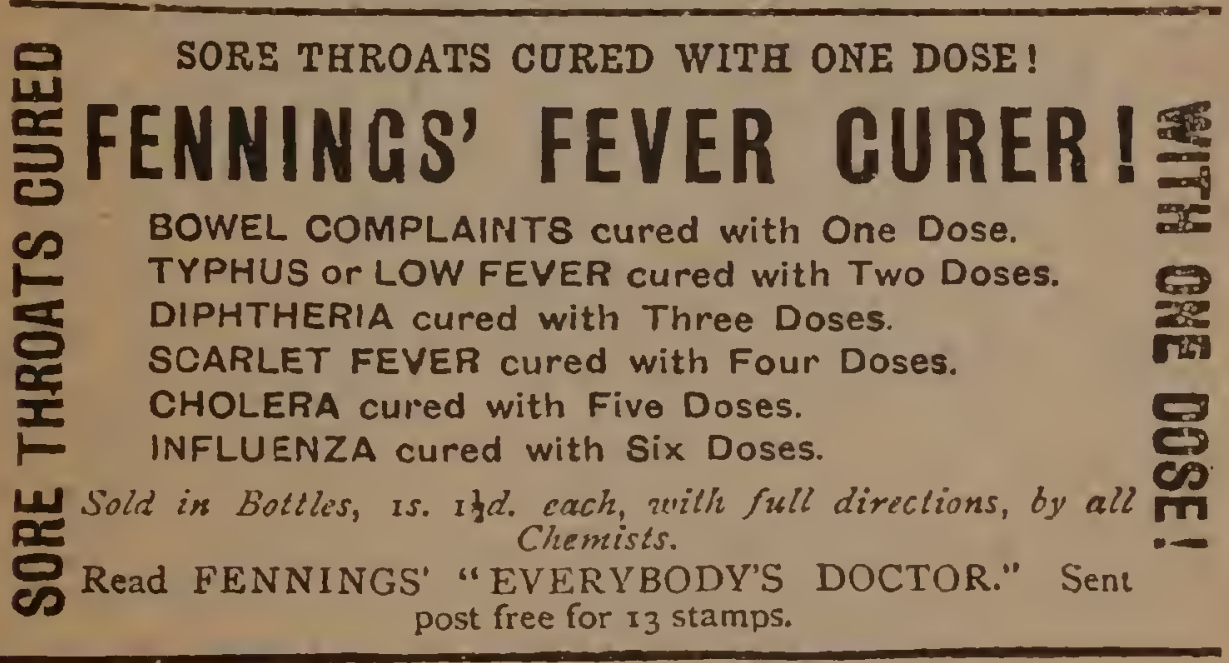

Observe on each of the genuine Powders is printed

FENNINGS' CHILDREN'S POWDERs, with my Trade Mark in the Centro"A Baby in a Cradle." 

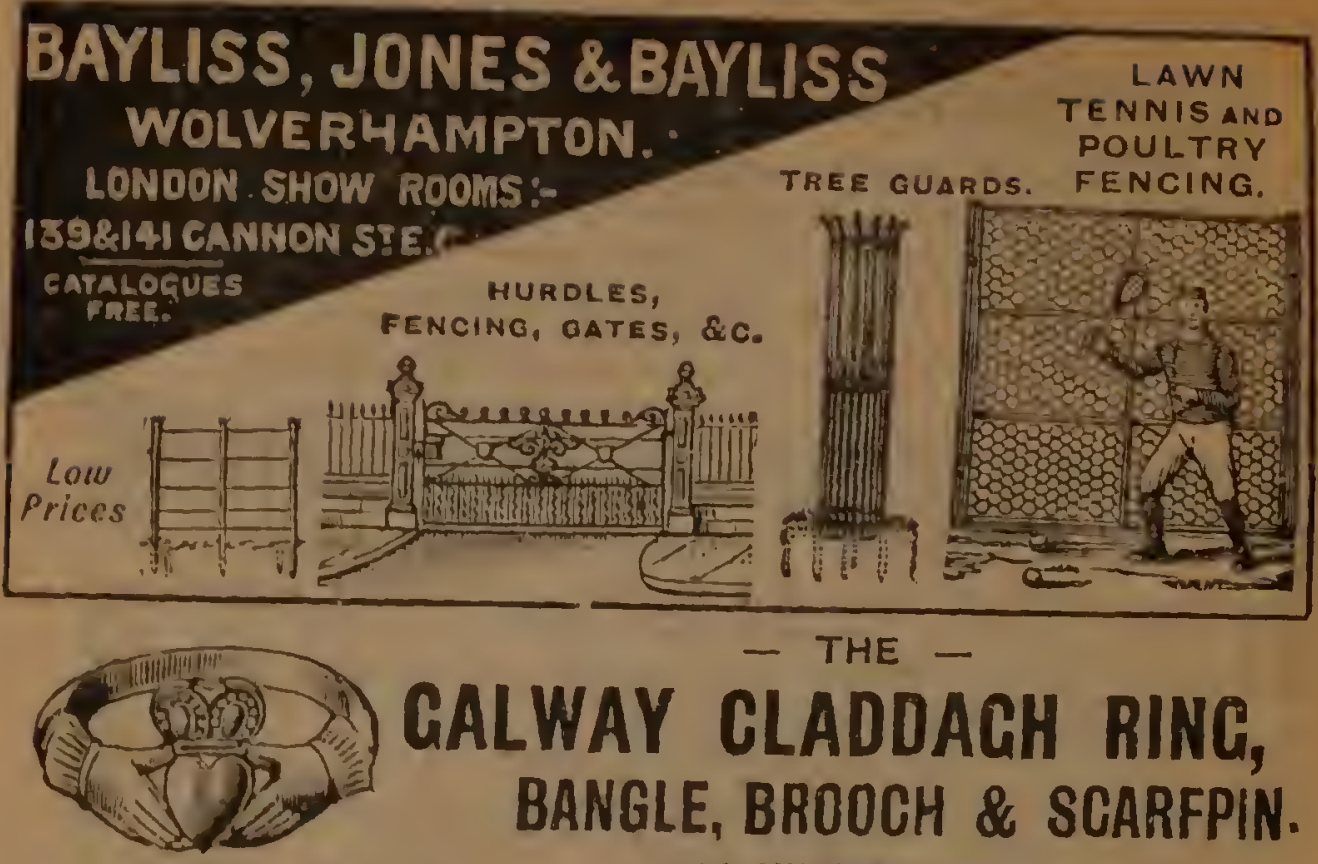

As SUPPLIED TO-

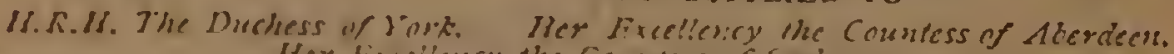

Hex finceliency the Combers of carrosam.

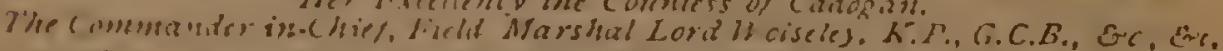
An ancien lrish design signifying "Love and Friendstip lieign. GOLD CLADI)AGII RINGS FROM 20\%

Connemira Marble and Irish Bog oak Jewcllery and Ornaments. Seml for Desirifize Particalirys.

T. DILLON, Irish Art Joweller, GALWAY \& ATHLONE, IRELAND.

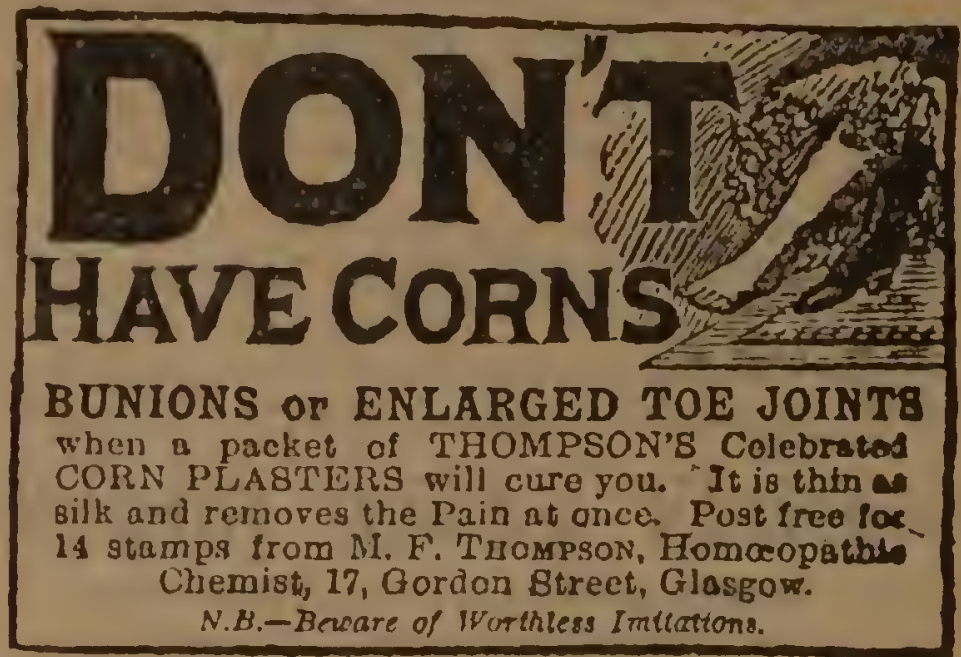

LADIES should take Dr Simpson's Arsenical

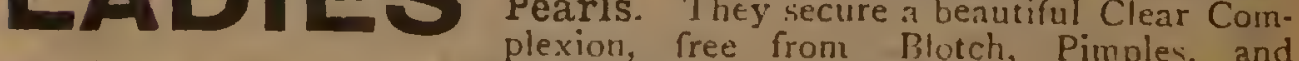
Rounhness, Fost free $2 / 9$ and 4/6," Altou, use Dr. Simpson s Arsenical Soap, which is invalualle, for Complexion. Tiablets lod. each. Box of 3 Tablets, 2/- Only from

M. F. THOMPSON, Homeopathic Chemist; 17, GORDON STREET, GLASGOW.

Best Selection in Scotland of

Sponges, Bath Gloves, Flesh Brushes, Perfumery, Toilet Requisites, \&c. 

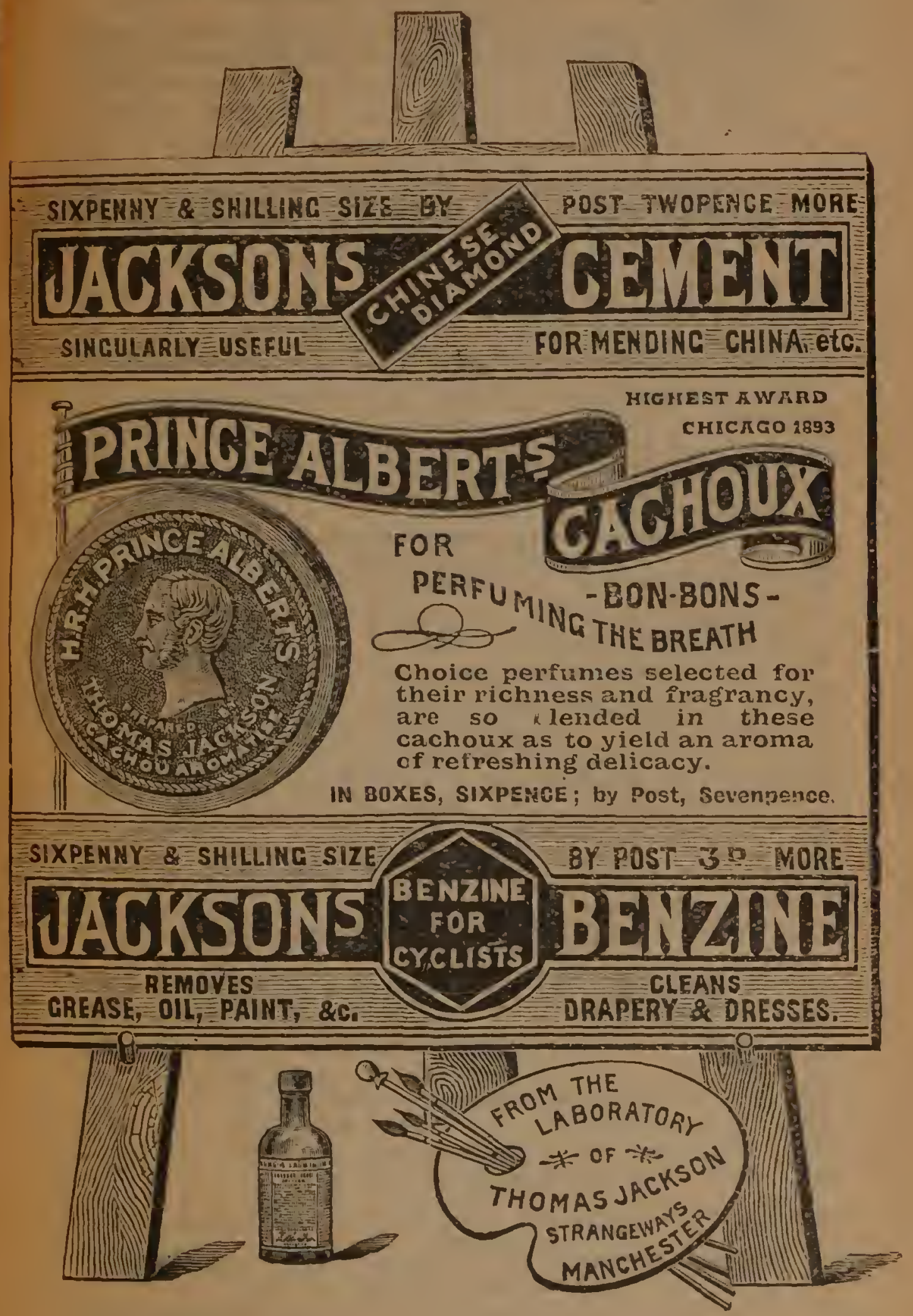


\section{READ FENNINGS' EVERY MOTHER'S BOOK.}

Ask your Chemist or Grocer, for a FREE Copy, or one will be sent POST FREE on ?,pnltcation by letter or post card. Direct A. FENNINGS, West Cowes, I.W.

\section{DO NOT LET YOUR CHILD DIE} Fennings' Children's Powders Prevent Convulsions,

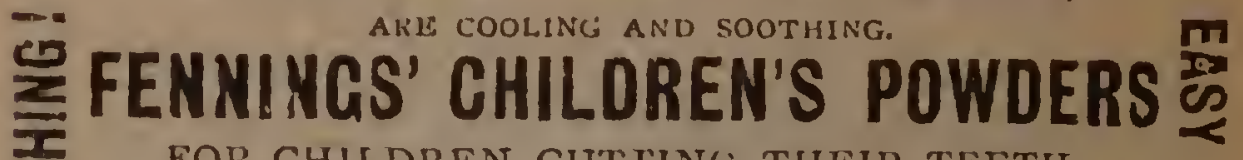

FOR CHILDREN CUTIING THEIR TEETH.

To preve te Convulions. (D) not contaiu Antimony, Calomel, $\rightarrow$

Opium, MIsrphia, or anything injurious to a tender babe.) $\mathbf{m}$

So'd in Stamped Box s, at rs. ritd. and 25 . gd. (great saving), in with full direction:. Sent post free for 15 stamps. Direct to

U Alitrib Fisnnings. West Cowes, I.W.

U Real FliNNINGS LVI:RY MO'IHFR'S BOOK, which

of contains Valuable Hints on Feeding, 'T"eething, Weaning, Sleep. ing. Sec. Ank your Chemist for a linee Coppy.

IIENINLiS liVIiRY M J IHER'S BHOK sent Post Free on application lyy letter or post vard. Direct, Alfred

FenNings, Weit Cuwes, L.W.

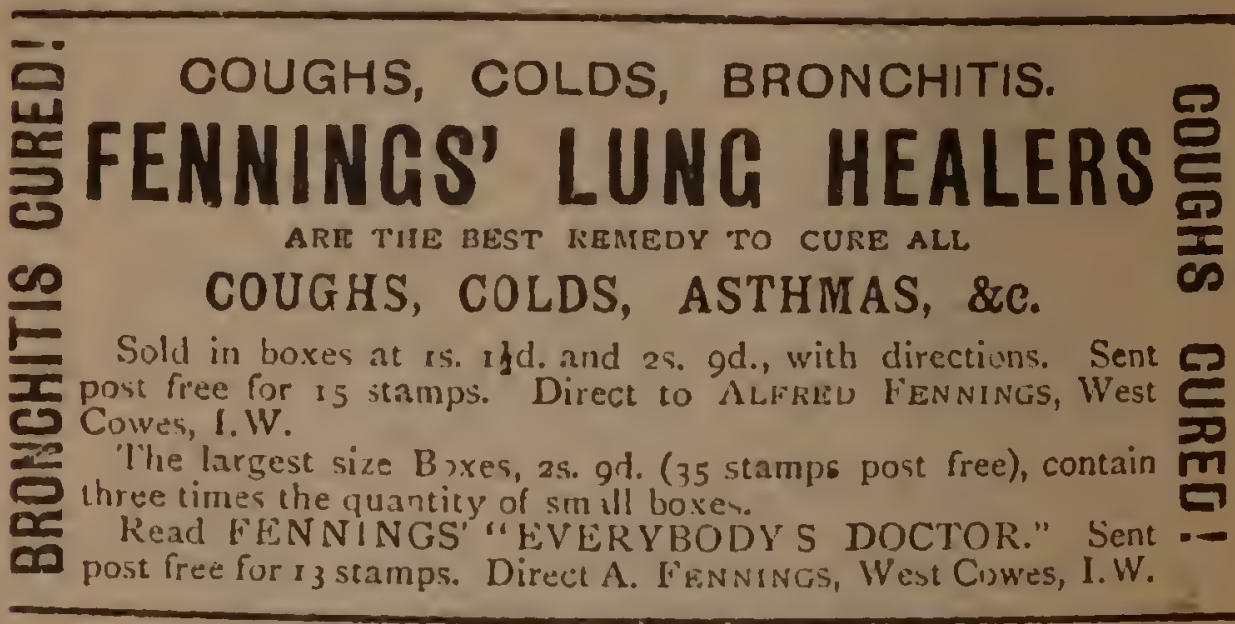

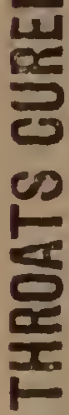

SORE THROATS CURED WITH ONE DOSE!

\section{FENNINGS' FEVER QURER}

BOWEL COMPLAINTS cured with One Dose.

TYPHUS or LOW FEVER cured with Two Doses.

DIPHTHERIA cured with Three Doses.

SCARLET FEVER cured with Four Doses.

CHOLERA cured with Five Dases.

INFLUENZA cured with Six Doses.

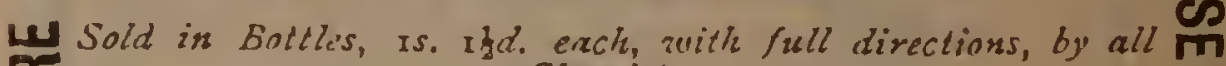

ce

Read FENNINGS" "EVERYBODY'S DOCTOR." Sent post free for $I_{3}$ stamps. 


\section{THERE IS NUTHING BETTER THAN

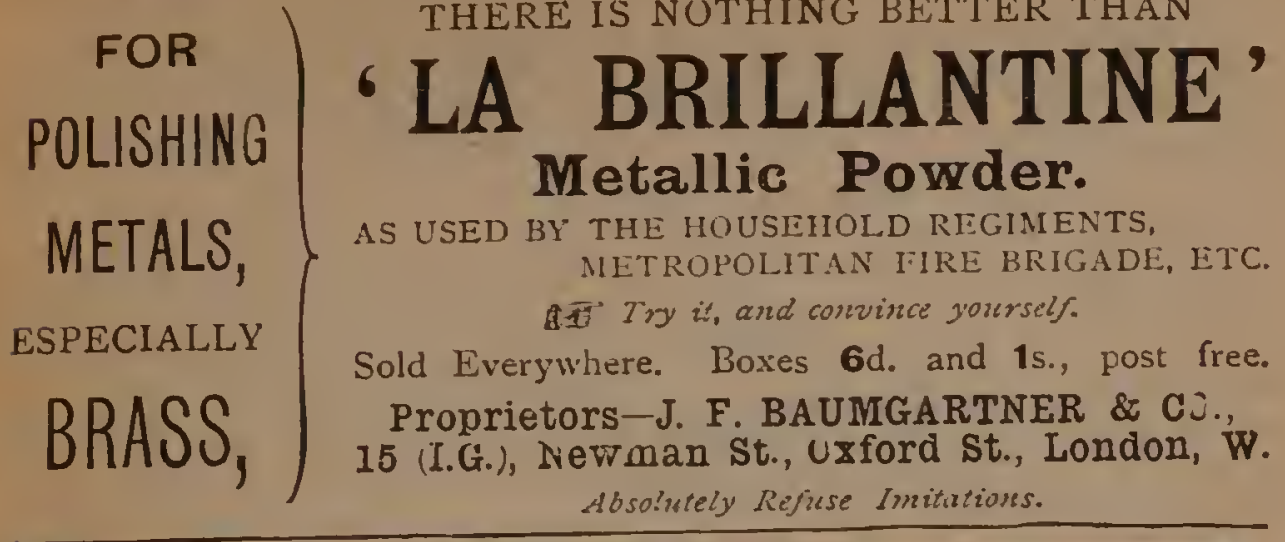

\section{CANTRELL \&
COCHRANE'S MINERAL WATERS Purveyors to Her Majesty's Houses of Parliarieat}

Manufacturers by special Appointment to H.R.H. the PRINCE OF WALES.

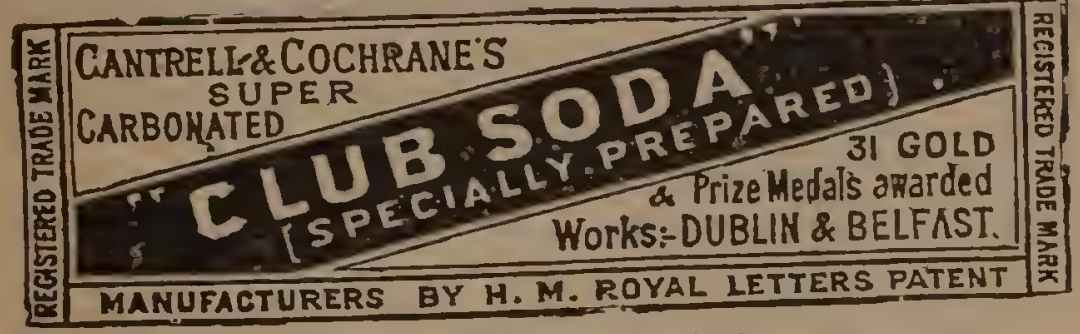

GINGER A LE, AROMATIC.

$$
\text { "SPARKLING" MONTSERRAT. }
$$

"CLUB ALE." "CLUB KOLA."

(NEW SPECIALITIES.)

GOLD and PRIZE MEDALS Awarded.

WORKS:-DUBLIN AND RELFAST.

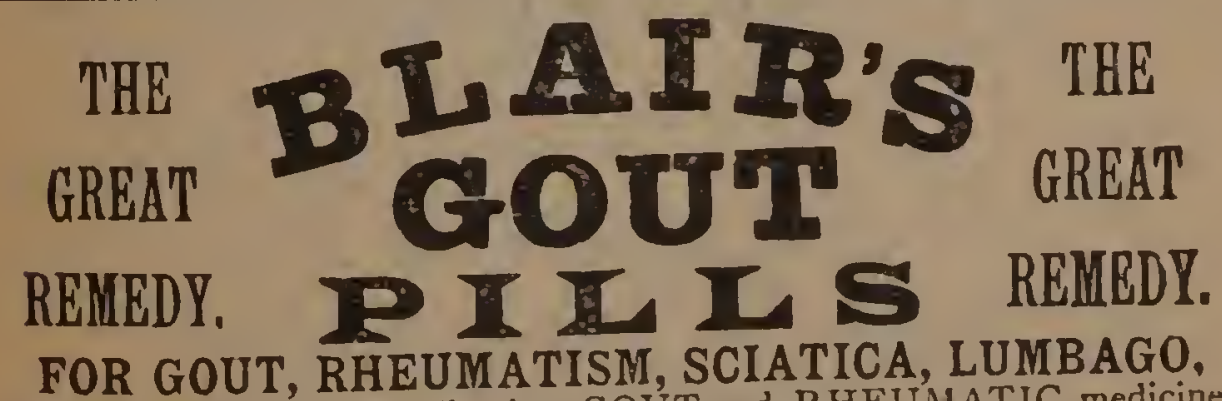

claim a superinrity over all other GOUT and RHEUMATIC medicines. They give relief from pain in a few hours, and a speedy CURE, without the clishtoct inronvenionce All Chemists ciad Siores, at $1 / 1$ ared $2 / 3$ por box. 
SULPHOLINE

Remoucs

Eruptiors,
Pimples,
Reples Disfigurements,

Ecze'ma, Bottles. Irricerson, Decreloping A Fair, Spotless Skin

\section{DEDEDP'O QUININE AND IRON}

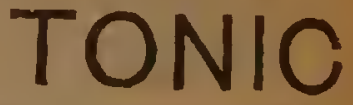

Improves appetite, promutes digestion, strengthens nerves, increases pulse, sives firmuess (1) the muscles, alters pale countenance, supulies deficient heat to weak circulatwons, overcomes bodily weariness and weakness, cures many: l'ainful complants,

Insist on having PEPPER'S TONIC.

6 MENIE, Ladies say these Towels are superior to all wher malies for cleanliness and comfort, and will last twice an long as any other Towel they have iried.

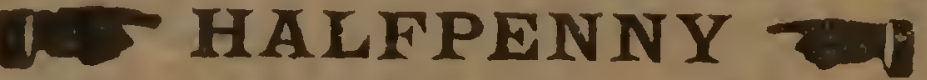

To be obtained from all thapers and Chemists. A FREE

SAMPldie will be sent to any lady naming these Guiden.

'Two dozen, post frec, 1/-

MLS HANES, TOUMET FOR

55, Fann Street, London, L.C. $\mathbf{O} \boldsymbol{\mathbf { L }} \boldsymbol{L}_{\text {LADIES. }}$

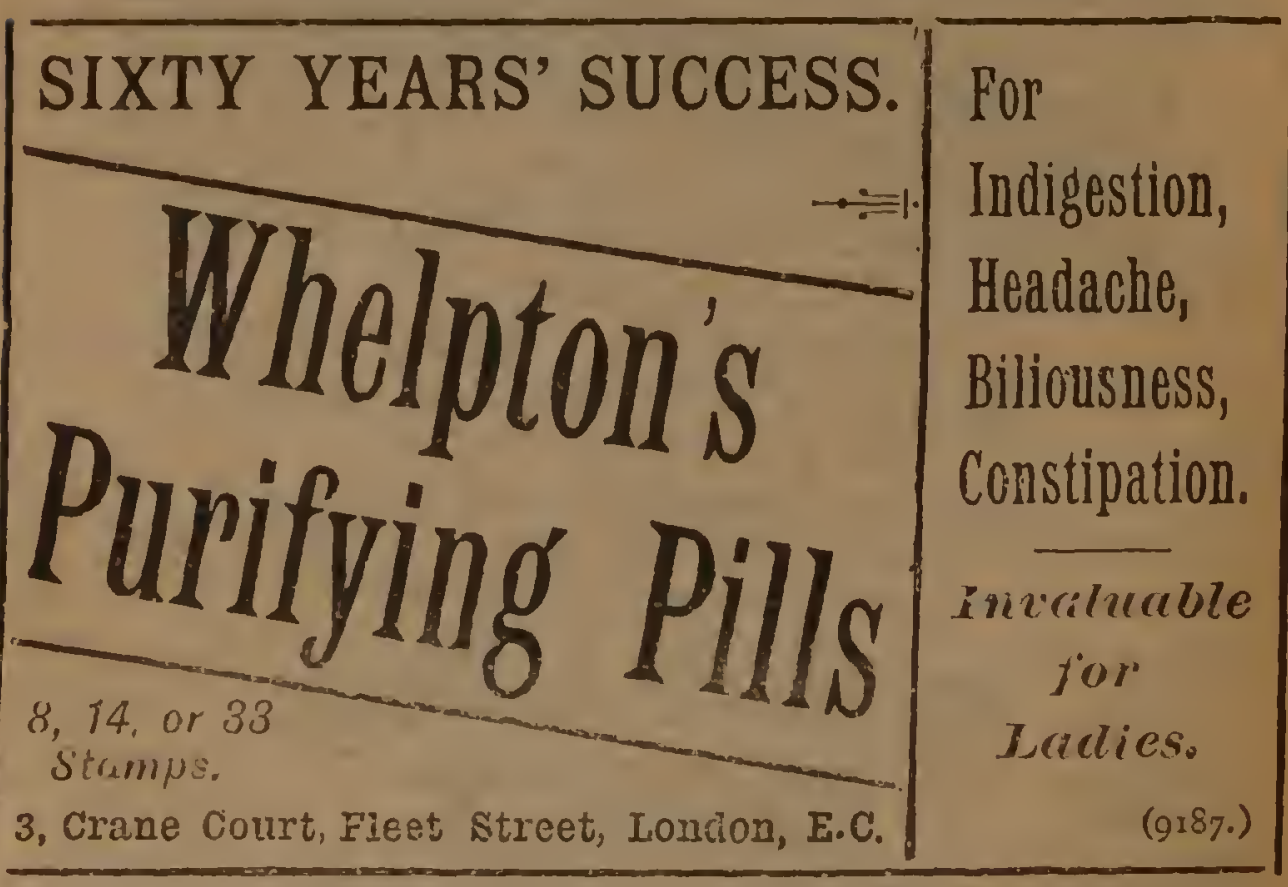

Dr. J.M.BARRIE says, "What I call the 'Arcadia' in 'My Lady Nicotine' is the

CRA Y E N I IXTURE

and $n 0$ other:"

Send for "Grickitt Notks," and Price List-post free,

J. J. CARRERAS, 7, WARDOUR STRELT, LONDON, W.

Agents in most Towns. 


\section{INSTANT RELIEF! RAPID CURE!}

\section{RHEUMATISM, GOUT,}

\section{LUMBAGO, \& SCIATICA,}

may be CURED or RELIEVED

by taking

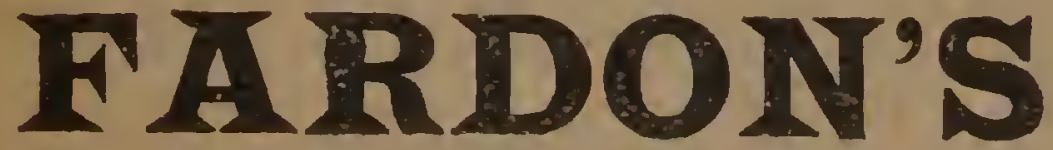

\section{INDIAN TINCTURE.}

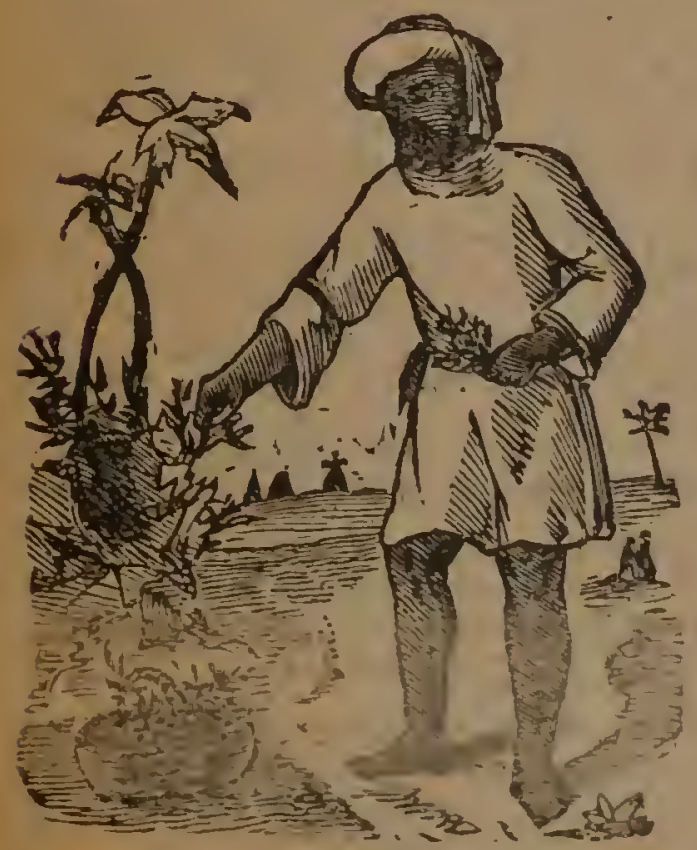

It is the quickest, safest, and most certain remedy for Rheumatism and all Pains in the Joints, \&c. A few doses give great relief. and if the Medicine is persevered with, cure results. It has been known for the past fifty years an the grent lient turat iy [or thi fantul malady.

To be obtained from all Chemists and Patent Iircdicine Vendors, in botties $11 \frac{1}{2}, 2 / 3$, and 46 ; or from the Froprietors-

\section{FARDON \& CO., MAIDSTONE.}




\section{GENERAL STEAM HAVIGATION COMPANY} 55. GREAT TOWER STREET, LONDON, E.C.

\section{LONDON AND EDINBURGH (GRANTON PIER).}

Every Wednesday and Saturday from each end.

iAlus: Clief Cabin, £1 2s, 0d.: Fore Cabin, 16s.; Return Tickets (aviliable for the reason). $£ 1$ 14s $0 \mathrm{~d}$. and $£ 14 \mathrm{~s} 6 \mathrm{~d}$.

In the nagniticent vessels of the Company on the Edinburgh route, the accommodation allotied to each parsenger is inusually spacious and very comfortable. The cuisine is excellent, and the charges moderate-comfort rather than an excessive rate of speed being the desideratum the Company offers to passengers. The vessels arrive at convenient hours, and at Gianton there are frequent trains to Edinburgh, which is a convenient centre from which to start for the Highlands, the Clyde, the Western Islands, and all
parts of Scotland.

\section{LONDON AND BORDEAUX,}

\section{SOUTH OF FRANCE AND THE PYRENEES}

From London and Bordeaux. Vierg Suluriay. Sec lime Table.

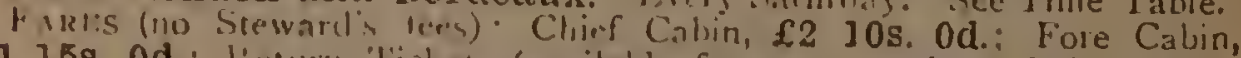

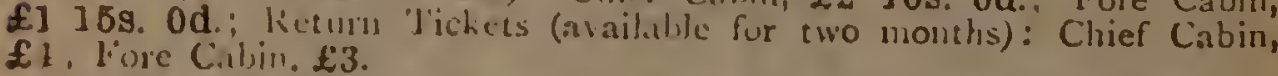

The magnificut urw Steamshup flimondelle, 3,000 tons measurement, 3, (x)o indicated horse power, titted wib electric light, and replete with encry convenience for pareengets, is now funning on this station.

Passenfere from lioricaux have the nption of landiag at Southanipton.

PYRENEES and back (Couk's Tours), mcluding hotel charges, provisions on board ship, rail, and carriage drives, \&ec.

11 days toirr, 9 guineas.

18 day's tour, 13 guineas.

These tours are deservedly popular.

LONDON AND HAMBURG ('Ii HARWICH, PARKESTON QUAY).

livery Wednesday and Saturday by Continental Express from Liverpool

Street Station at 8.40 p.m. The vessels leave Hamburg (Dalnann Quai) cvery Wednesday and Saturday at 11.30 p.m., or as soon after as the tide will permit.

A Special Train Service leaves Harwich for London and the Provinces on the arrival of the steamers.

Fares (Steward's fee included) between Lonion (Liverpoul Street) and Hamburg: First Class Rail and Saloon, $£ 1$ 17s. 6d.; S. cond Class Riil and Saloon, $£ 1$ 15s 9d.; Second Class Rail and Fore Cal,in, £1 5s. $9 d$. Return ?"ickets (avaiblile for two months): Firs Clas Rail and Salcon, E2 168. 3d.; Second Class Rail and Salwon, £2 13s. 9d.; Second Class Rail and Fore Cabin. $£ 1$ 18s. $9 \mathrm{~d}$.

The fast stenmers Seamiw and Peresrite, lighted with electricity, and with splendid passenger accommodation, are now running between Hamburg and Harwich.

LONDON TO HAMBURG (via THE THAMES).

Special Cheap Fares, allowing a stay of 3 to 5 days in Germany, and inclitling provisions whilst on the passage, are issued to Bicrcle Cluts and D. Parties of Gentlemen. Chief Cabin, return, $£ 2$ 15s. Od.

LONDON AND OSTEND.

Om and to Irongate and ST. KATHERINE'S WHARF (near the Tower). fom London to Ostend. Regular sailings twice a week.

F ARES (Steward's fee included): Chief Cabin, 78. 6d. or 6s. Return 1. kets (available for two months): Chief Cabin, 10s. 6d. or $9 \mathrm{~s}$.

\section{Swi. 'HEND, From LONDON RRIDFE WHARF.}

Daily during the season by the Company's Magnificent fast Saloon Steamers.
\& c. at cheap popular fares. The Company's new fast Saloon Steamer Eagle, one of the finest vessel on th. Thames, is now running.

G.S.N. CO.'S GUIDE, PRICE 3d. 


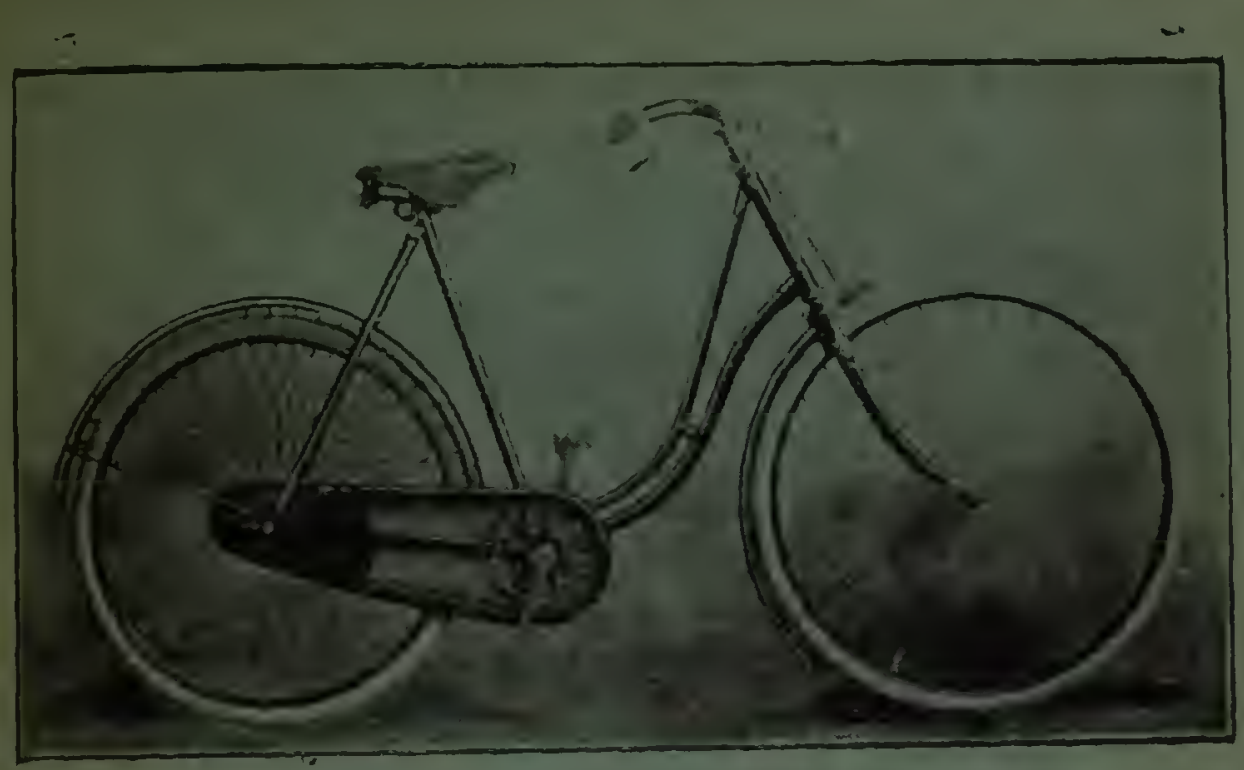

GRAND "EXCELSIOR" LADY'S SAFETY. COA PRICE \$17 60 KQ

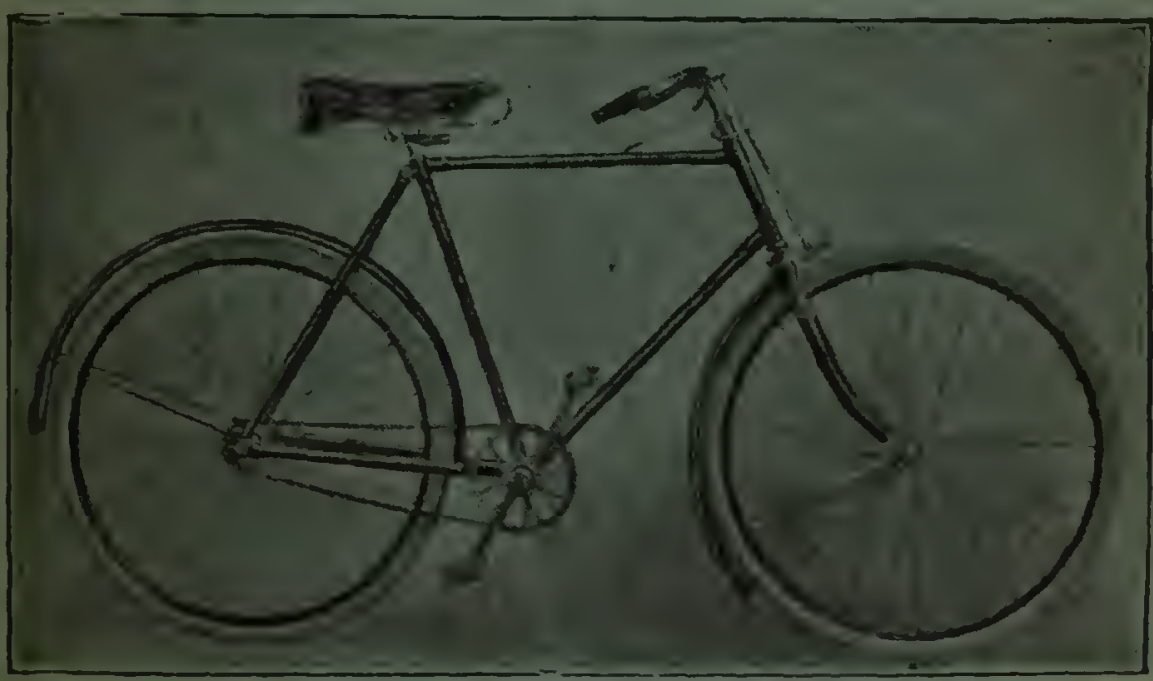

GRAND " EXCELSIOR" LIGHT ROADSTER. WO PRICE £16 160 Kم.

DROP A POST CARD FOR OUR 1899 ILLUSTRATED ... CATALOGUES. . .

BAYLISS, THOMAS \& CO., LTD., COVENTRY. Depots $\}$ LONDON-103, Newgate StREeT.
LiVERPOOL-10, St. GeORGE'B CREBCENT. 


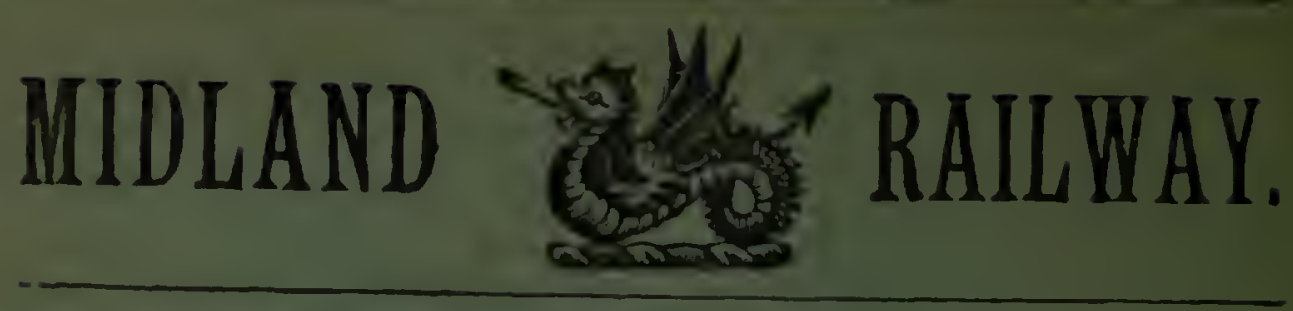

THE PICTURESQUE ROUTE PRINCIPAL HOLIDAY RESORTS

The Milland Line passes through the centre of England and Traverses tho BEST SCENERY IN THE MIDLAND COUNTIES and NORTH OF ENGLAND.

The "Midland" is the

MOST INTERESTING ROUTE TO SCOTLAND, einuracing the

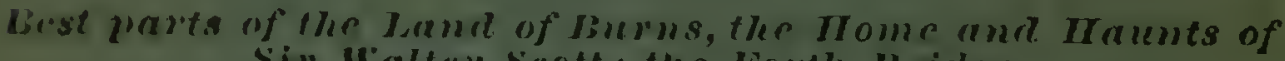
sir Wraltes scott; the Forth Hridye: and many other oljects of curiosity and interest.

BEFORE DECIDING

\section{WHERE TO SPEND THE HOLIDAYS}

APRLY FOR COPIES OF THE

\section{SPECIAL MOLIDAY PUBLICATIONS}

OP THR COMPANV, whICH COMPRISE-

rountry and Sersirle IIolidays, including List of Furni hed Apartments in the Country and by the Sea-side. Price 1rl. By l'ost $\approx$ ¿l.

Arueval Tourist Progremme, containing particulars of all the Conupany's Tourist Fares, Luggage Arrangements, \&c.

Illustruted Scotel Tourist I'vogromeme, containing particulars of Fares, Train Service, \&c., \&c., between Eingland and Scotland.

pocket Guide to the Mirland Ratlory, with numerous vignetted illustrationa. Price $\boldsymbol{G} \boldsymbol{d}$.

l'ocket Dirry and Ruide to the Iste of MTrus and the English Lalie District. Price $2 d$. Ry Post $3 d$.

"The Peuk of Derlygshive." Ry Post 4 d.

"Choose Aye the Millile Conirge." An illustrated account of the most interesting route to Scotland. Price 2d. By Post $3 r l$.

The Guides are on sale at all Railway Bookstalls, and Midland Bookin Ofices, and may also be obtained, along with Time Tables, 'Tourist Programmes, American and Continental Folders, and other publications, on asplication to the Midland Statiun Masters and Agents; to the Sulerintendent of the Line, Derby; or to

Dertbr. $x 800$.

GíO. H. TURNER, GENERAL Manager. 

Coaching and Mountaineering.

THE FORNESS RAILIVAY possesses the advantage of running through

1 the finest and most picturesque scenery in the country, and affords at the same time a means of direct communication to some of the most heasutiful and beaithful pleasure resorts. Along the whole route a series of $c^{f}$ arriog views present themselves in quick succession to the Tourist.

TOURIST TfCEETS, available for Two Calendar Months, are issued all the year round from all the principal Railway Stations to
Silverdale.
Bowness. Ravenglass.
Arnside.
Coniston Lake.
Ulverston.
Seascale.
Kents Bank.
Cark.
Furness Abbey.
Grange.
Ambleside.
Windermere
Silecroft.
(Lake Side).
St. Bees.

And bolders of these Tickets are allowed to break their journey at any iotermediate Station on the Furness Railway between Carnforth and their destination.

CEEAP WEEK.END and TEN.DAYS' TICKETS are issued every Friday and Saturday from the principal manufacturing towns in Derby. shire, Lancashire, Yorkshire, and the Midland Counties to the Lake Diatrict and Furness Coast Stations (including Ulverston).

WEEKLY and FORTNIGHTLY TICKETS FROM LONDON (Euston and Se. Pancras) are issued every Thursday from May 25 th to September 2Rth, to WINDERMERE, CONISTON, and principal Coast Stations on the Furness Railway, available for return on the following Monday, Thursday, Monday week, or Thursday fortnight, also from principal Stations on Furness Railway to London (Euston and St. Pancras) every Thursday, available for return on the following. Thursday or Thursday week. For particulars as to trains, fares, \&c., see bills and programmes.

TWENTY CTRCULAR LAKE' COACA TUUIR.

During the Summer Months various Circular Tours by Rail, Steam Yacht, and Char-à-banc, embracing the principal Places of Interest in the LAKE DISTRICT, can be made from Stations on the Furness Railway.

CHEAP DAY TICKETS by Ordinary Trains at Single Fare for Return Journey are issued daily ALL THE YEAR ROUND.

WEEK-END TICKETS at a Fare-and-a-Sixth are issued every Fridas, Saturday, and Sunday ALL THE YEAR ROUND, available to Return an the SUNDAY and FOLLOWING MONDAY or TUESDAY, to and from all Pleasure Resorts and the principal Stations on tho Furness Rallway.

WEEKIY and FAMILY TICKETS on WINDERMERE and CONISTON LAKES.

For full particulars of Circular Tours, Day and Week-end Tickets, Weekly Lake Tickets, \&c., see Bills and Programmes issued by the Company, gratis. FURNESS ABBEY.

Visitors to the Lakes, Isle of Man, and Belfast should not fail to see the far-famed ruins of Furness Abbey. Furness Abbey Hotel (refurnished and redecorated), under the management of Spiers and Pond, Limited, is one of the most comfortable hostelries in England. Electric Light Installation now being provided.

BARROW ROUTE to the ISLE OF MAN and BELFAST. SWIFT STEAMERS DAILY frOM BARROW to DOUGLAS, ISLE OP MAN from May roth to September 3 oth, and DIRECT DAILY SERVICE, BARROW to BELFAST, ALL THE YEAR ROUND.

The New Fast Steamer Duchess of Devonshire (zo knots) is now on the Belfast Daily Service. Full particulars as to Times of Sailing, Fares, \&c., can be obtained on application to Messrs. JAMES LITTLE \& CO., Barrow-in-Furness or Belfast; and THOMAS COOK \& SONS' OFFICES. ALFRED ASLETT,

Barrow.in-Farness, April, 8899 . Secretary and General Manager. 


\section{Glasgor \& South-Western Railway}

TIIE Glasgow and Sou'h-Western Railivay gives a Direct 1 Routo between Scotland and England.

It is in conjunction at Carlisle with the Midland Railway, the pincipal Termini being St. Enoch, Glasgow, and St. l'ancras, London, an 1 a Full and Lixpeditious Service is giren between Glasgow, Paisley, Greenock, Ayr, Ardrossan, Kilmarnock, Dumrrics, \&c., and Liverpool, Manchester, Bradford, Leeds, Sheffield, Bistol, Bath, Birmingham, Londun, \&c.

DIning Cars (First and Third Class) by the Mnrning and Afternoon Expresses, and Sleoping Car's by the Night Expresses, in each direction, between Glasgow (St. Enoch) and London (St. Pancras).

Lavatory Carriages (First and Third Class) by the principal Expresses.

Passengers between Scotland and England by this, the most Picturesque Route, pass through the heart of the Burns Country, and holders of Tourist Tickets to and from Glasgow, or Norih thereof, are allowed to travel vid Ayr (Burns' Birthplacc). Tickets are also valid for break of journey at Dumfries (Burns' burial-place).

Clydo Watering Places. - The Glasgon and SouthWesiem line to Greenock (Princes Pier) is the most convenient for Visitors to the whole of the Watering Places on the Firth of Clyde and Western Hlighlands and Islunds of Scotland, and Passengers holding Through Tickets to or from England have the option of visiting Gilasgow en roule.

The most Direct and Expeditious Route to the Island of Arran is vid Ardrossan; and to Millport, Campbeltown, \&ce, viâ Fairlie.

At Greenock, Ardrossan, and Fairlie, Trains run alongside Steamers, and regular connections are maintained by the Company's own rileet of Magnificent Steamers, also by the "Columba," "Lord of the Isles," \&c., to the Watering llaces on the Firth of Clyde.

The Ayrshire Coast.-Express Trains at convenient times are run between Glasgow and the various Coast Towns.

Full particulars of Trains, Fares, Tours, \&c., on application to C. E. Cockburn, Superintendent of the Line, St. Enoch Station, Glasgow.

Giasgow, 1899.

DAVID COOPER, Greneral Manager. 


\section{LONDON \& NORTH-WESTERN RALLWAY.}

\section{YQEST COAST ROYAL MAIL ROUTE}

BETWEEN

\section{ENGLAND AND IRELAND,}

\section{and between ENGLAND AND SCOTLAND.}

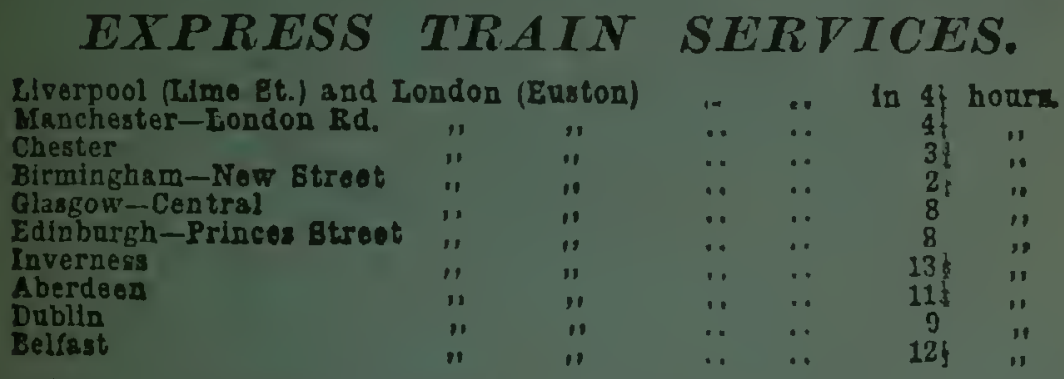

Bpecial Train Services are in operation between WILLESDEN and VICTORIA, WILLESDEN and HERNE HILL, WILLESDEN and the CRYSTAL PALACE and CROYDON, and WILLESDEN and SOUTHALL, connecting with the Lines SOUTH of the THAMES.

Train Services are also in operation between WILLESDEN and KENSINGTON (for Waterloo and the London and South-Western Railway), and between WILLESDEN, BROAD STREET, KEIV, and RICHMOND.

Sleeping Saloons by the night trains between London and Liverpool, Manchester, Holyhead, Edinburgh, Glasgow, Stranraer, Perth and Aberdeen; extra charge 5 s. for each berth, in addition to the ordinary first. class fare.

Breakfast, Luncheon, Tea, and Dining Cars between London and Manchester, Holyhead, Fleetwood, Liverpool, Birmingham, and Wolverhampton.

Corridor Trains with Refreshment and Dining Carg between London and Edinburgh and Glasgow.

Hotel Accommodation. - LoNDon (Euston Hotel), Liver pool (North. Hestern Hotel), Birmingham (Queen's Hotel), Prrston (Park Hotel), Crewe (Crewe Arms), Glasgow, (Central Station Hotel), Pentis (Station Hotel), Dublin (North-Western Hotel), Holviead (Station Hotel), Grernore, Bletchley (North-Western Hotel). The Accommodation provided at these hotels is of the highest standard, and the charges will be found reasonable.

Bot or Cold Luncheons in Baskets, are provider at all principal stations, 35 . including beer or wine, and $2 \mathrm{~s}$. $6 \mathrm{~d}$. without.

Tea Baskets, containing a Pot of 'Tea, Bread and Butter, and Cake, can be obtained at Preston, Llandudno Junction, Crewe, and Rugby, price rs, each.

Luggage collected, forwarded in advance, and delivered at a charge of 6 d. per Package.

Tourists' Arrangements, 1899.-Tourist Tickets are issued during the season (May rst to October 3rst) from the Company's principal stations to Scotland, the English Lake District, Ireland, North, South, and Central Wales, Malvern, Buxton, Stratfurd-on-Avon, Scarborough, Harrowgate, Southport, Blackpool, Morecambe, Islc of Man, Isle of Wight, Jersey and Guernsey.

Every information as to trains and fares can be obtained on application to Mr. Robert Tumbull, Superintendent of the Line, Euston Station, Losdon, N.W.

Euston Station, i8gg. 


\section{CALEDONIAN RAILWAY, TOURS IN SCOTLAND.}

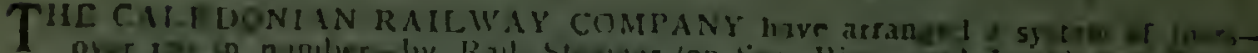

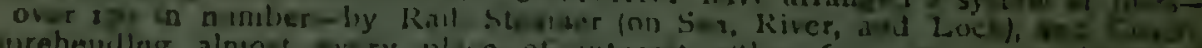

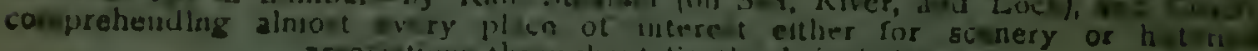
as nct tivus thromghout scutlinil, including-

ABERDEEN, ARBROATH, ARDROSSAR, AYR, BALLOCH, BRECHIN, EDZELI. OAILANDER, ORI GFF, COMRIE, DUMBARTON, DUMFRIES, DUNDEE, DUNAELD EDINBORGI, FORFAR, TLASCOW, GOUROCK, GREENOCK, INVERNE,
LHVERARAY, MOFFAT, MONTROSE, NAIRN, OBAN, FORT-WILLIAM, PAISLEY, PBEBLES, PERTH, ROTHESAY, ITLRLING, BIRATIPEFFE,

The Trosacks, Loch Ratrine, I och Lomont, Lock Eck, Loch Earr, Loch Tay, Loch

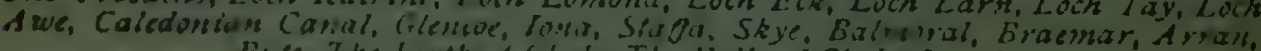
Bible. The Firth of Clyil, The fialls of Cljde, Gi., Enc.

af For dotalls Tomrints are recummented to procure a copy of the Calcdonian Cumpiny's "Touri t cuile"," prire 3r. Tichces for these Tours are issued at the

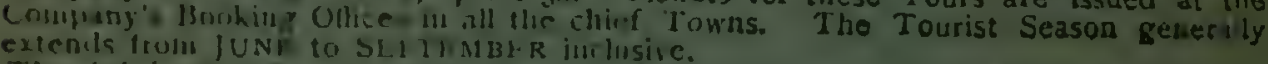

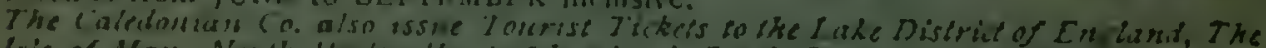

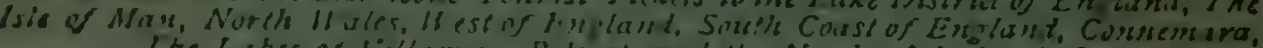

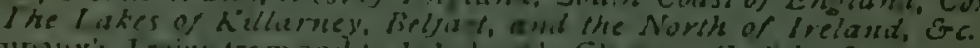

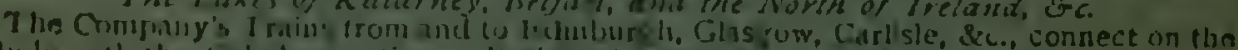

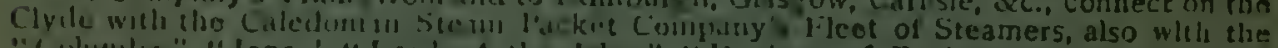
"L culumin," "Inn.1," "I Inrl ot the I.les," "Uubless of Rothesay." or "Ivauline,"

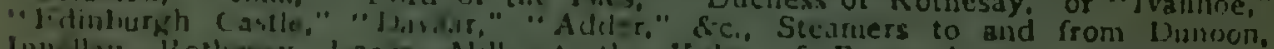

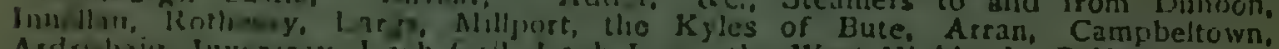
Arrsmlivip. Inveraray, Loch Loil, Locls Long, the West Highlands, Belfast, Isle of

Hy this Company's Tino P.sse niters from London. Ltverpool, and other places in Inglud, ! Inulugh, (ilissow, \&L., Sc, have the choice of "THBEB ROUTEB" to the

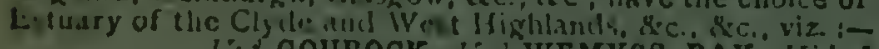

$$
\text { "W COUROCK, } l \text { WEMY8 BAY, Vid ARDROSBAN. }
$$

The Trutns run diriet on tu l'ier and alongside Steamer at Gourock and Ardrossan. Re erved Compurtum uts for I.adies travelling alone.

NI IV RUUl IU I.OCII L.UMOND AND THE TROSACHS.

Tho oprems of the 1 anarkshire alit Dumbartonshire Railway to Balloch affords a new Route furtravellers de ting to visit Loeh Lomond or the Trosachs. Passengers availing chenselves of the new route stirt from or arrive at the Central Low Level Station, which is close tu the present Glasgow Central Station.

An Improved Train Servi. o is nuw rum between Edinburglt (Princes Street) and Glasgow (coitral)-l'ie joumey being performed by Express Trains in a little over the hour.

An l'xprois service of 'Trains is al o run froin Edinbuigh (Princes Street) and Glasguw (Buclianan Sereet) to Seirling. Brtche of Allan, Dumblane, Lallander, Oban, Fort-Willian Crief, leuth, Duirre, Iiorlar, Arbroath, Montrose, Brechin, Aberdeen, Inverness, and the North and zice ties'sd.

RiliURN TICI:Cis-Glasgow and the North, Single Fare and Quarter. First and Third Cliw hy all 1 rains.

The CALIUONIAN, in cullunction with the LONDON AND NORTH.WBSTERN

West Coast (Royal Mail) Route between Scotland and England.

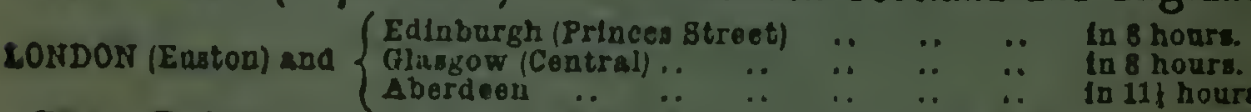

Direct Trains run from and to Glasgow (Central). Edinburgh (Princes Strret). Ardrosan, Kllmarnook, Gourock, Greenock, Paisley, Balloch, Dumbarton, Blranraer, 5tirling, Oban, Perth, Dundee. Forfar, Arbroath, Montrose, Aberdeob, Inverness, and other places in Scotland, to and from London (Euston), Birmingham, Brictol, Bath, Plymouth, Liverpool, Mancheater, Proston, Ponrith (for Lako Distrlet). Leede, Bradford, ce. e.

Lavatory Carriages (lirst and Third Class) on Principal Routes. Corridor Dining Trisins betwecn Edinburgh, Colaggow, and London-Day Expresses. Corridor Sieping Cirs on Trains between Lomdon, Glnsgow, Edinturgh. Perth, and A berleenNight Expresses. Pillow's and kizs available al nominalrates. Ommbuses for tho use of Family Parties are provided when previously ordered, in Glasgow, Liverpool, Manchester, London, \&ic.

For full particulars of Trains, Fares, Ece, see the Caledonian Railway Company's Time Tirsies.

\section{CENTRAL STATION HOTEL, GLASGOW,




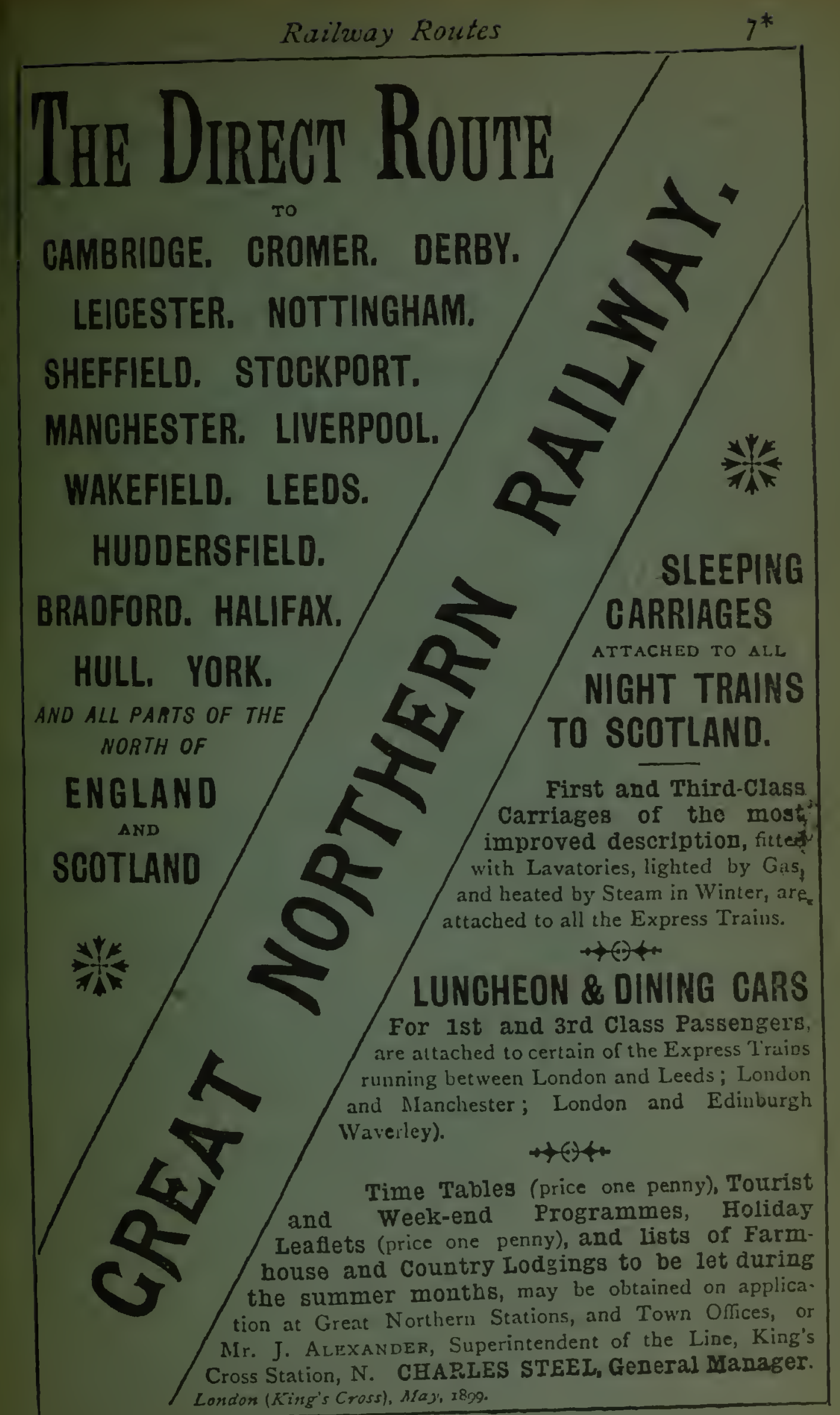




\section{NORTH BRITISH RAILWAY.}

TIIE NUKTH BRITISI RAILUAY SYSTEM is the Inost exterisive In Scoplan it directly scrves all the most impurtant districts of the Countey, and by arran. ments with otlier Railwa" Companies, with whom it is in alliance, or over who e bus it postesses liuming Powers, provides convenient and expeditious Through Combo glom.

TIE MOST DIRECT AND POPULAR ROUTE to the WEBT HIGHTAND8, OBAN, EC. is by the West Highland Line, by which there is an ample and expeditious Service of 'Trains, having 'l'hrough Carriages from London and Edinburgb during the summer, and from Glasgow all the year round, to Fort.William. and vice rexst, and connecting at Oban, Fort-William, and Banavie with Mr. David MacBrayne's Steamers to and from the Hebrides, Inverness, Caledonian Canal, \&c.

\section{THE COMPANX posmessen the BHORTEST ROUTE to and from the NORTE} wit the FORTH and TAY BRIDGES.

and Through Jixpress Trains are run daily between Edinbargh (Waverley and Hinymarket Stations) and Dunformiline. Allow, Stirling, and Perth, with Through Cinringes to and frour Iuvorness wit the Forth Bridge; and between Edtnburgh (IV, werley and Haymarket Stations) and Glasgow (Queen Sireet Station) and Dundeo, Arbroath, Montrose, Aberdoen, tc., vitt the Torth and Tay Bridges.

A Complete Service of 1 xprese. Trnins at frequent intervals is tul between Edinbargh (W,iverley inil Ifoymarket Stitinns) and Olasgow (Queen Strcet Station). passengers hiaving thu chuice of two routes, viz., vit Linlithgow and Falkirk, or wiit Airlirie and Contbrldge: and, In illition, the holuers of Feturn Tickets bave the privilege of iravelling by the Cilecluntian Company's Trains between the tho Citses without furtler charge.

FABT 8TEAMERB BAIt from and to CRAIGENDORAN PIER

In connectlon with the Company's traius, whicls run alongside the pier ; thereby afford. Ing convenlent acces to the various Watering Places on the Clyde, Grcenock, the Garelnch, Loch Long, Iloly Looli, the Islands of Bute and Arran, \&c. These steancrs also conncet at Dunoon during the summer with the "Colunba," "Ioud," "Lnrd of the Isles," and steamer for Arrall.

A Special Iixpress Train is run daily during the summer from Edinburgh direct to Craigendoran I'lex, on arrlval of the night trinins from London (King's Cross and St. Pancras), to enablo passengers to proceed by the smorning steamers. Express trains are also run frnm Cralgencinrn! Pier to Edlnburgh (Waverley), in connection with Through Fast 'T rains to London (King's Cross and St. Pancras).

\section{EXPRESB BERVICE WITH ENGLAND.}

TIBE LAST COAST ROYAL MAIL. ROUTR IS THE SHORTEST AND MOST POPULAR. Hopress Trialus are run dasly froni Aberdeen, Montrose, Arbroath, Dundeo (Tay I3ridge Station), vid Tay and Forth Bridges; Porth, Dunfermline, Allon, and StIrling. vis Forth Britgo; Glasgow (Queen Street), and Edtaburgh (Waverley Station), io Berwick, Newcastle, York, Leeds, Peterborough, London (King's Cross Station), and vire zerst. Many of the carriages on this route are built nis the corridor principle:

I:ASt COAST lilkir AND PIIIRD CLASS DINING TRAINS. - New Corridor Trains cnntuining First and Third Class Dining Suloons, now run daily between Edinuurgh (Wriverley) and Londion (King's Cross).

THI WAV KI.EY ROU [E. - The Waverley Route is most Interesting and attractive, and is the only route which enables tourists to visit Melrose (for Melrose Abbey and Abbotsfnrd). and St. Boswells (for Dryburgl Abbey). Express Trains are run disly from Aberueen, Montrose, Arbroath, Dundee (Tay Bridre Station), vid $\mathrm{T}$ ay and Forth Brudges: Perth, Dunfermline, Alloa, and Stlrling, vit the Forth Bridge; and Edinburgh (Waverley Station), to Carlisle, Manchester, Liverpool, Leeds, Slieffield, Birminglinm, Bristol, Bournemouth, London (St. Pancras). Ste, and vice versd. Lining Cars by thls Route between lidisiburgh (Waveriey) and London (St. Pancras).

Hullman Slceping Cars, Slecping Carriages, and First and Iltird Class l.aratory Carrlagesare run by both the above routes. Slocping berths myy he secured on applicition to Mr. D. DEUCHAKS, Superintendent of the Line, Edinburgh.

\section{RAIL, COACI, AND STEAMER CIRCULAR TOURS.}

To Invernoss, Fort. William (for Ben Nevis), Caledonian Canal, Weat ILlgblande, Firth of Clyde, Aberioyle, Troswachs, Ljch Katrine, and Lo h' Lomond. Trckets for Circular Tours, embracing the above-mentioned places, are is sued at Ediuburgh (Waverley and Haymarket Stations), Glasgow (Queen Street), and all other Principal Btations on the North Britiah Rallway.

SALOON AND FAMILY CARRIAGES AND RESERVED COMPARTMENTS are pro. vided for the conveyance of families or invalids, on terms which may be ascertained on application to the Superintendent of the Line, Edinburgh.

For particulars of Tours, Fares, and General Ariannenents, see the Company's Time Tables asd Tourist Prorramme, copies of uwhich may be oblained from sins of the Stationmusters, or from Mr. D. DEUCitars, Suferintendent of the Lins, Edinburgh.

EDINBURGH, 1899 .

J. CONACHER, General Manoger, 


\section{THE HIGHLAND RAILWAY \\ SUMMER HOLIDAYS.}

\section{The Dlrect Route to INYERNESS \& NORTH of SCOTLAND is via DUNKELD.}

Leaving Perth the Line runs by Dunkeld through the farfamed Pass of Killiecrankie, skirting the Deer Forest of Atholl, over the Gramplans, and through Strathspey, affording magnificent glimpses of Ben Machdul and the Cairngorms, on to Kingussie and Aviemore. From Avlemore a new and direct line to Invernoss, traversing scenery of the grandest description, has been constructed, shortening the time on the journey by an hour. By the old route the line runs past the ancient town of Forres (where the traveller can diverge and visit Elgin, with its magnificent Cathedral) and Nairn, "The Brighton of the North," to Inverness, the Capital of the Highlands. Parties staying at Inverness can have a choice selection of Tours at Reduced Fares,

\section{From INYERNESS Northyards}

the line skirts the Beauly Firth to Muir of Ord (from whence a Branch Line has been opened to Fortrose) on to Dingwall, from which point the traveller can visit the far-famed Strathpeffer Spa, "The Harrogate of the North," or proceed through grand and striking scenery to Kyle of Lochalsh, and thence by Steamer to the Isle of Sky $\theta$ and the Outer Hebrides, visiting on the route Loch Mareo and Gairloch, or proceed North through Ross, Sutherland, and Caithness to Thurso and Wick, visiting John o' Groat's House, and thence by Steamer to the Orlsney and Shetland Islands.

The whole Route affords an ever-varylng succession of the most Picturesque Scenery, and the

ITNEST SHOOTLNG AND FIBHING IN BCOTLAND.

Lists of furnlshed Lodgings at Farm Houses and other places In the Vicinity of the Highland Railway, may be obtained on application at any of the Highland Railway Stations or to the Superintendent of the line at Inverness,

Tourst Tickets are issued from the principal Stations in England and Scotland by this Route, slong which there is now increased Ilotel and Lodging accommodation.

For full particulars as to Trains, Through Carriages, Tours, Fares, Steamer and bach Connections, \&ce, see the Company's Time Tables and Tourist Programme.

T. A. WiLsCN, General Manager. 


\section{GREAT EASTERN RAILWAY.}

SEASIDE, and BROADS and RIUERS of NORFOLK and SUFFOLK.

CHEAP TICKETS ARE ISSUED AS INITR PY ALL TRAINS.

\begin{tabular}{|c|c|c|c|c|c|c|}
\hline LIVERPOOL STREET & \multicolumn{2}{|c|}{$\begin{array}{c}\text { TOURIST. } \\
\mathbf{A} \\
\end{array}$} & \multicolumn{2}{|c|}{$\begin{array}{l}\text { FORTNIGHILY. } \\
\text { Avallable for } \\
15 \text { Days. } \\
\text { B } \\
\end{array}$} & \multicolumn{2}{|c|}{$\begin{array}{l}\text { FHIDAY UK } \\
\text { SATURDAY TILL } \\
\text { TUESDAY. } \\
\text { C }\end{array}$} \\
\hline $\begin{array}{c}\text { FENCHURCHSTREET } \\
\text { to }\end{array}$ & $\begin{array}{l}\text { Ist } \\
\text { Class. }\end{array}$ & $\begin{array}{l}3 \text { rd } \\
\text { Class. }\end{array}$ & $\begin{array}{l}\text { Ist } \\
\text { Class } \\
\end{array}$ & $\begin{array}{l}\text { 3rd } \\
\text { Class. }\end{array}$ & $\begin{array}{l}\text { ist } \\
\text { Clais. }\end{array}$ & clas. \\
\hline $\left.\begin{array}{c}\text { Southend-on-Sea ... } \\
\text { (via Shenfield) } \\
\text { Burnh'm-on-Crouch }\end{array}\right\}$ & ${ }^{*} 8 / 8$ & $+1 / 2$ & $* 7 /$ & $4 / 4$ & $6 /$. & $3 / 6$ \\
\hline 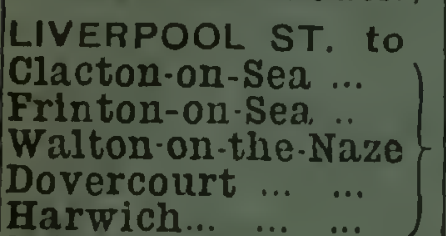 & $20 \%$ & $12 /$. & $17 / 6$ & $10 \%$ & $12 / 6$ & $7 / 6$ \\
\hline $\begin{array}{lccc}\text { Felixstowe } & \ldots & \ldots & \ldots \\
\text { Aldeburgh } & \ldots & \ldots & \ldots \\
\text { Southwold } & \ldots & \ldots & \ldots\end{array}$ & $\begin{array}{l}23 / 4 \\
27 / 9 \\
31 / 3\end{array}$ & $\begin{array}{l}14 / 3 \\
16 / 9 \\
18 / 5\end{array}$ & $\begin{array}{l}17 / 6 \\
25 / . \\
27 / 6\end{array}$ & $\begin{array}{l}10 \% \\
13 \% \\
15 \%\end{array}$ & $\begin{array}{l}12 \% \\
15 \% \\
20 \%\end{array}$ & $\begin{array}{l}7 / 6 \\
9 / 6 \\
10 \%\end{array}$ \\
\hline 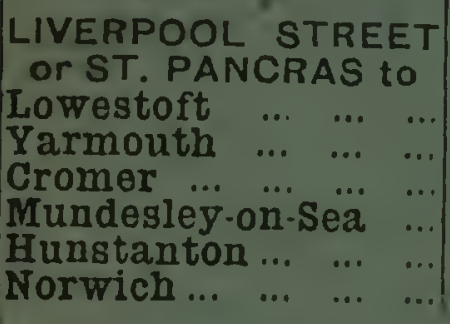 & $\begin{array}{l}33 /- \\
34 /- \\
34 /- \\
34 / . \\
30 / 6 \\
31 / 10\end{array}$ & $\begin{array}{l}19 / 9 \\
20 /- \\
20 /- \\
20 \%- \\
18 /- \\
18 / 11\end{array}$ & $\begin{array}{l}27 / 6 \\
27 / 6 \\
27 / 6 \\
27 / 6 \\
25 / .\end{array}$ & $\begin{array}{l}15 \% \\
15 \% \\
15 \% \\
15 \% \\
13 \%\end{array}$ & $\begin{array}{l}20 \% \\
20 \% \\
20 \% \\
20 \% \\
15 \%\end{array}$ & $\begin{array}{l}10 \% \\
10 \% \\
10 \% \\
10 \% \\
9 / 6\end{array}$ \\
\hline
\end{tabular}

A. Tourlst Tickets are issued daily throughnut the yer $r$ by any train, and are available for the return jouruey lyy any train as follows:- Those is ued to th Ist May to 3 sist October inclusive, lon any day un to and in ludug 3 rst of December; those issued from ist November 10 3oth A Aril inclusive on any day within two calendar months from the dite of istre.

B. Fortnightly. Tickets are issued daily, and are avallable for return by any of the advertised trains on any duy within fifteen days, including the days of issue

- Tourlst and Fortnightig Tickets to Burnharn ase issucd only from Moy to October inclusive.

c. Friday to Tuesday Tickets are issued cvery Friday and Saturiay, and aro available for return by any of the advertised trains on the day of i sue or on

Tourat, Fortnightly, and Fridgy to Tneeduesday followlng the date of i sue. are also issued at Great and Friday to Tuesday Tickets to the above seasile at it ins are also issued at Great Eastern stations within twelve miles of London, ald at the a vailable to and from London Line, at the same fares as from Liverpool Street, and re available to and from certain Stations other than that named thereon. The Fortni hily and Friday to Tuesday Tickets can be extended on aprilication at the scaside $5 t: 1=11$. For full particulars see the Company's Time Book and hand hills.

RESIDENTIAI. SEASON TICKETS at cheap rates are tssued hetween Iiver of Street and Southend, Clacton, Walton-on-Naze, Dovercourt, Harwich and Felisstowo. for periods of Twelve Months, Six Months, Three Months, One Month, Two Ve-k; and One Week. Full particulars may be obtained of the Sccretary, Liverpool Streyt
Station.

List of Farmhouse and Country Lodgings in the Eastern Counties, and Pamphlets on the Broads District of Norfolk and Suffolk and the Holiday Resorts in the Eastern Counties, can bo had gratis and post free on application to the Superintendent of the Line, Liverpool Street Station.

WILLIAMI BIRT, GENERAL MANAGAR.

Liverpool Stregt Station, LoNDON, E.C., April, 1899. 


\section{THE}

\section{DISTRICT' RAILWAY,}

EITHER BY ITS OWN LINE

OR BY ITS CONNECTIONS, SERVES

THE WHOLE OF, THE

\section{PLACES OF AMUSEMENT,}

INTEREST, AND ATTRACTION,

IN AND AROUND LONDON.

It is the most direct and quickest means of

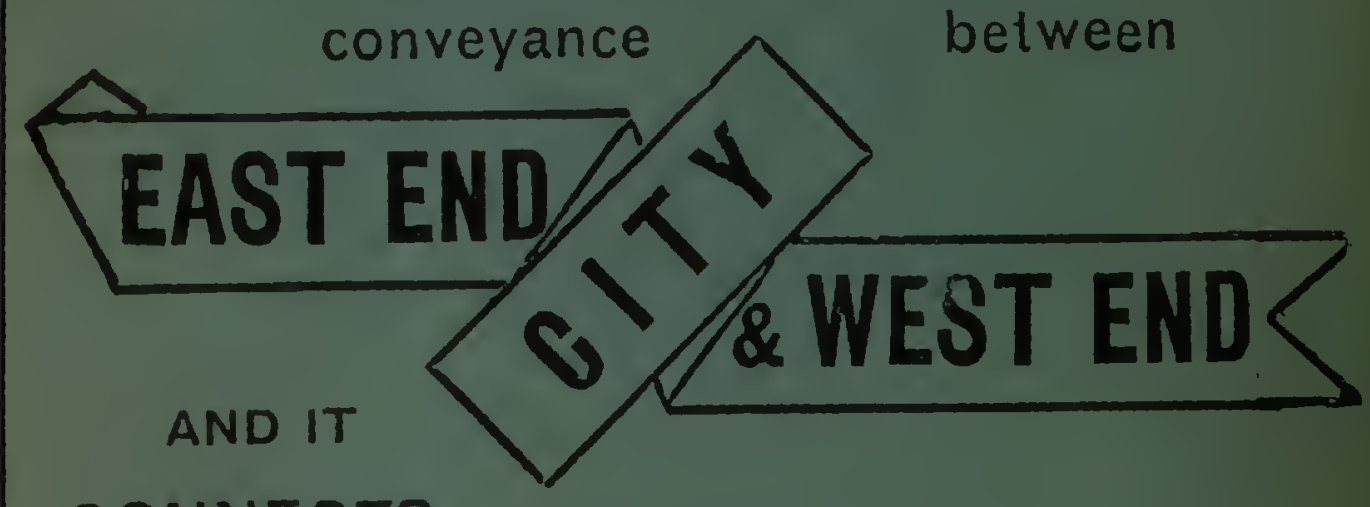

CONNECTS

WITH THE TERMINI OF ALL

THE RAILWAYS RUNNING INTO LONDON.

Through Bookings are in operation between the

DISTRICT LINE AND ALL STATIONS IN

LONDON AND THE SUBURBS.

Always ask for Tickets "VIÂ DISTRICT RAILWAY." 


\title{
South-Eastern \& Chatham \& Dover Railways
}

ROYAL MAIL EXPRESS SERVICES

\author{
TO THE
}
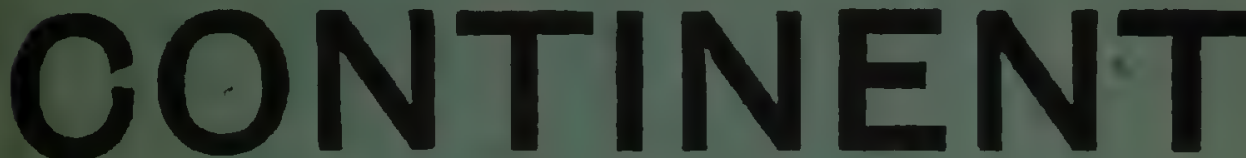

Via DOVER \& CALAIS, DOVER \& OSTEND, and FOLKESTONE \& BOULOGNE.

Leaving

Charing Cross ...

Cannon Street ...

Victoria ............

Holborn Viaduct

St. Paul's

\begin{tabular}{c|c|c|c|c|c|c}
$\mathrm{A}$ & $\mathrm{B}$ & $\mathrm{C}$ & $\mathrm{A}$ & $\mathrm{B}$ & $\mathrm{C}$ & $\mathrm{AC}$ \\
$\mathrm{I}, 2$ & $\mathrm{I}, 2$ & $\mathrm{r}, 2$ & $\mathrm{I}, 2$ & $\mathrm{I}, 2,3$ & $\mathrm{I}, 2$ & $\mathrm{I}, 2,3$ \\
a.m. & a.m. & a.m. & a.m. & p.m. & p.m. & p.m.
\end{tabular}

* Not calling at Cannon Street. + Daily.

A Via Calais. B Via Boulogne. C Via Ostend.

NOTE. - The above times are liable to alteration, and reference should be made to the Current Continental Time Book.

\section{FRIDAY, SATURDAY, OR SUNDAY TO TUESDAY TICKETS}

ARE ISSUED FROM

CHARING CROSS (West End), CANNON ST., \& LONDON BRIDGE. To

Canterbury, Chatham Central, Deal, Dover, Folkestone Central, Folkestone Junction, Hastings, Hythe, Lydd, Maidstone, Margate, New Brompton, New Romney (Littlestone-on-Sea), Ramsgate, Rochester, St. Lawrence, St. Leonards-on-Sea (Warrior Square), Sandgate, Sandling Junction, Sandwich, Shorncliffe Camp, Southborough, Strood, Tunbridge Wells, Walmer, and Whitstable-on-Sea.

Cheap Friday or Saturday to Tuesday Tickets Are issued from

Victoria (West End), Holborn Viaduct, \& St. Paul's, TO

Birchington-on-Sea, Broadstairs, Canterbury, Deal, Dover, Faversham, Herne Bay, Margate, Ramsgate, Sheerness, Sittingbourne (for Milton), Walmer, Westgate-on-Sea, Whitstable-on-Sea.

For fares and further particulars respecting the Cheap Tickets, see time-books and programme. ALFRED WILLIS, General Manager. 


\section{MIDLAND \& LONDON TILBURY \& SOUTHEND RILLWAYS.}

Ouring the Summer Months, commencing 1st April,

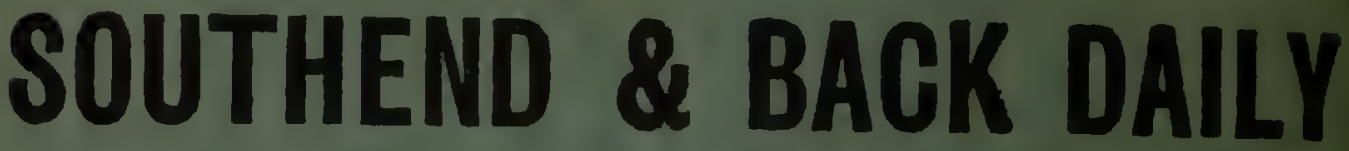

Third
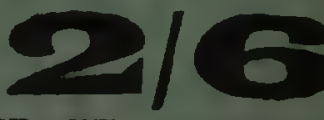

Class.

From FEITCHURCE STREET, Burdett Road, Stepney, Bromley, Plaistow, Upton Park, East Ham, Barking; LIVRRPOOt BTREET, Bishopsgate, Bethnal Green, Globe Road, Coborn Road, Stratford, Maryland Point, Forest Gate, vid Barking; also from 8T. PANCRA. Camden Road, Walthamstow, Leyton, Leytonstone, Wanstead Park; and stations on the Tottenham and Hampstead Line.

Tor Times of Cheap Trains-sec Timo Tables.

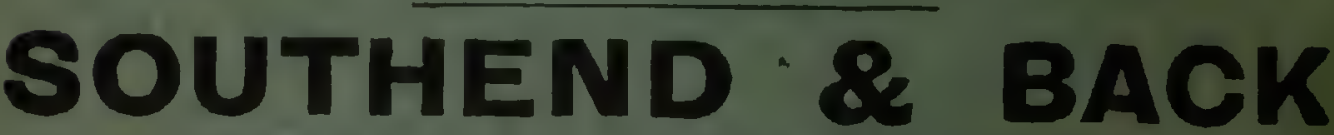

(FRIDAY TO TUESDAY TICKETS).

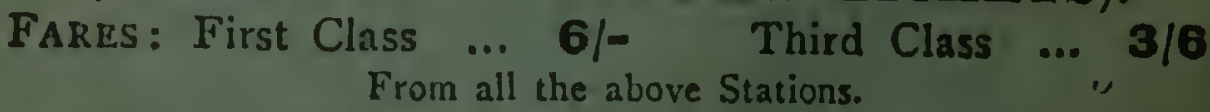

Fenchurch Street Terminus, Londun, E.C.

BY ORDER

\section{CIRCULAR TOURS}

GLASGOW AND THE WEST HIGHLANDS. NE WEEK'S PLEASURE.SAILING to the Outer Hebrides, by th magnificent new steamer "HEBRIDES". (electric light, bathro=r", and first-class passenger accommodation), sailing from GLAsGow on i Greenock every MONDAY for Islay, Collonsay, OBAn, Mull, SKy, U1ST, BARRA, \&C., affords the tourist a splendid opportunity of viewi the rugged scenery of the West of Skye and the Outer Islands.

Cabin for the Round, 35s. ; Board included, $65 \mathrm{~s}$.

uland of st. Kilda.-During the season special trips are macle to this for island, where passengers are given facilities for landing.

Cabin for the St. Kilda Trips, \&2 10s. ; Board included, \&4 4. JOHN MCCALLUM and Co.'s, 10, Ann Street (C1ty), GLASGOW

TWENTY-SECOND EDITION.

Brought down to the Autumn of 1898 .

Haydn's Dictionary of Dates.

Medium 8uo, Cloth, 21/-; Half-Calf, 151-; Full or Tree-Calf, $31 / 8$.

Containing over 1,300 pages, 12,000 Articles, and 140,000 Dates and Facts.

London: WARO, LOCK \& CO., LTD., Salisbury Square, E.C. 


\section{THE ISLE OF WIGHT. \\ (THE G.IRDEN OF ENGLAND.)}

WARM IN WINTER. COOL IN SUMMER.

\section{CHARMING \& YARIED SCENERY.}

\section{BEAUTIFUL WALKS \& DRIYES.}

Tin Best and Safest Bathing in the British Isles, BEAUTIFUL SANDS.

SAFE BOATING. YACHTING. COLFING.

FISHING (FRESH AND SALT WATER).

\section{DURING THE SEASON}

Ch ap railway excursions to all parts daily. Weekly Tickets, covering ue of all trains and all railways in the island (except Ryde Pier) fr seven days are issued at exceptionally low charges.

Pleasant and cheap steamboat excursions almost daily, round the Iland, Bournemouth, Weymouth, Swanage, Southampton, Southsea, Portsmouth (the first naval yard in the world), Cowes, \&c.

Good hotels, boarding, and lodging houses in all parts of the island at reasonable charges.

The principal towns and places of interest are Ryde, Cowes, Sandown, Shanklin, Ventnor, Freshwiter, "Totland Bay, Alum Bay, Newport, Caris, brooke, Osborne, Bunchurch, 'The Landslip, The Undercliff, Bembridge: St. Helen's, Brading.

Visitors can reach the island by rrequent sxpress trains from Waterloo, Victoria, London Bridge, Kensington, Clapham Junction, \&zc., either vid Portsmouth and Ryde, Stokes Bay and Ryde, Southampton and Cowes, or Lymington and Yarmouth.

Well appointed steamers connect at Ryde, Cowes, and Yarmouth with trains.

Through tickets to all island stations, Ist, and, and 3rd class, from all stations on the South Western and South Coast Kailuays. During the summer season, May ist to September 3 th, Tourist Tickets, availablo for Two Months, are issued from Walerlon, Victoria, London Bridge, Kensington, Clapham Junction, \&c. Also Cheap Four-Day (Saturday to Tuesday) Tickets, at a fare of $9 s$; and Eight and Eleven Day Tickets at a fare of $1 / \mathrm{s}$. (3rd class).

Cheap Week-End Tickets are also issued all the year round, by all crairs, on Fridays, Saturdays, and Sundays, available for return by any train up to the fullowing Tuesday, at the following fares-ist class retura, 230 ; and class return, 15s.; 3rd clase retura, $12 s$.

H. K. D.IY, MANAGER, I. W. Railway.

CHAS. L. CONACHER, MANAGER, I.W. Central Railway 


\section{LONDON \& SOUTH WESTERN RAILWAY.}

THE SHORTEST, QUICKEST, AND MOST DIRECT ROUTE BETWEEN LONDON AND THE WEST OF ENGLAND.

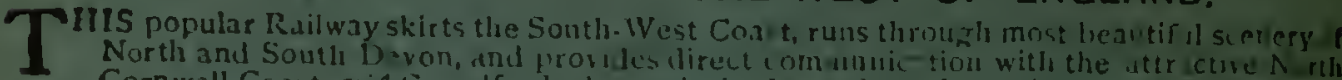
Cornwall Canst, vi Camelfurd, also with the Ise of Wight, wis l'ortsmuth If irt is, vid Stokes $13.1 y$, viis Suuthampton, Rnd vit Lyum żton.

It also sipplies fie juent services betwem Londint and the Thames Valley.

Passengers travelliug lyy the London and South Western expresses may, at Exeler, m ke connections for Corquay, Dartmouth, and South Devon: while at Plymoutli similar connections can be made for Falinou.h, l'enzance and South Cornwall.

EXPRESS TRAINS BETWERN LONDUN (WATERLOO) and

EXETER in 3 ! lours.

PLYMOUTH in 5 t liours.

BROCKENHURST (for NOW

Forest) in 2 loours.

PORTBMOUTH in a hours.

LFRACOMBE in of hours.
SW ANAGE In if hours.

SIDMOUTH in 4 hours.

BUDE in eif h urs.

WEYMOUTH in 3 hours.

RYDE in hours.

LYNTON in 7 hours.
BOURNEMOUTH in al hours. SOUTHAMPTON in 1 hours. VENTNOR in 3 hours.

BUDLEIGE SALTERTON In 4t hours

PADSTOW in 7 hours.

PUI.I.MAN CARS run in primeiful trins between London and BROCKENHURST

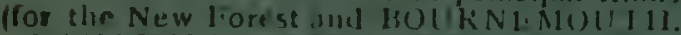

I. AVATURY ACCOMMUDATIUN fur 1St, and, and zri Class passengers is provided In all Trains to and Irom freter and l's mouth.

INVAIII, SAIUUV, MIII TAMIIY CARRIAGES, aISO COMPARTMENTS OF

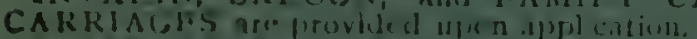

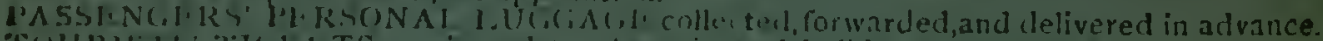

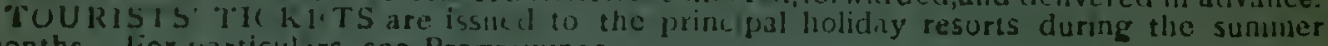
copths. lior particulars, soe Programines.

\section{STEAMSHIP SERVICES FROM SOUTHAMPTON}

LONDON and CHANNEL ISLANDS, Daily Service (Sundays excepted)

\section{LONDON TO GUERNSEY AND JERSEY.}

Fach Week-day.

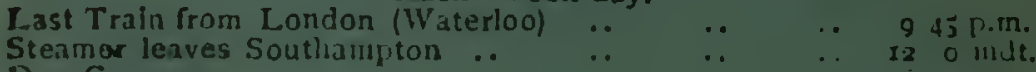

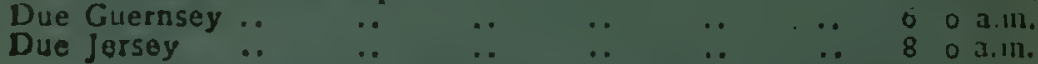

\section{JERSEY AND GUERNSEY TO LONDON.}

Each Week-day.

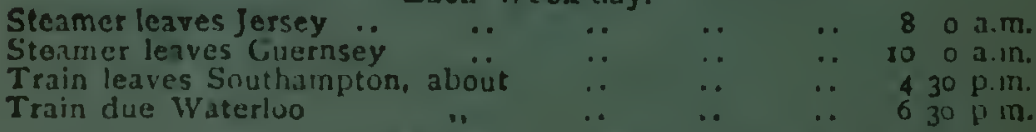

RETURN IAARES:-Iondon to Guernsey or Jersey (or vice versa) Ist Class, $438: a$ Class, 37s. 6.\%. aud 3 rd Class, 30 s., available for tivo montlis.

COKDON \& PARIS via Southampton, Havre \& Rouen. Drily Service (Sunday except d). LONDON TO PARIS EACH WEEK-DAY.

Last Train from London (Waterloo) ..

Steamer leaves Southanipton .. ..

Train leaves Havro $\quad . . \quad \ldots$

.. $\quad$.. 9 45 P.m.

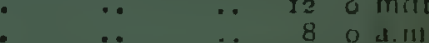

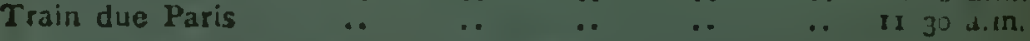

\section{PARIS TO LONDON EACE WEEK-DAY.}

\section{Last Traln from Paris (St. Lazaro)}

Steamer leaves Havre...

Train leaves Southampton

Train due London

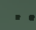

$\cdots$

RETURN FARES :-London to Havre in $3 I s .8 d$. , available for two inonths.

London to Paris (or vice versa) ist Class, 565. 8d, and and Class, 405 8u., availablo for one month.

BOUTHAMPTON to ST. MALO every Monday, Wednesday, and Frid.zy. ST. MALO TO SOUTHAMH ION every Munday, Weduesduy and Iraliy.

BOUTHAMPTON to CHERBOURG every Tues lay, Tliursilay and Saturdas, at ro.30 $\mathrm{m}$.

Last Train Leaves Waterloo Stition $8.5 \mathrm{p}$.

OHERBOURG to SOUTHAMPTON every Monday, Weduesday, and Frid iy at in $3^{n}$ p.r.

For full particulars apply to the Superintendent of the LIne, Waterloo St tI $\mathrm{n}, 5 \mathrm{E}$ CHA8. J. OWENS, General Manager. 


\section{LANCASHIRE AND YORRSHIRB RAILWAY. \\ DIRECT EXPRESS ROUTE BET MIRE}

\section{THE EAST AND WEST COASTS.}

\section{THROUGH FAST TRAINS}

between Liverpool. Manchester, and Principal Lancasbire Towns, and HALIFAX, BRADFORD, LEFDS, YORK, SCARBOROUGE, acd HEWCASTLE, in direct communication with Express Trains io and Irum all parts of tho North-Easteru system. Express Service botween LIVERPOOL and MANCBESTER in 40 minutes.

\section{AN EXCELLENT SERVICE OF TRAINS}

Is in operation between the Principal Stations in Lancashire and Yorkshire, an BLACEPOOL, LYTHAM, SOUTHPORT, and SCOTLAND. Fast Trains run vid Preston and the Caledonian Company's route, and via Hellifield, by the Midland Company's route, to all parts of Scotland.

\section{ROYAL MAIL ROUTE to the}

NORTH OF IRELAND via FLEETWOOD \& BELFAST.

The L. \& Y. and L. \& N. W. Company's Royal Mail Twin.screw Steamers sail daily (Sundays excepted), between Fleetwood and Belfast, open sea passage 5 hours. The steamers are lighted with electricity, and there are Dining Saloons, Ladies' Cabins, and Siate Rooms, replete with every modern comfort. Express Trains are run in connection with the Boats between Manchester, Liverpool, Bolton, Bradford, Leeds, Sheffield, York, Newcastle, Birmingham, London, and other Important Places, and Fleetwood.

The Fleetwood route will be found the most expeditious and convenient for the North of Ireland. Passengers and their luggage proceed direcs from the train to the steamer by a covered way. No expense is incurred in the transfer of luggage to and from the boats.

\section{ISLE OF MAN vid FLEETWOOD.}

From May rgth to May 3 oth inclusive, and from July rst until the eac of September, r899, the Isle of Man Steam Packet Company's Steamer, "Muna's Queen," will sail daily (Sundays excepted), hetween Fleetwood and Douglas, Isle of Man, at convenient hours. There is also a service on certain days between Fleetwood and Ramsey, vid Douglaw

ISLE OF MAN vid LIVERPOOL.

The Isle of Man Steam Packet Company's Steamers sail daily (Sundays excepted), between Liverpool and Douglas, Isle of Man, at conveniens bours: and also on certain days between Liverpool and Ramsey. Passen. gers and their luggage are conveyed Froo of Chargo hetween ihe Station and Isle of Man Steamers.

\section{CHEAP EXOURSION ARRANGEMENTS.}

Irory Friday and Saturday Woor-end THcirots (short date and lont date) are issued by any ordinary train from the principal stations to B'ack. pool, Fleetwood, I gtham, St. Anse's, Soutbport, Liverpool, Harroga:e, Scarborough, \&c., \&c.

Day and Harf-day Excursion Tickets are issued to Seaside and other It atering Ylaces several days each week during the season, and Touriss Tickets are issued to all parts of England, Ecotland, Wales, and ti.e Isle of Man.

The Company conveys Schools, Workpeople, and others, at reduced fares on application. Pic-nic and pleasure Parties are con ejed at cheap fares to various places of resort. For full particulars apply 10 Mr. Chas. J. Nicholson, Passenger Superintendent, Victoria Station, Munchester.

Manchesser.

J. H. Stafford, General Manager. 


\section{GREAT CENTRAL RAILWAY}

Tho Great Contral Rallway Company's Extension Line to London is the most modernly equipped

\section{EXPRESS ROUTE}

\section{LIYERPOOL, MANCHESTER, SHEFEIELD, AND ALL POINTS IN}

\section{UANCASHIRE and YORKSHIRE \\ TO}

THE DUKERIES (Worksop Station) NOTTINGHAM, LEICESTER, RUGBY, and LONDON,

\section{ALSO TO THE}

\section{SOUTH AND WEST OF ENGLAND.}

Fast Through Trains between

LIVERPOOL, SHEFFIELD, HULL \& GRIMSBY, and Express Connections from

EASTERN COUNTIES AND MANUFACTURING DISTRICTS OF YORKSHIRE AND LANCASHIRE.

Luncheon and Dining Cars on Special Express Trains MANCHESTER-SHEFEIELD-LONDON.

The Company's popular Steamers will sail regularly between Grimsby and Antwerp, Rotterdam, Hamburg, by whic cheap return tickets are issued, valid for I 6 days.

Full detail of the Train Service, Tourist Tickets, Excursion Trains, facilities to holders of ordinary Tickets, \&c., can be obtained from Mr. R. HAIG BROWN, Superi-tendent of the Line, London Road Station, Manchester, at the Stations, or the Company's Tourist and Excursion Agents, MEssrs. DEAN \& DAWSON at the undermentioned Offices :-

MANCHESTER, 49 , Piccadilly LIVERPOOL, 23, Water Street STOCKPORT, St. Petersgate OLDHAM, 2, Mumps
SHEFFIELD, 7, Haymarket and 218, West Street NOTTINGHAM, 6, Thurland St. LEICESTER, 25, Gallowtreegate

Mancheser. WILliam POLLITT, General ManaGer 


\section{A TRIP TO}

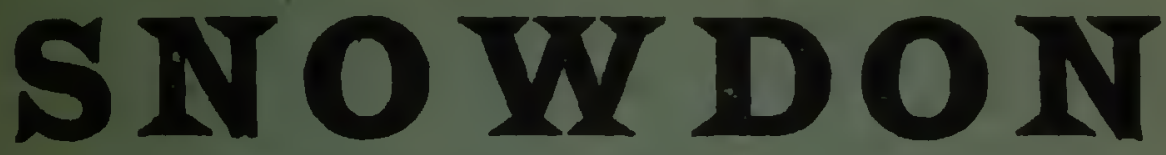

BEDDGELERT \& ABERGLASLYN

BY THE

NORTH WALES NARROW GAUGE (2-FT.) RAILWAY.

Which forms a Junction with the L. \& N.W. Railway

AT DINAS,

THRER MILES SOUTH OF CARNARVON.

\section{SHORTEST AND MOST}

\section{PICTURESQUE ROUTE.}

\section{TOURIST TICKETS}

(Ix and 3 rd Class) for Two Calendar Months, renewable up to 3 Ist December, aro issued from MAY Ist to October arst at the prinolpal stations in the United Kingdom to SNO YY DON Station.

Holders of these tickets can break the journey at Rbyl, Llandudno, and other North Wales Pleasure Resorts, conipleting the outwafd journey any fine day, visiting Beddgelert, Gelert's Grave, the noted Pass of Aberglaslyn, and other places of interest, or they can "do" SNOWDON.

Conveyances for Beddgelert meet all trains at Snowdon Station and fas. ungers showld secure Cheap Retum Coach tickats at that Station. Fare 16.

\section{Cheap Excursion Tickets}

will be issued during the season, June ist to September 3 oth (certain days excepted), from Rhyl, Llandudno, and all other stations on the Chester and Holybead Section, to Snowdon (late Rhyd-ddu) Station.

For full details as to fares, times, \&c., see bills issued by L. \& N.W. and North Wales Narrow Gauge Railway Companies, or apply to-

G. C. AITCHISON, Secretary and Traffic Manager.

Dinas Station, neat Cariarvon. 


\section{FESTINIOG RAILWAY,} NORTH WALES.

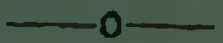

THIS celebrated Miniature Line, the original "TOY RAILWAY," and the world-renowned pioneer of narrow gauge railways, is situated in the centre of the finest scenery in the Principality. In its continuous ascent from Portmadoc to the Festiniog slate quarries it traverses, by means of sharp curves and gradients, a rugged but most picturesque tract of country, and in its windings along the hill sirlus at a great height above the valley it continually discloses fresh views of river, sea, and mountain, amongst which is comprised the grand panorama of the Snowdon range.

It is yearly visited by thousands of tourists, who are charmed with the novelty of the line and its surroundings.

It is reaclily accessible from all parts of the country, through Bettws y-Coed, via the London and North-Western Railway; or through Bala, via the Great Western Railway, changing in each case at Blaenau Festiniog; or through Barmouth or Aforwen, viâ the Cambrian Railway, changing at Minffurdd.

It forms the most direct route between the seaside resorts on the north, and those on the south and west coasts of North Wales.

CIRCULAR TOUB TICKETS are issued by the London and North.Western, Great Western, and Cambrian Railway Companies, available over the Line and in connection with four-horse coaches running through the Snowdon district.

J. S. Hughes, General Manager.

Portmadoc, 1899 . 


\section{CAMBRIAN RAILWAYS.

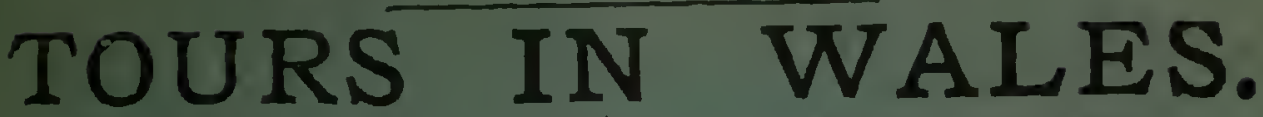 \\ BATHING, BOATING, FISHING (Sea, River, and Lake), \\ GOLFING, COÁCHING, MOUNTAINEERING. \\ TOINICTS TINVETS available for two months, issued throughout the year. TOURISTS TIOKETS from London and all principal statio is in England,}

Aberystwyth, Borth, Machynlleth, Aberdovey, Towph, Dolgelley Barmouth, Harlech, Portmadoc, Criccieth, Pwilheli, Llanidloes, Rhayader, Builth Wells, and Brecon.

CHEAP WEEK-END \& TEN DAYS TIGKETS OR SATURDAY THROUGHOUT THE YEAR from SHRETVSBURY, BIR. IINGHAM, WOLVERHAMPTON, STAFFORD, BURTON, DERBY, LEEDS. LEICESTER, HUDDERSFIELD, STOCKPORT, OLDHAM, MANCHESTER. PRESTON, BLACKBURN, ROCHDALE, BRADFORD, IVAKEFIELD, HALIFAX, BOLTON, WIGAN, WVARINGTON, CREWE, LIVERPOOL, STOKE, BIRKENHEAD, and other Stations to the CAMBRIAN WATERING PIACES.

CHEAP IVEEK.END TICKETS will be issued from LONDON (L.N.W. and G.W. Co.'s Stations) to Aberdovey, Aberystwyth, Barmouth, and Dolgelley, every rijay and Saturday, available to return on the following Sunday (where Train service permits). Monday or Tuesday.

Commencing May 24, and EVERY IVEDNESDAY durlng June, July, August, and September. CHEAP WEERLY AND FORTNIGHTLY TICKETS will be issued FROM LONDON to the Cambrian Coast and certain Inland Stations, available to rctum on the following Mouday, Wednesday, Monday week, or Wednesday week.

Tickets at tlie same fares are also issued to London during the same period, every Wednesday, available to return on the following Wednesday or Wednesday week.

ABOUT THIRTY RAIL AND COACH EXCURSIONS DAILT ro run from the Cambrian Railways, during the Summer Montlis, through the finest scenery in the Principality.

CICLING AND WALKING TOURS at cheap fares throughout tho Mountain, River, and Lake District of North and Mid-Wales.

For particulars see Rail and Coach Exalrsions Programme, issued gralis.

EXPRESS TRAINS, WITH Ist, 2nd. AND 3rd CLASS LAVATORY CARRIAGES LIGHTED WITH GAS,

LONDON TO ABERYSTWYTH, 6) HOURS; BARMOUTH, 7), Ape sun daily during the Season in connection with Fast Trains on the London and North Western and other Railways, between London, Liverpool, Manchester, Rirmingham, Stafford, Shrewsbury, Hereford, Merthyr, Cardif, Newport, (Mon), \&c., and Aberystwyth, Barmouth, \&c.

SEE THE CAMBRIAN' RAILWAYS' NEW AND:BEAUTIFUL ALBUM,

\section{"A SOUYENIR,"}

GEMS OF PICTURESQUE SCENERY IN WILD WALES. 55 SUPERB VIEWS. PRICE 6r.

At the principal Railway Bookstalls, the Company's Stations, and tho undermentioned Offices, \&c.

\section{PICTURESOUE WALES (Illustrated).}

The Officlal Guide Book to the Cambrian Railways, edited by Mr. GODFREY IJIRNER. Price 6d. can be obtained at the Bookstalls, and at the Company's Offices or Stations, also of Miessrs. W. J. Adams \& Sons, 59, Fleet Street, London, E.C.

FARM HOUSE AND COUNTRY LODGIXGS. - Attention is drawn to the lllustrated ramphlet issued by the Company.

\section{"LIST OF LODGINGS."}

rlice 1d. at the princlpal Railway Bookstalls and Company's Stations.

Time Tables. Tourist Programmes, Guide Books, and full particulars of Traits, Fires, \&c., may be obtained from Mr. W. H. GOUGH, Superintendent of the Line, Oswestry, at any of the Companys' Stations, and at the Cambrian Office, Crue-Woodo puidings, 17. Back Goree, LIVERPOOL, or on application to the undersigned. Also Buildings, 17 . Back Goree, LIVER POOL, or on application to the undersigned. Also

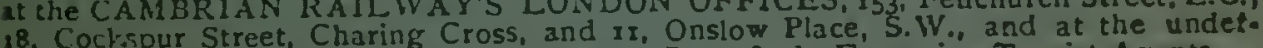
mentinned Offices of Messrs. Henry Gaz and Sons, Ltd., Excursion Tourist Agents. Northumberland Avenue, 19, Westbourne Grove, and

Ficcatilly Circus: BIRMINGHAM-Steph roson Place, New Street Station: MAK.

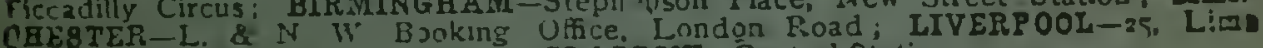
Etret. DTRLIT- 5 . Suffult Street; GLASGOW-Central Station.

Conpen oferes.

C. S. DENNISS,

Uincolsy, tigg.

Conesoi ranters. 


\section{Belfast and Northern Counties Railway.}

\section{COUNTY ANTRIM AS A TOURIST DISTRICT AND HEALTH RESORT.}

Good Boating, Bathing, Fishing, Golfing, Shooting, Cycling. JTIL $30 t h$ September, 1699 , Cheap Excursion Tickets availat It for
Sixteen Day's will be issued to Belfist, Larne, Portrush, (iiatut's Causeway, and Londondery, from London every altenate Friday, cons. mencing 23 rd June, and from principal Stations in Cheshire, Laucashire, and Yorkshire every Friday and Saturday, commencing Ist May.

Day Trips from Belfast by advertised trains to Portrush (for Giant's Causeway), I'ortstewart, Ballycastle, Parkmore (for Glenariff), Wbitehead,

\section{CIRCULAR TOURS.}

Vale of Glenariff and Antrim Coast.-Rail to Parkmore, Coach though Vale of Glenarift to Cushendall, and thence to Larne by the famous Coast Road and Kail; Larne to Belfast, or vice ierse. Fases, includiug Rail and Coach: 1 st Class, $9 / . ;$ and Clare, $7 / 6$; 3 rd Clase, $6 /$.

Antrim Coast and Clant's Causoway 'Tour. - Rail to Portrush, Electric 'Tran, Portrust to Giant's Causeway; Coach round Antrin Coast to Ianne; and Rail Larne to Belfast, or rice eiersa. Fares, includiug Kail and Coarts: 25 Clase, $21 \%$; and Class, 19\%; 3rd Class, 17\%.

Giant's Causeway, Donegal Highlands, and Lakes Erne.Roil, Beltast to Portrush; Electric Tram, Portrush to Giant's Causeway and back: Rail, Portrusli to Londonderry, and Londonderry to Fahan; Steamer, Fahan to Rathmullan; Coach to Rosapenna and tbrough the Donegal Highlands to Killybegs: Rail to Donegal; Coach to Ballyshannon and Kail co Bundoran and Castlecaldwell, thence by Lough Erile Steamer to Iinniskillen, and Kail to Belfast. Ist Class, 68/.; and Class, 69/6; 31d Class, $61 / 6$

\section{Motels under Ralluay Dumarment.}

8TATION HOTEL, B. \& N. C. Railway, Belfast.

This Hotel is elegantly furnished, lighted with elcctricity, and fitted with the most modern improvements. It will be found the most comfortable and converient Hotel in Belfast for Tourists, Commercial gentlemen, and otbers travelling to places in Ireland north of Belfast.

\section{THE NORTHERN COUNTIES RAILWAY HOTEL, PORTRUSH (GIANT' Causeway)}

Afords ample accommodation to Tourists visiting the Giant's Causcuay, as well as families and gentlemen wishing to reside at the Seaside. It is one of the best Hotels in Ireland, commanding a splendid view of sea and coast, containing besides numerous'suites of apartments over 120 bedrooms. Hot and Cold Sea-water Baths 'Bus attends all Trains. Table d'Hute daily. Combined Railway and Hotel Tickets are issued from Belfast at very cheap rates. For further par'iculars apply to

F. COX, Manager, Pontrugu.

\section{THE SHORTEST SEA PASSAGE BETWEEN GREAT BRITAIX} AND IRELAND IS viC LARNE AND STRANRAER.

Daily (Sundays excepted) and daylight sililings by the new fast Mail Sieamers, "Princess May" and "I'rincess Victoria." Two selvices (morning and evening) each way every week-day from 29 th. Nay till 3 oth September. Sea passage, 80 minutes; Port to Port, 2 hours. Trains run alongside Steamer at Stranraer and Larne. Through bookings between the principal stations in England and Scotland, and Nortb of Ireland.

For full particulars see 'Time Tables of the London and North Weste.t. Midland, Caledonian and Glasgow, and South Western Railuay Compariee, et aply to

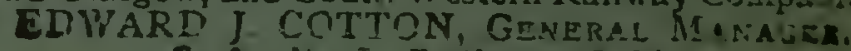

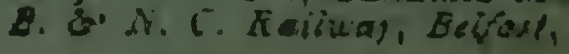




\section{GREAT NORTHERN RAILWAY \\ (IR耳IAND).}

TOURS I. JACLRSIONS in the

NORTH of IRELAND.

UNRIVALLED SCENERY. GOOD HOTELS. ..... CHEAP FARES.

\section{BOYNE}

VALLEY.

Bundoran

(The Brinhton of Ivelandi). Lough Erne. Enniskillen.

\section{$+1$}

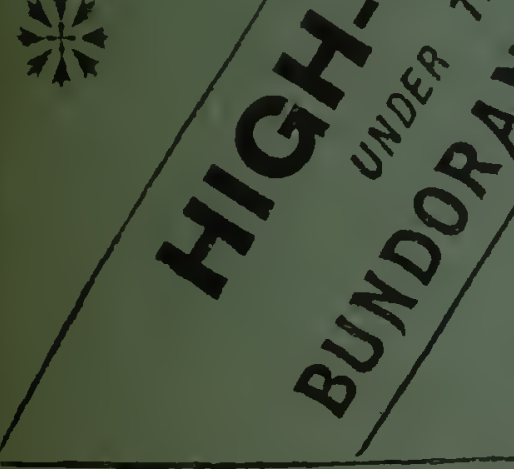

\section{The BEST IOUUT to the}

\section{Increased Facilities} eOr and New Tours.

Is by the Great Northern Railway of Ireland.

A New Coach Service of 100 Miles in County Donegal, through the finest scenery in Ireland, will be in operation from $19 t \mathrm{th}$ June to 30 th September.

For Time Tables, Programmes, \&ic., apply to the Superintendent of the Line, Aniens Street Station, Dubiiz, or to the Company's London Agent. G. K. TurnhaM, ? Charing Ceres. 


\section{"SUNNYSIDE OF IRELAND," \\ Fia}

\section{GREAT SOUTHERN \& WESTERN RAILWAY.}

\section{DIRECT ROUTE}

To the Chief Places of Interest in the South of Ireland.

Lakes of Killarney, Parknasilla, Kilkee, Blackwater Valley (Irish Rhine), Monastery of Mount Melleray, Blarney Castle. WATERING PLACES-

Queenstown, Youghal, Dungarvan, Glenbeigh, Waterville, \& Valencia.

\section{FIRST-CLASS HOTELS,}

Under the management of the Company and their allies, at Limerick Junction, Killarney, Parknasilla, Kenmare, Caragh Lake, and Waterville, the latter two being famous angling centres.

\section{EXPRESS TRAINS}

In connection with Steamers via Kingstown, Dublin, and Waterford.

Special Cheap Tourist Arrangements, -ALso-

Combined Rail and Hotel Tickets.

For particulars apply to Superintendent of the Line, Kingsbridge Station, Dublin; Irish Tourist Office, 2, Charing Cross, London; Messrs. Bullock \& Co., 22, Lime Street, Liverpool.

The Company's Illustrated Gujde ('Sunnyside of Ireland') cay ie had, post frce, 1s, from abovo addresses. 


\section{MIOLAND GREAT WESTERN RAILWAY OF IRELAND.}

\section{CONNEMARA, ACHILL,}

\section{AND WEST OF IRELAND.}

\section{CIRCOLAR TOURS}

From Dublin (Broadstone) to the Tourist, angling, and shooting resorts in the West of Ireland. Reduced fares for parties of two to four passengers.

\section{TOURIST TICKETS}

From the principal towns in England and Scotland for Connemara and Achill, are issued at the Offices of the Railway and Steam Pachet Companies and Tourists Agencies.

\section{EXCURSION TICKETS}

Are issued on Saturdays, First, Second, and Third Class, at single fares from Broadstone Station, Dublin, to Galway, Recess, Clifden, IVest. port, Mallaranny, Achill, \&c, available for return up to last train on following Monday Evening. These tickets are not available by the Down and Up Limited Mail Trains.

\section{BICYCLE TOURS}

Clifden to Westport, 38 miles vid Letterfrack and Leenane, or Clifden to Ballinrobe, 42 miles, viâ Leenane, Maam, Clonbur and Cong. Recess to Leenane, 18 miles, via Inagh Valley. Also Westport to MIallaranny and through Achill Island. The roads throughout Connemara and the West of Ireland are excellent for bicycling. Bicycles carried by Rail as Passengers' Luggage-50 miles, 6d. ; roo miles, gd.; 150 miles, Is.

\section{THE RAILWAY COMPANY'S NEW HOTELS}

At Mallaranny (on the Westport and Achill Branch) and at Recess (on the Galway and (lifden Branch), afford every comfort and convenience for visitors. Electric Light throughout. Terms moderate.

Hot and Cold Sea Water Baths are attached to Mallaranny Hotel. Boating, Bathing, and Free Fishing at Mallaranny.

Tourist Cars run from Ist June to 30 th September between Clifden and Westport, passing through Letterfrack (for Renvyle), Kylemore, and Leenare; and during the same period, the Railway Company's Long Cars will ply between Achill Station and Dugort, distance 9 miles; fare, $2 s .6 d$. Steamers ply on Galway Bay during the Tourist Season, to Arran Island, to Ballyvaughan, and also on Loch Corrib.

Applications for Time Tables, New Illustrated Tourist Guide (price 6d.), Tourist Programmes, and information as to fares, routes, and hotels, \&c., may be made at the Irish Tourist Office, 2, Charing Cross, London; to Mr. J. Hoey, 6o, Castle Street, Liverpool; Mr. J. F. Ritson, ISo, Buchanan - Street, Glasgow, or to the undersigned, 


\section{DUBLIN, WICKLOW, \& WEXFORD RAILWAY.}

Summer Excursions, 1899.

CHEAP DAY TRIPS, GRAND CIRCULAR TOURS, COMBINED RAIL \& HOTEL WEEK-END TICKETS, TO COUNTY WICKLOW ("THE GARDEN OF IRELAND"),

\section{INCLUDING :-}

VALE OF OVOCA, MEETING OF THE WATERS

(Balmoral of Ireland),

VALE OF CLARA, POWERSCOURT WATERFALL, CASTLE HOWARD, and numerous other places of Magnifioent Scenery for which this County is celebrated.

CAR DRIVES ARE TNCLUDED IN THE EXCURSTON \& TOURIST FARES TO MOST OF THE ABOVE-MEENTIONED PLACES.

\section{TOURIST \& EXCURSION TICKETS}

we lssued from the principal stations in England and Scotland to stations in the Counties of Wicklow and Wexford.

For full particulars see Company's lllustrated Tourist Guide, which can be bad at the principal Railway Bookstalls, Irish Tourist Office, 2, Charing Cross, London, or apply to

JOHN COGHLAN, Traffic ifanager.

W'esilans Rosa Forminus, Duódiw. 


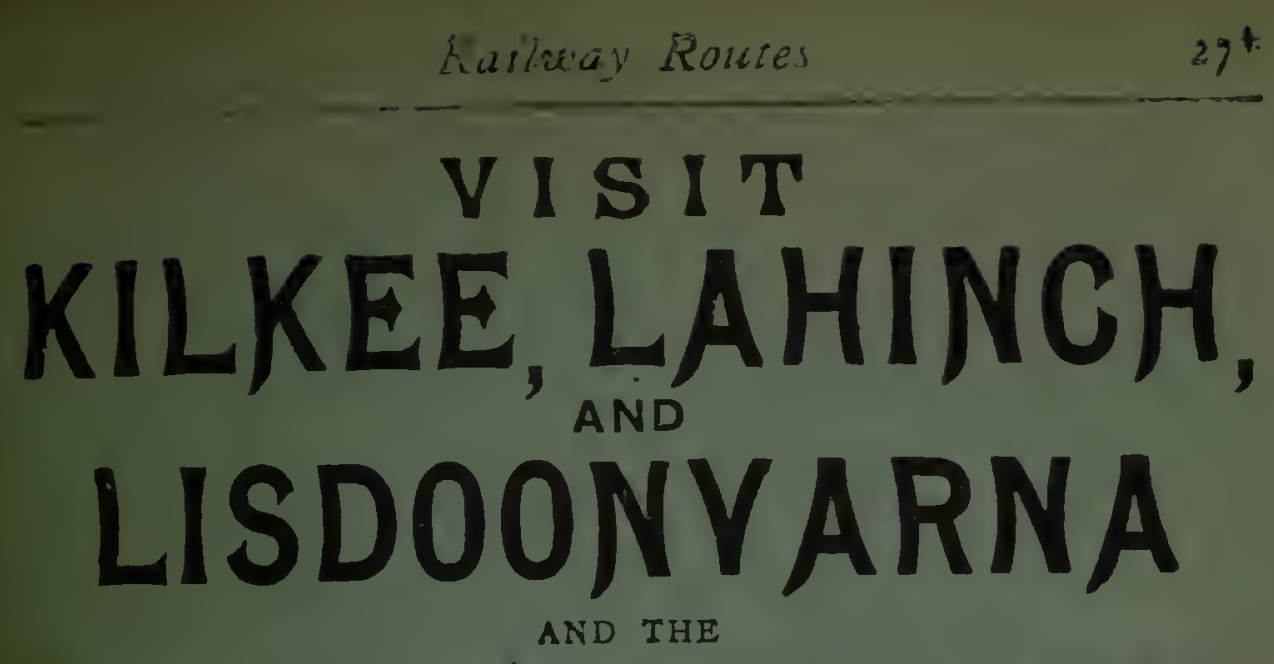

UNRIVALLED CLIF́F and COAST SCENERY OF

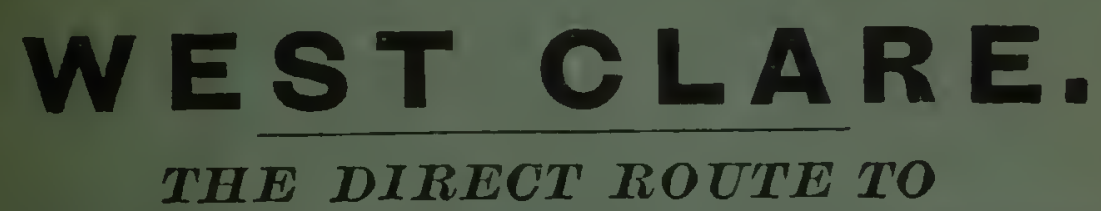

These famous Health and Pleasure Resorte West and South Clare Railways.

From ENNIS to ENNISTYMION (for Lisdoonvarna);

LAHINCH (for the Golf Greens and the Cliffs of Moher),

MILTOWN MALBAY (for Spanish Foirt), and

\section{K厂工灭耳亚。}

NEW AND OIRECT ROUTE BETWEEN

KiLlarney AND CONNEMARA.

The West and South Clare Railways,

\section{Coach and Steamer Services,}

INAUGURATED BY THE BOARD OF WORKS,

GIVE A THROUGH CONNECTION FROM KILLARNEY, GLENGARRIFF AND LISTOWEL TO TABERT, KLLUSH, KILKKEE, LAHUNCH, LISDOONVARNA

ENNIS, CONNEMARA, DUBLIN, AND THE NORTH OF IRELAND, AND IICE VERSA.

THROUGH TOURIST TICKETS are issued at the principal Railway Stations in Ireland and England; also at the Office of Messrs. Thos. Cook - mol Son, and Messrs. Henry Gaze and Sons; and at the Irish Railway Companies' Tourist Office, 2, Charing Cross, London, S.W.

For information as to Fares, Routes, Hotels, Golfing, Fishing, \& , soply to-

I'est Clars Failesay, Essip, 1898. 


\section{GRAND HOLIDAY SEA TRIPS (Magnificent Coast Scenery). LONDON \& DUBLIN SOUTH OF ENGLAND}

The best route for Cornwall, Devon, Wilts, Sussex, Kent, Essex, Hants, and Surrey, and for the Scilly Islands, the Isle of Wight. the Channol Islands and Franco.

THE LARGE AND POWEREUL STEAMERS OF THE BRITISH \& IRISH STEAM PACKET COMPANY, LIMITED, Filted with electric light, and with superior accommodation for Pas ensers, leave London and Dublin twice a week, callin both was it Portsmouth, Southampton, Plymouth and Falnoutl.

Salling DaVS F rrom Lnumon-Sundrys and rednestay.s. Sallig DaVS From Dublin-Wedmesdays and Suturila!s. F L E E T :-

"Lady Roberts,"... ... I,462 tons |"Lady Wolceley,"... ... 1, 124 tons

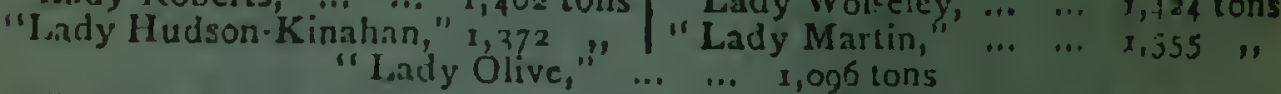

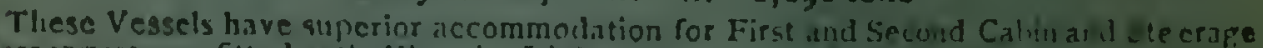
Thasengers, are fitted with lileciric J.ikht, hilve Deck State Kooms, Sinuke Koulis, Bath Kooms, and carrs Stewarils and sievardesves.

Circular Tours from LONDON to Killarney, and South of Ireland, Isle of Man, Glasgow, \&C., from SOU'TH OF ENGLANU Ports to Connomara and West of Ireland (Juno to September) and from DUBLIN to Chrunel Islands and France viri Southampton.

Scilly Islands. - Passengers for these charming Islands land at Falmouth and travel wiả Penzance.

\section{SPECIAL CHEAP EXCURSION TICKETS}

First and Second Cabin, available for 16 days, are issued from Ist of April to end of September, between Dublin and Falmouth, Plymouth, Southampton, and Portsmouth at a Single Fare and a Cuarter.

Ordinary Return Tiekets aro availuble for thee months.

Private Cabins can be reserved on payment of extra charge on early application being madefor same.

Tourists will find much interesting information in Longley's Holiday Guides, entitled "A Run to Dublin," and "Four Channel Ports," also Company's Illustrated Handbook giving all particulars as to Fares, \&ac. Sent post free from any of the Company's Ofices, or obtainable on board the Steamers.

AGENTS:-3o, Even QuAY, Duslir, Carolin \& Egan. London: James Hartley \& Co., I9, Leadenhall Street, E.C. : North Quay, Eastern lasin, Tondon Docks, E. Plymouth : R. Clark \& Son, Millbay Pier; H. J. Waring \& Co., Millbay Pier. Southantpton: Le Feuvre \& Son, 8, Gloucester Square. Falmoutr: W. \& E. C. Carne, Market Street. Porismoutu:-J. M. Harris, ro, Broad Street.

Tickets aro also issued by Messrs. THOS. COOK \& SON, and HENRY GAZE \& SONS.

Cbief Obces:-3, North Wall, Dublin. $-\mathbf{A}$. W. Bgan, Secrelary.

Telegraphic Address:- "AVE, DUBLIN." 
THE GLASGOW, DUBLIN, \& LONDONDERRY STEAM PACKET COMPANY (Ltd.)

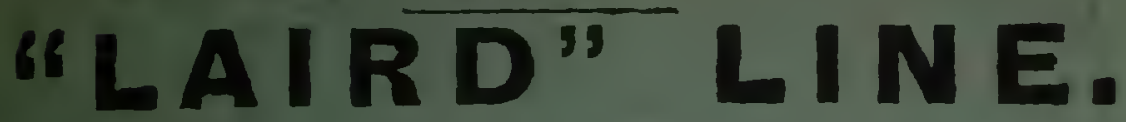

First-Class Passonger Steamers Sall as under, viz.:

GORECAMBE to LONDONDERRY. - Fares-Single, 12/6 \& 6/.: hery Tuesday and Saturday

ONDUNDERRY to MORECAMBE.-

Rersy Monday and Thursday.

Return, 20\% \& 8!.

Excursion-

M RECAMBE to DUBLIN.-Every

Mondas; Wednesday and Friday

Tyeday, Thursday, and Saturday

\section{ATTRACTIVE TOURS FROM MORECAMBE.}

vetracing the GIANT'S CAUSEWAY, PORTRUSH, COLERAINE, LONDONDERRY, DONEGAL HIGHLANDS, BELFAST, SLIGO, CONNEMIARA, DUBLIN, KILLARNEY, and the Picturesque COUNTY WICKLOW.

La:coW to LONDONDERRY.-Every Monday, Tuesday, Thursday and Friday.

If 32.0 PDERRY to GUASGOW, -Every Tuesday, Wednesday, Friday and Satur.

farEs-Cabin, single, 12/6; Retarn (Two Montha), 17/6; 8teersge, 8ingle, 4/-

cap Circular Bookings, GLA'SCOW to LONDONDERRY, thence BELFAST and Home, vz LARNE and STRANRAER. Cabin and Third Class, 22/9 ; Steorago ard Third Class, 15/-

CLASGOW to COLERAINE.-Every Monday and Thursday at $2.0 \mathrm{p.m}$.

COLERAINE to GLASGOW. - Every Tuesday and Saturday, Afternoon tide.

-GLASCiOW to PORTRUSH (for Glant's Causeway). - Daylight Service during Season. Erery Tuesday, Thursday, and Saturday, from zoth June until September.

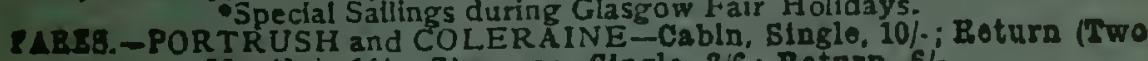
Monthy), 14/.; Eteorag, Blnglo, 3/6; Roturn, $6 \%$

CLASGOW to DUBLIN. - Every Tuesday, Thursday, and Saturday, at a.0 p.m.

DLBLIN to GLASGOW.-Every Tuesday, Thursday, and Saturday, alternately, at

60 and Afternoon tide.
GLASCOW to SLICO. Every Wednesday and Saturday .. ... (See Sailing Bills).

LIGU to GLASGOW.-Every Wednesday and Saturday ... $\quad \ldots$ do.

CLASCOW to BALLINA and WESTPORT .. $\quad . \quad \cdots \quad \ldots \quad \ldots$ do.

BALLINA and WESTPORT to GLASGOW Cabla, Bingle, 12,6; Return, 20\%; Steerage, single. 6\%:; Retarn, 8\%.

ATTRACTIVE TOURS FROM GLASGOW. Cab. Cab. Stge.

LOVIONDERY BELFAST, and Home, vit LARNE and ist. \& 3rd. \& 3rd STRANRAER, or vice versa

TO LONDONDERRY, ENNISKILLLEN, DUBLIN" and Home, $83 / 6 \quad 25 / 11 \quad 16 / 2$

GLASCOW to LONDONDERRY, per direct Steamer, "ines, BELFAST and DUBLIN pez Rail, and back by direct

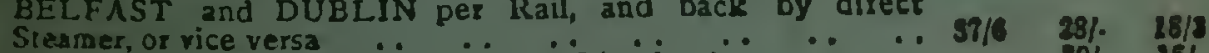

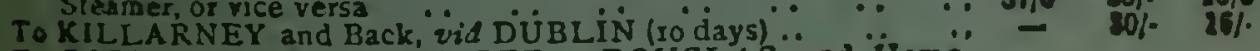

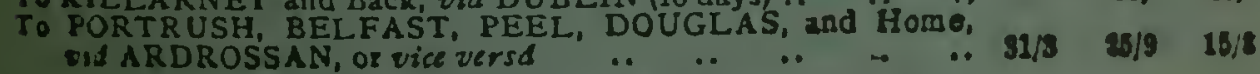

SPLENDID COASTING TRIP

To DUBLIN, thence MORECAMBE, thence LONDONDERRY and Home.

Fare lor Bound Trip.-Cabtn, $32 / 6$; Steerage, 14/-

Thls Tour ray be commenced at any point, and taken whichever way the Tourlst may prefer.

DIRECT COMMUNICATION between LIVERPOOL and LARNE, and PORT.

RUSH and WESTPORT. For further particulars see Sailing Bills.

Tos full particulars apply to A. A. Laird and Co., Londonderry; D. Fall and Son, or fan Caluw ell and Son, Portrush and Coleraine; James Harper and Co., Sligo: Wells a f Holohan, Dublin: Thos. Cook and Son, Dublin and Belfast; Alex, A. I.aird and Co. Ballina; A. M. O Malley, Westport; O. Carr, Morecambe Harbour; M. Langlands and Sus, Liverpool; Alex. A. Laird \& Co., Larne; and ALEXANDER A." LAIRD \& CO.,

Custom House Quay, Greenock; and 52, Roberteon Street, Glasgor. 


\section{GLASGOW AHD THE HICHLANDS.}

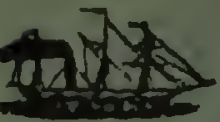

TXTEKLY CIRCUILAR TOUR by the favourite stetsin

"DUNARA CASTLE," from Glasgew, every Thus

day, at 2.0 p.m., and from Greenock, at 9.0 p.mi., for Culuney, Iona, Mull, Tyree, Skye, Harris, Uist, and Barra. Keturt. ing to Glasgow on Wedneiday. Affords to tourists the opportunity ef acot - week's sea voyage, and, at the same time, a pannraruic view of tha magnificent scenery of the Outer Hebrides. Return cabin fare, incloci e meals, $C_{3} 55$. Occasional special trips to tbe island of St. Kilda. Retura cabin fare, including nueals, $\ell_{4} 45$.

Berths may be booked at the offices of the Clyde Shipping Co., 13t, Leadenlaall Street; and the Carron Co., 87 to 93, Lower East Smith ed, Londow. Time bills, with maps, and berths secured, on application tu MAR'IIN ORMIE., 20, Robertson Sireel, Glalgow.

\section{Norway, Denmark, and Germany,}

The First Class Passenger Steamers of The Leith, Hull, and Hamburt Gteam Packet Company, Ltd., sail as under-noted (unless preveute fi, che weather or unforeseen circumstauces) :-

from Leith to Christiansand, every Thursday, for Hergen, the Has d. anger, Sxtersdal, and Ctristiania. Returning every Friday.

From Leith to Copenthagen, every Thursday, for Gothenburg the Gos Canal, and Stockholm. Keturning cvery Thursday.

From Leith to Hamburg, cvery Wednesday and Saturday, for dolln, Dresden, Vienna, Munich, the Harz Mummains, the Rbine, and Siowes land, Keturning every Monday and Friday.

Cabin Fares to or from Leith (including provisions) :-Copenhagen io ( hrintiansand, single, £3 3s. Od., return, £5 5s. Od. Han:Lurg, ingl, £2 lOs. Od., return, £4 4s. Od. These rickets issued un boird flis. oue hour before the advertised salling hour.

Through Fares (including Provisions to and from Continent) - Tu Christiania, £4 Os. Od. To Bergen, $£ 4$ 7s. 6 d. To Berlin; $£ 3$ 10s. Od

\section{CIRCULAR TOURS.}

A HAwDBOOK may be had on application, with maps and details of then, and of the inost interesting Tours amons

\section{THE FJELDS AND FJORDS OF NORWAY.}

Fares for the Round:-LFITH and BACK. TuUR 1,- Ilamburt Kiel, Copenlıagen, Christiansand, \&6 6s. Od. Tour Ij-Manilur, Lubeck, Copenhagen, Christiansand, $£ 8$ Gs. Od. Tour III.-Hemlure, Berlin, Rostock, Copenliagen, Christiansand, $£ 7$ lls. Od.

The above Fares are Cabin and and Class Ruil, but ast Class Rail Tickers at to husd if desired.

Tickets are also issued for three extensions to SWEDEN at $\& 28 \$ 5 \mathrm{~d}$, S5 149. 9d., and \&6 4s. IId. respectively, enabling tourists to visit th famous Gota Canal and Stockholm. Particulars on application.

\section{HOLIDAY TOURS IN NORWAY.}

Ten Days for $£ 8$ 8s. Od. : Seventeen Days for $£ 10$ 10s. Od., includir: all expenses. Full particulars on application.

Passengers wishing through tickets for any of the tours must write tu the office not later than the day before sailing, stating whith tour they iuten! to take. The tours may be taken in either direction, and the joirney broken at any point. For further details and particulars of sailings to Bremen, Hull, Newcastle, Sunderland, \&c., apply to the Hanagers.

JAMES CURRIE \& CO. $1.811 \mathrm{H}$ 


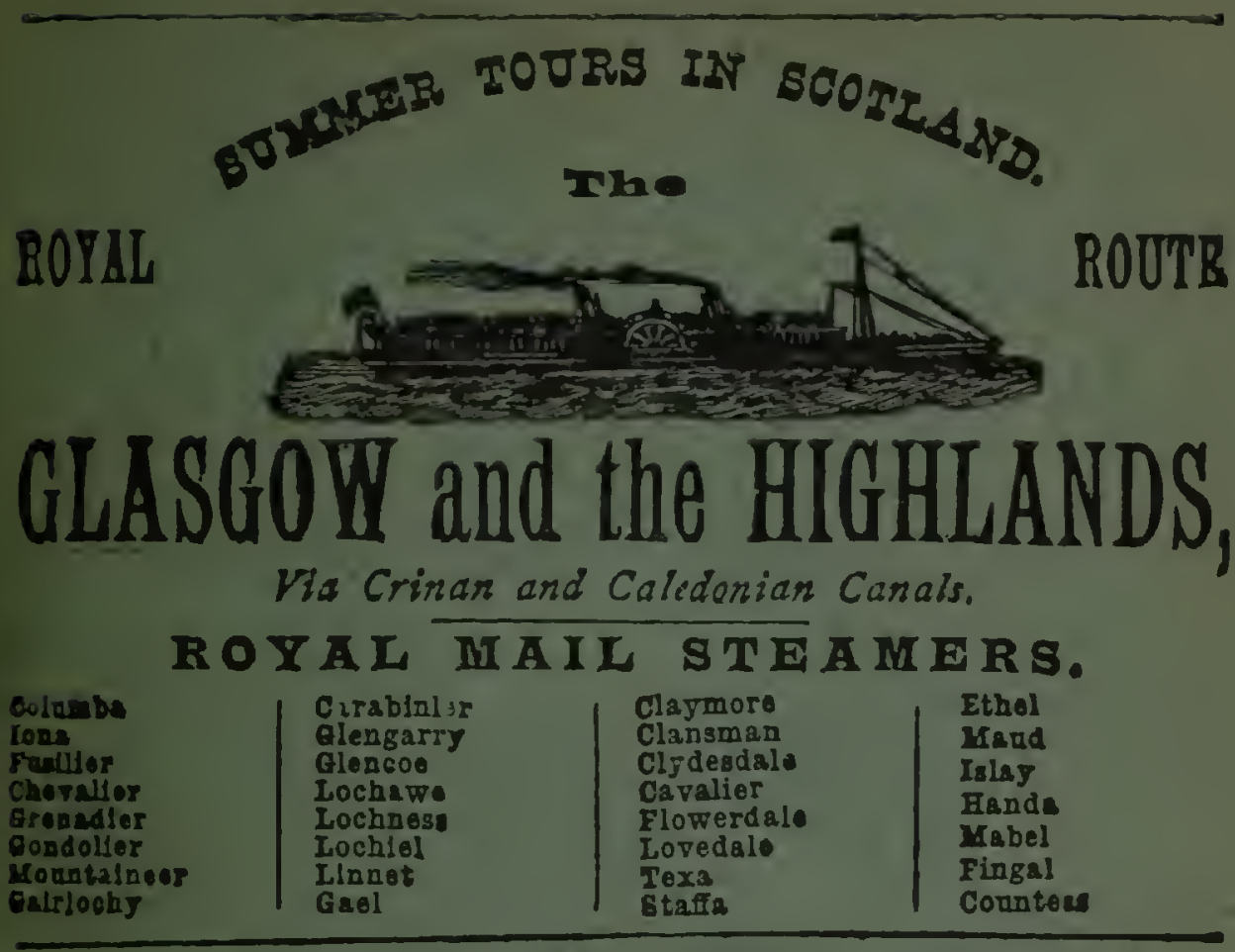

\section{THE ROYAL MAIL SWIFT PASSENGER BTEAMER,

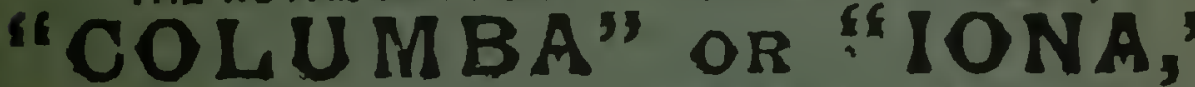

ails dail from May till October, from Glasgow at 72. m., and from Greenock al 8.40 L m. Princes Pier 9 a.m., Gourock 9.25 a.m., Dunoon $9.30 \mathrm{a.m}$., in conpection witb express trains from London and the south, Edinburgh and Glasgow, \&c., and for KYLES OF BuTz, TARBERT, and ARDRISHAig, con. reying passengers for OBAN, GLencoz, INVERnESS, LOCH AWE, LOCH I OMOND, LOCH KATRIME, THE TROSSACHS, STAFFA, and IONA, MULL, SKYL. GAIRLOCH, LOCHINVER, STOKNOWAY, THURSO, EC.

A WHOLE DAY'S SAIL BY THE "COLUMBA" OR "IONA" From Glasgow to Ardrishaig and back (180 miles).

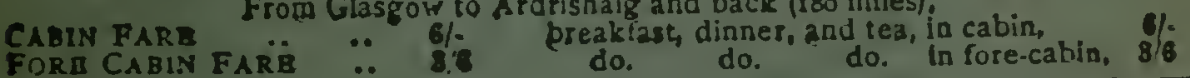

FORI CABIN FARB .. Be do. do. do. in fore-cabin, $8 / 6$

TOURS TO THE WEST HIGHLANDS (occupying about a week), BY STEAMSEIP

"OLAXMORE" Or "CLANSMAN,"

Via sfull of Kintyre, going and returning through the Sounds of Jurn, Mull, and Skye, callitily at Oban, Tobermory, Portrel, STOR NOWAY, and intermediate places.

CABIN RETURN FARE, with superior sleeping accommodation, 45 s. Or, Inolualing Mosis, 808.

The route is through scenery rich in bistorical interest and unequalled for randeur and variety. These vessels leave Glasgow every Monday and Thuraday about 12 noon, and Greenock about 6 p.m., returning from Gtornoway every Monday and Thursday morning.

The Steamship CAVALIER will leave Glasgow every Monday at Ir a.m. and Greenock at 5 p.m., for Inverness and back (viâ Mull of Kintyre), leaving Inverness every Thursday morning. Cabin fare for the trip, with first-class sleeping accommedation, $40 /-$; or, including meals, $70 \%$

OFFICIAL GUIDE BOOK, ILLUSTRATED, 6 d. ; cloth, so.

Tourst Programme sent free on asplication to the Owner. DAVID MACBRAYNE, 119, Hope Street, GLASGOW. 
A. W. WHITE \& CO., Ltd.

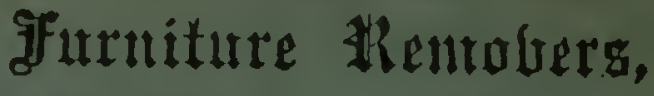

THE HAMPSHIRE PANTECHNICONS, PORTSMOUTH, SOUTEAMPTON,

BOURNEMOUTH, WINCHESTER.

General Carriers and Yarehousemen. sole Agents to the Great Western Builuay Company. RSTIMATRS FRER.
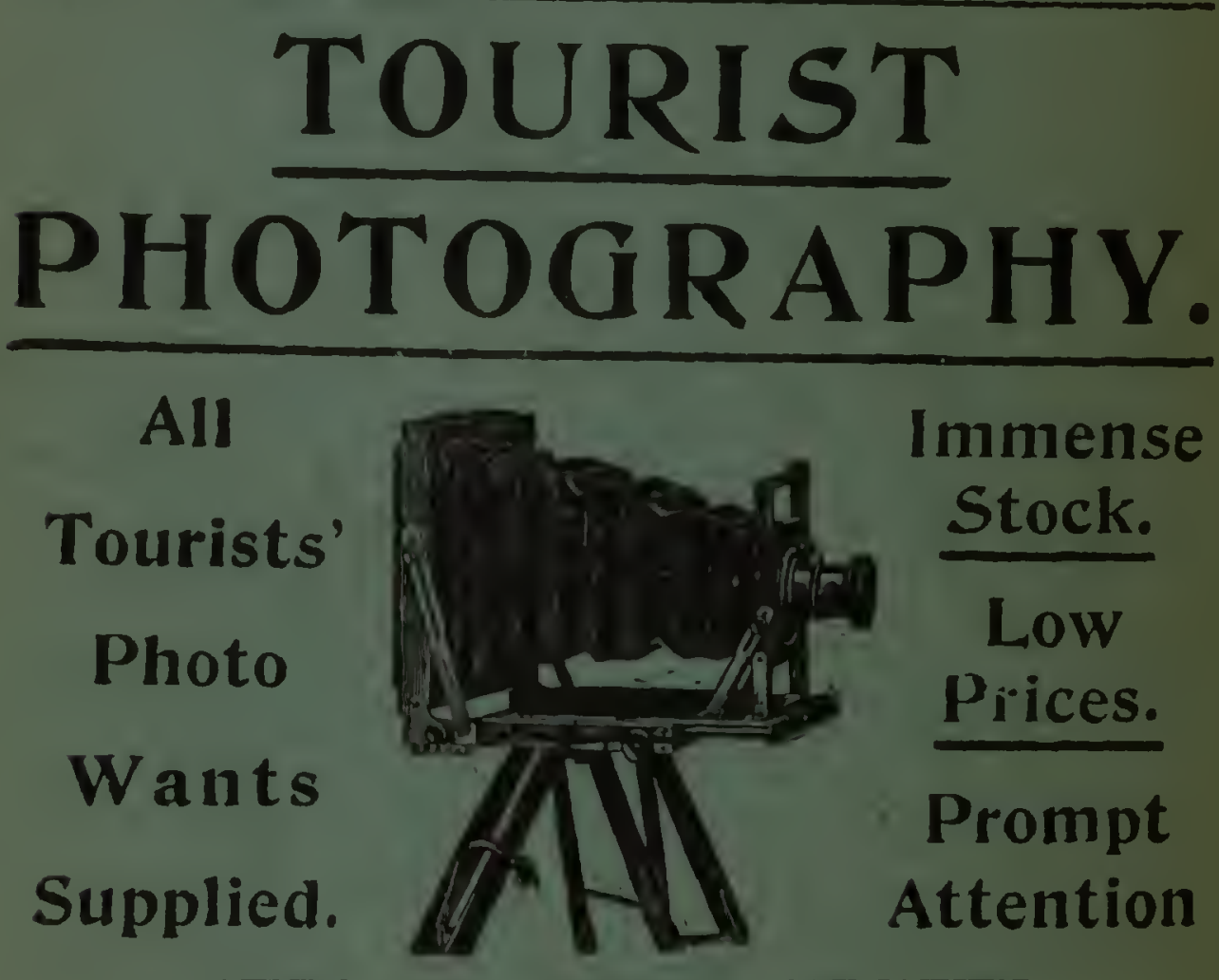

POCKET CAMERAS, PLATES.

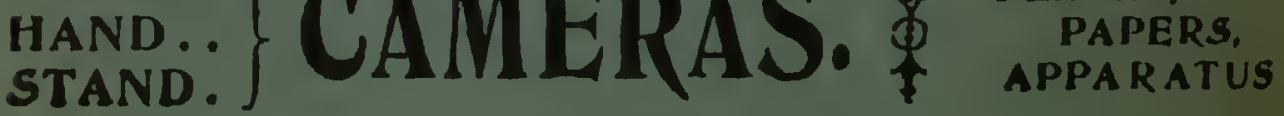

DARK ROOM for Use of Travellers. Dobsons 扯 Curtis Bros. Ll:

Io, Suffolk St., DUBLIN. 


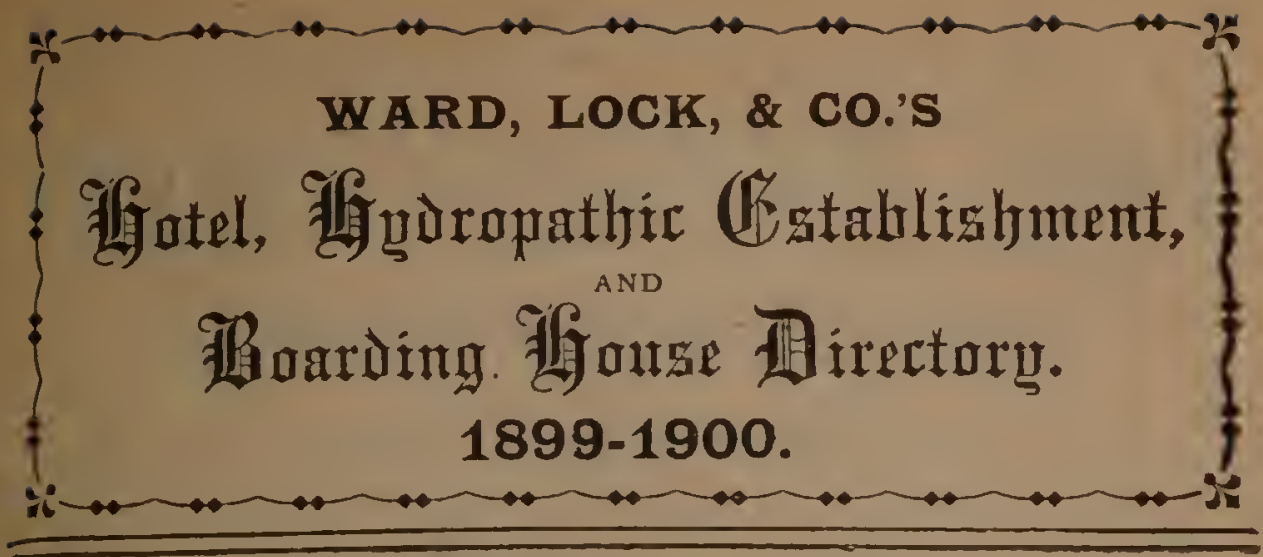

INDEX.

PALE PAGE

PAGE

\begin{tabular}{l|l|l} 
Aberdeen ........... & 2 & Giant's Causeway $2 I$
\end{tabular}

Ambleside ........... I 8 Grasniere .......... 20

Belfast ............. 3 Harrogate ........ 22

Bettws-y-Coed..... 3 . Hexham ......... 44

Bideford .......... 3,4

Ilfracombe ........ 23

Bowness ........... I 7

Blair Atholl ........ 4

Boscastle .......... 8

Bournemouth ..... 5

Bundoran .......... 4

Buxton .....6 6, 7,8,9

Caragh Lake $\ldots . . .29$

Carrigart ........... I I

Colwyn Bay ........ 9

Cruden Bay ...... Io

Dartmoor ............ II

Douglas ........... II

Dublin ...... I\%, I3, I 4

Dundee .............. I4

Dunkeld ........... I5

Edinburgh ...... I5, IE

Exeter

Ilkley.............. 24

Inverness .......25, 25

Kenilworth ........ 28

Kenmare .......... 29

Kerry Fjords ..... 29

Keswick........... I9, 20

Killarney ........ 27, 30

Leaningto $\ldots . . . \ldots .3$. 3 I

Liverpool ....... 32, 33

Llandudno .......... 30

Loch Awe....... 33, 34

Loch Katrine ..... $\quad 34$

Loch Lomond ..... 34

London .............. 35

Lynmouth.......... 35

Matlock............ 36

Newby Bridge..... 20

Oban ............. $3^{6,37}$

Oxford ............. 37

Parknasilla ........ 29

Patterdale ........... I9

Perth ............... $3^{8}$

Pitlochry ............ $3^{8}$

Plymouth ......... $\quad 38$

Rostrevor .......... 39

St. Asaph .......... 39

Sandown ........... 27

Sidmouth ........... 40

Stratford-on-Avon 40

Strathpeffer ........ 4 I

Teignmouth ....... 42

Tintagel............ 42

Torquay ........... 43

Ventuor $\ldots . . . . .26,27$

Warrenpoint........ 44

Warwick .......... 44

Waterville.......... 29

Wemyss Bay ..... 45

Windermere ........ 18

Is UNDOUBTEDLY the BEST and most RELIABLE medium.

TARIFFS OF RATES, POST FREE.

London: (Chief Office) 25, Cannon St., E.C. ; Northumberland Avemue, S.W.

\begin{tabular}{c|c|c|c|c} 
Liverpool: & Paris : & Hamburg: & Boston: & New York: \\
4, Redcross & 47, Rue & 47, Anlsinck & I21, Water & Wireet. \\
Cambon. & Strasse. & Street. & Broadway: \\
\hline
\end{tabular}




\section{THE PALACE HOTEL, ABERDEFN.}

("ITIIIN TUL STATION).

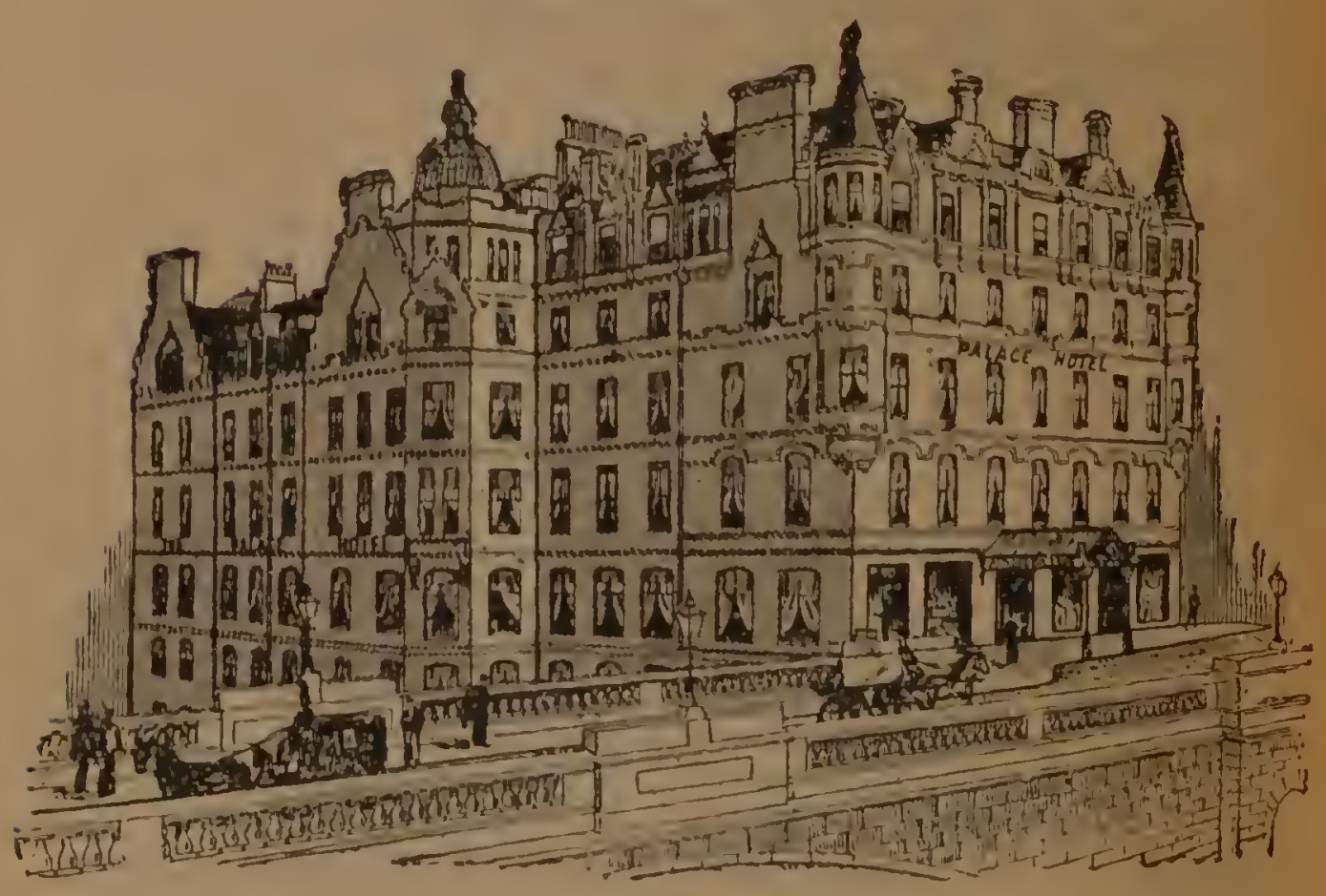

Owned and Managed by the Great North of Scotland Railway Co.

EQUIPIED WITH EVERY MODERN ACCOMMODATION FOR COMFORT. LIGHTFD HY EIECTRICITY. MECHANICALLY VENTILATED. LIETS.

\section{EXCELLENT CUISINE. MODERATE CHARGES.}

\section{Hotel Porters attend all trains.}

JERSONALI, PATRONISED by 'Their Royal Highnosses the I PRINCE and PRINCE SS OF WAIFS, The WUKE and DUCHESS OF CONNAUGHT, The DUKE and NUCHESS OF YORK, The EMPRESS FREDERICK OF GFRMANY, PRINCE IS CHRISTIAN and PRINCESS VICTORIA, PRINCESS HENRY OF BATTHNBERG, The MAROUIS and MARCHIONESS OF LORNE, PRINCE and PRINCESS CHARLESOF DENMARK, The FIPRESS EUGENIE, The KING OF PORTUGAL, The KING OF THE BELGIANS, The MARUUIS OF SALISBURY, LORD KITCHENER OF KHARTOUM, and many Distinguished Visitors.

Miss MICKILLIAM, MANAGR.

The CRUDEN BAY HOTEL, also owner and manged by the Greet North of Scotland Rallway Company, see page 10. 


\section{EGLINTON \& WINTON HOTEL, HIGH STREET, BELFAST.}

First-class Family and Commercial, SPLENDIDLY SITUATED.

rram Cars pass the door. Handsome Billiard \& Smoking Rooms. Omuibuses attend all Trains and Stermen's.

NIGHT PORTER.

TERMS MODERATE.

Telenthnue Nn. 2 \&. JOHN MANTELL. Proprietor:

BETTWS-Y-COED.

LLUGWY VIEW PRIVATE HOTEL

CLOSE to the Pont-y-Pair. "Jourists, Families, and Gentlemen visiting Kettws-y-( oed $C$ will find the above fluce replete with all that cin be desired. Ferms moderate un application. CAB EOR HIRE. O. WDWARDS, PROHRIETOK

\section{B I D E F O D .}

\section{CENTRAL FOR THE WHOLE OF NORTH DEVON.}

Including WESTWARD HO! CI.OVELLV, HARTLAND, BUI)I, ILFRACOMBE, and LYNTON.

Coaches in the Season to Above Places.
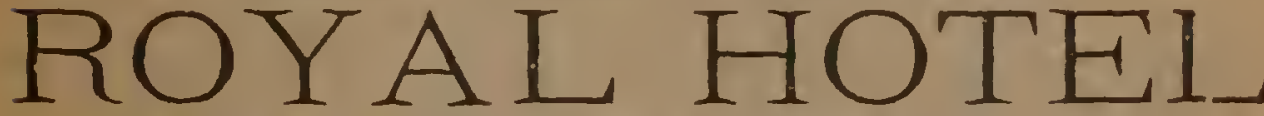

Adjoining Rallway Station. Magnificent Views.

THE MOST MODERN HOTLL IN WEST OF ENGIANI.

Replete with every convenience and confort.

COMPLETELY SHELTERED FROM EAST \& NORTH.EAST WINDS.

Lofiy, perfectly ventilated, and handsonely furnished roonı.

FORMING CHARMING SUMMER AND WINTER FIESORT.

One of the mildest and bealthiest in the lingdon.

COTINENTAL COURTYARD.

Fxcellent hunting neighbourhood. Finest Stabling and Lock-up C oaclihouse in Devonshire. Refreshment Koom and luxurious Double Billiard Koom, with direct ent:ance from Railway Flatform.

SAVE OMNIBUS AND PORTERAGE

Porlers attend every Train. French and German spoken.

SPECIALLY REOUGED WINTER TARIFF AND BOARDING TERMS.

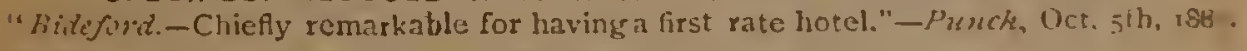

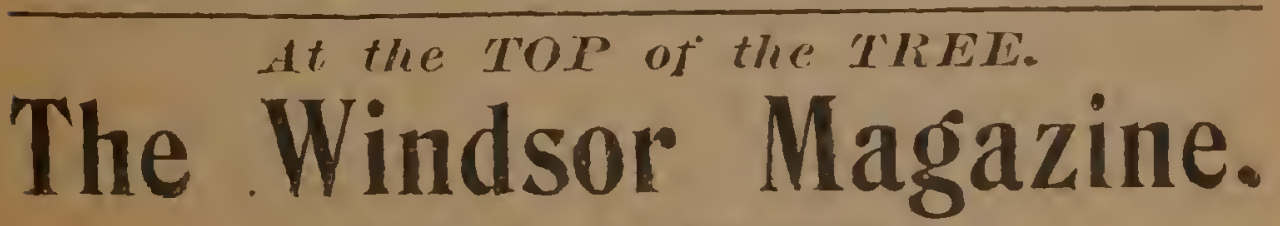




\section{BIDEFORD.}

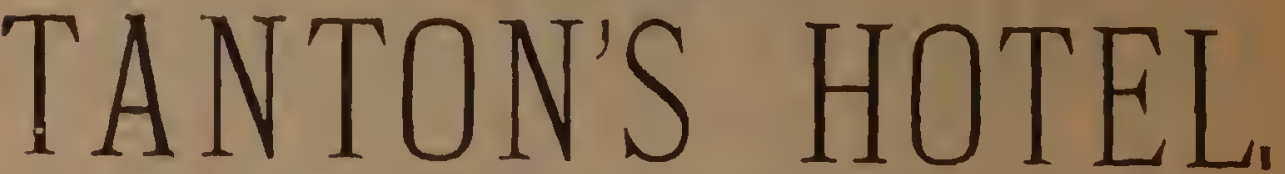

FINEST, best, and only uninterrupted Views. OverF looking River Torridge and Old Bridge. Enlarged. Refurnished. Every Comfort. Posting, Coaching, Hunting, Golfing, Fishing. Write for Tariff and Boarding Terms. Special Tariff for Golfers. Central for Westward Ho! Clovelly, Hartland, Bude, Lynton, and Ilfracombe.

\section{ATHOLL ARMS HOTEL \\ AND POSTING ESTABLISHMENT. (ADJOINING THE STATION.)

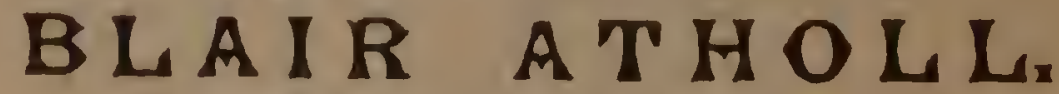 \\ D. MACDONALD and SONS, PROPRIETORs.}

NE of the largest and best appointed hotels in the C Highlands. Magnificent Coffee Room and Ladies' Drawing lioom. Table d'hôte daily during the season. Boarding terms on application.

13lair Atholl is much the nearest and most central point from which to visit Killiecrankie, the Queen's View, Lochs Tummel and Rannoch, Glen Tilt, Braemar, the Falls of Bruar, Garry, Tummel, and Fender; the Grounds of Blair Castle, \&.c.; and it is the most convenient resting-place for breaking the long railway journey to and from the North of Scotland.

The Bridge across the Tarff is now open, and the excursion through Glen Tilt to Braemar can be safely made.

$$
\text { GOLF COURSE. }
$$

POSTING DEPARTMENT Complete and Extensive.

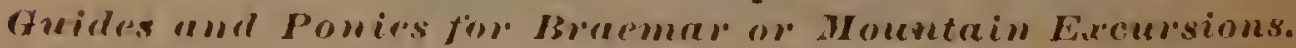

\section{Gt. Northern Railway Hotel.} BUNDORAN, CO. DONEGAL.

THIS First-class Hotel has been furnished and provided in best modern 1 form. It comprises spacious Drawing, WVriting, Coffee, Smoking, and Billiard Rooms; also Hot and Cold Salt and Fresh Water Baths, fitted with all the latest improvements. The situation is unparalleled, commanding magnificent views of Donegal Bay and the Mountain Ranges on both sides. Most favourable position for Anglers. First-class Golf Links adjoin the Hotel, and are free to visitors. ITnequalled Sea Bathing. For Terms apply to the Manager. Combined Railway and Hotel Tickets are issued from all the principal stations on tho Great. Northern Railway (Ireland) to above Hotel. 
"THE HOTEL DE LUXE of the SOUTH."

The late Mr. EDIIUND YATES, on his last sojourn here (ruth November, 1892), wrote in the Visitors' Book: "A Charming Hotel, excellently' conducted; perfect in cumfort, cleanliness, and cookery."

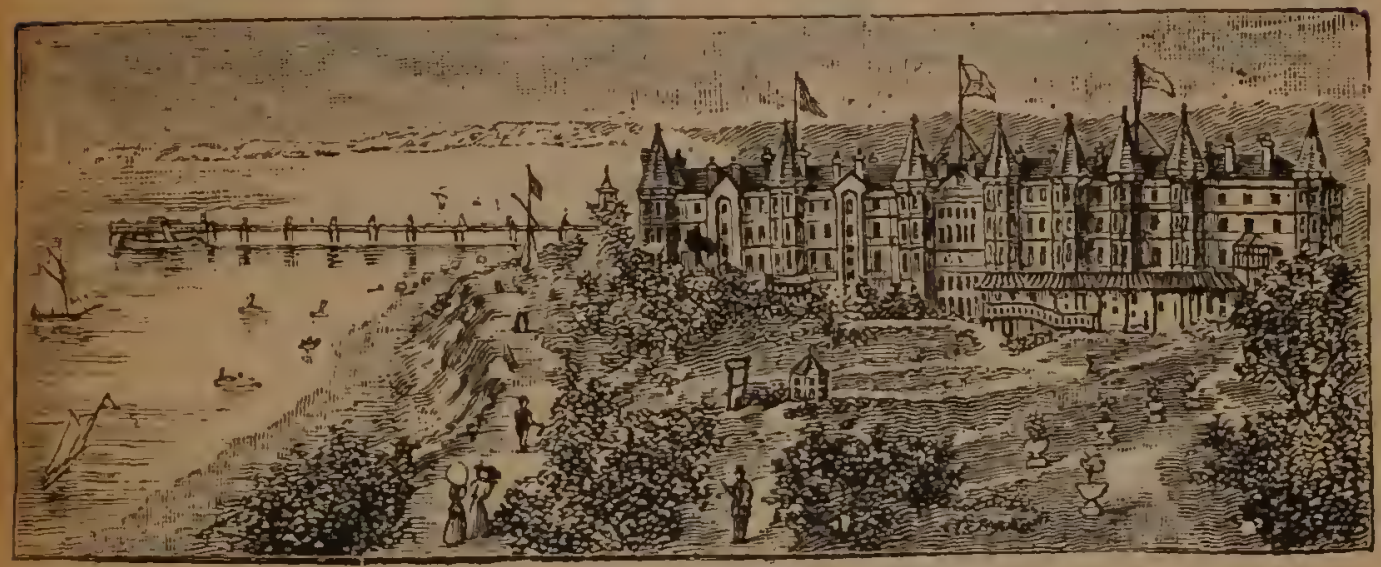

\section{BOURNEMOUTH, ENGLAND.}

(18 Miles from Southampton).
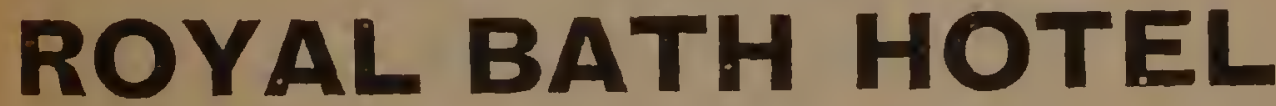

"HOTEL DE LUXE OF THE SOUTH."

Patronised by H.R.H. the Prince of Wales, H.I.M. the Empress Eugenie, H.R.H. the Duchess of Albany, H.M. the King of the Belgians, the inte Lord Beaconsfield, and other distinguished personages.

UNRIVALLED POSITION, overlooking the Bay, and completely protected by Pine Woods from North and East Winds.

Stands in its Own Charming Grounds of Five Acres, Facing Sea. Sea Frontage of 1,000 feet.

Hotel Private Ommibus meets trains. Due South.

Two Night Watchrnen.

Sanitary arrangements by JeNNingin, of Lomilun.

LIVERY S ABLES AND LAUNDRY ATTACHED. Superb Bathing. Lovely Climate. Charming Scenery. Finest Golf Links in England.

NotE. - The British Medical Association selected this Hotel for their, Headquarters, Reception, Ball, and Banquet, July, 18gr.

6S. At all Rooksellers and Bnokstalls. J. C. Snaith's New Novel. $6 S$. "Willow, The King:"

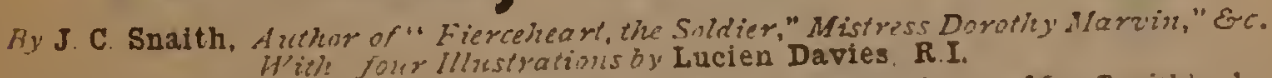

.. A novel which cricketers are certain to hail with enthusiasm. Mr. Snaith's description of the fortunes of tho day is one of the most humorous accounts of a ericket scription of the fortunes of thro day is one who will not laugh over the narratire. The story is capital, and no cricketer, who wants a hearty laugh, will be disappointed in perusing it. - Daily Telegraph.

"N. Snaith has written the best ericket novel I have ever read. The hewine is drawn with amazine vigor and vividness. Her wit, her volleying repartee, her humour, are almost incredibly brilliant. - Siar.

WARD, LnCK \& Co., Ltd., Salisbury Square, London, E.C. 


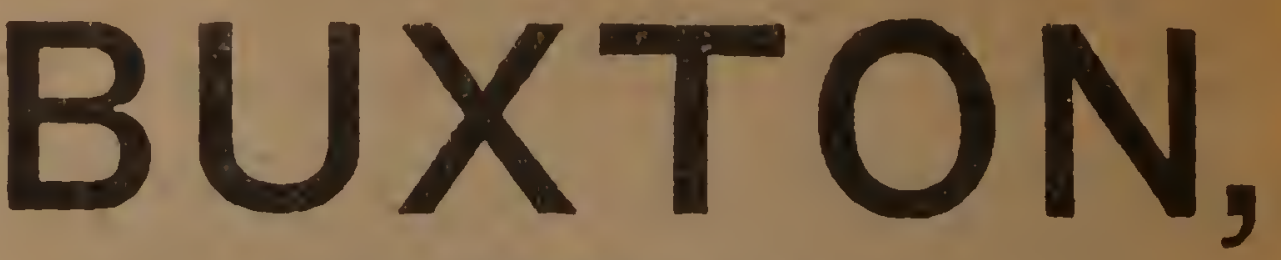

DERBYSHIREx

IIGIIEST TOHN IY ENGLAND.

On the Mountain Limestone, 1,000 feet above sea level.

Centre of the picturesque Peak District.

Pure Air. Charming Scenery.

\section{HOT MINERAL-WATER BATHS}

For GOUT, RHEUMATISM, SCIATICA, LUMBAGO, \&c. Natural Temierature $82^{\circ}$ Famrenheit.

FINEST PUBLIC GARDENS AT ANY HEALTH RESORT IN EUROPE, WITH PAVILION, THEATRE,

CONCERT HALL, TENNIS, BOWLS, \&C, \&C. GOLI LINKS (18 HOLES).

For ILLUSTRATED GUIDE, with Taritfs of the leading Hotels, Hydropathics, - Boarding and Lodging Houses; send postage ( $1 \frac{1}{2} \mathrm{~d}$.) to

CHIEF CLERK, TOWN HAIL, BUXTON, DERBYSHIREz 

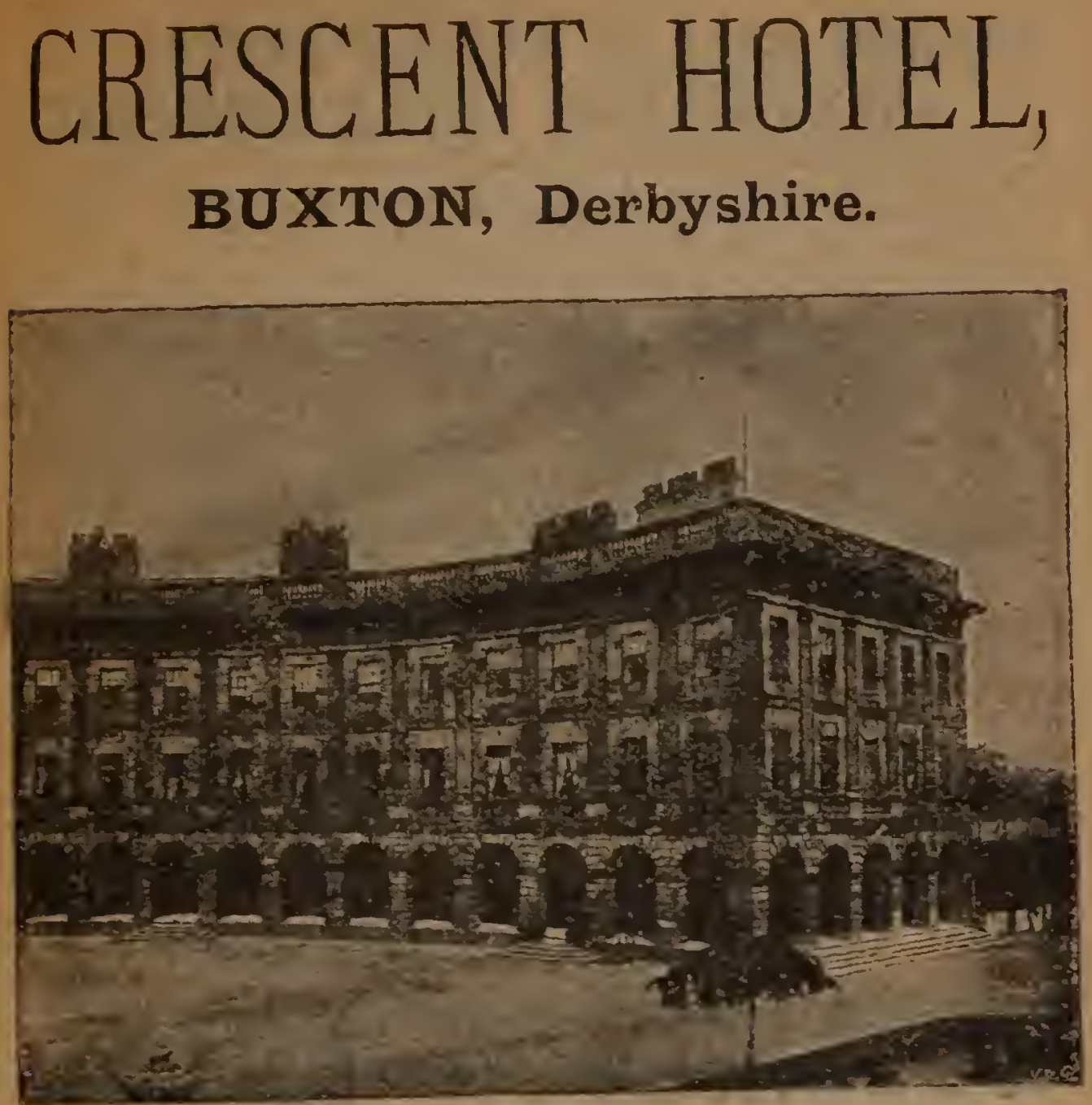

THIS First-class Hotel occupies the best situation, being 1 near the Railway Stations, and connected by Covered Colonnade with the Baths, Wells, Pavilion, Gardens, Theatre, ic. Buxton Golf Links one mile from the Hotel. The New Pump Room is immediately opposite the Ilotel. Table d'Hote at $6.30 \mathrm{pm}$. in the Splendid Dining Room (one of the finest in the Kingdom).

PCBLIC DINING, DHAWING, BILETARD, SHOKING, AND READING ROOMS.

Excellent Cuisine. Choice Wines and Cigars.

$$
\text { C. J. SMIITTER, PROTRIETOR. }
$$

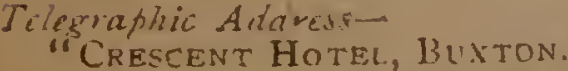

National Telefhone, No. 20.

TERMS MODERATE \& INCLUSIVE. 


\section{B U X TON. \\ HADDON HALL \& HADDON GROVE HYDROPATHIC ESTABLISHMENTS.}

SPACIOUS accommod tion, including Recreation, Billiard, Smoke, and Dark Kooms, Temnis and Croquet Lawns, \&c. Thorough treatment for Rhenmatism, Gour, \&c. Electric, Massage, and all kinds of Hydro. pathic laths ; also the celebrated "Nauheim Baths" and Movements given for Heart Affections by thoronghly experienced Autendants. Station 'Bus meets trains only when advi-ed. Poultry and Dairy Prodnce frum our own Farm. Note.- Bus runs hourly' to and from the Pump Room Mineral Baths, and Pavilion Gardens, free for visitors staying at the above Hydros. Telephone $N_{0} \quad$ For terma, apply C. E. HAl.L. Prorrietur.

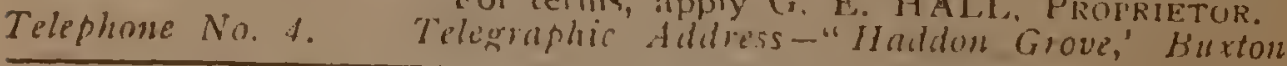

\section{HUIION, DEIBISIIIRE. BUXTON HYDROPATHIC.}

GIJUATEl over One thousand Feet ahove the Seat I.evel. Sheltered $D$ from the North and Bast: overlooking the l', lir Gardens, and close to the celebrated Mineral Wello and 1, ths. MAGNIFICENT PUBLIC ROOMS.

AMERICAN ELEVATCR. ELECTRIC LIGHT. Hydropathic Bath of every description, Electric Bathi, Massage, Electro.
Massage, and the Nauheim I'reat llent.

Tennis, (; Jlf, Hunttng, Fishing. Cinderella Dancs every Saturday. Telegriplic Adiless - "Comfortable, Buxtun." Natronal Telephone, No. 5. Apply-Mr. LOMAS.

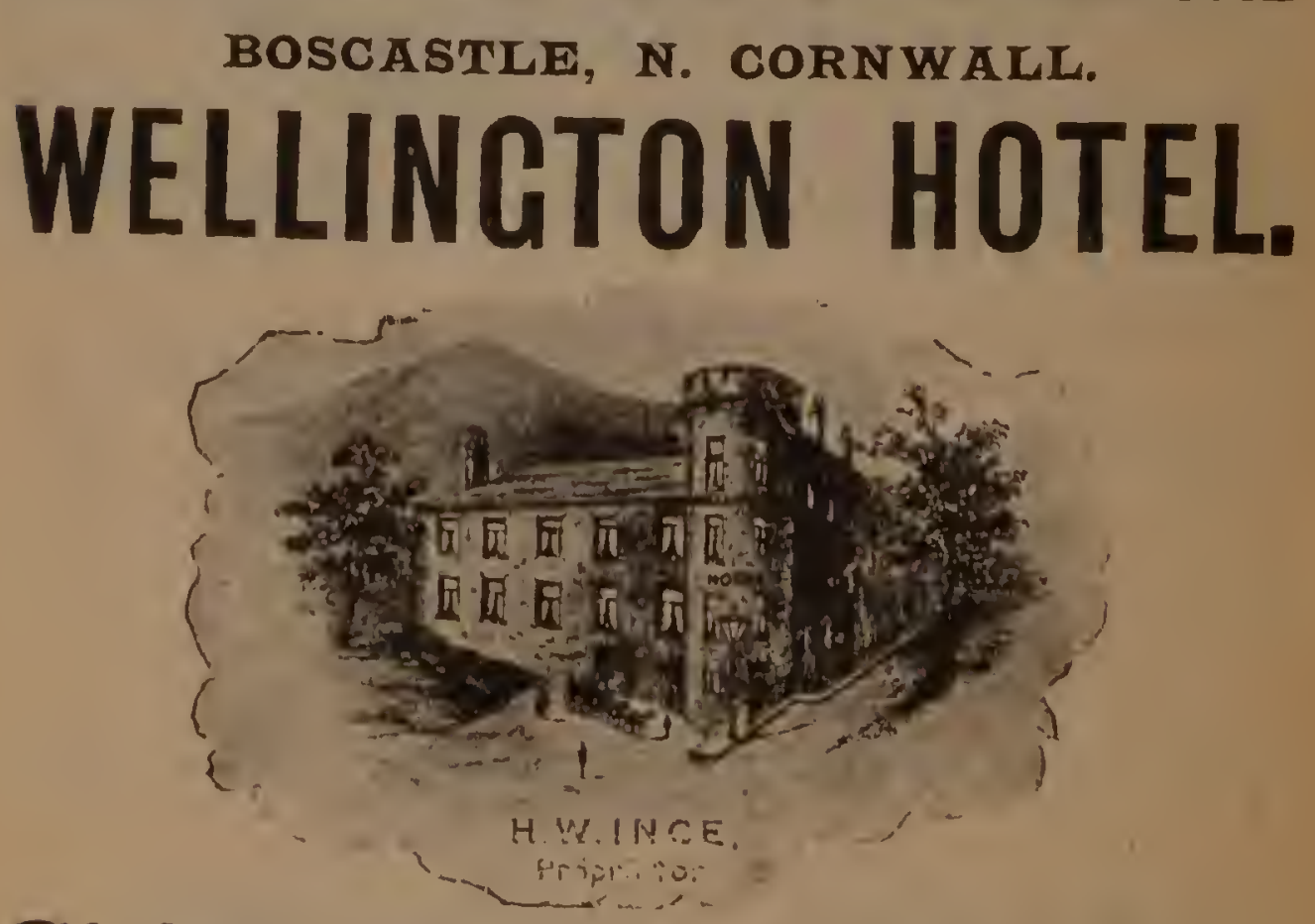
COACHING, Hunting, Fishing, Boating, Shooting. Bracing Air. Excellent Cuisine and Attendance. STATION : CAMELFORD, L. S.W.R. 


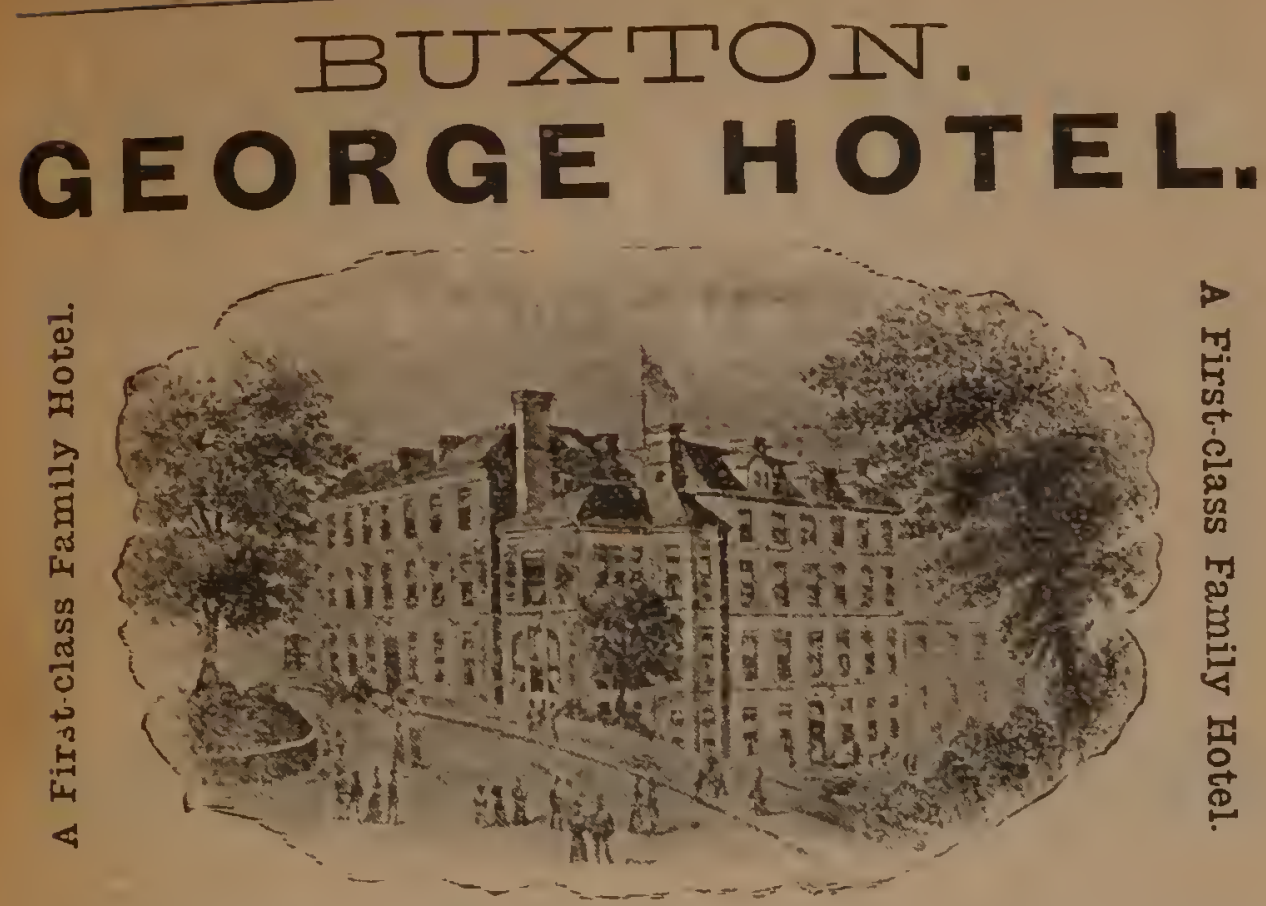

DUFLIC Dining and Drawing Ruons; Reading, Smoke, and Billiard 1 Roons; Private Sitting Ruomi, and Rooms en Suite. Tabl = d'Hôte at 6.30 p.m. The Hotel is detacbed, pleasantly situated with southern aspect, is close to Baths, Gardens, Church, and Railway Stations, and has special suites of Rooms without staircases for Invalids.

IV. F. MILL, Proprietor.

\section{COLWYN BAY, NORTH WALES.}

Jfitst=Clags Jfantly Wrotel,

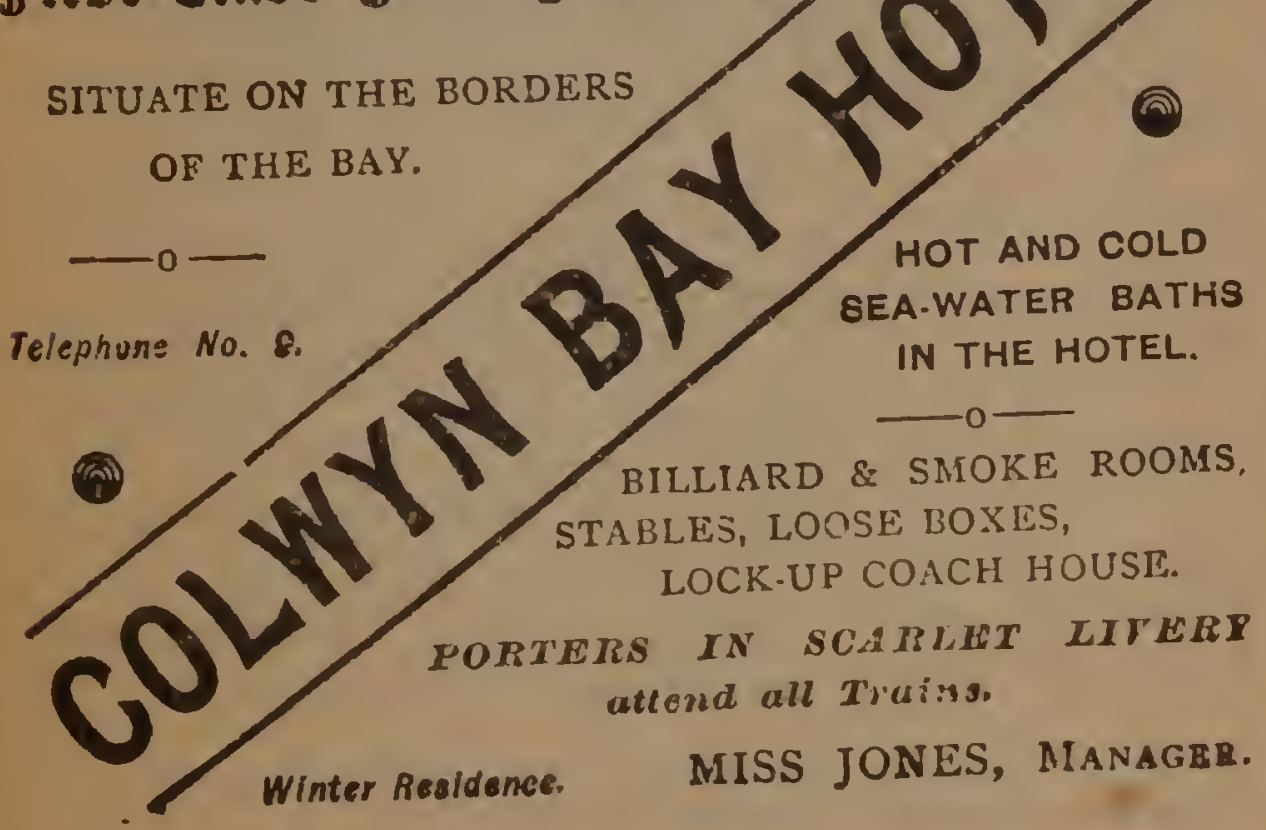




\section{NEW SEASIDE AND GOLFING RESORT.}

\section{CRUDEN BAY.}

30 MIL. "BY RAIL, FROM ABERDEEN.

line sindy be. 'over two nules long, excoptionally well adapted w. Sea bathing and Promenading.
BOATING.
FISHING:
ATTRACTIVE ROCK SCENERY. HEALTHY CLIMATE. BRACING AIR.

The GOLF COURSE of 18 holes, laid out by the Railway Company, is pronounced by Harry Vardon. Willie Fernie. and other distinguished ciolfers who played in the recent Tourna. ment, to be one of the best in the $n$ irgdom

\section{CRUDEN BAY HOTEL}

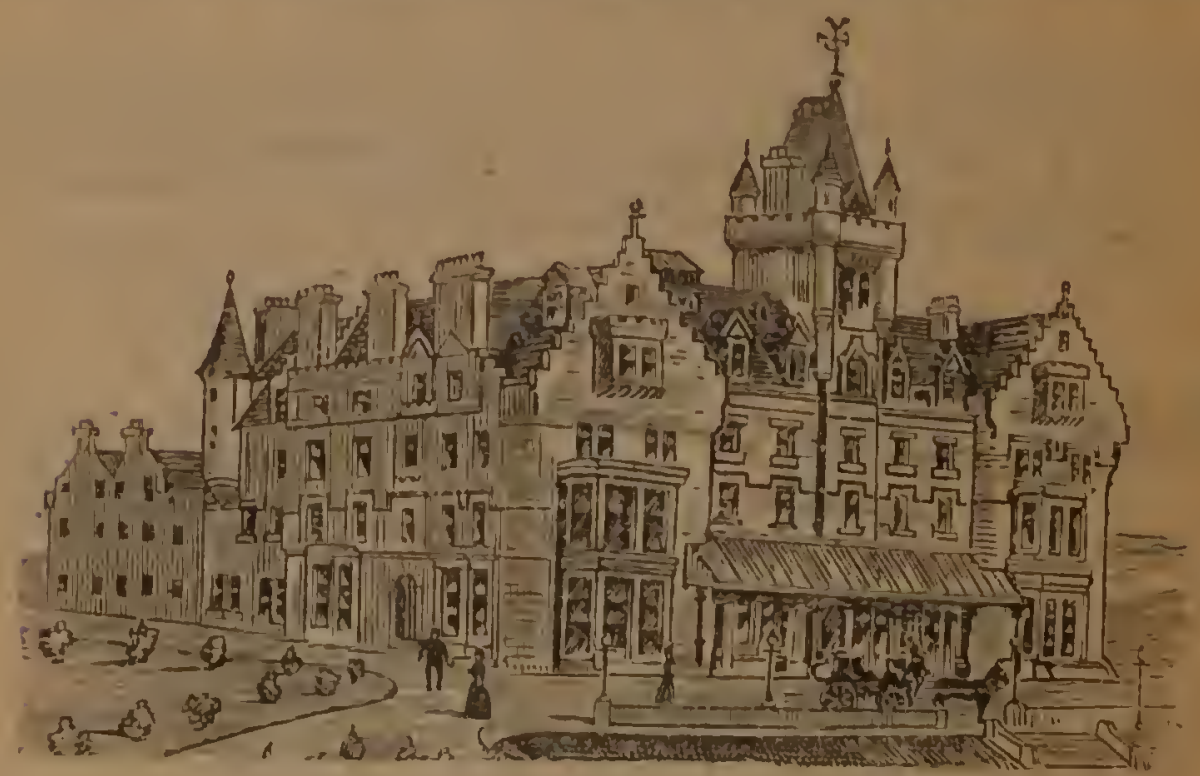

Owned and Managed by the Great North of Scotland Railway Co.

\section{NOW O.T'EN.}

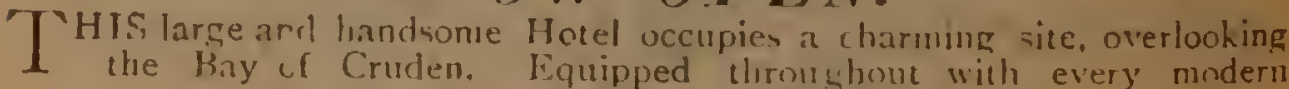
accommodation for comiort.

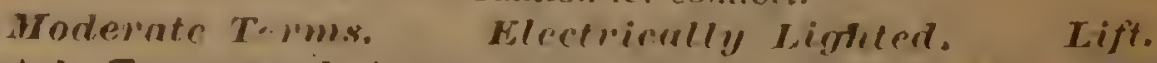

Electric Tram way between the Railway Station and the Hotel. Special accommodation and convenimces for Golfers. Abundant supply of pure water. Perfect Sanitation.

BOWLING GREENS. TENNIS COURTS. CROQUET LAWNS Addrens enquiries to Mrss McKIIAMAM, Talace Hotel, Aberdeen, or to Manager, Cructen liaj Hotel, Port Erroll.

The PALACE HOTEL, ABERDEEN, also owned aud managed by the Gresi North of Scotland Rallway Company, see page 2. 
Carrigart (Co. Donegal)-Dartmoor-Douglas 11

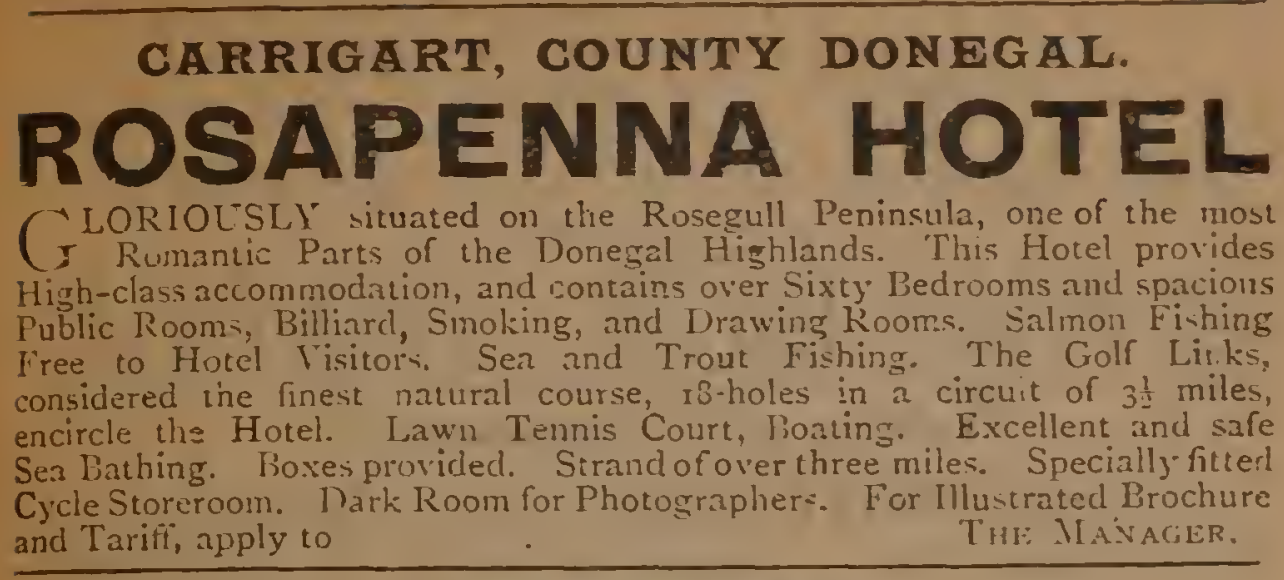

\title{
DARTMOOR.
}

\section{TWO BRIDGES HOTEL, NEAR PRINCETOWN.}

CENTRE of the Moor, and close to the West Dart, where good fishing may ve obtained. Bath Room, hot and cold supply. Water and Sanitary Arrangements perfect.

HENRY TRINAMAN, Proprietor.

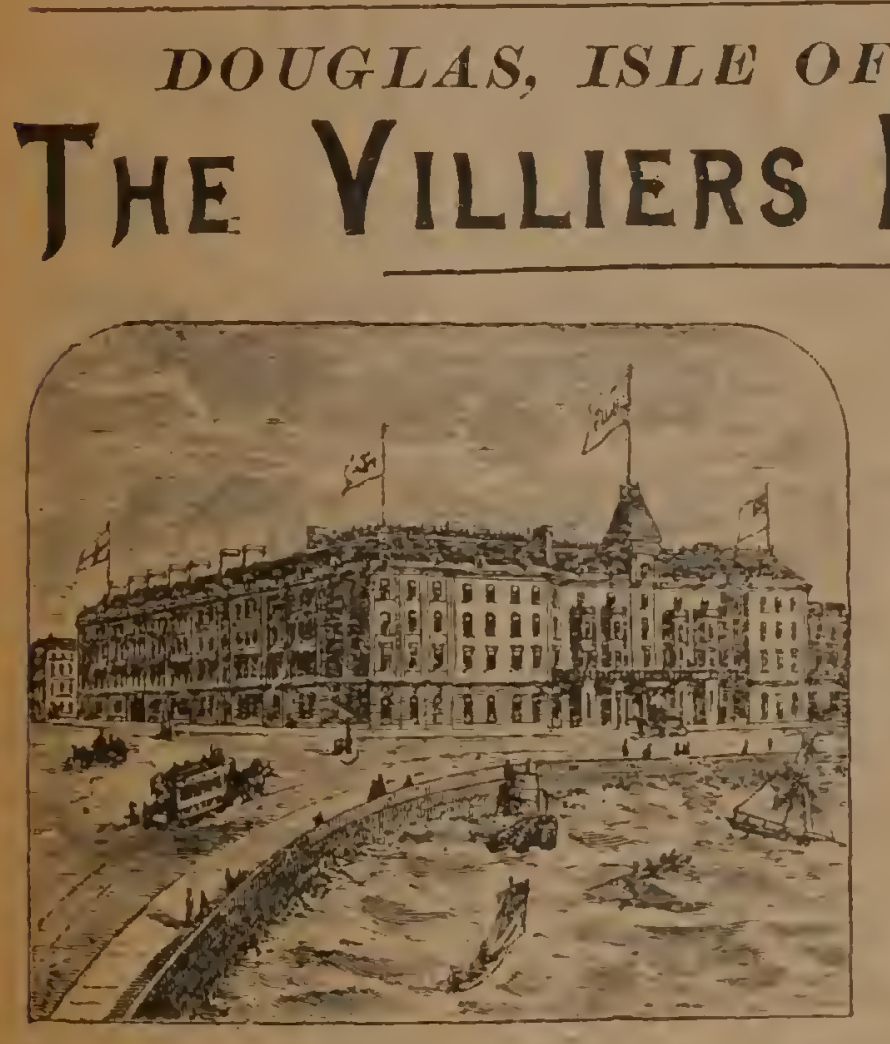

\begin{abstract}
THIS HOTEI., l.eading Hotel on the Island, is beautifully situated on the nargin of Douglas liay; and cluse to the Landing Pier. Luxurious Large Drawing Koon. com. manding a magniticent viell of the whole Bay and Headlands. The Cornfort of Guests a Speciality. Lift to every foor.
\end{abstract}

Inclusiue Terms, froin 9 - pror alay. sprecial arrangements for prerties.

Tariff upon application to THE, MARAGER, MR. F. CLULOV, Late. of Midland Railway Hotels. 


\section{DUEIIN.}

THE CLARENCE HOTELS CO., LTD., HOTELS.

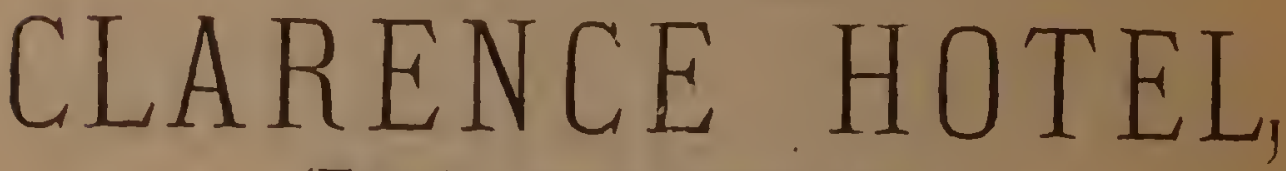

(Family and Commercial,)

\section{WELLINGTON QUAY, DUBLIN.}

TABLE. 1)HOTE at 2.15, and from 5 to $80^{\circ}$ clock Naily. Five Courses, 1 2i. Kestaurant. Soups, lish, lintree, Junts, Sweets, Rc., frum 12 o'clock datly. Special luncheon, Three Courses, 1/. Lighty Firsto Class Bedrooms, from \%/ per Night. No Atten! ance Charged.

Telegrams: "CLARENCE, IUUBL.IN" Tolephone: 69j.

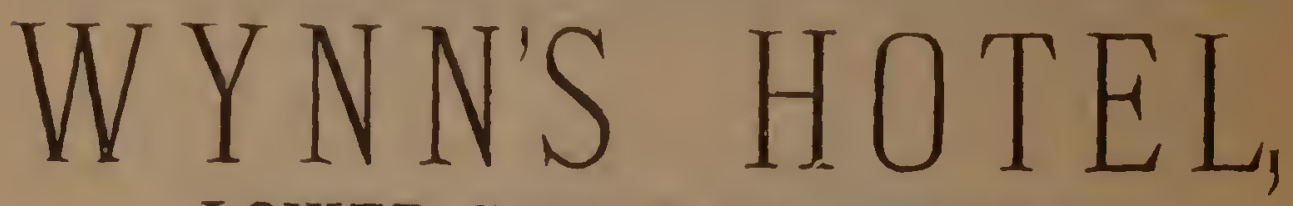

LOWER ABBEY ST., DUBLIN. (Nenly built.)

TABLE D'HOTE DAILY,

2 o'clock, and on Sundays at 4 o'clock.

Five Courses, 2 s.

Coffee Rooms, Commercial Rooms, Ladies' Sitting Rooms, Excellent Bedrooms.

NEW BILLIARD ROOM NOW OPEN.

BILLIARDS, PYRAMIDS, POOL.

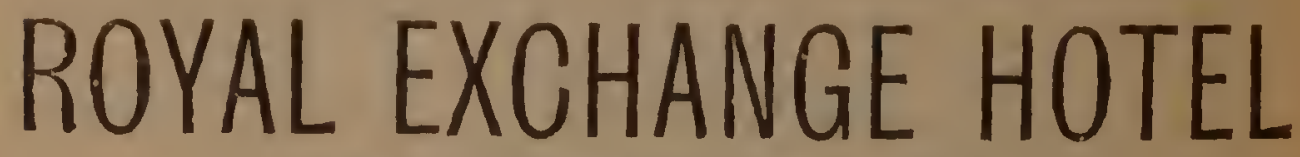

PARLIAMENT STREET.

Commercial and Family.

CENTRALLY SITUATED.

STOCK ROOMS.

Forty First-class Bedrooms. 2/. per Night.

No attendance charged

Telegrams-"COMEORT, IUULIN:" Telephone-695.

Proprietors, the Clarence Hotels Co., Limited.

HENRY G. KILBEY, General Manager. 


\section{U B L I N . \\ THE GRESHAM HOTEL,}

SACKVILLE STREET.

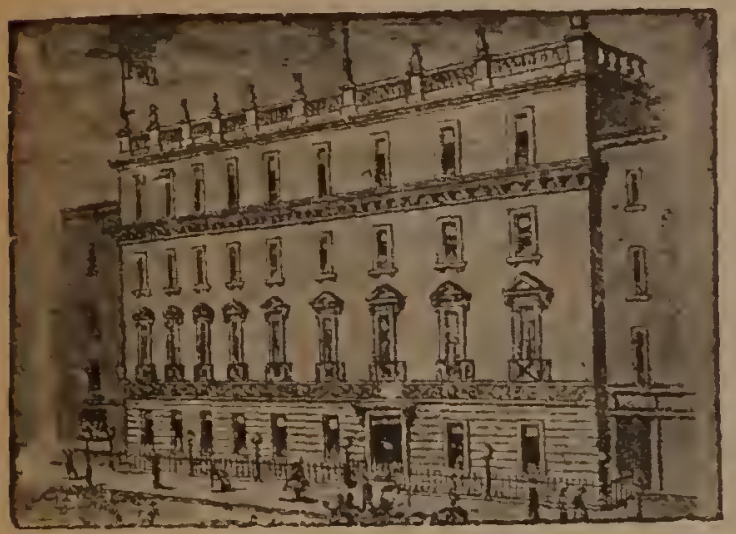

NE of the leading Hotels in Ireland. Spacious and lofty saloons on grnumel floor. Electric Light. First. class Cuisine.

Moderate Charges. Ladies' Toilet and Bathroons.

Perfect Sanitary System certified oy

Sir CHARLES CAMERON.

Tariff can be had on application to the Manager.

\section{IMPERIAL HOILIS, LOWER SACKVILLE STREET, DUBL・P,}

Dirtctry orposite the Gharal fost Orfice and Telegraph Officr.

THE MOST CENTRAL IN THE CITY.

COFFEE ROOM AND MAGNIFICENT DINING ROOM.

Splendid Ladies' Coffee Room.

Billiard Room, Smoke Room, Lavatories, and Baths. MODERATE CHARGES.

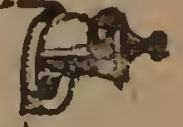




\section{HOTEL METROPOLE, Sackville Street, DUBLIN.}

GIRST-CLASS. Splendid Situation. Electric Light all ferfect Samilation and Ventilation. Everything up to date.

TEIIMS HODERATE.

G. J. CAPSiE:, MaNaciER.

Telegrams-" METROPOI.K. WUHI.IN."

\section{MORAN'S TEMPERANCE HOTEL,}

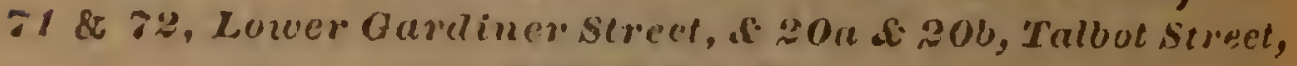
D U BLIN .

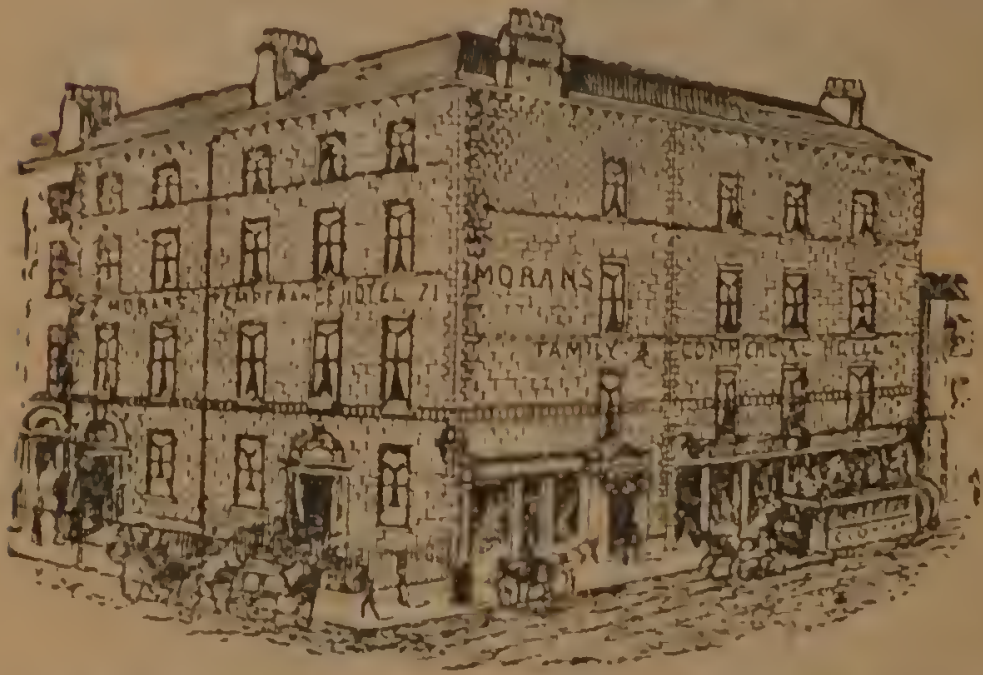

SITUATION most within two meins utes walk of Great Northera Rallway, I ust on House. Ceneral Post ifhce, and close to cross. Channel sleamers, trinty College, lanks.putilic Orties. ctc. Night Porter. Ninu Savalary Drainage Sistem. carried out whder areclicists of

IV. KAYE PARRY, M.A., C.E., elC. Teiegrams:

DIoran's Hotel, Dublin.

Large, airy, and well-appointed Bed Billiard and Smoking Rooms

HEDS. 1/6 to 2/. BREAKFASTS, from 1/. to 1/6.

IINNERS from $1 / 6$ to 2/6 LIGHTED BY ELECTRICITY.

HOT A.D COLDBATHS NO CHARCE FOR ATTENDANCE.

Telephone 914.

I. MORAN, PROPRIETOR.

'丁H E

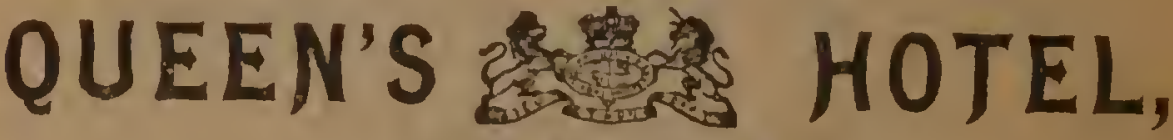 D U N DEE.}

A First-Class Family and Commercial Hotel, HANDSOME BILLIARD, SMOKIAG, AND STOCK ROOHS, MAgNificent VIEWS OF THE: RIVER and TAY BRIDGE. A 'Bus from the Holel awaits the arrival of all Trains S T A P I N G 
BIRNAM, DUNKELD.

THE BIRNAM HOTEL.

"Make we our march towards Birnam."-Macbeth

THIS old-established high-class FAMILI HOTEL, only one minute's 1 walk from the Highland Railway Station, Dunkeld, stands in its uwn grounds on the banks of the river Tay, and on the site of the funtous Rirnam Woud. It has been remodelled and most elegantly refurmished throughout; also the sanitary arrangements entirely renovated. Tilegraphic Address-" HOTEL, BIRNAM." TARIFF MODERATE. 'Bus meets the Braemar Coach and the Trains free of charge.

SALMON A N D TROUT EIS H I N G. EDWARD CESARI, Pronrietor. And of Lodore Hutel, Keswick.

\section{A R LIN G ${ }^{3}$ S}

REGENT TEMPERANGE HOTEL

20, WATERLOO PLACE,

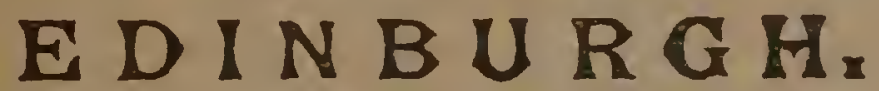

Under the personal management of Miss DARLING.

Telegraphic Address-

Telephone No. 1086.

"Darling's Hotel, Edinburgh."

ESTABLISHED OVER HALF A CENTURY.

CRANSTON'S

W
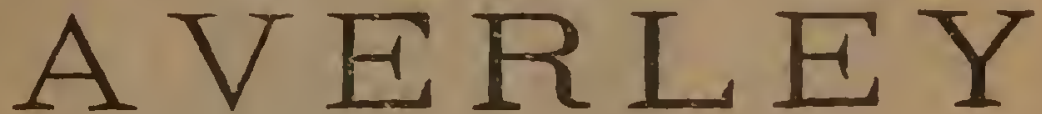

\section{TEMPERANCE MOTELS.}

\section{EDINBURGY -}

OLD WAVERLEY. 43, PRINCES STREET - Telegrams, "Waverle y, Fdinburgh.' ACCOMMUAATION FORR 200 TISITORS. PASSENGEK ELEVATOR.

Largest Temperance Hotel in Kingdom. Specially adapted for families Recommended by bradshare's 'Cournsi Gurde as "the Cheapest and best Iemperance Hotel they had ever seen," and by the late Mr. J. B. GoUGri "as thie only Honne

NEW WAVERIEY, WATERLOO PLACE.-Telegtams, "IVanhoe, Edinburgh."

First-class Corimercial House. Well-lighted Stock-Roons on ground floor from

\section{LONDON}

37. KING STREET, CHFAPSIDE.-Telegrams, "Redgauntlet, London."

The unrivalled position ol the I.ondon W'averley in the business centre of the City offersexceptional advantage to persons visiting Lond on eit her on business or pleasure.

\section{GLA SGOW -}

172, SAUCHIEHALL STREET. - Telegrams, "Waverley Hotel, Glasgow."

The Business here now carried on by Mrs. MASON, daugluter of the late

Mr. CRANSTON.

The Hotel is situated in one of the finest and busiest thoronghfares in the City.

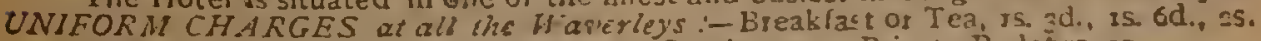

Yublic Dinner, 2S. ; Bedrooms, 1s. 6d. : Service, 25. ; Private Pasloürs, 35.

DAUTION:-Parties are particularly reguested to see that theg are taken to CRANSTON'S WAVERLETS. 


\section{EDINBURGH. \\ THE COCKBURN HOTEL, Adjoining Waverley Station.}

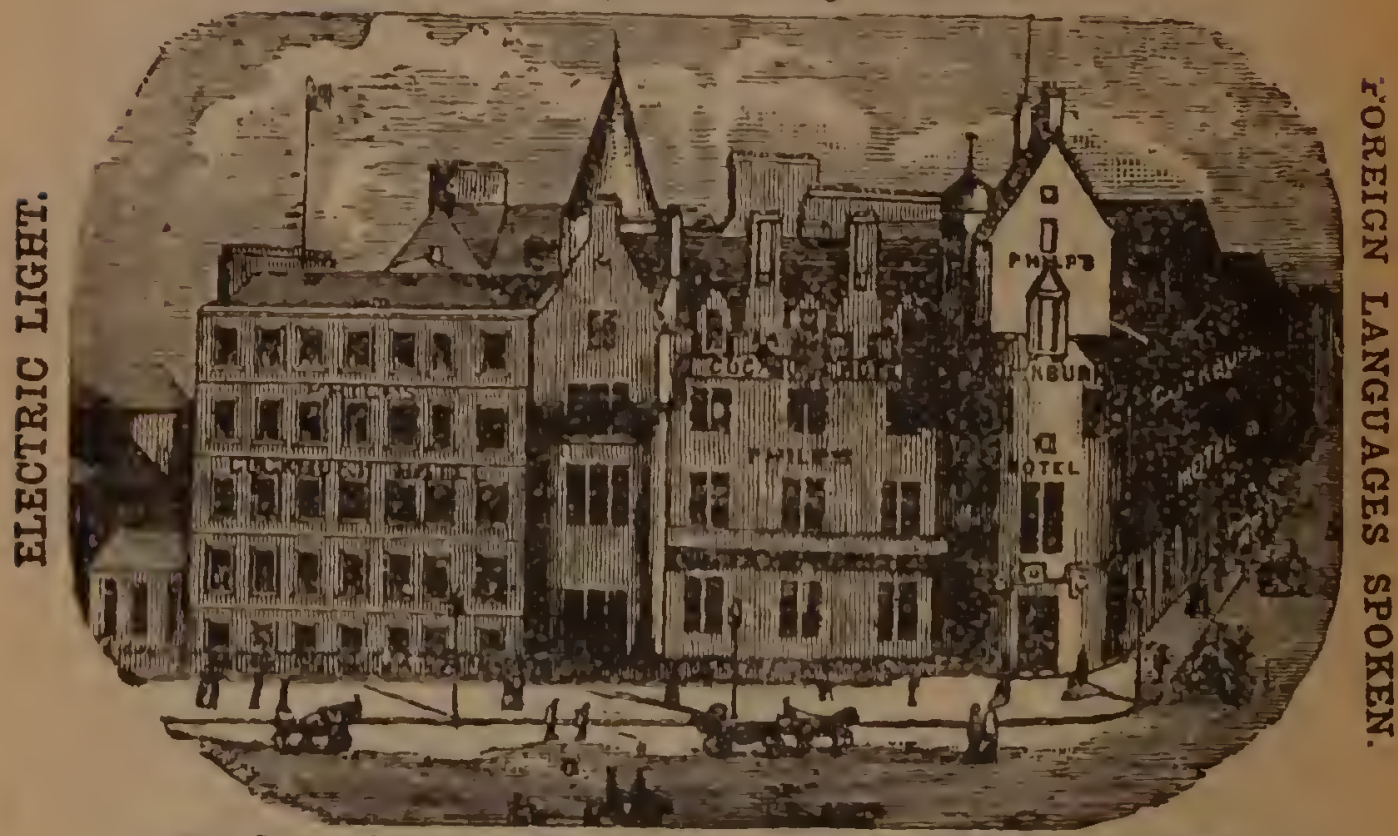

No Intoxicating Drinks. Passenger Elevator.

JOHN MACPHERSON, PROPRIETOR.

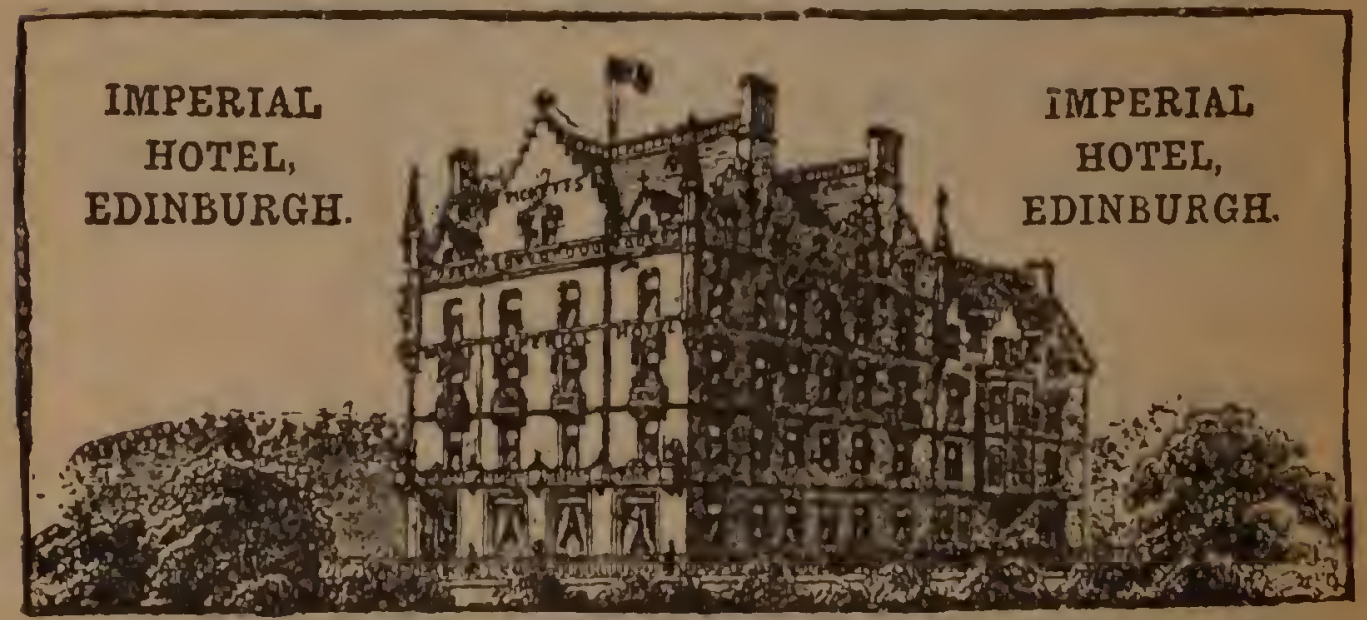

NEARIST IIOTLL to the Waverley (principail Station, overlooking Princes Sereet W Gariens and Scott's Monmment. The building is detached, and used solely for Hotel Purposes. Headquarters of the Cyclists Tourists Club.

R. S W. PICKIETT, PROIRIETORS.

BIGGEST! BRIGHTEST!! BEST!!! THE

WINDSOR MAGAZINE PRICE SITPENCE.

ALWAYS AT THE TOP OF THE TREE. 


\section{BELSFIELD HOTEL, WINDERMERE, BOWNESS BAY.}

Telepbone No. 123

Telegrams - " BELSFIELD, WINDERMERE."

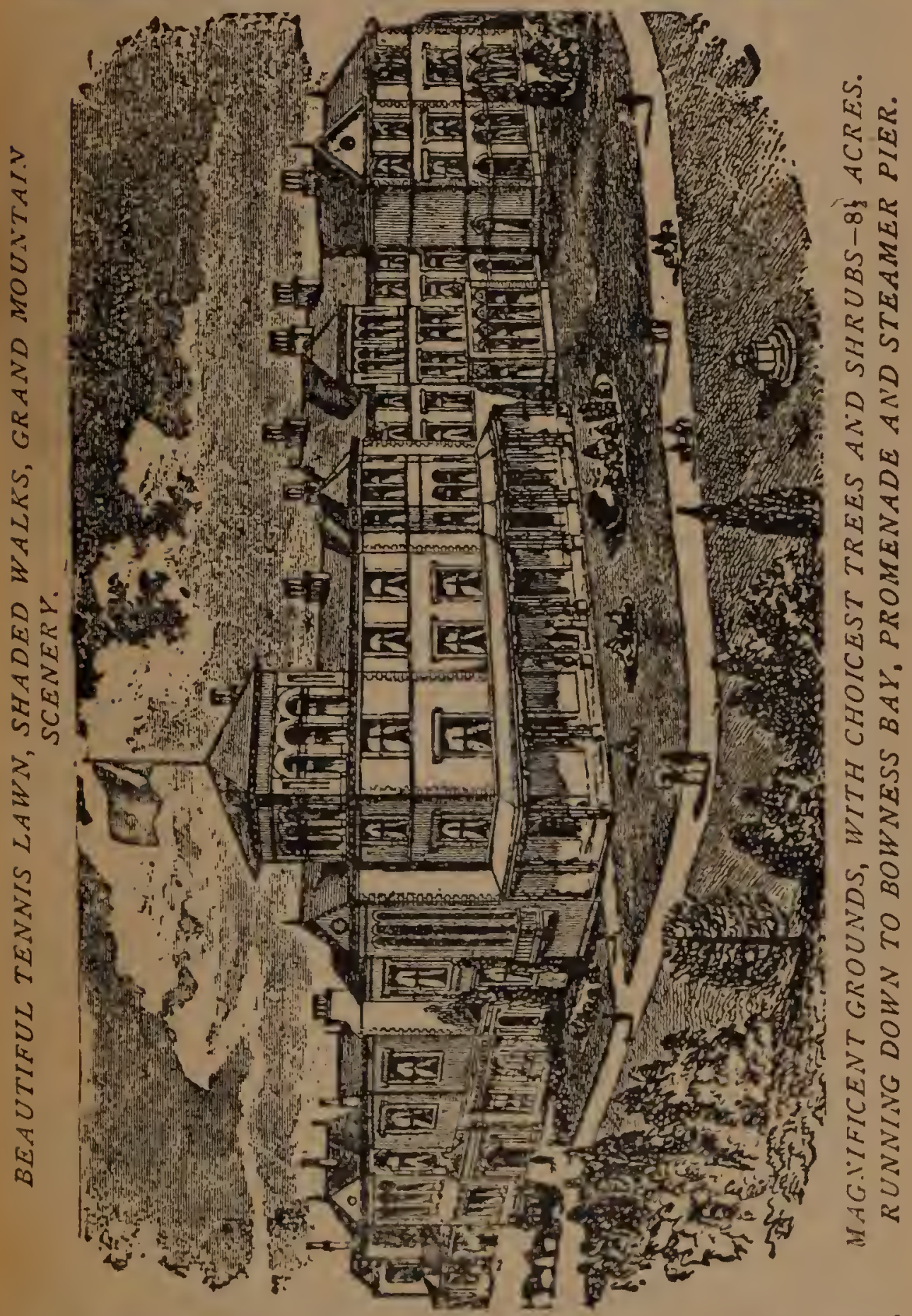

Largest and leading Hotel in the Lake District now opened fur visitors. Four-in-hand Coaches Daily to places of interest. Billiards, Boating, Fishing, and Golf.

A. D. MCLEOD, PROPRIETOR.

(Late of Gairloch Hotel, Ross-shurei 


\section{E NGLISH LAKES.}

$-\rightarrow+(x)+\cdots$

WINDERMERE HydRO;

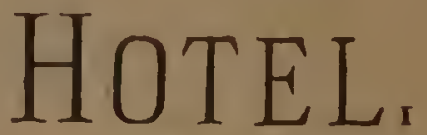

FIRST-CLASS TABLE.

VISITORS SUPPLY THEIR OWN WINES.

NEAR GOLF COURSE.

VIEWS OF LAKE AND MOUNTAIN UNSURPASSED. For PRO'i?liCTUS, Address The Manager.

\section{THE ENGLISH LAKES. AMBLESIDE THE PRINCIPAL CENTRE.}

A REFERENCE to any map of the Lake District will clcarly show that A Ambleside is situated in the immediate centre. Communication is made by Water and by Coach with all parts of the district, cambining to favour $A$ mbleside as an unrivalled sojourning place The chief hotels are:

\section{THE SALUTATION, THE QUEEN'S,}

\section{THE WINDERMERE WATERHEAD,}

all of which are commodious and high-class, and offer every homely comfort to visitors. Private Coaches and Carriages of every description may also be obtained.

\section{TAYLOR'S FOUR-IN-HAND STAGE COACHES}

run daily from the Hctels and the Steamer Pier for Keswick, Coniston, Uliswater, and the Langdale. For time tahles apply at the aforenamed Wwith, Taylor's Coach Office, Ambleside, or various offices en route.

THOMAS TAYIOR, PROPRIETOR. 


\section{CUMBERLAND LAKES. \\ THE KESWICK HOTEL. \\ (NOW LIGHTED BY ELECTRICITY.)}

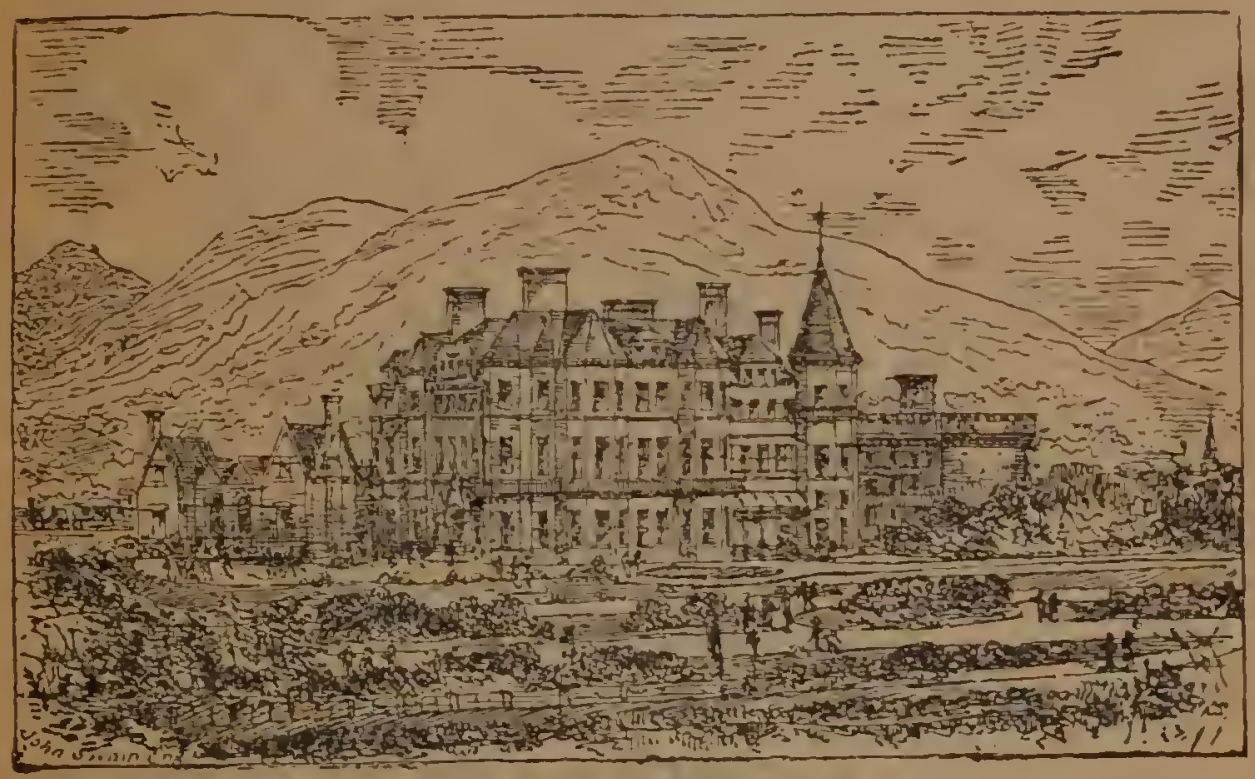

THIS Hotel, the largest and most commodious in the Lake District, stands in its own grounds, of several acres. It commands the finest and most extensive views of the surrounding sceners, and Scawfell Pike, Helvellyı, and Skicldaw are distinctly visible from the colfee room windows. Visitors are permitted to fish in the Greta. Excellent Cuisine. Moderate Tariff. BILLIARDS, LAWN IENNS., \&c. HOT AND COLn BATHS. Private and public coaches to Buttermere daily during the Season. Posting to all partiof the district. BOATIEN, GUIDES, \&C. WV. WILSON. PROPRIETUR.

\section{ULLSWATER HOTEL, PATTERDALE, PENRITH.}

$\mathrm{NE}$ of the largest and best situated Hotels in the district, bordering on Ullswater, which is unquestionably the Lake which combines the greatest variety of scenery. Helvellyn and Airey Force are within a short distance.

\section{CERTIFIED SANITATION.}

Visitors can reach Ullsivater Hotel-

From Penrith, by Coach and Boat, at From Ambleside, by Coach, Salutation Hotel

From Keswick, by Rail to Troutbeck, thence Coach to Ullswater a.m.

$\begin{array}{llll}8.25 & 11.15 & 1.45 & 4.50\end{array}$

9.45

4.30

10.0

4.35

Private carriages will meet any train at either Penrith or Tru.tbeck Station on receipt of letter or telegram. Table d'Hôte at 7.30 p.m. Lawn Tennis, Boats, Ponies, \&c., f.c. Tariff on application. Telegraphic address, "Bownass, Glenridding." 


\section{KESWICK, DER WEN'IYA'LER. \\ THE LODORE HOTEL.}

"How does the water coms down at Lodore."-Southey.

FIRST-CI.ASS. Situaled at the Head of the Lake, near the celebrated Fitls of Lodore. Commands the view of the whole Derwentwater, its romantic Islints, and majestic Monntains. It bas been remo'elle i, re-decorated and re-furnished. Sanitary' arrangenients entirely renovated.' Trout Fishing free. linating. Steam Yacht. Posting. Terms moderate. Boarding. Telegraph Office in Hotel. Omnibus in connection with all Trains and Coaches from $W$ indermere and Ambleside.

\section{THE BORROWDALE HOTEL}

And High-Class Bodming Establishment.

UNDIER THE SAME MANAGEMENT

CHARMINGIYY simated at the Hiad of Derwentwater. Re-modelled, (- re-furnished, ald Stuila y Arrangements entirely renovated. Free Trout li-hing. Boatiug. P'onti.g. Siean Yacht. Telegraph Office in Hote. Bonding Term.s from £2 10s. per week; liberal table.

olsin of liseneme Howel, Deskelit. N.S. EDWARD CESARI, Proirietor.

\section{THE MAGAZINE FOR YOU \\ IS THE I YMINDSOR."}

\section{ENGLISH LAKE 8 . \\ SWAN HOTEL, NEWBY BRIDGE.}

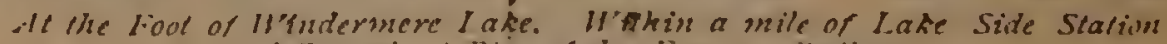
and Stermboal lic of the finrness liailoway.

ONIE ot the oldest Hostelries in the English Lake District, and patronised for a D century nast by the Celebritles of the rlay, the good old-fashoned style being studionsly retained hy the present l'roprietor. Tariff ecomomrically arranged. One of the most charming Retreats in the I.ake Distict. For Bmting. Fishing Igreatly Immoved). Iovely WValks and Irives, and for retiremen, this Hotel is unsurpassed in the District.

EDWIN WAUr;it say:s-" Home-like and well furnished."

NATHANIEL IIAWTHOKNIT sias - "Tlic gen of the IAakes."

G(iII)E GENPRALI.I" Sal- "One of the loveliest beauty siots."

Improved Servlce of Through Trains. Spaclous Coffee Room. Table d'Hote, Separate Tables. Lunchoons and Afternoon Teas a Speciallty.

Posirl Adires.s: Swan Hotel, Newby Bridge, Ulverston. 7 clegrams: "Revell, Newby Briclye." "Bus meets Trains aml Bont. WM. T. RliVELL. PROPRIETOK.

"The loveliest spot that man hath ever found."-Wordsworth.

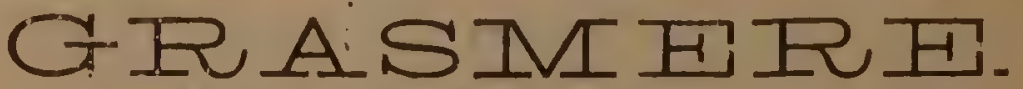

IIEART ON TMH TAKR DINTIRICT.

\section{PRINCE OF WALES LAKE HOTEL.}

Reautifully situated, with lawns sloping to the margin of the Lake. Home and burial place of the poet Wordsworth. Coaching to Ullswater, Coniston, the Langdales and the round of Lake Thirlmere. 


\section{조표표.

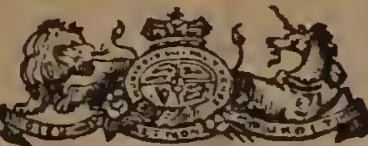

ROYALCLARENCE HOTEL

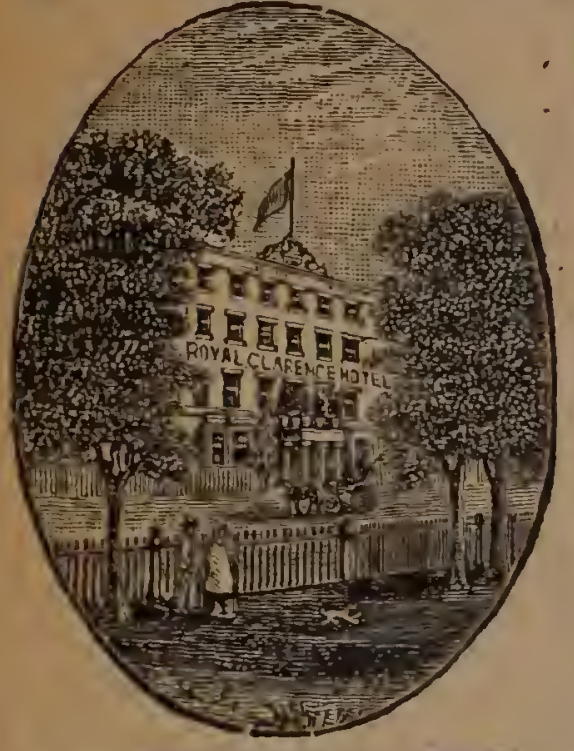

FACING GRAD OLD 1 CATHEDRAL. Central. and the quiet and comfort of a country. mansion. Moderate tariff. Omnibuses meet trains. Post Horses and Carriages. Table d'Hôte, 7.0 p m.

J. HEADON STANBURY,

PROPRIETOR.

$A N D$ AT THE

GRAND HOTEL, PLYMOUTH.

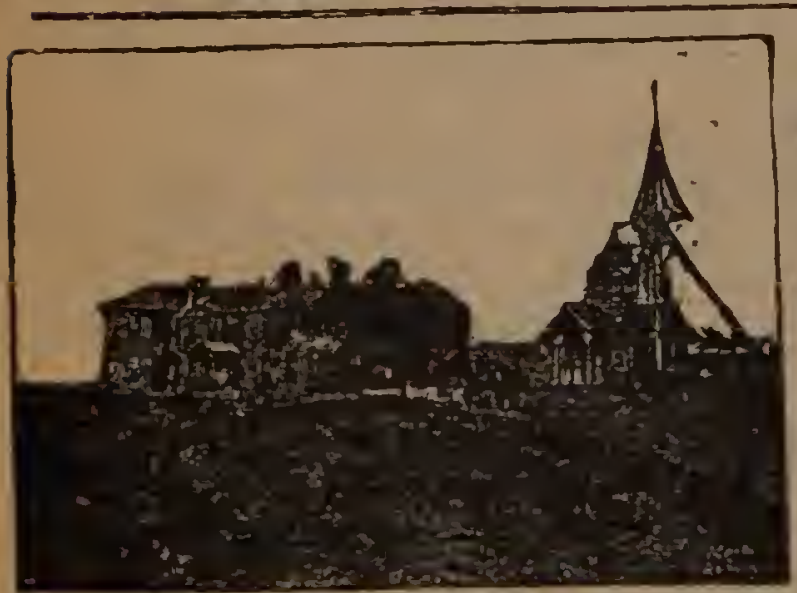

GIANT'S CAUSE WAY.

CAUSEWAY HOTEL.

FIRST - CLASS Tourisıs' $F$ Hotel, overlooking the Atlantic. and close to the Causeway.

The Giant's Causeway Tramway runs direct froin Portrush Railway Station to the Hotel grounds. Golf Links adjacent.

Lele rians:

"Causeway Hotel,

BUSHMILLS:

\section{CHAS. M. SHELDON'S WORKS.}

Crowen suo, wropper, Gr.; Cloth, 1.s.

IN HIS STEPS.

THE CRUCIFIXION OF PHILLIP

STRONG.

RICHARD BRUCE.
ROBERT HARDY'S SEVEN

DAYS.

MALCOM KIRK.

HIS BROTHER'S REEPER.

THE TWENTIETH DOOR.

LONDON: WARD, LOCK \& CO., LIMHLLi). 


\section{HARROGATE,}

\section{THE QUEEN OF INLAND WATERING PLACES,}

IS situate upon lofty table-land, in the West Riding of Yorkshire, twenty 1 miles from York, nearly the same distance from Leeds and Bradford, two hundred miles from London and Edinburgh, and seventy miles each fiom the Gcrman Ocenn and the Irish Channel. Placed in the centre of the island, at an altitude of four to six hundred feet above sen level, it possesses an atmosphere remarkable alike for purity, dryness, and all the invigorating salubrity of true highland air. Harrogate is a place of many waters, possessing springs, which in number and variety are positively unique. In no other health resort in Europe (if in the world) are found MEDICINAL SPRINGS approachng in number and variety those of this favoured place.

Within an area of two miles, there are fully

\section{Eighty Springs of Mineral Waters}

of almost every kind, ranging from mild and strong sulphurs to the most powerful chalybente known to analysts.

\section{The peerless Climatic Advantages}

of Harrogate, conpled with the unexampled curative range of its mineral watcrs, nuquestionably place it in the very forefront of British health resurts.

\section{The Average Death Rate for last Seven Years is} 12.3 per Thousand,

being lower, we believe, than any other watering place in the Uniter Kingrlom. It will be rendily understood, therefore, that Harrogate waters are effectual in the cure of a wide range of diseases, especially those of the skin, scurvy, rheumatism, and the distressing series arising from nerve exhaustion, "jaded brain," \&. c. For the successful treatment of these and other disurders, there are

\section{Handsome New Pump Rooms, where the various kinds} of Water are Dispensed, and Winter Garden.

Bathing Establishments, with every kind of treatment of the most complete and varied character at the

Victoria Baths and the Royal Baths, and Splendid Turkish Baths;

whilst tourists who visit Harrogate for recrention will find hotels, boarding houses, and lodging houses fully equal to those of any other healih resort, together with

The Spa Concert Rooms and Pleasure Grounds, The Theatre. St. James' Hall, Montpelier Winter Garden, The Valley Park, \&c., \&c.

Harrogate is also the centre of a district remarkably rich in

Antiquities, Natural and Rural Beauties, \&c., including the ancient city of York, and the still more ancient Aldboro', the castles of Knaresboro', Ripley, Harewood, Gilling, Richmond, Ec., the abbeys of Bolton, Fountains, Jervaulx, Rievaulx. \&c., the valleys of the Whare, the Nidd and the Ure, Brimbam Locks, Ilkley, Plumpton Rocks, \&.., S.c.

The principal springs of the town, together with the Royal Pump Room, the Victoria Battis, and Royal Baths and Gardens belong to the Corporation of Harrogate. Any further information sespectin? Baths and Waters may be oltained from Mr. WILLIAM BENNETT, General Manager of Baths and Wells, The Royal Barhs. 
The Oldest Established Family and Commercial Boarding House in

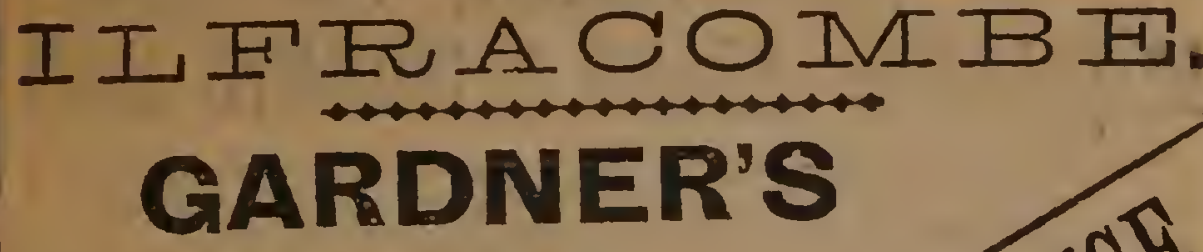

Is one of the Largest,

Most Central, and

Most Reasonable in

Ilfracombe.

nNu

$10 \mathrm{~N}$
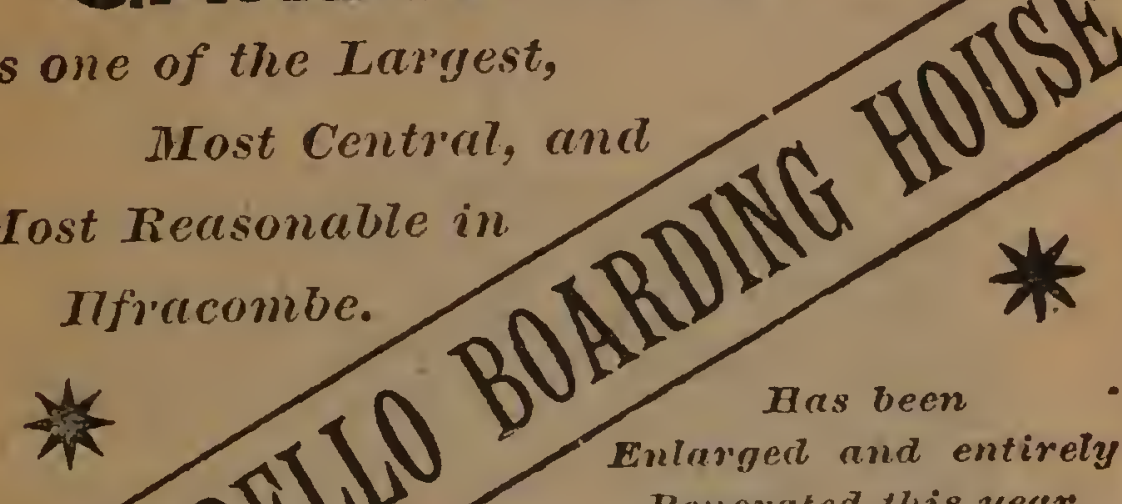

Has been

$\frac{11}{11}$

ก) 1

Enlanger and entirely

Renovated this year.

Boarding Terms by Day or Week, Strictly Moderate and no Extras.

10

1 N

N11

Dining Hall.

Commercial Room.

Three minutes' walk from sea.

FIRST-CLASS BEDROOM ACCOMMODATION WITH GOOD SEA VIEW.

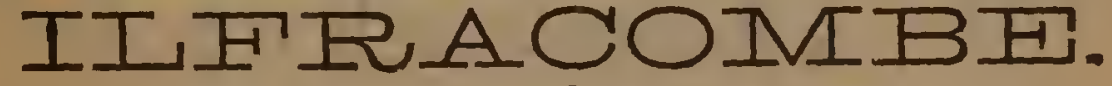

THE GRANVILLE

FIRST-CLASS BOARDING ESTABLISHMENT

(A BONA FIDE TEMPERANCE HOUSE).

FINEST Drawing Room in Ilfracombe. Forty Pedrooms. Baths. I Balconies. Position unrivalled. Close to the shore, I20 feet above sea level, and having magnificent sea and land views.

W. R. FOSTER, Proprietor.

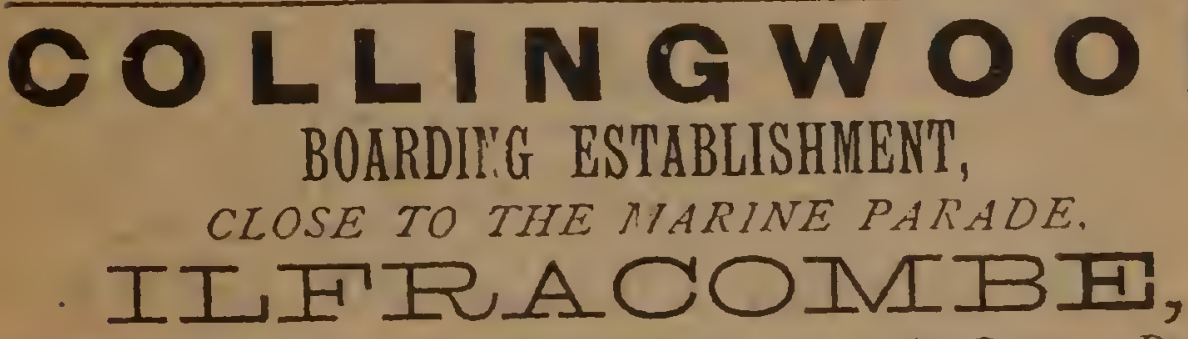

Is situated in the very best part of the town, close tn the Capstone Parade, and commanda a full VIEW OF THE SEA.

LAKGE DINING ROOM ( 4.5 feet by 30 feet). DRAWING ROOM (28 feet by 4 feet) opening to Balcony. SMOKING and PILLIARD ROOMS. 100 BEDROOMS. HOT and COLD BATHS.

For tariff apply to the PropRteror. 


\section{GA ILKLEY. Ko MOORLANDS HYDRO \& PRIVATE HOTEL.}

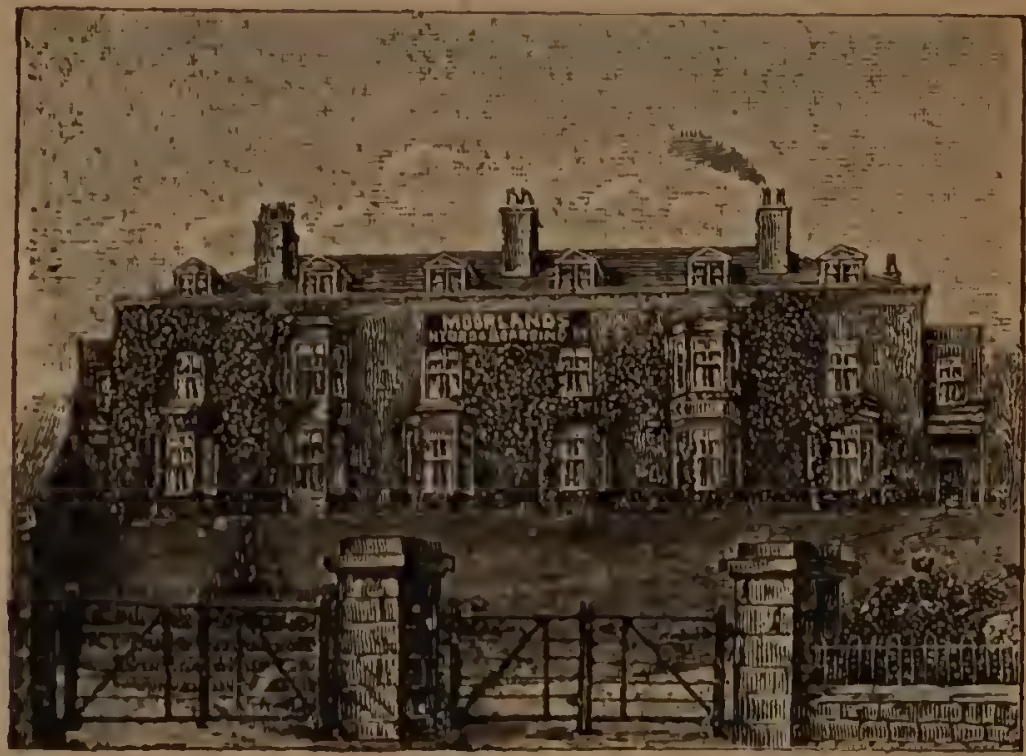

FIVli hundrort fret ahnre the sca levol. Stands In Its own Grounds. In the beat posituon in IIKLBY. Near tho Tarn. Adjoins the Moors. Fire ninutes from Station. Near Golf Links. Having undergone extensive alterntions and improve. IItents, the establishment will be lound adapted for both Invalids and Visitors. For Tarif, apply AL_BlERT ROBINSON, MANAGER.

\section{CRAIGLA N D S}

\section{Hydropathic Establishment,} ILKLEY.

Resident Physician-HENRY DOBSON, M.D., C.M., (Edin.).

F STABLISHED mearly HAI,F A CFNTURY. Craiglands cin F. accommodate Hundred and Seventy Patients and Visitors. It occupies a superior and sheltered position, possosses Beautifnl Pleasure Grounds. Complete Suites of BATHS, inc uding Turkish and Russian. An elegant Smoke Room; a superb Billiard Room, conta ning three tables. Magnificent Recreation Hall, a Liberal Diet, and all the appointments of a First-class Sanatorium, together with a most

REASONABLE \& INCLUSIVE TARIFF.

REDUCED WINTER TERMS. 
IN YERNESS.

THE HIGHLAND RALLWAY STATION HOTEL

\author{
PATIONISED BT ROFALTF.
}

RECENTLY reconstructed and refurnished. Large Smoking-room, $R$ Double Drawing Room, Reading and Writing Room, Commercial Room, Handsome Entrance Hall, Cloakroom, and Hair-dressing Saloon.

There is a First Class Restaurant on the Station Platiorm, also good stockrooms.

The Hotel and Refreshment Rooms at Kyle of Lochalsh, and the Refreshment Rooms at Forres, Kingussie, Ballinluig, Inverness, Dingwall and Bonar Bridge, are all under the same inanagement. Luncheon, Tea, and Breakfast Baskets can be obtained at any of the above-mentioned rooms.

H. C. IVOOI.F, MANAGER.

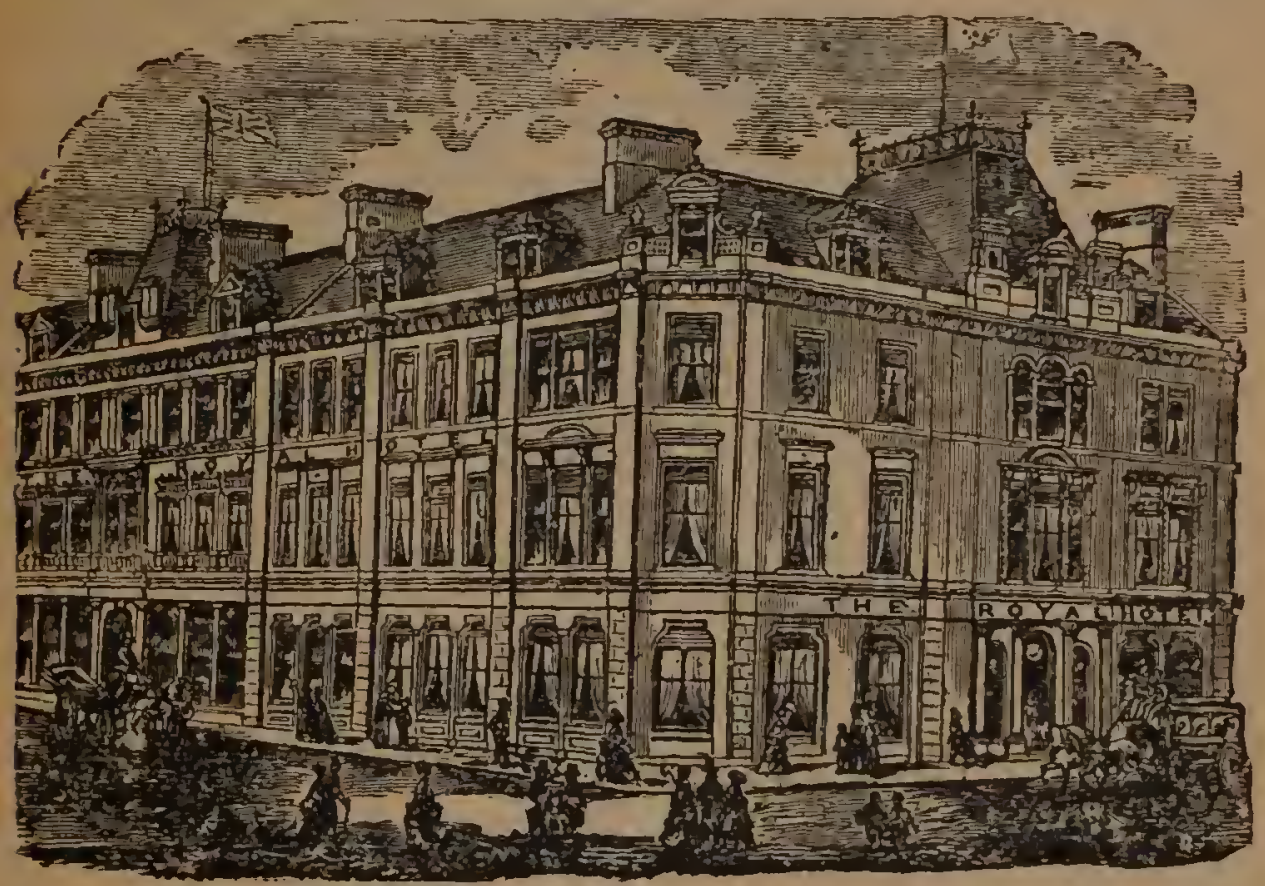

THE ROYAL HOTEL INYERNESS FIRST-CLASS HOTEL. THE ROYAL HOTEL, INVERNESS, Fvery Home Comfort.

UNDER THE STRICT PERSONAL SUPERINTENDENCE OF THE PROPRIETOR. An Omnibus attends all the Canal Steamers.

THE HOTEL PORTERS AWAIT THE ARRIVAL OF ALI TRAINS

\title{
A REMARKABLE BOOK.
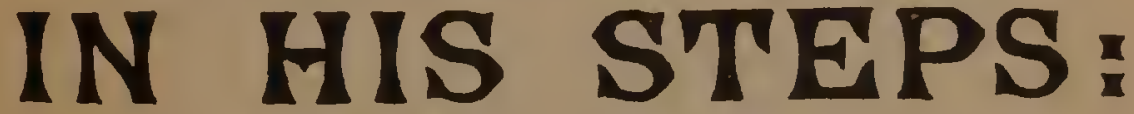 \\ WHAT WOULD JESTIS DO?
}

Crown 8vo, Wrapper, with Frontispiece, 6d. ; also cloth, 1s.; and

Large Crnwn 8vo, cloth gilt, llluntrated, 18. 6d.

The Sundav Scrool Chronicle says:-" "In His Steps' may claim to he in relizious circles the book of the hour. We hear of ministers all over London and the Provinces making it the text of svmpathetic sermons, and of whole congregations boing supplied with copies."

London: WARD, LOCK \& CO., LTD., Salisbury Square, E.C. 


\section{Waverley Hotel, Inverness.}

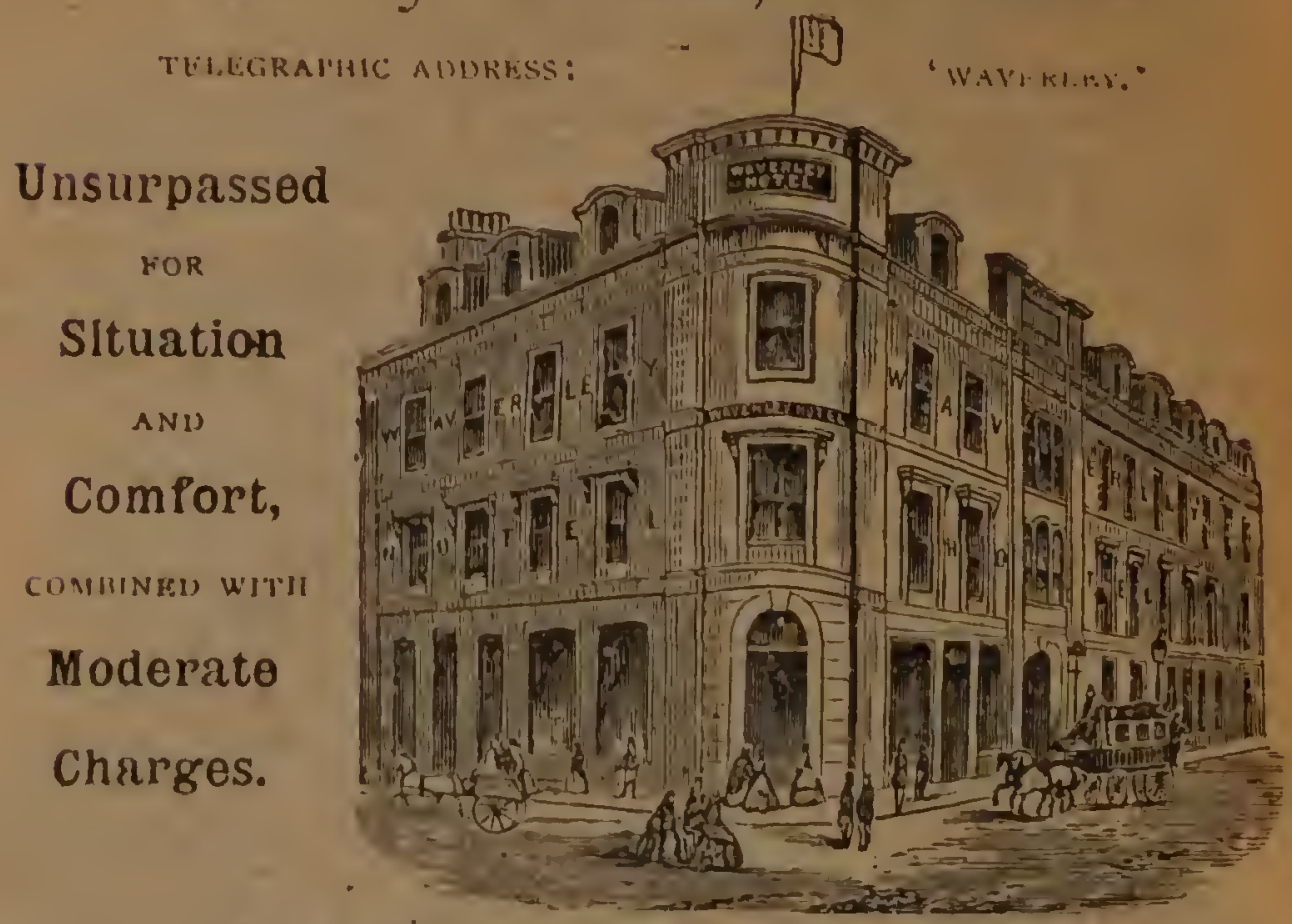

ONH MINUTE'S WAIK TROM TME RAILWAY STATION.

Purter of the Hotel attends all traius, and an omnibus runs in connection with the Caledonian Canal steamers.

D. DAVIOSOON, PROPRIETOR.

\section{Y E N T N O R.

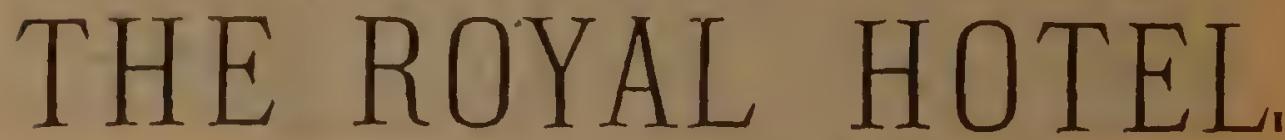

Rebullt, Re-decorated, and Fur lished by Schoolbred \& Co.

PATRONISED BY THE QUEEN AND ROYAL FAMILY,

Distinguished English, American, and Continental Families.

CTANDING in its own charming grounds of four aeres. S Magnificent Sea View. Public Drawing, 1)ining, Coffee, Keading, Smoking. and Billiard Rooms. Private Suites of Apartments. Conservatory, Lawn Tennis, \&c. Carriages of all descriptions, Saddle Horses, excellent Stabling. High-class Cuisine.

TABLE D'HOTE, SEPARATE TABLES.

French. Aevman, Italinn, and Dutch Spoken TERMS MODERATE.

Tariff and all particulars uton afplication

H. ClOOTS, PROPRIETOR. 


\section{SANDOWN, ISLE OF WIGHT. \\ OCE
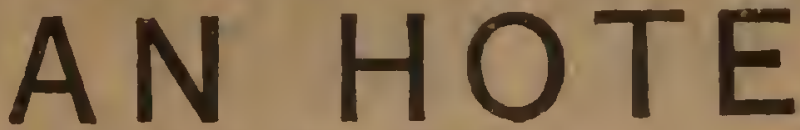 \\ Facing the sea.}

"A model of comfort and luxury."-Pall Mall Gazctic.

"Replete with every cuinfort of a palace."-Dialy Télegraph.

Exquisitely Furnished. Cuisine Unsurpassed. Passenger Lift to all Floors. Sea Baths on all Floors.

Tariff and all further particulars on application to THE MANAGFr.

YENTNOR, ISLE OF WIGHT.

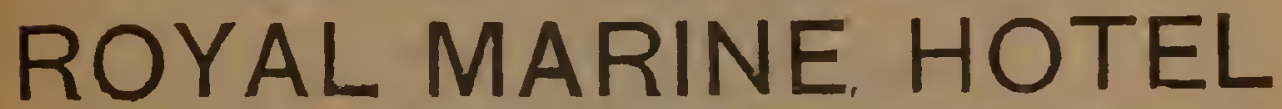

Patronlsed by the Queen and H.R.H. Princess Beatrice

(whose Arms are by special permission displayed).

THIS Hotel has been under the same management for nver fifty years. 1 Finest Sea View in the Undercliff. Large Public Rooms Elegant Suites of Pruate Apartments. Communicating Bath Rooms, \&c

ELECTRIC LIGHT THROUGHOUT.

BUSH \& JUDD, PROPRIETORS.

\section{LAKES OF' KILLARNEY. GRAHAM'S (OLD) HOTEL,} THE GLEBE, near Eranciscan Chureh.

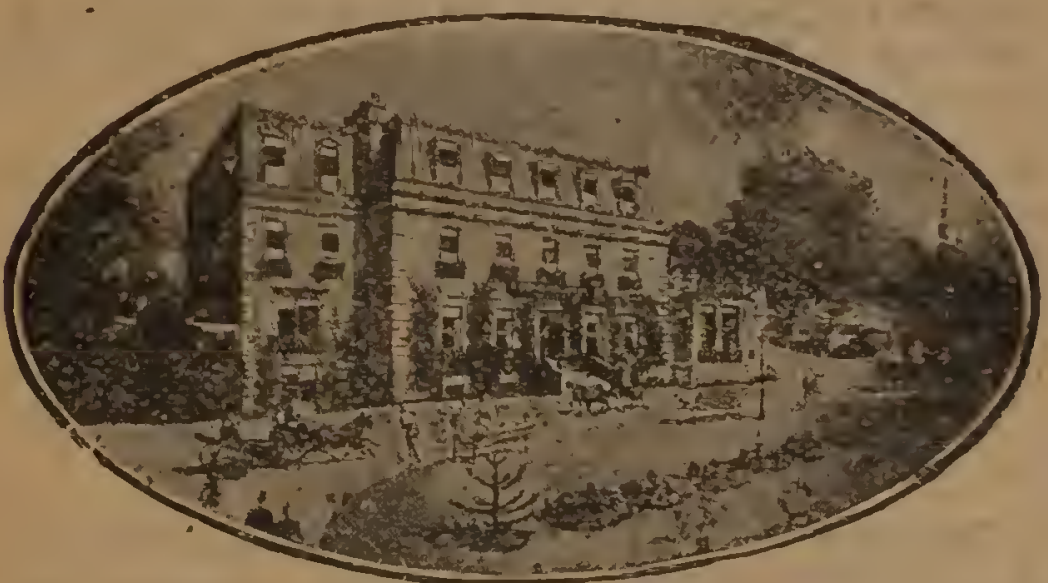

F.you want to see the L.7kes at a moderate cost, stat at this Hotel, as we lave 1 cur own Boats. Cars, Waygonettes, and mike un parties every day during the Sezson This Hotel is centrally situated for the scenery, and a short clistance only from the Lakes. It has good Dining Rooms and Drawing Roons, with fiano and organ Guod airy Bedrooms, l,awn Tennis and Grounds. Write for Graham s Programme and Tours, for 1,2 , or 3 day, nost free. or H. Kaze is Snns, Dublin, for Coupons. SEASON TARIFF-86 per day. inclugive. IEIECTRIC ITGHT THROUGHOUT: BILIIARDS.

We attend all Trains with Cnnveyance to Hotel, Free of Charge. SFECIAT WINTER TARIFF. JOHN GRAHAM. 


\section{"THE ABBEY" HOTEL, KENILWORTH.}

\section{CIIARLAS E. CLEVELy, PROPRIETOR.}

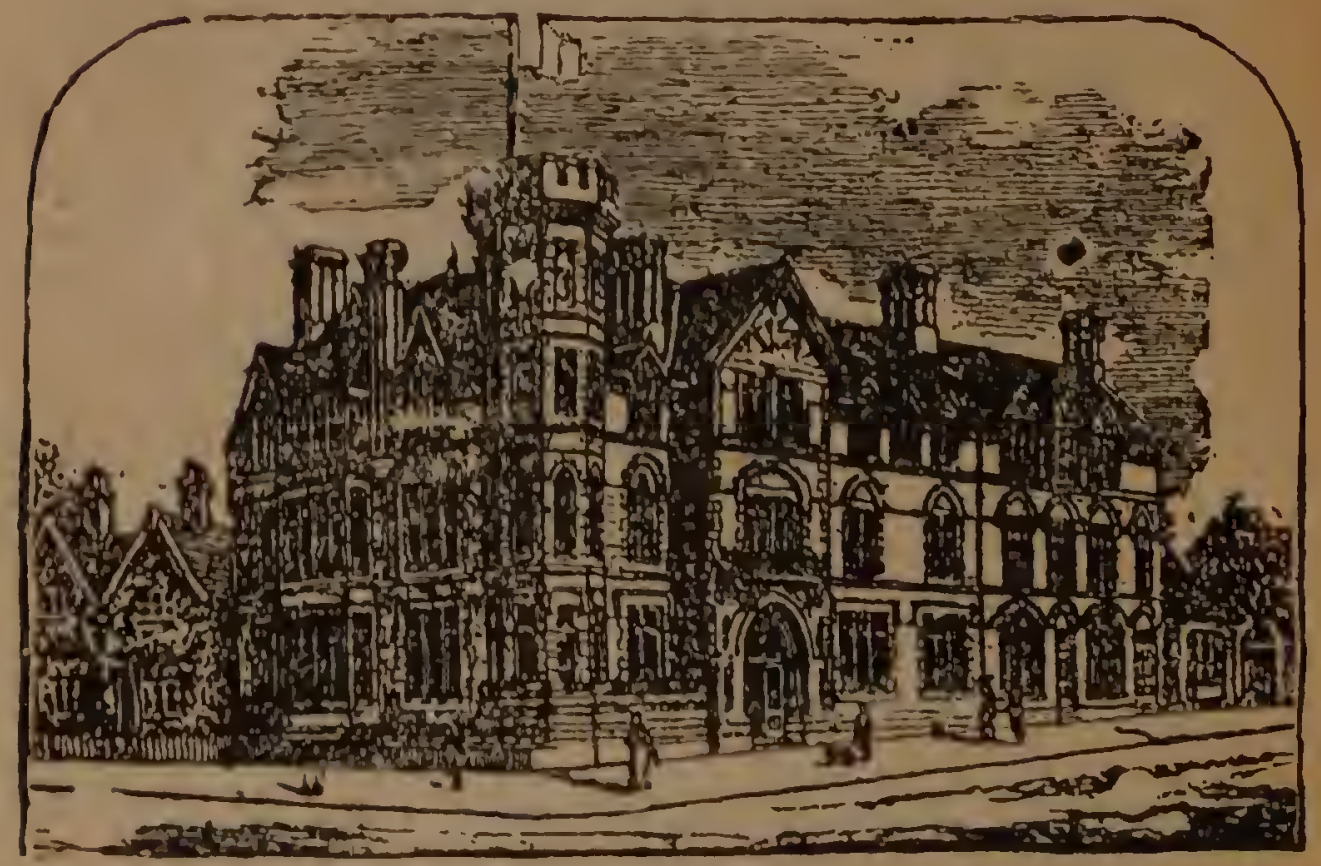

THIS HCIEL, recently rebuilt and fitted with all the most approved 1 sanitary appliances, electric bells, \&c., is delightfully situated, overlooking the ruins of the historic Castle and Abbey.

T'wo Four-in-hand Coaches pass the bouse each day. The Golf Links are within three minutes' walk, and are consided anong the finest in the Midllands. Lawn tennis courts, large garden, exallent stabling, carriagts of all descriptions, saddle horses, \&:c.

"The Abbey" is central for Warwick, Leamington, Coveniry, and Strattord-on Avon; and is within four minutes' walk of the Railway Station. Frequent and rapid trains to all parts.

The Proprietor has been largely connected with Hotel life in the U.S.A., and American tourists will find everything up to their highest standard.

MODERATE CHARGES. TARIFF ON APPLICATION. 


\title{
COUNTY KERRY.
}

\section{SOUTHERN HOTELS, \\ LIMITED.}

\section{HEALTH \& PLEASURE RESÓRTS.}

\author{
Shooting, Fishing, Golf, Boating. Bathing. c:s.
}

\section{SOUTHERN HOTEL, PARKNASILLA.}

ELIGHTFULLY situated in own grounds (upwards of zos acres) on 1 an inlet of the sea. Magnificent and romantic scenery; ; an ideal Holiday resort in summer; and, owing to its shelterer fasition and mild climate, a veritable Jrish Riviera in winter. Coachos to Waterville and Kennare daily, during Tourist Season.

A large NEW HOTEL, one of the finest in the Uni:e " ingdom, has recently been completed bere, and fitted with Turkish and $\mathrm{H}=t$ and Cold Sea Water Baths.

\section{SOUTHERN HOTEL, WATERYILLE.}

$\mathrm{O}^{\mathrm{N}}$ the shore of Lough Currane, and within half a mile of the sea Salinon and Trout fishing commences here on Ist February, and the house is already well known to Anglers from all parts of Great Britain and Ireland. This Hotel has been enlarged, and every modern improvement introduced.

Coaches to Parknasilla and Kennare, and aiso to Cajirciveen daily, during Tourist Season.

\section{SOUTHERN HOTEL, CARAGH LAKE.}

WITHIN half a mile of G. S. \& W. Ra?waj Station; beautifully Wituated on the shore of Caragh Lake, and surrounded by unrivalled scenery. The Cumpanv has secured extensive and exclusive Fishing and Shooting rights, and good Links for the use of its guests. Salmon and Loch Leien Trout Haichery in own gromids. This Hotel has also been enlarged and improvd, and now contains spacious Coffee Room, Drawing Room, Billiard Room, Smokiug Room, !rirge aná lofty Bedrooms, Private Sitting Rooms, etc.

\section{SOUTHERN HOTEL, KEHIMERE.}

THIS House has been quite recently built, and will be found replete with 1 every modern comfort and convenience, including Eiectric Light. It is just on the outskirts of the town, and commands a grand view of the Kenmare Sound and surrounding country. Coaches run daily during the Tor. int Season from this Hotel to Parkna-illa, Waterville, and Cahirciveen, and al so to Glengarriff and Killarney. Passengers on either of these lamous Coach Routes will find Kenmare a convenient and attractive resting place.

Full particulars of any of the above Hote!s may be obtained on application to the GENFRAL $M$ \& VAGER

\section{KENMARE, CO. KERRY.}

Illustrated Pamphlet, "The Lakes \& Fjords of Kerry." post free. 


\section{LAKE HOTEL, LAKES OF KILLARNEY.}

UNDER NEW MANAGEMENT.

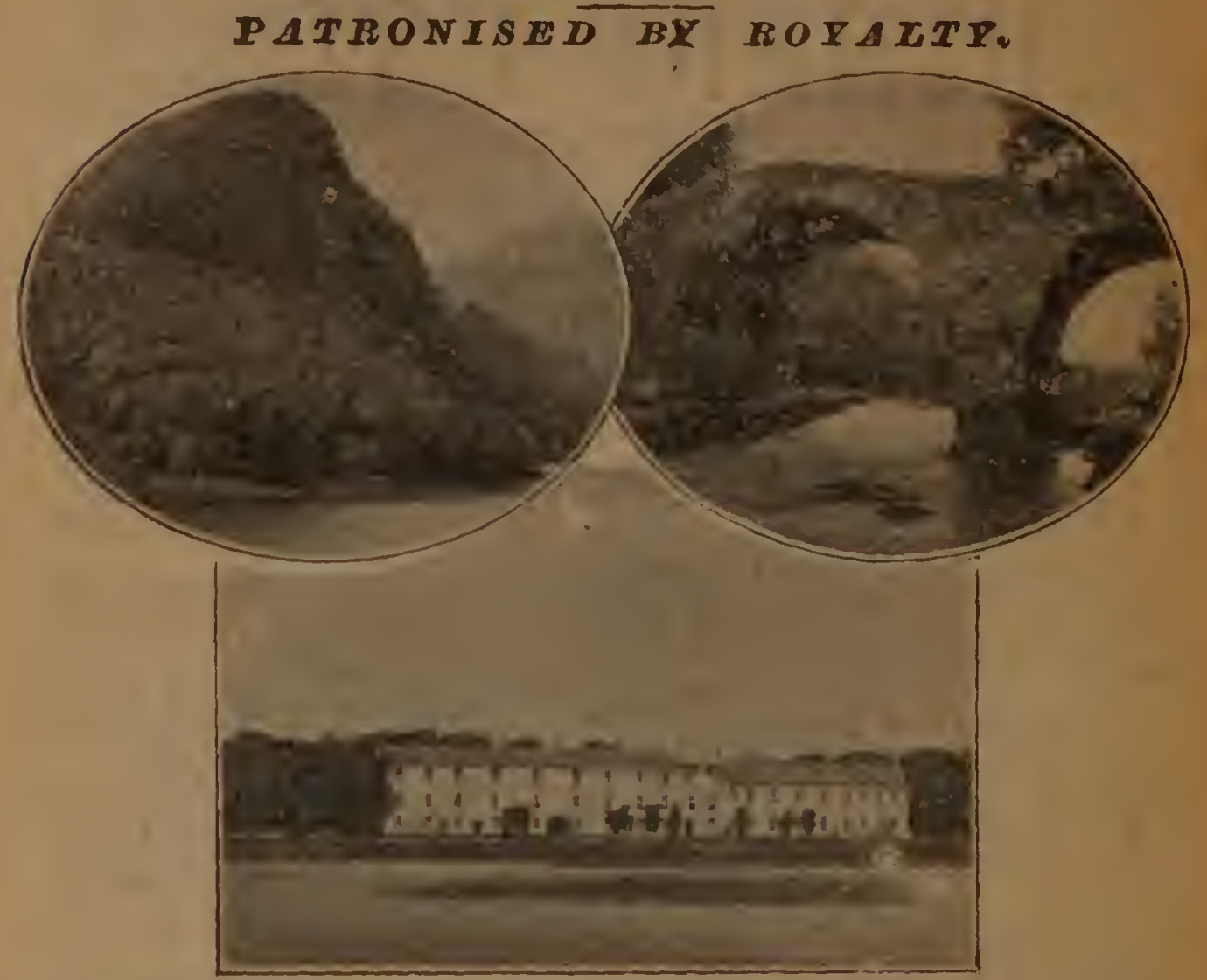

NOTICE OF THE PRFSS. - "The situation of the Hotel is unsurpassed. Occupying the centre of the circle described by the mountain ranges of Mangerton, Torc. Eagle's Nest, Purple Momntains, Giena, Toomies, Liap, and Carrantual, it concentrites in ono view all thit is gracelul, picturesque, and sublime in the scencry of Killarney."Harper's Halldbook for 2 ravellers in Europe and the East.

Billiards. Tennis. Golf within easy distance. Bicycles for hire on the premices. Boats free to Anglers. Free Fi-hing. Electric Light through. out. First-class Cuisine. Terms Moderate.

Address-MANAGER, Lake Flotel, Ltd., Killarney. N. E.-Exenersions start Daily from Holel Grounds. Moderale charges. Firsto dass atotointments.

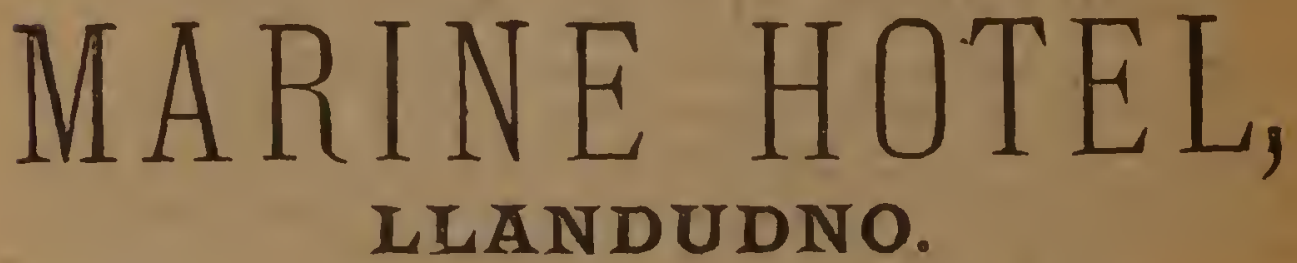

First-Class Family Hotel, Fronting the Parade and Sea.

THE RESIDENCE OF HER MAJESTY THE QUEEN

OF ROUMANIA, SEASON 1830. 


\section{Royal Leamington Spa.}

"England's central garden"-a title it may justly and proudly claim-is rcknowledged by all whose good fortune it has been to visit or reside in it to be the most charming inland watering place in the country. Its mild and salubrious air-its valuable and health-restoring mineral springs and bathsits extensive ornamental grounds and gardens-the wide and well-keot streets and avenues, the latter branching off in every direction tbrough the suburbs of the town-the magnificent Parade, teeming at all seasons of ine year with life and gaiety-all combine to render the "Royal Spa" a most delightful place to live in. Referring to the health of the Royal Spa, the returns of the Registrars. General have time after time proved it to be one of the hea.lthiest of all towns in the kingdom. To obtain this result nothing. has been spared by the town authorities as regards sanilary measures and supplying the borough with an abundant and pure supply of water.

\section{THE ROYAL PUMP ROOMS AND BATHS}

are a great attraction to the resilents and visitors, and below will be found particulars of this favourite resort. The spring at the Pump Rooms has been found by recent analysis to contain thirty.two _ ains more saline matter to the rint than any other spring in the lown.

TABLE OF AVERAGE CONTENTS, WITHOUT DECIMAL FRACTIONS, OF AN IMPERIAL PINT OF THE LEAMINGTON

MINERAL, WATERS.

Saline residue fier inperial pint.

\begin{tabular}{|c|c|c|c|}
\hline $\begin{array}{c}\text { Sulphate of } \\
\text { soda. }\end{array}$ & $\begin{array}{c}\text { Chloride of } \\
\text { sodium. }\end{array}$ & $\begin{array}{c}\text { Chloride of } \\
\text { calcium. }\end{array}$ & $\begin{array}{c}\text { Chloride of } \\
\text { niagnesium. }\end{array}$ \\
\hline 23 to so grains. & 40 to 60 grains. & 20 grains. & 3 to 12 grains. \\
\hline
\end{tabular}

With bromide, iodine, carbonic acid gas, free oxygen, and sulphuretted hydrogen gas in proportions varying with the spring selected for analysis.

The Chalybeate Spring contains peroxide of irun, in considerable quantity, in addition.

About one pint of water in the day is the usual quantity taken when its aperiene effect is desired. The early period of the morning is generally chosen for its administration-one half being reserved until twenty minutes" brisk exercise has followed the first dose; but its adoption requires particular rules in individual cases, acco,ding to their peculiarities, of which the resident medical men are the best judges. Great benefits result in its administration in derangement of the digestive functions, visceral ob. structions, cutaneous diseases. Paralytic affections, gout, and rheumatism generally relieved by a course of bathing in combination with the internal use of the water and other means.

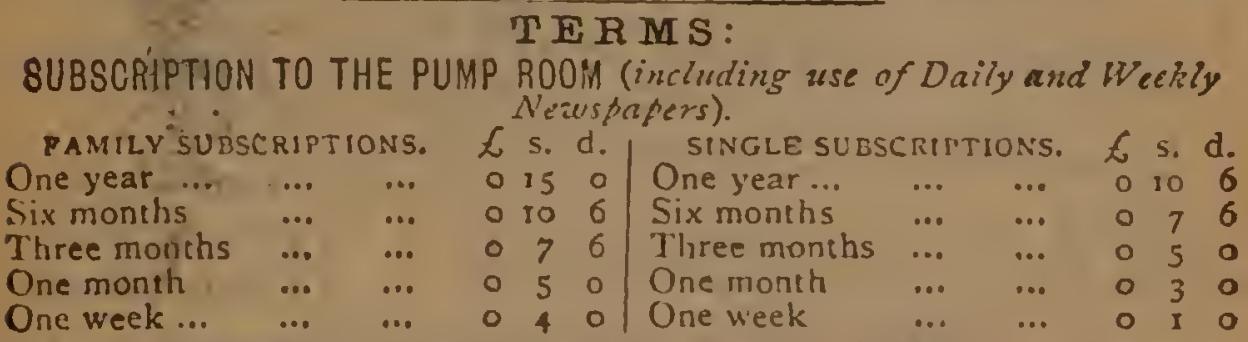

Jolnt Tickets for PUMP ROOM and JEPHSON GARDENS, are issued to visitors at the following reduced rates:

Family tickets, three months, $15 \%$ : one month, $8 \%$ : one week, $5 \%$

Single ticket. three months, $8 \%$; ane month, $5 \%$ : one week. $1 / 6$

2tao Large Assembly Koom is supplied with Dailg Papers for the use of Subscribers. Lor bire of Large Pump Room for meetings, entersainments, \&́c., pind terms, apply to tbe Manager, 


\section{LIVERPOOL.}

COMPTON HOTEL, CHURCH STREET,

Opposite the Cathedral Gardens.

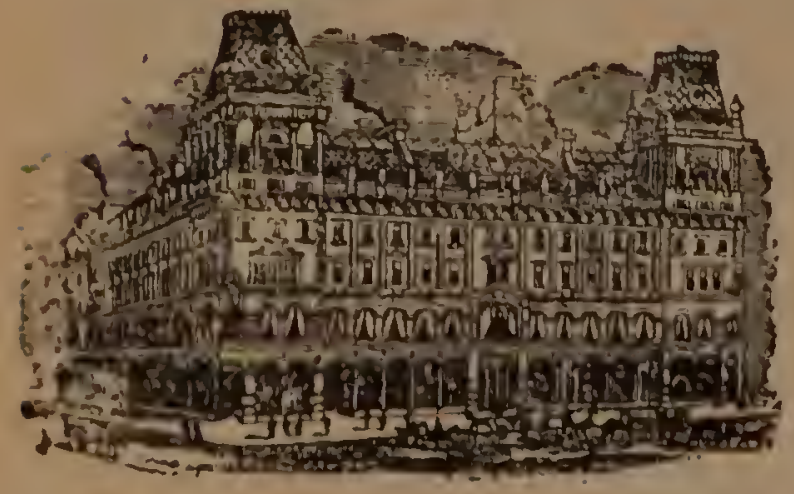

W. Russeu, Proprietor.

Application for Tarifl solicited.
TIIIS Hotcl, for liamilies and 1 Gentlenen, occupies the finest position in Liverpool. Unrivalled iur coufort and excellent cuisine.

THE Spacious Coffee Room 1 acljoin the Ladies' Drawing Romm, l'rivate Sitting, Dining, Arljitration, Commercial, Stock, Milliard and Smoking Rouns, \&ic.

A DJACENT to the best Shops. A 1.aw Courts, Kailwaj Stations, shipping Offioes, $\$ \subset \mathrm{c}$. : and near the Kiver Landing Stage.

Moderate Fixed Charges Luggage Conveyed Free

\section{LIVERPOOL.}

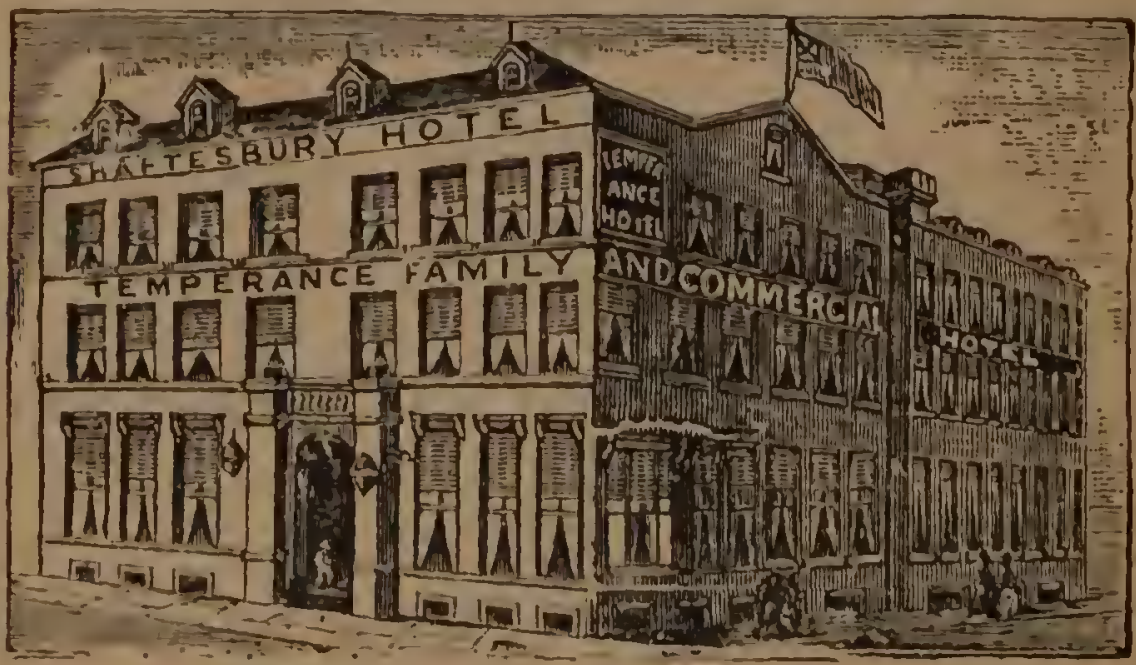

\section{SHAFTESBURY HOTEL, MOUNT PLEASANT.}

A First-Class Temperance, Family, and Commercial Hotel. About three minutes' walk from Lime Street and Central Stations, and abnut tell minute.' walk from Landing Stage. Electric Light. Good Stock Roons. 100 Rooms. Moderate Tarif.

Telegrams - "Shaftesbury Hotel, Liverpool." Telephone 729. 


\section{LAURENCE'S}

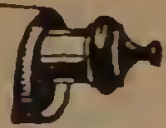

Temperance, Commercial, and Family

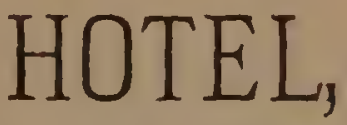

20 \& $2 I, C L A Y T O N$ SQUARE,

$$
\text { LIVERPOOL. }
$$

THIS Hotel contains upwards of roo ROOMS, including 1 COFFEE ROOM, PRIVATESITTING ROOMS. BILLIARD and SMOKE ROOM. The BED ROOMS are well ventilated and comfortably furnished.

The Midland and London and North-Western Stations are avithin three minutes' walk, and the Lancashire and Yorkshire Station and Landing Stage within a convenient distance.

\section{CHARGES STRICTLY MODERATE.}

\section{LOCH A WE.}

\section{PORTSONACHAN HOTEL,}

THE OLDEST ESTABLISHED HOTEL ON LOCH AWE HAVING FIRST-CLASS ANGLING FACILITIES.

THIS Hotel has superior advantages, being beautifully located, and easy. 1 of access, only half an hour's journey from luch Awe Station (Callender and Oban Railway), where Cameron's Steamers, "Caledonia," or "Kilchurn Castle," will meet the principal trains during the season, and wil also meet any train by arrangement with thr Proprittor. I-elters delivered twice, and despatched three times, daily. Posta), Telegraph. and Money Order Office in Hotel Buildings. Presbylerian and Fpiscopalian Churches within easy walking distance of the Hotel.

TENNIS COURT. BEAUTIFUL DRIVES. FIRST.CLASS BOATS \& EXPERIENCED BOATMEN. COMPLETE POSTING ESTABLISHMENT. CHARGES MODERATE.

THOMAS CAMERON, PROPRIETOR.

(Originator of the Oban, Loch Awe, and Glenant Circular Tow\%). Telegraphic Address-"CAMERON, PORTSONACHAN."

Note. -THE "CALEDONIA" is a new Twin Screw Steel Steamer, which has been built to meet the requirements of my increased traffic, and is constructed with a view to the comfort and convenience of passengers. 


\section{LOCH AWE AND DALMALLY HOTELS}

(CONNFCTID BY TLLJIJONE).

SITUATED AMONGST MAGNIFICENT SCENERY.

VIEWS UNRIVALLED.

The Centre of Numerous Daily Iixcursions to Places of Great Beauty and Historical Interest.

Salmon Fishing unthe kiver Orchy, and Trout Fishing on Loch Awc, Fre. BOATINL, HI\}.LIARDS, LAWN IFNNIS, CARRIAGES, SE.

The above hoteli an now the Great Centre for hreaking the journey either groing vorth or south. Hussengers by the London Mail have time to hreaklast and then

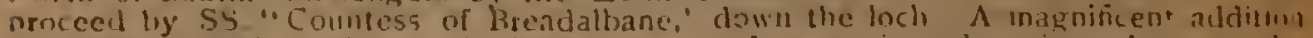
has been adiled tu the I,och Awe Hulel, and extensive alteratiuns rome to the Dalmaliy Hotol. D). IRRASFR, I'ROPKIF IOK.

\section{INVERSNAID HOTEL, LOCH LOMOND,}

THIS IOTEI, is centrally situated in the Scottinh Lake District, amidat unrivalleat scenery. In the neighbourhwod are malny places of interest, stich as Rob Roy's Cave, the islands on Loch lomond, on sume of which are the remains of feudal srongholis, and, wishin a few yatsts of the hotel, Inveranaid Falls, rendered lanolle by iVordsworth in his poen, "lo a Highlant Girl."

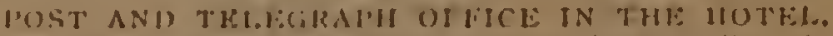

Coaches 10 and from Loch Katrine, several times datly, during summer, in contrection with sailings of sienner for the l'Tossachs.

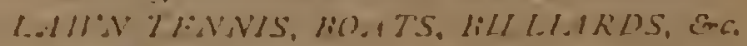

TROUT FISHING ON THE LOCH, FREE.

PARITES BOARDEl ISY IVIEK OR MONTH FXCFPT IN AUGUST. ROBBLRT BLAIR, PROPRIETOR.

\section{The Trossachs Hotel, LOCH KATRINE.}

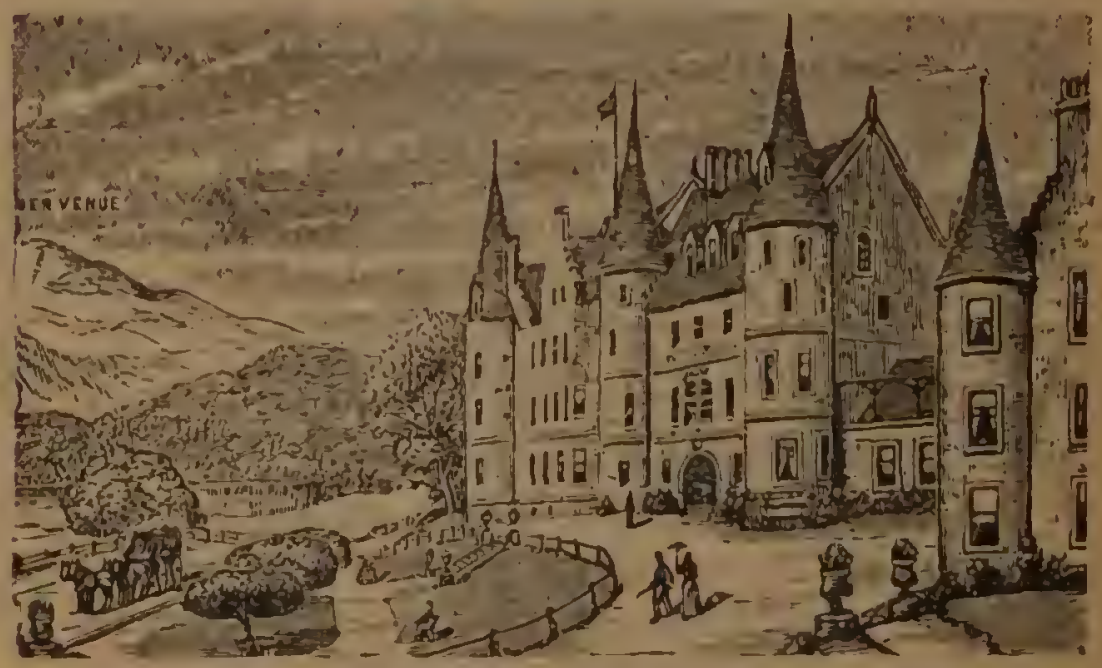

PARTIES boarded by the week on special terms, excepting from istb July to rsth September. Boats for fishing and excursions on $L$ och Katrine and Loch Achray. All coaches to and from Callander stop here for Iunch. Posting in all its branches, both at Callander and Trossachs. Post and Telegraph Office in the Hotel. ROBERT BLAIR, PROPRIETOR. 
VISITORS TO LONDON.

\section{TRANTER'S TEMPERANCE HOTEL,}

6. to 9, BRIDGEWATER SQUARE, BARBICAN, E.C. MOST CENTRAL FOR BUSINESS OR PLEASURE.

Close to Aldersgate Street Metropolitan Railway Station, and near St Paul's Cathedral, General Poit Oitice, and AL L. Places of Interest. Home-like. Higlily-kespectable and Select. BED and BREAKFAST from 3s. TEA from 1s to 1s. 9d. All ather charge: cqually moderaic. No charge for attendance. Iistalublied rä̌z Highly Recom. mended. Clean and Quiet. Electric Light Throughout.

WRITE FOR "Visitors' Guide" showing " How to Spend a Week (or longer) in London," with Tariff and Testimonials combined. Post free on application. Telegraphic Address-"HEALTHIEST," LONDON. Night Porter.

ORIGINALLY ESTABLISHED A.D. 1850.

\section{LONDON.}

Preisig's \& Horner's Temperance Hotel $1 \%$ (d) 19, Euston Roced, King's Cross

(Opposite Great Northern and Midland Stations).

Suites of Apartments, 6s. per day. Good Bedrooms from 2s. Tea or Breakfast 1s. to $2 \mathrm{~s}$.

VISITORS WILT. FIND IT REPLETE WITH IIONH COMFORTS

LYNMOUTH, NORTH DEYON.
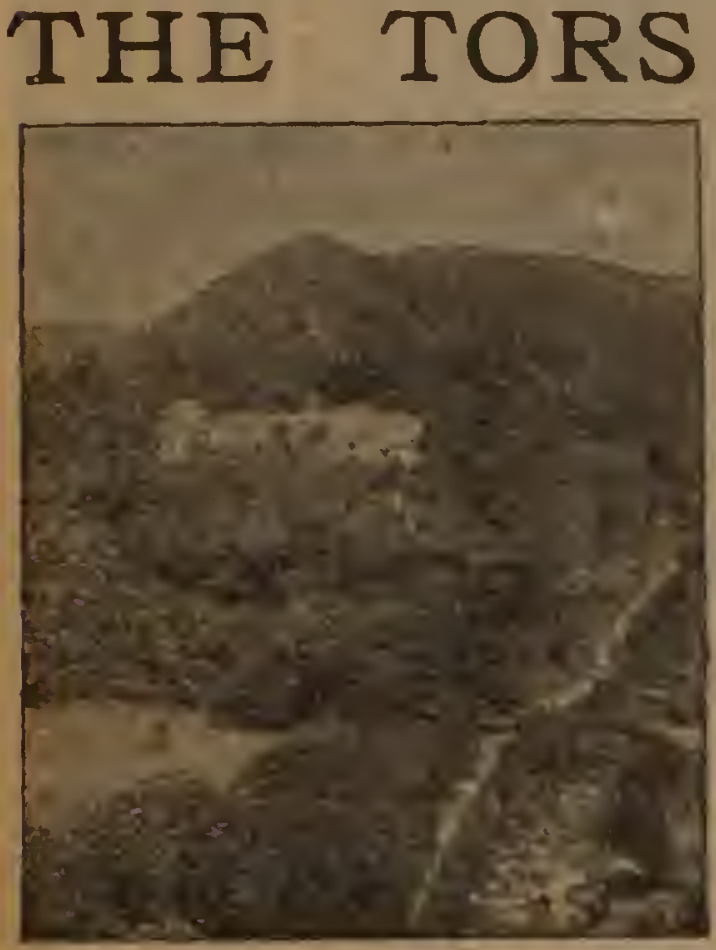

HOTEL.

300 feet immedirtely nbove the sert.

THE finest position 1 in the Vest of England for Land and SeaViews, Sunshine and Health, as stated by several eminent medical men.

The only Hotel on the SUNNY SIDE of the Lyn Valley.

The Quecu says : "As per. fect as it is possible for any Hotel to be.

Telegrams:

"TORS, LYNMOUTH."

N.B.-AN EXPERIENCED CHEF.

W. \& K. RIDDELL, PROPRIEIORS. 


\section{MATLOCK BATH. \\ THE NEW BATH HOTEL}

ENTIRELY re-furnished and re-decorated by Messrs. Warings and Messrs. E Goodalis. A First-class Famlly and Residential Hotel, with all modern improve. ments and every comfort, standing in its 'wn extensive and Urnamental Grounds, situatod in the most picturesque part of the s'eak of Derbyshire. Good Fishing in the district. Coffee Roon, Drawing Room. Smoke and Billiard Rooms, Privale Sitting Rooms. Lakge Natural Tepid Swimming Bath in the Hotel. Stabling and Coach Houses. Sanitary arringements perfect. Ten minutes from Railway Station.

\section{BATH TERRACE HOTEL}

Adjoining. Under same Management. A comfortable Family and Commercial Hotel, with every convenience. Excellent accommorlation for Cyclists. Tarif Moderate. National Teleshane No. 39. Apply to MANAGER.

\section{SUTHERLAND'S}

\section{GREAT WESTERN HOTEL.}

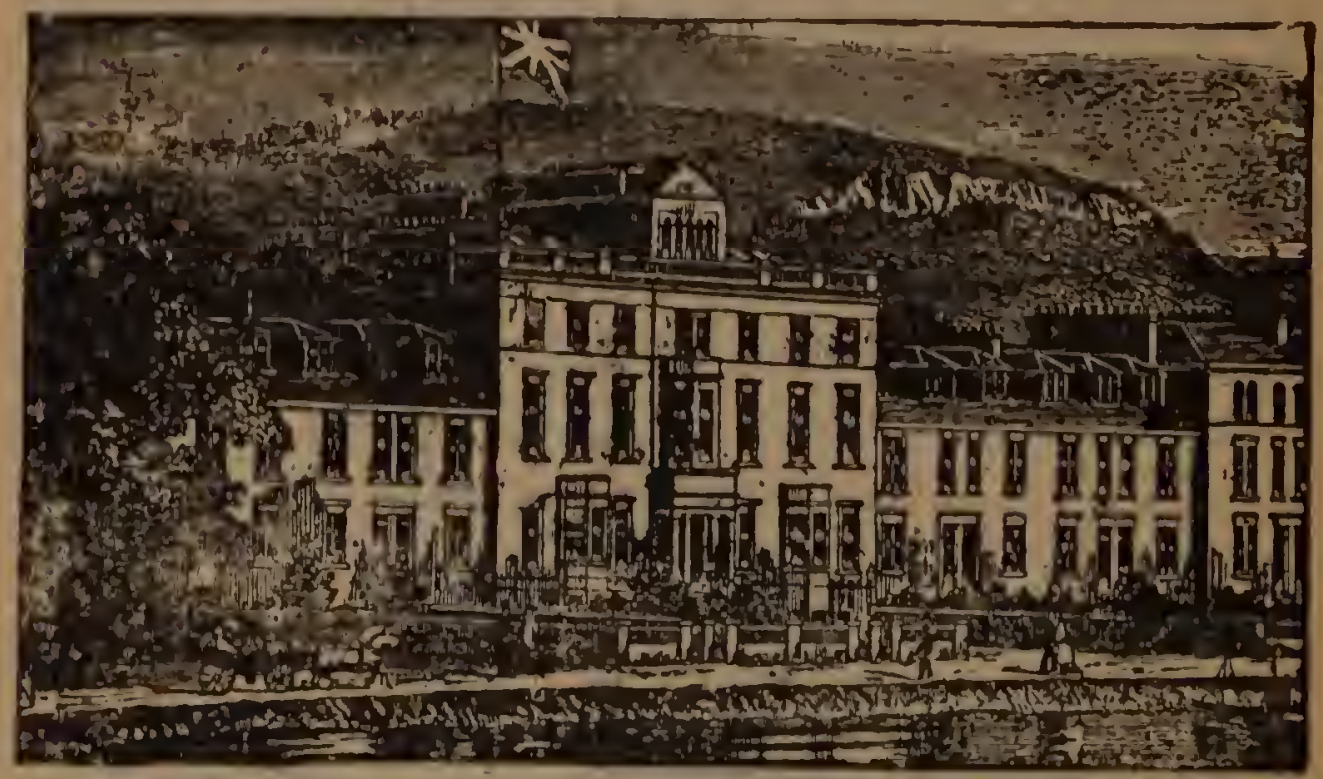

LARGEST AND LEADING HOTEL IN OBAN. Beautifully situated. Replete with every comfort.

NO CHARGE FOR OMNIBUS TO AND FROM TRAINS AND STEAMERS.

\section{ALL ABOUT INCOME TAX, HOUSE DUTY, AHD LAND TAX.}

Nere and Rerised Edition, brought up to Easter, 1898. By C. Forwarn. Crown 8vo, cloth, 18.

Being a plain, practical guide to taxpayers on Assessments, Appeals, Reductions, and Repayments. With Examples of the Official Forms currectly filled.

LONDON : WARD, LOCK \& CO., LIMITED. 


\section{O B A N.}

\section{KING'S ARMS HOTEL.}

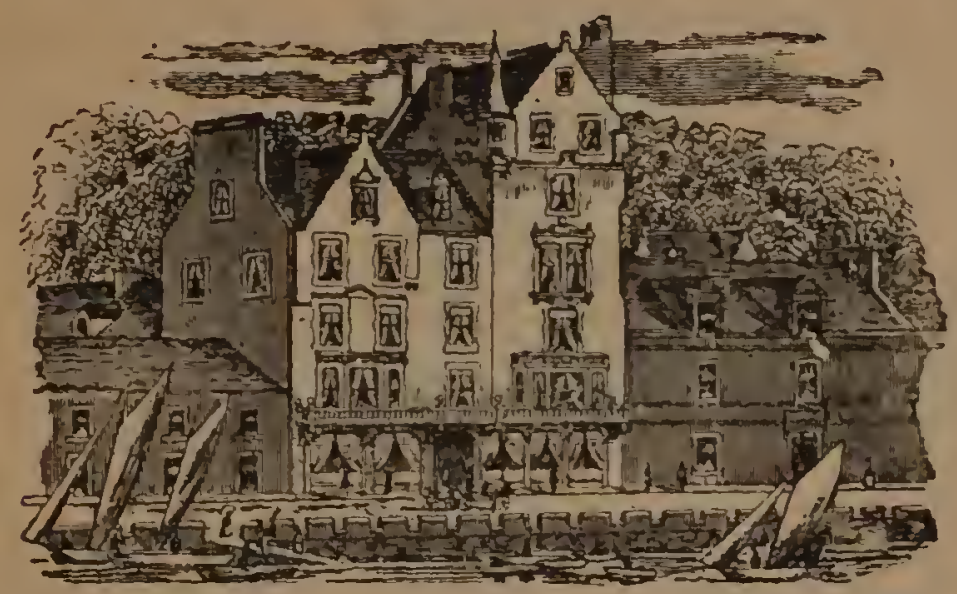

REBUILT AND ENLARGED. FACING THE BAY. CI.OSE TO STATION AND PIER.

Billiard and Smoking Rooms. 'Bus not necessary. GOLF, ELSHING, \& BOATING.

A. M'TAVISH, PROPRIETOR.

In connction with the Richmond Arms Hotel, Temintoul, wia Grantoun and Ballindallo h.

\section{O X F O R D.}

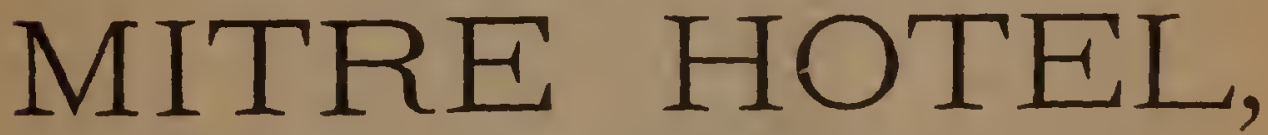

In the centre of the finest street in Europe.

This well-known First-class Hotel for Ladies and Gentlemen, contains Dining, Drawing, Reading, and Smoking Rooms.

BILLIARD ROOMS, AND GOOD STABLING. ELECTRIC LIGHT. Tariff on application to the MANAGERESS. 


\section{PLYMOUTH.}
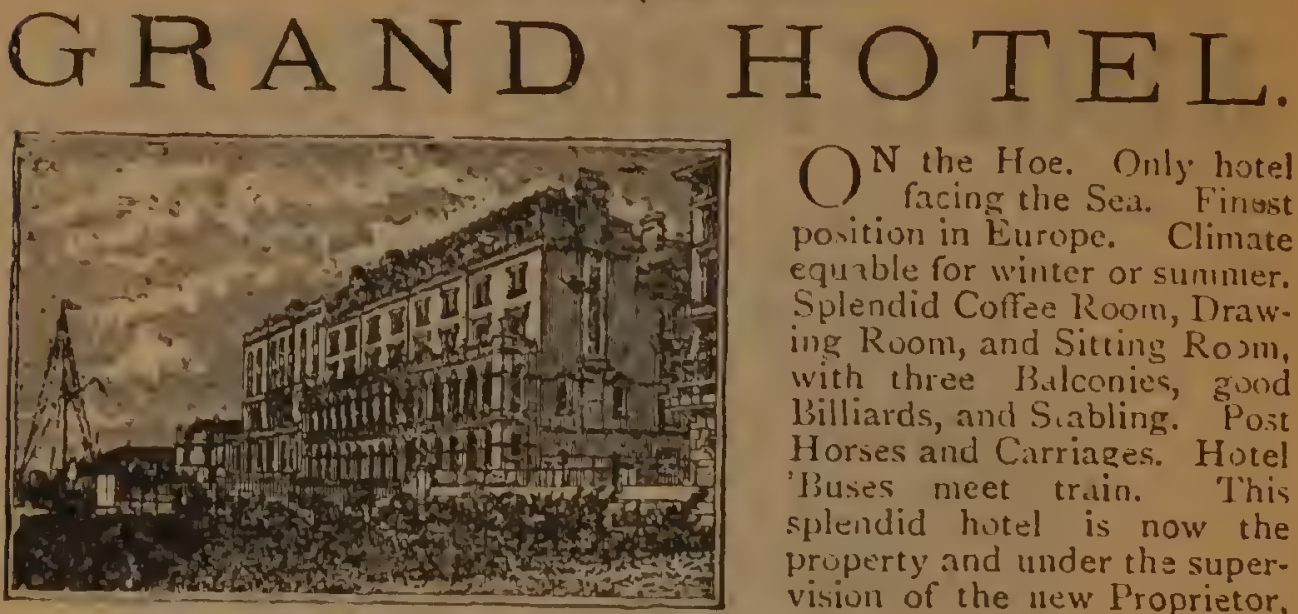

O N the Hoe. Only hotel povition in Europe. Climate equable for winter or summer. Splendid Coffee Room, Draw: ing Room, and Sitting Rosm. with three Bulconies, good liilliards, and Stabling. Post Horses and Carriages. Hotel 'Buses neet train. This splendid hotel is now the property and under the supervision of the new Proprietor,

Table d'hôte 7.0 p.m. Hydraulic Passen zer Lift. J. HEADON STANBURY. Teleplone No. 143.

ALSO ROYAL CIARENCE HOTEL, EXETER.

\section{I'ETH. \\ WAVERLEY HOTEL.}

SPICCALI,Y built to meet the requirements of Commercial Gentlemen, Tourists, and others. Under New Proprietorship and Management. It contains all the latest improvement.s, replete with every comfort. Its bedroom; are second to none in Perth, and it is situated in the best part of the Citv. Parties Boarded on reasonable terms. Magnificent Coffee Room. Drawing Room and Private Writing Roour. Sultes of Apartments. Hot and Cold Bachs. Tiwo minutes' walk from the Cieneral Station by main entrance. Purters will meet the trains.

CHARGES MODERATE. HEADQUARTERS, C.T.C. Wines and Spirits of the Finest Quality. NEYV BILLIARD ROOM.

I'elegrams : "Waverley Hotel," Perth

Telephone Number, 165.

D. Y. PROUDFOOT, PROPRIETOR.

\section{FISHER'S HOTEL, PITLOCHRY.}

(PRIVATE ENTRANCE FROM STATION.)

EXCURSION COACHES DAILY DURING SUMMER.

TROUT FISHING.

\section{Large Crowin 8z'o, leatherette, cut flush, $44^{8}$ pagess, 350 Engrainings. BEETON'S SHILLING GARDENING.}

Never at any time has so large and complete a Work on Cardening been offered to the pub'ic at so low and insignificant a price.

London: WARD, I.OCK \& CO., 1.TN., Salisbury Square, E.C. 


\section{ROSTREVOR. \\ The rentane of Ireland.}

\section{THE MOURNE HOTEL,}

Originally built by the Earl of Kilmorey to develop this unrivalled courist resort.

MILITARY BANDS, GOLF, TENNIS, COACHING, FISHING AND BOATING.

MAGNIFICENT BATH-ROOM, HOT AND COLD, SALT AND FKESH WATEK.

Mew ano effeient Management. Terms Moserate.

\section{THE ROSTREVOR HOTEL,} (Late SANXTER'S),

\section{ROSTREVOR.}

$R$ EDECORATED and refurnished throughout. Hot and IR cold, fresh and sea-water baths; boating, fishing, golf, etc. Combined Railway and Hotel Coupons issued from all the principal stations on Great Northern Railway.

E. SIIITH, PROPRIETOR.

(Late of bhe Mourre and Woodside Holeis.)
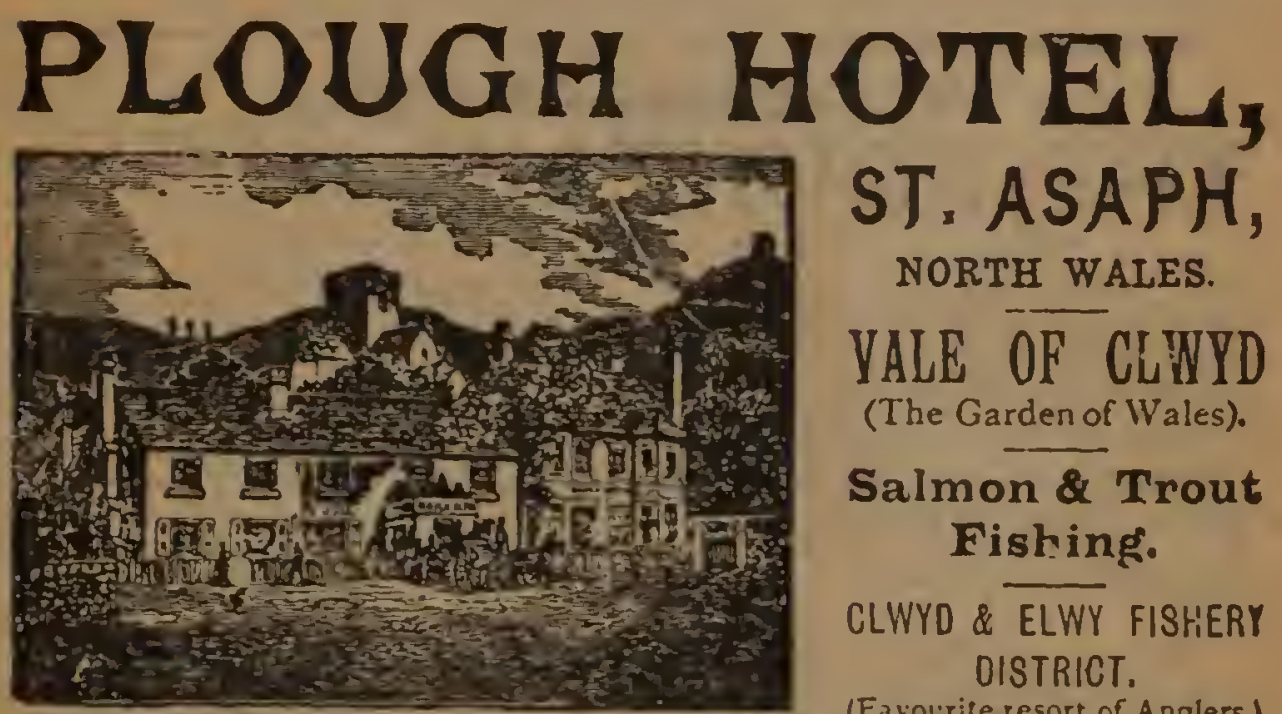

ST. ASAPH, NORTH WALES.

VALE OF CLWYD (The Garden of Wales).

Salmon \& Trout Fishing. CLWYD \& ELWY FISHERY DISTRICT.

(Favourite zesort of Anglers.)

Tariff and all particulars on application to the Proprietor.

WARD, LOCK \& CO.'S NEW POPULAR SHILLING

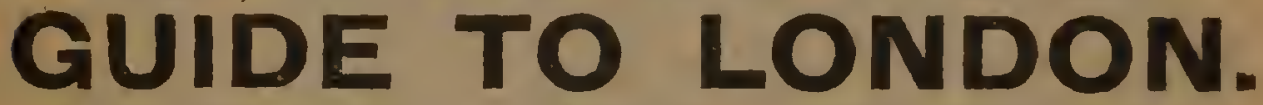

Limp Cloth, Round Corners, 376 Pages. Over 100 Illuntrati ns and mumerous Maps and Plans. Dencribed by the Daily Telegrinth in "One of the Chapest Books Ever Publisbed."

London: WARD, L.OCK \& CO., LIMITED, Salisbury Squate. H.C. 


\section{KNOWLE HOTEL, SIDMOUTH, S. DEYON.}

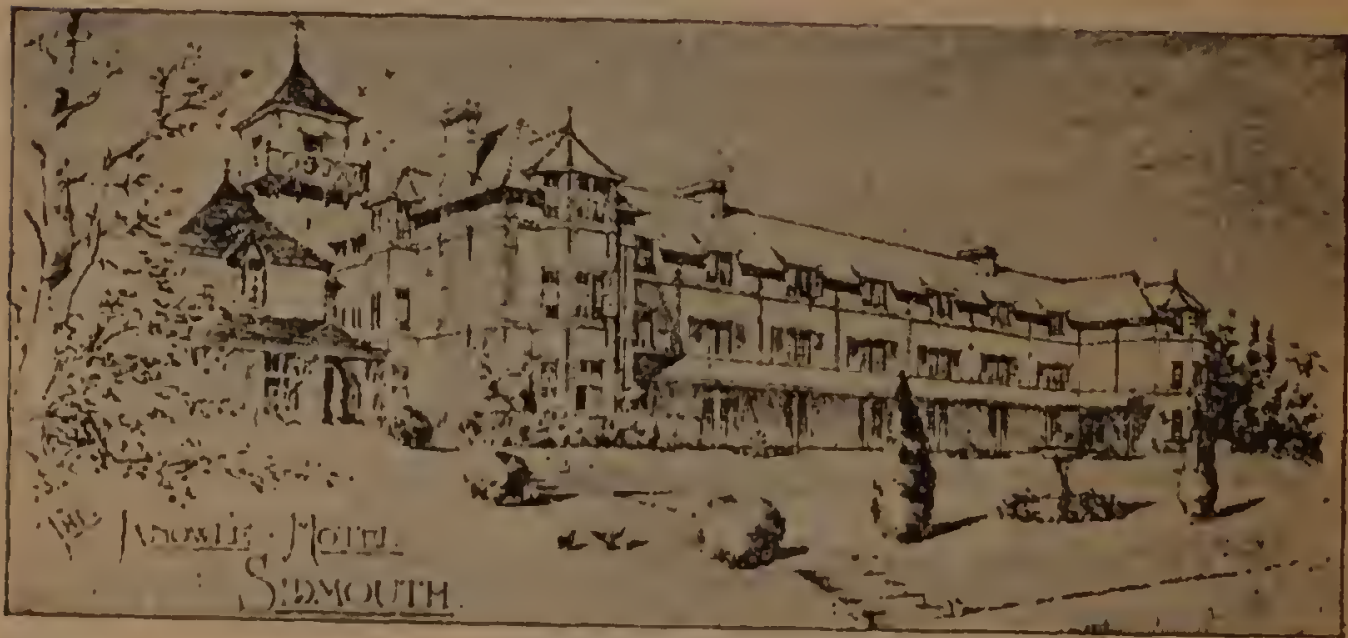

A FIRST-CLASS FAMILY HOTEL, situated half a mile A from, and overlooking the Sea. All rooms face south or south-west. Lovely Views. The greatest attention paid to Cuisine and Wines. TERMS MODERATE. Grounds twenty acres.

\section{STRATFORD-ON-AYON.

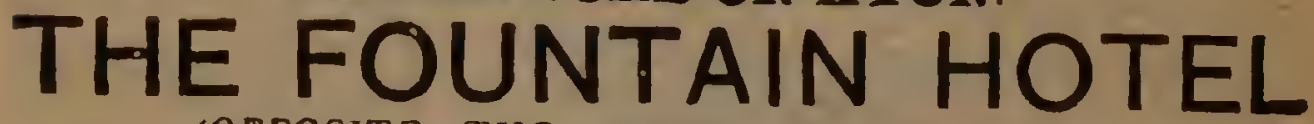 \\ (OPPOSITE THE AMEIICAN FOUNTAIN).}

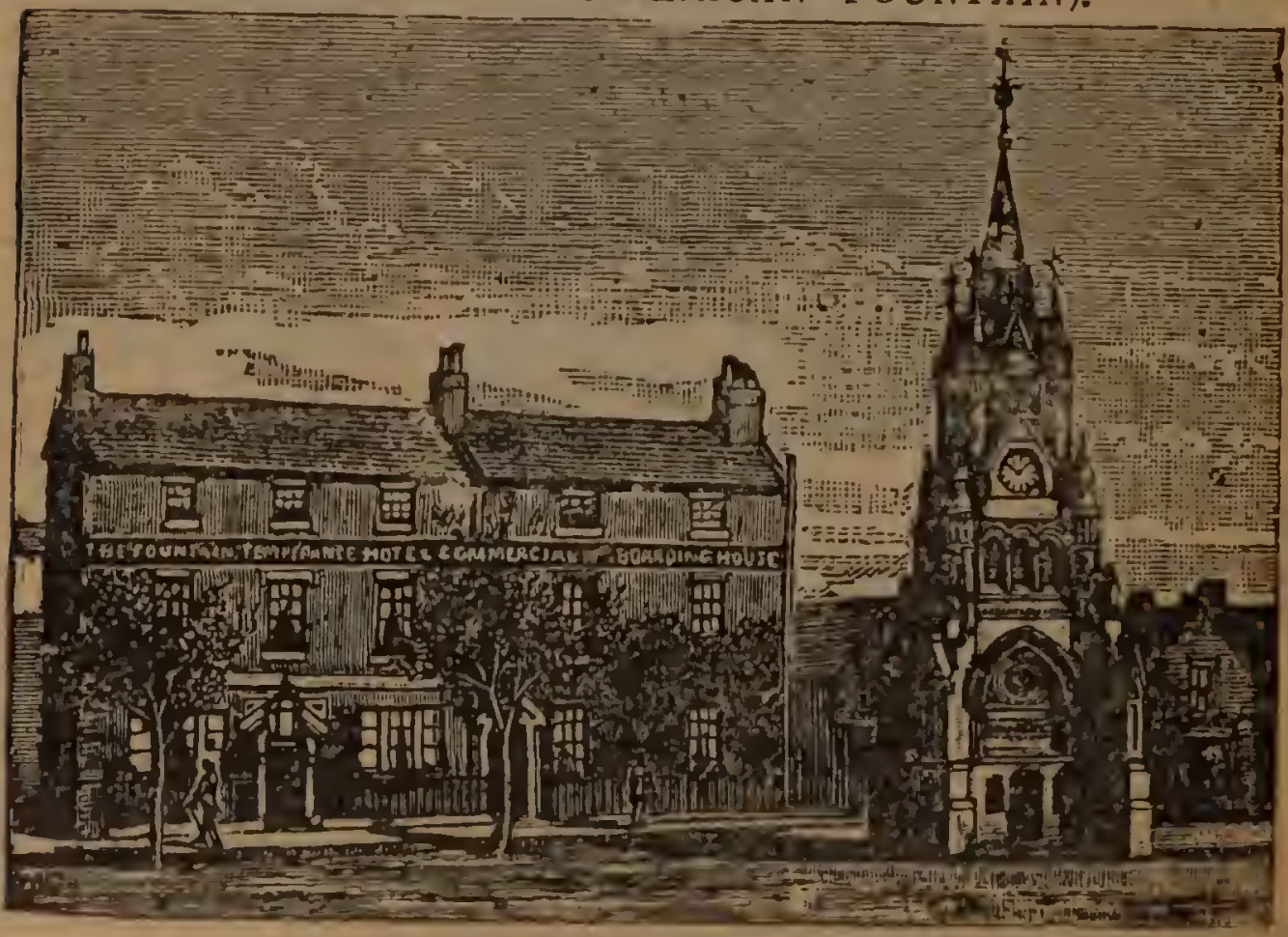




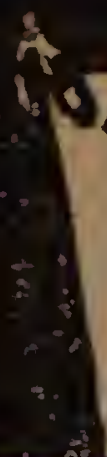

\section{HOTEL,}

D I The Oldest Establisbed and
Leading Hotel in

STRATHPEFFER

SUPBRIOR SALMON ANGLING AOCHS. PISHING IN SEVER L

HIGHEST SITUATION IN STRATHPEFFER

FOUR HUNDRED FEET ABOVE THE SEA.

THE Hotel stands in its own grounds, and is secluded enough to secure to visitors the privacy and quiet of an ordinary country residence. Contains SPACIOUS PUBLIC ROOMS, CONSERVATORIES, LIBRARY, BALL and RECIEATION ROOMS. Close to the GOLF COURSE, CYCLE COURT in Hotel Grounds Professional Attendants, Bicycles on Hire. A. WALLACE, ManaGar

\section{HIGHLAND SULPHUR SPA,}

STRATHPEFFER, ROSS-SHIRE.

These Vaters are among the Strongest in Europe, and are Unrivalled in Great Britain in the treatment of

CHRONIC RHEUMATISM, DISEASES OF THE SKIN, AND

AFPECTIONS OF TEE LIVER AND KIDNEYS.

Superlor Efferuescing Chalybeate Spring, unique in this cmintry. Su'phur. Peat, and Plne Baths. Douches in great variety. Massage, etc.

The Principal and Largest Hotel is the
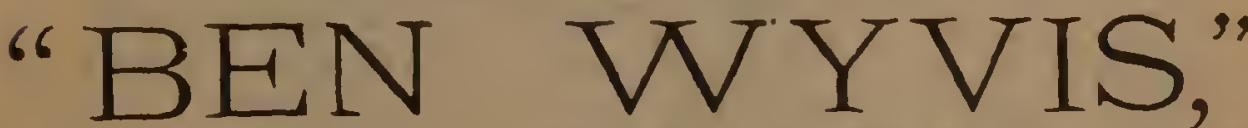

'Two minutes' walk from the Railway Station, the Mineral Wells and Baths, and the Post and Trlegraph Offices. Contains Spacious New Dining Hall and Magnificent Drawing Rooms, Public and Private Apartments, en suite.

BILLIARDS, READING, AND RECREATION ROOMS,

BOWLING AND TENNIS GREENS.

The Hotel is boautifully situated in its own Grounds, and commands a splendld view of Ben Wyvis ("the mourtain of stoms") and scenery unsurpassed in Seotland. Witbin ten minutes' walk of Golf Course. Superior Salmon and Trout Fishing, Frec. 


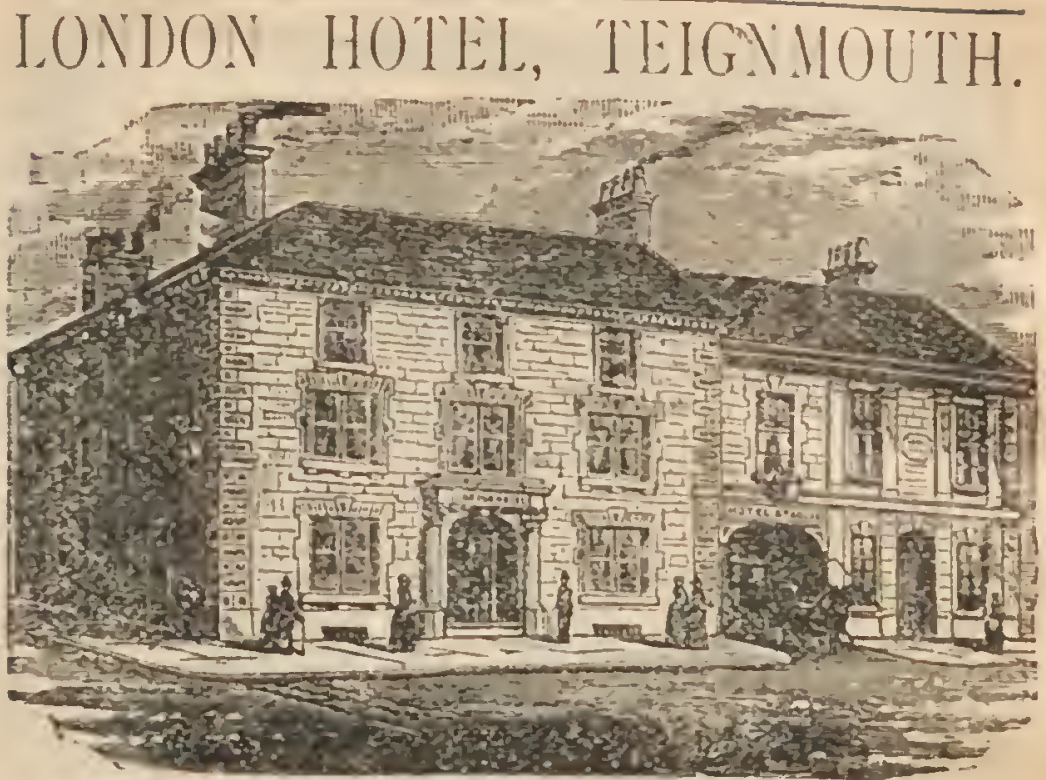

OLDEST AND MOST COMFORTABLF COMMERCIAL AND FaMILY HOTEL. lilliards. Smoking Koorn. Coffee and and Theatrical Performances. Hutel porter meets all Trains concers, un application. Good Stabling. H. A. Mcl3Rl'J)E, Probrirtok.

\section{TINTAGEL, CORNWALL. KING ARTHUR'S CASTLE HOTEL.}

(Camelford Station, L, \& S. W\%. K.)

"THF MOSI ROMANTIC SPOI" IN FINGIAND."

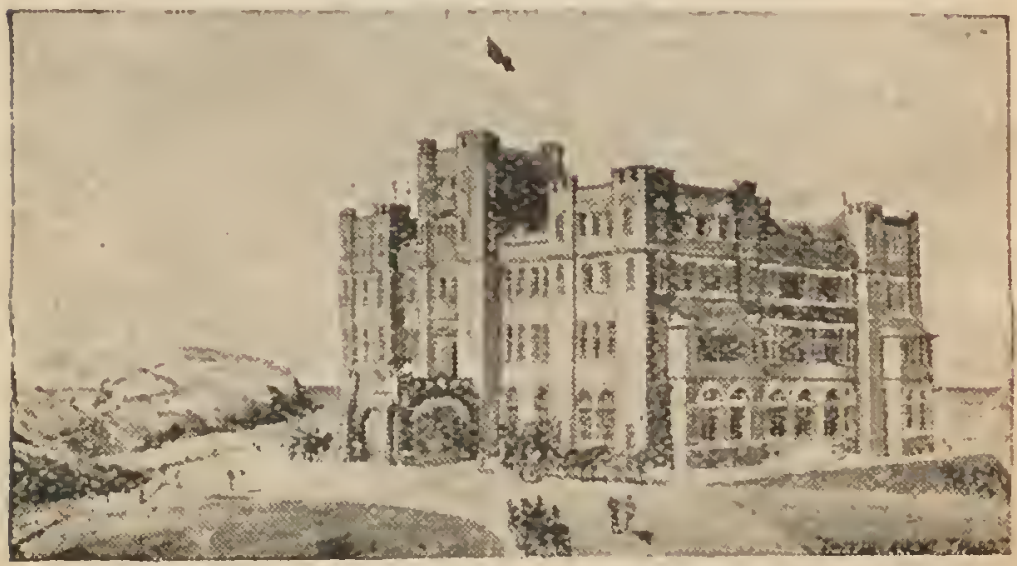

Neu ['alatial Hotel. oserlooking the lar-faned Ruing of King Arthur's Strongbold. Magnificent Views of the Atlantic and rugged Cornish coist. Bracing Climate. Electric Light. Golf, l.ift Hot and Cold Sea Water Batbs, and every Luxury. Stands on the spot where "Tennyson received his inspiration for his "Idylls of the King." 


\section{T O R Q U A Y.}

\section{Roslin Hall Boarding Establishment.}

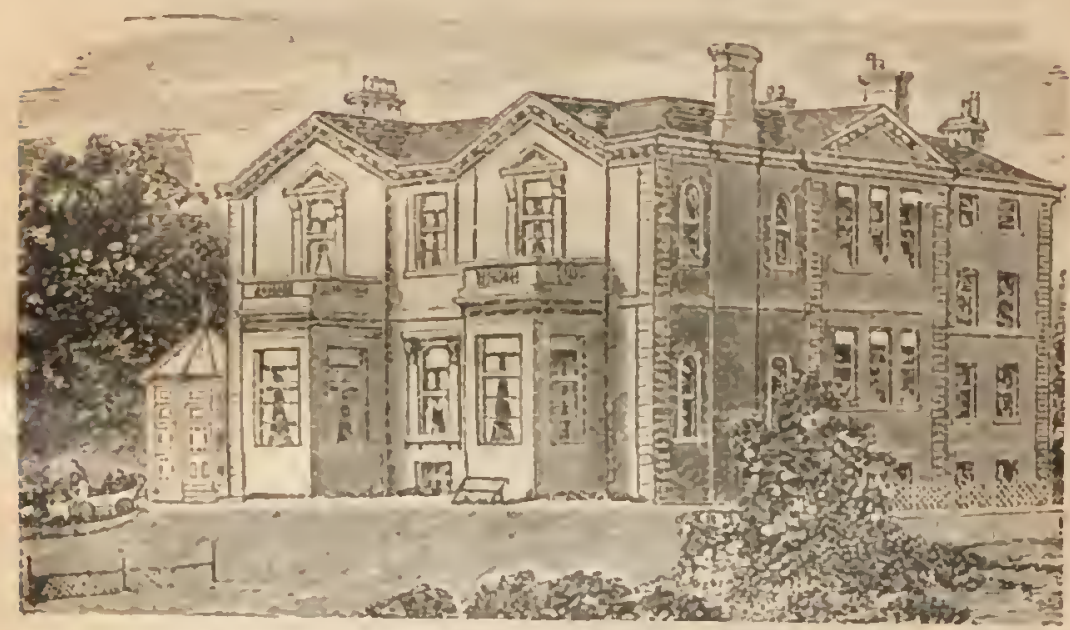

Ciose to all places of interest. Grounds extend to Sea front. Terms Moderate. Cuisine Excellent.

MR. \& WRS. WII.IAM GRESIIAM.

\section{WESTERN HOTEL, TORQUAY.}

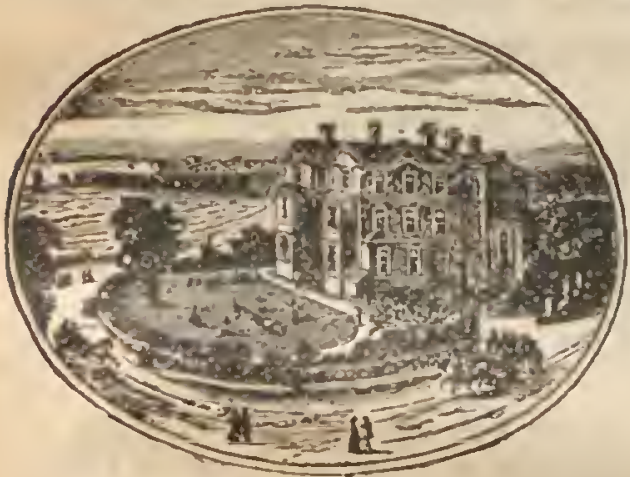

(Personally fatronised by membirs of the Rogul Fiamely.

High-class Family Henel. Equally snitahle as a Summer or Winter fesort Ilagnilicent view from every winduw. For lerms, apply to J'kopsiffiok. Charges exiremtigy inodenate. "en pensian" or by tariff.

\section{HAYDN'S DICTIONARY OF DATES.}

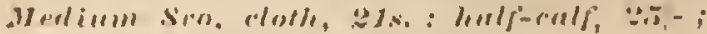
full or tren rall, :31s. Goll.

L.ONDOX: 11.AKD, I.OCK \& CO., L.TD., Silising Sumare, T.C. 


\section{Tynedale Hydropathic Mansions,} HEXHAM, NORTHUMBERLAND.

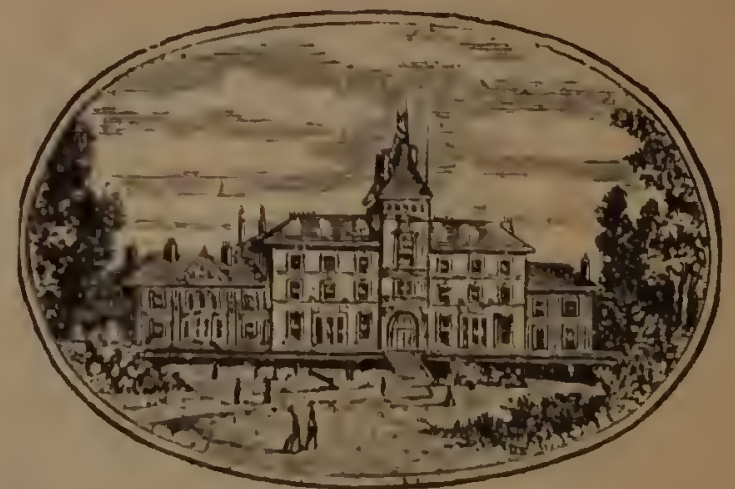

A Favourite Health Resort, beautifully situatea. overlooking the Valley of the Tyne.

PURITY OF AIR UNSURPASEED. REPLETE WITH EVERY COMFORT.

TERMS FROM 22 2S. PER WEEK. FRANK G. GRANT, PROPRIETOR.

\section{Gt. Northern Railway Hotel. WARRENPOINT, CO. DOINN.}

THIS HOTEL is situated amidst the beautiful Scenery of the Monrne 1 Mountains, and facing Carlingford Lough. It has recently been enlarged by the addition of handsume Drawing, Dining, and Billiard Rooms; also Hot and Cold Salt and Fresh Water Baths. Golf Links within easy reach. Sta Bathing. For Terms apply to the Manager.

Combined Railw:y and Hot 1 Tickets are issued from all the principal Stations on the Great Northern Railway (Ireland) to above Hotei.

\section{WAR WICK. \\ WOOLPACK HOTEL,}

first-ollass efumily nnd commerrial.

WITHIN a few minutes' walk of St. Mary's Church, The Castle, and W. Farl of veycester's Hospital; and centra iv situated for visiting GuY's Cliffe, Kenilworth, Stonleigh abiey, Charlecote Park, and STRATPORD-ON-AVON.

\section{LADIES' COFFEE ROOM.}

POST HORSES AND CARRIAGES. EXCELLENT STABLING. MISS KNAPP, PROPRIETORS. 
WEMYSS BAY HYDROPATHIC,

\section{SKELMORLIE, N,B.,}

WITHIN ONE HOUR FROM GLASGOW

(by Wemyss Bay Railuay).

SITUATED on Skelnorlie Heights, overlooking ibe Firth of Clyde, and $S$ commanding a perfect panorama of the most varied and Leautiful scenery in Scotlanc

Che BATHS have been newly constructed, and are among tho FINEST IN SCOTLAND.

NEW SEA WATER SWIMMING BATH.

Direct dav service from Euston at 10.0 a.m. durirg the season.

By Appointment to

Connaught and

BOURNE
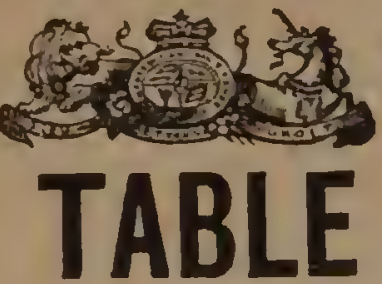

H.R.H. the Duke of the Royal Family.

Pints 3s. 6d., Quarts 4s. 6d. per Dozen.

Three dozen and six dozen cases carriage paid.

R. M. MILLS \& CO., BOURNE, LINCOLNSHIRE.

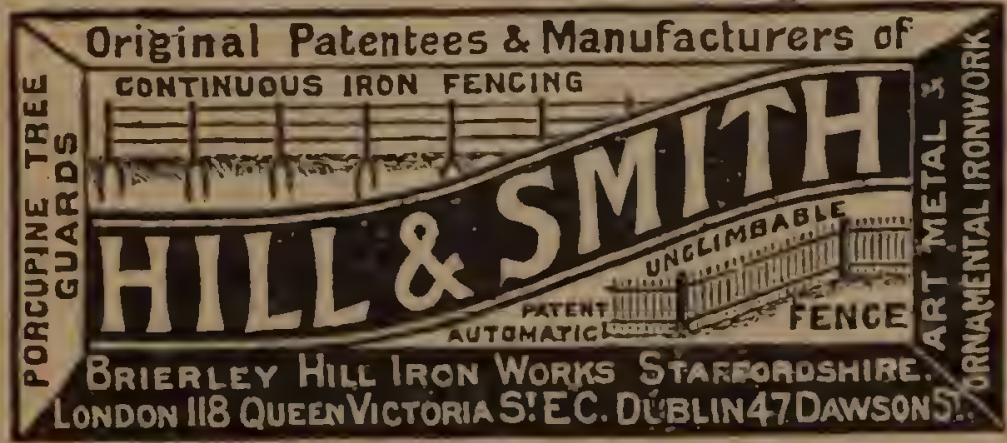

"THE BEST COOKERY BOOK IN THE WORLD."

620th 7HOUSAND.

Strongly bound, half-roan, $7 / 6$; cloth gilt, bevelled bnarda, gilt edges, 8/6 half-calf or half-morocco, $12 / 6$; elegant full tree calf, 18/-

MRS. BEETON'S BOOK OF HOUSEHOLD MANAGEMENT.

Enlarged and Improved Edition, including 360 additional pages of New Recipes and New Engravings, or in all about 1,700 pages, with Thousand: of R.cipes and Instructions, Hundreds of Engravings and New Coloured Cookery Plates.

London: WARD, LOCK \& CO., LTD., Salicbury Sq., E.C. 


\section{POPULAR NOVELS \\ by Guy Boothby.}

Special and Original Designs.

Each volume attractively illustrated by Stanley $L$. Wood and others.

$$
\text { Croncen Sio, cloth will, trimmititions, } 55 .
$$

Mr. RUUYARD KIPL.ING solis-

"Mr. Guy" Boothlyy has come to great homours now. Hig nane is large upen hoarelings, his hooks sell like hot cakes, and he lecpss a level head through it all. I've met him several times in bingland, and lie added to my already large respect for him."

\section{PHAROS, THE EGYPTIAN.}

"This powerful novel is weird, wonderful, and soul-thrillingMr. Boothby succeeds in making it almost real, and its marreis and mysteries almost credible. There never was in this world so strange and wonderful a love story, and Mr. Guy Boothby's admirers will probal,y agree that the most marrellous fiction he has ever produced is "Phiros, the Egyptian." "-Siotsman.

\section{ACROSS THE IVORLD FOR A WIFE.}

THE LUST OF HATE.

BUSHIGRAMS.

THE FASCINATION OF THE KING.

DR. NIKOLA.

THE BEAUTIFUL WHITE DEVIL.

A BID FOR FORTUNE; or, Dr. Nikola's Vendetta.

IN STRANGE COMPANY: A Story of Chili and the Southern Seas.

THE MARRIAGE OF ESTHER: A Torres Straits Sketch.

LONDON: WARD, LOCK \& CO., LTD. 


\section{NEW COMPLETE LIBRARY EDITION OF G. J. Whyte-Melville's Novels. Large crown Szo, woth gilt, 3s. 6d. per volume.}

TIIE late G. J. Wirte-Menvillis, uniting, as he did, the qualities of poet, nurelist, spurtsman, and leader of suciety. has long been acknowlerged to stand above rivalry when dealing with sport and the romance of old. Although the sale of hi.j works has always heen large, the publishers feel that the tine has now arrived to issue an edition niore worthy of his fame, and have therefore pleasure in announcing a monthly issue of his novels, complete in about twenty-five volumes. Each volume will be illustrated by front-rank altists. well printed from type specially cast, on best antique paper, and neatly and handsomely bound in cloth gilt.

x. KATERFELTO: A Story of Exmoor. With four illustrations by LUCY E. KEMP. WELCH.

2. CERISE: A Tale of the Last Century. With fou: illustrations by G. P. JACONB-Hoon.

3. SARCHEDON: A Legend of the Great Queen. With, four illustrations by S. E. WALLER.

4. SONGS AND VERSES, and THE TRUE CROSS. With five illustrations by S. E. WALLER.

5. MARKET HARBOROUGH, and INSIDE THE BAR, With four illustrations by JOIN CIIARLTON.

6. BLACK BUT COMELY: The Adventures of Jano Lee. With four illustrations by S. E. WALLER.

7. ROSINE, \& SISTER LOUISE. With four illustrations by G. P. JACOMB-HOOD.

6. KATE COVENTRY. With four illustrations by LUCY E. KEMP-IVELCH.

9. ROY'S WIFE. With four illustrations by G. P. JACOMBHOOD.

I0. THE GLADIATORS: A Tale of Rome and Judæa. With four illustrations by J. AMBROSE: IVALTON.

II. HOLMBY HOUSE: A Tale of Old Northamptonshire. With four illustrations by LUCY E. KEMP. WELCH.

LONINA: WARD, LOCK \& CO., LTD. 


\section{You cannot beat the Best! \\ THE}

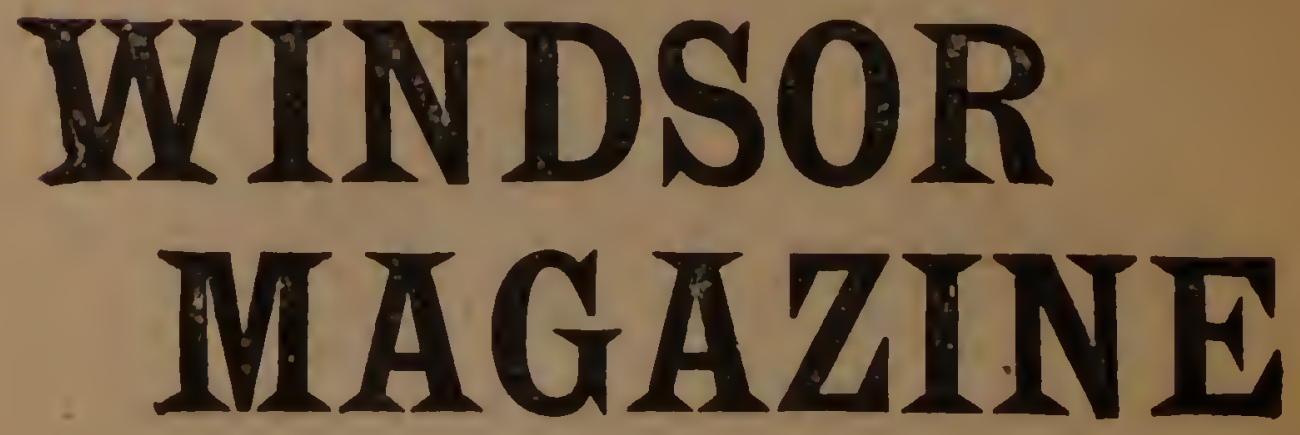

Always containe the BEST WORK by the

BEST AUTHORS AND ARTISTS.

It has eclipsed every other Sixpenny Magazine, and has achieved the most Brilliant Success of the day.

It Holds the Record

for giving the Best Serial Story of the Year.

It Holds the Record

for giving Splendid Exclusive Articles by recognised specialists.

It Holds the Record

for being the Most Varied, the Most Entertaining, and the Most Instructive of Magazines.

Zhe "Zimes" calls it "Wonderful."

LONDON : WARD, LOCK \& CO., LTD. 
F R E E B Y POST.

The most Valuable acquisition to the Toilette WHICH HAS BEEN DISCOVERED FOR MANY YEARS IS

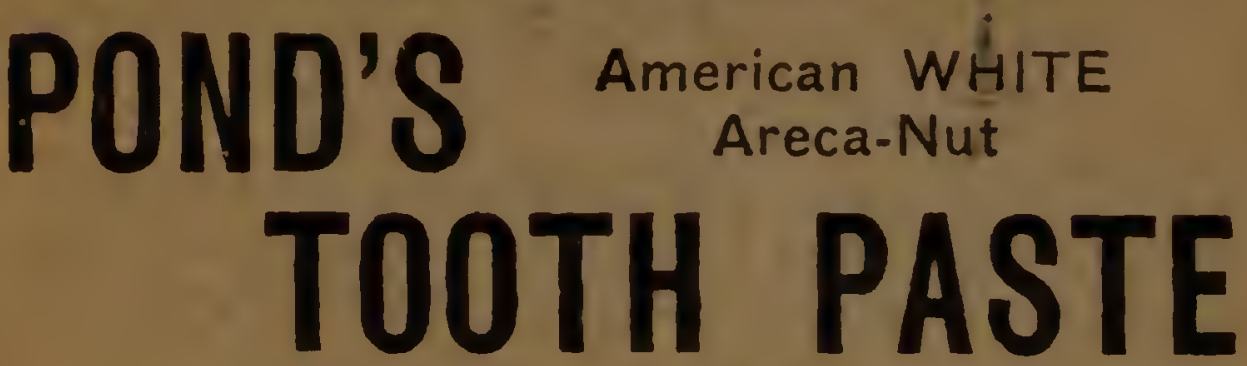

From Professor P. L. SIMMONDS, F.R.C.I., F.S.S., \&c.

GenTlemen, -I have much pleasure in certifying that I have now used your WHATE ARECA-N UT TOOTH PASTE for some time with great pleasure and advantage, and I have warmly recommended it to my friends.

29, Cheapside, Novimber 21, 1870. P. L. SIMMONDS.

Price 1s., 2s. 6at., and $4 s$.

\section{DE COURCY'S}

\section{Tooth-Nerve Destroyer}

An Instant Cure for Tooth-ache. Palnless and niost easy in application. ONE 8HILLING.

Among numerous Testimonials received the P,oprietor is permitted to print the following Order sent to hill :-

"Whitehall, Lichfield, Nov, 26. -DEAR Sik, -Oblige by sending a Shilling Pactet of your excellent Nerve Destruyer; I find it a most effectual remedy for Tooth-ache. Enclosed are twelve stamps.

"M. De Courcy." "Yours truly, C. F. HENRY."

\section{DE COURCY'S}

\section{ENAMEL FOR STOPPING DECAYED TEETH}

NO MIXINGI ONE SHILLINGI

Whlte, Elegant, and Durable: Easy, Certain, Painless; Warm in Applicution, it PREVENTS TOOTH-ACHÉ RECURRING.

AUTHORITATIVE TESTIMONIAL.

"Dr Courcy's Evamel I strongly recommend as a very valuable invention for Stopping Decayed Teeth.

"April 24, 1856. EZRA HARLE, Surgeon and L.A.C."

\section{Prepared only by-}

POND SON, 68, Fleet Street, LONDON.

Broadway, New York; Vineland, New Jersey: and Hamilton (City), Canada; Madras; Bombay; Calcutta. 
MANUPACTORERS BY APPOINTMENT TO

IIER MA:ESTY THE QUEEN, HIS MAJESTY

THE KING OF ITALY,

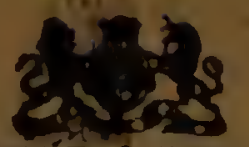

HIS MAJESIY

THE

HIS MAJESTY THE KING OF SIAM.

HER MAJESTY THE QUEEN REGENT OF HOLLAND,

H.R.H. THE PRINGE OF WALE8, dc, \&c.

\section{Paris Exhibition, 1878, 'THE GRAND PRIZE'}

\section{(Special Gold Medal and Dipioma of Honour)}

The Highest Distinction the Fibhihion could confer, and the only

"GRANI Plizli" given to the Biscuit Trade, was awarded to

\section{HUNTLEY

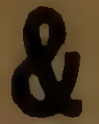 \\ PALM

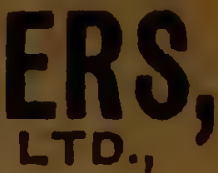
Biscuit IDamutacturers,

\section{READING \& LONDON,}

THE FOILOWING, IEING THE TERMS OF THE AIVARD:

"Maison hors ligne, connue du Monde eusier pour son Imnense Produc. tiun et pour l'Hexcellente Qualité de ses Pruduits."

"Umivalled House, known throughout the world for its enormous pro. duction, and for the Excellent Quality of its Manufactures."

The Highest A wards guen for Biscuits to any English Howse were made to RUNISEY is PALAERS, at the following Exhibitions for "Hxcellence of Qucility" :

London, 1851. London, 1862. Havre, 1868.
Lima, 1872. Vienna, 1873. Paris, 1865. Santiago, 1876.
Paris, 1867. Amsterdam, 1869 Lyons, 1872.

International Health Exhibition, London, 1884, Gold Medal,

$$
\text { ALsO THK }
$$

DIPLOMA OF HONOUR (twice conferred) and the GOLD MEDAL of the "National Academy of Agriculture, Manufactures \& Commerce," Paris.

These Biscuits are made of the finest materials; and from their great variety of Shape aud Flavour, acknowledged Superiority of inake and fine keeping qualities, they bave obtuined a very extrofsive and increasing sale ii) England, on the Continent, and in the various Markets throughout the World.

HUNTLEY \& PALMERS' BISCUITS, \&c., may be obtained of the principal Italian Warehousemen, Grocers, \&c., in the United Kingdom, and elsewhere. 


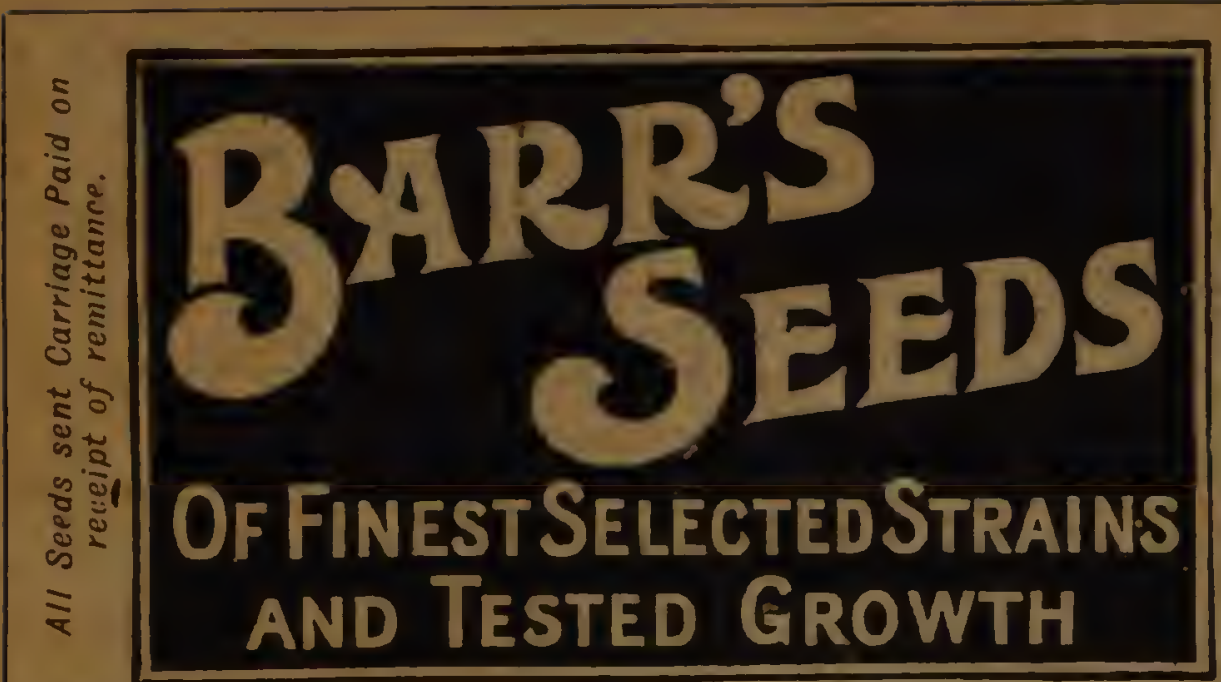

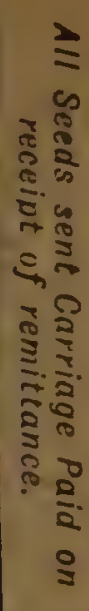

BA IRR'S Seed Guide contains a Select List of the best Vegetables, and the inost beautiful Flowers for Garien and Greenhouse. It is full of Practical Hints, and will be found invaluable to Gardeners, Amateurs, and Exluibitors. Sent free on atfiticatios.

$\boldsymbol{B A R R} \boldsymbol{S}$ Catalogue of Hardy Perennials and Alpires, ready in Febriary. free.

BARR'S Spring Catalogue of Bulbs and Tubers for planting, from February to April. Rearly is Famuary, fiee.

BARR's Cata!ogue of Beautiful Daffodils, realy in Angust, free.

BAIR'S Autumn Catalogue of the Best Bulbs for Garden and Green. house, ready ist Sefiember. free.

BARR \& SONS, 12 \& 13, KING STREET, Aurserues-LONG DITTON, Surrey isurbiton Station, S.W. Railway).

\section{THE MOST NUTRITIOUS.}
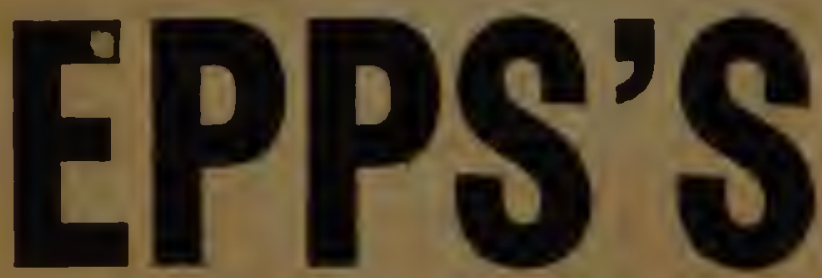

\section{GRATEFUL-COMFORTING.}
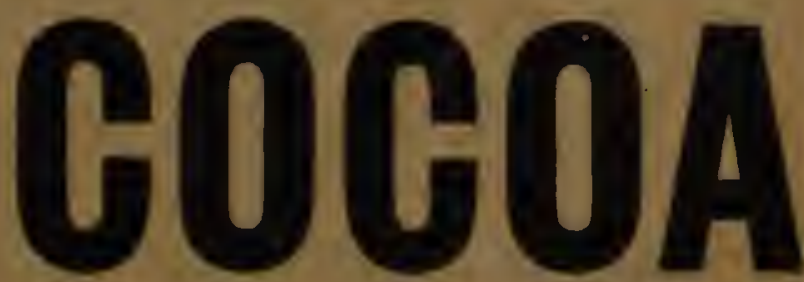

\section{BREAKFAST-SUPPER.}


AEW HAVEN - ISEPPE:

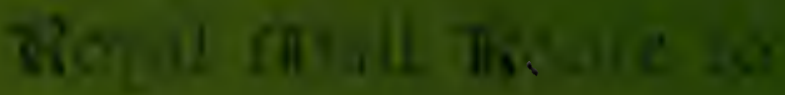

DF $7 \mathrm{RS}$ and the

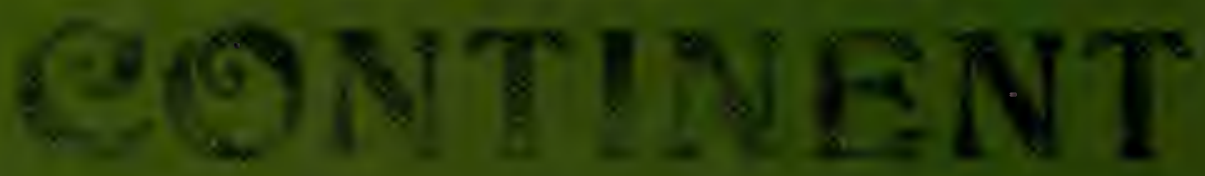

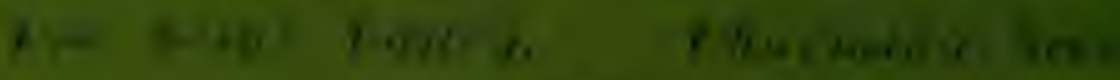

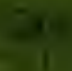

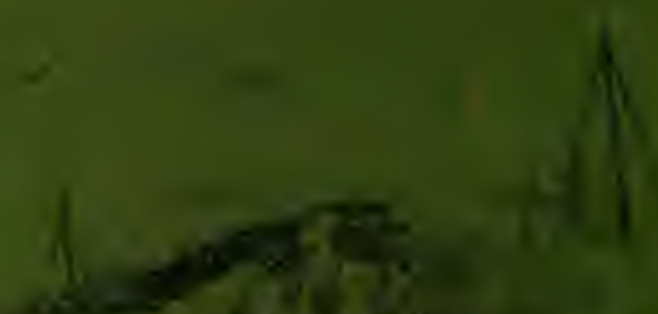

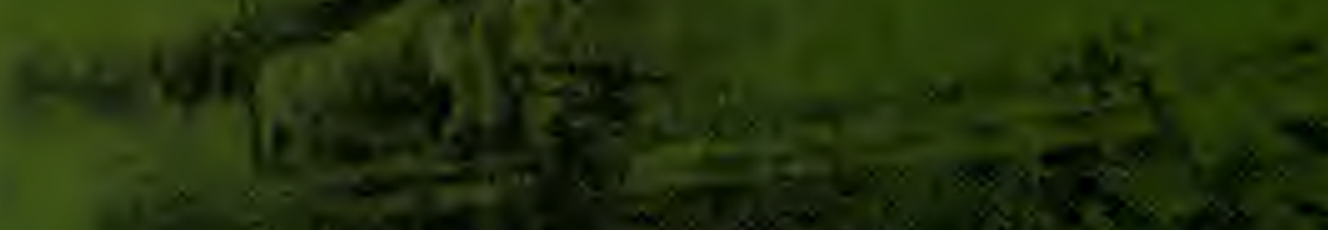

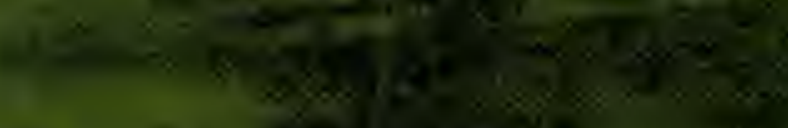

exts 19
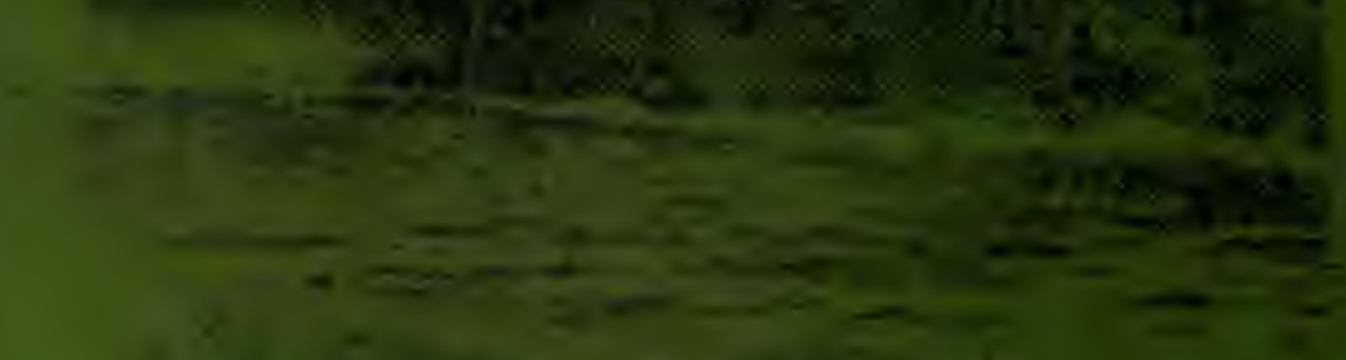

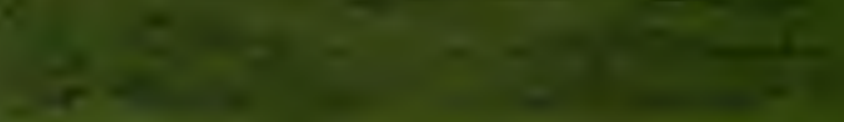

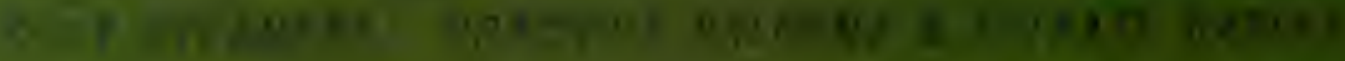

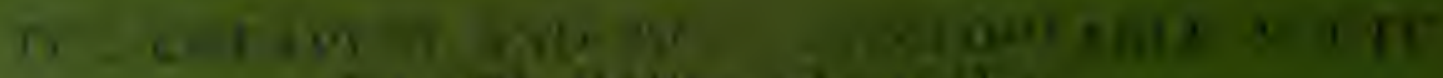

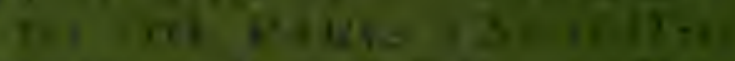

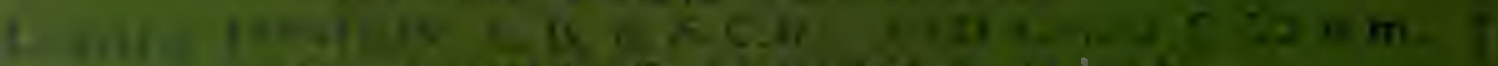

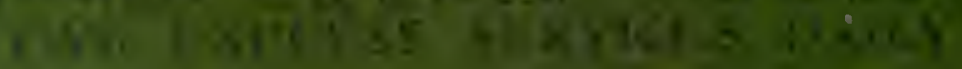

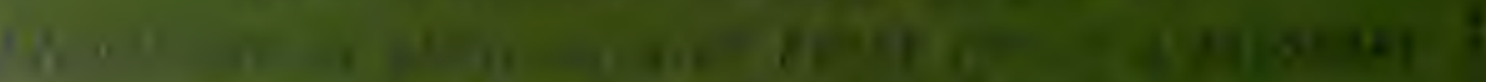

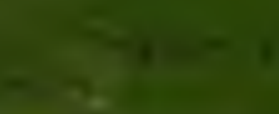

8 